


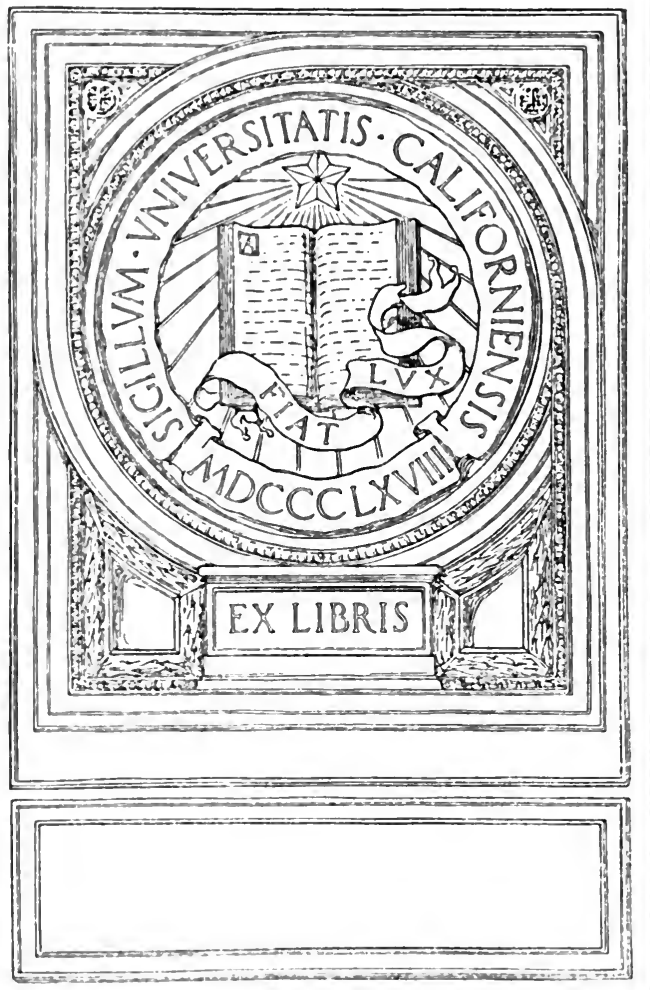


$4=(x-2)$

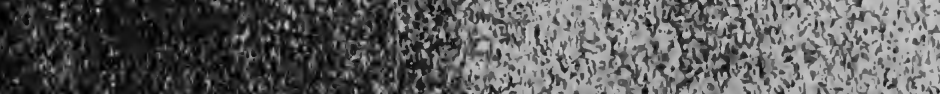

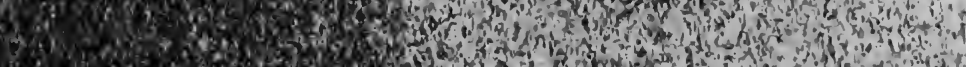

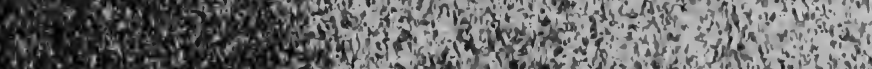

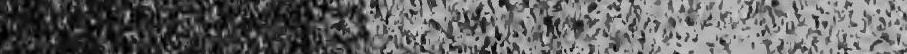

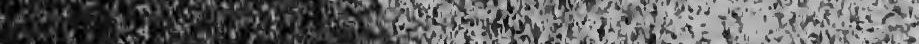

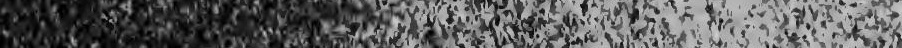

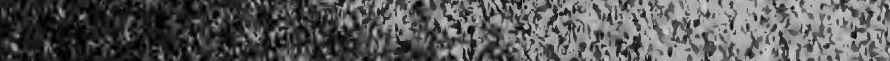

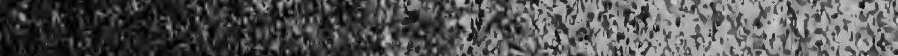
63 (2)

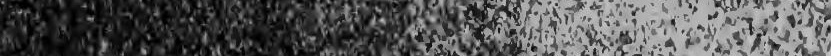

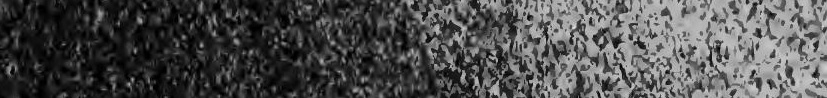

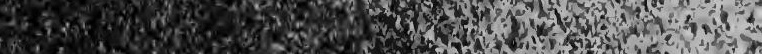

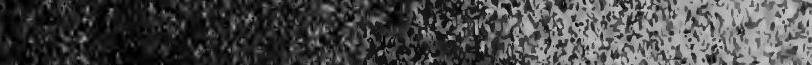

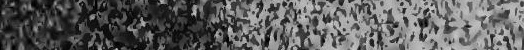

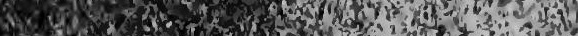

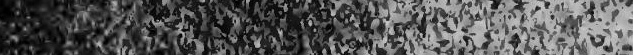

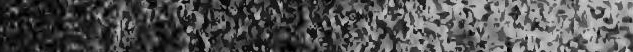

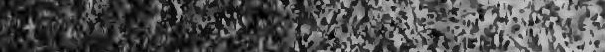

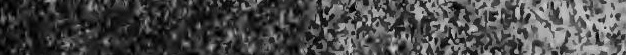

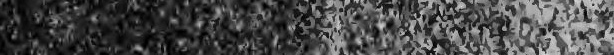
4 4.

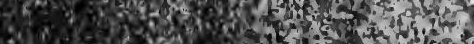

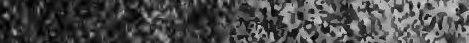
M.

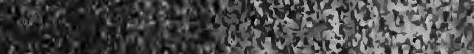

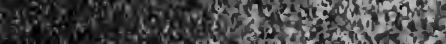

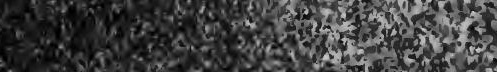

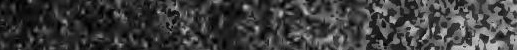

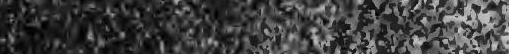

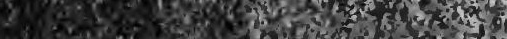

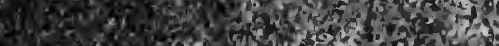

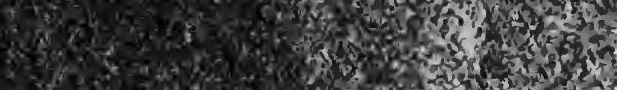

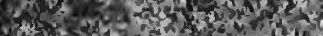

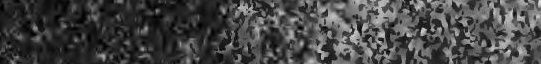

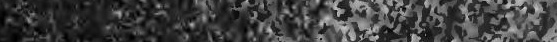

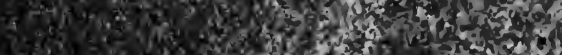

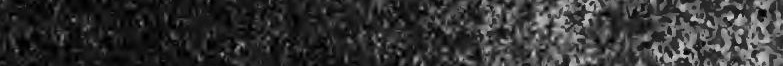

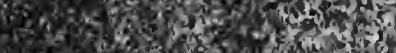
W. and

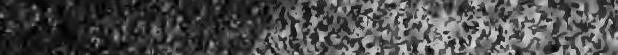

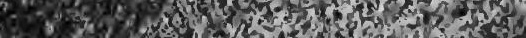

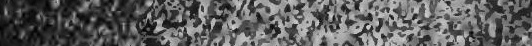

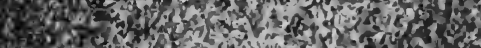

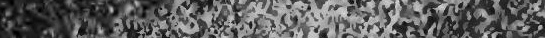

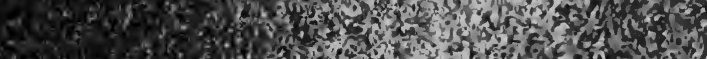
(5) 10 (3) 2070 3.

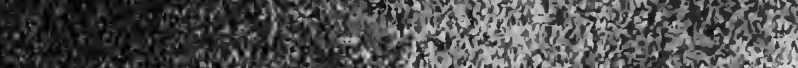

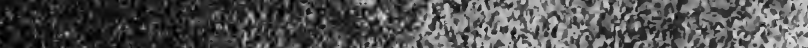

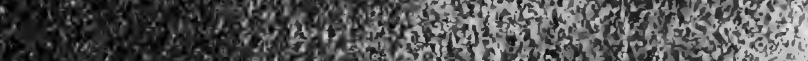

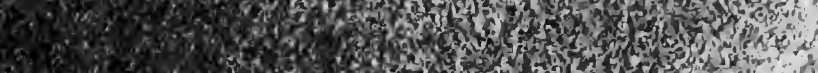



i. :je

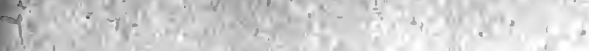

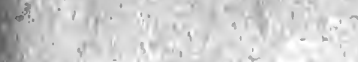

I.

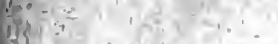

3 ?

oxinter

$0+1,7=$

(3) $x+2,0$

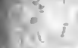

7. $7 x^{1}$

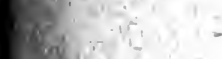

(

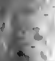

(1) 
. 


\section{THE $\cdot$ P 0 E T S}

OF TIIE

\section{NINETEENTH CENTURY.

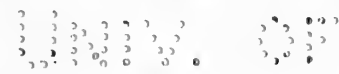 \\ OSELETED NND EDITED \\ BY THE \\ REV. ROBERT ARIS WILLMOTT, \\ INCUMBENT OF BEARWOOD.}

WITH ENGLISH AND AMERICAN ADDITIONS,

ARRANGED BY

EVERT A. DUYCKINCK,

EDITOR OF TIIE CYCLOPEDIA OF AMERICAN LITERATURE.

ILLUSTRATED WITH ONE HUNDRED AND FORTY-ONE ENGRAVINGS, DRAWN BY EMINENT ARTISTS.

N E W Y O K :

HARPER \& BROTHERS, PUBLISHERS, FRANKLIN SQUARE. 
918

W 738

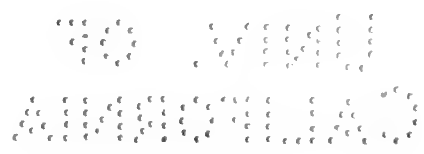

Entered according to Act of Congress, in the year $187 \mathrm{I}$, by HARPER \& BROTHERS,

In the Office of the Librarian of Congress, at Washington. 


\section{P R E F A C E.}

VenY suggestive of musical and pleasant thoughts is the Picturegallery which this Preface opens; and among them is the recollection of the manner in which these choice Word-paintings have been contributed by the Authors, or their representatives; always with liberal promptness, and'sometimes with expressions of personal good-will, to be gratefully treasured. Nor can I forget the generous enterprise of the Publishers, and the tasteful skill of the Brothers Dalziel, by whom the grace and the beauty of the pencil have been translated into the popular language of their own Art.

The Volume embraces a period of about eighty-five years, for the first Canto of the Minstrel appeared in 1771; Beattie survived Cowper only three years; while Percy, exchanging the friendship of Goldsmith for that of Scott, lived into the eleventh year of this century. The dates of these poets might seem to exclude them from our calendar; but, in truth, the fancy of the present age was largely inspired and moulded by the past; and the sentiment of the Minstrel, the naturalness of the Task, and the simplicity of the Reliques, very strikingly. reappear in Campbell, Wordsworth, and Scott. Nor has the embellished landscape of Darwin been without imitators; while the footprints of Rogers are easily traced in the trim garden-paths of IIayley. One member of the classic band will be less familiar to general readers: I allude to Professor Crowe, whose descriptive poem is written with fine taste, and in choice numbers. The traveller, walking from Charmouth to Lyme, discovers Lewesdon Hill on the right hand, and forming one of the boundaries to a rich vale chequered by enclosures.

Our Poetry owes many beauties to womanly genius, and in the following pages some specimens of it will be found. The "Psyche" of 
Mary Tighe yet lives in the memory of 'Taste; but Scotland furnishes a greater name: "If you wish to speak of a real poet," Scott said to Ballantyne, "Joanna Baillie is now the highest genius of our country." He numbered the description of Orra's madness with the sublimest scenes ever written, and compared the language to Shakspeare's. The Songs of Mrs. Hemans afford a lively contrast. It was her misfortune that she wrote to live, instead of living to write. Her compositions, therefore, are unequal; but in her best pieces the eye is delighted by the glow and colour, and the ear is soothed by the varied cadenceoften delicious, never harsh. The visionary tenderness and romanee of Mrs. Radeliffe are breathed over the Address to Melancholy, and the Song of a Spirit. The quotation from Hannah More was chosen for the subject which it offered to the Artist, who has so happily embodied it in his genre sketches. The chaste elegance of Mrs. Barbauld is of a higher order; and very true poetic feeling and utterance are conspicuous in the local pictures and the tender Sonnets of Charlotte Smith, which Miss Seward, clever in her spite, called "everlasting duns upon pity."

One name in the tuneful Sisterhood has a home interest for me. It seems but yesterday that the shutters were shut in "Our Village," and Mary Russell Mitford went from among us. While turning over the leaves of this book, I have thought of the kindly welcome with which she would have greeted the illustration of her own "Rienzi," if I had taken it to her on one of these soft autumn days which she loved so much, and when her familiar lanes and dingles wear their sweetest colours. She had compared her old abode to a bird-cage that might be laid on a shelf, or hung upon a tree; and her latest dwelling was hardly less odd, or dwarfish. But there, also, she had a cool retreat out of doors, in the shade of her garden, and I see her sitting in it now with table and book; constant to all her little heresies of taste; reading the interminable Richardson every year, preferring wood-embers to the fairest moonbeams that ever lighted lovers, and panegyrising the nightingale's song, if aceompanied by the moan of the pigeon.

But the Brotherhood has names, also, to be remembered by me with very sincere regard. When $I$ read the description of the dying 
Adam by James Montgomery - a passage exquisite in conception, imagery, and language - the author is before me as I saw him in my early youth. Lisle Bowles is another name to be marked with a white stone. A delightful spot was Bremhill - indeed, is still - with the quaint garden, and the swans, Snow-drop and Lily, sailing up to the parlour window to inquire after their dinner, and Peter the hawk, and the Vicar holding his watch to his ear, to make sure that he had not grown deaf since breakfast. Southey visited the Parsonage when the loveable old man was in his seventy-third year, and presented to the eye of his friend the most entertaining mixture that could be of untidiness, simplicity, benevolence, timidity, and good-nature; but nobody smiled at his oddities more heartily than the owner. The poetical merits of Bowles are great. His sonnets delighted Coleridge, and even Byron acknowledged the excellence of The Missionary.

Of all the elder poets of our time, my examples are less numerous than I had hoped to give. The lines of Wordsworth on Tintern Abbey are omitted from want of room; and the most striking effort of Southey's imagination, the agony of Kailyal at her father's flight, was ill adapted for pictorial use. The fame of Coleridge, however, will not suffer loss by resting on Genevieve, who has caught a new grace from the hand of Millais. Among these earlier poems, the reader will be attracted by the Legend of Kilmeny, which, for a moment, lifts the Shepherd to the side of Burns; by the sunshiny morals of Praed, who reminds me of an Ariosto brought up in England; and by the seaviews and the Dutch painting of Crabbe.

If I could have turned my Preface into an illustrated eatalogue, these poems would have furnished agreeable notes; for to many some little story is attached; as in the case of Keats, whose Ode to the Nightingale was written in the spring of 1819 , when the fatal disease lay so heavy at his heart, that Coleridge, meeting him in a lane near Highgate, remarked - "There is death in that hand." The stanzas beginning "The sun upon the Weirdlaw Hill" become more affecting. when we are told that Scott composed them during the languor of sickness, and that they mark the very spot of their birth, now clothed by rich woodlands, the work of the Poet's hand. The Elm Tree might also claim a paragraph, to tell of the solemn Avenue which 
inspired it ; and certainly "Umbrageous Ham" has not been mused in by a more genial visitor, since the frequent feet of Thomson broke the shadows. The noble verses - "Wine of Cyprus" - should recall the memory of the blind Scholar to whom they were addressed; and the compositions of Frances Brown will lose a charm if the shadow on her eyes be forgotten. But of living Pocts I may not speak. They are here to speak for themselves in tones of harmony, grandeur, and pathos, to which few ears, I suppose, will be deaf. The list might have been enlarged, but a great Constituency can only be represented by a few Members.

R. A. Williott.

St. Cathapine's, October 2, 1856.

\section{AMERICAN PREFACE.}

The volume of "Poets of the Nineteenth Century," edited by the Rev. R. A. Willaotт, a most loving and judicious critic of English literature, is here preserved entire, with some important extensions. The selections have been increased from four hundred to six hundred and seventy-four pages, and a proportional addition has been made to the number of Engravings. The new material, in both instances, will be found indicated in the Table of Contents.

The work of Mr. Willmott was confined to writers of his own country. In the present volume a liberal space has been given to American authors, illustrated by American artists. Additional illustrations of English poems are furnished from the pencils of painters of eminent merit, making the work a very comprehensive representation of the art of the day as applied to literature. 


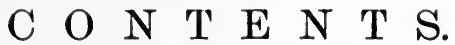

A Star prefixed to the Titles indicates matter added in the present American Edition.

\section{JAMES BEATTIE}

THE POET IN YOUTII MORNING LANDSCAPE CALM AND STORM

A VAlley among the IILLS RETIREMENT

\section{WILLIAM COWPER.}

YARDLEY OAK

LINES TO MY MOTHER'S PICTURE

\section{WILLIAM HAYLEY.}

THE VISION OF SERENA

JAMES HURDIS.

RURAL SOUNDS 24

\section{CHARLOTTE SMITH.}

THE SWALLOW 26 SONNET WRITTEN AT THE CLOSE OF SPRING 29 SONNET SONNET ON THE DEPARTURE OF THE NIGHT-

INGALE . FROM "BEACHY HEAD"

ANNA SEWARD.

SONG 35

ERASMUS DARWIN.

MARCH OF CAMBYSES

THREE IMPRESSIONS OF ANTIQUE GEMS TASTE

\section{WILLIAM CROWE.}

PAG K THOMAS PERCY.

TIE FRIAR OF ORDERS GRAY 47

GENTLE RIVER. 51

\section{GEORGE CRABBE.}

A GIPSY ENCAMPMENT $\ldots \ldots \ldots \ldots \ldots \ldots \ldots \ldots, 55$

MARINE VIEWS ........................... 57

A GOOD VIllager........................ 62

THE PARTING LOOK......................6 65

\section{MARY TIGHE.}

PSYCHE GAZING UPON THE LOVE-GOD ...... 66

\section{ANN RADCLIFFE.}

TO MELANCHOLY ........................... 69 SONG OF A SPIRIT ....................... 71

\section{ANNA LETITIA BARBAULD.}

A SUMMER EVENING's MEditation.......... 73

A petition ............................. 77

\section{HANNAH MORE.}

FLORIO AND HIS FRIEND.

\section{W. LISLE BOWLES.}

RETURN TO OXFORD....................... 88

oN THE RHINE............................. ib.

THE CELL OF tHE MISSIONARY............ 90

THE HOME OF THE OLD INDIAN .......... 92

LANDING AT TYNEMOUTH................... 97

THE BURIAL PLACE ....................... 98

SUNRISE 


\section{SAMUEL ROGERS.}

THE OLD HOUSE.

MOTHER AND CHILD

\section{AMELIA OPIE.}

THE ORPIAN BOY'S TALE................... 106

\section{WILLIAMI SPENCER.}

TO THE LADY ANNE HAMILTON

* WIFe, childres, AND FRIENDs.

\section{LORD BYRON.}

THE PRISONER OF CHILLON

THE DREAM

\section{PERCY BYSSHE SHELLEY.}

WRTTTEN IN DEJECTION NEAR NAPLES.... 131 To NighT

SPRINO

\section{JOHN KEATS.}

ODE TO A NIGHTINGALE.

SAMUEL TAYLOR COLERIDGE. LOVE.

\section{WILLIAM WORDSWORTH.} THE GLORY OF IMAGINATION

A Clovd pictere......................... 144

Dros ................................. 146

INCIDENT AT BRUGES .................. 150

A JEWISH FAMILY...................... 152

* a portrait ............................... 154

* LUCY ..................................... 155

- soNvet composed cPon westmisster BRIDGE 156

\section{CHARLES IAMB.}

UESTER-A REMEMBRANCE

VERSEY FOR AN ALBUM

HENRY KIRKE WHITE.

TUE HERB ROSEMARY
WASHINGTON ALLSTON.

* america to great britain 162

* rosalie.................................. 163

* A FragMeNT ............................. 164

RICHARD HENRY DANA.

* THE HUSBAND'S AND WIFE'S GRAVE.... 165

* a clump of daisies.................. 169

SAMUEL WOODWORTH.

* THE OLD OAKEN BUCKET

\section{WALTER SCOTT.}

THE SUN UPON THE WEIRDLAW HILL..... 172

MARMION-DYING......................... 174

THE BURNING OF ROKEBY.............. 176

\section{THOMAS CAMPBELL.}

THE SOLDIER'S DREAM................... 180

THE EXILE OF ERIN....................... 181

DRINKING SONG OF MUNICI .............. 183

LOCHIEL'S WARNING....................... 184

HOHENLINDEN ............................ 187

BATTLE OF THE BALTIC................... 189

YE MARINERS OF ENGLAND .................191

\section{RICHARD HENRY WILDE.}

* stanzas ............................... 194

\section{JAMES MONTGOMERY.}

THE DEATH OF ADAM .................. 195

\section{JOANNA BAILLIF.}

THE PIIREXZY OF ORRA

\section{JAMES GRAHAME}

THE SABBATH ........................... 202

SUNDAY TO THE SHIPWRECKED ........... 204

A SABBATH WALK in sUMmer........... 206

ROBERT BLOOMFIELD.

LAMBS AT PLAY ........................ 210

THE YARMER'S BOY IN THE YIELDS ....... 212 
EBENEZER ELLIOTT.

* burNs

* a Poet's ePItapil

* SPRING

216

THOMAS MOORE.

THE LAMENT OF THE PERI FOR IIND. NOURMAHAL

\section{CHARLES WOLFE}

THE BURIAL OF SIR JOHN MOORE 221

\section{ALLAN CUNNINGHAM.}

THE POET'S BRIDAL-DAY SONG

A WET SHEet AND A Flowixg SEA

SIDNEY WALKER.

TO A GIRL IN HER THIRTEENTH YEAR.... 227

JAMES HOGG.

THE RAPTURE OF KILMENY

\section{CHARLES SPRAGUE.}

* tTIE WINGEd Worshippers

* THE BROTHERS

\section{FELICIA HEMANS.}

THE CORONATION OF INEZ DE CASTRO.... 238 THE MESSAGE TO THE DEAD .............. 242 THE RETURN

\section{MARY RUSSELL MITFORD.}

RIENZI AND HIS DAUGHTER. SONG.

\section{LYDIA HUNTLEY SIGOURNEY.}

* the indian summer

* THE holy DEAD

* talk with the sea.

\section{REGINALD HEBER.}

THE PASSAGE OF THE RED SEA.......... 254

* lines addressed to Mrs. heber ...... 258

* LiNes WRITten to A MARCH
ROBERT SOUTHEY.

PAOKK

THE VISIT OF MADOC. - - SCENE AMONG

THE WELSH IHLLS ................... 26

THE WORLD OF WOE .................... 263

THALABA IN THE TENT OF MOATII ........ 265

SUNLIGHT ON THE OCEAN ................ 270

CAROLINE BOWLES (MRS. SOUTHEY).

* SUNDAY EVENING 271

\section{JOHN LEYDEN.}

TO THE EVENING STAR................ 275

TO $\triangle$ N INDIAN GOLD COIN................ 277

\section{JOHN CLARE.}

* MARY LEE.

JOHN G. C. BRAINARD.

* SALMON RIVER 282

* THE BLACK FOX OF SALMON RIVER .... 284

EDWARD COATE PINKNEY.

* a Health............................... 286

* a picture-song......................... 287

CLEMENT C. MOORE.

* A visit from st. Nicholas............. 288

\section{BERNARD BARTON.}

TO THE EVENING PRIMRose

WILLIAM SOTHEBY.

RHINEFIELD, -A LODGE IN THE NEW FOREST................................... 293

SKIRID, A HILL NEAR ABERGAVENNY...... 294

ON Crossing the aNGLesey strait to BANGOR AT MIDNIGHT.................. $i b$.

\section{WILLIAM CULLEN BRYANT.}

* SONG OF MARION's MEN

* gretr river ........................... 298

* the death of the flowers ........... 301

* THE laNd OF dREAMs .................. 302

* the hunter of the prairies ......... 304 


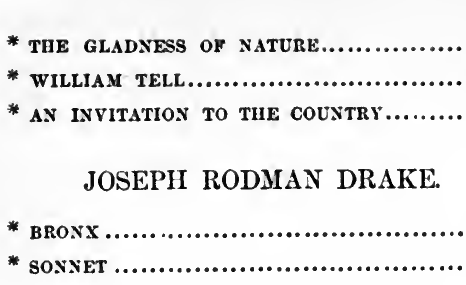

FITZ GREENE HALLECK.

* RED JACKET

* CoNNecticut

* oN tue deatil of JosepH RodmaN dRake 32]

\section{HORACE SMITH.}

* the first of March

\section{GEORGE DARLEY.}

* harvest home.

\section{WINTIIROP MACKWORTII PRAED.}

CHILDHOOD AND HIS VISITORS

TIIE TICAR.

a CHARADE.

\section{THOMAS HOOD.}

THE ELM TREE-A DREAM IN THE WOODS 332

\section{THOMAS PRINGLE.}

AFAR IN THE DESERT

\section{WALTER SAVAGE LANDOR.} THF WATER - NYMPII APPEARING TO THE SIEPIERL

RODERIGo ANI JULIAY

\section{JOSEPII BLANCO WHITE.}

* NigHT ANI DEATII

\section{JOIIN KEBLE}

THE LILIFS OF TIE FIELD

CHLDREX's THANKFLLNESS
HENRY HART MILMAN.

THE HEBREW WEDDING ................... 361

THE COMING OF THE JUDGE.............. 363

\section{LEIGH HUNT.}

AN ITALLAN GARDEN 368

ABOU BEN ADHEM

\section{GEORGE CROLY.}

THE ALHAMBRA......................... 369

FLORA ................................. 371

SAMUEL FERGUSON.

* the forging of the aNchor 372

\section{JOHN MOULTRIE.}

THE THREE SONS......................... 375

“FORGET THEE

THOMAS BABINGTON MACAULAY. THE SPANISH ARMADA $\ldots \ldots \ldots \ldots \ldots \ldots \ldots . . . . .379$

\section{WILLIAM MOTHERWELL.}

* Jeanie morkison........................ 382

* they cone! tile merry summer noNtis 385

* A SOLEM. CoNCEIT ...................... 386

\section{IIENRY TAYLOR.}

ARTEVELDE IN GHENT ................... 389

ERNESTO................................. 396

\section{DAVID MACBETII MOIR.}

* casa warpy. 399

\section{RICHARD CIIENEVIX TREYCH.} TIE SPILT PEARLS

\section{RAIPII WALDO EMERSON.}

"tie himble-bfe ........................ 406

CHARLES FENNO HOFFMANN.

358 * SPARKLING AND BRJGIT 408 
GEORGE P. MORRIS.

* woodman, spare that tree.

* PoEtry

\section{RALPH HOYT.}

* sNOW-A WINTER SKETCH

WILLIAM GILMORE SIMMS.

* blfssings oN CHILdREN

NATHANIEL PARKER WILLIS.

* UXSEex spirits

* little florence gray 420

\section{HENRY ALFORD.}

HYMN TO THE SEA

WILLIAM MAKEPEACE THACKERAY.

* the ballad of bouillabaisse

* THE END OF THE PLAY.

\section{ALFRED TENNYSON.}

THE MAY QUEEN

* Morte D’arthur

* EDWARD GRAY

* ture Goose

BREAK, BREAK, BREAK

PHILIP PENDLETON COOKE.

* florence vaxce

* young rosalie LEE

JOHN GREENLEAF WHITTIER.

* MaUd MUller.

* GONE.

EDGAR ALLAN POE.

* THE RAVEN

HENRY WADSWORTH LONGFELLLW.

* hyMs to the NIGHT

* Resignation

* KING WITlaf's DRINKING-HoRN.

* EXCELSIOR
HENPY THEODORE TUCKEIMAN.

OLIVER WENDELL HOLMES.

* the last leaf.................... 485

* oN LeNding a pUNCh-Bowl............. 488

\section{ALFRED B. STREET.}

* A FOREST NOOK

\section{ROBERT BROWNING.}

TWO IN THE CAMPAGNA ................ 494

EVELYN HOPE .......................... 497

ELIZABETH BARRETT BROWNING. WINE OF CYPRUS

\section{CHARLES KINGSLEY.}

THE THREE FISHERS.................... 505

THE SANDS OF DEE $\ldots . . \ldots \ldots \ldots \ldots \ldots \ldots \ldots . \ldots 606$

* THE DAY OF THE LORD ................ 507

WILLIAM EDMONSTOUNE AYTOUN.

* the bURIaL-Marci of dundeE......... 508

\section{THOMAS DAVIS.}

THE் SACK OF BALTIMORE

EDWARD BULWER LYTTON. EVA

\section{BRYAN WALLER PROCTER.}

THE HISTORY OF A LIFE................. 526

WITUIN AND wITHOUT.................... 527.

\section{EDWIN ATHERSTONE.} BatTLE SCENES

\section{MARY HOWITT.}

THE BALLAD OF RICHARD BURNELL. 533

MATTHEW ARNOLD. * to A GIPSY CHLLD BY THE SHORE ...... 547 
PAGE

W. C. BENNETT.

* BABY's SHOLS

* LILIAN's EPITAPII .

\section{ALEXANDER SMITH.}

SCENE-THE BANKS OF A RIVER....... 552 PICTURES . . . . . . . . . . . . . . 554

\section{PHILIP JAMES BAILEY.}

A SUMmer Nigilt.

WORDS

PORTRAIT OF A LADY

\section{SHERIDAN KNOWLES.}

THE APPE.AL AND THE REPROOF ...... 560

\section{GCRALD MASSEY.}

OUR WFE WIITH ROSE.

THAT MERRY, MERRY MAY .........566 BABE CHiststabel............. 568 WILLIAM ALLINGHAM. CIIARLES MACKAY.

YOUTII AND SORROW

\section{FRANCES BROWN.}

THE IIOPE OF TIE IRESURRECTION 574

ALI, TIINGS NEW

\section{THOMAS WILLIAM PARSONS.}

* sorresto

579

* saint peray................. 581

\section{JAMES RUSSEL LOWELL.}

* the sisging ledves ............. 584

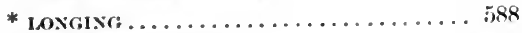

* auf wientrenehlis! . . . . . . . . . . 589

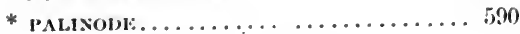

\section{MARIA I,OWELL.}

* THE ALPINE SHEEI? 592

THOMAS BUCHANAN READ.

* THE Warsine sphixc.

* TIL Closing scExk
WILLIAM ALLEN BUTLER. 599

\section{BAYARD TAYLOR.}

* DAlghteli of EGYPT . . . . . . . . 6 610

* ox THE SEA................. $i b$.

* BEDOUIX soNG............... 611

W. D. HOWELLS.

* saint chiristopher ............6613

HENRY M. ALDEN.

* THE ANCIENT "LADY OF SORROW"....615

R. H. STODDARD.

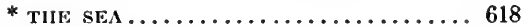

* on thie pier................. ib.

* TIE SKY IS THICK UPON THE SEA.... 619

JULIA C. R. DORR.

* THE DRUMMER-Boy's FUNERAL . . . . . 620

DAN'TE G. ROSSETTI.

* the sea-Linits . . . . . . . . . . 623

L CHRISTINA GABRIELLA ROSSETTI.

* ${ }_{\Lambda}$ BIRTIIDAY .................. 624

* siNg No SAD SONGS FOR ME........ ib.

\section{CHARLES A. SWINBURNE.}

* before parting ...............626

E. C. STEDMAN.

* THE DOOR-STEP . . . . . . . . . . 628

* darkNess aNd tile shadow....... 630

CHARLES G. HALPINE (MILES O'REIILY).

* IESIGNED 631

\section{GEORGE ELIOT.}

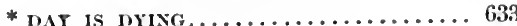

* spisixg ......................6. 634

* it was ix the prime...........665 ETIEL LYNN BEERS.

$596 \mid *$ A DOG'S-1 AY EXDED ............ 636 
LUCY LARCOM.

PAGE

rAoE

S. S. CONAN'T,

ALICE CARY.

* " wHOU THAT DRAWEST ASIDE THE CURTAIN".

639

* a dreaM of fairies ............ 652

COME OUT TO THE SIDE OF TIE SEA" 649

* dirge for a soldier .............6.659

GEORGE H. BOKER.

* SONNET .......................660

PHCEBE CARY.

* vREAMIS AND REALITIES............ 643

WAL'T WHITMAN.

* PRoUd MUSIC OF THE STORM........661 JOHN HAY.

* MY CASTLE in SPAiN

ANNIE C. KETCHUM.

* woMlav's LOVE 



\section{LIST OF ILLUSTRATIONS.}

A Star prefixed to the Titles indicates new Illustrations in the present American Edition.

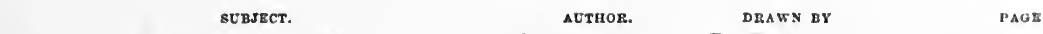
The Poet in Youtil.........................Beattie ............. Foster ............... 1

A Valley a mong the Hills................ Ditto............W. Harvey.............. 6

RetrineneNt ................................... Ditto............Ditto................... 8

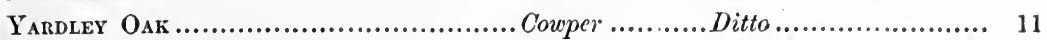

Lines to yy Mothen's Pictlie.............Ditto.............. Gilbert.............. 17

The Vision of Serexa .......................Hayley............ Hughcs............... 21

Rural Sounds ................................Hurdis..........H. Weir................ 24

Tue Swallow ...............................Charlotte Smith.B. Foster.............. 26

FroM "Beachy Head" .....................Ditto............Ditto................... 31

Tre Snepherd's Houe................... Ditto.............Ditto...................... 33

TASTE .......................................Darwin.........T. Dalziel ............... 39

LeweSdon Hill..............................Crowe............. Foster............... 41

The Thirsty Lamb......................Ditto............Ditto.................... 44

The Friar of Orders Gray................Pe Pey ............ Tenniel .............. 47

Gextle River................................Ditto............Ditto.................. 53

A Gipsy Excanparext.........................Crabbe............ Foster............... 55

Marine Views:-Calm......................Ditto............E. Duncan.............. 59

Sтовм .................................. Ditto............ Ditto ................... 61

A Good Villager............................ Ditto.............. R. Clayton ............ 62

To Melancholy ............................Ann Radcliffe...B. Foster ................ 69

A Summer Evening's Meditation ...........A. L. Barbauld.Ditto ................... 73

Florio and his Friend:-The Lodvge...... Hannah More...J. Godwin................ 78

The Opera...............................Ditto........... Ditto ................... 86

On the Rhrne .................................Bowles ...........J. D. Harding.......... 89

The Home of the Old Indax.............. Ditto.............W. Harvey.............. 95

Laxding at TrNemoutr ........................Ditto.............T. Dalziel ................ 97

Sunrise........................................ Ditto............W. Harvey.............. 101

The Old House.............................Rogers...........G. Dodgson............. 103

The Orphan Bor's Tale.....................Amelia Opie ....T. Dalziel ............... 107

The Prisoner of Chillox.....................Byron.............F. M. Brown............. 113 


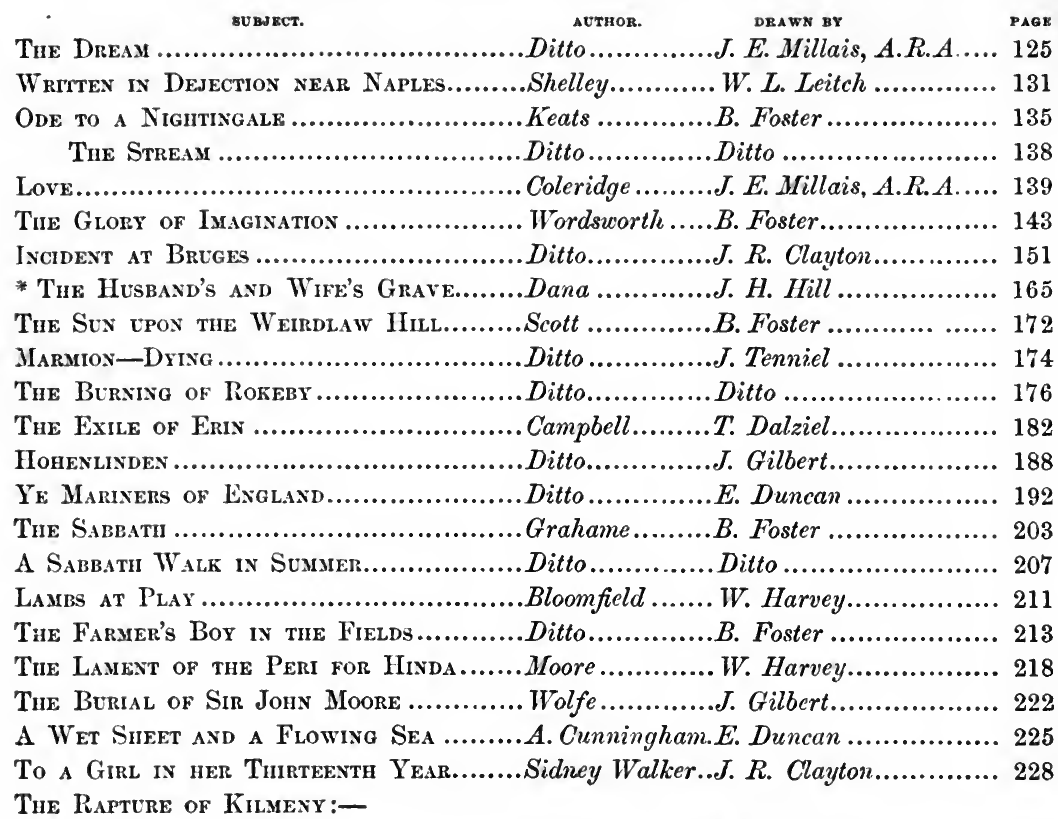

The Land of Thovgut.

Hogg

W. Harvey.............. 232

Tue Lanely Glex.

Ditto.

Ditto.

The Coronation of Inez de Castro.

Felicia Hcmans.J. Gilbert

Rienzi avd his Daughter

M. R. Mitford...J. Tennicl.

246

* Tue Indian Scmmer

Sigourney........J. H. Hill.

249

The Visit of Madoc Southey

J. Gilbert

261

Thalaba in the Tent of Moati

Ditto.

W. Harvey

265

To the Evenisg Star

Leyden.

G. Dodgson

275

* A Visit from St. Nicuolas.

C. C. Moor

F. O. C. Darley.......... 288

To the Evenisg Primrose

B. Barton

Ditto

291

Rinnefield, - A Lodge in the New Forest. Sotheby.

W. Harvey

293

* Song of Marion's Men

Bryant

F. O. C. Darley .

295

* Grees River

Ditto.

J. H. Hill

298

* Tue Hester of tie Prairies.

Ditto

F. O. C. Darley.

304

* Tue Gladness of Nature

Ditto

.J. H. Hill.

307

* Bronx

Drake.

J. W. Casilear.

* Red Jacket

IIalleck.

F. O. C. Darley

314

* Connecticet

Ditto.

Ditto

The Vicar.

Praed

.J. Gilbert

The Elm Tree:-The Avenef

T. Hood

Cr. Dodgson

Tue Woomman

Ditto

Ditto. 
รัยงะст.

AUTHOR.

DRAWN BY

PAGE

Afar in the Desert

Pringle.

W. Harvey

347

The Water-Nymph appearing to the SHep-

Herd.........................................Landor ..........F. R. Pickersgill, A.R.A. 351

Tue Lilies of the Field

Keble.

B. Foster .................. 356

The Hebrew Wedding.

Jilman...

.E. H. Corbould........... 362

Av Italian Garden

Leigh Hunt.

G. Dodgson

366

The Alhambra

Croly

W. Harvey

369

Tue Turee Sons.

Moultrie.

J. Gilbert.

375

Tre Spanish Armada

Macaulay

Ditto.

379

Artevelde in Ghent.

Taylor

J. R. Clayton

392

The Spilt Pearls

Trench

W. Harvey

404

* Snow-a Winter Sketch

Hoyt

F. O. C. Darley

* Blessings on Culldrex

Simms

Ditto

Hymn to the Sea.

Alford.

E. Dunean

424

The May Queen.

Tennyso

T. Dalziel.

432

New-year's Eve

Ditto

Ditto.

434

Conclusion

Ditto

Ditto.

436

TAILPIECE.

Ditto

Ditto.

* Morte d'Arthur:-

* Excalibur.

Ditto

D. Maclise

439

* Death Scene.

Ditto

Ditto.

* Edward Gray

Ditto

J. E. Millais.

449

* The Goose

Ditto

W. Mulready

451

* Break, Break, Break

Ditto

C. Stanfield.

454

* Maud Muller

Whittier.

F. O. C. Darley.

459

* The Raven

Poe

Ditto

466

* Hyma to the Night

Longfellow.

J. Gilbert

471

* Resignation

Ditto

Ditto

473

* King Witlaf's Drinking-Horn:-

* The Carouse.

Ditto

Ditto.

476

* Monk Readivg

Ditto

Ditto.

477

* Exceisior

Ditto.

F. O. C. Darley

479

* West Polnt.

Tuckerman .

J. W. Casilear..

482

* The Last Leaf.

Holmes

F. O. C. Darley

* On lending a Punch-Bowl.

Ditto.

Ditto 488

* A Forest Nook

Street

J. H. Hill.

491

Two in the Campagna

R. Brovning ....E. A. Goodall

Wine of Cyprus

E. B. Browning.e.

499

.Kingsley ........T. Dalziel................ 505

The Three Fishers.

Davis .............James Godwin ........... 514

The Sack of Baltimore

Bulwer Lytton..J. Gilbert.

Tue Srpaxger Surtor...

Ditto

T. Dalzicl.

The Returs

Ditto

Ditto.

523

The History of a Life

Procter

D. Edwards 526 
$\begin{array}{llll}- \text { SEBJECT. } & \text { AUTHOR. PRAWX BY PAGE }\end{array}$ Withis Axd Withovt ......................Ditto...........James Godwin.......... 528 B.ATtLe Scexes.............................Atherstone......E. H. Corbould.......... 530 Richapd BurNell:-

Young Burnell and Alice ..............Mary Howitt....James Godwin........... 534

The Marriage of Alice ................ Ditto............ Ditto ................... 540

Burinel axd Alice is the Temple GARDENS

Ditto.............. Ditto. 546

The Basks of a River....................... Sinith.......... Foster................ 553

Pictures ................................... Ditto........... Ditto.................. 555

A Summer Night ............................ Bailey ........... Ditto.................... 557

The Appeal axd tue Reproof ............. Knowles.......... Tenniel............... 560

Otr Wee White Rose ........................Masscy ........... R. Clayton.......... 565

That Merry, Merry May ...................Ditto............D. Edwards............ 567

Autumal Sowxet .............................Allinghame...... G. Dodgson ............. 570

Youtu axd Sorrow ..........................Mackay.........E. H. Cor.bould.......... 573

The Hope of the Restrrectiox ............ Brown ........... Ditto.................. 575

* Tie Sisging Leaves........................J. R. Lovell .....J. H. Hill............... 584

* The Wayside Sprixg ......................Read ............Ditto .................. 596

* Nothixg to Wear:-

* The Lady ...................W. A. Butler... A. Hoppin .......... 599

* The BegGar ................. Ditto........ Ditto .............609

* St. Cinmstopher ................W. D. Howells................613

* Tire Drumare-Boy's Funeral.........J. C. R. Dorr...Sol. Eytinge, Jr. . . ...620

* Resigned ......................... G. Halpine. . Ditto .............. 631

* A Dog's DAr ExDed :-

* Id le axd Dreanixg............E. L. Beers .... Ditto ............636

* Tire Graves................. Ditto........ Ditto ............ (63S

* A Dreali of Fairies:-

* Helex Sittixg ox tile Grass ...... S. S. Conant ... Ditto .............. 6i氵2

* A Tilolsand Merry Sirites....... Ditto......... Ditto ............ 657

* DOLOHES :-

* Fishers is then Bonts........... C. Ketchum..Charles Parsons....... 668

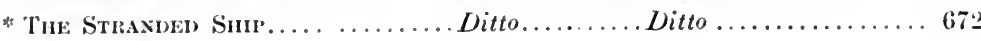




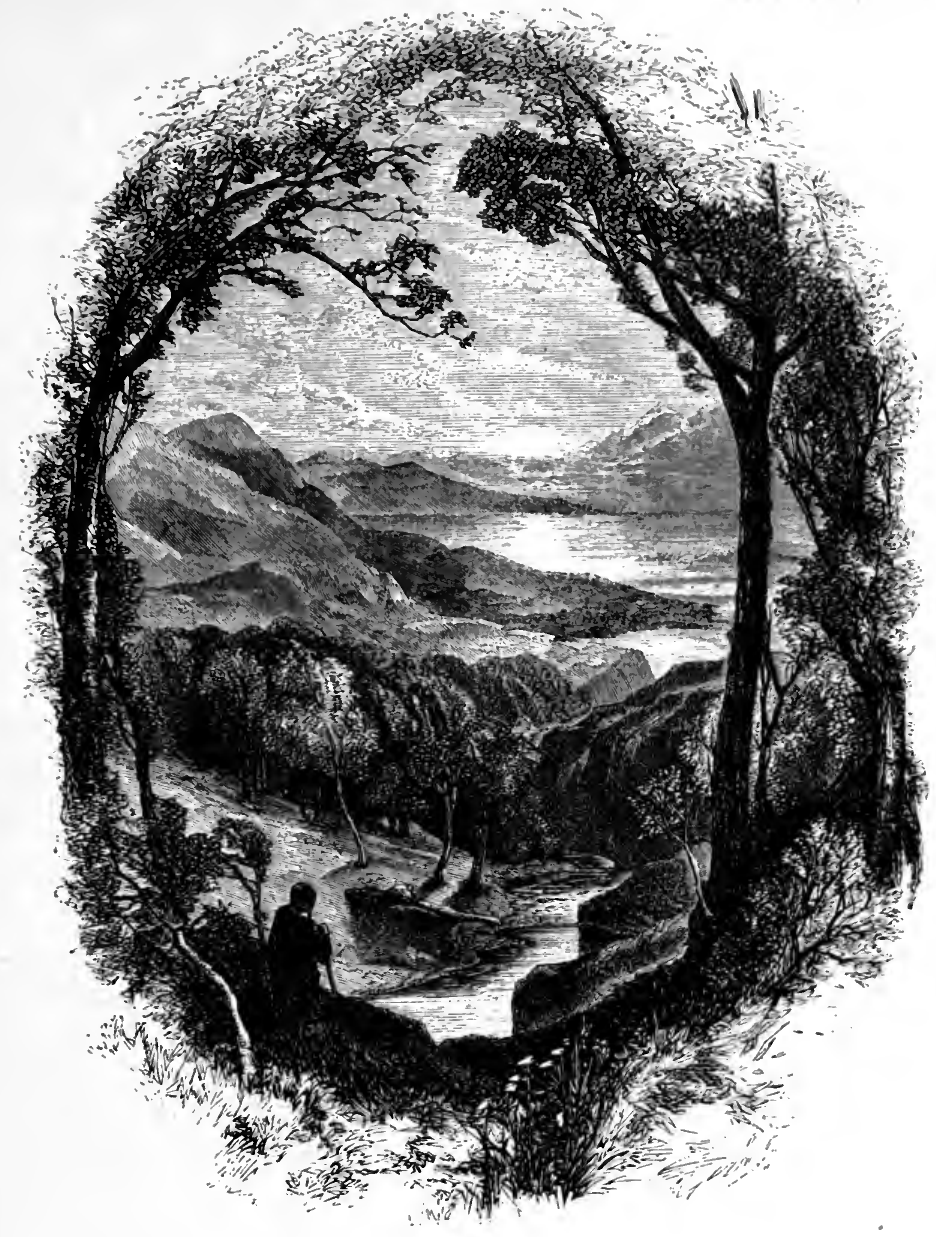

\section{BEATTIE.}

\section{THE POET IN YOUTH.}

Lo! where the stripling, wrapt in wonder, roves

Beneath the precipice o'erhung with pine, 
And sees on high, amidst th' encircling groves; From cliff to cliff the foaming torrents shine; While waters, woods, and winds in concert join, And Echo swells the chorus to the skies.

Would Edwin this majestic scene resign

For aught the huntsman's puny craft supplies?

Ah! no; he better knows great Nature's charms to prize.

And of the trac'd the uplands, to survey, When o'er the sky advane'd the kindling dawn, The crimson cloud, blue main, and mountain grey, And lake, dim gleaming on the smoky lawn:

Far to the West the long, long vale withdrawn, Where twilight loves to linger for awhile; And now he faintly kens the bounding fawn, And villager abroad at early toil, But, lo! the sun appears! and heaven, earth, ocean smile.

And oft the eraggy cliff he lov'd to climb, When all in mist the world below was lost.

What dreadful pleasure! there to stand sublime, Like shipwreck'd mariner on desert coast, And view th' enormous waste of vapour, toss'd In billows, lengthening to th' horizon round, Now scoop'd in gulfs, with mountains now emboss'd:

And hear the voice of mirth and song rebound, Flocks, herds, and waterfills, along the hoar profound:

In truth, he was a strange and wayward wight,

Fond of each gentle and each dreadful scenc.

In darkness and in storm he found delight;

Nor less, than when on ocean-wave serene

The southern sun diffusd his dazzling sheen.

E'en sad vicissitude amms his soul;

And if a sigh would sometimes intervene,

And down his cheek a tear of pity roll,

A sigh, a tear so sweet he wishid not to control. 
See, in the rear of the warm sunny shower The visionary boy from shelter fly;

For now the storm of summer rain is o'er, And cool, and fresh, and fragrant is the sky. And, lo! in the dark East, expanded high, The rainbow brightens to the setting sun!

Fond fool, that deem'st the streaming glory nigh;

How vain the chase thine ardour has begun! 'Tis fled afar, ere half thy purpos'd race be run.

When the long-sounding curfew from afar Loaded with loud lament the lonely gale, Young Edwin, lighted by the evening star, Lingering and listening, wander'd down the vale. There would he dream of graves and corses pale, And ghosts that to the charnel-dungeon throng, And drag a length of clanking chain, and wail, 'Till silene'd by the owl's terrific song,

Or blast that shrieks by fits the shuddering aisles along.

Or, when the setting moon, in erimson dyed, Hung o'er the dark and melancholy deep, To haunted streams, remote from man, he hied, Where fays of yore their revels wont to keep; And there let Faney rove at large, till sleep

A vision brought to his entrancèd sight.

And first, a wildly murmuring wind 'gan creep

Shrill to his ringing ear; then tapers bright, With instantaneous gleam, illum'd the vault of night.

Anon in view a portal's blazon'd arch

Arose; the trumpet bids the valves unfold;

And forth an host of little warriors march, Grasping the diamond lance and targe of gold. Their look was gentle, their demeanour bold, And green their helms, and green their silk attire; And here and there, right venerably old, 
- The long-rob'd minstrels wake the warbling wire, And some with mellow breath the martial pipe inspire.

With merriment, and song, and timbrels clear,

A troop of dames from myrtle bowers advance; The little warriors doff the targe and spear, And loud enlivening strains provoke the dance. They meet, they dart away, they wheel askance; To right, to left, they thrid the flying maze; Now bound aloft with vigorous spring, then glance Rapid along: with many-colour'd rays Of tapers, gems, and gold, the echoing forests blaze.

MORNING LANDSCAPE.

But who the melodies of morn ean tell?

The wild brook babbling down the mountain side;

The lowing herd; the sheepfold's simple bell;

The pipe of early shepherd dim descried

In the lone valley; echoing far and wide,

The clamorous horn along the eliffis above;

The hollow murmur of the ocean tide;

The hum of bees, the linnet's lay of love, And the full choir that wakes the universal grove.

The cottage-curs at early pilgrim bark;

Crown'd with her pail, the tripping milkmail sings;

The whistling ploughman stalks afield; and, hark!

Down the rough slope the ponderous waggon rings;

Through rustling corn the hare astonishd springs; 


\section{BEATTIE.}

Slow tolls the village clock the drowsy hour; The partridge bursts away on whirring wings;

Deep mourns the turtle in sequester'd bower, And shrill lark carols clear from her aërial tower.

CALM AND STORM.

Ort when the winter storm had ceas'd to rave, He roam'd the snowy waste at even, to view 'The cloud stupendous, from th' Atlantic wave High towering, sail along th' horizon blue:

Where, 'midst the changeful scenery ever new, Fancy a thousand wondrous forms descries, More wildly great than ever pencil drewRocks, torrents, gulfs, and shapes of giant size, And glitt'ring cliffs on cliffs, and fiery ramparts rise

Thence musing onward to the sounding shore, The lone enthusiast oft would take his way, Listening, with pleasing dread, to the deep roar

Of the wide-weltering waves. In black array

When sulphurous clouds roll'd on th' autumnal day;

E'en then he hasten'd from the haunt of man,

Along the trembling wilderness to stray,

What time the lightning's fierce career began, And 'o'er heaven's rending arch the rattling thunder ran. 


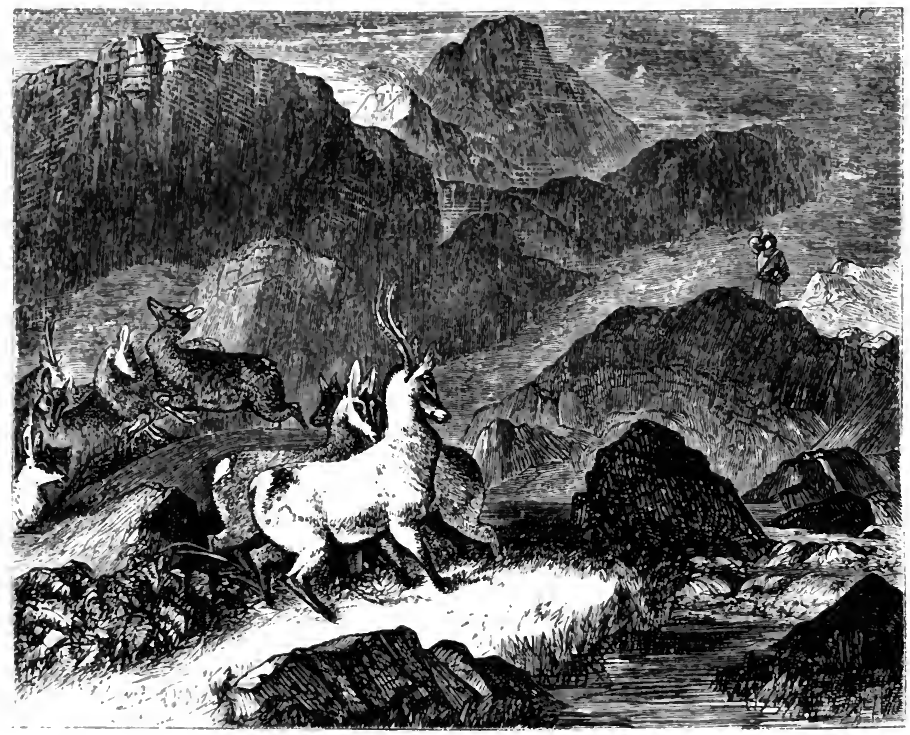

A VALLEY AMONG THE HILLS.

'Tuimer he hied, enamour'd of the scene;

For rocks on rocks pil'd, as by magic spell,

Here scorch'd with lightning, there with ivy green,

Fenced from the north and east this savage dell.

Southward a mountain rose with easy swell,

Whose long, long groves eternal murmur male:

And toward the western sim a streamlet fell,

Where, through the eliffs, the eye remote survey il

Blue hill-, and glittering waves, and skies in gold arraydl. 
Along this narrow valley you might see The wild deer sporting on the level ground, And, here and there, a solitary tree, Or mossy stone, or rock with woodbine crown'ci. Oft did the cliff's reverberate the sound Of parted fragments tumbling from on high; And from the summit of that craggy mound The piercing eagle oft was heard to cry, Or, on resounding wings, to shoot athwart the sky.

One cultivated spot there was, that spread Its flowery bosom to the noonday beam, Where many a rosebud rears its blushing head, And herbs for food with future plenty teem. Sooth'd by the lulling sound of grove and stream, Romantic visions swarm on Edwin's soul: He minded not the sun's last trembling gleam, Nor heard from far the twilight curfew toll; When slowly on his ear these moving accents stole:

"Hail, awful scenes, that calm the troubled breast, And woo the weary to profound repose! Can passion's wildest uproar lay to rest, And whisper comfort to the man of woes?

Here Innocence may wander, safe from foes, And Contemplation soar on seraph wings.

O Solitude! the man who thee foregoes, When lucre lures him, or ambition stings, Shall never know the source whence real grandeur springs." 


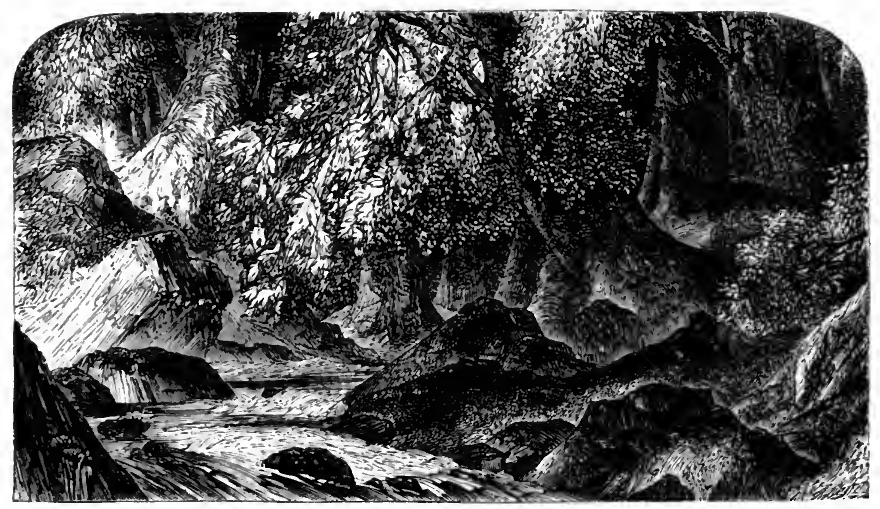

\section{RETIREMENT.}

WHEx in the crimson cloud of even, The lingering light decays, And Hesper on the front of heaven

His glittering gem displays;

Deep in the silent vale, unseen, Beside a lulling stream,

$\Lambda$ pensive youth, of placid mien, Indulg'd this tender theme:

"Ye cliffs, in hoary grandeur pil'd, High o'er the glimmering dale; Ye woods, along whose windings wild

Murmurs the solemn gale:

Where Mclanclioly strays forlorn,

And Woe retires to weep,

What time the wan moon's yellow horn

Gleams on the western deep: 


\section{BEAT'TIE.}

"To you, ye wastes, whose artless charms

Ne'er drew Ambition's eye,

Scap'd a tumultuous world's alarms,

To your retreats I fly.

Deep in your most sequester'd bower

Let me at last recline,

Where Solitude, mild, modest Power,

Leans on her ivied shrine.

"How shall I woo thee, matchless Fair?

Thy heavenly smile how win?

Thy smile that smooths the brow of Care,

And stills the storm within?

$\mathrm{O}$, wilt thou to thy favourite grove

Thine ardent votary bring,

And bless his hours, and bid them move

Serene, on silent wing?

"Oft let Remembrance sooth his mind

With dreams of former days,

When, in the lap of Peace reclin'd,

He fram'd his infant lays;

When Fancy rov'd at large, nor Care

Nor cold Distrust alarm'd,

Nor Envy with malignant glare

His simple youth had harm'd.

"'Twas then, O Solitude! to thee

His early vows were paid,

From heart sincere, and warm, and free,

Devoted to the shade.

Ah! why did Fate his steps decoy

In stormy paths to roam,

Remote from all congenial joy?-

$\mathrm{O}$, take the Wanderer home! 


\section{RETIREMENT.}

"Thy shades, thy silence, now be mine, Thy charms my only theme;

My haunt the hollow cliff, whose pine Waves o'er the gloomy stream;-

Whence the scar'd owl on pinions gray Breaks from the rustling boughs, And down the lone vale sails away To more profound repose.

" $\mathrm{O}$, while to thee the woodland pours

Its wildly warbling song, And balny, from the bank of flowers,

The zephyr breathes along;

Let no rude sound invade from far,

No vagrant foot be nigh, No ray from Grandeur's gilded car Flash on the startled eye.

"But if some pilgrim through the glade Thy hallow'd bowers explore, $\mathrm{O}$ guard from harm his hoary head, And listen to his lore;

For he of joys divine shall tell, 'That wean from earthly woe, And triumph o'er the mighty spell That chains his heart below.

"For me, no more the path invites Ambition loves to tread;

No more I climb those toilsome heights, By guileful Hope misled:

Leaps my fond fluttering heart no more

'To Mirtli's enlivening strain ; For present pleasure soon is o'er, And all the past is vain." 


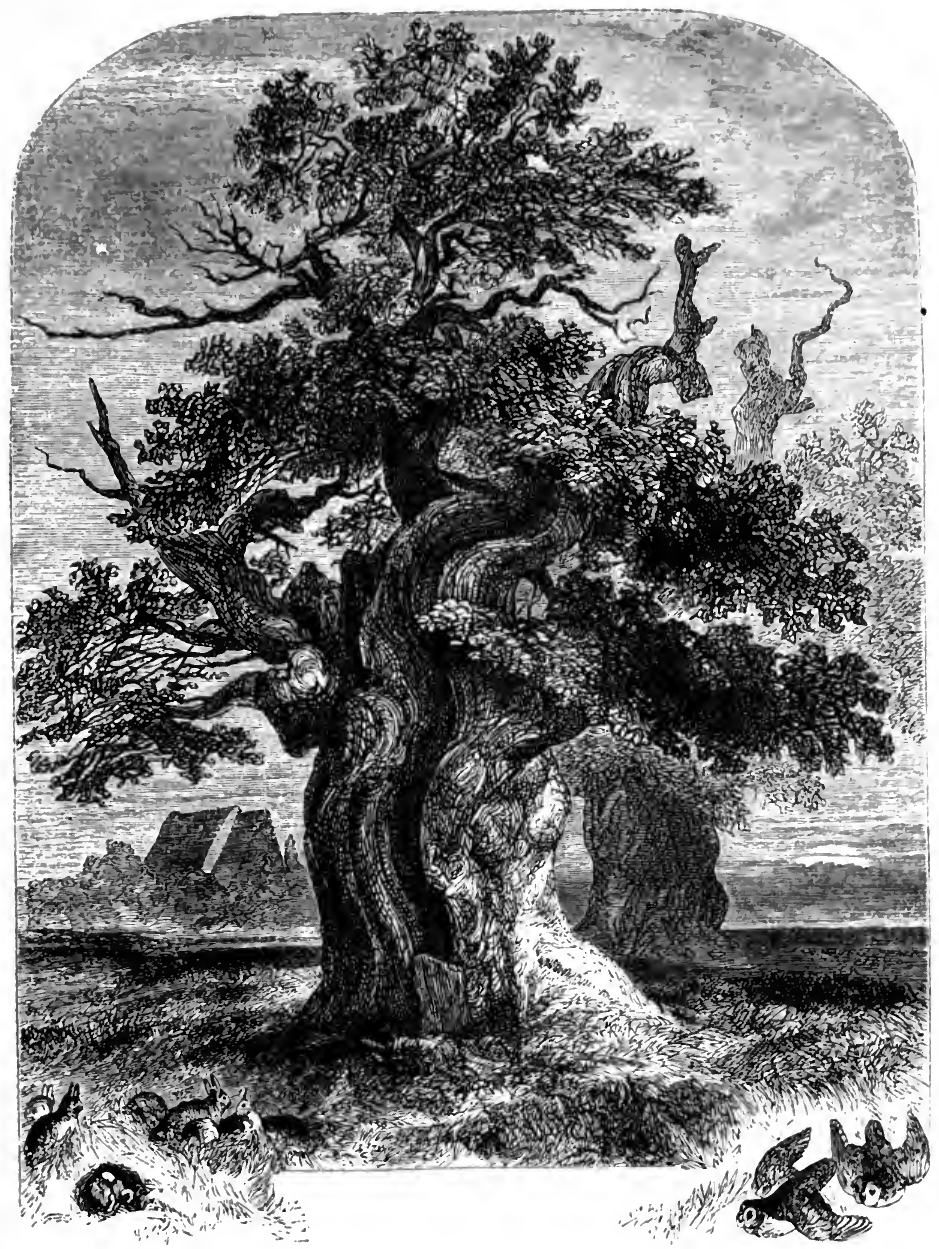

\section{COWPER.}

\section{YARDLEY OAK.}

Survivor sole, and hardly such, of all That once liv'd here, thy brethren, at my birth, 


\section{YARDLEY OAK.}

(Since which I number threescore winters past,)

A shatter'd vet'ran, hollow-trunk'd perhaps,

As now, and with excoriate forks deform,

Relies of ages! could a mind, imbued

With truth from Heaven, created thing adore,

I might with reverence kneel, and worship thee.

It seems idolatry with some excuse,

When our forefather Druids in their oaks

Imagin'd sanctity. The conscience, yet

Unpurified by an authentic act

Of amnesty, the meed of blood divine,

Loy'd not the light, but, gloomy, into gloom

Of thickest shades, like Adam after taste

Of fruit proscribed, as to a refuge, fled.

Thou wast a bauble once-a cup and ball, Which babes might play with; and the thievish jay;

Seeking her food, with ease might have purloin'd The auburn nut that held thee, swallowing down Thy yet close-folded latitude of boughs

And all thine embryo vastness at a gulp.

But Fate thy growth decreed; autumnal rains

Beneath thy parent tree mellow'd the soil

Design'd thy cradle; and a skipping deer,

With pointed hoof dibbling the glebe, prepar'd

The soft receptacle, in which, secure,

Thy rudiments should sleep the winter through.

So Fancy dreams. Disprove it, if ye can, Ye reas'ners broad awake, whose busy seareh Of argument, employ'd too oft amiss, Sifts half the pleasures of short life away!

Thou fell'st mature; and in the loamy clod, Swelling with vegetative force instinct, Did burst thine egrg, as theirs the fabled Twins, 


\section{COWPER.}

Now stars; two lobes, protruding, pair'd exact;

A leaf succeeded, and another leaf, And, all the elements thy puny growth

Fost'ring propitious, thou becam'st a twig.

Who liv'd, when thou wast such? O could'st thou speak, As in Dodona once thy kindred trees

Oracular, I would not curious ask

The future, best unknown, but at thy mouth, Inquisitive, the less ambiguous past.

By thee I might correct, erroneous oft,

The clock of history, facts and events

Timing more punctual, unrecorded facts

Recovering, and misstated setting right,-

Desp'rate attempt, till trees shall speak again!

Time made thee what thou wast, king of the woods;

And Time hath made thee what thou art-a cave For owls to roost in. Once thy spreading boughs O'erhung the champaign; and the num'rous flocks That graz'd it stood beneath that ample cope Uncrowded, yet safe-shelter'd from the storm. No flock frequents thee now. Thou hast outliv'd Thy popularity, and art become (Unless verse rescue thee awhile) a thing Forgotten, as the foliage of thy youth.

While thus through all the stages thou hast push'd Of treeship-first a seedling, hid in grass;

Then twig; then sapling; and, as cent'ry roll'd Slow after century, a giant-bulk

Of girth enormous, with moss-cushion'd root Upheav'd above the soil, and sides emboss'd With prominent wens globose-till at the last The rottenness, which 'Time is charged t' inflict On other mighty ones, found also thee. 
What exhibitions various hath the world Witness'd of mutability, in all

That we account most durable below!

Change is the diet on which all subsist, Created changeable, and change at last

Destroys them. Skies uncertain now the heat

Transmitting cloudless, and the solar beam

Now quenching in a boundless sea of clouds-

Calm and alternate storm, moisture and drought,

Invigorate by turns the springs of life

In all that live, plant, animal, and man,

And in conclusion mar them. Nature's threads,

Fine passing thought e'en in her coarsest works,

Delight in agitation, yet sustain

'The force that agitates, not unimpair'd;

But, worn by frequent impulse, to the cause

Of their best tone their dissolution owe.

Thought cannot spend itself, comparing still The great and little of thy lot, thy growth

From almost nullity into a state

Of matchless grandeur, and declension thence, Slow, into such magnificent decay.

Time was, when, settling on thy leaf, a fly

Could shake thee to thy root-and time has been

When tempests could not. At thy firmest age

Thou liadst within thy bole solid contents,

'That might have ribb'd the sides and plank'd the deck

Of some flagg'd admiral; and tortuous arms,

The shipwright's darling treasure, didst present

'To the four-quarter'd winds, robust and bold,

Warp'd into tough knee-timber, many a load!

but the axe spar'd thee. In those thriftier days

Oaks fell not, hewn by thousands to supply:

The bottomless demands of contest, wag'd

For senatorial honours. Thus to Time

The task was left to whittle thee away 
With his sly scythe, whose ever-nibbling edge

Noiseless, an atom, and an atom more,

Disjoining from the rest, has, unobserv'd,

Achiev'd a labour which had far and wide,

By man perform'd, made all the forest ring.

Embowell'd now, and of thy ancient self

Possessing nought but the scoop'd rind, that seems

A huge throat calling to the clouds for drink,

Which it would give in rivulets to thy root,

Thou temptest none, but rather much forbidd'st

The feller's toil, which thou could'st ill requite.

Yet is thy root sincere, sound as the rock,

A quarry of stout spurs and knotted fangs,

Which, crook'd into a thousand whimsies, clasp

The stubborn soil, and hold thee still erect.

So stands a kingdom whose foundation yet

Fails not, in virtue and in wisdom laid,

Though all the superstructure, by the tooth

Pulverized of venality, a shell

Stands now, and semblance only of itself!

Thine arms have left thee. Winds have rent them of

Long since, and rovers of the forest wild,

With bow and shaft, have burnt them. Some have left

A splinter'd stump, bleach'd to a snowy white;

And some, memorial none where once they grew.

But life still lingers in thee, and puts forth

Proof not contemptible of what she can,

Even where death predominates. The Spring

Finds thee not less alive to her sweet force

Than yonder upstarts of the neighb'ring wood,

So much thy juniors, who their birth received

Half a millennium since the date of thine. 


\section{YARDLEY OAK.}

But since, although well qualified by age 'To teach, no spirit dwells in thee, nor voice May be expected from thee, seated here On thy distorted root, with hearers none, Or prompter, save the scene, I will perform Myself the oracle, and will discourse In my own ear such matter as I may.

One man alone, the father of us all, Drew not his life from woman; never gaz'd, With mute unconsciousness of what he saw, On all around him; learn'd not by degrees, Nor ow'd articulation to his ear; But, moulded by his Maker into man, At once upstood intelligent, survey'd All creatures, with precision understood 'Their purport, uses, properties, assign'd To each his name significant, and, fill'd With love and wisdom, render'd back to Hear'n In praise harmonious the first air he drew.

He was excus'd the penalties of dull Minority: no tutor charg'd his hand With the thought-tracing quill, or task'd his mind With problems. History, not wanted yet, Lean'd on her elbow, watching 'Time, whose course, Eventful, should supply her with a theme. 


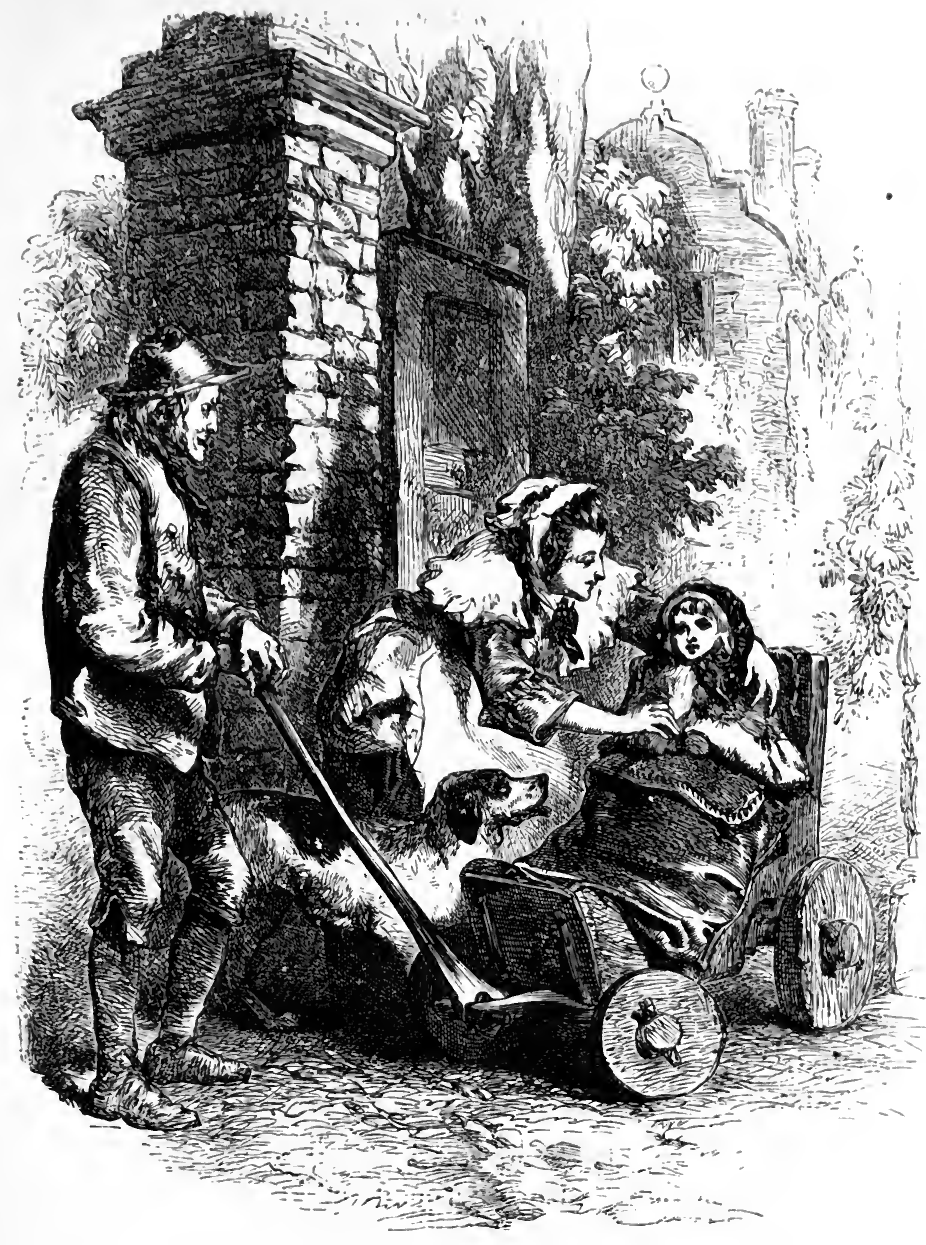

LINES TO MY MOTHER'S PICTURE.

O TInAt those lips had language! Life has pass'd With me but roughly since I heard thee last.

Those lips are thine-thy own sweet smile I see, 'The same that oft in childhood solac'd me;

Voice only fails, else how distinct they say,

"Grieve not, my child, chase all thy fears away!" 
The meek intelligence of those dear eyes

(Blest be the art that can immortalize, The art that baffles Time's tyrannic claim

To quench it,) here shines on me still the same.

Faithful remembrancer of one so dear,

O welcome guest, though unexpected here!

Who bidst me honour with an artless song,

Affectionate, a mother lost so long.

I will obey, not willingly alone,

But gladly, as the precept were her own; And, while that face renews my filial grief, Fancy shall weave a charm for my relief; Shall steep me in Elysian reverie,

A momentary dream that thou art she.

My mother! when I learn'd that thou wast dead, Say, wast thou conscious of the tears I shed?

Hover'd thy spirit o'er thy sorrowing son, Wretch even then, life's journey just begun?

Perhaps thou gav'st me, though unfelt, a kiss; Perhaps a tear, if souls can weep in blissAh, that maternal smile!-it answers-Yes. I heard the bell toll'd on thy burial day, I saw the hearse that bore thee slow away, And, turning from my nursery window, drew A long, long sigh, and wept a last adieu!

But was it such? It was.-Where thon art gone, Adieus and farewells are a sound unknown. May I but meet thee on that peaceful shore, The parting words shall pass my lips no more! Thy maidens, griev'd themselves at my concern, Oft gave me promise of thy quick return; What ardently I wish'd, I long believ'd, And, disappointed still, was still deceiv'd; By expectation every day beguil'd, Dupe of to-morrow even from a child. Thus many a sad to-morrow came and went, Till, all my stock of infant sorrow spent, 
I learn'd at last submission to my lot, But, though I less deplor'd thee, ne'er forgot.

Where once we dwelt our name is heard no more, Children not thine have trod my nurs'ry floor; • And where the gard'ner Robin, day by day, Drew me to school along the public way, Delighted with my bauble coach, and wrapp'd In scarlet mantle warm, and velvet capp'd, 'Tis now become a history little known, That once we call'd the pastoral house our own. Short-liv'd possession! but the record fair, That memory keeps of all thy kindness there, Still outlives many a storm, that has effac'd A thousand other themes less deeply trac'd. Thy nightly visits to my chamber made, That thou mightst know me safe and warmly laid;All this, and, more endearing still than all, Thy constant flow of love, that knew no fall, Ne'er roughen'd by those cataracts and breaks, That humour interpos'd too often makes; All this still legible in memory's page, And still to be so to my latest age, Adds joy to duty, makes me glad to pay Such honours to thee as my numbers may;

Perhaps a frail memorial, but sincere, Not scorn'd in heaven, though little notic'd here.

Could Time, his flight revers'd, restore the hours, When, playing with thy vesture's tissued flowers, The violet, the pink, and jessamine, I prick'd them into paper with a pin, (And thou wast happier than myself the while, Would'st softly speak, and stroke my head, and smile,)

Could those few pleasant days again appear, Might one wish bring them, would I wish them here?

I would not trust my heart; - the dear delight

Seems so to be desir'd, perhaps I might.But no-what here we call our life is such, 
- So little to be lov'd, and thou so much, That I should ill requite thee to constrain Thy unbound spirit into bonds again.

-Thou, as a gallant bark from Albion's coast (The storms all weather'd, and the ocean cross'd) Shoots into port at some well-haven'd isle, Where spices breathe, and brighter seasons smile, There sits quiescent on the floods, that show Her beauteous form reflected clear below, While airs impregnated with incense play Around her, fanning light her streamers gay; So thou, with sails how swift! hast reach'd the shore, "Where tempests never beat, nor billows roar;" And thy lov'd consort, on the dangerous tide Of life, long since has anchor'd by thy side. But me, scarce hoping to attain that rest, Always from port withheld, always distress'd,Me howling blasts drive devious, tempest-toss'd, Sails ripp'd, seams op'ning wide, and compass lost, And day by day some current's thwarting force Sets me more distant from a prosperous course. Yet $O$ the thonght, that thou art safe, and he! That thought is joy, arrive what may to me. My boast is not that I deduce my birth From loins enthron'd, and rulers of the earth; But higher far my proud pretensions rise,The son of parents pass'd into the skies.

And now, farewell!-'Time unrevok'd has run Ilis wonted course, yet what I wish'd is done. By contemplation's help, not sought in vain, I seem t' have liv'd my childhood o'er again; 'To have renew'd the joys that once were mine Withont the sin of violating thine; And while the wings of Fancy still are free, And I can view this mimic show of thee, Time has but half succeeded in his theftThyself remov'd, thy pow'r to soothe me left. 


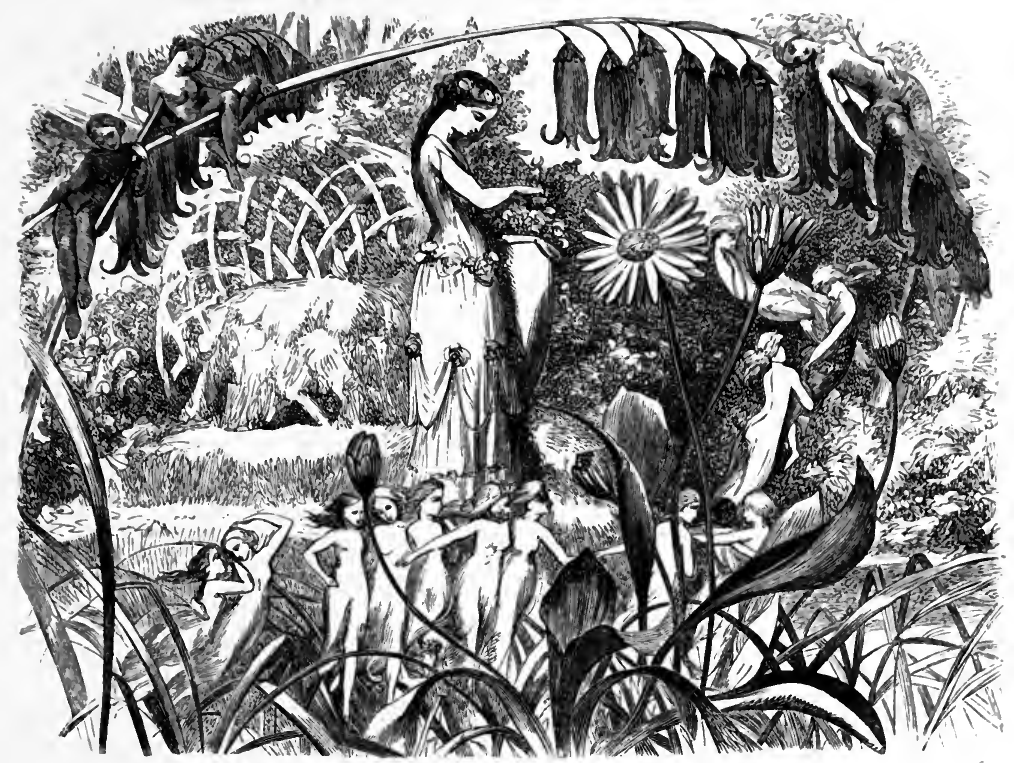

\section{HAYLEY.}

\section{THE VISION OF SERENA.}

"Well may'st thou bend o'er this congenial sphere;

For Sensibility is Sovereign here.

Thou seest her train of sprightly damsels sport,

Where the soft spirit holds her rural court;

But fix thine eye attentive to the plain,

And mark the varying wonders of her reign."

As thus she spoke, she pois'd her airy seat

High o'er a plain exhaling every sweet;

For round its precincts all the flowers that bloom

Fill'd the delicious air with rich perfume;

And in the midst a verdant throne appear'd, 


\section{THE VISION OF SERENA.}

In simplest form by graceful fancy rear'd, And deck'd with flowers; not such whose flaunting dyes Strike with the strongest tint our dazzl'd eyes;

But those wild herbs that tend'rest fibres bear, And shun th' approaches of a damper air.

Here stood the lovely ruler of the scene,

And beauty, more than pomp, announe'd 'The Queen.

The bending snowdrop and the briar-rose,

The simple circle of her crown compose;

Roses of every hue her robe adorn,

Except th' insipid rose without a thorn.

Of that enchanting age her figure seems,

When smiling nature with the vital beams

Of vivid youth, and Pleasure's purple flame,

Gilds her accomplish'd work, the female frame,

With rich luxuriance tender, sweetly wild,

And just between the woman and the child.

Her fair left arm around a vase she flings,

From which the tender plant mimosa springs;

'Towards its leaves, o'er which she fondly bends,

The youthful fair her vacant hand extends

With gentle motion, anxious to survey

How far the feeling fibres own her sway;

The leaves, as conscious of their Queen's command,

Suceessive fall at her approaching hand;

While her soft breast with pity seems to pant, And shrinks at every shrinking of the plant.

Around their sovereign, on the verdant ground,

Sweet airy forms in mystic measures bound.

Unnumber'd damsels different charms display,

Pensive with biss, or in their pleasures gay.

But, the bright triumphs of their joy to check,

In the clear air there hangs a dusky speck;

It swells-it spreads-and rapid, as it grows,

O'er the gay scene a chilling shadow throws.

The soft Serena, who beheld its flight,

Suspects no evil from a cloud so light; 
But, ah! too soon, with pity's tender pain, She saw its dire effect o'er all the plain:

Sudden from thence the sounds of anguish flow,

And joy's sweet earols end in shrieks of woe.

Here gloomy 'Terror, with a shadowy rope,

Seems, like a Turkish mute, to strangle Hope.

But pangs more cruel, more intensely keen,

Wound and distract their sympathetic Queen.

With fruitless tears she o'er their misery bends;

From her sweet brow the thorny rose she rends,

And, bow'd by grief's insufferable weight,

Frantic she curses her immortal state:

The soft Serena, as this curse she hears,

Feels her bright eye suffus'd with kindred tears.

The guardian Power survey'd her lovely grief,

And spoke in gentle terms of mild relief:

"For this soft tribe they heaviest fear dismiss,

And know their pains are transient as their bliss:

Rapture and agony, in Nature's loom,

Have form'd the changing tissue of their doom;

Both interwoven with so nice an art,

No power can tear the twisted threads apart;

Yet happier these, to Nature's heart more dear,

Than the dull offspring in the torpid sphere,

Where her warm wishes, and affections kind,

Lose their bright current in the stagnant mind.

Here grief and joy so suddenly unite,

That anguish serves to sublimate delight."

She spoke; and, ere Serena could reply,

The vapour vanish'd from the lucid sky,

The nymphs revive, the shadowy fiends are fled,

The new-born flowers a richer fragrance shed,-

While on the lovely Queen's enchanting face,

Departed sorrow's faint and fainter trace

Gave to each touching charm a more attractive grace. 


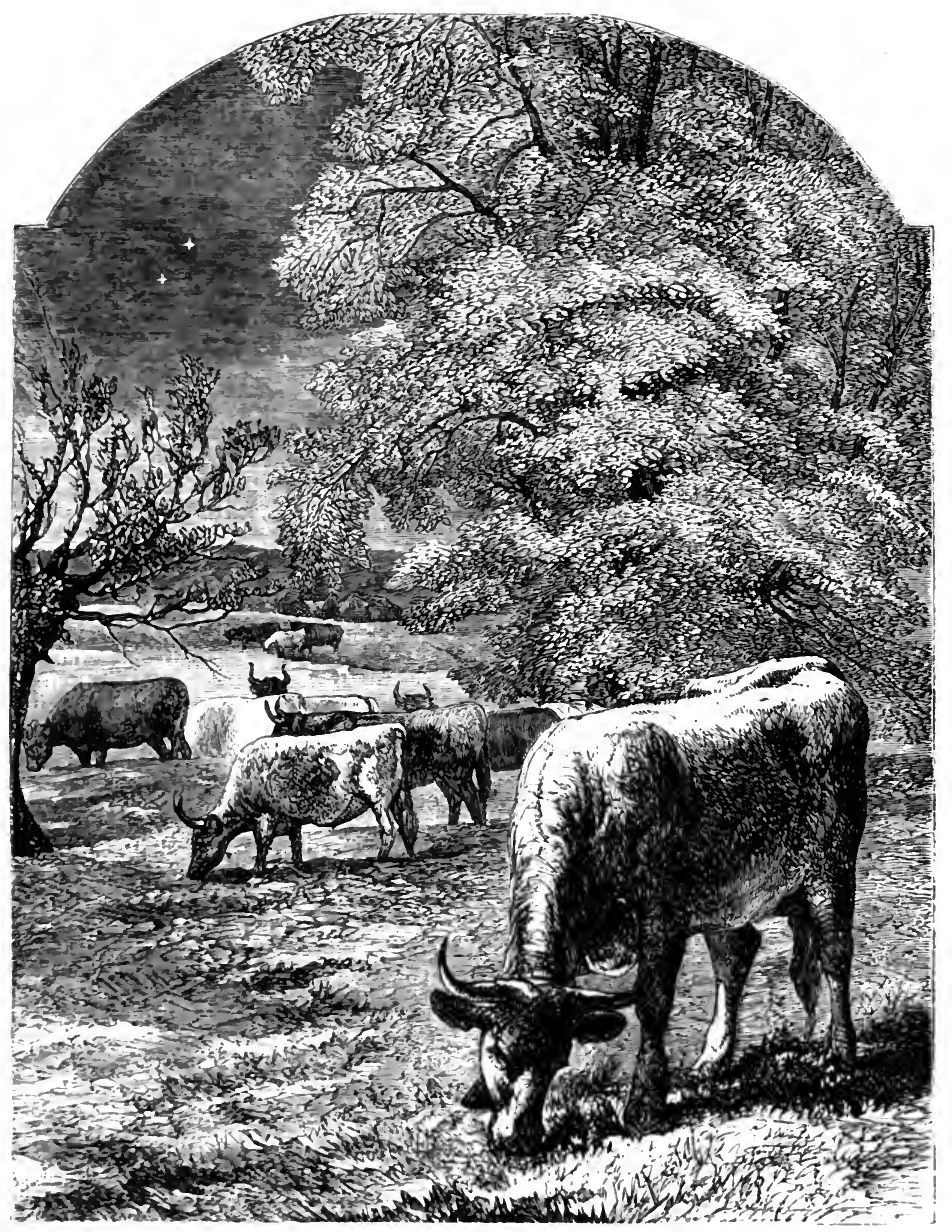

\section{HURDIS.}

RIRAL SOTNDS.

lie nothing heard, Sare the firr-distant murmur of the decp- 


\section{HURDIS.}

Or the near grasshopper's incessant note, That snug beneath the wall in comfort sits, And chirping imitates the silvery chink Of wages told into the ploughman's palmOr gentle curlew bidding kind good night To the spent villager, or ere his hand The cottage taper quench-or grazing ox His dewy supper from the savoury herb Audibly gathering-or cheerful hind From the lov'd harvest feast returning home, Whistling at intervals some rustic air.

Such rural sounds,

If haply notic'd by the musing mind, Sweet interruption yield, and thrice improve The solemn luxury of idle thought. If not abroad I sit, but sip at home The cheering beverage of fading eve, By some fair hand, or ere it reach the lip, With mingled flavour tinctur'd of the cane And Asiatic leaf, let the mute flock, As from the window studious looks mine eye, Steal fold-ward nibbling o'er the shadowy downLet the reluctant milch-kine of the farm Wend slowly from the pasture to the pail.

Let the glad ox, unyok'd, make haste to field, And the stout wain-horse, of encumbrance stript, Shake his enormous limbs with blund'ring speed, Eager to gratify his famish'd lip With taste of herbage and the meadow-brook. 


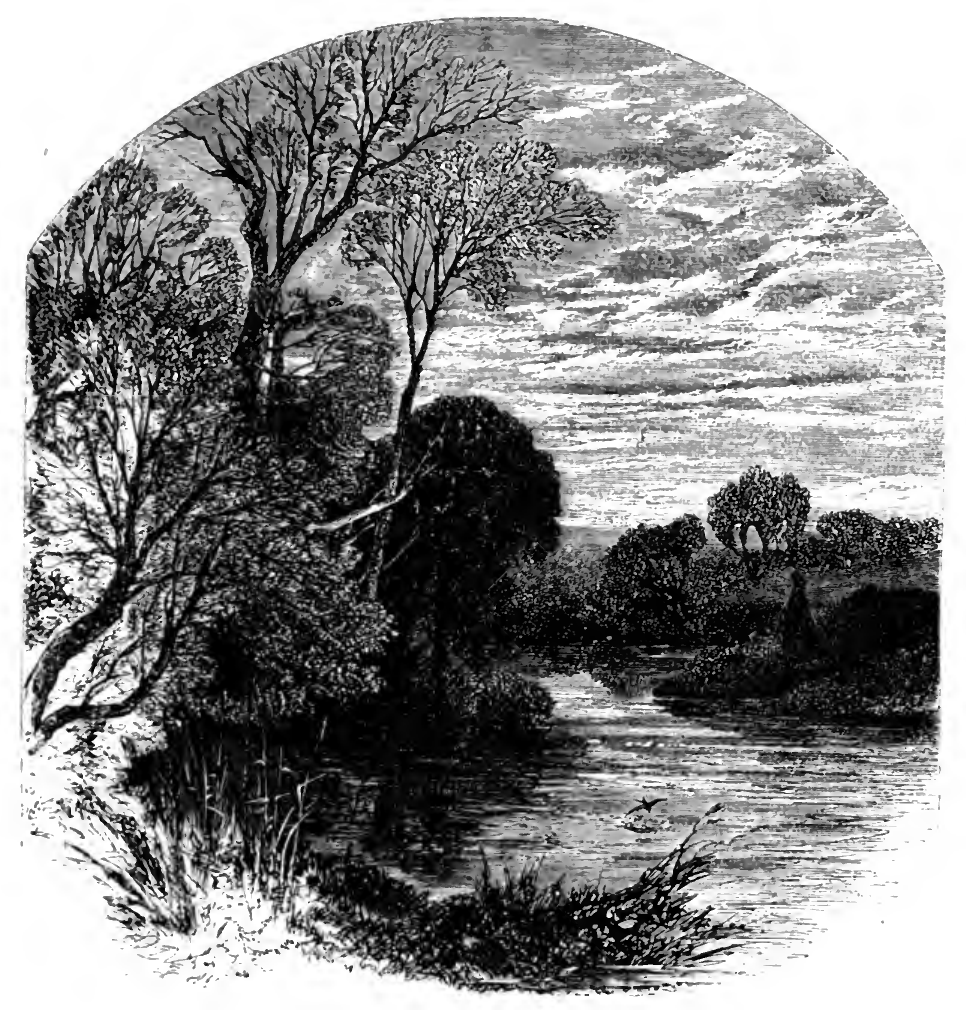

\section{CHARLOTTE SMITH.}

THE SWALLOW.

Tur gorse is yellow on the heath,

The banks with speedwell flowers are gay,

The waks are buddingr and bensath,

The hawthorn soon will bear the wreath,

The silver wreath of May. 
The welcome guest of settled Spring,

The Swallow, too, is come at last;

Just at sunset, when thrushes sing,

I saw her dash with rapid wing,

And hail'd her as she pass'd.

Come, summer visitant, attach

To my reed-roof your nest of clay, And let my ear your music eatch, Low twittering underneath the thatch, At the grey dawn of day.

As fables tell, an Indian Sage,

The Hindustani woods among,

Could in his desert hermitage,

As if 'twere mark'd in written page,

Translate the wild bird's song.

I wish I did his power possess,

That I might learn, fleet bird, from thee,

What our vain systems only guess,

And know from what wild wilderness

You came across the sea.

I would a little while restrain

Your rapid wing, that I might hear

Whether on clouds that bring the rain,

You sail'd above the western main,

The wind your charioteer.

In Afric, does the sultry gale,

Through spicy bower, and palmy grove,

Bear the repeated Cuckoo's tale?

Dwells there a time, the wandering Rail,

Or the itinerant Dove? 
Were you in Asia? O relate,

If there your fabled sister's woes

She seem'd in sorrow to narrate;

Or sings she but to celebrate

Her nuptials with the rose?

I would inquire how, journeying long The vast and pathless ocean o'er, You ply again those pinions strong, And come to build anew among

The scenes you left before;

But if, as cooler breezes blow, Prophetic of the waning year, You hide, though none know when or how,

In the cliff's excavated brow,

And linger torpid here;

Thus lost to life, what favouring dream

Bids you to happier hours awake;

And tells, that dancing in the beam,

The light gnat hovers o'er the strean,

'The May-fly on the lake?

Or if, by instinct taught to know

Approaching dearth of insect food,

To isles and willowy aits you go, And crowding on the pliant bough,

sink in the dimpling flood:

How learn ye, while the cold waves boom

Your deep and oosy couch above, The time when flowers of promise bloom, And call you from your transient tomb, To light, and life, and love? 
Alas! how little can be known,

Her sacred veil where Nature draws;

Let baffled Science humbly own, Her mysteries understood alone

By Hıм who gives her laws.

SONNET WRITTEN AT THE CLOSE OF SPRING.

TuE garlands fade that Spring so lately wove,

Each simple flower, which she had nurs'd in dew, Anemones, that spangled every grove,

The primrose wan, and harebell mildly blue.

No more shall violets linger in the dell,

Or purple orchis variegate the plain, Till Spring again shall call forth every bell,

And dress with humid hands her wreaths again.

Ah, poor humanity! so frail, so fair,

Are the fond visions of thy early day,

Till tyrant passion, and corrosive care,

Bid all thy fairy colours fade away!

Another May new buds and flowers shall bring;

Ah! why has happiness no second spring? 
Shovid the lone wanderer, fainting on his way, Rest for a moment of the sultry hours, And, though his path through thorns and roughness lay, Pluck the wild rose or woodbine's gadding flowers, Wearing gay wreaths beneath some sheltering tree, The sense of sorrow he awhile may lose; So have I sought thy flowers, fair Poesy!

So charm'd my way with Friendship and the Muse.

But darker now grows life's unhappy day, Dark with new clouds of evil yet to come, Her pencil, sickening, Fancy throws away, And weary Hope reclines upon the tomb, And points my wishes to that tranquil shore, Where the pale spectre Care pursues no more.

\section{SONNE'T ON THE DEPARTURE OF THE NIGHTINGALE.}

SwEer poet of the woods, a long adieu!

Farewell, soft minstrel of the early year!

Ah! 'twill be long ere thou shalt sing anew,

And pour thy music on the night's dull ear.

Whether on Spring thy wandering flights awạit,

Or whether silent in our groves you dwell,

The pensive Muse shall own thee for her mate,

And still protect the song she loves so well.

With cautions step the love-lorn youth shall glide

'Thro' the lone brake that shides thy mossy nest;

And shepherd-girls from eyes profine shall hide

The gentle birl, who sings of pity hest:

For still thy voice shall soft affections move,

And still be dear to sorrow, and to love? 


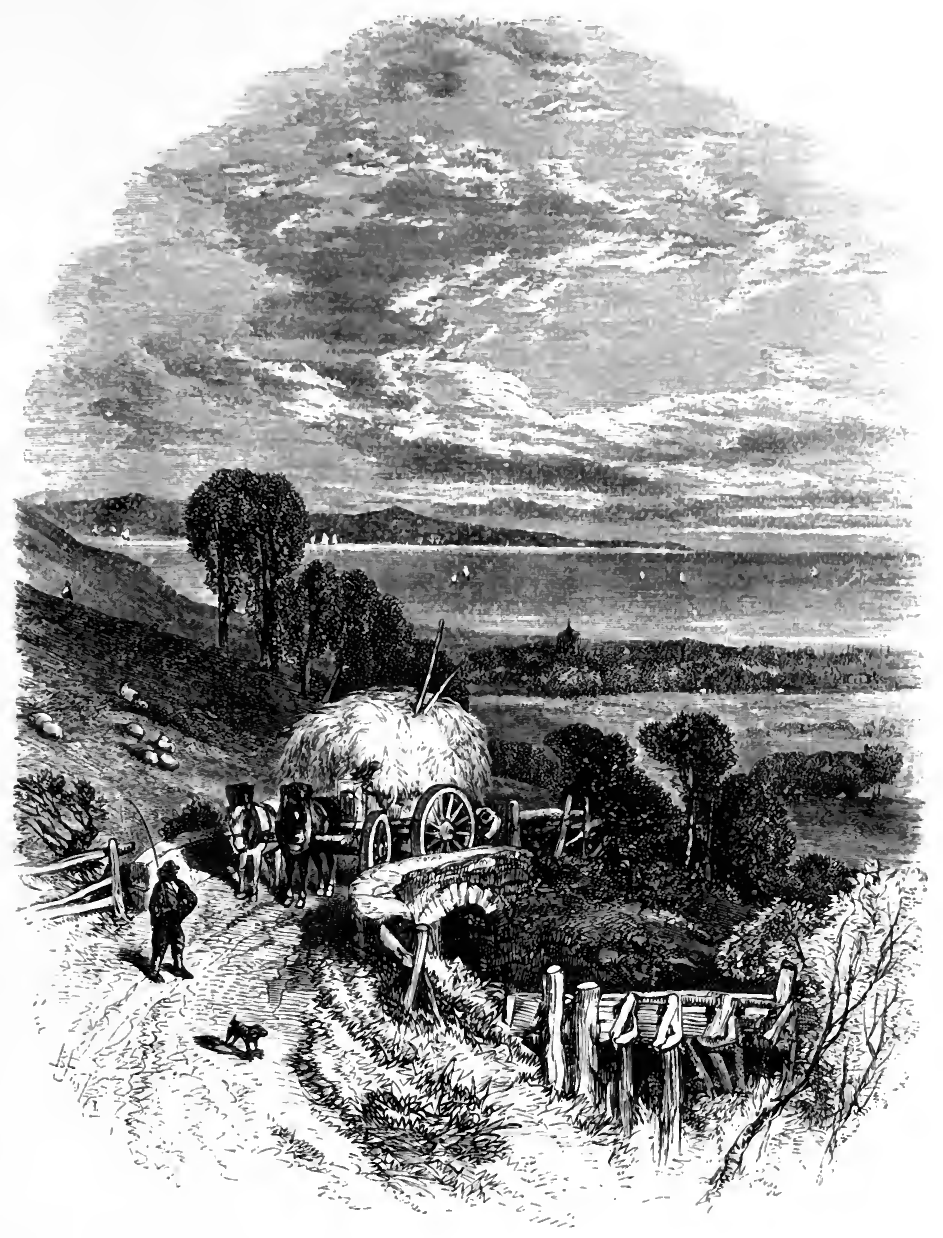

FROM "BEACHY HEAD."

I oxce was happy, when, while yet a child

I learn'd to love these upland solitudes, And when, elastic as the mountain air, To my light spirit care was yet unknown, And evil unforeseen :- early it. came, 
And childhood scarcely past, I was condemn'd,

A guiltless exile, silently to sigh,

While Memory, with faithful pencil, drew

The contrast; and regretting, I compar'd

With the polluted smoky atmosphere

And dark and stifling streets, the southern hills,

That, to the setting sun their graceful heads

Rearing, o'erlook the frith, where Vecta breaks

With her white rocks the strong impetuous tide,

When western winds the vast Atlantic urge

'To thunder on the coast. Haunts of my youth !

Scenes of fond day-dreams, I behold ye yet!

Where 'twas so pleasant by thy northern slopes

To climb the winding sheep-path, aided of $t$

By scatter'd thorns; whose spring branches bore

Small woolly tufts, spoils of the vagrant lamb

There seeking shelter from the noonday sun:

And pleasant, seated on the short soft turf,

To look beneath upon the hollow way

While heavily upward mov'd the labouring wain,

And stalking slowly by, the sturdy hind,

'To ease his panting team, stopp'd with a stone

The grating wheel.

Advancing higher still,

The prospect widens, and the village chureh

But little, o'er the lowly roofs around,

Rears its grey belfry, and its simple vane;

Those lowly roofs of thatch are half conceal'd

By the rude arms of trees, lovely in Spring,

When on each bough the rosy tinctur'd bloom

Sits thick, and promises autumnal plenty.

For even those orchards round the Norman farms,

Which, as their owners mark the promis'd fruit,

Console them for the vineyards of the South,

Surpass not these.

Where woods of ash, and beech,

And partial copses, fringe the green hill foot, 
The upland shepherd rears his modest home;

There wanders by a little numeless stream

That from the hill wells forth, bright now and clear, Or after rain with chalky mixture grey,

But still refreshing in its shallow course

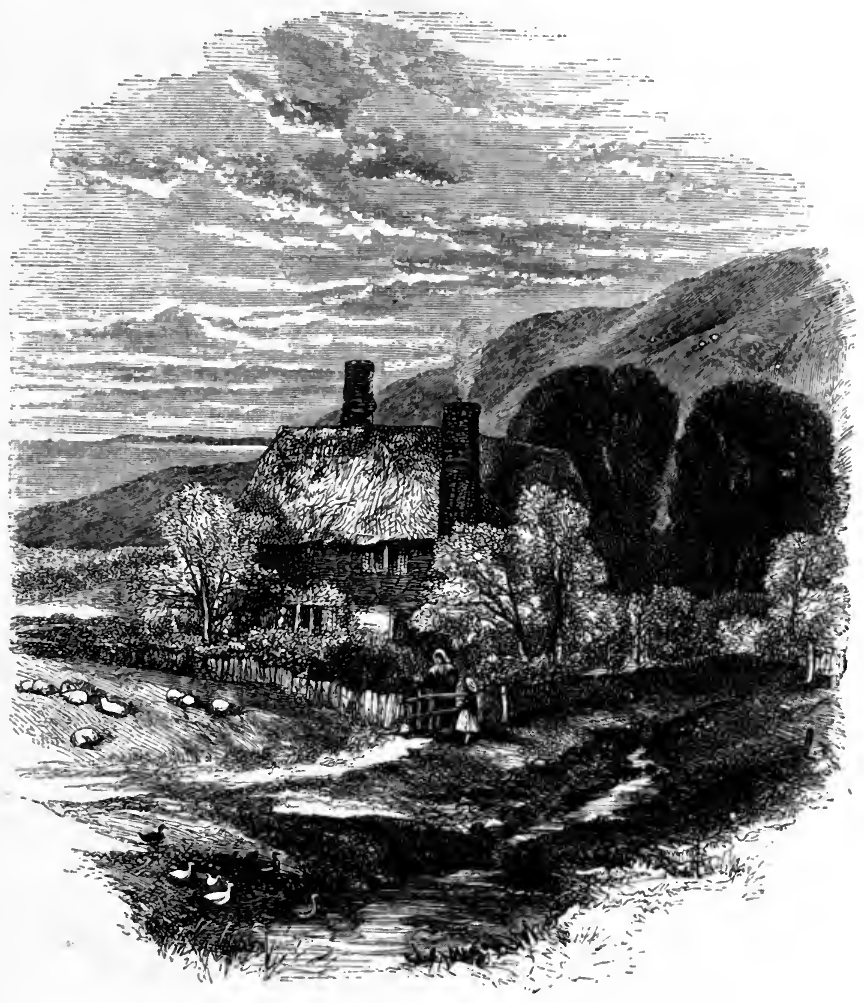

The cottage garden; most for use design'd,

Yet not of beauty destitute. The vine

Mantles the little casement; yet the briar

Drops fragrant dew among the July flowers;

And pansies ray'd, and freak'd and mottled pinks 
Grow among balm, and rosemary and rue; There honeysuckles flaunt, and roses blow Almost uncultur'd: some with dark green leaves Contrast their flowers of pure unsullied white;

Others like velvet robes of regal state

Of richest crimson; while, in thorny moss Enshrin'd and cradled, the most lovely wear The hues of youthful beauty's glowing cheek.With fond regret I recollect e'en now In Spring and Summer what delight I felt Among these cottage gardens, and how much Such artless nosegays, knotted with a rush By village housewife or her ruddy maid, Were welcome to me; soon and simply pleas'd, An early worshipper at Nature's shrine, I lov'd her rudest scenes-warrens, and heaths, And yellow commons, and birch-shaded hollows, And hedgerows, bordering unfrequented lanes Bower'd with wild roses, and the clasping woodbine, Where purple tassels of the tangling vetch With bittersweet and bryony inweave, And the dew fills the silver bindweed's cupsI lov'd to trace the brooks whose humid banks Nourish the harebell, and the freckled pagil; And stroll among o'ershadowing woods of beech, Lending in Summer from the heats of noon A whispering shade; while haply there reclines Some pensive lover of uncultur'd flowers, Who from the tumps, with bright green mosses clad, Plucks the wood sorrel with its light thin leaves, Heart-shap'd, and triply-folded, and its root Creeping like beaded coral; or who there Gathers, the copse's pride, anemones, With rays like golden studs on ivory laid Most delicate: but touch'd with purple clonds, Fit crown for April's fair but changeful brow. 


\section{ANNA SEWARD.}

\section{SONG.}

Frou thy waves, stormy Lannow, I fly;

From the rocks, that are lash'd by their tide;

From the maid, whose cold bosom, relentless as they,

Has wreck'd my warm hopes by her pride!-

Yet lonely and rude as the scene,

Her smile to that scene could impart

A charm, that might rival the bloom of the vale-

But away, thou fond dream of my heart!

From thy rocks, stormy Lannow, I fly!

Now the blasts of the winter come on,

And the waters grow dark as they rise!

But 'tis well! they resemble the sullen disdain

That has lour'd in those insolent eyes.

Sincere were the sighs they represt,

But they rose in the days that are flown!

Ah, nymph! unrelenting and cold as thou art,

My spirit is proud as thine own.

From thy rocks, stormy Lannow, I fly!

Lo! the wings of the sea-fowl are spread

To escape the loud storm by their flight;

And these caves will afford them a gloomy retreat

From the winds and the billows of night;

Like them, to the home of my youth,

Like them, to its shades I retire;

Receive me, and shield my vex'd spirit, ye groves,

From the pangs of insulted desire!

To thy rocks, stormy Lannow, adieu! 


\section{DARWIN.}

\section{MARCH OF CAMBYSES.}

Whes Hearen's dread justice smites in crimes o'ergrown 'The blood-nurs'd tyrant on his purple throne, Gnomes! your bold forms unnumber'd arms outstretch, And urge the vengeance o'er the guilty wretch. Thus when Cambyses led his barbarous hosts From Persia's rocks to Egypt's trembling coasts, Defiled each hallow'd fane, and sacred wood, And, drunk with fury, swell'd the Nile with blood; Wav'd his proud banner o'er the Theban states, And pour'd destruction through her hundred gates; In dread divisions march'd the marshall'd bands, And swarming armies blacken'd all the lands, By Memphis these to Ethiop's sultry plains, And those to Ammon's sand-encircled fanes. Slow as they pass'd the indignant temples frown'd, Low curses muttering from the vaulted ground; Long aisles of cypress wav'd their deepen'd glooms, And quivering spectres grinn'd amid the tombs; Prophetic whispers breath'd from Sphinx's tongue, And Memnon's lyre with hollow murmurs rung; Burst from each pyramid expiring groans, And darker shadows stretch'd their lengthen'd cones, Day after day their dreadful rout they steer, Lust in the van, and rapine in the rear.

Gnomes! as they march'd, you hid the gather'd fruits, The bladed grass, sweet grains, and mealy roots;

Scar'd the tired quails, that journey o'er their heads, Retain'd the locusts in their earthy beds; bade on your sands no night-born dews distil, Stay'd with vindietive hands the scanty rill. Loud o'er the camp the fiend of Famine shrieks, Calls all her brood, and clamps her hundred beaks; 
O'er ten square leagues her pennons broad expand, And twilight swims upon the shuddering sand; Perch'd on her crest the griffin Discord clings, And giant Murder rides between her wings; Blood from each clotted hair, and horny quill, And showers of tears in blended streams distil; High pois'd in air her spiry neck she bends, Rolls her keen eye, her dragon-claws extends, Darts from above, and tears at each fell swoop With iron fangs the decimated troop.

Now o'er their head the whizzing whirlwinds breathe, And the live desert pants, and heaves beneath; Tinged by the crimson sun, vast columns rise Of eddying sands, and war amid the skies, In red arcades the billowy plain surround, And whirling turrets stalk along the ground. -Long ranks in vain their shining blades extend, To demon-gods their knees unhallow'd bend.Wheel in wide circle, form in hollow square, And now they front, and now they fly the war, Pierce the deaf tempest with lamenting cries, Press their parch'd lips, and close their bloodshot eyes. -Gnomes! o'er the waste you led your myriad powers, Climb'd on the whirls, and aim'd the flinty showers!

Onward resistless rolls the infuriate surge, Clouds follow clouds, and mountains mountains urge; Wave over wave the driving desert swims, Bursts o'er their heads, inhumes their struggling limbs; Man mounts on man, on camels camels rush, Hosts march o'er hosts, and nations nations crush,Wheeling in air the winged islands fall, And one great earthy ocean covers all!Then ceased the storm, - Night bow'd his Ethiop brow To earth, and listen'd to the groans below,-Grim Horror shook,-awhile the living hill Heaved with convulsive throes, -and all was still! 
ANTIQUE GEMS.

THREE IMPRESSIONS OF ANTIQUE GEMS.

THE EAGLE.

So, when with bristling plumes the bird of Jove

Vindictive leaves the argent fields above,

Borne on broad wings the guilty world he awes, And grasps the lightning in his shining claws.

THE CIILD SLEEPING.

No voice so sweet attunes his eares to rest, So soft no pillow as his mother's breast !-

-Thus charm'd to sweet repose, when twilight hours Shed their soft influence on celestial bowers, The Cherub Innocence, with smile divine, Shuts his white wings, and sleeps on Beauty's shrine.

LOVE RIDING ON THE LION.

So playful Lore on Ida's flowery sides

With ribbon-rein the indignant lion guides;

Pleased on his brindled back the lyre he rings, And shakes delirious rapture from the strings; Slow as the pausing monarch stalks along, Sheaths his retractile claws, and drinks the song, Soft nymphs on timid step the triumph view, And listening fawns with beating hoofs pursue; With pointed ears the alarmed forest starts, And love and music soften savage hearts. 


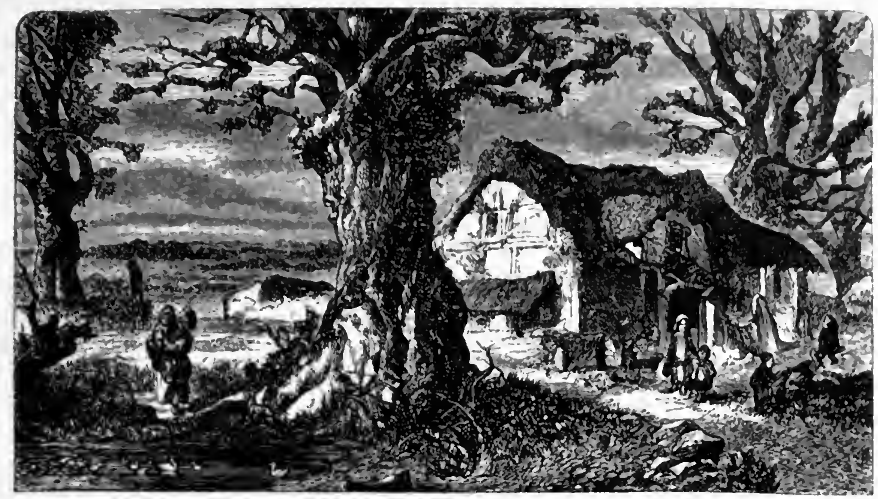

TASTE.

If the wide eye the wavy lawns explores, The bending woodlands, or the winding shores, Hills, whose green sides with soft protuberance rise, Or the blue concave of the vaulted skies;Or scans with nicer gaze the pearly swell Of spiral volutes round the twisted shell; Or undulating sweep, whose graceful turns Bound the smooth surface of Etrurian urns, When on fine forms the waving lines impress'd Give the nice curves, which swell the female breast;

The countless joys the tender mother pours

Round the soft cradle of our infant hours, In lively trains of unextinct delight

Rise in our bosoms recognised by sight;

Fond Fancy's eye recals the form divine, And Taste sits smiling upon Beauty's shrine.

Where Egypt's pyramids gigantic stand, And stretch their shadows o'er the shuddering sand; Or where high rocks, o'er ocean's dashing floods, Wave high in air their panoply of woods; 
Admiring Taste delights to stray beneath

With eye uplifted, and forgets to breathe;

Or, as aloft his daring footsteps climb,

Crests their high summits with his arm sublime.

Where mouldering columns mark the lingering wreck

Of Thebes, Palmyra, Babylon, Balbec ;

The prostrate obelisk, or shatter'd dome,

Uprooted pedestal, and yawning tomb,

On loitering steps reflective Taste surveys

With folded arms and sympathetic gaze;

Charm'd with poetic Melancholy treads

O'cr ruin'd towns and desolated meads;

Or rides sublime on Time's expanded wings,

And views the fate of ever-changing things.

When Beauty's streaming eyes her woes express,

Or Virtue braves unmerited distress;

Love sighs in sympathy, with pain combin'd,

And new-born Pity charms the kindred mind;

The enamour'd Sorrow every cheek bedews,

And Taste impassion'd woos the tragic Muse.

The rush-thatch'd cottage on the purple moor,

Where ruddy children frolic round the door,

The moss-grown antlers of the aged oak,

The shaggy locks that fringe the colt unbroke,

The bearded goat with nimble eyes, that glare

'Through the long tissue of his hoary hair,

As with quick foot he climbs some ruin'd wall

And crops the ivy, which prevents its fill;

With rumal charms the tranquil mind delight,

And form a pisture to th' admiring sight.

While Taste with pleasure bends his eye surpris'd

In modern days at Nature unchastis'd. 


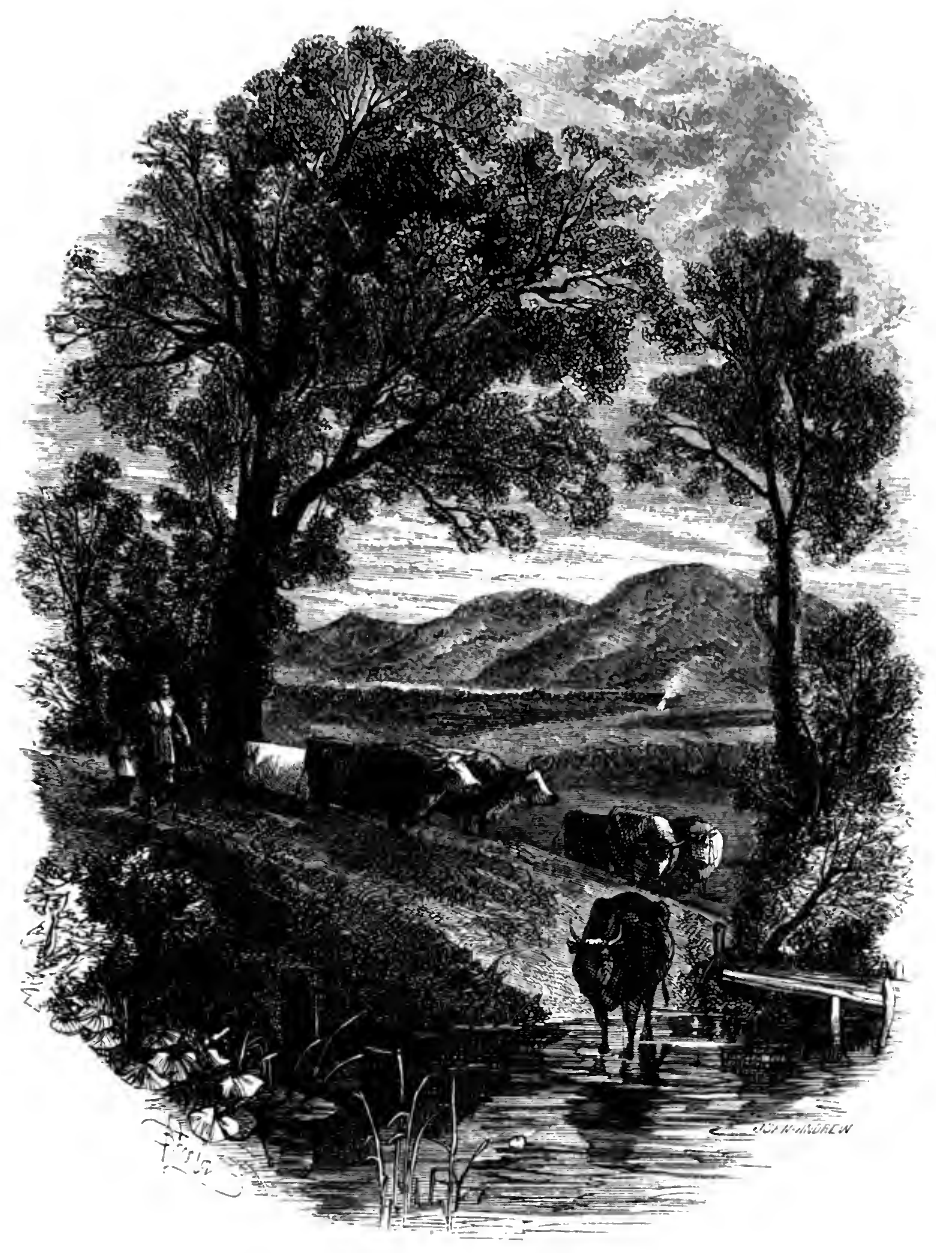

\section{CROWE.}

\section{LEWESDON HILL.}

How changed is thy appearance, beauteous Hill! Thou hast put off thy wintry garb, brown heath And russet fern, thy seemly-colour'd cloak, To bide the hoary frosts and dripping rains 
Of chill December, and art gaily robed In livery of the spring: upon thy brow A cap of flowery hawthorn, and thy neck Mantled with new-sprung furze and spangles thick Of golden bloom; nor lack thee tufted woods Adown thy sides: tall oaks of lusty green, The darker fir, light ash, and the nesh tops Of the young hazel join, to form thy skirts In many a wary fold of verdant wreath : So gorgeously hath Nature drest thee up Against the birth of May; and, rested so, Thou dost appear more gracefully array'd Than fashion-mongering fops, whose gaudy shows, Fantastical as are a sick man's dreams, From vanity to costly vanity

Change ofter than the moon. Thy comely dress, From sad to gay returning with the year, Shall grace thee still till Nature's self shall change,

These are the beauties of thy woodland scene At each return of Spring: yet some delight Rather to view the change; and fondly gaze On fading colours, and the thousand tints Which Autumn lays upon the varying leaf: I like them not, for all their boasted hues Are kin to sickliness; mortal decay Is drinking up their vital juice; that gone, They turn to sear and yellow. Should I praise Such false complexions, and for beauty take A look consumption-bred? $\Lambda$ s soon, if grey Were mixt in young Louisa's tresses brown, I'd eall it beautiful variety,

And therefore doat on her. Yet I can spy $A$ beaty in that fruitful change, when comes 'The yellow $\Lambda$ utumn, and the hopes o' the year Brings on to golden ripeness; nor dispraise The pure and spotless form of that sharp time, 


\section{CROWE.}

When. January spreads a pall of snow O'er the dead face of th' undistinguish'd earth. Then stand I in the hollow comb beneath, And bless this friendly mount, that weather-fends

My reed-roof'd cottage, while the wintry blast

From the thick North comes howling; till the Spring Return, who leads my devious steps abroad, To climb, as now, to Lewesdon's airy top.

From this proud eminence on all sides round Th' unbroken prospect opens to my view, On all sides large; save only where the head Of Pillesdon rises, Pillesdon's lofty Pen : So call (still rendering to his ancient name Observance due) that rival Height south-west, Which, like a rampire, bounds the vale beneath. There woods, there blooming orchards, there are seen Herds ranging, or at rest beneath the shade Of some wide-branching oak; there goodly fields Of corn, and verdant pasture, whence the kine, Returning with their milky treasure home, Store the rich dairy; such fair plenty fills The pleasant vale of Marshwood, pleasant now, Since that the Spring hath deck'd anew the meads With flowery vesture, and the warmer sun Their foggy moistness drain'd; in wintry days Cold, vapourish, miry, wet, and to the flocks Unfriendly, when autumnal rains begin To drench the spungy turf; but ere that time The careful shepherd moves to healthicr soil, Rechasing, lest his tender ewes should coath In the dank pasturage. Yet not the fields Of Evesham, nor that ample valley named Of the White Horse, its antique monument Carved in the chalky bourne, for beauty and wealth Might equal, though surpassing in extent, This fertile vale, in length from Lewesdon's base 


\section{LEIVESDON HILL.}

Extended to the sea, and water'd well

By many a rill; but chief with thy clear stream, Thou nameless Rirulet, who, from the side Of Lewesdon softly welling forth, dost trip Adown the valley, wandering sportively.

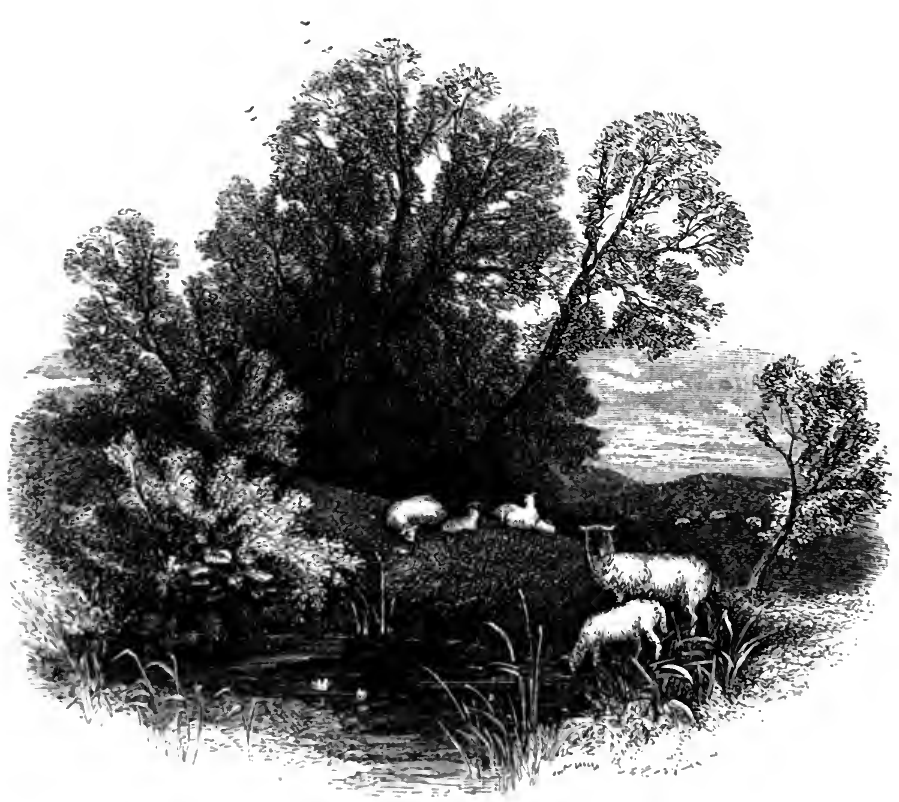

Alas! how soon thy little course will end! How soon thy infant stream shall lose itself

In the salt mass of waters, ere it grow

'To name or greatness! Yet it flows along Untainted with the commerce of the world. 
Nor passing by the noisy haunts of men;

But through sequester'd meads, a little space,

Winds secretly, and in its wanton path

May cheer some drooping flower, or minister

Of its cool water to the thirsty lamb:

Then falls into the ravenous sea, as pure

As when it issued from its native hill.

How is it vanish'd in a hasty spleen,

The Tor of Glastonbury! Even but now

I saw the hoary pile cresting the top

Of that north-western hill; and in this Now

A cloud hath pass'd on it, and its dim bulk

Becomes annihilate, or if not, a spot

Which the strain'd vision tires itself to find.

And even so fares it with the things of earth

Which seem most constant: there will come the cloud

That shall enfold them up, and leave their place

A seat for Emptiness. Our narrow ken

Reaches too far, when all that we behold

Is but the havoc of wide-wasting Time,

Or what he soon shall spoil. His out-spread wings

(Which bear him like an eagle o'er the earth)

Are plumed in front so downy soft, they seem

To foster what they touch, and mortal fools

Rejoice beneath their hovering: Woe the while!

For in that indefatigable flight

The multitudinous strokes incessantly

Bruise all beneath their cope, and mark on all

His secret injury: on the front of man

Grey hairs and wrinkles; still as Time speeds on,

Hard and more hard his iron pennons beat

With ceaseless violence; nor overpass,

Till all the creatures of this nether world

Are one wide quarry; following dark behind,

The cormorant Oblivion swallows up

The carcases that Time has made his prey. 


\section{LEWESDON HILL.}

But hark! the village clock strikes nine-the chimes Merrily follow, tuneful to the sense

Of the pleased clown attentive, while they make

False-measured melody on crazy bells.

$\mathrm{O}$ wondrous power of modulated sound !

Which, like the air, (whose all-obedient shape

Thou mak'st thy slave,) canst subtilly pervade

The yielded avenues of sense, unlock

The close affections, by some fairy path

Winning an easy way through every ear,

And with thine unsubstantial quality

Holding in mighty chains the hearts of all;

All, but some cold and sullen-temper'd spirits

Who feel no touch of sympathy, or love.

Yet what is music, and the blended power

Of voice with instruments of wind and string?

What but an empty pageant of sweet noise!

'Tis past; and all that it has left behind

Is but an echo dwelling in the ear

Of the toy-taken fancy, and beside,

A void and countless hour in life's brief day.

\section{Now I descend}

To join the worldly crowd; perchance to talk,

To think, to act as they: then all these thoughts,

That lift th' expanded heart above this spot

To heaven!y musing, these shall pass away,

(Even as this goodly prospect from my view,)

Hidden by near and earthy-rooted cares.

So passeth human life-our better mind

Is as a Sunday's garment, then put on

When we have nought to do; but at our work

We wear a worse for thrift. 


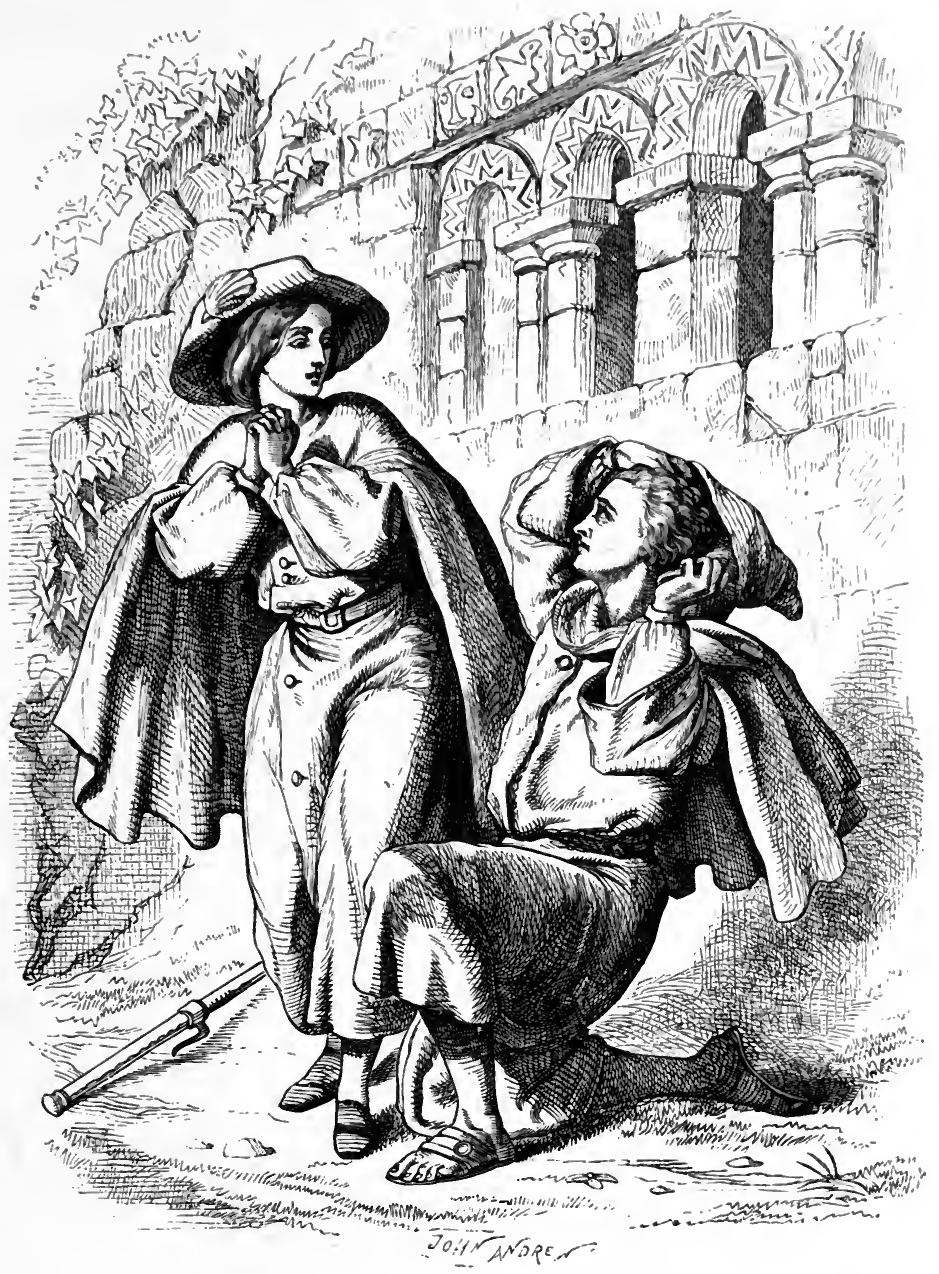

PERCY.

THE FRIAR OF ORDERS GRAY.

IT was a friar of orders gray

Walkt forth to tell his beades; 


\section{THE FRIAR OF ORDERS GRAY.}

And he met with a lady faire

Clad in a pilgrime's weedes.

"Now Christ thee sare, thou reverend friar,

I pray thee tell to me,

If ever at yon holy shrine

My true love thou didst see?"

"And how should I know your true love From many another one?"

" $\mathrm{O}$, by his cockle hat, and staff, And by his sandal shoone;

"But chiefly by his face and mien, That were so fair to view;

His flaxen locks that sweetly curl'd, And eyne of lovely blue."

"O lady, he is dead and gone!

Lady, he's dead and gone!

And at his head a green grass turfe, And at his heels a stone.

"Within these holy cloysters long

He languisht, and he dyed, Lamenting of a ladye's love, And 'playning of her prile.

"IJere bore him barefaced on his bier Six proper youths and tall, And many a tear bedew'd his grave

Within yon kirk-yard wall."

"And art thou dead, thou gentle youth, And art thou dead and gone!

And didst thou dye for love of me!

Break, crucl heart of stone!" 
"O weep not, lady, weep not soe:

Some ghostly comfort seek :

Let not vain sorrow rive thy heart,

Ne teares bedew thy cheek."

"O do not, do not, holy friar, My sorrow now reprove;

For I have lost the sweetest youth

That e'er won ladye's love.

"And nowe, alas! for thy sad losse,

I'll evermore weep and sigh:

For thee I only wisht to live,

For thee I wish to dye."

"Weep no more, lady, weep no more,

Thy sorrowe is in vaine:

For violets pluckt the sweetest showers

Will ne'er make grow againe.

"Our joys as winged dreams doe flye;

Why, then, should sorrow last?

Since grief but aggravates thy losse,

Grieve not for what is past."

"O say not soe, thou holy friar;

I pray thee, say not soe:

For since my true-love dyed for mee,

'Tis meet my teares should flow.

"And will he never come again?

Will he ne'er come again?

Ah! no, he is dead and laid in his grave,

For ever to remain.

"His cheek was redder than the rose;

The comeliest youth was he! 


\section{THE FRIAR OF ORDERS GRAY.}

But he is dead and laid in his grave:

Alas! and woe is me!"

"Sigh no more, lady, sigh no more, Men were deceivers ever:

One foot on sea and one on land, To one thing constant never.

"Hadst thou been fond, he had been false, And left thee sad and heavy;

For young men ever were fickle found, Since summer trees were leafy."

"Now say not soe, thou holy friar, I pray thee say not soe;

My love he had the truest heart:

$O$ he was ever true!

"And art thou dead, thou much-lov'd youts, And didst thou dye for mee?

Then farewell home; for evermore A pilgrim $I$ will bee.

"But first upon my true-love's grave My weary limbs I'll lay, And thrice I'll kiss the green grass-turf

That wraps his breathless clay."

"Yet stay, fair lady: rest awhile

Beneath this cloyster wall:

See through the hawthorn blows the cold wind, And drizzly rain doth fall."

"O stay me not, thou holy friar;

O stay me not, I pray:

No drizaly rain that falls on me

Can wash my fault away." 


\section{PERCY.}

"Yet stay, fair lady, turn again,

And dry those pearly tears;

For see beneath this gown of gray

Thy owne true-love appears.

"Here, forc'd by grief, and hopeless love, 'These holy weeds I sought;

And here amid these lonely walls

To end my days I thouglit.

"But haply, for my year of grace

Is not yet pass'd away,

Might I still hope to win thy love,

No longer would I stay."

"Now farewell grief, and welcome joy

Once more unto my heart;

For since I've found thee, lovely youtl,

We never more will part."

\section{GENTLE RIVER.}

Gentue river, gentle river,

Lo, thy streams are stain'd with gore, Many a brave and noble captain

Floats along thy willow'd shore.

All beside thy limpid waters,

All beside thy sands so bright, Moorish Chiefs and Christian Warrior's

Join'd in fierce and mortal fight. 


\section{GENTLE RIVER.}

Lords, and dukes, and noble princes,

On thy fatal banks were slain:

Fatal banks, that gave to slaughter

All the pride and flower of Spain.

There the hero, brave Alonzo,

Full of wounds and glory, died:

There the fearless Urdiales

Fell a vietim by his side.

Lo! where yonder Don Saavedra

Through their squadrons slow retires;

Proud Seville, his native city,

Proud Seville his worth admires.

Close behind, a renegado

Loudly shouts with taunting ery:

"Yield thee, yield thee, Don Saavedra;

Dost thou from the battle fly?

"Well I know thee, haughty Christian,

Long I liv'd beneath thy roof;

Oft I've in the lists of glory

Seen thee win the prize of proof.

"Well I know thy aged parents,

Well thy blooming bride I know;

Seven years I was thy captive,

Seven years of pain and woe.

"May our Prophet grant my wishes,

IIaughty Chief, thou shalt be mine;

'Thou shalt drink that cup of sorrow,

Which I drank when I was thine." 


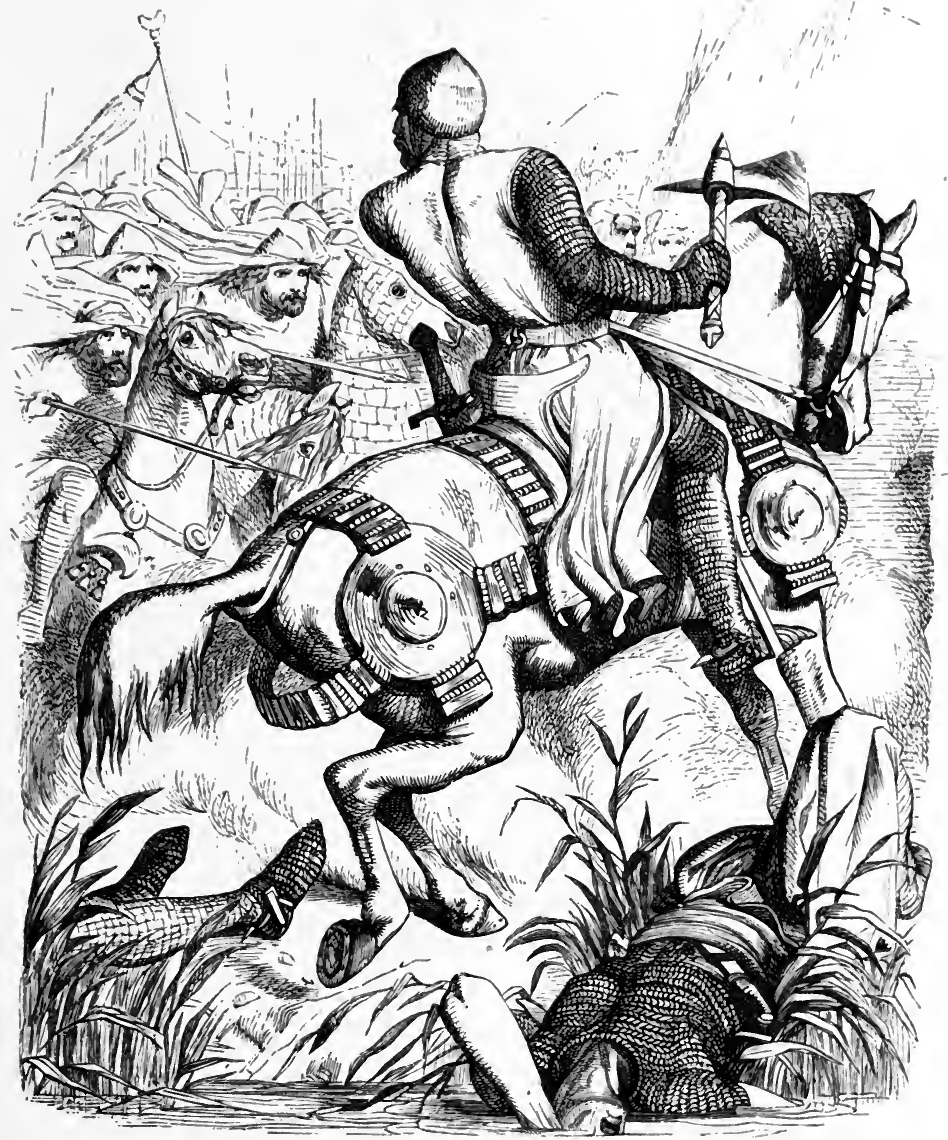

Like a lion turns the warrior

Back he sends an angry glare:

Whizzing came the Moorish javelin,

Vainly whizzing through the air. 
GENTLE RIVER.

Back the hero, full of fury,

Sent a deep and mortal wound:

Instant sunk the Renegado,

Mute and lifeless on the ground.

With a thousand Moors surrounded,

Brave Saavedra stands at bay:

Wearied out, but never daunted,

Cold at length the warrior lay.

Near him fighting, great Alonzo

Stout resists the Paynim bands;

From his slaughter'd steed dismounted

Firm intrench'd behind him stands.

Furious press the hostile squadron,

Furious he repels their rage:

Loss of blood at length enfeebles:

Who can war with thousands wage!

Where yon rock the plain o'ershadows, Close beneath its foot retir'd, Fainting, sunk the bleeding hero, And without a groan expir'd. 


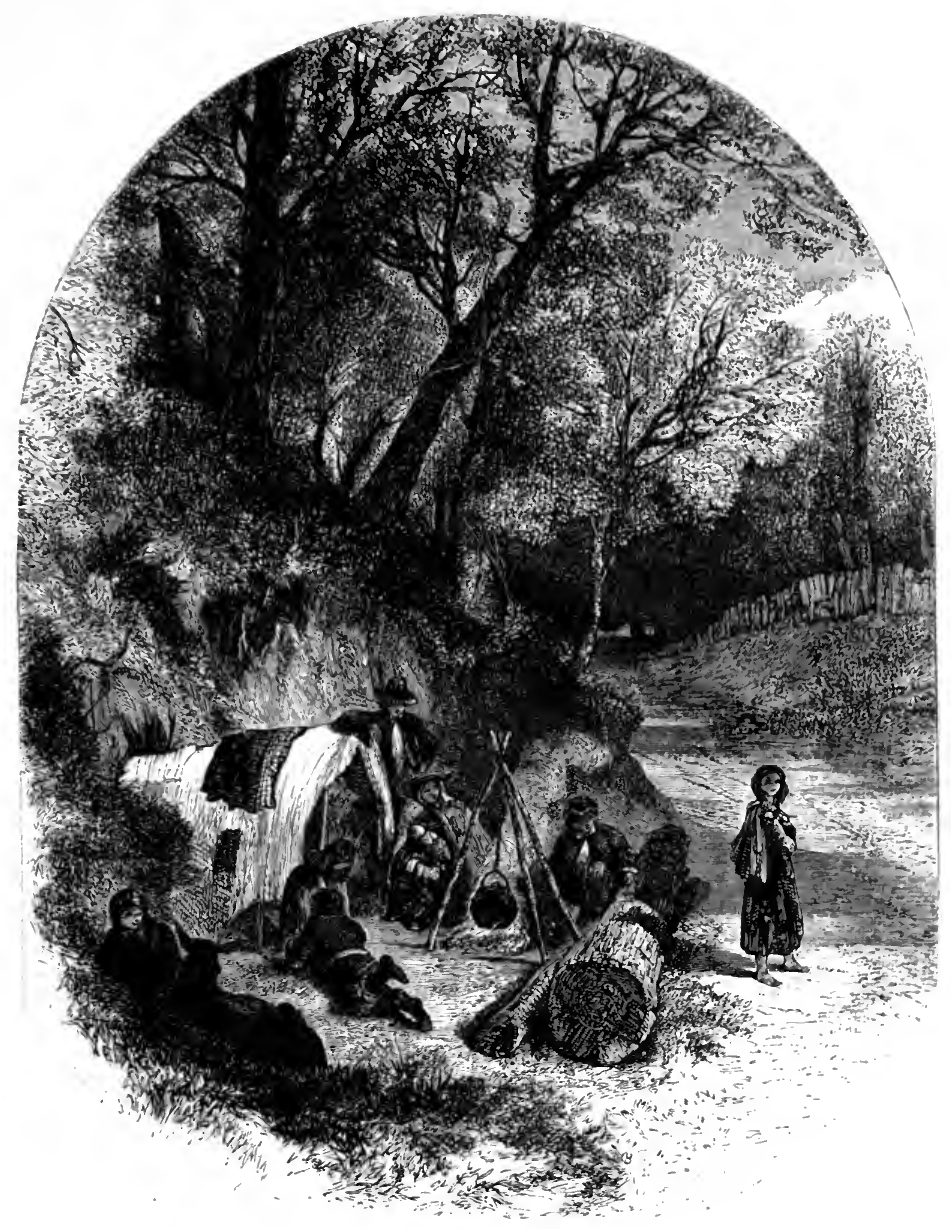

\section{CRABBE.}

\section{A GIPSY ENCAMPMENT.}

Agais, the country was enclosed, a wide

And sandy road has banks on either side;

Where, lo! a hollow on the left appear'd, And there a Gipsy tribe their tent had rear $d$; 


\section{A GIPSY ENCAMPMENT.}

'Twas open spread, to catch the morning sun, And they had now their early meal begun, When two brown boys just left their grassy seat, The early 'Trav'ller with their prayers to greet:

While yet Orlando held his pence in hand, He saw their sister on her duty stand;

Some twelve years old, demure, affected, sly, Prepared the force of early powers to try; Sudden a look of languor he descries, And well-feign'd apprehension in her eyes; 'Train'd, but yet savage, in her speaking face He mark'd the features of her vagrant race;

When a light laugh and roguish leer express'd

The vice implanted in her youthful breast: Forth from the tent her elder brother came, Who seem'd offended, yet forbore to blame The young designer, but could only trace The looks of pity in the 'Trav'ller's face: Within, the Father, who from fences nigh Had brought the fuel for the fire's supply, Wateh'd now the feeble blaze, and stood dejected by. On ragged rug, just borrow'd from the bed, And by the hand of coarse indulgence fed, In dirty patchwork negligently dress'd, Reclin'd the Wife, an infant at her breast;

In her wild face some touch of grace remain'd, Of vigour palsied and of beauty stain'd; Her bloodshot eyes on her unheeding mate Were wrathful turn'd, and seem'd her wants to state, Cursing his tardy aid-her Mother there With gipsy-state engross'd the only chair; Solemn and dull her look; with such she stands And reads the milk-maid's fortune in her hands, Tracing the lines of life; assum'd through years, Each feature now the steady falsehood wears; With hard and savage eye she views the food, And grudging pinches their intruding brood. 
Last in the group, the worn-out Grandsire sits, Neglected, lost, and living but by fits:

Useless, despis'd, his worthless labours done, And half proteeted by the vicious Son,

Who half supports him; he with heavy glance

Views the young ruffians who around him dance;

And, by the sadness in his face, appears

To trace the progress of their future years:

Through what strange course of misery, vice, deceit, Must wildly wander each unpractis'd cheat!

What shame and grief, what punishment and pain, Sport of fierce passions, must each child sustain-

Ere they like him approach their latter end, Without a hope, a comfort, or a friend!

\section{MARINE VIEWS.}

BE it the Summer-noon: a sandy space The ebbing tide has left upon its place; Then just the hot and stony beach above, Light twinkling streams in bright confusion move; (For heated thus, the warmer air ascends, And with the cooler in its fall contends)Then the broad bosom of the ocean keeps An equal motion; swelling as it sleeps, Then slowly sinking; curling to the strand, Faint, lazy waves o'erereep the rigid sand, Or tap the tarry boat with gentle blow, And back return in silence, smooth and slow. 
Ships in the caim seem anchor'd; for they glide On the still sea, urg'd solely by the tide:

Art thou not present, this calm scene before, Where all beside is pebbly length of shore, And far as eye can reach, it can discern no more?

Yet sometimes comes a ruffling cloud to make The quiet surface of the ocean shake;

As an awaken'd giant with a frown

Might show his wrath, and then to sleep sink down.

View now the Winter-storm! above, one cloud, Black and unbroken, all the skies o'ershroud: Th' unwieldy porpoise through the day before, Had roll'd in view of boding men on shore;

And sometimes hid and sometimes show'd his form, Dark as the cloud, and furious as the storm.

All where the eye delights, yet dreads, to roam, The breaking billows cast the flying foam Upon the billows rising-all the deep Is restless change; the waves so swell'd and steep, Breaking and sinking, and the sunken swells, Nor one, one moment, in its station dwells:

But nearer land you may the billows trace, As if contending in their watery chase;

May watch the mightiest till the shoal they reach, 'Then break and hurry to their utmost stretch;

Curld as they come, they strike with furious force, And then, re-flowing, take their grating course, Raking the rounded flints, which ages past Roll'd by their rage, and shall to ages last

Far off the Petrel in the troubled way Swims with her brood, or flutters in the spray; She rises often, often drops again, And sports at ease on the tempestuous main.

High oer the restless deep, above the reach Of gumner's hope, rast flocks of Wild-ducks stretch; Far as the eye can glance on either side, In a broad spatce and level line they glide; 


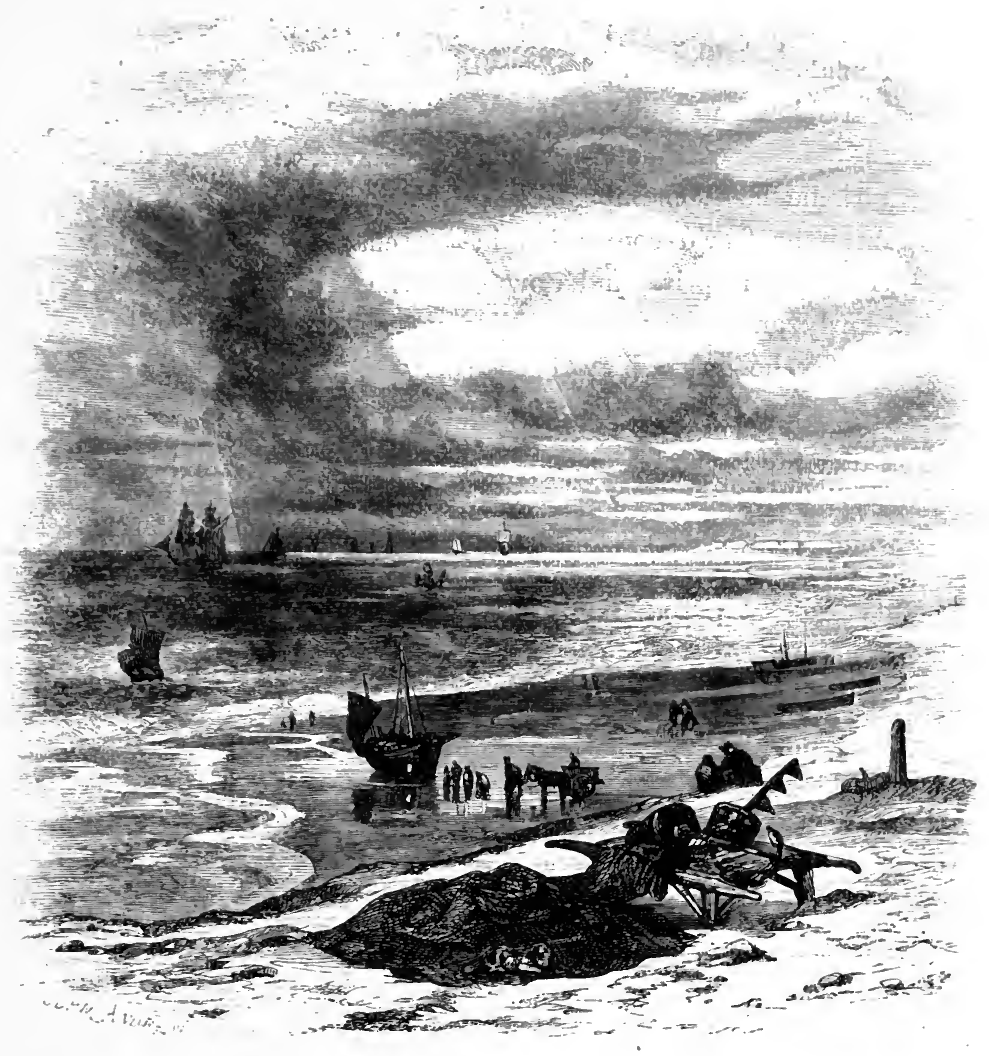

All in their wedge-like figures from the north, Day after day, flight after flight, go forth.

In-shore their passage tribes of sea-gulls urge, And drop for prey within the sweeping surge; Oft in the rough opposing blast they fly Far back, then turn, and all their force apply, While to the storm they give their weak complaining cry; 
Or clap the sleek white pinion to the breast, And in the restless ocean dip for rest.

Darkness begins to reign; the louder wind Appals the weak, and awes the firmer mind; But frights not him whom evening and the spray

In part conceal-yon Prowler on his way:

Lo! he has something seen; he runs apace, As if he fear'd companion in the chase;

He sees his prize, and now he turns again, Slowly and sorrowing-"Was your search in vain?" Gruffly he answers, "'Tis a sorry sight!A seaman's body: there'll be more to-night!"

Hark to those sounds! they're from distress at sea: How quick they come! What terrors may there be! Yes, 'tis a driven vessel: I discern

Lights, signs of terror, gleaming from the stern.

Others behold them too, and from the town

In various parties seamen hurry down;

Their wives pursue, and damsels, urged by dread,

Lest men so dear be into danger led;

Their head the gown has hooded, and their call

In this sad night is piercing like the squall;

They feel their kinds of power, and when they meet, Chide, fondle, weep, dare, threaten, or entreat.

. See one poor girl, all terror and alarm, Has fondly seiz'd upon her lover's arm;

"Thou shalt not venture;" and he answers "No!

I will not:"-still she cries, "Thou shalt not go."

No need of this; not here the stoutest boat

Can through such breakers, o'er such billows float;

Yet may they view these lights upon the beach,

Which yield them hope whom help can never reach.

From parted clouds the moon her radiance throws

On the wild waves, and all the danger shows;

But shows them beaming in her shining vest, Terrific splendour! gloom in glory dress'l ! 
CRABBE.

This for a moment, and then clouds again

Hide every beam, and fear and darkness reign.

But hear we not those sounds? Do lights appear?

I see them not! the storm alone I hear:

And lo! the sailors homeward take their way;

Man must endure-let us submit and pray.

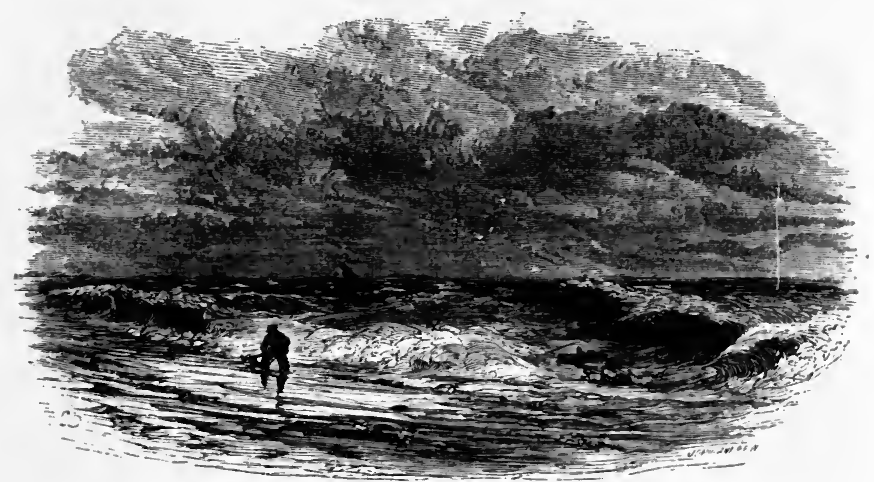




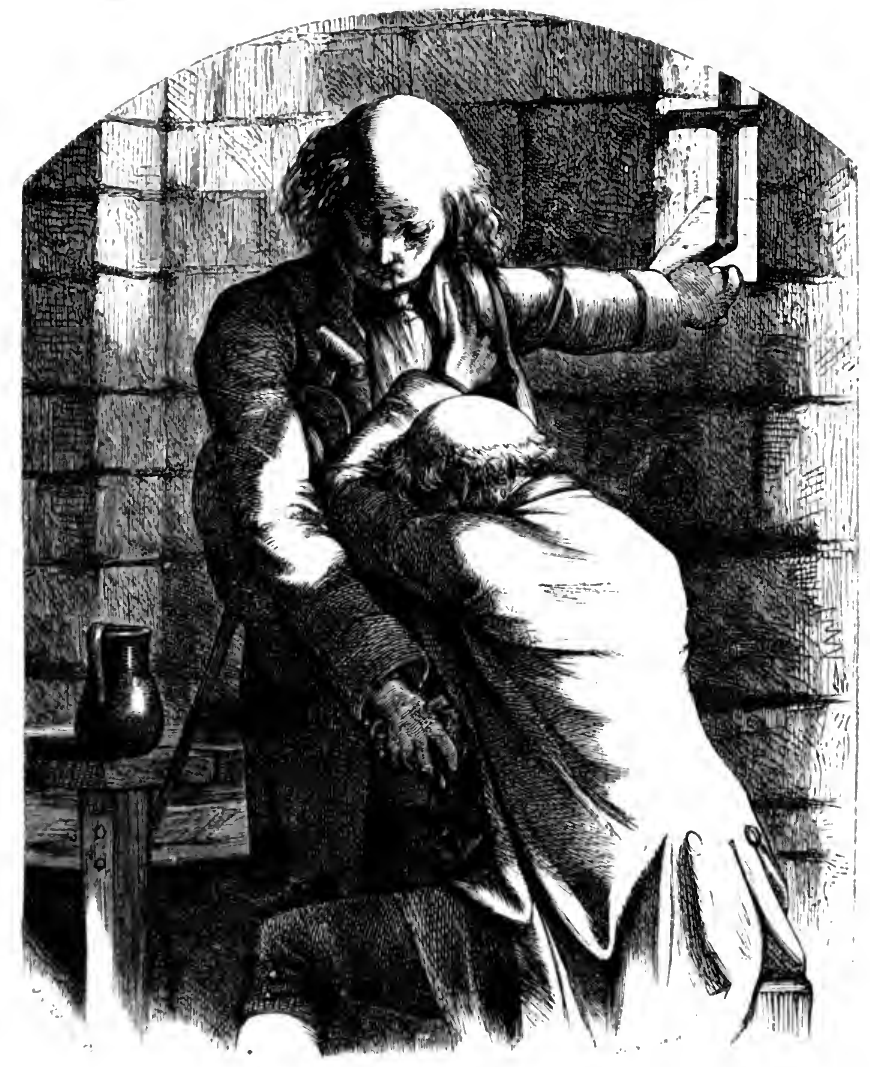

A GOOD VILLAGER.

Nexp to these ladies, but in nought allied, A moble peasant, Isatac Ashford, died.

Noble he was, contemning all things mean,

Iis truth unguestion'd, and his soul serene:

Of no man's presence Isaac felt afraid;

At no man's question Isaac look'd dismay'd; 


\section{CRABBE.}

Shame knew him not, he dreaded no disgrace, Truth, simple truth, was written in his face:

Yet while the serious thought his soul approv'l,

Cheerful he seem'd, and gentleness he lov'd;

'To bliss domestic he his heart resign'd,

And with the firmest had the fondest mind;

Were others joyful, he look'd smiling on,

And gave allowance where he needed none;

Good he refus'd with future ill to buy,

Nor knew a joy that caus'd Reflection's sigh;

A friend to Virtue, his unclouded breast

No envy stung, no jealousy distress'd;

(Bane of the poor! it wounds their weaker mind,

To miss one favour, which their neighbours find:)

Yet far was he from stoic pride remov'd;

He felt humanely, and he warmly lov'd:

I mark'd his action, when his infant died, And his old neighbour for offence was tried;

The still tears, stealing down that furrow'd cheek, Spoke pity, plainer than the tongue can speak. If pride were his, 'twas not their vulgar pride, Who, in their base contempt, the great deride; Nor pride in learning,-though my clerk agreel, If fate should call him, Ashford might succeed;

Nor pride in rustic skill, although we knew

None his superior, and his equals few:-

But if that spirit in his soul had place,

It was the jealous pride that shuns disgrace;

A pride in honest fame, by virtue gain'd, In sturdy boys to virtuous labours train'd;

Pride in the power that guards his country's coast, And all that Englishmen enjoy and boast;

Pride in a life that Slander's tongue defied,-

In fact, a noble passion, misnam'd Pride.

He had no party's rage, no sect'ry's whim; Christian and countrymen were all with him: True to his church he came; no Sunday-shower 


\section{A GOOD VILI.AGER.}

Kept him at home in that important hour;

Nor his firm feet could one persuading sect,

By the strong glare of their new light direct:-

"On hope, in mine own sober light, I gaze,

But should be blind, and lose it, in your blaze."

In times severe, when many a sturdy swain

Felt it his pride, his comfort, to complain;

Isaac their wants would soothe, his own would hide,

And feel in that his comfort and his pride.

At length he found, when seventy years were run,

His strength departed, and his labour done;

When he, save honest fame, retain'd no more,

But lost his wife, and saw his children poor:

'Twas then a spark of - say not discontent-

Struck on his mind, and thus he gave it vent:-

"Kind are your laws ('tis not to be denied,)

That in yon House, for ruin'd age, provide,

And they are just; - when young we give you all,

And for assistance in our weakness call._-

Why then this proud reluctance to be fed,

To join your poor, and eat the parish bread?

But yet I linger, loth with him to feed,

Who gains his plenty by the sons of need;

He who, by contract, all your paupers took,

And gauges stomachs with an anxious look:

On some old master I could well depend;

See him with joy, and thank him as a friend;

But ill on him, who doles the day's supply,

And counts our chances who at night may die:

Yet help me, Heav'n! and let me not complain

Of what I suffer, but my fate sustain."

Such were his thoughts, and so resign'd he grew;

Daily he plac'd the Workhouse in his view!

But came not there, for sudden was his fate,

He dropp'd, expiring, at his cottage gate.

I feel his absence in the hours of prayer,

And view his seat, and sigh for Isaac there: 


\section{CRABBE.}

I see no more those white locks thinly spread Round the bald polish of that honour'd head; No more that awful glance on playful wight, Compell'd to kneel and tremble at the sight, To fold his fingers, all in dread the while, Till Mister Ashford soften'd to a smile;

No more that meek and suppliant look in prayer, Nor the pure faith (to give it force) are there:But he is blest, and I lament no more A wise good man contented to be poor.

\section{THE PARTING LOOK.}

Oxe day he lighter seem'd, and they forgot The care, the dread, the anguish of their lot; They spoke with cheerfulness, and seem'd to think, Yet said not so, "Perhaps he will not sink:" A sudden brightness in his look appear'd, A sudden vigour in his voice was heard;She had been reading in the Book of Prayer, And led him forth, and placed him in his chair; Lively he seem'd, and spoke of all he knew, The friendly many and the favourite few:

Not one that day did he to mind recal But she has treasur'd, and she loves them all; When in her way she meets them, they appear Peculiar people,-death has made them dear. He named his Friend, but then his hand she press'd, And fondly whispered, "Thou must go to rest." "I go," he said; but as he spoke, she found His hand more cold, and fluttering was the sound! Then gazed affrighten'd; but she caught a last, A dying look of love,-and all was past! 


\section{MARY TIGHE.}

PSYCHE GAZING UPON THE LOVE-GOD.

Allow'd to settle on celestial eyes, Soft Sleep, exulting, now exerts his sway, From Psyche's anxious pillow gladly flies

'To veil those orbs, whose pure and lambent ray

The Powers of heaven submissively obey.

Trembling and breathless then she softly rose,

And seized the lamp, where it obscurely lay,

With hand too rashly daring to disclose

The sacred veil which hung mysterious o'er her woes.

Twice, as with agitated step she went,

The lamp, expiring, shone with doubtful gleam,

As though it warn'd her from her rash intent;

And twice she paus'd, and on its trembling beam

Gazed with suspended breath, while voices seem

With murmuring sound along the roof to sigh;

As one just waking from a troublous dream,

With palpitating heart and straining eye,

Still fix'd with fear remains, still thinks the danger nigh.

Oh, daring Muse! wilt thou indeed essay

To paint the wonders which that lamp could show?

And canst thou hope in living words to say

The dazzling glories of that heavenly view?

Ah! well I ween that, if with pencil true 
That splendid vision could be well exprest,

The fearful awe imprudent Psyche knew,

Would seize with rapture every wondering breast, When Love's all-potent charms divinely stood confest.

All imperceptible to human touch,

His wings display celestial essence light;

The clear effulgence of the blaze is such,

The brilliant plumage shines so heavenly bright,

That mortal eyes turn dazzled from the sight;

A youth he seems in manhood's freshest years.

Round his fair neck, as clinging with delight,

Each golden curl resplendently appears,

Or shades his darker brow, which grace majestic wears;

Or o'er his guileless front his ringlets bright

Their rays of sunny lustre seem to throw,

That front than polish'd ivory more white!

His blooming cheeks with deeper blushes glow

Than roses scatter'd o'er a bed of snow:

While on his lips, distill'd in balmy dews, (Those lips divine that even in silence know

The heart to touch,) persuasion to infuse,

Still hangs a rosy charm that never vainly sues.

The friendly curtain of indulgent sleep

Disclos'd not yet his eyes' resistless sway,

But from their silky veil there seem'd to peep

Some brilliant glances with a soften'd ray,

Which o'er his features exquisitely play,

And all his polish'd limbs suffuse with light;

Thus through some narrow space the azure day,

Sudden its cheerful rays diffusing bright,

Wide darts its lucid beams, to gild the brow of night.

His fatal arrows and celestial bow

Beside the couch were negligently thrown, 
Nor needs the god his dazzling arms, to show His glorious birth, such beauty round him shone As sure could spring from Beauty's self alone; The gloom which glow'd o'er all of soft desire, Could well proclaim him Beauty's cherish'd son; And Beauty's self will of these charms admire, And steal his witehing smile, his glance's living fire.

Speechless with awe, in transport strangely lost, Long Psyche stood with fix'd adoring eye;

Her limbs immovable, her senses tost

Between amazement, fear, and ecstasy,

She hangs enamour'd o'er the deity-

'Till from her trembling hand extinguish'd falls

The fatal lamp.-He starts-and suddenly

'Tremendous thunders echo through the halls, While ruin's hideous crash bursts o'er the affrighted walls.

Dread Horror seizes on her sinking heart, A mortal ehillness shudders at her breast; Ier soul shrinks fainting from Death's icy dart, The groan searce utter'd dies but half-exprest, And down she sinks in deadly swoon opprest;

But when, at lengtl, awakening from her trance

The terrors of her fate stand all confest,

In vain she casts around her timid glance, The rudely frowning scenes her former joys enhance.

No traces of those joys, alas! remain;

$A$ desert solitude alone appears.

No verlant shade relieves the sandy plain,

The wille-spread waste no gentle fountain cheers,

One barren face the dreary prospect wears;

Nought through the vast horizon meets her eye

'To calm the dismal tumult of her fears,

No trace of human habitation nigh,

A sandy wild beneath, above a threatening sky. 


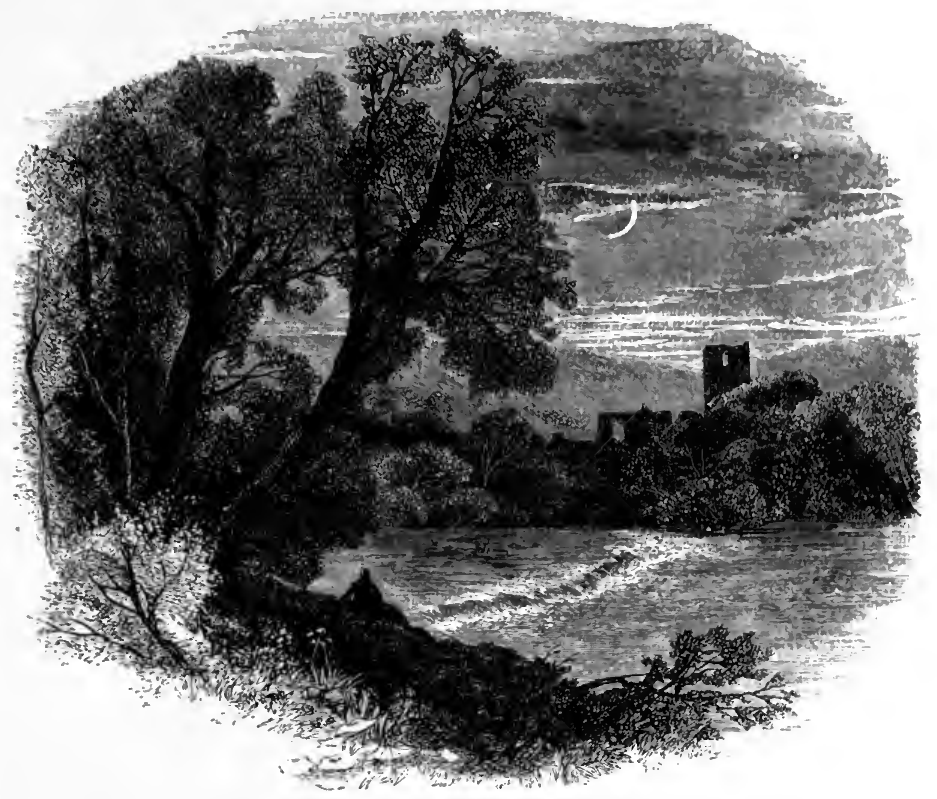

\section{ANN RADCLIFFE.}

\section{TO MELANCHOLY.}

SPIRIT of love and sorrow,-hail!

Thy solemn voice from far I hear, Mingling with Evening's dying gale, Hail, with this sadly-pleasing tear!

Oh, at this still, this lonely hour, Thine own sweet hour of closing day, Awake thy lute, whose charmful power Shall call up Fancy to obey; 
To paint the wild romantic dream,

That meets the poet's musing eye, As on the bank of shadowy stream

$\mathrm{He}$ breathes to her the fervid sigh.

O lonely spirit! let thy song

Lead me through all thy sacred haunt;

The minster's moonlight aisles along,

Where spectres raise the midnight chaunt.

I hear their dirges faintly swell!

Then sink at once in silence drear, While, from the pillar'd cloister's cell, Dimly their gliding forms appear!

Lead where the pine-woods wave on high, Whose pathless sod is darkly seen, As the cold moon, with trembling eye,

Darts her long beams the leaves betweer.

Lead to the mountain's dusky head, Where, far below, in shades profound, Wide forests, plains, and hamlets spread, And sad the chimes of vesper sound.

Or guide me where the dashing oar

Just breaks the stillness of the vale:

As slow it tracks the winding shore,

To meet the ocean's distant sail :

'To pebbly banks that Neptune laves, With measur'd surges, loud and deep;

Where the dark cliff bends o'er the waves, And wild the winds of Autumn sweep.

'There pause at midnight's spectred hour, And list the long-resounding gale; And catch the fleeting moonlight's power

O'er foaming seas and distant sail. 
ANN RADCLIFFE.

SONG OF A SPIRIT.

IN the sightless air I dwell,

On the sloping sunbeams play;

Delve the cavern's inmost cell,

Where never yet did daylight stray.

I dive beneath the green sea waves,

And gambol in the briny deeps;

Skim every shore that Neptune laves,

From Lapland's plains to India's steeps.

Oft I mount with rapid force,

Above the wide earth's shadowy zone,

Follow the day-star's flaming course,

Through realms of space to thought unknown;

And listen to celestial sounds

That swell in air, unheard of men,

As I wateh my nightly rounds

O'er woody steep and silent glen.

Under the shade of waving trees,

On the green bank of fountain clear,

At pensive eve $I$ sit at ease,

While dying music murmurs near.

And oft, on point of airy clift

That hangs upon the western main,

I watch the gay tints passing swift,

And twilight veil the liquid plain. 
Then, when the breeze has sunk away, And Ocean scarce is heard to lave, For me the sea-nymphs softly play Their dulcet shells beneath the wave.

Their dulcet shells!-I hear them now;

Slow swells the strain upon mine ear;

Now faintly falls-now warbles low, Till rapture melts into a tear.

The ray that silvers o'er the dew, And trembles through the leafy shade, And tints the scene with softer hue, Calls me to rove the lonely glade;

Or hie me to some ruin'd tower, Faintly shown by moonlight gleam, Where the lone wanderer owns my power, In shadows dire that substance seem;

In thrilling sounds that murmur woe, And pausing silence make more dread; In music breathing from below Sad, solemn strains, that wake the dead.

Unseen I move-unknown am fear'd ;Fancy's wildest dreams I weave; And oft by bards my voice is heard

To die along the gales of eve. 


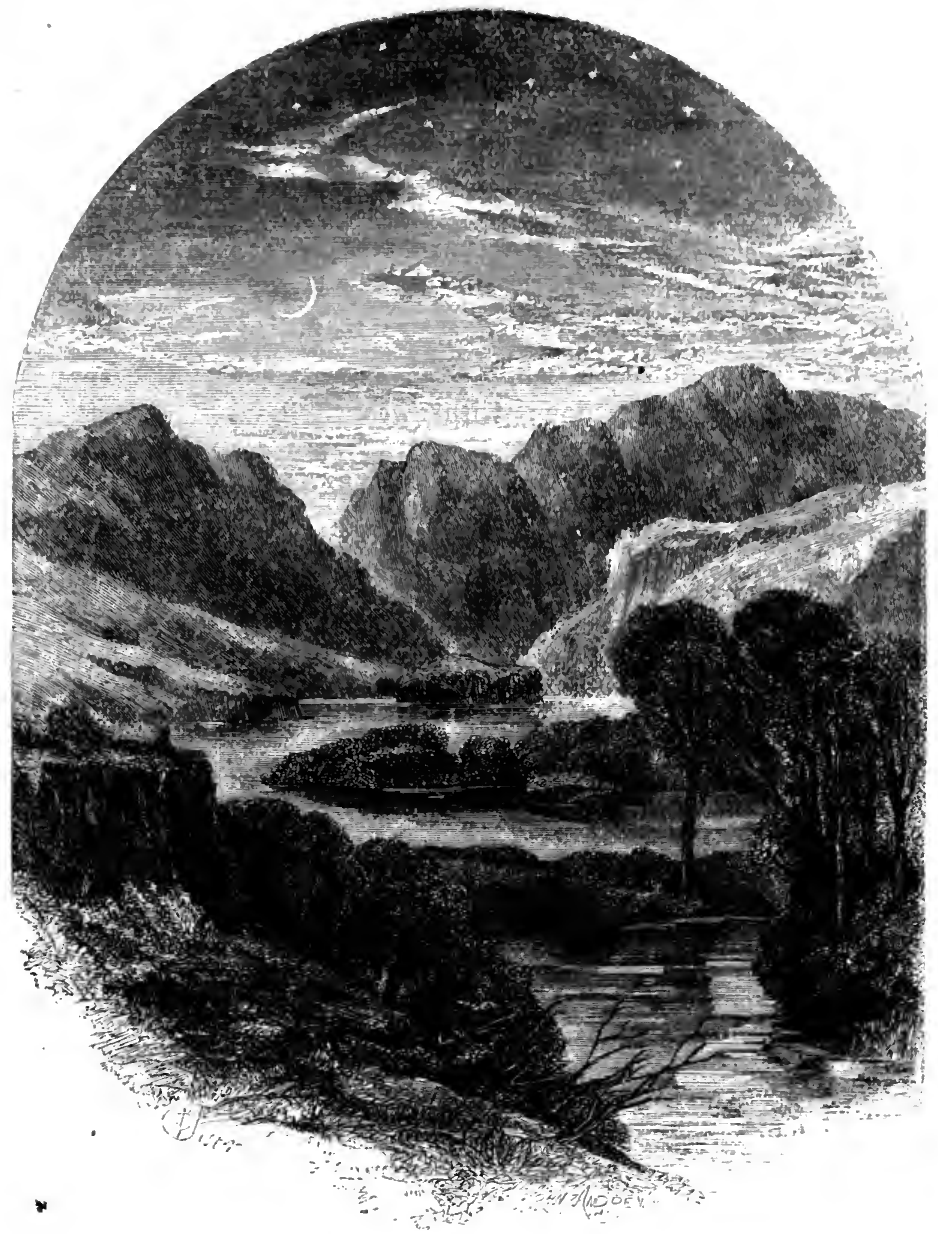

ANNA LETITIA BARBAULD.

\section{A SUMMER EVENING'S MEDITATION}

"One sun by day, by night ten thousand shine."-Jousk.

'Tis past,- - the sultry tyrant of the South

Has spent his short-liv'd rage; more grateful hours 


\section{A SUMMER EVENING'S MEDITATION.}

Move silent on; the skies no more repel

The dazzled sight, but, with mild maiden beams

Of temper'd lustre, court the cherish'd eye

To wander o'er their sphere; where hung alof't

Dias's bright crescent, like a silver bow,

New strung in heaven, lifts its beamy horns

Impatient for the night, and seems to push

Her brother down the sky. Fair Vexus shines

Even in the eye of day; with sweetest beam

Propitious shines, and shakes a trembling flood

Of soften'd radiance with her dewy locks.

The shadows spread apace; while meeken'd Eve,

Her cheek yet warm with blushes, slow retires

Through the Hesperian gardens of the West,

And shuts the gates of Day. 'Tis now the hour

When Contemplation, from her sunless haunts,

The cool damp grotto, or the lonely depth

Of unpiere'd woods, where wrapt in solid shade

She mus'd away the gaudy hours of noon,

And fed on thoughts unripen'd by the sun,

Moves forward; and with radiant finger points

'To yon blue coneave swell'd by breath divine,

Where, one by one, the living eyes of heaven

Awake, quick kindling o'er the face of ether

One boundless blaze; ten thousand trembling fires,

And dancing lustres, where th' unsteady eye,

Restless and dazzled, wanders unconfin'd

$\mathrm{O}$ er all this ficld of glories; spacious field,

And worthy of the Master: He, whose hand

With hieroglyphics elder than the Nile

Inseribed the mystie tablet; hung on high

To public gaze, and said, Adore, O man!

The finger of thy GoD. From what pure wells

Of milky light, what soft o'erflowing urn,

Are all these lamps so fill'd?-these friendly lamps,

For ever streaming o'er the azure deep

'Io point our path, and light us to our lome. 
How soft they slide along their lucid spheres! And, silent as the foot of 'Time, fulfil Their destin'd courses. Nature's self is hush'd, And, but a scatter'd leaf, which rustles through The thick-wove foliage, not a sound is heard To break the midnight air; though the rais'd ear, Intensely listening, drinks in every breath. How deep the silence, yet how loud the praise! But are they silent all? or is there not A tongue in every star that talks with man, And woos him to be wise? nor woos in vain: This dead of midnight is the noon of thought, And Wisdom mounts her zenith with the stars. At this still hour the self-collected soul Turns inward, and beholds a stranger there Of high descent, and more than mortal rank; An embryo God; a spark of fire divine, Which must burn on for ages, when the sun (Fair transitory creature of a day!)

Has clos'd his golden eye, and, wrapt in shades, Forgets his wonted journey through the East. Ye citadels of light, and seats of Gods! Perhaps my future home, from whence the soul, Revolving periods past, may oft look back, With recollected tenderness, on all The various busy scenes she left below, Its deep-laid projects and its strange events, As on some fond and doting tale that sooth'd Her infant hours-O be it lawful now To tread the hallow'd cirele of your courts, And with mute wonder and delighted awe Approach your burning confines. Seized in thought, On Fancy's wild and roving wing I sail, From the green borders of the peopled earth, And the pale moon, her duteous, fair attendant; From solitary Mars; from the vast orb 
Of Jupiter, whose huge gigantic bulk

Dances in ether like the lightest leaf;

To the dim verge, the suburbs of the system,

Where cheerless Saturn 'midst his wat'ry moons

Girt with a lueid zone, in gloomy pomp,

Sits like an exiled monarch: fearless thence

I launch into the trackless deeps of space,

Where, burning round, ten thousand suns appear,

Of elder beam, which ask no leave to shine

Of our terrestrial star, nor borrow light

From the proud regent of our scanty day;

Sons of the morning, first-born of creation,

And only less than Hin who marks their track,

And guides their fiery wheels. Here must I stop,

Or is there anght beyond? What hand unseen

Impels me onward through the glowing orbs

Of habitable nature, far remote,

To the dread confines of eternal night,

To solitudes of waste unpeopled space,

The deserts of creation, wide and wild;

Where embryo systems and unkindled suns

sleep in the womb of chaos? Fancy droops,

And Thought, astonish'd, stops her bold career.

But oh, thou mighty Mind! whose powerful word

Said, Thus let all things be, and thus they were,

Where shall I seek thy presence? how unblam'd

Invoke thy dread perfection?

II tave the broad eye-lids of the morn beheld thee?

Or does the beamy shoulder of Orion

Support thy throne? Oh, look with pity down

On erring, guilty man; not in thy names

Of terror clad; not with those thunders arm'd

That conscious Sinai felt, when fear appall'd

'The scatter'd tribes; thou hast a gentler voice, That whispers comfort to the swelling heart, Abashd, yet longing to behold her Maker! 
But now my soul, unus'd to stretch her powers In flight so daring, drops her weary wing, And seeks again the known accustom'd spot, Drest up with sun, and shade, and lawns, and streams, A mansion fair and spacious for its guests, And all replete with wonders. Let me here, Content and grateful, wait th' appointed time, And ripen for the skies: the hour will come When all these splendours bursting on my sight Shall stand unveil'd, and to my ravish'd sense Unlock the glories of the world unknown.

\section{A PETITION.}

If the soft hand of winning Pleasure leads By living waters, and through flowery meads, Where all is smiling, tranquil, and serene, And vernal beauty paints the flattering scene, Oh! teach me to elude each latent snare, And whisper to my sliding heart,-Beware! With caution let me hear the Syren's voice, And doubtful, with a trembling heart rejoice. If friendless in a vale of tears I stray, Where briers wound, and thorns perplex my way, Still let my steady soul thy goodness see, And, with strong confidence, lay hold on 'Thee;

With equal eye my various lot receive, Resign'd to die, or resolute to live;

Prepar'd to kiss the sceptre or the rod, While God is seen in all, and all in God. 


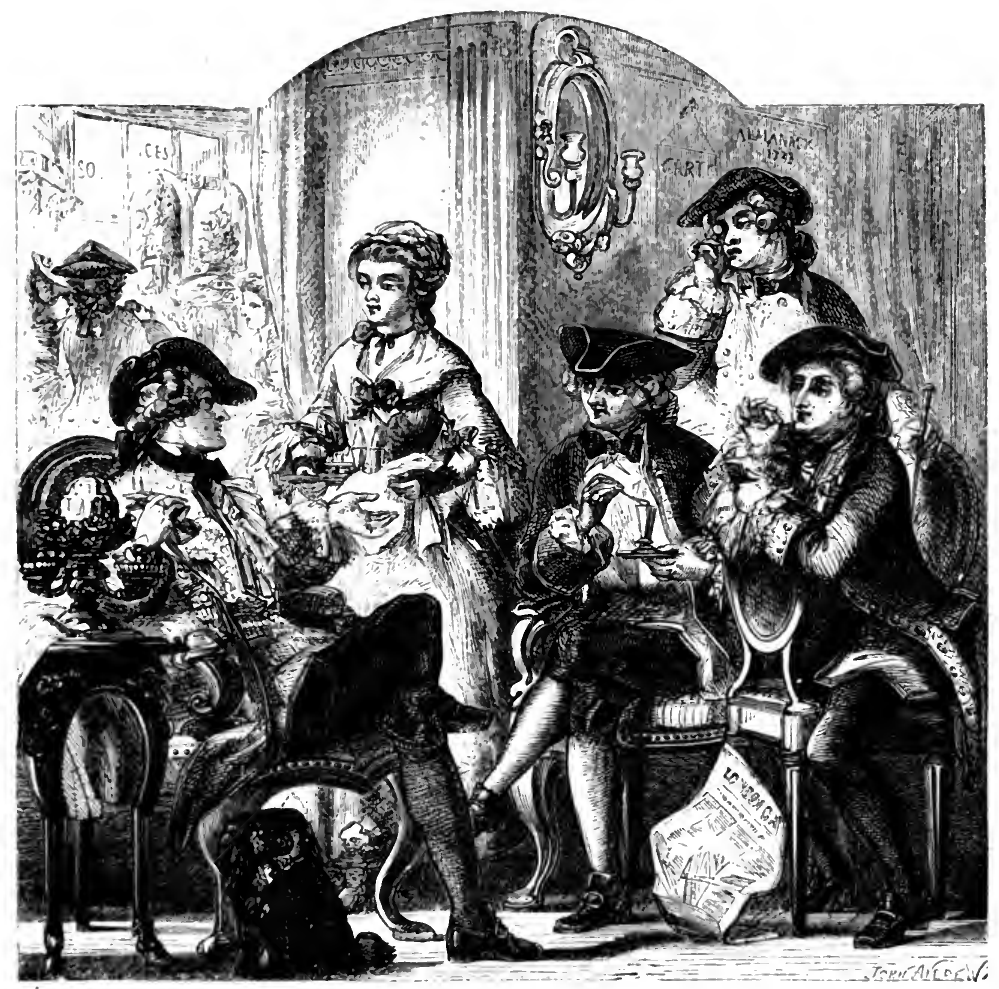

HANNAH MORE.

FLORIO AND HIS FRIEND

TWO PORTRAITS.

Flono, a youth of gay renown,

Who figurd much about the town,

Had pass'd, with general approbation,

The morlish forms of education ; 
Knew what was proper to be known, 'Th' establish'd jargon of Bon-ton;

Had learnt, with very moderate reading, The whole new system of good breeding:

He studied to be cold and rude, Though native feeling would intrude:

Unlucky sense and sympathy

Spoilt the vain thing he strove to be.

For Fuonio was not meant by nature,

A silly or a worthless creature:

He had a heart dispos'd to feel,

Had life and spirit, taste and zeal;

Was handsome, generous; but, by fate,

Predestin'd to a large estate!

Hence, all that grac'd his op'ning days

Was marr'd by pleasure, spoil'd by praise.

The Destiny, who wove the thread

Of Fronio's being, sigh'd, and said, "Poor youth! this cumbrous twist of gold, More than my shuttle well can hold, For which thy anxious fathers toil'd, Thy white and even thread has spoil'd:

'Tis this shall warp thy pliant youth.

From sense, simplicity, and truth;

Thy erring fire, by wealth misled,

Shall scatter pleasures round thy head,

When wholesome discipline's control

Should brace the sinews of thy soul;

Coldly thou'lt toil for learning's prize, For why should he that's rich be wise?"

The gracious Master of mankind,

Who knew us vain, corrupt, and blind,

In merey, though in anger, said,

'That man should earn his daily bread;

His lot inaction renders worse,

While labour mitigates the curse;

The idle life's worst burdens bear, 
And meet, what toil escapes, despair!

Forgive, nor lay the fault on me,

This mixture of mythology;

The Muse of Paradise has deign'd

With truth to mingle fables feign'd;

And though the Bard that would attain

The glories, Milton, of thy strain,

Will never reach thy style or thoughts,

He may be like thee-in thy faults!

Exhausted Fronio, at the age

When youth should rush on glory's stage,

When life should open fresh and new,

And ardent Hope her schemes pursue;

Of youthful gaiety bereft,

Had scarce an unbroach'd pleasure left;

IIe found already to his cost,

The shining gloss of life was lost;

And Pleasure was so coy a prude,

She fled the more, the more pursued;

Or if o'ertaken and caress'd,

He loath'd and left her when possess'd.

But Fronio knew the Worro; that science

Sets sense and learning at defiance;

He thought the World to him was known,

Whereas he only knew the Town;

In men this blunder still you find,

All think their little set-Mankind.

Though high renown the youth had gain'd,

No flagrant crimes his life had stain'd,

No tool of falsehood, slave of passion;

But spoilt by Custon, and the Fasmox.

Though known among a certain set,

IIe dill not like to be in debt;

He shudder'd at the dicer's box,

Nor thought it very heterodox

That tralesmen should be sometimes paid,

And bargains kept as well as made. 
His growing credit, as a sinner, Was that he lik'd to spoil a dinner;

Made pleasure and made business wait;

And still, by system, came too late;

Yet 'twas a hopeful indication

On which to found a reputation:

Small habits, well pursued, betimes

May reach the dignity of erimes;

And who a juster claim preferr'd

Than one who always broke his word?

His mornings were not spent in vice,

'Twas lounging, sauntering, eating ice ;

Walk up and down St. James's Street,

Full fifty times the youth you'd meet:

He hated cards, detested drinking,

But stroll'd to shun the toil of thinking;

'Twas doing nothing was his curse,-

Is there a vice can plague us worse?

'The wretch who digs the mine for breac,

Or ploughs, that others may be fed,

Feels less fatigue than that decreed

To him who cannot think, or read.

Not all the peril of temptations,

Not all the conflict of the passions,

Can quench the spark of Glory's flame,

Or quite extinguish Virtue's name,

Like the true taste for genuine saunter,

Like Sloth, the soul's most dire enchanter.

The active fires that stir the breast

Her poppies charm to fatal rest;

They rule in short and quick succession,

But Sцотн keeps one long, fast possession:

Ambition's reign is quickly clos'd,

'Th' usurper Rage is soon depos'd;

Intemperance, where there's no temptation,

Makes voluntary abdication;

Of other tyrants short the strife, 


\section{FLORIO AND HIS FRIEND.}

But Indolence is king for life:

'The despot twists, with soft control,

Eternal fetters round the soul.

Yet though so polish'd Fronio's breeding,

Think him not ignorant of reading:

For he, to keep him from the vapours,

Subscrib'd at Hooknay's, saw the papers;

Was deep in poet's-corner wit;

Knew what was in italics writ;

Explain'd fictitious names at will;

Each gutted syllable could fill.

There oft, in paragraphs, his name

Gave symptom sweet of growing fame;

'Though yet they only serv'd to hint

That Frorio lov'd to see in print

His ample buckles' alter'd shape,

His buttons chang'd, his varying cape ;

And many a standard phrase was his

Might rival bore, or banish quiz.

'The man who grasps this young renown, And early starts for Fashion's erown.

In time that glorious prize may wield, Which clubs and ev'n Newmarket yield.

He studied while he dress'd, for, true 'tis,

IIe read Compendiums, Extracts, Beauties, Abrégés, Dictionnaires, Recueils,

Mercures, Journaux, Extraits, and Feuilles:

No work in substance now is follow'd,

'The chemic extract only's swallow'd.

He lik'd those literary cooks.

Who skim the cream of others' books;

And ruin half an author's graces

liy plucking bon mots from their places.

IIe wonders any writing sells

But these spiced mushrooms and morells.

Ilis palate rorks alone can touch

Where every mouthful is bonne bouche. 
Some phrase that with the public took

Was all he read of any book;

For plan, detail, arrangement, system,

He let them go, and never miss'd 'em.

Of each new Play he saw a part,

And all the anas had by heart:

He found whatever they produce

Is fit for conversation-use ;

Learning so ready for display,

A page would prime him for a day:

They cram not with a mass of knowledge,

Which smacks of toil, and smells of college,

Which in the memory useless lies,

Or only makes men-good and wise.

This might have merit once, indeed,

But now for other ends we read.

A friend he had, Bellatio hight,

A reasoning, reading, learned wight;

At least, with men of Florio's breeding,

He was a prodigy of reading.

He knew each stale and vapid lie

In tomes of French philosophy;

And these, we fairly may presume,

From Pyrruo down to David Hune,

'Twere difficult to single out

A man more full of shallow doubt:

He knew the little sceptic prattle,

The sophist's paltry arts of battle;

Talk'd gravely of th' Atomic dance,

Of moral fitness, fate, and chance;

Admir'd the system of Lucretics,

Whose matchless verse makes nonsense specious!

To this his doctrine owes its merits,

Like pois'nous reptiles kept in spirits;

Though sceptics dull his schemes rehearse,

Who have not souls to taste his verse.

Beldario founds his reputation 
On dry, stale jokes about Creation; Would prove, by argument circuitous, The combination was fortuitous.

Swore priests' whole trade was to deceive, And prey on bigots who believe;

With bitter ridicule could jeer, And had the true free-thinking sneer. Grave arguments he had in store, Which had been answer'd o'er and o'er; And us'd, with wondrous penetration, The trite, old trick of false citation; From ancient authors fond to quote

A phrase, or thought, they never wrote. Upon his highest shelf there stood The Classics, neatly cut in wood; And in a more commodious station, You found them in a French translation: He swears, 'tis from the Greek he quotes, But keeps the French-just for the notes. He worshipp'd certain modern names Who history write in epigrams, In pointed periods, shining phrases, And all the small poetic daisies Which crowd the pert and florid style, Where fact is dropt to raise a smile; Where notes indecent or profime Serve to raise doubts, but not explain: Where all is spangle, glitter, show, And truth is overlaid below:

Arts scorn'd by History's sober Muse, Arts Clanexpos disdain'd to use.

Whate'er the subject of debate, 'Twas larded still with sceptic prate; Begin whatever theme you will, In unbelief' he lands you still:

The gool, with shame I speak it, feel Not half this proselyting zeal: 
While cold their Master's cause to own,

Content to go to heav'n alone,

The infidel, in liberal trim,

Would carry all the world with him;

Would trust his wife, friend, kindred, nation,

Mankind-with what? Annihilation.

Though Florio did not quite believe him,

He thought, why should a friend deceive him?

Much as he prized Bellario's wit,

He lik'd not all his notions yet;

He thought him charming, pleasant, odd,

But hop'd one might believe in God;

Yet such the charms that grac'd his tongue,

He knew not how to think him wrong.

Though Flonio tried a thousand ways,

Truth's insuppressive torch would blaze:

Where once her flame has burnt, I doubt

If ever it go fairly out.

Yet, under great Beluario's care,

He gain'd each day a better air;

With many a leader of renown,

Deep in the learning of the Town,

Who never other science knew,

But what from that prime source they drew;

Pleas'd, to the Opera they repair,

To get recruits of knowledge there;

Mythology gain at a glance,

And learn the Classics from a dance:

In Ovid they ne'er car'd a groat

How far'd the vent'rous Argonaut;

Yet charm'd they see Medea rise

On fiery dragons to the skies.

For Dido, though they never knew her

As Maro's magic pencil drew her,

Faithful and fond, and broken-hearted,

Her pious Vagabond departed,

Yet, for Didone how they roar ! 


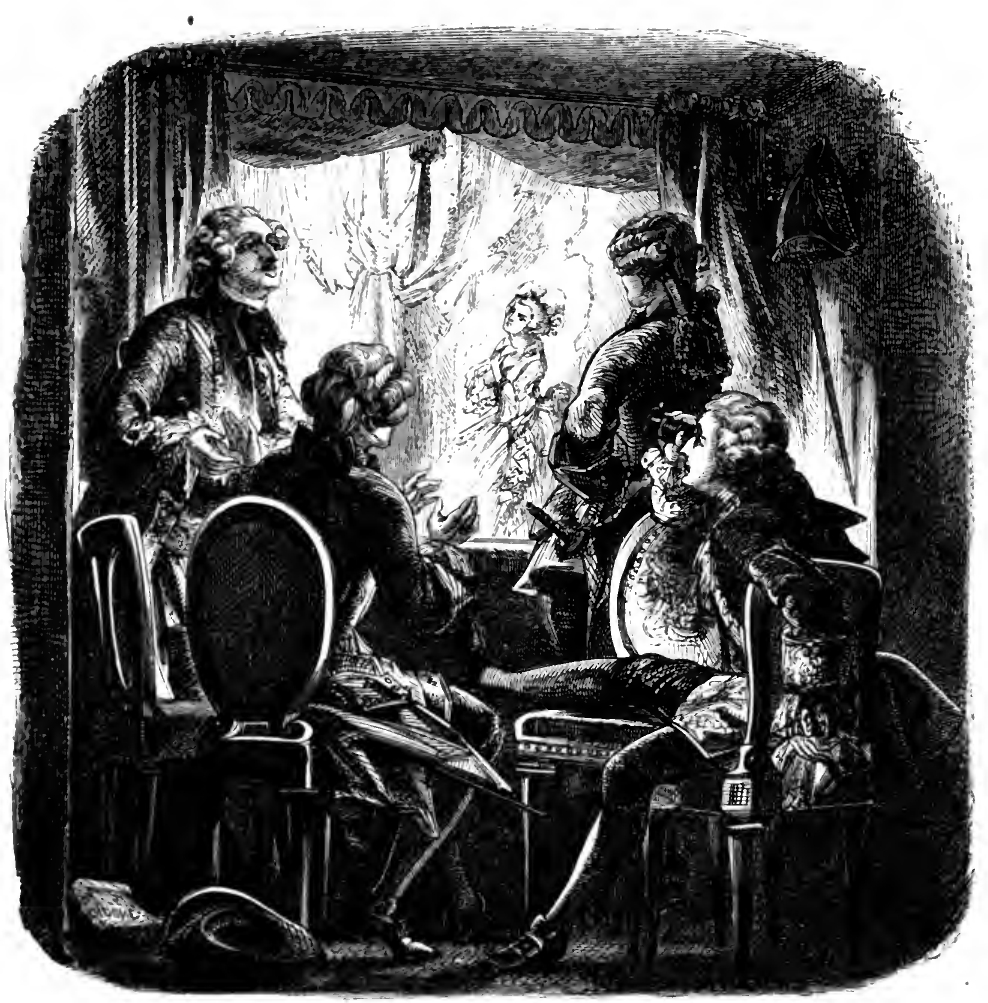

And Cara! Cara! loud encore.

One taste Beilanio's soul possess'd, 'The master-passion of his breast;

It was not one of those frail joys, Which, by possession, quickly cloys;

This bliss was solid, constant, true,

"Twats action, and 'twas passion too, For though the business might be finish'd, 
The pleasure scarcely was diminish'd;

Did he ride out, or sit, or walk, He liv'd it o'er again in talk; Prolong'd the fugitive delight, In words by day, in dreams by night. 'Twas eating did his soul allure, A deep, keen, modish Epicure; Though once this name, as I opine, Meant not such men as live to dine; Yet all our modern Wits assure us, That's all they know of Epicunus: They fondly fancy, that repletion Was the chief good of that fam'd Grecian.

To live in gardens full of flowers, And talk philosophy in bowers, Or, in the covert of a wood, To descant on the sovereign good, Might be the notion of their founder, But they have notions vastly sounder: Their bolder standards they erect, To form a more substantial sect; Old Epicunus would not own 'em, A Dinner is their summum bonum;

More like you'll find such sparks as these 'To Epicurus" deities ;

Like them, they mix not with affairs, But loll and laugh at human cares.

To beaux this difference is allow'd, They choose a sofa for a cloud. Bellario had embrac'd with glee This practical philosophy. 


\section{BOWLES.}

\section{RETURN TO OXFORD.}

\section{- CHERWELL.}

Cherwer.t! how pleased along thy willow'd edge Erewhile I stray'd; or when the morn began

'To tinge aloft the turret's golden fan, Or Evening glimmer'd o'er the sighing sedge, And now, reclin'd upon thy banks once more,

I bid the pipe FAREwell, and that sad lay

Whose music on my melancholy way I woo'd, beneath thy willows waving hoar, Seeking to rest-till the returning sun

Of joy beam out, as when Heavex's humid bow Shines silent on the passing storm below; Whate'er betide, yet something have I won Of solace, that may bear me on serene, 'Till Eve's dim hand shall elose the sinking scene.

\section{ON THE RHINE.}

'Twas morn, and beantiful the mountains' brow,IImy with the clusters of the bending vine-

shone in the early light, when on the Rurse We sallil, and heard the waters round the prow In murmurs parting; varying as we go, Rocks after rocks come forward and retire, As some grey convent-wall, or sunlit spire Starts up, along the banks, unfolding slow. 


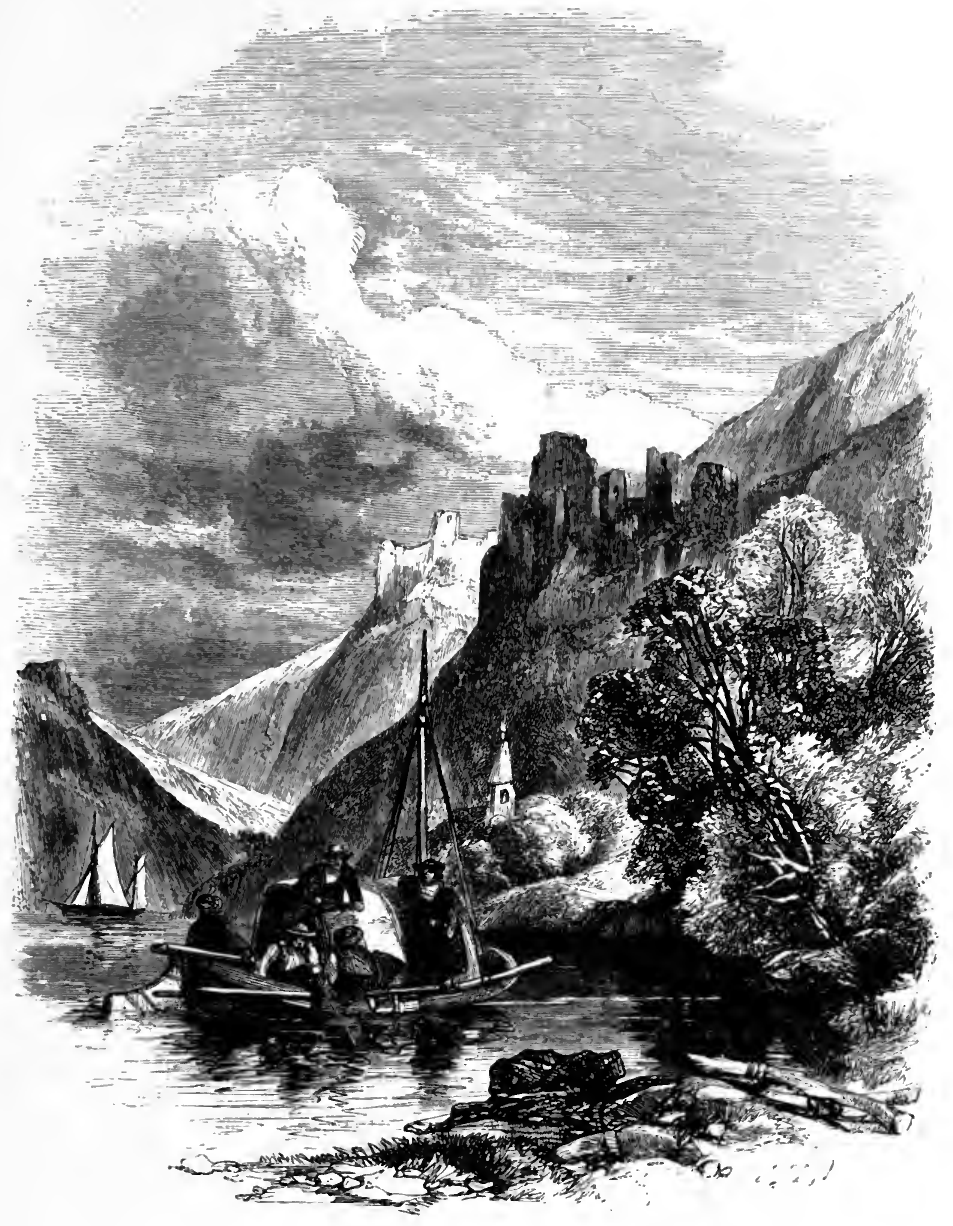

Here castles, like the prisons of despair,

Frown as we pass! - There, on the vineyard's side, The bursting sunshine pours its streaming tide;

While Grief, forgetful amid scenes so fair,

Counts not the hours of a long summer's day,

Nor heeds how fast the prospect winds away. 


\section{THE CELL OF THE MISSIONARY.}

Frovting the ocean, but beyond the ken Of public view, and sounds of murm'ring men,Of unhewn roots compos'd, and gnarlèd wood, A small and rustic Oratory stood:

Upon its roof of reeds appear'd a cross, The porch within was lin'd with mantling moss;

A crucifix and hour-glass, on each side-

One to admonish seem'd, and One to guide;

This, to impress how soon life's race is o'er;

And that, to lift our hopes where time shall be no more.

O'er the rude porch, with wild and gadding stray,

'The clust'ring copu weav'd its trellis gay:

Two mossy pines, high bending, interwove

Their aged and fantastic arms above.

In front, amid the gay surrounding flowers,

A dial counted the departing hours,

On which the sweetest light of summer shone, -

A rude and brief inscription mark'd the stone:-

"To count, with passing shade, the hours,

I plac'd the dial 'nid the flowers,

That, one by one, came forth, and died,

Blooming, and with'ring, round its side.

Mortal, let the sight impart

Its pensive moral to thy heart!"

Just heard to trickle through a covert near, And soothing, with perpetual lapse, the ear,

A fount, like rain-drops, filter'd through the stone,-

And, bright as amber, on the shallows shone.

Intent his fairy pastime to pursue,

And, gem-like, hovering o'er the violets blue, 
The humming-bird, here, its unceasing song Heedlessly murmur'd all the summer long; And when the winter came, retir'd to rest, And from the myrtles liung its trembling nest, No sounds of a conflicting world were near;

The noise of ocean faintly met the ear,

That seem'd, as sunk to rest the noon-tide blast,

But dying sounds of passions that were past;

Or closing anthems, when, far off, expire

The lessening echoes of the distant choir.

Here, every human sorrow hush'd to rest, His pale hands meekly cross'd upon his breast, Axselso sat: the sun, with west'ring ray, Just touch'd his temples, and his locks of grey.

There was no worldly feeling in his eye;The world to him "was as a thing gone by." Now, all his features lit, he rais'd his look, Then bent it thoughtful, and unclasp'd the book; And whilst the hour-glass shed its silent sand, A tame opossum lick'd his wither'd hand. That sweetest light of slow-declining day, Which through the trellis pour'd its slanting ray, Resting a moment on his few grey hairs, Seem'd light from heaven sent down to bless his pray'rs.

When the trump echo'd to the quiet spot, He thought upon the world, but mourn'd it not; Enough if his meek wisdom could control, And bend to mercy, one proud soldier's soul; Enough, if while these distant scenes he trod, He led one erring Indian to his God. 
THE HOME OF THE OLD INDIAN.

\section{THE HOME OF THE OLD INDIAN.}

Beneatu aërial eliffs, and glittering snows, The rush-roof of an aged warrior rose, Chief of the mountain tribes: high, overhead, The Andes, wild and desolate, were spread, Where cold Sierras shot their icy spires, And Chillax trail'd its smoke, and smould'ring fires.

$A$ glen beneath-a lonely spot of rest-

Ilung, scarce discover'd, like an eagle's nest.

Summer was in its prime; - the parrot-flocks

Darken'd the passing sunshine on the rocks;

The chrysomel and purple butterfly,

Amid the clear blue light, are wand'ring by;

The humming-bird, along the myrtle bow's, With twinkling wing, is spinning o'er the flow'rs,

The woodpecker is heard with busy bill,

The mock-bird sings-and all beside is still.

And look! the eataraet, that bursts so high

As not to mar the deep tranquillity,

'The tumult of its dashing fall suspends,

And, stealing drop by drop, in mist descends;

'Through whose illumin'd spray and sprinkling dews,

Shine to the adverse sun the broken rainbow hues.

Check'ring, with partial shade, the beams of noon,

And arching the grey rock with wild festoon,

Ilere, its gay net-work, and fantastic twine,

The purple eogul threads from pine to pine,

And oft, as the fresh airs of morning breathe,

Dips its long tendrils in the stream beneath.

'There, through the trunks, with moss and lichens white, The sunshine darts its interrupted light, 
And, 'mid the cedars' darksome boughs, illumes, With instant touch, the lori's scarlet plumes.

So smiles the scene; - but can its smiles impart

Aught to console yon mourning warrior's heart?

He heeds not now, when, beautifully bright,

The humming-bird is eircling in his sight;

Nor e'en, above his head, when air is still,

Hears the green woodpecker's resounding bill;

But, gazing on the rocks and mountains wild,

Rock after rock, in glittering masses, pil'd

To the volcano's cone, that shoots so high

Grey smoke, whose column stains the eloudless sky,

He cries, "Oh! if thy spirit yet be fled

'To the pale kingdoms of the shadowy dead,-

In yonder track of purest light above,

Dear, long-lost object of a father's love,

Dost thou abide? or, like a shadow come,

Circling the scenes of thy remember'd home,

And passing with the breeze? or, in the beam

Of evening, light the desert mountain-stream?

Or at deep midnight are thine accents heard,

In the sad notes of that melodious bird,

Which, as we listen with mysterious dread,

Brings tidings from our friends and fathers dead?

Perhaps, beyond those summits, far away,

Thine eyes yet view the living light of day;

Sad, in the stranger's land, thou mayst sustain

A weary life of servitude and pain,

With wasted eye gaze on the orient beam,

And think of these white roeks and torrent-stream,

Never to hear the sunmer cocoa wave,

Or weep upon thy father's distant grave."

YE, who have wak'd, and listen'd with a tear, When cries confus'd, and clangours roll'd more near' With murmur'd prayer, when Mercy stood aghast, 
As War's black trump peal'd its terrific blast, And o'er the wither'd earth the armèd giant pass'd. YE, who his track with terror have pursued, When some delightful land, all blood-imbued, He swept; where silent is the champaign wide, That echo'd to the pipe of yester-tide, Save, when far off, the moonlight hills prolong The last deep echoes of his parting gong;

Nor aught is seen, in the deserted spot Where trail'd the smoke of many a peaceful cot, Save livid corses that unburied lie, And conflagrations, reeking to the sky; Come listen, whilst the causes I relate That bow'd the warrior to the storms of fate, And left these smiling scenes forlorn and desolate.

In other days, when, in his manly pride, 'Two children for a father's fondness vied,Oft they essay'd, in mimic strife, to wield His lance, or laughing peep'd behind his shield.

Oft in the sun, or the magnolia's shade, Lightsome of heart, as gay of look, they play'd, Brother and sister: She, along the dew, Blithe as the squirrel of the forest, flew; Blue rushes wreath'd her head; her dark brown hair Fell, gently lifted, on her bosom bare;

Her necklace shone, of sparkling insects made, That flit, like specks of fire, from sun to shade.

Light was her form; a clasp of silver brac'd The azure-dyed ichella round her waist;

Her ancles rung with shells, as, unconfin'd, She danc'd, and sung wild carols to the wind. With snow-white teeth, and laughter in her eye,So, beatutiful in youth, she bounded by.

Yet kindness sat upon her aspect bland,The tame alpaca stood and lick'd her hand; She brought him gather'd moss, and lov'd to deck With flow'ry twine his tall and stately neck, 


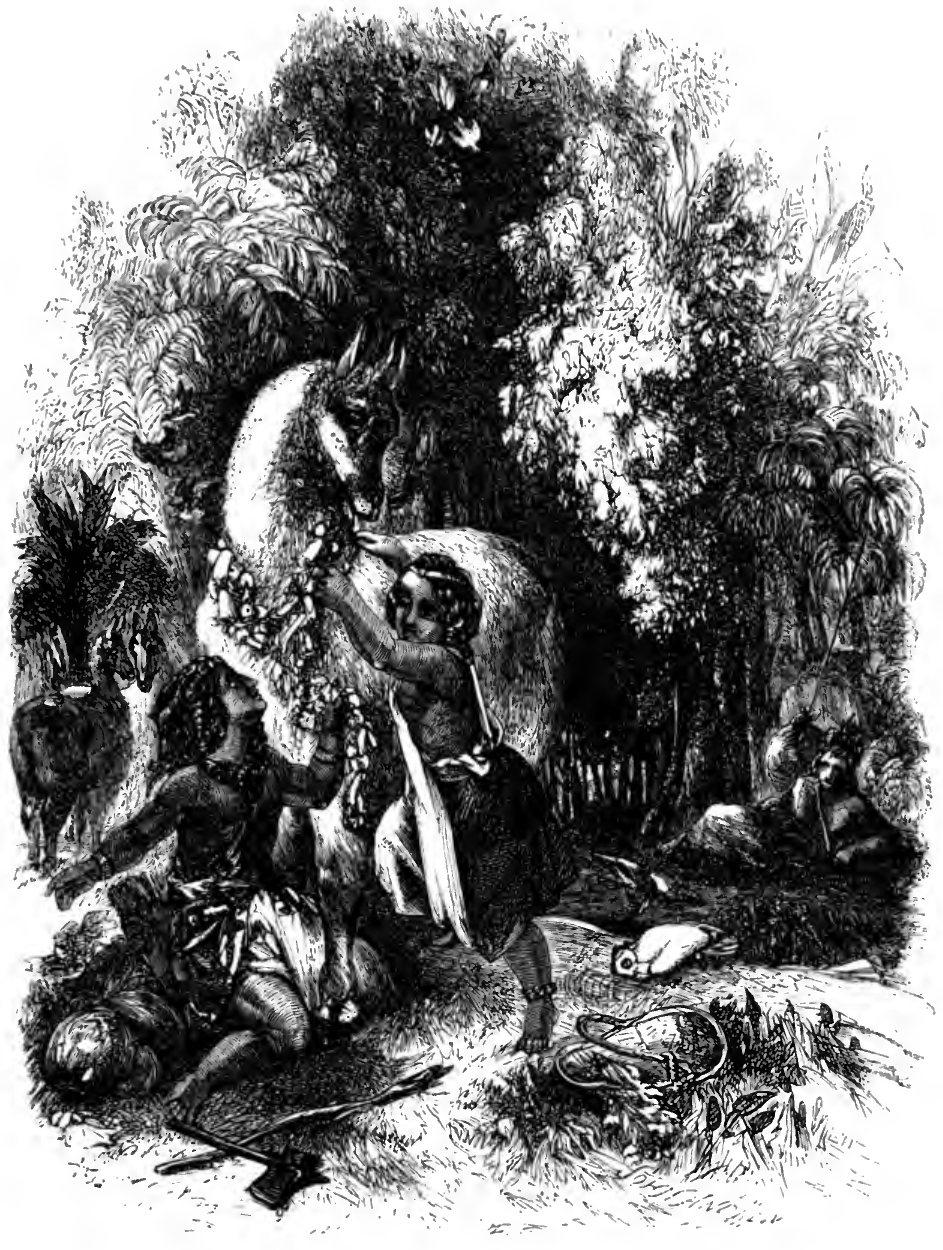

Whilst he with silent gratitude replies,

And bends to her caress his large blue eyes.

These children danc'd together in the shade,

Or stretch'd their hands to see the rainbow fade; 
Or sat and mock'd, with imitative glee, The paroquet, that laugh'd from tree to tree;

Or through the forest's wildest solitude, From glen to glen the marmozet pursued;

And thought the light of parting day too short, 'That call'd them, ling'ring, from their daily sport.

In that fair season of awak'ning life, When dawning youth and childhood are at strife;

When on the verge of thought gay boyhood stands 'Tip-toe, with glist'ning eye and outspread hands; With airy look, and form and footsteps light, And glossy locks, and features berry-bright, And eye like the young eaglet's to the ray Of noon, unblenching, as he sails away;

A brede of sea-shells on his bosom strung, A small stone hatchet o'er his shoulders slung, With slender lance, and feathers blue and red, That like the heron's crest wav'd on his head,Buoyant with hope, and airiness, and joy, Lautaro was the loveliest Indian boy:

Taught by his sire, ev'n now he drew the bow, Or track'd the jaguar on the morning snow; Startled the condor on the craggy height; 'Then silent sat, and mark'd its upward flight, Lessening in ether to a speck of, white.

But when th' impassioned Chieftain spoke of war, Smote his broad breast, or pointed to a scar,spoke of the strangers of the distant main, And the proud banners of insulting Spain,Of the barb'd horse and iron horseman spoke, And his red gods, that, wrapp'd in rolling smoke, Roard from the guns, - the Boy, with still-drawn breati, IIung on the wondrous tale, as mute as death;

'Then rais'd his animated eyes, and cried,

"O! Let Me perisil hy MY father's Side!" 


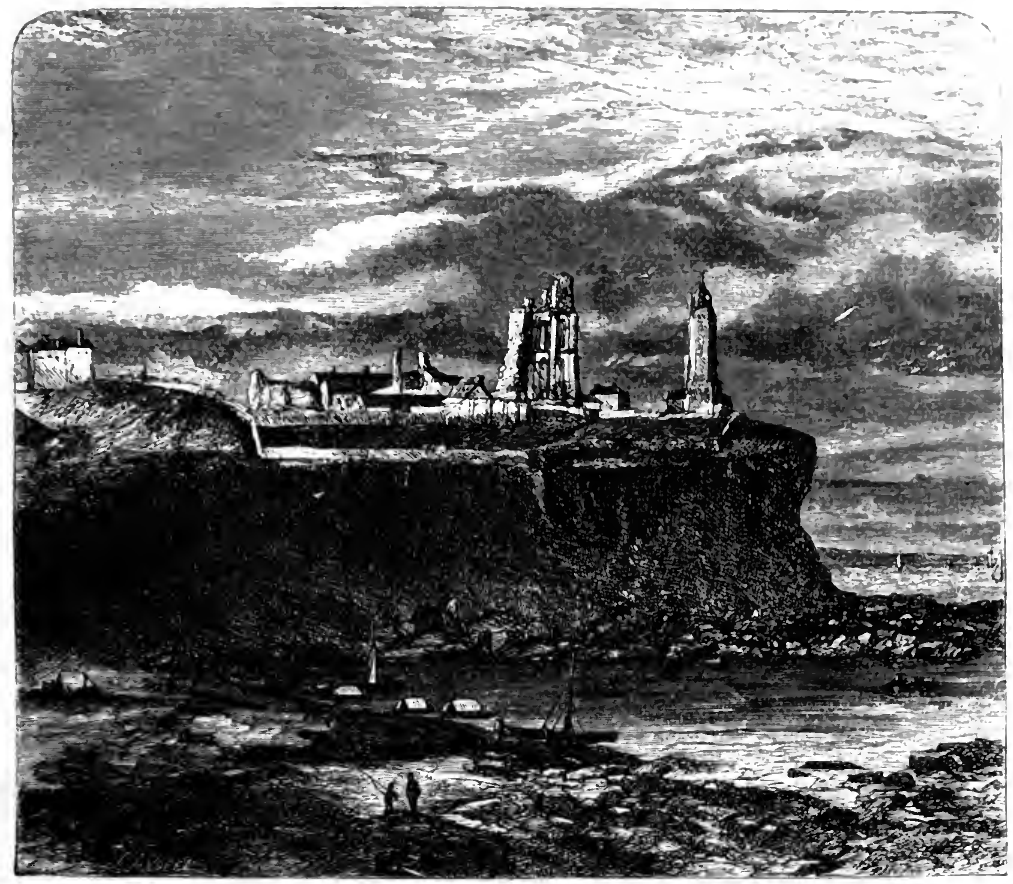

LANDING AT TYNEMOUTH.

As slow I. climb the cliff's ascending side, Much musing on the track of terror past,

When o'er the dark wave rode the howling blastPleas'd I look back, and view the tranquil tide That laves the pebbled shore: and now the beam

Of evening smiles on the grey battlement

Of yon forsaken tower that Tive has rent;

The lifted oar far off with transient gleam

Is touch'd, and hush'd is all the billowy deep, 
O'er-spent; oh! when on wakeful Memory's breast

Shall stillness steal like this, and kindred rest? Then some sweet harmonies might soothe her sleep, Harmonies, on the wandering minstrel's lyre, Like airs of parting day, that, as they breathe, expire.

\section{THE BURIAL PLACE.}

The Indian, sad and still, Pac'd on from wood to vale, from vale to hill; Her infant, tir'd, and hush'd awhile to rest, Smil'd, in a dream, upon its mother's breast; The pensive mother grey Anselmo led:

Behind, Lautaro bore his Father dead.

Beneath the branching palms they slept at night; The small birds wak'd them ere the morning light. Before their path, in distant view, appear'd The mountain-smoke, that its dark colımn rear'd O'er Axwes' summits, in the pale blue sky, Lifting their icy pinnacles so high.

Four days they onward led their eastern way:

On the fifth rising morn before them lay

Cunldax's lone glen, amid whose windings green The Warrior's lov'd and last abode was seen.

No smoke went up, - -stillness was all around, Save where the waters fell with soothing sound, Save where the Thenca sung so loud and clear, And the bright humming-bird was spinning near. 


\section{BOWLES.}

Yet here all human tumults seen'd to cease, And sunshine rested on the spot of peace;

The myrtles bloom'd as fragrant and as green As if Lautaro scarce had left the scene,And in his ear the falling water's spray Seem'd swelling with the sounds of yesterday. -

"Where yonder rock the aged cedars shade, There shall my father's bones in peace be laid."

Beneath the cedars' shade they dug the ground;

The small and sad communion gather'd round.

Beside the grave stood aged Izdabel, And broke the spear, and cried, "Farewell!-farewell!" Lautaro hid his face, and sigh'd "Adieu!" As the stone hatchet in the grave he threw. The little child, that to its mother clung, With sidelong looks, that on her garment hung, Listen'd, half-shrinking, as with awe profound, And dropt its flowers, unconscious, on the ground.

The Alpaca, grown old, and almost wild, Which poor Olola cherish'd, when a child, Came from the mountains, and, with earnest gaze, Seem'd as rememb'ring those departed days, When his tall neck he bent, with aspect bland, And lick'd, in silence, the caressing hand!

And now Anselmo, his pale brow inclin'd, The Warrior's relies, dust to dust, eonsign'd With Christian rites, and sung, on bending knee, "Eternam pacem doxa, Domine."

Then, rising up, he clos'd the holy book, And lifting in the beam his lighted look, (The cross, with meekness, folded on his breast,)"Here, too," he eried, "my bones in peace shall rest!

Few years remain to me, and never more Shall I behold, O Spain, thy distant shore! 


\section{SUNRISE.}

Here lay my bones, that the same tree may wave O'er the poor Christian's and the Indiax's grave. Then may it-(when the sons of future days

Shall hear our tale, and on the hillock gaze)Then may it teach, that charity should bind, Where'er they roam, the brothers of mankind! The time shall come, when wildest tribes shall hear Thy voice, O Christ! and drop the slaught'ring spear."

\section{SUNRISE.}

'Tis dawn:- the distant Andes' rocky spires, One after one, have caught the orient fires. Where the dun condor shoots his upward flight, His wings are touch'd with momentary light. Meantime, beneath the mountains' glittering heads,

A boundless ocean of grey vapour spreads, That o'er the champaign, stretching far below, Moves on, in cluster'd masses, rising slow, 'Till all the living landscape is display'd

In various pomp of colour, light, and shade; Hills, forests, rivers, lakes, and level plain, Iess'ning in sunshine to the southern main. The Llama's fleece fumes with ascending dew; 'The gem-like humming-birds their toils renew; 


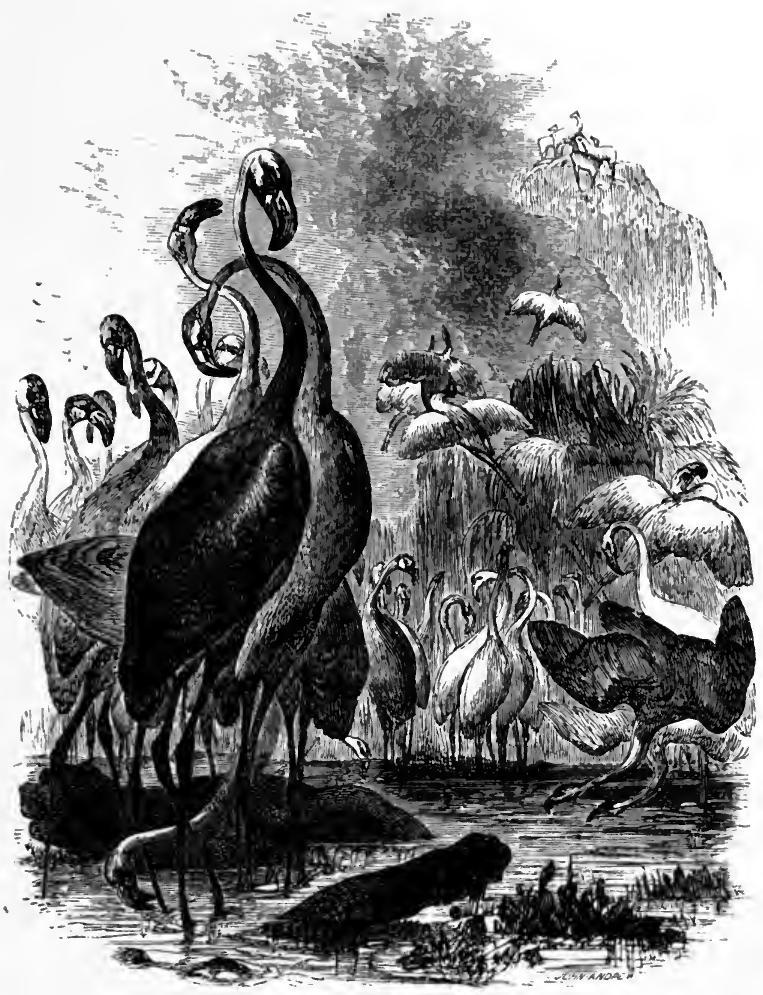

And see, where yonder stalks, in crimson pride, 'The tall flamingo, by the river's side,-

Stalks, in his richest plumage bright array'd, With snowy neck superb, and legs of length'ning shade. 


\section{ROGERS.}

THE OLD HOUSE.

Mark yon old Mansion frowning thro' the trees, Whose hollow turret woos the whistling breeze. 'That casement, arch'd with ivy's brownest shade, First to these eyes the light of heaven convey'd. The mould'ring gateway shows the grass-grown court, Once the calm scene of many a simple sport; When nature pleas'd, for life itself was new, And the heart promis'd what the fancy drew. See, through the fractur'd pediment reveal'd, Where moss inlays the rudely sculptur'd shield, The martin's old, hereditary nest-

Long may the ruin spare its hallow'd guest!

As jars the hinge, what sullen echoes call!

Oh haste, unfold the hospitable hall!

That hall, where once in antiquated state, The chair of justice held the grave debate.

Now. stain'd with dews, with cobwebs darkly hung,

Oft has its roof with peals of rapture rung;

When round yon ample board, in due degree,

We sweeten'd every meal with social glee.

The heart's light laugh pursued the circling jest, And all was sunshine in each little breast. 'Twas here we chas'd the slipper by the sound; And turn'd the blind-fold hero round and round. 'Twas here, at eve, we form'd our fairy ring; And Fancy flutter'd on her wildest wing. 


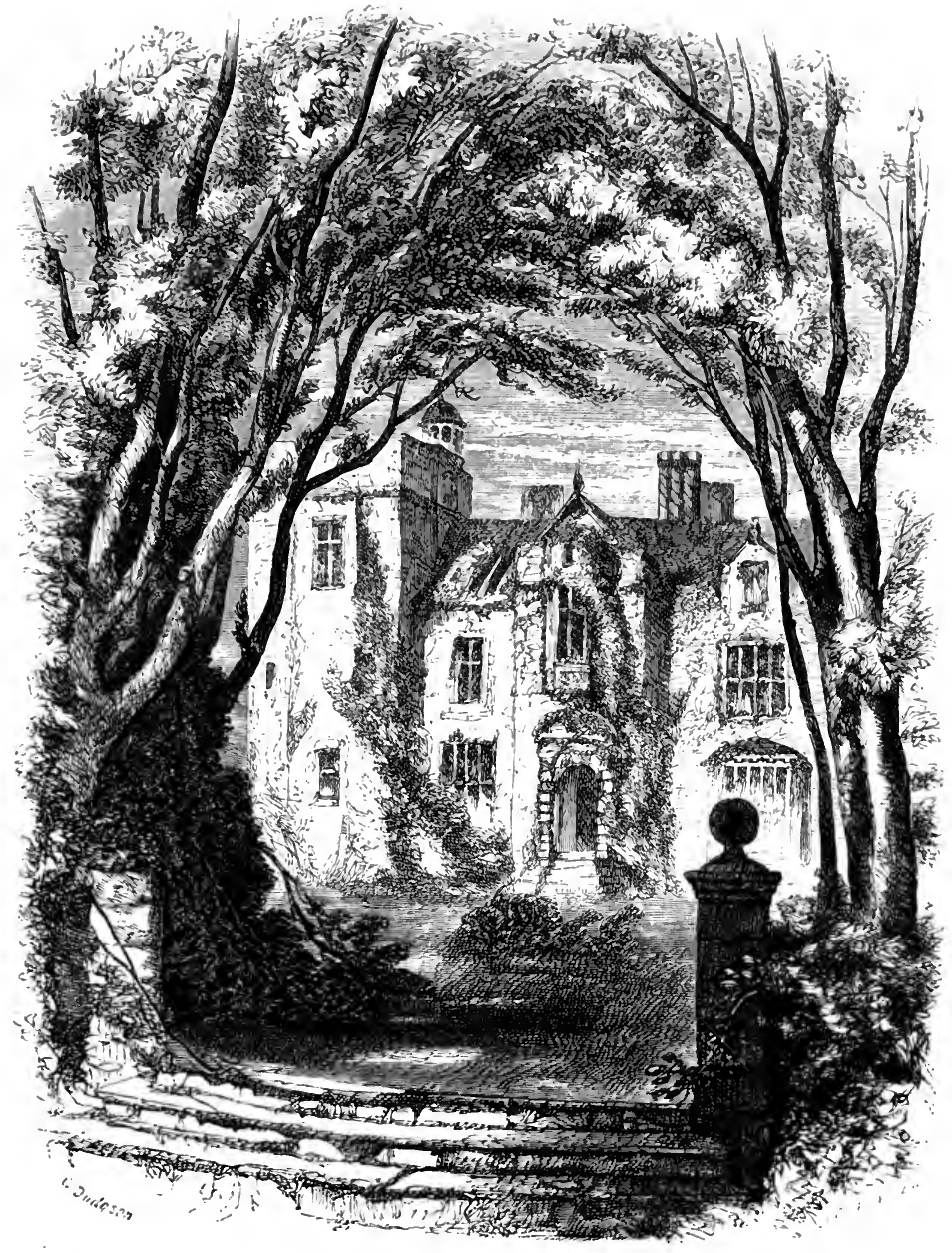

Giants and genii elaim'd each wondering ear; And orphan-sorrows drew the ready tear. Oft. with the babes we wander'd in the wood, Or view'd the forest-feats of Robin Hood; 
Oft, fancy led, at midnight's fearful hour With startling step we scal'd the lonely tower;

O'er infant innocence to hang and weep, Murder'd by ruffian hands, when smiling in its sleep.

As o'er the dusky furniture I bend,

Each chair awakes the feelings of a friend.

'The storied arras, source of fond delight,

With old achievements charms the wilder'd sight;

And still, with heraldry's rich hues imprest,

On the dim window glows the pictur'd crest.

The screen unfolds its many-colour'd chart,

The elock still points its moral to the heart.

That faithful monitor 'twas heaven to hear,

When soft it spoke a promis'd pleasure near;

And has its sober hand, its simple chime,

Forgot to trace the feather'd feet of Time?

'The massive beam, with curious carving wrought,

Whence the caged linnet sooth'd my pensive thought;

'Those muskets, eased with venerable rust;

'Those once-lov'd forms, still breathing thro' their dust;

Still from the frame, in mould gigantic cast,

Starting to life-all whisper of the Past!

\section{MOTHER AND CHILD.}

TuE day arrives, the moment wish'd and fear'd:

The child is born, by many a pang endear'd:

And now, the Mother's ear has caught his ery!

Oh! grant the cherub to her asking eye.

He comes:- he dasps him! To her bosom prest,

Ile drinks the balm of life, and drops to rest.

Ifer by her smile how soon the Stramger knows;

IIow soon by his the glad discovery shows! 
As to her lips she lifts the lovely boy,

What answering looks of sympathy and joy!

IIf walks, he speaks. In many a broken word

His wants, his wishes, and his griefs are heard;

And ever, ever to her lap he flies,

When rosy Sleep comes on with sweet surprise.

Lock'd in her arms, his arms across her flung,

(That name most dear for ever on his tongue,)

As with soft accents round her neck he clings, And, cheek to eheek, her lulling song she sings,

How blest to feel the beatings of his heart,

Breathe his sweet breath, and kiss for kiss impart;

Watch o'er his slumbers like the brooding dove, And, if she can, exhaust a mother's love!

But soon a nobler task demands her care, Apart she joins his little hands in prayer, Telling of Him who sees in secret there: And now the volume on her knee has caught His wandering eye-now many a written thought

Never to die, with many a lisping sweet,

His moving, murmuring lips endeavour to repeat.

Released, he chases the bright butterfly;

Oh, he would follow-follow through the sky!

Climbs the gaunt mastiff slumbering in his chain, And chides and buffets, clinging by the mane;

Then runs, and kneeling by the fountain-side, Sends his brave ship in triumph down the tide,

A dangerous voyage; or, if now he can,

If now he wears the habit of a man,

Flings off the coat so much his pride and pleasure, And, like a miser digging for his treasure, His tiny spade in his own garden plies, And in green letters sees his name arise! Where'er he goes, for ever in her sight, She looks, and looks, and still with new delight. 


\section{AMELIA OPIE.}

THE ORPHAN BOY'S TALE.

Stur, Lady, stay, for mercy's sake,

And hear a helpless Orphan's tale:

Ah! sure my looks must pity wake;

'Tis want that makes my cheek so pale.

Yet I was once a mother's pride,

And my brave father's hope and joy;

But in the Nile's proud fight he died-

And I am now an orphan boy.

Poor foolish ehild! how pleased was I, When news of Nelson's victory came, Along the erowded streets to fly, And see the lighted windows flame!

To force me home my mother sought,

She could not bear to see my joy;

For with my father's life 'twas bought,

And made me a poor orphan boy.

The people's shouts were long and loud,-

My mother, shudd'ring, closed her ears;

"Rejoice! rejoice!" still cried the crowd,-

My mother answer'd with her tears.

"Why are you crying thus," said I,

"While others laugh and shout with joy?"

She kiss'd me-and, with such a sigh!

she eallil me her poor orphan boy. 


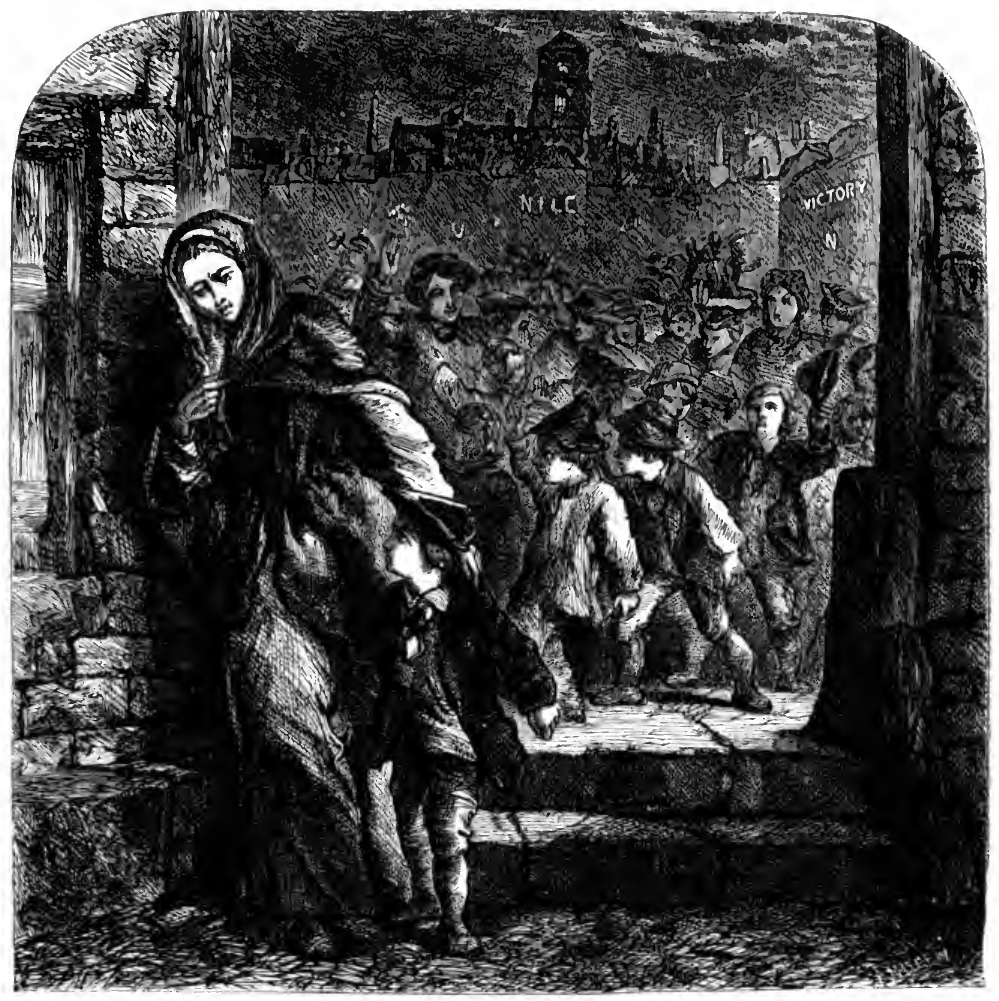

"What is an orphan boy?" I cried, As in her face I look'd and smiled; My mother through her tears replied, "You'll know too soon, ill-fated child!" And now they've toll'd my mother's knell, And I'm no more a parent's joy,-O Lady,-I have learnt too well What 'tis to be an orphan boy. 
Oh! were I by your bounty fed!-

Nay, gentle Lady, do not chide,-

Trust me, I mean to earn my bread;

The sailor's orphan boy has pride.

Lady, you weep!-ha! - this to me?

You'll give me clothing, food, employ?

Look down, dear parents! look, and see

Your happy, happy orphan boy.

\section{WILLIAM SPENCER}

TO THE LADY ANNE HAMILTON.

'Too late I stay'd, forgive the crime, Unheeded flew the hours;

How noiseless falls the foot of Time

That only treads on flowers!

What eye with clear account remarks

'The ebbing of his glass,

When all its sands are diamond sparks

That dazzle as they pass!

Ah! who to sober measurement

'Time's happy swiftness brings,

When birds of Paradise have lent

Their plumage for its wings? 
SPENCER.

WIFE, CHILDREN, AND FRIENDS.

WHEN the black-lettered list to the gods was presented

(The list of what fate for each mortal intends),

At the long string of ills a kind goddess relented,

And slipped in three blessings-wife, children, and friends.

In vain surly Pluto maintained he was cheated,

For justice divine could not compass its ends;

The scheme of man's penance he swore was defeated,

For earth becomes heaven with-wife, children, and friends.

If the stock of our bliss is in stranger hands vested,

The fund, ill-secured, oft in bankruptcy ends;

But the heart issues bills which are never protested,

When drawn on the firm of-wife, children, and friends.

Though valour still glows in his life's dying embers,

The death-wounded tar, who his colours defends,

Drops a tear of regret as he dying remembers

How bless'd was his home with-wife, children, and friends.

The soldier, whose deeds live immortal in story,

Whom duty to far-distant latitudes sends,

With transport would barter old ages of glory

For one happy day with-wife, children, and friends.

Though spice-breathing gales on his caravan hover,

Though for him Arabia's fragrance ascends,

The merchant still thinks of the woodbines that cover

The bower where he sat with-wife, children, and friends. 


\section{WIFE, CHILDREN, AND FRIENDS.}

The day-spring of youth still unclouded by sorrow,

Alone on itself for enjoyment depends;

But drear is the twilight of age, if it borrow

No warmth from the smile of-wife, children, and friends.

Let the breath of renown ever freshen and nourish

The laurel which o'er the dead favourite bends;

O'er me wave the willow, and long may it flourish,

Bedewed with the tears of-wife, children, and friends.

Let us drink, for my song, growing graver and graver,

To subjects too solemn insensibly tends;

Let us drink, pledge me high, love and virtue shall flavour

The glass which I fill to-wife, children, and friends. 


\section{BYRON.}

\section{THE PRISONER OF CHILLON.}

Mr hair is grey, but not with years;

Nor grew it white .

In a single night,

As men's have grown from sudden fears:

My limbs are bow'd, though not with toil,

But rusted with a vile repose,

For they have been a dungeon's spoil,

And mine has been the fate of those

To whom the goodly earth and air

Are bann'd, and barr'd-forbidden fare;

But this was for my father's faith

I suffer'd chains and courted death;

That father perish'd at the stake

For tenets he would not forsake;

And for the same his lineal race

In darkness found a dwelling-place.

We were seven-who now are one.

Six in youth, and one in age,

Finish'd as they had begun,

Proud of Persecution's rage ;

One in fire, and two in field,

Their belief' with blood have seal'd;

Dying as their father died,

For the God their foes denied:

Three were in a dungeon cast,

Of whom this wreck is left the last. 
There are seven pillars of Gothic mould, In Chillon's dungeons deep and old;

There are seven columns, massy and grey, Dim with a dull imprison'd ray,A sunbeam which hath lost its way, And through the crevice and the cleft Of the thick wall is fallen and left, Creeping o'er the floor so damp, Like a marsh's meteor lamp:

And in each pillar there is a ring,

And in each ring there is a chain;That iron is a cankering thing,

For in these limbs its teeth remain, With marks that will not wear away, Till I have done with this new day, Which now is painful to these eyes, Which have not seen the sun so rise For years-I cannot count them o'er; I lost their long and heavy score When my last brother droop'd and died, And I lay living by his side.

'They chain'd us each to a column stone, And we were three-yet, each alone; We could not move a single pace, We could not see each other's face, But with that pale and livid light 'That made us strangers in our sight;

And thus, together-yet apart, Fetter'd in hand, but join'd in heart, "Twas still some solace, in the dearth Of the pure elements of earth, To hearken to each other's speech, And each turn comforter to each, With some new hope, or legend old, Or song heroically bold; 


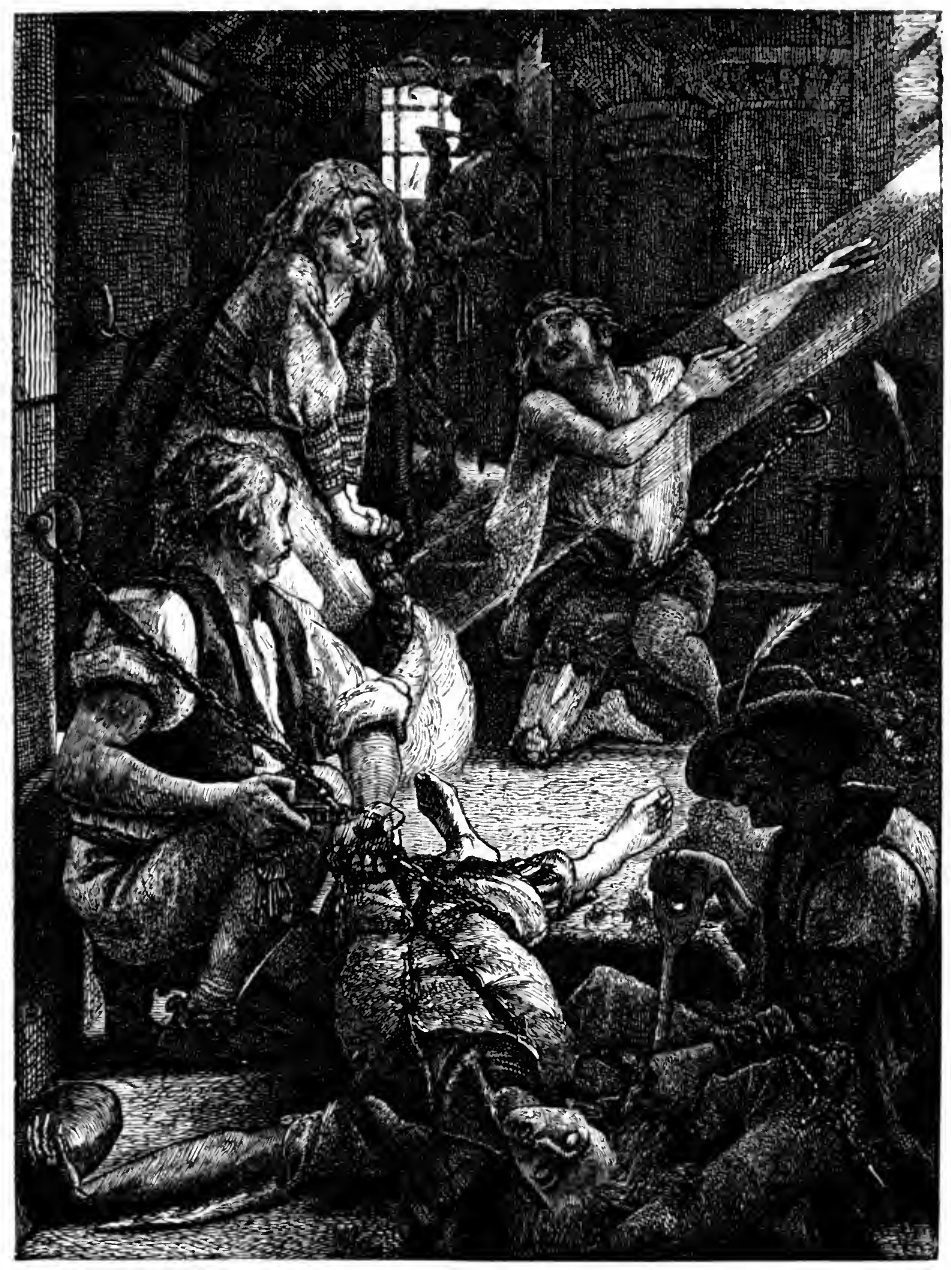

But even these at length grew cold.

Our voices took a dreary tone, An echo of the dungeon stone,

A grating sound-not full and free, 
As they of yore were wont to be:

It might be fancy-but to me

They never sounded like our own.

I was the eldest of the three,

And to uphold and cheer the rest

I ought to do-and did-my best;

And each did well in his degree.

The youngest, whom my father loved

Because our mother's brow was given

To him-with eyes as blue as heaven,-

For him my soul was sorely moved:

And truiy might it be distrest

To see such bird in such a nest;

For he was beautiful as day-

(When day was beautiful to me

As to young eagles, being free)-

A polar day, which will not see

A sunset till its summer's gone,

Its sleepless summer of long light,

The snow-clad offspring of the sun:

And thus he was as pure and bright,

And in his natural spirit gay,

With tears for nought but others' ills,

And then they flow'd like mountain rills,

Unless he could assuage the woe

Which he abhorr'd to view below.

The other was as pure of mind,

But form'd to combat with his kind;

Strong in his frame, and of a mood

Which 'gainst the world in war had stood,

And perish'd in the foremost rank

With joy: but not in chains to pine:

His spirit wither'd with their clank; 


\section{BYRON.}

I saw it silently decline-

And so, perchance, in sooth, did mine:

But yet $I$ forced it on to cheer

Those relics of a home so dear.

He was a hunter of the hills,

Had follow'd there the deer and wolf;

To hin this dungeon was a gulf, And fetter'd feet the worst of ills.

Lake Leman lies by Chillon's walls :

A thousand feet in depth below

Its massy waters meet and flow;

Thus much the fathom-line was sent

From Chillon's snow-white battlement,

Which round about the wave enthrals:

A double dungeon wall and wave

Have made-and like a living grave.

Below the surface of the lake

The dark vault lies wherein we lay,-

We heard it ripple night and day;

Sounding o'er our heads it knock'd;

And I have felt the winter's spray

Wash through the bars when winds were high

And wanton in the happy sky;

And then the very rock hath rock'd,

And I have felt it shake, unshock'd,

Because I could have smiled to see

The death that would have set me free.

I said my nearer brother pin'd,

I said his mighty heart declin'd;

He loath'd and put away his food;

It was not that 'twas coarse and rude,

For we were used to hunter's fare,

And for the like had little care: 
The milk drawn from the mountain goat Was changed for water from the moat, Our bread was such as captive's tears Have moisten'd many a thousand years, Since man first pent his fellow-men Like brutes within an iron den;But what were these to us or him? These wasted not his heart, or limb. My brother's soul was of that mould Which in a palace had grown cold, IIad his free breathing been denied The range of the steep mountain's side. But why delay the truth?-He died. I saw, and could not hold his head, Nor reach his dying hand-nor dead,Though hard I strove, but strove in vain, To rend and gnash my bonds in twain. He died-and they unlock'd his chain, And scoop'd for him a shallow grave Even from the cold earth of our cave.

I begg'd them, as a boon, to lay IIis corse in dust whereon the day Might shine-it was a foolish thought, But then within my brain it wrought, That even in death his freeborn breast In such a dungeon could not rest. I might have spared my idle prayer'They coldly laugh'd-and laid him there: The flat and turfless earth above The being we so much did love. IIis empty chain above it leant, Such murder's fitting monument!

But he, the favourite and the flower, Most cherish'd since his natal hour, Ilis mother's image in fair face, 


\section{BYRON.}

The infant love of all his race,

His martyr'd father's dearest thought,

My latest care, for whom I sought

To hoard my life, that his might be

Less wretched now, and one day free;

He too, who yet had held, untir'd,

A spirit natural or inspir'd,

He, too, was struck, and day by day

Was wither'd on the stalk away.

Oh, God! it is a fearful thing

To see the human soul take wing

In any shape, in any mood:-

I've seen it rushing forth in blood,

I've seen it on the breaking ocean

Strive with a swoln convulsive motion,

I've seen the sick and ghastly bed

Of Sin delirious with its dread:

But these were horrors-this was woe

Unmix'd with such-but sure and slow:

He faded, and so calm and meek,

So softly worn, so sweetly weak,

So tearless, yet so tender-kind,

And griev'd for those he left behind;

With all the while a cheek whose bloom

Was as a mockery of the tomb,

Whose tints as gently sunk away

As a departing rainbow's ray-

An eye of most transparent light,

That almost made the dungeon bright,

And not a word of murmur-not

A groan o'er his untimely lot,-

A little talk of better days,

A little hope-my own to raise,

For I was sunk in silence-lost

In this last loss, of all the most;

And then the sighs he would suppress

Of fainting nature's feebleness, 
More slowly drawn, grew less and less:

I listen'd, but I could not hear-

I call'd, for I was wild with fear;

I knew 'twas hopeless, but my dread

Would not be thus admonishèd;

I call'd, and thought I heard a sound-

I burst my chain with one strong bound,

And rush'd to him: I found him not;

$I$ only stirr'd in this black spot,

$I$ only liv'd-I only drew

The accursed breath of dungeon dew;

The last-the sole-the dearest link

Between me and the eternal brink,

Which bound me to my failing race,

Was broken in this fatal place.

One on the earth, and one beneath-

My brothers-both had ceas'd to breathe :

I took that hand which lay so still,

Alas! my own was full as chill;

I had not strength to stir, or strive,

But felt that I was still alive-

A frantic feeling, when we know

'That what we love shall ne'er be so.

I know not why

I could not die;

I had no earthly hope-but faitl, And that forbade a selfish death.

What next befel me then and there

I know not well-I never knew; First came the loss of light, and air,

And then of darkness too:

I harl no thought, no feeling-none-

Among the stones I stood a stone,

And was, scarce conscious what I wist,

As shrubless crags within the mist; 
For all was blank, and bleak, and grey:

It was not night-it was not day,

It was not even the dungeon-light,

So hateful to my heary sight,

But vacancy absorbing space,

And fixedness-without a place

There were no stars-no earth-no time--

No check-no change-no good-no crime-..

But silence, and a stirless breath

Which neither was of life nor death;

A sea of stagnant idleness,

Blind, boundless, mute, and motionless!

A light broke in upon my brain-

It was the carol of a bird;

It ceas'd, and then it came again,

The sweetest song ear ever heard;

And mine was thankful till my eyes

Ran over with the glad surprise,

And they that moment could not see

I was the mate of misery;

But then by dull degrees came back

My senses to their wonted track:

I saw the dungeon walls and floor

Close slowly round me as before,

I saw the glimmer of the sun

Creeping as it before had done,

But through the crevice where it eame

That bird was pereh'd, as fond and tame

And tamer than upon the tree;

A lovely bird with azure wings,

And song that said a thousand things,

And seem'd to say them all for me!

I never saw its like before,

I ne'er shall see its likeness more:

It seem'd, like me, to want a mate,

But was not half so desolate, 
And it was come to love me when

None lived to love me so again,

And cheering from my dungeon's brink, Had brought me back to feel and think.

I know not if it late were free,

Or broke its eage to perch on mine,

But knowing well eaptivity,

Sweet bird! I could not wish for thine!

$\mathrm{Or}$ if it were, in wingèd guise,

A visitant from Paradise;

For-Heaven forgive that thought!-the while

Which made me both to weep and smile,

I sometimes deem'd that it might be

My brother's soul come down to me;

But then at last away it flew,

And then 'twas mortal-well I knew,

For he would never thus have flown,

And left me twice so doubly lone,-

Lone-as the corse within its shroud;

Lone-as a solitary eloud,

A single cloud on a summer day,

While all the rest of heaven is clear,

A frown upon the atmosphere,

That hath no business to appear

When skies are blue, and earth is gay.

- A kind of change came in my fate,

My keepers grew compassionate;

I know not what had made them so,

They were inur'd to sights of woe,

But so it was:-my broken chain

With links unfasten'd did remain,

And it was liberty to stride

Along my cell from side to side,

And up and down, and then athwart,

And tread it over every part; 
And round the pillars one by one, Returning where my walk begun, Avoiding only, as I trod,

My brothers' graves without a sod;

For if I thought with heedless tread

My step profan'd their lowly bed,

My breath came gaspingly and thick, And my crush'd heart fell blind and sick.

I made a footing in the wall,

It was not therefrom to escape,

For I had buried one and all,

Who loved me in a human shape;

And the whole earth would henceforth be

A wider prison unto me:

No child-no sire-no kin had I,

No partner in my misery.

I thought of this, and I was glad,

For thought of them had made me mad;

But I was curious to ascend

To my barr'd windows, and to bend

Once more, upon the mountains high, The quiet of a loving eye.

I saw them-and they were the same, They were not changed like me in frame;

I saw their thousand years of snow

On high - their wide long lake below, And the blue Rhone in fullest flow;

I heard the torrents leap and gush

O'er channell'd rock and broken bush;

I saw the white-wall'd distant town, And whiter sails go skimming down; And then there was a little isle, Which in my very face did smile, 
The only one in view;

A small green isle, it seem'd no more, Scarce broader than my dungeon floor, But in it there were three tall trees, And o'er it blew the mountain breeze, And by it there were waters flowing, And on it there were young flowers growing,

Of gentle breath and hue.

The fish swam by the castle wall, And they seem'd joyous each and all ; The eagle rode the rising blast, Methought he never flew so fast As then to me he seem'd to fly; And then new tears came in my eye, And I felt troubled-and would fain $I$ had not left my recent chain; And when I did descend again, The darkness of my dim abode Fell on me as a heavy load;

It was as is a new-dug grave, Closing o'er one we sought to save,And yet my glance, too much opprest, I Iad almost need of such a rest.

It might be months, or years, or days,I kept no count-I took no note;

I had no hope my eyes to raise, And clear them of their dreary mote;At last men came to set me free, I ask'd not why, and reck'd not where:

It was at length the same to me, Fetter'd or fetterless to be,

I learn'd to love despair.

And thus, when they appear'd at last, And all my bonds aside were cast, These heavy walls to me had grown 


\section{BYRON.}

A hermitage-and all my own!

And half I felt as they were come

To tear me from a second home:

With spiders I had friendship made,

And watch'd them in their sullen trade,

Had seen the mice by moonlight play,

And why should I feel less than they?

We were all inmates of one place,

And I, the monarch of each race,

Had power to kill-yet, strange to tell!

In quiet we had learn'd to dwell-

My very chains and I grew friends,

So much a long communion tends

To make us what we are:-even I

Regain'd my freedom with a sigh.

\section{THE DREAM.}

Ovr life is twofold: Sleep hath its own world,

A boundary between the things misnam'd

Death and existence: Sleep hath its own world, And a wide realm of wild reality,

And dreams in their development have breath, And tears, and tortures, and the touch of joy;

They leave a weight upon our waking thoughts, They take a weight from off our waking toils, They do divide our being; they become

A portion of ourselves as of our time, And look like heralds of eternity;

They pass like spirits of the past-they speak

Like sibyls of the future; they have power- 
The tyranny of pleasure and of pain;

They make us what we were not-what they will, And shake us with the vision that's gone by, The dread of vanish'd shadows-Are they so? Is not the past all shadow? What are they? Creations of the mind?-The mind can make Substance, and people planets of its own With beings brighter than have been, and give

A breath to forms that ean outlive all flesh.

I would recall a vision which I dream'd Perchance in sleep-for in itself a thought, A slumbering thought, is eapable of years, And curdles a long life into one hour.

I saw two beings in the hues of youth Standing upon a hill, a gentle hill, Green and of mild declivity, the last As 'twere the eape of a long ridge of such, Save that there was no sea to lave its base, But a most living landscape, and the wave Of woods and cornfields, and the abodes of men Scatter'd at intervals, and wreathing smoke Arising from such rustic roofs; - the hill Was crown'd with a peeuliar diadem Of trees, in cireular array, so fix'd Not by the sport of nature, but of man: These two, a maiden and a youth, were there Gazing-the one on all that was beneath, Fair as herself-but the boy gazed on her; And both were young, and one was beautiful: And both were young-yet not alike in youth. As the sweet moon on the horizon's verge, The maid was on the eve of womanhood; 'The boy had fewer summers, but his heart Had far outgrown his years, and to his eye There was but one belovèd face on earth, 


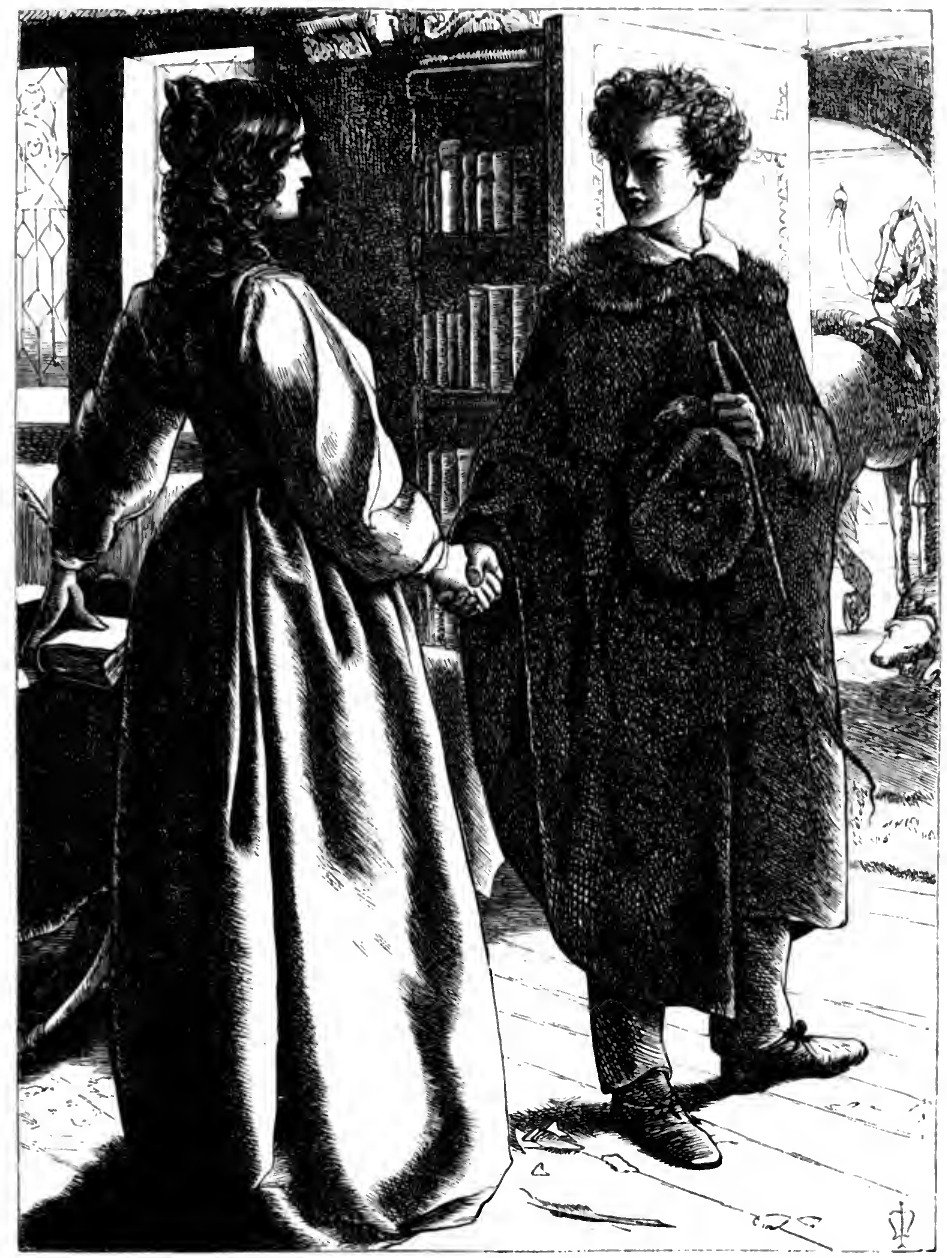

And that was shining on him: he had look'd Upon it till it could not pass away;

He had no breath, no being, but in hers:

She was his voice; he did not speak to her, But trembled on her words: she was his sight, 
For his eye follow'd hers, and saw with hers, Which colour'd all his objects:- he had ceas'd To live within himself; she was his life, The ocean to the river of his thoughts, Which terminated all; upon a tone,

A touch of hers, his blood would ebb and flow, And his cheek change tempestuously-lis heart Unknowing of its cause of agony.

But she in these fond feelings had no share:

Her sighs were not for him; to her he was

Even as a brother-but no more; 'twas much, For brotherless she was, save in the name Her infant friendship had bestow'd on him;

Herself the solitary scion left

Of a time-honour'd race. It was a name

Which pleas'd him, and yet pleas'd him not-and why?

Time taught him a deep answer-when she loved

Another; even now she loved another,

And on the summit of that hill she stood,

Looking afar if yet her lover's steed

Kept pace with her expectancy, and flew.

A change came o'er the spirit of my dream.

There was an ancient mansion, and before

Its walls there was a steed caparison'd:

Within an antique Oratory stood

The Boy of whom I spake; he was alone,

Aul pale, and pacing to and fro: anon

He sate him down, and seized a pen, and traced

Words which I could not guess of; then he lean'd

His bow'l head on his hands. and shook as 'twere

With a convulsion-then arose again,

And with his teeth and quivering hands did tear

What he had written, but he shed no tears.

And he did alm himself, and fix his brow

Into a kind of quiet: as he paus'd, 


\section{BYRON.}

The Lady of his love re-enter'd there;

She was serene and smiling then, and yet

She knew she was by him belov'd,-she knew,

For quickly comes such knowledge, that his heart

Was darken'd with her shadow, and she saw

That he was wretehed, but she saw not all.

He rose, and with a cold and gentle grasp

He took her hand; a moment o'er his face

A tablet of unutterable thoughts

Was traced, and then it faded, as it came;

He dropp'd the hand he held, and with slow steps

Retir'd, but not as bidding her adieu,

For they did part with mutual smiles; he pass'd

From out the massy gate of that old Hall,

And, mounting on his steed, he went his way;

And ne'er repass'd that hoary threshold more.

A change came o'er the spirit of my dream.

The Boy was sprung to manhood: in the wilds

Of fiery climes he made himself a home,

And his soul drank their sunbeams: he was girt

With strange and dusky aspects; he was not

Himself like what he had been; on the sea

And on the shore he was a wanderer;

There was a mass of many images

Crowded like waves upon me, but he was

A part of all; and in the last he lay

Reposing from the noontide sultriness,

Couch'd among fallen columns, in the shade

Of ruin'd walls that had surviv'd the names

Of those who rear'd them; by his sleeping side

Stood camels grazing, and some goodly steeds

Were fasten'd near a fountain; and a man

Clad in a flowing garb did watch the while,

While many of his tribe slumber'd around:

And they were canopied by the blue sky, 
So cloudless, clear, and purely beautiful, That God alone was to be seen in heaven.

A change came o'er the spirit of my dream. 'The Iady of his love was wed with one Who did not love her better:-in her home, A thousand leagues from his,-her native home, She dwelt, begirt with growing Infancy, Daugliters and sons of Beauty,-but behold! Upon her face there was the tint of grief, The settled shadow of an inward strife, And an unquiet drooping of the eye, As if its lid were charg'd with unshed tears. What could her grief be?-She had all she loved, And he who had so loved her was not there 'To trouble with bad hopes, or evil wish, Or ill-repress'd affliction, her pure thoughts. What could her grief be? She had loved him not, Not given him cause to deem himself beloved, Nor could he be a part of that which prey'd Upon her mind-a spectre of the past.

$A$ change came o'er the spirit of my dream. The Wand'rer was return'd.-I saw him stand Before an altar-with a gentle bride;

Her face was fair, but was not that which made 'The starlight of his boyhood; - as he stood Even at the altar, o'er his brow there came The self-same aspect, and the quivering shock

That in the antique Oratory shook

His bosom in its solitude; and then-

$\Lambda s$ in that hour-a moment o'er his face

The tablet of unutterable thoughts

Was traced-and then it faded as it came, And he stood calm and quet, and he spoke 
The fitting vows, but heard not his own words, And all things reel'd around him; he could see

Not that which was, nor that which should have been--

But the old mansion, and the accustom'd hall, And the remember'd chambers, and the place, The day, the hour, the sunshine, and the shade, All things pertaining to that place and hour, And her who was his destiny, came back And thrust themselves between him and the light: What business had they there at such a time?

A change came o'er the spirit of my dream. The Lady of his love;-oh! she was changed, As by the sickness of the soul; her mind Ilad wander'd from its dwelling, and her eyes, They had not their own lustre, but the look Which is not of the earth; she was become The queen of a fantastic realm; her thoughts Were combinations of disjointed things; And forms impalpable and unperceiv'd Of others' sight familiar were to hers. And this the world calls phrenzy; but the wise Have a far deeper madness, and the glance Of melancholy is a fearful gift; What is it but the telescope of truth? Which strips the distance of its fantasies, And brings life near in utter nakedness, Making the cold reality too real!

A change came o'er the spirit of my dream. The Wand'rer was alone as heretofore;

The beings which surrounded him were gone, Or were at war with him; he was a mark For blight and desolation, compass'd round With Hatred and Contention; Pain was mix'd 
In all which was serv'd up to him, until, Like to the Pontic monarch of old days, He fed on poisons, and they had no power, But were a kind of nutriment; he lived Through that which had been death to many men, And made him friends of mountains: with the stars And the quick Spirit of the Universe He held his dialogues; and they did teach To him the magic of their mysteries. 'To him the book of Night was open'd wide, And roices from the deep abyss reveal'd A marvel and a secret. Be it so.

My dream was past; it had no further change. It was of a strange order, that the doom Of these two creatures should be thus traced out Almost like a reality-the one To end in madness-both in misery. 


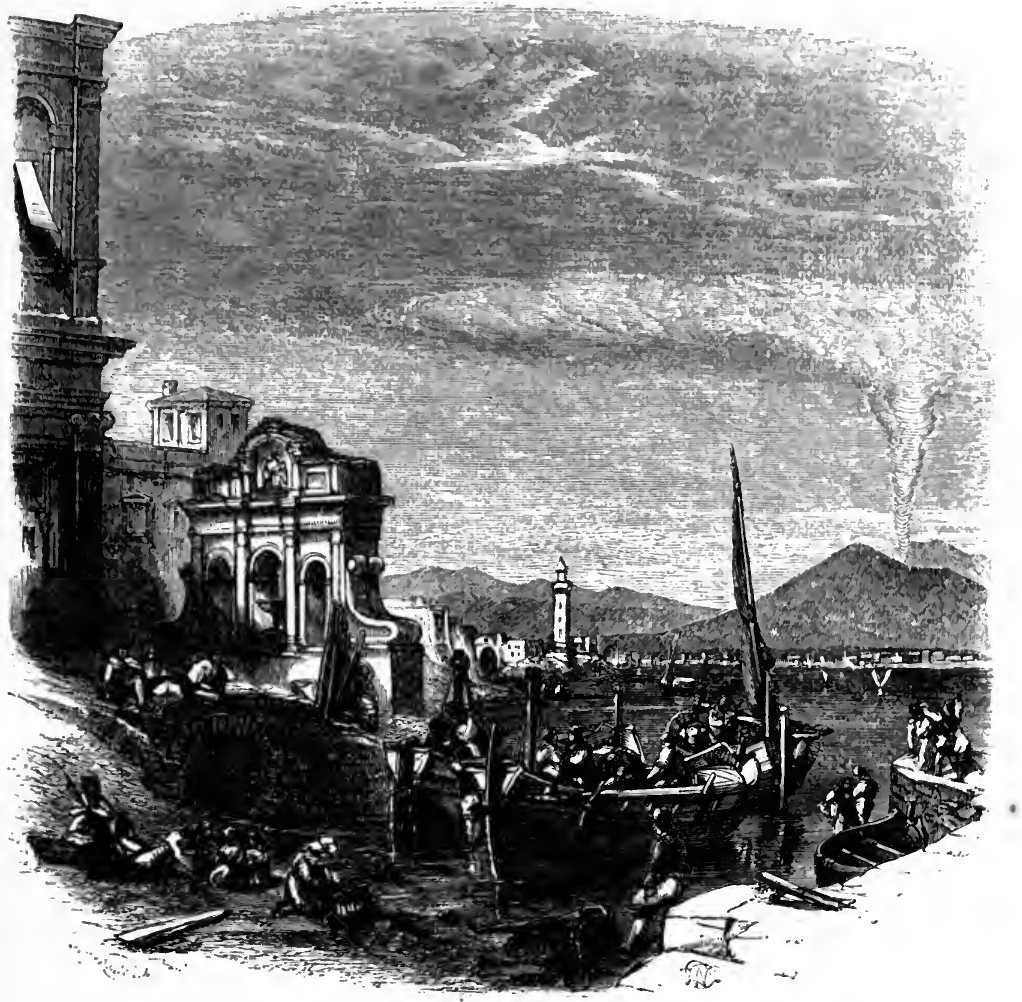

SHELLEY.

WRITTEN IN DEJECTION NEAR NAPLES.

The sun is warm, the sky is clear,

The waves are dancing fast and bright,

Blue isles and snowy mountains wear 
The purple noon's transparent light.

The breath of the moist earth is light

Around its unexpanded buds;

Like many a voice of one delight,

The winds, the birds, the ocean floods, The city's voice itself is soft, like Solitude's.

I see the deep's untrampled floor

With green and purple sea-weeds strown;

I see the waves upon the shore,

Like light dissolv'd in star-showers, thrown.

I sit upon the sands alone,

The lightning of the noon-tide ocean

Is flashing round me, and a tone

Arises from its measur'd motion.

How sweet! did any heart now share in my emotion.

Alas! I have nor hope nor health,

Nor peace within, nor calm around,

Nor that content, surpassing wealth,

The sage in meditation found,

And walk'd with inward glory crown'd -

Nor fame, nor power, nor love, nor leisure.

Others I see whom these surround-

Smiling they live, and call life pleasure;-

'To me that cup has been dealt in ansther measure.

Yet now despair itself is mild,

Even as the winds and waters are;

I could lie down like a tired child,

And weep away the life of eare

Which I have borne, and yet must bear,

Till death, like sleep, might steal on me.

And I might feel in the warm air

My cheek grow wet, and hear the sea

Breathe o'er my dying brain its last monotony. 


\section{SHELLEY.}

Some might lament that I was cold,

As $I$, when this sweet day is gone,

Which my lost heart, too soon grown old,

Insults with this untimely moan :-

They might lament,-for I am one

Whom men love not-and yet regret;

Unlike this day, which, when the sun

Shall on its stainless glory set,

Will linger, though enjoy'd, like joy in memory yet.

\section{TO NIGHT.}

Swirtis walk over the western wave, Spirit of Night!

Out of the misty eastern cave, Where, all the long and lone daylight, Thou wovest dreams of joy and fear, Which make thee terrible and dear,Swift be thy flight!

Wrap thy form in a mantle grey,

Star-inwrought!

Blind with thine hair the eyes of Day, Kiss her until she be wearied out,

Then wander o'er city, and sea, and sand,

Touching all with thine opiate wand-

Come, long-sought!

When I arose and saw the Dawn,

I sigh'd for thee ;

When light rode high, and the dew was gone, 
TO NIGH'T.

And noon lay heavy on flower and tree,

And the weary Day turn'd to his rest,

Lingering like an unloved guest,

I sigh'd for thee.

Thy brother Death came, and cried,

Wouldst thon me?

Thy sweet child Sleep, the filmy-eyed,

Murmur'd like a noon-tide bee,

Shall I nestle near thy side?

Wouldst thou me? And I replied,

No, not thee!

Death will come when thou art dead,

sioon, too soon-

Sleep will come when thou art fled:

Of neither would I ask the boon,

I ask of thee, beloved Night--

Swift be thine approaching flight,

Come soon,- - soon!

\section{SPRING.}

O SPrisa! of hope, and love, and youth, and gladness, White-wing'd emblem! brightest, best, and fairest!

Whence comest thou, when with dark Winter's sadness

The tears that fide in sunny smiles thou sharest?

Sister of joy! thou art the child who wearest

'Thy mother's dying smile, tender and sweet;

'Thy mother Autumn, for whose grave thou bearest

Fresh flowers, and beams like flowers, with gentle feet

Disturbing not the leaves which are her winding-sheet. 


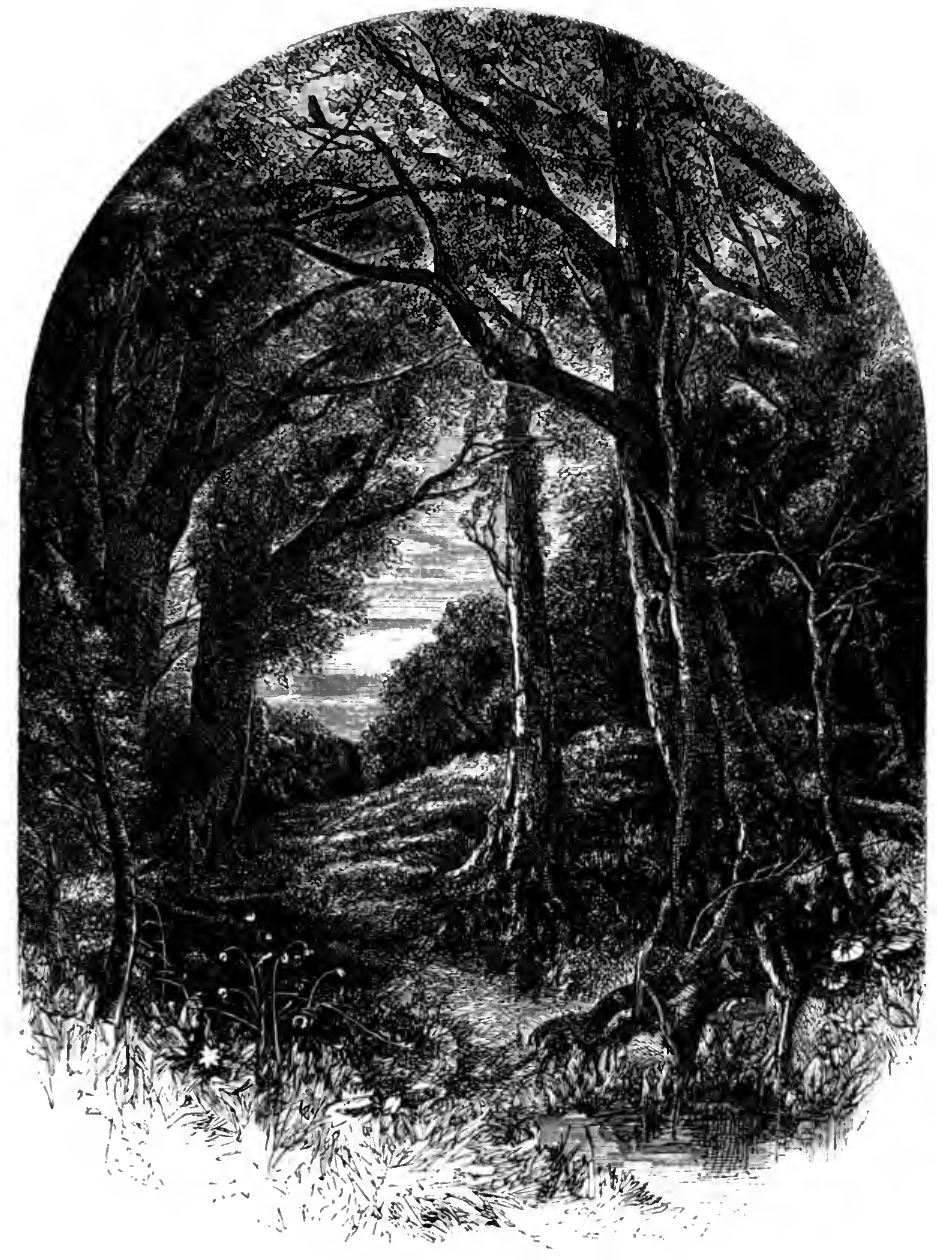

KEATS.

ODE TO A NIGHTINGALE.

Mr heart aches, and a drowsy numbness pains My sense, as though of hemlock I had drunk, 
Or emptied some dull opiate to the drains

One minute past, and Lethe-wards had sunk:

'Tis not through envy of thy happy lot,

But being too happy in thy happiness,-

'That thou, light-wingèd Dryad of the trees,

In some melodious plot

Of beechen green, and shadows numberless,

Singest of summer in full-throated ease.

$O$ for a draught of vintage, that hath been

Cool'd a long age in the deep-delvèd earth, Tasting of Flora and the country-green,

Dance, and Provençal song, and sun-burnt mirth!

$O$ for a beaker full of the warm South,

Full of the true, the blushful Hippocrene,

With beaded bubbles winking at the brim,

And purple-stainèd mouth !

That I might drink, and leave the world unseen, And with thee fade away into the forest dim:

Fade far away, dissolve, and quite forget

What thou among the leaves hast never known, The weariness, the fever, and the fret,

Here, where men sit and hear each other groan, Where palsy shakes a few, sad, last grey hairs,

Where youth grows pale, and spectre-thin, and dies;

Where but to think is to be full of sorrow, And leaden-eyed despairs;

Where Beauty cannot keep her lustrous eyes,

Or new Love pine at them beyond to-morrow.

Away! away! for I will fly to thee,

Not dharioted hy Bacchus and his pards, But on the viewless wings of Poesy,

Though the dull brain perplexes and retards: 
Already with thee! tender is the night, And haply the Queen-Moon is on her throne,

Cluster'd around by all her starry Fays;

But here there is no light,

Save what from heaven is with the breezes blown

'Through verdurous glooms and winding mossy ways.

I cannot see what flowers are at my feet, Nor what soft incense hangs upon the boughs, But, in embalmcd darkness, guess each sweet Wherewith the seasonable month endows The grass, the thicket, and the fruit-tree wild;

White hawthorn, and the pastoral eglantine;

Fast-fading violets cover'd up in leaves;

And mid-May's eldest child,

The coming musk-rose, full of dewy wine,

The murmurous haunt of flies on summer eves.

Darkling I listen; and, for many a time

I have been half in love with easeful Death, Call'd him soft names in many a musèd rhyme,

To take into the air my quiet breath;

Now more than ever seems it rich to die,

'To cease upon the midnight with no pain,

While thou art pouring forth thy soul abroad

In such an ecstasy!

Still wouldst thou sing, and I have ears in vain

To thy high requiem become a sod.

Thou wast not born for death, immortal Bird!

No hungry generations tread thee down;

The voice I hear this passing night was heard

In ancient days by emperor and clown: 
Perhaps the self-same song that found a path Through the sad heart of Ruth, when, sick for home, She stood in tears amid the alien corn;

The same that ofttimes hath

Charm'd magic casements, opening on the foam Of perilous seas, in faëry lands forlorn.

Forlorn! the very word is like a bell

To toll me back from thee to my sole self! Adieu! the fancy eannot cheat so well

As she is famed to do, deceiving elf.

Adieu! adieu! thy plaintive anthem fades

Past the near meadows, over the still stream,

Up the lill-side; and now 'tis buried deep

In the next valley-glades:

Was it a vision, or a waking dream?

Fled is that musie:-do I wake or sleep?

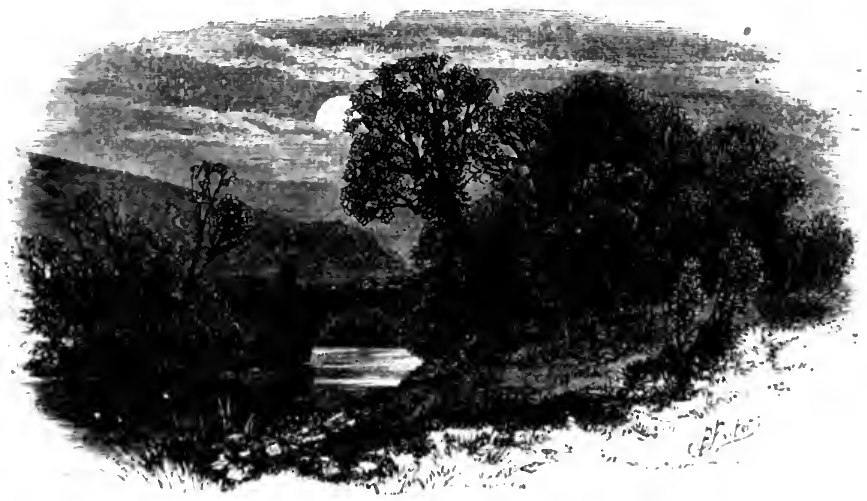




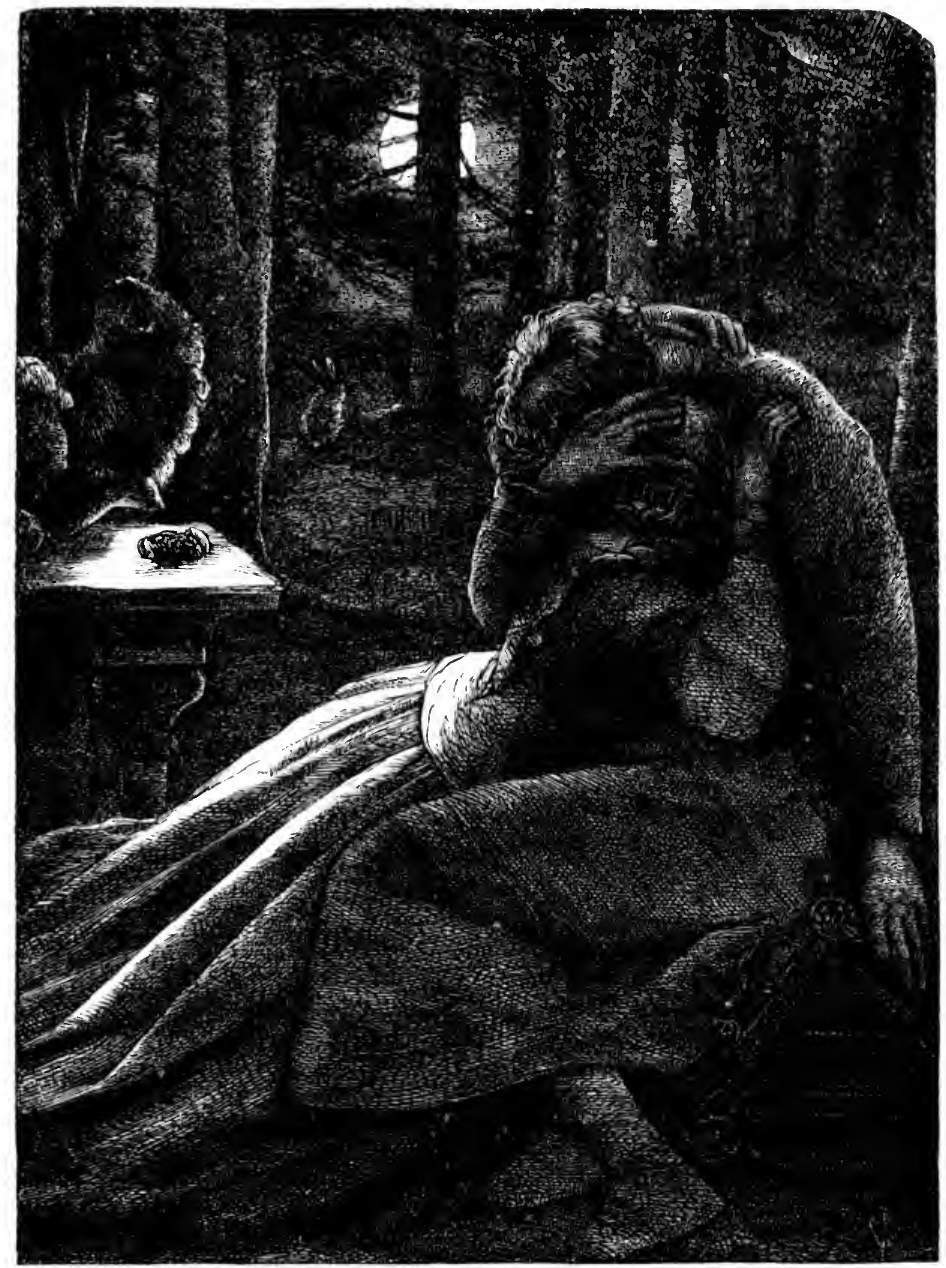

\section{COLERIDGE.}

LOVE.

Alr thoughts, all passions, all delights,

Whatever stirs this mortal frame, 
All are but ministers of Love, And feed his sacred flame.

Oft in my waking, dreams do I

Live o'er again that happy hour, When midway on the mount I lay

Beside the ruin'd tower.

The moonshine, stealing o'er the scene, Had blended with the lights of eve; And she was there, my hope, my joy, My own dear Genevieve!

She lean'd against the armèd man, The statue of the armèd knight; She stood and listen'd to my lay Amid the lingering light.

Few sorrows hath she of her own, My hope! my joy! my Genevieve! She loves me best, whene'er I sing 'The songs that make her grieve.

I played a soft and doleful air, I sang an old and moving storyAn old rude song that suited well

That ruin wild and hoary.

She listen'd with a flitting blush, With downeast eyes, and modest grace; For well she knew, I could not choose

But gaze upon lier face.

I told her of the Knight that wore

Upon his shicld a burning brand; And that for ten long years he wooed The Ladly of the Land. 


\section{COLERIDGE.}

I told her how he pined: and, ah!

The low, the deep, the pleading tone,

With which I sang another's love,

Interpreted my own.

She listen'd with a flitting blush,

With downcast eyes, and modest grace;

And she forgave me that I gazed

Too fondly on her face!

But when I told the cruel scorn

Which erazed this bold and lovely Knight, And that he cross'd the mountain-woods,

Nor rested day nor night;

That sometimes from the savage den, And sometimes from the darksome shade, And sometimes starting up at once

In green and sunny glade,-

There came, and look'd him in the face, An angel beautiful and bright; And that he knew it was a Fiend, This miserable Knight!

And that, unknowing what he did, He leaped amid a murderous band, And saved from outrage worse than death The Lady of the Land;

And how she wept and elasp'd his knees, And how she tended him in vainAnd ever strove to expiate

The scorn that erazed his brain;

And that she nursed him in a cave;

And how his madness went away When on the yellow forest-leaves

A dying man he lay; 


\section{LOVE.}

His dying words-but when I reached That tenderest strain of all the ditty, My faltering voice and pausing harp

Disturbed her soul with pity!

All impulses of soul and sense Had thrilled my guileless Genevieve, The musie and the doleful tale,

The rich and balmy eve;

And hopes, and fears that kindle hope, An undistinguishable throng;

And gentle wishes long subdued, Subdued and cherish'd long!

She wept with pity and delight, She blushed with love and virgin shame; And, like the murmur of a dream, I heard her breathe my name.

Her bosom heaved-she stept aside; As conscious of my look, she steptThen suddenly, with timorous eye

She fled to me and wept.

She half inelosed me with her arms, She pressed me with a meek embrace; And, bending back her head, looked up And gazed upon my face.

'Twas partly love, and partly fear, And partly 'twas a bashful art 'That I might rather feel, than see, 'The swelling of her heart.

I calm'd her fears; and she was calm, And told her love with virgin pride; And so I won my Generieve, My bright and beauteous Bride! 


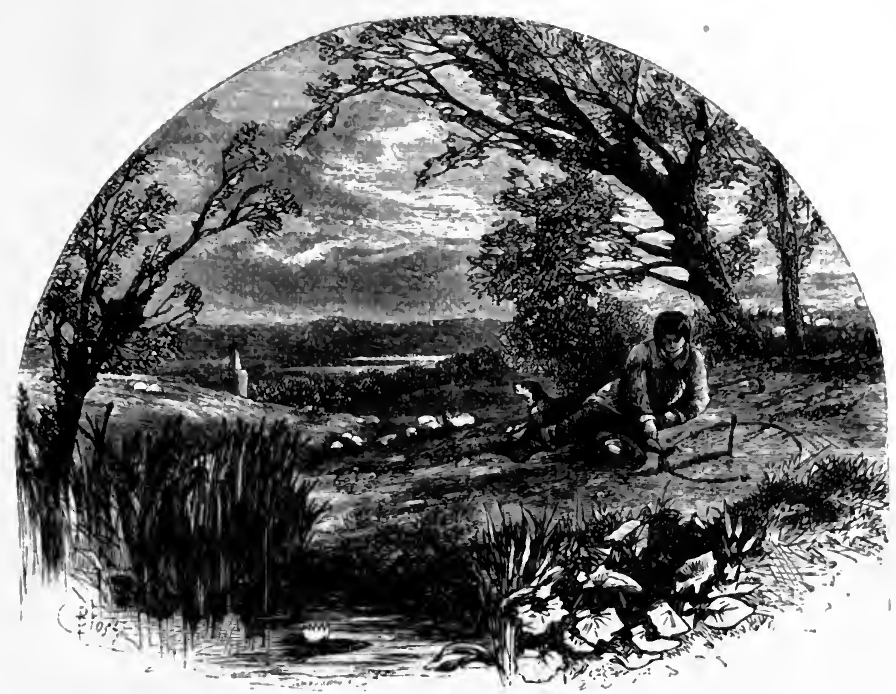

WORDSWORTH.

THE GLORY OF IMAGINATION.

The Shepherd-lad, that in the sunshine carres,

On the green turf, a dial-to divide

The silent hours; and who to that report

Can portion out his pleasures, and adapt,

Throughout a long and lonely summer's day,

His round of pastoral duties, is not left

With less intelligence for moral things

Of gravest import. Early he perceives,

Within himself, a measure and a rule,

Which to the sun of truth he can apply,

That shines for him, and shines for all mankind.

Experience daily fixing his regards 


\section{A CLOUD PIC'TURE.}

On Nature's wants, he knows how few they are, And where they lie, how answer'd and appeas'd: This knowledge ample recompense affords For manifold privations; he refers

His notions to this standard; on this rock

Rests his desires; and hence, in after life, Soul-strengthening patience and sublime content. Imagination-not permitted here

To waste her powers, as in the worldling's mind, On fickle pleasures, and superfluous cares, And trivial ostentation-is left free

And puissant to range the solemn walks Of time and nature, girded by a zone That, while it binds, invigorates and supports. Acknowledge, then, that whether by the side Of his poor hut, or on the mountain-top, Or in the cultur'd field, a Man so bred ('Take from him what you will upon the score Of ignorance or illusion) lives and breathes For noble purposes of mind: his heart Beats to th' heroic song of ancient days; His eye distinguishes, his soul creates.

\section{A CLOUD PICTURE.}

So was he lifted gently from the ground, And with their freight homeward the shepherds movid 'Through the dull mist, I following-when a step,

A single step, that freed me from the skirts

Of the blind vapour, open'd to my view

Glory heyond all glory ever seen

By waking sense, or by the dreaming soul!

'Th' appearance, instantaneously disclos'd, 


\section{WORDSWOR'TH.}

Was of a mighty city-boldly say

A wilderness of building, sinking far

And self:withdrawn into a boundless depth,

Far sinking into splendour-without end!

Fabric it seem'd of diamond and of gold,

With alabaster domes and silver spires,

And blazing terrace upon terrace, high

Uplifted: here, serene pavilions bright,

In avenues disposed; there, towers begirt

With battlements that on their restless fronts

Bore stars-illumination of all gems!

By earthly nature had th' effect been wrought

Upon the dark materials of the storm

Now pacified; on them, and on the coves

And mountain-steeps and summits, whereunto

The vapours had receded, taking there

Their station under a cerulean sky.

Oh, 'twas an unimaginable' sight! -

Clouds, mists, streams, watery rocks, and emerald turf:

Clouds of all tincture, rocks and sapphire sky,

Confus'd, commingled, mutually inflam'd,

Molten together, and composing thus,

Each lost in each, that marvellous array

Of temple, palace, citadel, and huge

Fantastic pomp of structure without name,

In fleecy folds voluminous enwrapp'd.

Right in the midst, where interspace appear'd

Of open court, an object like a throne

Under a shining canopy of state

Stood fix'd; and fix'd resemblances were seen

To implements of ordinary use,

But vast in size, in substance glorified;

Such as by Hebrew Prophets were beheld

In vision-forms uncouth of mightiest power

For admiration and mysterious awe.

This little Vale, a dwelling-place of Man,

Lay low beneath my feet; 'twas visible- 


\section{DION.}

I saw not, but I felt that it was there.

That which I saw was the reveal'd abode

Of Spirits in beatitude: my heart

Swell'd in my breast. - "I have been dead," I cried, "And now I live! Oh! wherefore do I live?"

And with that pang I pray'd to be no more!

\section{DION.}

(SEE PLUTARCH.)

SERENe, and fitted to embrace, Where'er he turn'd, a swan-like grace Of haughtiness without pretence, And to unfold a still magnificence, Was princely Dion, in the power And beauty of his happier hour. And what pure homage then did wait On Dion's virtues, while the lunar beam Of Plato's genius, from its lofty sphere, Fell round him in the grove of Academe, Softening their inbred dignity austere-

That he, not too elate

With self-sufficing solitude,

But with majestic lowliness endued, Might in the universal bosom reign, And from affectionate observance gain Help, under every change of adverse fate.

Five thousand warriors- $O$ the rapturous day! Each crown'd with flowers, and arm'd with spear and shield. Or ruder weapon which their course might yield. To Syracuse advance in bright array. 


\section{WORDSWORTH.}

Who leads them on? The anxious people see

Long-exiled Dion marching at their head;

He also crown'd with flowers of Sicily,

And in a white, far-beaming corslet clad!

Pure transport, undisturb'd by doubt or fear,

The gazers feel; and, rushing to the plain,

Salute those strangers as a holy train,

Or blest procession (to the Immortals dear),

That brought their precious liberty again.

Lo! when the gates are enter'd, on each hand,

Down the long street, rich goblets fill'd with wine

In seemly order stand,

On tables set, as if for rites divine;-

And, as the great Deliverer marches by,

He looks on festal ground with fruits bestrown;

And flowers are on his person thrown

In boundless prodigality;

Nor doth the general voice abstain from prayer,

Invoking Dion's tutelary care,

As if a very Deity he were!

Mourn, hills and groves of Attica!一and mourn

Ilissus, bending o'er thy classic urn!

Mourn, and lament for him whose spirit dreads

Your once sweet memory, studious walks, and shades!

For him who to divinity aspired,

Not on the breath of popular applause,

But through dependence on the sacred laws

Framed in the schools where Wisdom dwelt retired,

Intent to trace th' ideal path of right

(More fair than heaven's broad causeway paved with stars)

Which Dion learn'd to measure with sublime delight;

But he hath overleap'd th' eternal bars;

And, following guides whose craft holds no consent

With aught that breathes th' ethereal element,

Hath stain'd the robes of civil power with blood

Unjustly shed, though for the public good. 


\section{DION.}

Whence doubts that came too late, and wishes vain, Hollow excuses, and triumphant pain ;

And oft his cogitations sink as low

As, through the abysses of a joyless heart,

The heaviest plummet of despair can go-

But whence that sudden check? that fearful start?

He hears an uncouth sound-

Anon his lifted eyes

Saw, at a long-drawn gallery's dusky bound,

A Shape of more than mortal size

And hideous aspect, stalking round and round !

A woman's garb the phantom wore,

And swiftly swept the marble floor-

Like Auster whirling to and fro,

His force on Caspian foam to try;

Or Boreas when he scours the snow

That skins the plains of Thessaly,

Or when aloft on Mænalus he stops

His flight, 'mid eddying pine-tree tops!

So, but from toil less sign of profit reaping,

The sullen Spectre to her purpose bow'd,

Sweeping-vehemently sweeping-

No pause admitted, no design avow'd!

"Avaunt, inexplicable guest! avaunt!"

Exclaim'd the Chieftain- "let me rather see

The coronal that coiling vipers make;

The torch that flames with many a lurid flake,

And the long train of doleful pageantry

Which they behold, whom vengeful Furies haunt;

Who, while they struggle from the scourge to flee,

Move where the blasted soil is not unworn,

And, in their anguish, bear what other minds have borne!"

But Shapes that come not at an earthly call,

Will not depart when mortal voices bid;

Lords of the visionary eye, whose lid, 


\section{WORDSWORTH.}

Once raised, remains aghast, and will not fall!

Ye gods, thought he, that servile Implement

Obeys a mystical intent!

Your Minister would brush away

The spots that to my soul adhere;

But should She labour night and day,

They will not, cannot disappear;

Whence angry perturbations,-and that look

Which no philosophy can brook!

Ill-fated Chief! there are whose hopes are built Upon the ruins of thy glorious name;

Who, through the portal of one moment's guilt, Pursue thee with their deadly aim!

O matchless perfidy! portentous lust

Of monstrous crime! that horror-striking blade,

Drawn in defiance of the gods, hath laid

The noble Syracusan low in dust!

Shudder'd the walls-the marble city weptAnd sylvan places heav'd a pensive sigh;

But in calm peace th' appointed Victim slept, As he had fall'n in magnanimity;

Of spirit too capacious to require

That Destiny her course should change; too just

To his own native greatness to desire

That wretched boon, days lengthen'd by mistrust.

So were the hopeless troubles, that involved

The soul of Dion, instantly dissolved.

Releas'd from life, and cares of princely state,

He left this moral grafted on his Fate :"Him only pleasure leads, and peace attends, Him, only him, the shield of Jove defends, Whose means are fair and spotless as his ends." 
INCIDENT AT BRUGES.

\section{INCIDENT AT BRUGES.}

Iv Brugès town is many a street

Whence busy life hath fled;

Where, without hurry, noiseless feet

The grass-grown pavement tread.

There heard we, halting in the shade

Flung from a convent-tower,

A harp that tuneful prelude made

To a voice of thrilling power.

The measure, simple truth to tell,

Was fit for some gay throng;

Though from the same grim turret fell

The shadow and the song.

When silent were both voice and chords,

The strain seem'd doubly dear,

Yet sad as sweet,- -for English words

Had fall'n upon the ear.

It was a breezy hour of eve;

And pinnacle and spire

Quiver'd and seem'd almost to heave

Cloth'd with innocuous fire;

But, where we stood, the setting sun

Show'd little of his state;

And, if the glory reach'd the Nun,

'Twas through an iron grate.

Not always is the heart unwise,

Nor pity idly borne,

If even a passing Stranger sighs

For them who do not mourn. 


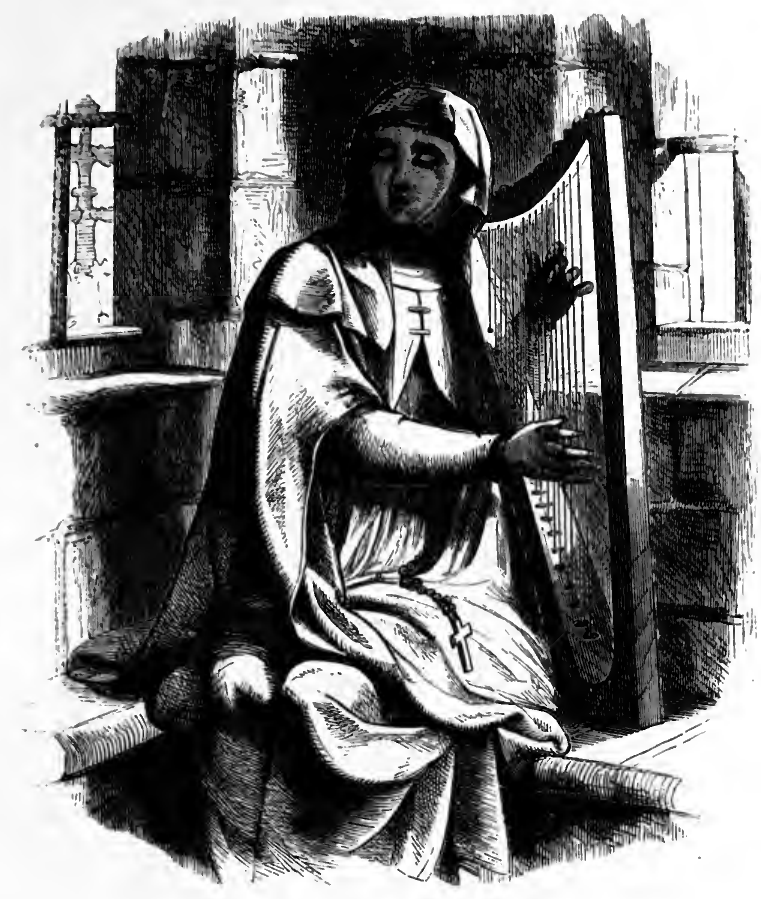

Sad is thy doom, self-solaced dove, Captive, whoe'er thou be!

$\mathrm{Oh}$ ! what is beauty, what is love, And opening life to thee?

Such feeling press'd upon the soul, A feeling sanctified

By one soft trickling tear that stole From the Maiden at my side:

Less tribute could she pay than this, Borne gaily o'er the sea, Fresh from the beauty and the bliss Of English liberty? 
$\Lambda$ JEWISH FAMILY.

A JEWISH FAMILY.

IN A SMALL VALLEY OPPOSITE ST. GOAR, UPON THE RHINE.

Genius of Raphael! if thy wings

Might bear thee to this glen,

With faithful memory left of things

To pencil dear and pen,

Thou wouldst forego the neighbouring Rhine, And all his majesty-

A studious forehead to incline

O'er this poor family.

The Mother-her thou must have seen,

In spirit, ere she came

To dwell these rifted rocks between,

Or found on earth a name;

An image, too, of that sweet Boy

Thy inspirations give-

Of playfulness, and love, and joy,

Predestined here to live.

Downcast, or shooting giances far, How beautiful his eyes,

That blend the nature of the star

With that of summer skies!

I speak as if of sense beguil'd;

Uncounted months are gone,

Yet am I with the Jewish Child,

That oxquisite Saint John. 


\section{WOIDSWORTH.}

I see the dark-brown curls, the brow, The smooth transparent skin, Refin'd, as with intent to show The holiness within;

The grace of parting Infancy By blushes yet untam'd;

Age faithful to the mother's knee, Nor of her arms asham'd.

Two lovely Sisters, still and sweet As flowers, stand side by side;

Their soul-subduing looks might cheat The Christian of his pride;

Such beauty hath th' Eternal pour'd Upon them not forlorn, Though of a lineage once abhorr'd, Nor yet redeem'd from scorn.

Mysterious safeguard, that, in spite Of poverty and wrong, Doth here preserve a living light, From Hebrew fountains sprung;

That gives this ragged group to cast.

: Around the dell a gleam Of Palestine, of glory past, And proud Jerusalem! 
$\Lambda$ PORTRAIT.

\section{A PORTRAIT.}

SHe was a phantom of delight

When first she gleamed upon my sight;

A lovely Apparition, sent

To be a moment's ornament;

Her eyes as stars of 'Twilight fair;

Like 'Twilight too her dusky hair;

But all things else about her drawn

From May-time and the cheerful Dawn;

A dancing Shape, an Image gay,

To haunt, to startle, and waylay.

I saw her upon nearer view,

A Spirit, yet a Woman too!

Her household motions light and free, And steps of virgin liberty;

A countenance in which did meet

Sweet records, promises as sweet;

A Creature, not too bright or good

For human nature's daily food;

For transient sorrows, simple wiles,

Praise, blame, love, kisses, tears, and smiles.

And now I see with eye serene The very pulse of the machine;

A Being breathing thoughtful breath,

A Traveller between life and death;

The reason firm, the temperate will,

Endurance, foresight, strength and skill;

A perfect Woman, nobly planned

To warn, to comfort, and command;

And yet a Spirit still, and bright

With something of an angel light. 


\section{WORDSWOR'TH.}

\section{LUCY.}

Three years she grew in sun and shower,

Then Nature said, "A lovelier flower

On earth was never sown;

This Child I to myself will take;

She shall be mine, and I will make

A Lady of my own.

Myself will to my darling be

Both law and impulse: and with me

The Girl, in rock and plain,

In earth and heaven, in glade and bower,

Shall feel an overseeing power

To kindle or restrain.

She shall be sportive as the Fawn That wild with glee across the lawn

Or up the mountain springs;

And hers shall be the breathing balm, And hers the silence and the calm

Of mute insensate things.

The Floating Clouds their state shall lend

To her; for her the willow bend:

Nor shall she fail to see

Even in the motions of the Storm

Grace that shall mould the Maiden's form

By silent sympathy.

The Stars of Midnight shall be dear

To her; and she shall lean her ear

In many a secret place

Where Rivulets dance their wayward round, And beauty born of murmuring sound

Shall pass into her face. 
And vital feelings of delight

Shall rear her form to stately height,

Her virgin bosom swell;

Such thoughts to Lucy I will give

While she and I together live

Here in this happy Dell."

Thus Nature spoke.-The work was doneHow soon my Lucy's race was run!

She died, and left to me

This heath, this calm, and quiet scene;

The memory of what has been,

And never more will be.

\section{SONNET}

COMPOSED UPON WESTMINSTER BRIDGE, SEPT. 3, 1803.

EARTI has not any thing to show more fair: Dull would he be of soul who could pass by A sight so touching in its majesty: This City now doth like a garment wear The beauty of the morning; silent, bare, Ships, towers, domes, theatres, and temples lie Open unto the fields, and to the sky; All bright and glittering in the smokeless air. Never did sun more beautifully steep

In his first splendour valley, rock or hill; Ne'er saw I, never felt, a calm so deep. The river glideth at his own sweet will: Dear God! the very houses seem asleep; And all that mighty heart is lying still! 


\section{A M B.}

\section{HESTER.-A REMEMBRANCE.}

When maidens such as Hester die, Their place ye may not well supply, Though ye among a thousand try, With vain endeavour.

A month or more hath she been dead, Yet cannot I by force be led To think upon the wormy bed And her together.

A springy motion in her gait, A rising step, did indicate Of pride and joy no common rate, That flush'd her spirit-

I know not by what name beside I shall it call :-if 'twas not pride, It was a joy to that allied She did inherit.

Her parents held the Quaker rule, Which doth the human feeling cool; But she was train'd in Nature's school, Nature had blest her.

A waking eye, a prying mind,

A heart that stirs, is hard to bind,

A hawk's keen sight ye cannot blind,

Ye could not Hester. 
My sprightly neighbour, gone before

To that unknown and silent shore,

Shall we not meet, as heretofore,

Some summer morning,

When from thy cheerful eyes a ray Hath struck a bliss upon the day, A bliss that would not go away,

A sweet forewarning?

\section{VERSES FOR AN ALBUM.}

Fresh clad from heaven in robes of white,

A young probationer of light,

Thou wert, my soul, an Album bright,

A spotless leaf; but thought, and care, And friends, and foes, in foul or fair, Have written "strange defeature" there.

And Time, with heaviest hand of all, Like that fierce writing on the wall, Hath stamp'd sad dates he can't recall.

And Error, gilding worse designs, Like speckled snake that strays and shinesBetrays his path by crooked lines.

My scalded eyes no longer brook Upon this ink-blurr'd thing to look.

Go-shut the leaves-and clasp the book ! 


\section{KIRKE WHITE.}

\section{THE HERB ROSEMARY.}

SwEET scented flower! who art wont to bloom

On January's front severe,

And o'er the wintry desert drear

To waft thy waste perfume!

Come, thou shalt form my nosegay now, And I will bind thee round my brow;

And as $I$ twine the mournful wreath,

I'll weave a melancholy song,

And sweet the strain shall be, and long,

The melody of death.

Come, funeral flower! who lov'st to dwell

With the pale corse in lonely tomb,

And throw across the desert gloom

A sweet decaying smell.

Come, press my lips, and lie with me

Beneath the lowly alder-tree;

And we will sleep a pleasant sleep,

And not a care shall dare intrude,

To break the marble solitude,

So peaceful, and so deep.

And hark! the wind-god, as he flies,

Moans hollow in the forest-trees,

And sailing on the gusty breeze,

Mysterious music dies.

Sweet flower! that requiem wild is mine,

It warns me to the lonely shrine, 


\section{ODE TO DISAPPOINTMENT.}

The cold turf altar of the dead; My grave shall be in yon lone spot, Where as I lie, by all forgot, A dying fragrance thou wilt o'er my ashes shed.

\section{ODE TO DISAPPOINTMENT.}

Cose, Disappointment, come!

Not in thy terrors clad;

Come in thy meekest, saddest guise;

Thy chastening rod but terrifies

The restless and the bad.

But I recline

Beneath thy shrine,

And round my brow resign'd thy peaceful cypress twine.

Though Fancy flies away

Before thy hollow tread,

Yet Meditation, in her cell,

Hears with faint eye the ling'ring knell,

That tells hèr hopes are dead;

And though the tear

By ehance appear,

Yet she can smile, and say, My all was not laid here!

What is this passing scene?

A peevish April day!

$\Lambda$ little sun, a little rain,

And then night sweeps along the plain,

And all things fade away.

Man (soon discuss'd)

Yields up his trust,

And all his hopes' and fears lie with him in the dust. 
KIRKE WHITE.

Oh, what is Beanty's power?

It flourishes and dies;

Will the cold earth its silence break,

To tell how soft, how smooth a cheek

Beneath its surface lies?

Mute, mute is all

O'er Beauty's fall ;

Her praise resounds no more when mantled in her pall.

The most belov'd on earth

Not long survives to-day;

So music past is obsolete,

And yet 'twas sweet, 'twas passing sweet,

But now 'tis gone away.

Thus does the shade

In memory fade,

When in forsaken tomb the form belov'd is laid.

Then, since this world is vain,

And volatile, and fleet,

Why should I lay up earthly joys

Where rust corrupts, and moth destroys,

And cares and sorrows eat?

Why fly from ill

With cautious skill,

When soon this hand will freeze, this throbbing heart be still?

Come, Disappointment, come :

Thou art not stern to me;

Sad monitress! I own thy sway,

A votary sad in early day,

I bend my knee to thee.

From sun to sun

My race will run;

I only bow, and say, My God, Thy will be done!. 


\section{ALLSTON.}

\section{AMERICA TO GREAT BRITAIN.}

AlL hail! thou noble land, Our Fathers' native soil!

$\mathrm{O}$, stretch thy mighty hand,

Gigantic grown by toil,

O'er the vast Atlantic wave to our shore!

For thou with magie might

Canst reach to where the light

Of Phœbus travels bright

The world o'er!

The Genius of our clime,

From his pine-embattled steep,

Shall hail the guest sublime;

While the Tritons of the deep

With their conchs the kindred league shall proclaim.

Then let the world combine,-

O'er the main our naval line

Like the milky-way shall shine

Bright in fame!

Though ages long have past

since our Fathers left their home,

Their pilot in the blast,

O'er untravelled seas to roam,

Yet lives the blood of England in our veins!

And shall we not proclaim

That blood of honest fame

Which no tyranny can tame

By its chains? 
ALLSTON.

While the language free and bold

Which the Bard of Avon sung,

In which our Milton told

How the vault of heaven rung

When Satan, blasted, fell with his host;-

While this, with reverence meet,

Ten thousand echoes greet,

From rock to rock repeat

Round our coast;-

While the manners, while the arts,

That mould a nation's soul,

Still cling around our hearts,-

Between let Ocean roll,

Our joint communion breaking with the Sun:

Yet still from either beach

The voice of blood shall reach,

More audible than speech,

"We are One."

\section{ROSALIE.}

"O Pour upon my soul again

That sad, unearthly strain,

That seems from other worlds to plain;

Thus falling, falling from afar,

As if some melancholy star

Had mingled with her light her sighs,

And dropped them from the skies!

"No,-never came from aught below

This melody of woe,

That makes my heart to overflow, 


\section{A FRAGMENT.}

As from a thousand gushing springs, Unknown before; that with it brings This nameless light, - if light it be,-

That veils the world $I$ see.

"For all I see around me wears

The hue of other spheres;

And something blent of smiles and tear's

Comes from the very air I breathe.

$\mathrm{O}$, nothing, sure, the stars beneath

Can mould a sadness like to this,-

So like angelic bliss."

So, at that dreamy hour of day

When the last lingering ray

Stops on the highest cloud to play,So thought the gentle Rosalie,

As on her maiden reverie

First fell the strain of him who stole

In music to her soul.

\section{A FRAGMENT.}

WISE is the face of Nature unto him

Whose heart, amid the business and the cares,

The cumning and bad passions, of the world, Still keeps its freshness, and can look upon her

As when she breathed upon his schoolboy face

IIer morning breath, from o'er the dewy beds

Of infunt riolets waking to the sun ;-

When the young spirit, only recipient,

So drank in her beauties, that his heart

Would reel within him, joining jubilant

The dance of brooks and waving woods and flowers. 


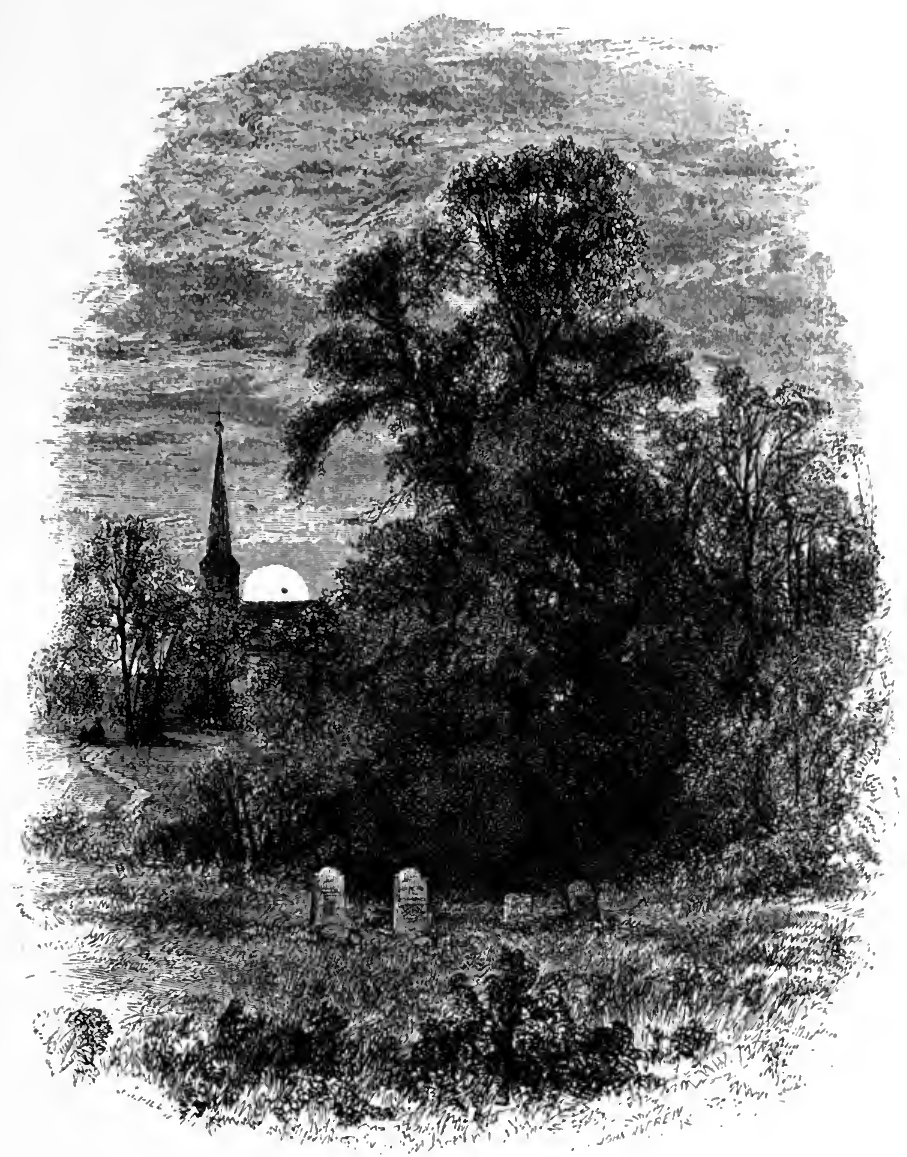

\section{DANA.}

THE HUSBAND'S AND WIFE'S GRAVE.

Husbaxd and wife! No converse now ye hold, As once ye did in your young days of love, 
On its alarms, its anxious hours, delays,

Its silent meditations, its glad hopes,

Its fears, impatience, quiet sympathies;

Nor do ye speak of joy assured, and bliss

Full, certain, and possess'd. Domestic cares

Call you not now together. Earnest talk

On what your children may be, moves you not.

Ye lie in silence, and an awful silence;

'Tis not like that in which ye rested once

Most happy - silence eloquent, when heart

With heart held speech, and your mysterious frames,

IIarmonious, sensitive, at every beat

'Touch'd the soft notes of love.

Insensible, unheeding, folds you round;

Stillness profound,

And darkness, as a stone, has seal'd you in.

A way from all the living, here ye rest:

In all the nearness of the narrow tomb,

Yet feel ye not each other's presence now.

Dread fellowship! together, yet alone.

Is this thy prison-house, thy grave, then, Love?

And doth death cancel the great bond that holds

Commingling spirits? Are thoughts that know no bounds.

But, self-inspired, rise upward, searching out

The eternal Mind-the Father of all thought-

Are they become mere tenants of a tomb?

Dwellers in darkness, who th' illuminate realms

Of unereated light have visited and lived?

Lived in the dreadful splendour of that throne,

Which One, with gentle hand the veil of flesh

Lifting, that hung 'twixt man and it, reveal'd

In glory? throne, before which even now

Our souls, moved by prophetic power, bow down

Rejoicing, yet at their own natures awed?

Souls that Thee know by a mysterious sense, 
DANA.

Thou awful, unseen presence-are they quenched,

Or burn they on, hid from our mortal eyes

By that bright day which ends not, as the sun

His robe of light flings round the glittering stars?

And with our frames do perish all our loves?

Do those that took their root and put forth buds,

And their soft leaves unfolded in the warmth

Of mutual hearts, grow up and live in beauty,

Then fade and fall, like fair unconscious flowers?

Are thoughts and passions that to the tongue give speech,

And make it send forth winning harmonies,

That to the eheek do give its living glow,

And vision in the eye the soul intense

With that for which there is no utterance-

Are these the body's accidents? no more?

To live in it, and when that dies, go out

Iike the burnt taper's flame?

Oh, listen, man!

A voice within us speaks that startling word, "Man, thou shalt never die!" Celestial voices

Hymn it unto our souls: according harps,

By angel fingers touch'd when the mild stars

Of morning sang together, sound forth still

The song of our great immortality:

Thick clustering orbs, and this our fair domain,

The tall, dark mountains, and the deep-toned seas

Join in this solemn, universal song.

Oh, listen, ye, our spirits ; drink it in

From all the air! 'Tis in the gentle moonlight;

'Tis floating midst day's setting glories; Night,

Wrapped in her sable robe, with silent step

Comes to our bed and breathes it in our ears:

Night, and the dawn, bright day, and thoughtful eve,

All time, all bounds, the limitless expanse,

As one vast mystic instrument, are touch'd 
By an unseen, living Hand, and conscious chords Quiver with joy in this great jubilee.

The dying hear it; and as sounds of earth Grow dull and distant, wake their passing souls To mingle in this heavenly harmony.

Why is it that I linger round this tomb?

What holds it? Dust that cumber'd those I mourn.

They shook it off, and laid aside earth's robes, And put on those of light. They're gone to dwell In love-their God's and angels'. Mutual love, That bound them here, no longer needs a speech For full communion; nor sensations strong, Within the breast, their prison, strive in vain To be set free, and meet their kind in joy. Changed to celestials, thoughts that rise in each, By natures new, impart themselves, though silent. Each quick'ning sense, each throb of holy love, Affections sanctified, and the full glow Of being, which expand and gladden one, By union all mysterious, thrill and live In both immortal frames: Sensation all, And thought, pervading, mingling sense and thought! Ye pair'd, yet one! wrapped in a consciousness Twofold, yet single-this is love, this life!

Why call we, then, the square-built monument, The upright column, and the low-laid slab, Tokens of death, memorials of decay?

Stand in this solemn, still assembly, man, And learn thy proper nature; for thou see'st, In these shaped stones and letter'd tables, figures Of life: More are they to thy soul than those Which he who talk'd on Sinai's mount with God Brought to the old Judeans-types are these, Of thine eternity. 


\section{DANA.}

I thank thee, Father,

That at this simple grave, on which the dawn

Is breaking, emblem of that day which hath

No close, Thou kindly unto my dark mind

Hast sent a sacred light, and that away

From this green hillock, whither I had come

In sorrow, Thou art leading me in joy.

\section{A CLUMP OF DAISIES.}

YE daisies gay,

This fresh spring day

Close gathered here together,

To play in the light,

To sleep all the night,

To abide through the sullen weather;

Ye creatures bland,

A simple band,

Ye free ones, linked in pleasure,

And linked when your forms

Stoop low in the storms,

And the rain comes down without measure;

When wild clouds fly

Athwart the sky,

And ghostly shadows, glancing,

Are darkening the gleam

Of the hurrying stream,

And your close, bright heads gayly dancing; 


\section{A CLUMP OF DAISIES.}

Though dull awhile, Again ye smile;

For, see, the warm sun breaking;

The stream's going glad,

'There's nothing now sad,

And the small bird his song is waking.

The dew-drop sip

With dainty lip!

The sun is low descended.

And, Moon! softly fall

On troop true and small!

Sky and earth in one kindly blended.

And, Morning! spread

Their jewelled bed

With lights in the east sky springing!

And, Brook! breathe around

Thy low murmured sound!

May they move, ye Birds, to your singing!

For in their play

I hear them say,

Here, man, thy wisdom borrow;

In heart be a child,

In word, true and mild:

Hold thy faith, come joy, or come sorrow. 


\section{WOODWORTH.}

\section{THE OLD OAKEN BUCKET.}

How dear to this heart are the scenes of my childhood,

When fond recollection presents them to view;

The orchard, the meadow, the deep tangled wild wood,

And every loved spot, which my infancy knew;

The wide-spreading pond, and the mill which stood by it,

The bridge and the rock where the cataract fell;

The cot of my father, the dairy-house nigh it,

And e'en the rude bucket which hung in the well.

The old oaken bucket, the iron-bound bucket,

The moss-covered bucket which hung in the well.

That moss-covered vessel I hail as a treasure;

For often, at noon, when returned from the field,

I found it the source of an exquisite pleasure,

The purest and sweetest that nature can yield.

How ardent I seized it with hands that. were glowing,

And quick to the white pebbled bottom it fell;

Then soon, with the emblem of truth overflowing,

And dripping with coolness, it rose from the well;

The old oaken bucket, the iron-bound bucket,

The moss-covered bucket arose from the well.

How sweet from the green mossy brim to receive it, As, pois'd on the curb, it inclined to my lips!

Not a full blushing goblet could tempt me to leave it,

Though fill'd with the nectar that Jupiter sips.

And now far removed from the loved situation,

The tear of regret will intrusively swell, As fancy reverts to my father's plantation,

And sighs for the bucket which hangs in the well;

The old oaken bucket, the iron-bound bucket,

The moss-covered bucket which hangs in his well. 


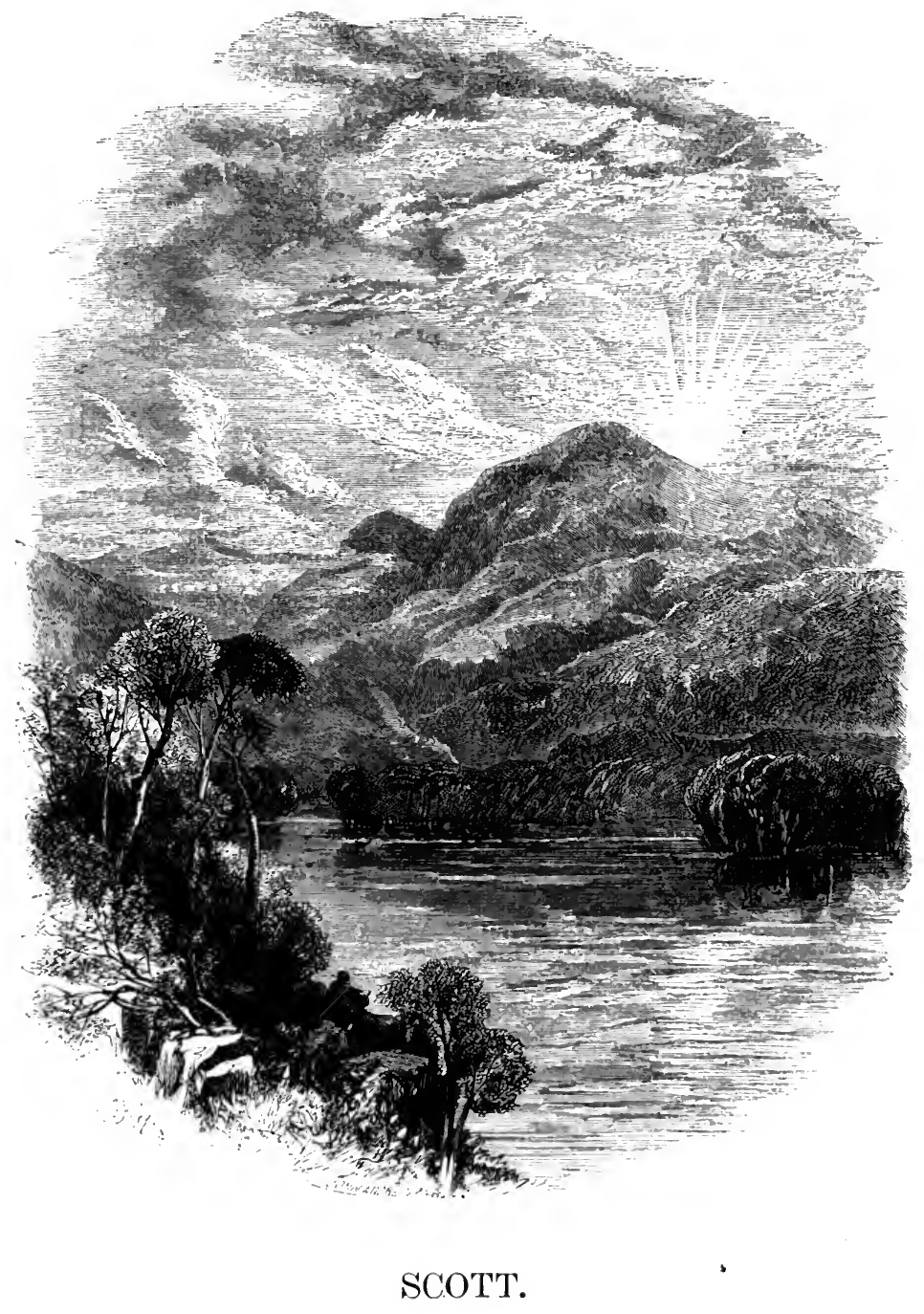

THE SUN UPON THE WEIRDLAW HILL.

Tue sun upon the Weirdlaw Hill,

In Ettrick's vale, is sinking sweet; 


\section{SCO'TT.}

The westland wind is husht and still,

The lake lies sleeping at my feet.

Yet not the landscape to mine eye

Bears those sweet hues that once it bore;

Though Evening, with her richest dye,

Flames o'er the hills of Ettrick shore.

With listless look along the plain,

I see Tweed's silver current glide, And coldly mark the holy fane

Of Melrose rise in ruin'd pride.

The quiet lake, the balmy air,

The hill, the stream, the tower, the trecAre they still sweet as once they were,

Or is the dreary change in me?

Alas! the warp'd and broken board,

How can it bear the painter's dye?

The harp of strain'd and tuneless chord,

How to the minstrel's skill reply?

To aching eyes each landscape lours,

To feverish pulse each gale blows chill;

And Araby, or Eden's bowers,

Were barren as this moorland hill. 


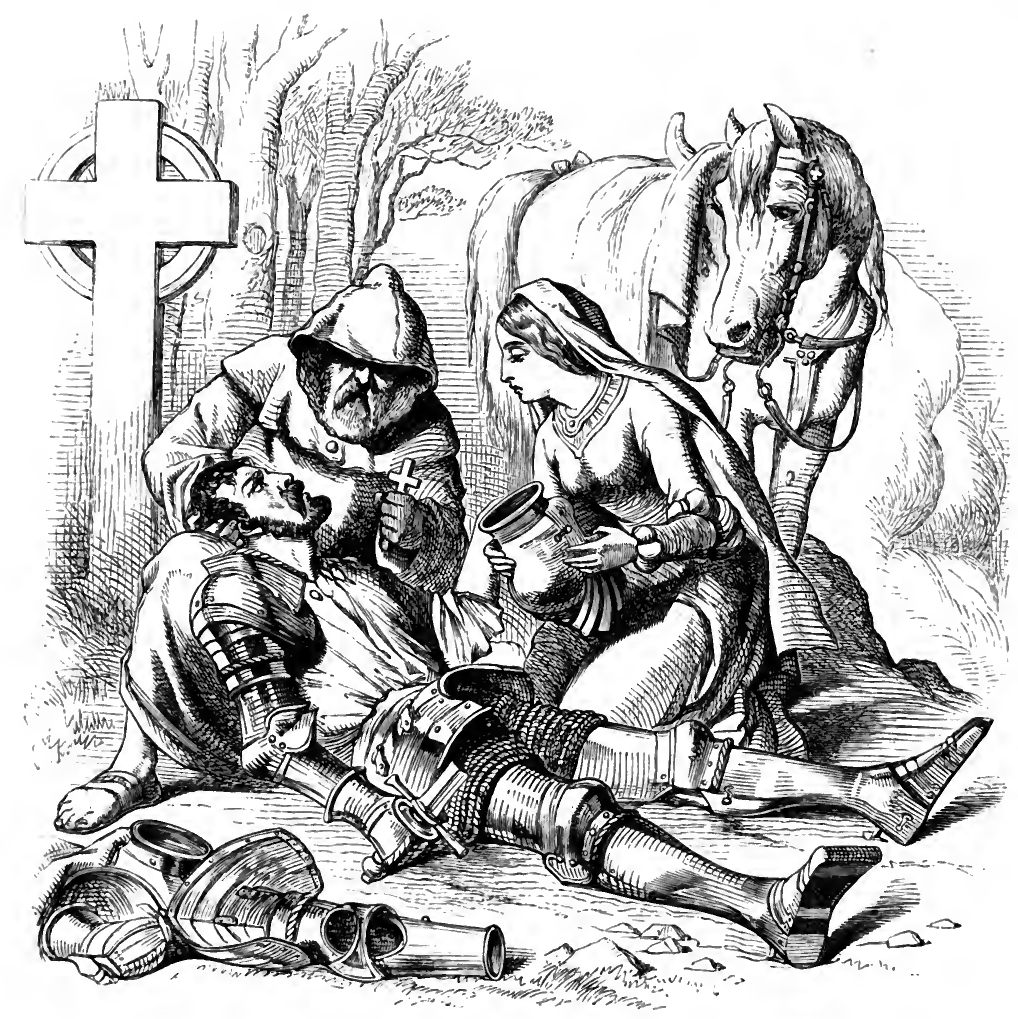

MARMION-DYING.

'Tney parted, and alone he lay;

Clare drew her from the sight away, Till pain wrung forth a lowly moan, And half he murmur'd,_- "Is there none, Of all my halls have nurst, Page, squire, or groom, one cup to bring Of blessed water from the spring, To slake my dying thirst?" 
O Woman! in our hours of ease, Uncertain, coy, and hard to please, And variable as the shade By the light quivering aspen made; When pain and anguish wring the brow,

A ministering angel thou!-

Scarce were the piteous accents said, When, with the Baron's casque, the maid

To the nigh streamlet ran:

Forgot were hatred, wrongs, and fearsThe plaintive voice alone she hears, Sees but the dying man.

She stoop'd her by the runnel's side,

But in abhorrence backward drew; For, oozing from the mountains wide, Where raged the war, a dark-red tide

Was curdling in the streamlet blue.

Where shall she turn? behold her mark

A little fountain cell,

Where water, clear as diamond-spark,

In a stone basin fell.

Above, some half-worn letters say,

Mrink . manrn . pilgrim . itritk . mut . pran .

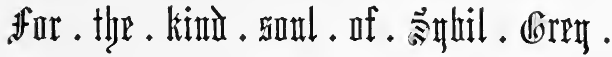

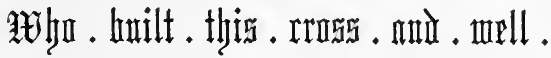

She fill'd the helm, and back she hied, And with surprise and joy espied

A Monk supporting Marmion's head-

A pious man, whom duty brought

'To dubious verge of battle fought,

To shrive the dying, bless the dead. 


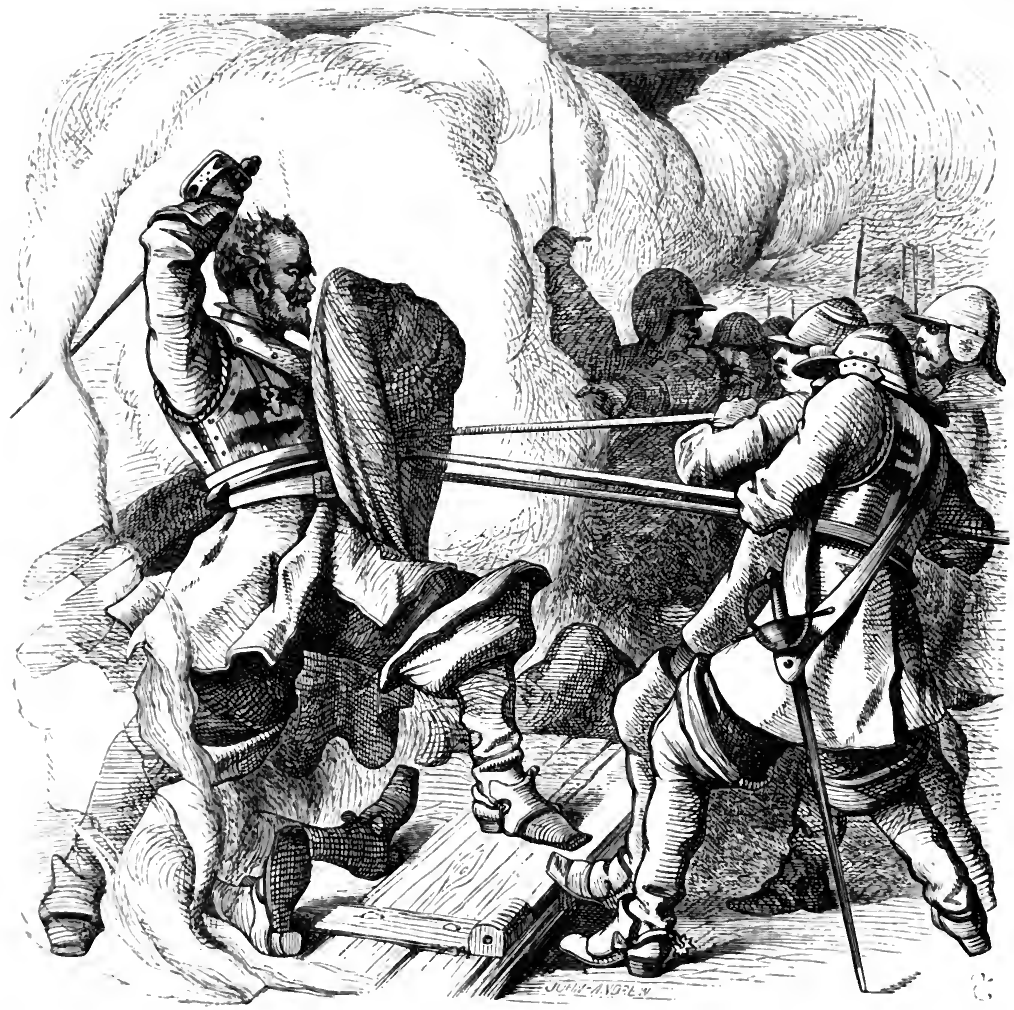

THE BURNING OF ROKEBY.

Sron murkier clouds the IIall enfold, 'Than e'er from battle-thunders roll't-

So dense, the combatants searce know To aim or to avoid the blow.

Simoth'ring and blindfold grows the fight But soon shall dawn a dismal light! 
'Mid cries, and clashing arms, there came

The hollow sound of rushing flame;

New horrors on the tumult dire

Arise-the Castle is on fire !

Doubtful, if chance had east the brand,

Or frantic Bertram's desperate hand.

Matilda saw-for frequent broke

From the dim easements gusts of smoke.

Yon tower, which late so clear defin'd

On the fair hemisphere reclin'd,

That, pencill'd on its azure pure,

The eye could count each embrasure,

Now, swath'd within the sweeping cloud,

Seems giant spectre in his shroud;

Till, from each loophole flashing light,

A spout of fire shines ruddy bright,

And, gathering to united glare,

Streams high into the midnight air;

A dismal beacon, far and wide

That waken'd Greta's slumbering side.

Soon all beneath, through gallery long

And pendant arch, the fire flash'd strong,

Snatching whatever could maintain,

Raise, or extend, its furious reign ;

Startling, with closer cause of dread,

The females who the conflict fled,

And now rush'd forth upon the plain,

Filling the air with clamours vain.

But ceas'd not yet, the Hall within,

The shriek, the shout, the earnage-din,

Till bursting lattices give proof

The flames have caught the rafter'd roof:

What! wait they till its beams amain

Crash on the slayers and the slain?

Th' alarm is eaught - the drawbridge falls -

The warriors hurry fiom the walls; 
But, by the conflagration's light, Upon the lawn renew the fight.

Each straggling felon down was hew'd, Not one could gain the shelt'ring wood;

But forth th' affirighted harper sprung, And to Matilda's robe he clung. Her shriek, entreaty, and command, Stopp'd the pursuer's lifted hand.

Denzil and he alive were ta'en;

The rest, save Bertram, all are slain.

And where is Bertram?-Soaring high, The general flame ascends the sky; In gather'd group the soldiers gaze Upon the broad and roaring blaze, When, like infernal demon, sent

Red from his penal element, 'To plague and to pollute the airHis face all gore, on fire his hairForth from the central mass of smoke The giant form of Bertram broke! His brandish'd sword on high he rears, Then plung'd among opposing spears; Round his left arm his mantle truss'd, Receiv'd and foil'd three lances' thrust;

Nor these his headlong course withstood,

Like reeds he snapp'd the tough ash-woot.

In vain his foes around him clung;

With matchless force aside he flung Their boldest, -as the bull at bay 'osses the ban-dogs from lis way, Through forty foes his path he made, And safely gain'd the forest glade.

Scarce was this final conflict o'er, When from the postern Redmond bore Wilfrid, who, as of life bereft, 
Had in the fatal Hall been left,

Deserted there by all his train ;-

But Redmond saw, and turn'd again.

Beneath an oak he laid him down,

That in the blaze gleam'd ruddy brown,

And then his mantle's clasp undid;

Matilda held his drooping head,

Till, given to breathe the freer air,

Returning life repaid their care.

He gazed on them with heavy sigh,-

"I could have wish'd even thus to die!"

No more he said-for now with speed

Each trooper had regain'd his steed;

The ready palfreys stood array'd,

For Redmond and for Rokeby's Maid;

'Two Wilfrid on his horse sustain,

One leads his charger by the rein.

But oft Matilda look'd behind,

As up the Vale of Tees they wind,

Where far the mansion of her sires

Beacon'd the dale with midnight fires.

In gloomy arch above them spread,

The clouded heaven lower'd bloody red;

Beneath, in sombre light, the flood

Appear'd to roll in waves of blood.

Then, one by one, was heard to fall

The tower, the donjon-keep, the hall.

Each rushing down with thunder sound, A space the conflagration drown'd; 'Till, gathering strength, again it rose, Announc'd its triumph in its close, Shook wide its light the landscape o'er, Then sunk-and Rokeby was no more! 


\section{CAMPBELL.}

\section{THE SOLDIER'S DREAM.}

Orn bugkes sang truce-for the night-cloud had lowerd, And the sentinel stars set their watch in the sky; And thousands had sunk on the ground overpower'd, The weary to sleep, and the wounded to die.

When reposing that night on my pallet of straw, By the wolf-scaring fagot that guarded the slain, At the dead of the night a sweet vision I saw; And thrice ere the morning I dreamt it again.

Methought from the battle-field's dreadful array, Far, far I had roam'd on a desolate track, Till Autumn-and sunshine arose on the way

To the house of my fathers, that welcomed me back.

I flew to the pleasant fields, travers'd so oft In life's morning march, when my bosom was young;

I heard my own mountain-goats bleating aloft, And knew the sweet strain that the corn-reapers sung.

Then pledged we the wine-cup, and fondly I swore

From my home and my weeping friends never to part:

My little ones kiss'd me a thousand times o'er,

And my wife sobb'd aloud in her fulness of heart.

"Stay-stay with us!-rest! thou art weary and worn!"(And fain was their war-broken soldier to stay;)

But sorrow return'd with the dawning of morn, And the voice in my dreaming ear melted away! 
THE EXILE OF ERIN.

Triere came to the beach a poor Exile of Erin,

The dew on his thin robe was heavy and chill;

For his country he sigh'd, when at twilight repairing

To wander alone by the wind-beaten hill.

But the day-star attraeted his eye's sad devotion;

For it rose o'er his own native isle of the ocean,

Where once, in the fire of his youthful emotion,

He sang the bold anthem of Erin-go-bragh.

"Sad is my fate!" said the heart-broken stranger:

"The wild deer and wolf to a covert ean flee,

But I have no refuge from famine and danger,-

A home and a country remain not to me.

Never again, in the green sunny bowers

Where my forefathers lived, shall I spend the sweet hour:

Or cover my harp with the wild-woven flowers,

And strike to the numbers of Erin-go-bragh.

"Erin, my country! though sad and forsaken,

In dreams I revisit thy sea-beaten shore;

But, alas! in a far foreign land I awaken,

And sigh for the friends who can meet me no more!

Oh cruel fate! wilt thou never replace me

In a mansion of peace, where no perils ean chase me?

Never again shall my brothers embrace me!

They died to defend me, or live to deplore!

"Where is my eabin-door, fast by the wild wood?

Sisters and sire! did ye weep for its fall?

Where is the mother that look'd on my childhood?

And where is the bosom-friend, dearer than all? 


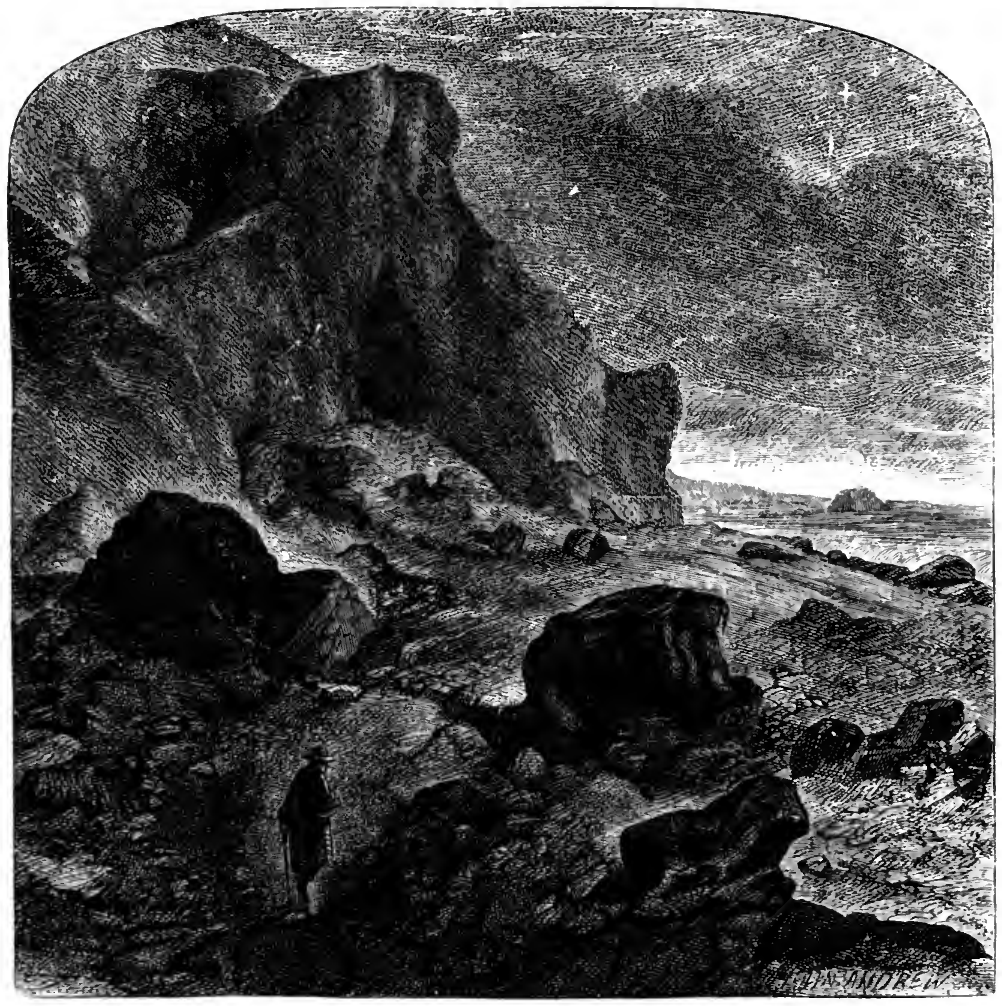

Ah! my sad heart! long abandon'd by pleasure!

Why did it dote on a fast-fading treasure?

Tears, like the rain-drop, may fall without measure, But rapture and beauty they cannot recall.

"Yet all its sarl recollections suppressing,

One rying wish my lone bosom can draw:

Erin! an exile bequeaths thee his blessing,

Land of my forefathers! Eirin-go-bragh!

Buried and rold, when my heart stills her motion,

Green be thy fields, sweetest isle of the ocean!

And thy harp-striking bards sing aloud with devotion,-

"Lilia mavournin,-Erin-go-bragh!", 


\section{CAMPBELL.}

\section{DRINKING SONG OF MUNICH.}

SweEt Iser! were thy sunny realm

And flowery gardens mine,

Thy waters I would shade with elm,

To prop the tender vine.

My golden flagons I would fill

With rosy draughts from every hill;

And, under each green spreading bower,

My gay companions should prolong

The feast, the revel, and the song,

To many an idle sportive hour.

Like rivers crimson'd by the beam

Of yonder planet bright,

Our balmy cups should ever stream

Profusion of delight;

No eare should touch the mellow heart,

And sad or sober none depart;

(For wine can triumph over woe;)

And Love and Bacchus, brother powers, Should build in Iser's sunny bowers

A Paradise below? 
LOCHIEL'S WARNING.

\section{LOCHIEL'S WARNING.}

WIZARD.

LochicL, Lochiel, beware of the day,

When the Lowlands shall meet thee in battle-array!

For a field of the dead rushes red on my sight, And the elans of Culloden are scatter'd in fight: They rally, they bleed for their kingdom and crown,Woe, woe to the riders that trample them down! Proud Cumberland prances, insulting the slain, And their hoof-beaten bosoms are trod to the plain.

But hark! through the fast-flashing lightning of war, What steed to the desert flies frantic and far?

"Tis thine, O Glenullin! whose bride shall await, Like a love-lighted wateh-fire, all night at the gate.

A steed comes at morning-no rider is there;

But its bridle is red with the sign of despair.

Weep, Albin! to death and captivity led;

Oh, weep! but thy tears cannot number the dead; For a merciless sword on Culloden shall wave-

Culloden that reeks with the blood of the brave.

\section{LOCIIIEL}

(io, preach to the coward, thou death-telling seer!

()", if gory Culloden so dreadful appear,

Draw, dotard, around thy old wavering sight, This mantle, to eover the phantoms of fright.

WIZARL.

IIa! langh'st thon, Lochiel, my vision to scorn?

Proud bird of the mountain, thy plume shall be torn!

say, rushd the bold eagle exultingly forth,

From his home, in the dark-rolling elouds of the North? 
Lo! the death-shot of foemen outspeeding, he rode

Companionless, bearing destruction abroad:

But down let him stoop from his lavoc on high!

Ah! home let him speed-for the spoiler is nigh.

Why flames the far summit? Why shoot to the blas:

Those embers, like stars from the firmament cast?

'Tis the fire-show'r of Ruin, all dreadfully driven

From his eyrie, that beacons the darkness of hearen.

$\mathrm{O}$ crested Lochiel! the peerless in might,

Whose banners arise on the battlement's height,

Heaven's fire is around thee, to blast and to burn;

Return to thy dwelling! all lonely return!

For the blackness of ashes shall mark where it stood,

And a wild mother scream o'er her famishing brood.

\section{LOCHIEL.}

False Wizard, avaunt! I have marshall'd my clan:

Their swords are a thousand, their bosoms are one!

They are true to the last of their blood and their breath,

And like reapers descend to the harvest of death.

Then welcome be Cumberland's steed to the shock!

Let him dash his proud foam, like a wave on the rock!

But woe to his kindred, and woe to his cause,

When Albin her claymore indignantly draws!

When her bonneted chieftains to victory crowd, Clanronald the dauntless, and Moray the proud, All plaided and plumed in their tartan array-

WIZARD.

-Lochiel, Lochiel! beware of the day;

For, dark and despairing, my sight I may seal,

But man cannot, cover what God'would reveal:

'Tis the sunset of life gives me mystical lore,

And coming events cast their shadows before.

I tell thee, Culloden's dread echoes shall ring

With the bloodhounds that bark for thy fugitive king. 


\section{LOCHIEL'S WARNING.}

Lo! anointed by Heaven with the vials of wrath, Behold, where he flies on his desolate path!

Now, in darkness and billows, he sweeps from my sightRise! rise! ye wild tempests, and cover his flight!... . ... 'Tis finish'd. Their thunders are hush'd on the moors;

Culloden is lost, and my country deplores.

But where is the iron-bound prisoner? Where?

For the red eye of battle is shut in despair.

Say, mounts he the ocean-wave, banish'd, forlorn, Like a limb from his country cast bleeding and torn? Ah, no! for a darker departure is near;

The war-drum is muffled, and black is the bier; His death-bell is tolling; oh! merey, dispel Yon sight, that it freezes my spirit to tell! Life flutters convulsed in his quivering limbs, And his blood-streaming nostril in agony swims. Accurs'd be the fagots that blaze at his feet, Where his heart shall be thrown, ere it ceases to beat, With the smoke of its ashes to poison the gale-

LOCHIEL.

-Down, soothless insulter! I trust not the tale; For never shall Albin a destiny meet

So black with dishonour, so foul with retreat.

'Tho' my perishing ranks should be strew'd in their gore,

Like ocean-weeds heap'd on the surf-beaten shore,

Lochiel, untainted by flight or by chains,

While the kindling of life in his bosom remains,

Shall vietor exult, or in death be laid low,

With his back to the field, and his feet to the foe!

And, leaving in battle no blot on his name,

Look proudly to Ileaven from the death-bed of fame. 


\section{CAMPBELL.}

\section{HOHENLINDEN.}

Ox Linden, when the sun was low, All bloodless lay th' untrodden snow; And dark as winter was the flow Of Iser, rolling rapidly.

But Linden saw another sight, When the drum beat, at dead of night, Commanding fires of death to light The darkness of her scenery.

By torch and trumpet fast array'd, Each horseman drew his battle-blade, And furious every charger neigh'd, To join the dreadful revelry.

Then shook the hills, with thunder riven; Then rush'd the steed to battle driven; And, louder than the bolts of heaven, Far flash'd the red artillery.

But redder yet that light shall glow On Linden's liills of stainèd snow, And bloodier yet the torrent flow Of Iser, rolling rapidly.

'Tis morn, but scarce yon level sun Can pierce the war-elouds, rolling dun, Where furious Frank, and fiery Hun, Shout in their sulph'rous canopy. 


\section{HOHENLINDEN.}

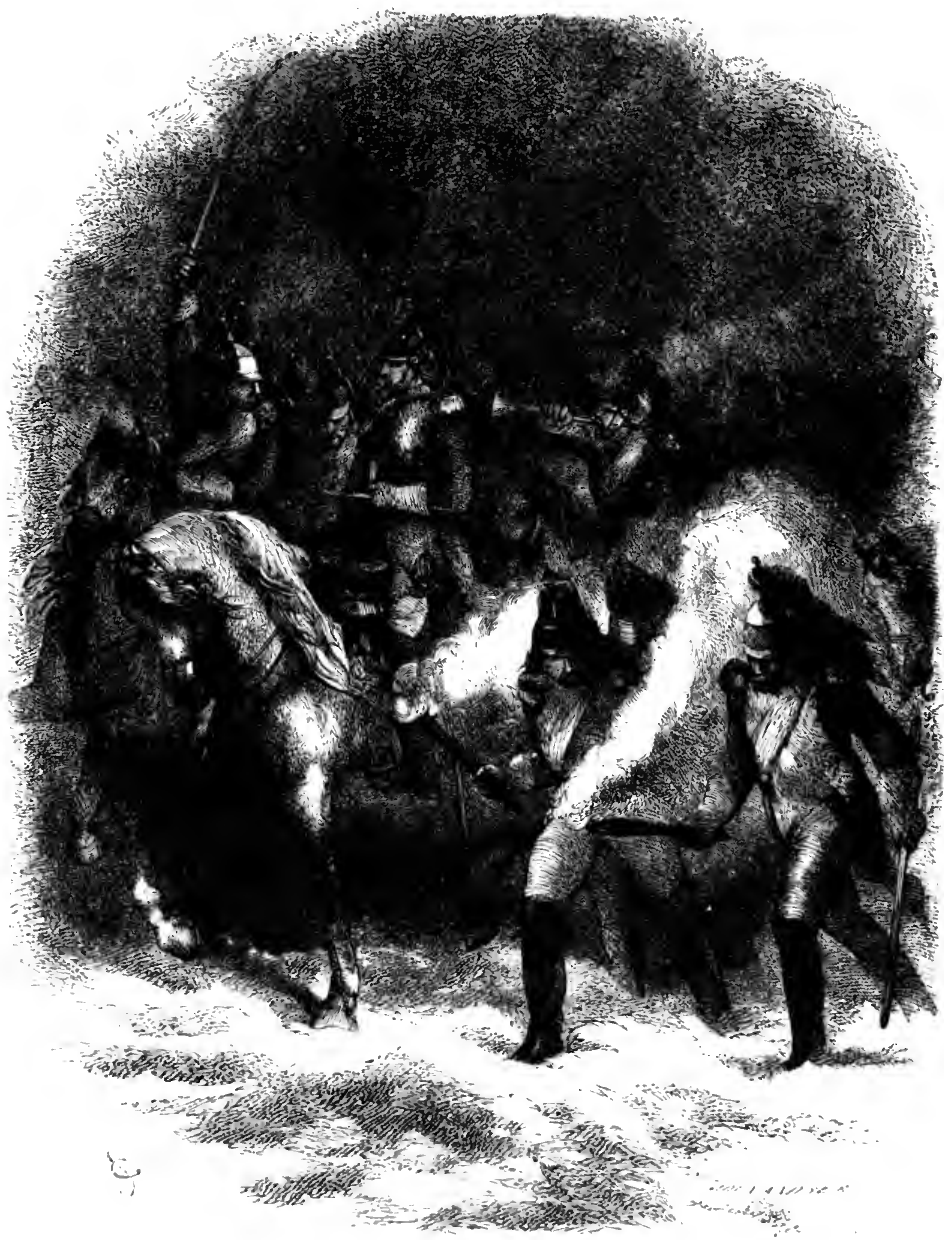

The combat decpens. On, ye brave,

Who rush to glory, or the grave!

Wave, Munich, all thy banners wave:

And charge with all thy chivalry! 


\section{CAMPBELI.}

Few, few shall part, where many meet!

'The snow shall be their winding-sheet, And every turf beneath their feet

Shall be a soldier's sepulchre!

\section{BATTLE OF .THE BALTIC.}

Of Nelson and the North, Sing the glorious day's renown, When to battle fierce came forth All the might of Denmark's crown, And her arms along the deep proudly shone;

By each gun the lighted brand, In a bold determined hand, And the Prince of all the land Led them on.-

Like leviathans afloat,

Lay their bulwarks on the brine;

While the sign of battle flew

On the lofty British line:

It was ten of April morn by the chime:

As they drifted on their path, There was silence deep as death;

And the boldest held his breath

For a time.-

But the might of England flush'd .

To anticipate the scene;

And her van the fleeter rush'd

O'er the deadly space between.

"Hearts of oak!" our captain cried; when each gun 
From its adamantine lips

Spread a death-shade round the ships,

Like the hurricane eclipse

Of the sun.-

Again! again! again!

And the havoc did not slack,

Till a feeble cheer the Dane

To our cheering sent us back:

Their shots along the deep slowly boom:

Then ceas'd-and all is wail,

As they strike the shatter'd sail;

Or, in conflagration pale,

Light the gloom.-

Out spoke the victor then,

As he hail'd them o'er the wave:

"Ye are brothers! ye are men!

And we conquer but to save:-

So peace instead of death let us bring:

But yield, proud foe, thy fleet,

With the crews, at England's feet,

And make submission meet

To our King." -

Then Denmark blest our chief

That he gave her wounds repose;

And the sounds of joy and grief

From her people wildly rose,

As Death withdrew his shades from the day;

While the sun look'l smiling bright

O'er a wide and woful sight,

Where the fires of funeral light

Died away.-

Now joy, Old England, raise!

For the tidings of thy might, 
By the festal cities' blaze,

Whilst the wine-cup shines in light;

And yet, amidst that joy and uproar,

Let us think of them that sleep,

Full many a fathom deep,

By thy wild and stormy steep,

Elsinore!-

Brave hearts! to Britain's pride

Once so faithful and so true,

On the deck of fame that died,

With the gallant, good Riou;-

Soft sigh the winds of Heaven o'er their grave!

While the billow mournful rolls,

And the mermaid's song condoles,

Singing glory to the souls

Of the brave!

YF MARINERS OF ENGLAND.

Ye Mariners of England!

That guard our native seas;

Whose flag has braved, a thousand years,

The battle and the breeze!

Your glorious standard launch again,

To match another foe!

And sweep through the deep,

While the stormy winds do blow;

While the battle rages loud and long,

And the stormy winds do blow. 


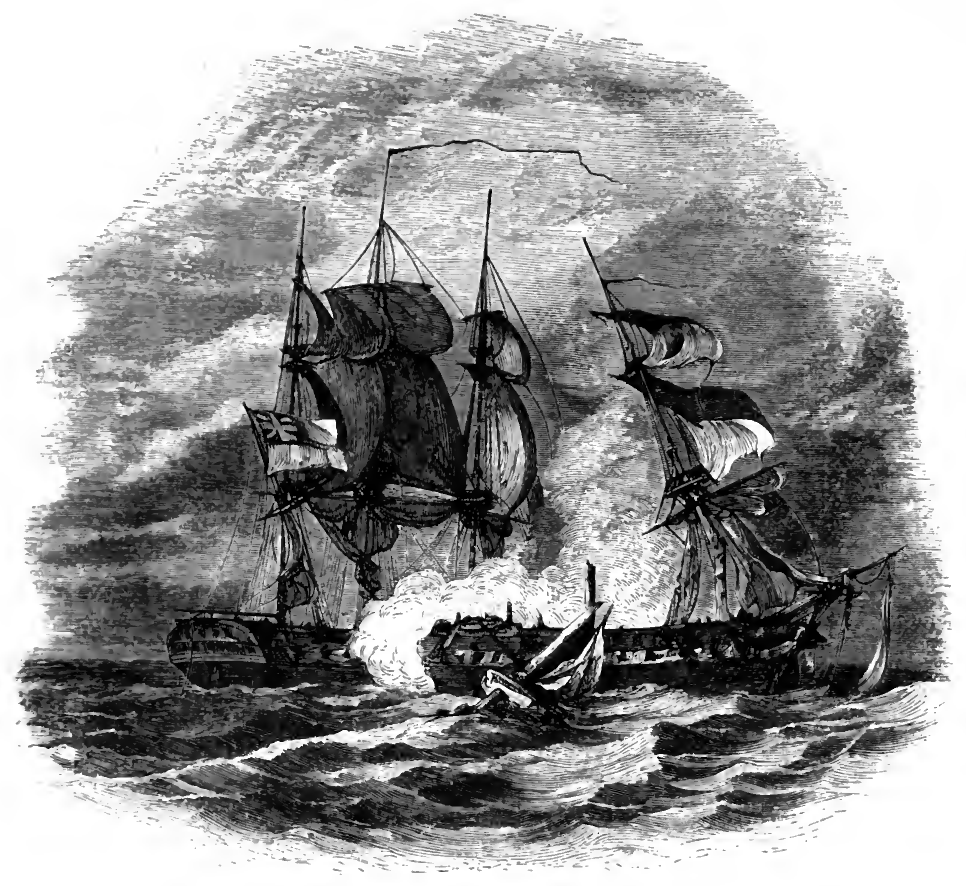

The spirits of your fathers

Shall start from every wave!

For the deck it was their field of fame,

And Ocean was their grave:

Where Blake and mighty Nelson fell,

Your manly hearts shall glow,

As ye sweep through the deep,

While the stormy winds do blow;

While the battle rages loud and long,

Asd the stormy winds do blow. 


\section{CAMPBELL.}

Britannia needs no bulwarks,

No towers along the steep;

Her march is on the mountain-waves,

Her home is on the deep.

With thunders from her native oak,

She quells the floods below-

As they roar on the shore,

When the stormy winds do blow;

When the battle rages loud and long,

And the stormy winds do blow.

The meteor flag of England

Shall yet terrific burn,

Till danger's troubled night depart,

And the star of peace return.

Then, then, ye ocean-warriors!

Our song and feast shall flow

To the fame of your name,

When the storm has ceased to blow;

When the fiery fight is heard no more,

And the storm has ceased to blow. 


\section{WILDE.}

\section{STANZAS.}

MY life is like the summer rose

That opens to the morning sky, But ere the shades of evening close,

Is scatter'd on the ground-to die!

Yet on the rose's humble. bed

The sweetest dews of night are shed,

As if she wept the waste to see-

But none shall weep a tear for me!

My life is like the autumn leaf

That trembles in the moon's pale ray,

Its hold is frail-its date is brief,

Restless-and soon to pass away!

Yet, ere that leaf shall fall and fade,

The parent tree will mourn its shade,

The winds bewail the leafless tree,

But none shall breathe a sigh for me!

My life is like the prints, which feet

Have left on Tampa's desert strand;

Soon as the rising tide shall beat,

All trace will vanish from the sand;

Yet, as if grieving to efface

All vestige of the human race,

On that lone shore loud moans the sea, But none, alas! shall mourn for me! 


\title{
JAMES MONTGOMERY.
}

\author{
THE DEATH OF ADAM.
}

The sun, in summer majesty on high,

Darted his fierce effulgence down the sky;

Yet dimm'd and blunted were the dazzling rays,

His orb expanded through a dreary haze,

And, circled with a red portentous zone,

He look'd in sickly horror from his throne:

When higher noon had shrunk the lessening shade,

Thence to his home our father we convey'd,

And stretch'd him, pillow'd with his latest sheaves,

On a fresh couch of green and fragrant leaves.

Here, though his sufferings through the glen were known,

We chose to watch his dying-bed alone,

Eve, Seth, and I.-In vain he sigh'd for rest,

And oft his meek complainings thus express'd:

"Blow on me, Wind! I faint with heat! O bring

Delicious water from the deepest spring;

Your sunless shadows o'er my limbs diffuse,

Ye Cedars! wash me cold with midnight dews;

Cheer me, my friends! with looks of kindness cheer;

Whisper a word of comfort in mine ear;

These sorrowing faces fill my soul with gloom-

This silence is the silence of the tomb."

The sun went down, amidst an angry glare

Of flushing clouds, that crimson'd all the air;

The winds brake loose; the forest-boughs were torn, And dark aloof the eddying foliage borne; 


\section{THE DEATH OF ADAM.}

Cattle to shelter scudded in affright;

The florid Evening vanish'd into night:

Then burst the hurricane upon the vale,

In peals of thunder, and thick-volley'd hail;

Prone rushing rains with torrents whelm'd the land;

Our cot amidst a river seem'd to stand;

Around its base, the foamy-crested streams

Flash'd through the darkness to the lightning's gleams;

With monstrous throes an earthquake heaved the ground;

The rocks were rent, the mountains trembled round.

Amidst this war of elements, within

More dreadful grew the sacrifice of sin,

Whose victim on his bed of torture lay,

Breathing the slow remains of life away.

Erewhile, victorious faith sublimer rose

Beneath the pressure of collected woes;

But now his spirit waver'd, went and came,

Like the loose vapour of departing flame,

Till at the point, when comfort seem'd to die

For ever in his fix'd unclosing eye,

Bright through the smouldering ashes of the man,

The saint brake forth, and Adam thus began:-

"O ye who shudder at this awful strife,

This wrestling agony of Death and Life,

Think not that He, on whom my soul is cast,

Will leave me thus forsaken to the last;

Nature's infirmity alone you see;

My chains are breaking, I shall soon be free:

Though firm in God the spirit holds her trust,

The flesh is frail, and trembles into dust.

Thou, of my faith the Author and the End!

Mine early, late, and everlasting Friend!

The joy, that once Thy presence gave, restore,

Ere I am summon'd hence, and seen no more;

Down to the dust returns this earthly frame-

Receive my spirit, Lord! from whom it came." 
He closed his eyelids with a tranquil smile, And seem'd to rest in silent prayer awhile: Around his couch with filial awe we kneel'd, When suddenly a light from heaven reveal'd A Spirit, that stood within the unopen'd door, The sword of God in his right hand he bore;

His countenance was lightning, and his vest Like snow at sun-rise on the mountain's crest; Yet so benignly beautiful his form, His presence still'd the fury of the storm; At once the winds retire, the waters cease; His look was love, his salutation "Peace!"

Our Mother first beheld him, sore amazed, But terror grew to transport, while she gazed.-"'Tis he, the Prince of Seraphim! who drove Our banish'd feet from Eden's happy grove. Adam, my Life, my Spouse, awake!" she cried;

"Return to Paradise; behold thy Guide!

O let me follow in this dear embrace!"

She sunk, and on his bosom hid her face.

Adam look'd up; his visage changed its hue, Transform'd into an Angel's at the view. "I come!" he cried, with faith's full triumph fir'd, And in a sigh of ecstasy expir'd.

The light was vanish'd, and the vision fled; We stood alone, the living with the dead; The ruddy embers, glimmering round the room, Display'd the corpse amidst the solemn gloom; But o'er the scene a holy calm repos'd, The gate of heaven had open'd there, and clos'd. 


\section{JOANNA BAILLIE.}

\section{THE PHRENZY OF ORRA.}

Hartman. Is she well?

Theobald. Her body is.

Hart. And not her mind? oh, direst wreck of all!

That noble mind!-But 'tis some passing seizure, Some powerful movement of a transient nature;

It is not madness!

Theo. 'Tis Heaven's infliction; let us call it so;

Give it no other name.

Eleanora. Nay, do not thus despair; when she beholds us, She'll know her friends, and, by our kindly soothing,

Be gradually restored-

Alice. Let me go to her.

Theo. Nay, forbear, I pray thee;

I will myself with thee, my worthy Hartman, Go in and lead her forth.

Orra. Come back, come back! the fierce and fiery light!

Theo. Shrink not, dear love! it is the light of day.

Orra. Have cocks crow'd yet?

Theo. Yes; twice I've heard already Their matin sound. Look up to the blue skyIs it not daylight there? And these green boughs Are fresh and fragrant round thee; every sense 'Tells thee it is the cheerful early day.

Orra. Aye, so it is; day takes his daily turn, Rising between the gulfy dells of night, Like whiten'd billows on a gloomy sea. 
Till glow-worms gleam, and stars peep through the dark, And will-o'-the-wisp his dancing taper light, They will not come again.

[Bending her ear to the ground.

$$
\text { Hark, hark ! aye, hark ! }
$$

They are all there: I hear their hollow sound Full many a fathom down.

Theo. Be still, poor troubled soul! they'll ne'er returnThey are for ever gone. Be well assured

'Thou shalt from henceforth have a cheerful home,

With crackling fagots on thy midnight fire,

Blazing like day around thee; and thy friends-

Thy living, loving friends-still by thy side,

To speak to thee and cheer thee. See, my Orra!

They are beside thee now; dost thou not know them?

Orra. No, no! athwart the wav'ring garish light, Things move and seem to be, and yet are nothing.

Elea. My gentle Orra! hast thou then forgot me?

Dost not thou know my voice?

Orra. 'Tis like an old tune to my ear return'd.

For there be those who sit in cheerful halls,

And breathe sweet air, and speak with pleasant sounds;

And once I liv'd with such; some years gone by,-

I wot not now how long.

Hughobert. Keen words that rend my heart! thou hadst a home, And one whose faith was pledged for thy protection.

Urston. Be more composed, my Lord; some faint remembrance Returns upon her, with the well-known sound

Of voices once familiar to her ear.

Let Alice sing to her some fav'rite tune,

That may lost thoughts recall.

Orra. Ha, ha! the witch'd air sings for thee bravely.

[Alice sings.

Hoot owls through mantling fog for matin birds?

It lures not me.-I know thee well enough:

The bones of murder'd men thy measure beat,

And fleshless heads nod to thee-Off, I say! 
Why are ye here?-That is the blessed sun.

Elea. Ah, Orra! do not look upon us thus;

These are the voices of thy loving friends

That speak to thee; this is a friendly hand

That presses thine so kindly.

Hart. Oh, grievous state! what terror seizes thee?

Orra. Take it away! It was the swathèd dead;

I know its clammy, chill, and bony touch.

Come not again; I'm strong and terrible now:

Mine eyes have look'd upon all dreadful things;

And when the earth yawns, and the hell-blast sounds,

I'll bide the trooping of unearthly steps,

With stiff, elench'd, terrible strength.

Hugh. A murd'rer is a guiltless wretch to me.

Hart. Be patient; 'tis a momentary pitch;

Let me encounter it.

Orra. Take off from me thy strangely-fasten'd eye;

I may not look upon thee-yet I must.

Unfix thy baleful glance. Art thou a snake?

Something of horrid power within thee dwells.

Still, still that powerful eye doth suck me in

Jike a dark eddy to its wheeling core.

Spare me! O spare me, Being of strange power,

And at thy feet my subject head I'll lay.

Elea. Alas, the piteous sight! to see her thus,

The noble, generous, playful, stately Orra!

Theo. Out on thy hateful and ungenerous guile!

'Think'st thou I'll suffer o'er her wretched state

The slightest shadow of a base control?

[Raising Orra from the ground.

No; rise, thou stately flower with rude blasts rent;

As honour'd art thou with thy broken stem

And leaflets strew'd, as in thy summer's pride.

I've seen thee worshipp'd like a regal Dame,

With every studied form of mark'd devotion,

Whilst I, in distant silence, scarcely proffer'd

Ev'n a plain soldier's courtesy; but now, 


\section{JOANNA BAILLIE.}

No liege man to his crownèd mistress sworn,

Bound and devoted is as I to thee;

And he who offers to thy alter'd state

The slightest seeming of diminish'd rev'rence,

Must in my blood-(To Hartman $)-\mathrm{O}$ pardon me, my friend!

'Thou'st wrung my heart.

Hart. Nay, do thou pardon me,-I am to blame:

Thy nobler heart shall not again be wrung.

But what can now be done? O'er such wild ravings

There must be some control.

Theo. O none! none! none! but gentle sympathy, And watchfulness of love.

My noble Orra!

Wander where'er thou wilt, thy vagrant steps

Shall follow'd be by one, who shall not weary,

Nor e'er detach him from his hopeless task;

Bound to thee now as fairest, gentlest beauty

Could ne'er have bound him.

Alice. See how she gazes on him with a look,

Subsiding gradually to softer sadness,

Half saying that she knows him.

El. There is a kindness in her changing eye. 


\section{GRAHAME.}

THE SABBATH.

How still the morning of the hallow'd day!

Mute is the voice of rural labour, hush'd

The plough-boy's whistle, and the milk-maid's song.

The scythe lies glittering in the dewy wreath

Of tedded grass, mingled with fading flowers,

That yestermorn bloom'd waving in the breeze;

Sounds the most faint attract the ear,-the hum

Of early bee, the trickling of the dew,

The distant bleating, midway up the hill.

Calmness sits throned on yon unmoving cloud.

To him who wanders o'er the upland leas,

The blackbird's note comes mellower from the dale;

And sweeter from the sky the gladsome lark

Warbles his heaven-tun'd song; the lulling brook

Murmurs more gently down the deep-worn glen;

While from yon lowly roof, whose circling smoke

O'er-mounts the mist, is heard, at intervals,

The voice of Psalms, the simple song of praise.

With dove-like wings Peace o'er yon village broods;

The dizzying mill-wheel rests; the anvil's din

Hath ceas'd; all, all around is quietness.

Less fearful on this day, the limping hare 


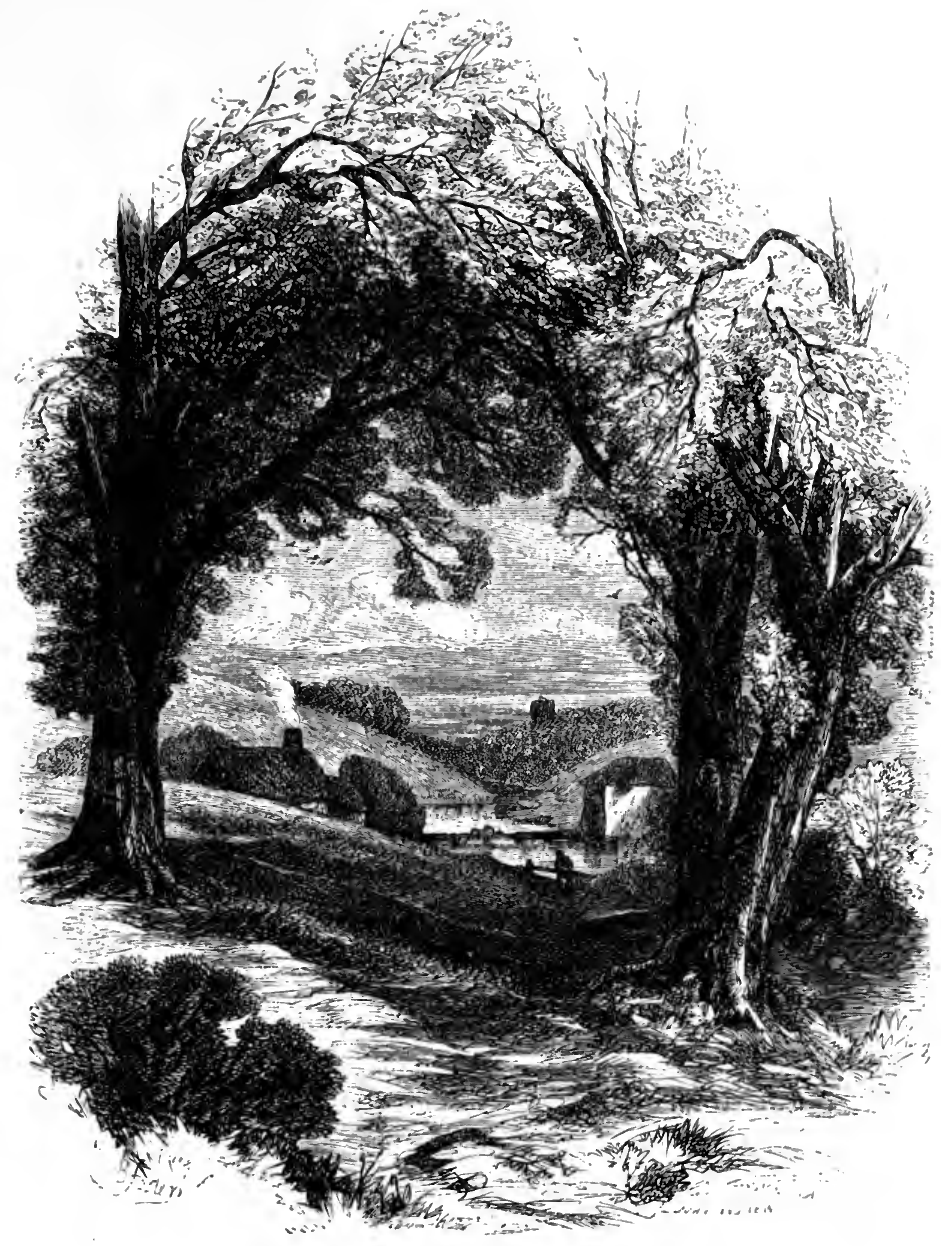

Stops, and looks back, and stops, and looks on man, Her deadliest foe. The toil-worn horse, set free, Unheedful of the pasture, roams at large; And as his stiff unwieldy bulk he rolls, His iron-arm'd hoofs gleam in the morning ray. 


\section{SUNDAY TO THE SHIPWRECKED.}

Oн! my heart bleeds to think there now may live One hapless man, the remnant of a wreck, Cast on some desert island of that main Immense, which stretches from the Cochin shore To Acapulco. Motionless he sits, As is the rock his seat, gazing whole days, With wandering eye, o'er all the watery waste; Now striving to believe the albatross

A sail appearing on the horizon's verge; Now vowing ne'er to cherish other hope Than hope of death. Thus pass his weary hours, 'Till welcome evening warn him that 'tis time Upon the well-notch'd calendar to mark Another day, another dreary day,Changeless.

$$
\text { But yet by him, }
$$

The Hermit of the Deep, not unobserv'd The Sabbath passes; - 'tis his great delight. Each seventh eve he marks the farewell ray, And loves, and sighs to think, 一that setting sun Is now empurpling Scotland's mountain-tops, Or, higher risen, slants athwart her vales, Tinting with yellow light the quivering throat Of day-spring lark, while woodland birds below Chaunt in the dewy shade. Thus, all night long He watches, while the rising moon describes The progress of the day in happier lands. And now he almost fancies that he hears The chiming from his native village church: 
And now he sings, and fondly hopes the strain May be the same that sweet ascends at home In congregation full,-where, not without 'a tear, They are remember'd who in ships behold The wonders of the deep: he sees the hand, 'The widow'd hand, that veils the eye suffus'd; ' He sees his orphan'd boy look up, and strive 'The widow'd heart to soothe. His spirit leans On Grod.-

-Calm he views

The far-exploding firmament, and dares

To hope-one bolt in mercy is reserv'd

For his release; and yet he is resign'd

To live: because full well he is assur'd

Thy Hand does lead him, thy right Hand upholds.

And thy right Hand does lead him! Lo! at last, One sacred eve, he hears, faint from the deep, Music remote, swelling at intervals, As if the embodied spirit of sweet sounds Came slowly floating on the shoreward wave: The cadence well he knows-a hymn of old, Where sweetly is rehears'd the lowly state Of Jesus, when his birth was first announced, In midnight music, by an angel choir, To Bethlehem's shepherds, as they watch'd their flocks. Breathless, the man forlorn listens, and thinks It is a dream. Fuller the voices swell; He looks, and starts to see, moving along, A fiery wave, (so seems it,) crescent form'd, Approaching to the land; straightway he sees

A towering whiteness; 'tis the heaven-fill'd sails That waft the mission'd men, who have renounced Their homes, their country, nay, almost the world, Bearing glad tidings to the farthest isles Of ocean, that the dead shall rise again. Forward the gleam-girt castle coast-wise glides, It seems as it would pass away.-To cry 
The wretched man in vain attempts, in vain, Powerless his voice as in a fearful dream-

Not so his hand; he strikes a flint, - a blaze

Mounts from the ready heap of wither'd leaves:

The music ceases; acents harsh succeed,

Harsh, but most grateful; downward drop the sails;

Ingulf'd the anchor sinks; the boat is launch'd;

But cautious lies aloof till morning dawn:

Oh then the transport of the man, unus'd

To other human voice beside his own,-

His native tongue to hear! he breathes at home,

Though earth's diameter is interpos'd.

Of perils of the sea he has no dread,

Full well assur'd the mission'd bark is safe,

Held in the hollow of the Almighty's Hand.

\section{A SABBATH WALK IN SUMMER.}

Deligntfut is this loneliness; it calms

My heart; pleasant the cool beneath these elms,

That throw across the stream a moveless shade.

Here Nature in her midnoon whisper speaks:

How peaceful every sound! the ring-dove's plaint,

Moan'd from the twilight centre of the grove,

While every other woodland lay is mute,

Save when the wren flits from her down-eoved nest,

And from the root-sprigs trills her ditty clear,-

The grasshopper's of pausing chirp,-the buzz,

Angrily shrill, of moss-entangled bee, 


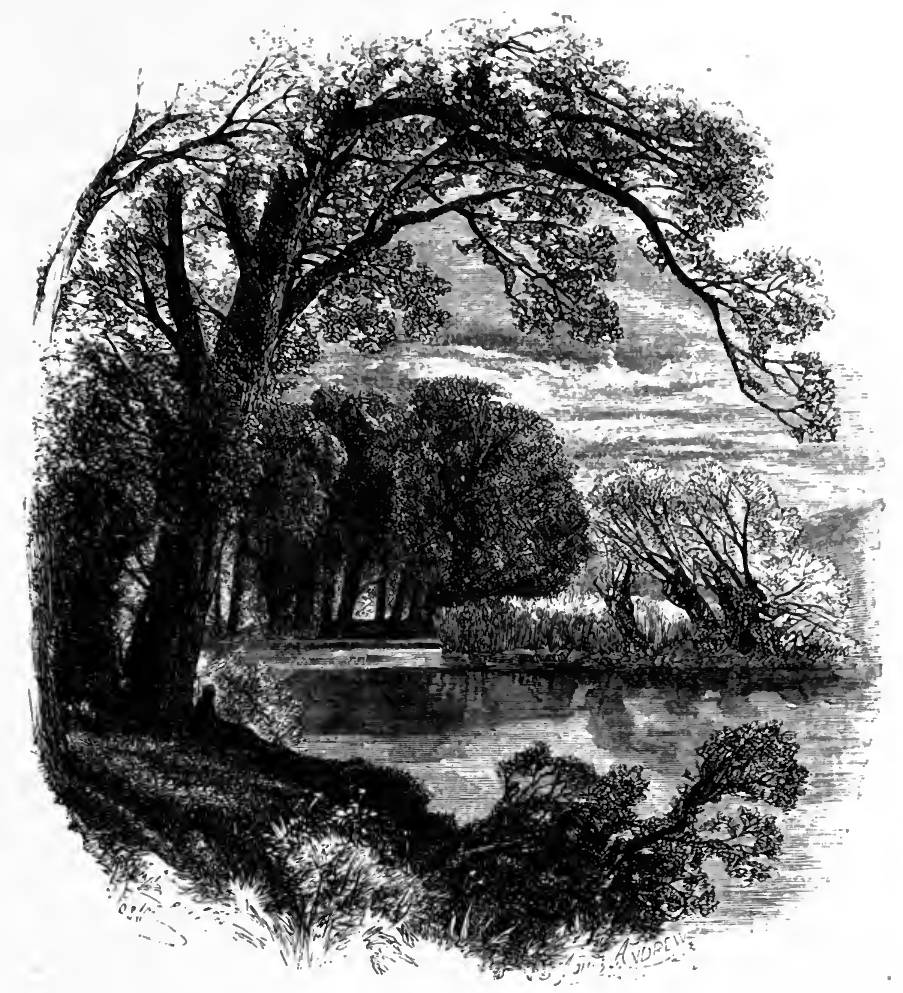

That, soon as loos'd, booms with full twang away,The sudden rushing of the minnow shoal, Scar'd from the shallows by my passing tread. Dimpling the water glides, with here and there A glossy fly, skimming in circlets gay The treacherous surface, while the quick-eyed trout Watches his time to spring; or, from above, 
Some feather'd dam, purveying 'mong the boughs,

Darts from her perch, and to her plumeless brood

Bears off the prize :- sad emblem of man's lot!

He, giddy insect, from his native leaf,

(Where safe and happily he might have lurk'd,)

Elate upon ambition's gaudy wings,

Forgetful of his origin, and, worse,

Unthinking of his end, flies to the stream;

And if from hostile vigilance he 'scape,

Buoyant he flutters but a little while,

Mistakes the inverted image of the sky

For heaven itself, and, sinking, meets his fate.

Now, let me trace the stream up to its source

Among the hills; its runnel by degrees

Diminishing, the murmur turns a tinkle.

Closer and closer still the banks approach,

Tangled so thick with pleaching bramble-shoots,

With brier, and hazel branch, and hawthorn spray,

That, fain to quit the dingle, glad I mount

Into the open air; grateful the breeze

That fans my throbbing temples! smiles the plain

Spread wide below: how sweet the placid view!

But, oh! more sweet the thought, heart-soothing thought,

That thousand and ten thousands of the sons

Of toil partake this day the common joy

Of rest, of peace, of viewing hill and dale,

Of breathing in the silence of the woods,

And blessing Нгм who gave the Sabbath-day.

Yes, my heart flutters with a freer throb,

To think that now the townsman wanders forth

Among the fields and meadows, to enjoy

'The coolness of the day's decline; to see

His children sport around, and simply pull

The flower and weed promiscuous, as a boon,

Which proudly in his breast they smiling fix. 


\section{GRAHAME.}

Again I turn me to the hill, and trace The wizard stream, now searce to be discern'd; Woodless its banks, but green with ferny leaves, And thinly strew'd with heath-bells up and down.

Now, when the downward sun has left the glens, Each mountain's rugged lineaments are traced Upon the adverse slope, where stalks gigantic 'The shepherd's shadow thrown across the chasm, As on the topmost ridge he homeward hies. How deep the hush! the torrent's channel, dry, Presents a stony steep, the echo's haunt. But hark, a plaintive sound floating along! 'Tis from yon heath-roof'd shielin; now it dies Away, now rises full; it is the song Which $\mathrm{He}$ who listens to the halleluias Of choiring Seraphim delights to hear; It is the music of the heart, the voice Of venerable age, - of guileless youth, In kindly circle seated on the ground Before their wicker door. Behold the man! The grandsire and the saint; his silvery locks Beam in the parting ray; before him lies, Upon the smooth-cropt sward, the open Book, His comfort, stay, and ever-new delight; While heedless, at his side, the lisping boy Fondles the lamb that nightly shares his couch. 


\section{BLOOMFIELD.}

\section{A M B A T P L A Y.}

Loosed from the winding lane, a joyful throng,

See o'er yon pasture how they pour along!

Giles round their boundaries takes his usual stroll,

Sees every gate secur'd, and fences whole:

High fences, proud to charm the gazing eye,

Where many a nestling first essays to fly;

Where blows the woodbine, faintly streak'd with red,

And rests on every bough its tender head;

Round the young ash its twining branches meet,

Or crown the hawthorn with its odour sweet.

Say, ye that know, ye who have felt and seen

Spring's morning sniles, and soul-enlivening green,

Say, did you give the thrilling transport way?

Did your eye brighten, when young lambs at play

Leap'd o'er your path with animated pride,

Or grazed in merry clusters by your side?

Ye who can smile, to wisdom no disgrace,

At the arch meaning of a kitten's face;

If spotless innocence, and infant mirth,

Excites to praise, or gives reflection birth;

In shades like these pursue your favourite joy,

Midst Nature's revels, sports that never cloy.

$\Lambda$ few begin a short but vigorous race, And indolence, abash'd, soon flies the place:

Thus challeng'd forth, see thither one by one,

From every side assembling playmates rum: 


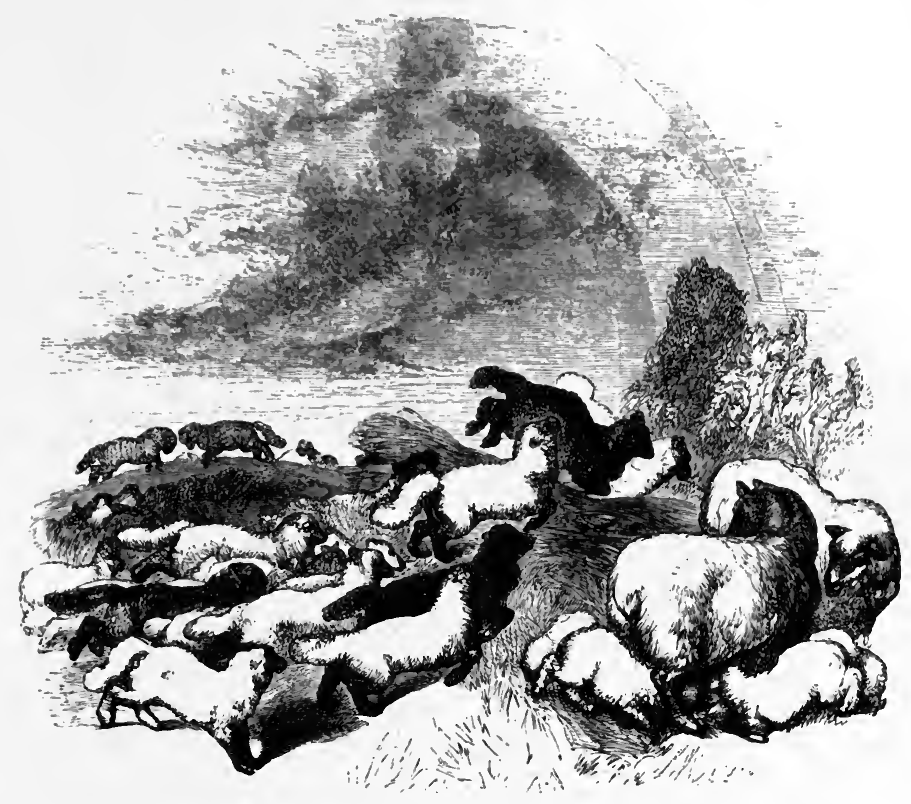

A thousand wily antics mark their stay,

A starting crowd impatient of delay.

Like the fond dove, from fearful prison freed, Each seems to say, "Come, let us try our speed ;" Away they scour, impetuous, ardent, strong, The green turf trembling as they bound along; Adown the slope, then up the hillock climb, Where every mole-hill is a bed of thyme. There panting stop; yet scarcely can refrain; A bird, a leaf, will set them off again: Or, if a gale with strength unusual blow, Scattering the wild-brier roses into snow, Their little limbs increasing efforts try, Like the torn flower the fair assemblage fly. 
THE FARMER'S BOY IN THE FIELDS.

THE FARMER'S BOY IN THE FIELDS.

Sho' up from broad rank blades that droop below, The nodding wheat-ear forms a graceful bow, With milky kernels starting full, weigh'd down, Ere yet the sun hath tinged its head with brown; Whilst thousands in a flock, for ever gay, Loud-chirping sparrows welcome in the day, And from the mazes of the leafy thorn Drop one by one upon the bending corn. Giles with a pole assails their close retreats, And round the grass-grown dewy border beats; On either side completely overspread, Here branches bend, there corn o'ertops his head. Green covert, hail! for thro' the varying year No hours so sweet, no scene to him so dear. IIere Wisdom's placid eye delighted sees IIis frequent intervals of lonely ease, And with one ray his infunt soul inspires, Just kindling there her never-dying fires, Whence solitude derives peculiar charms, Aud heaven-directed thought his bosom warms. Just where the parting bough's light shadows play, Scarce in the shade, nor in the scorching day, stretchid on the turf he lies, a peopled bed, Where swarming insects creep around his head. The small dust-colourd beetle climbs with pain O'er the smooth plantain leaf, a spacions plain! 'Thence higher still, by countless steps convey'd, He gains the summit of a shiv'ring blade, And flirts his filmy wings, and looks around, Exulting in his distance from the ground. 


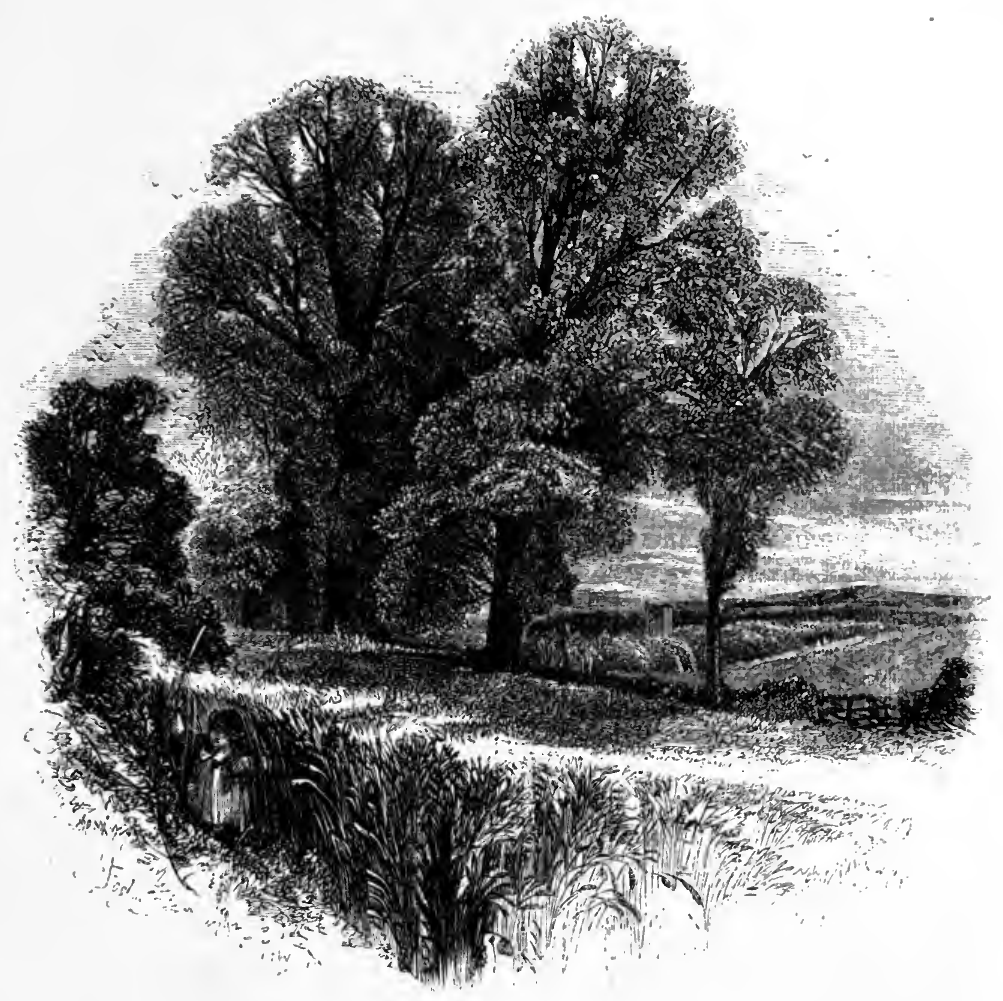

The tender speekled moth here daneing seen, 'The vaulting grasshopper of glossy green, And all prolific Summer's sporting train, Their little lives by various powers sustain.

But what can unassisted vision do?

What, but recoil where most it would pursue;

His patient gaze but finish with a sigh, When music waking speaks the sky-lark nigh ! 
Just starting from the corn she cheerly sings, And trusts with conscious pride her downy wings; Still louder breathes, and in the face of day Mounts up, and calls on Giles to mark her way. Close to his eyes his hat he instant bends, And forms a firiendly telescope, that lends Just aid enough to dull the glaring light, And place the wandering bird before his sight; Yet oft beneath a cloud she sweeps along, Lost for awhile, yet pours her varied song. He views the spot, and as the cloud moves by, Again she stretches up the clear blue sky; Her form, her motion, undistinguish'd quite, Save when she wheels direct from shade to light: 'The fluttering songstress a mere speck became, Like fancy's floating bubbles in a dream;

He sees her yet, but yielding to repose, Unwittingly his jaded eyelids close.

Delicious sleep! From sleep who could forbear, With no more guilt than Giles, and no more eare?

Peace o'er his slumbers waves her guardian wing, Nor Conseience once disturbs him with a sting: IIe wakes refresh'd from every trivial pain, And takes his pole and brushes round again. 


\section{ELLIOTT.}

\section{BURNS.}

That heaven's belov'd die early,

Prophetic Pity mourns;

But old as Truth, although in youth,

Died giant-hearted Burns.

Oh that I were the daisy

That sank beneath his plough,

Or, "neighbour meet," that "skylark sweet?"

Say, are they nothing now?

That mouse, "our fellow mortal,"

Lives deep in Nature's heart;

Like earth and sky, it cannot die

'Till earth and sky depart.

'Thy Burns, child-honour'd Scotland!

Is many minds in one;

With thought on thought, the name is fraught,

Of glory's peasant son.

'Thy Chaucer is thy Milton,

And might have been thy 'Tell;

As Hampden fought, thy Sidney wrote,

And would have fought as well.

Be proud, man-childed Scotland!

Of earth's unpolished gem;

And "Bonny Doon," and "heaven aboon,"

For Burns hath hallowed them. 
Be proud, though sin-dishonour'd, And grief baptized thy child; As rivers run, in shade and sun, He ran his courses wild.

Grieve not, though savage forests Look'd grimly on the wave, Where dim-eyed flowers and shaded bowers Seem'd living in the grave.

Grieve not, though, by the torrent, Its headlong course was riven, When o'er it came, in clouds and flame, Niagara from heaven!

For sometimes gently flowing, And sometimes chafed to foam, O'er slack and deep, by wood and steep,

He sought his heavenly home.

\section{A POET'S EPITAPH.}

Stol, Mortal! Here thy brother lies,

The Poet of the poor;

Ilis books were rivers, woods, and skies,

'The meadow and the moor;

Ilis teachers were the torn heart's wail,

The tyrant and the slave, 'Thr street, the factory, the jail,

The palace-and the grave!

Sin met thy brother every where!

And is thy brother blamed? 
From passion, danger, doubt, and care,

He no exemption claim'd.

The meanest thing, earth's feeblest worm

He fear'd to scorn or hate;

But, honouring in a peasant's form

The equal of the great.

He bless'd the Steward, whose wealth makes

'The poor man's little more;

Yet loath'd the haughty wretch that takes

From plunder'd labour's store.

A hand to do, a head to plan,

A heart to feel and dare-

'Tell man's worst foes, here lies the man

Who drew them as they are.

\section{SPRING.}

A GaIn the violet of our early days

Drinks beauteous azure from the golden sun,

And kindles into fragrance at his blaze;

'The streams, rejoic'd that Winter's work is done,

Talk of to-morrow's cowslips, as they run.

Wild apple, thou art blushing into bloom!

Thy leaves are coming, snowy-blossom'd thorn!

Wake, buried lily! spirit, quit thy tomb!

And thou, shade-loving hyacinth, be born!

Then, haste, sweet rose! sweet woodbine, hymn the morn,

Whose dew-drops shall illume with pearly light

Each grassy blade that thick embattled stands

From sea to sea, while daisies infinite

Uplift in praise their little glowing hands,

O'er every hill that under heav'n expands. 


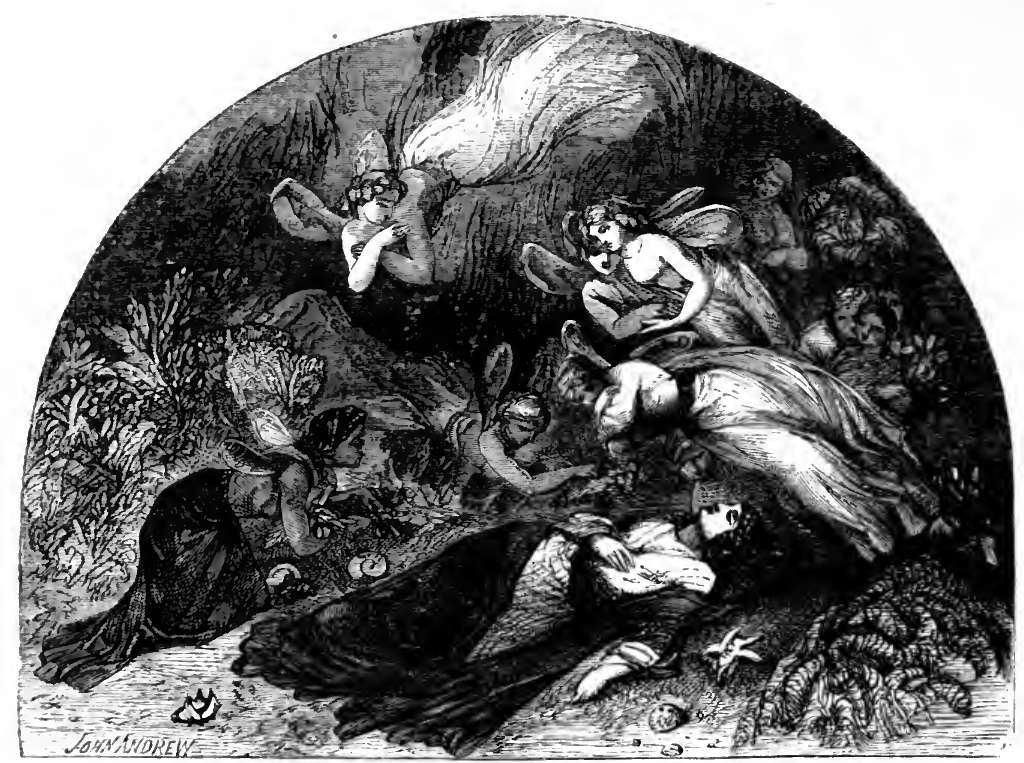

\section{MOORE.}

THE LAMENT OF THE PERI FOR HINDA.

Farewert, - farewell to thee, Araby's daughter !

('Thus warbled a Peri beneath the dark sea,)

No pearl ever lay, under Oman's green water,

More pure in its shell than thy Spirit in thee.

Oh! fair as the sea-flower close to thee growing, How light was thy heart till love's witchery came, Like the wind of the South o'er a summer lute blowing, And hush'd all its music and wither'd its frame!

But long, upon Arahy's green sumny lighlands, Shall maids and their lovers remember the doom 
Of her, who lies sleeping among the Pearl Islands,

With nought but the sea-star to light up her tomb.

And still, when the merry date-season is burning,

And calls to the palm-groves the young and the old.

The happiest there, from their pastime returning,

At sunset, will weep when thy story is told.

The young, village-maid, when with flowers she dresses

Her dark flowing hair for some festival day, Will think of thy fate till, neglecting her tresses,

She mournfully turns from the mirror away.

Nor shall Iran, belov'd of her Hero! forget thee-

Though tyrants wateh over her tears as they start,

Close, close by the side of that Hero she'll set thee,

Embalm'd in the innermost shrine of her heart.

Farewell-be it ours to embellish thy pillow

With every thing beauteous that grows in the deep;

Each flower of the rock and each gem of the billow

Shall sweeten thy bed and illumine thy sleep.

Around thee shall glisten the loveliest amber

That ever the sorrowing sea-bird has wept;

With many a shell, in whose hollow-wreath'd chamber,

We, Peris of Ocean, by moonlight have slept.

We'll dive where the gardens of coral lie darkling,

And plant all the rosiest stems at thy head;

We'll seek where the sands of the Caspian are sparkling,

And gather their gold to strew over thy bed.

Farewell-farewell-until Pity's sweet fountain

Is lost in the hearts of the fair and the brave,

They'll weep for the Chieftain who died on that mountain.

They'll weep for the Maiden who sleeps in this wave. 
NOURMAHAL.

NOURMAHAL.

THE BEALTY OF EXPRESSION.

'There's a beauty, for ever unchangingly bright, Like the long sunny lapse of a summer day's light, Shining on, shining on, by no shadow made tender, Till Love falls asleep in the sameness of splendour.

This was not the beauty,-oh! nothing like this, That to young Novmuninal gave such magic of bliss;

But that loveliness, ever in motion, which plays like the light upon autumn's soft shadowy days, Now here and now there, giving warmth as it flies From the lips to the check, from the cheek to the eyes, Now melting in mist, and now breaking in gleams, Like the glimpses a saint hath of Heav'n in his dreams!

When pensive, it seem'd as if that very grace,

That charm of all others, was born with her face;

And when angry-for ev'n in the tranquillest elimes light breezes will ruffle the blossoms sometimesThe short, passing anger but seem'd to awaken

New beauty, like flow'rs that are sweetest when shaken.

If tenderness touch'd her, the dark of her eye

At once took a darker, a heavenlier dye,

From the depth of whose shadow, like holy revealings

From innermost shrines, cane the light of her feelings!

Then her mirtlı-oh! 'twas sportive as ever took wing

From the heart with a burst, like the wild-bird in spring;-

Illumid by a wit that would fascinate sages,

Yet playfiul as Peris just loos'd from their cages,

While her laugh, full of life, without any control

But the swert one of gracefulness, rung from her soul;

And where it most sparkled no grance could discover,

In lip, cheek, or eyes, for she brightend all over,-

like any fair lake that the breeze is upon,

When it breaks into dimples and laughs in the sun. 


\section{WOLFE.}

THE BURIAL OF SIR JOHN MOORE.

Nor a drum was heard, not a funeral note,

As his corse to the rampart we hurried;

Not a soldier discharged his farewell shot

$\mathrm{O}$ 'er the grave where our hero we buried

We buried him darkly, at dead of night, The sods with our bayonets turning,

- By the struggling moon-beam's misty light, And the lantern dimly burning.

No useless coffin enclosed his breast,

Nor in sheet nor in shroud we wound him;

But he lay like a warrior taking his rest, With his martial cloak around him.

Few and short were the prayers we said, And we spoke not a word of sorrow;

And we steadfastly gazed on the face of the dead,

And we bitterly thought of the morrow.

We thought, as we hollow'd his narrow bed, And smooth'd down his lonely pillow, That the foe and the stranger would tread o'er his head, And we far away on the billow!

Lightly they'll talk of the spirit that's gone, And o'er his cold ashes upbraid him;-

But little he'll reek, if they let him sleep on

In the grave where a Briton has laid him.

But half of our heavy task was done, When the elock struck the hour for retiring; 


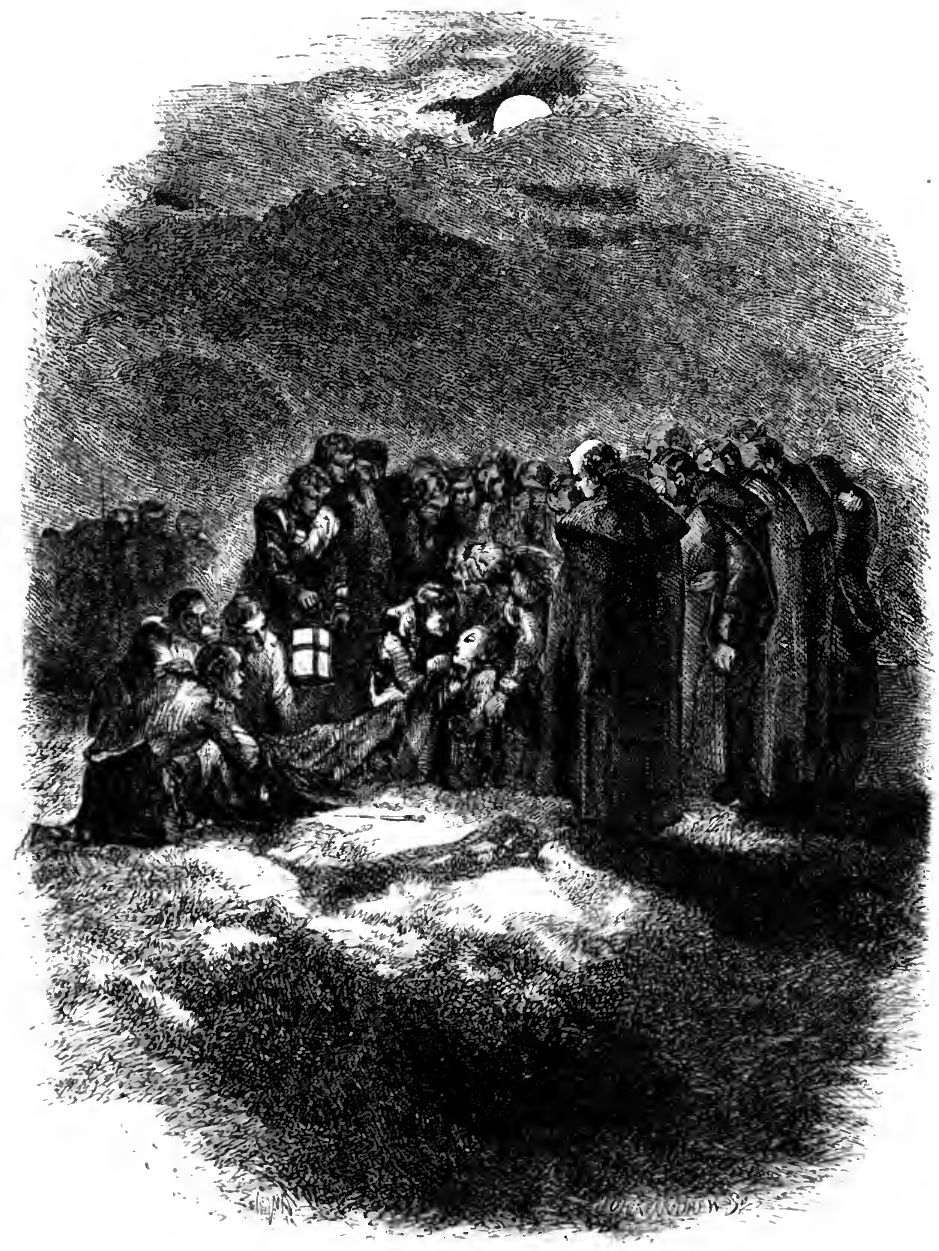

And we heard the distant and random gun Of the enemy sullenly firing.

Slowly and sarlly we laid him down,

From the field of his fame fresh and gory;

We carved not a line, and we raised not a stone-

But we left him alone with his glory! 


\section{CUNNINGHAM.}

\section{THE POET'S BRIDAL-DAY SONG.}

Oн! my love's like the steadfast sun, Or streams that deepen as they run.

Nor hoary hairs, nor forty years,

Nor moments between light and tears,

Nor nights of thought, nor days of pain,

Nor dreams of glory dream'd in vain;

Nor mirth, nor sweetest song that flows

To sober joys, and softer woes,

Can make my heart or fancy flee,

One moment, my sweet wife, from thee.

Even while I muse, I see thee sit

In maiden bloom and matron wit;

Fair, gentle as when first I sued

Ye seem, but of sedater mood;

Yet my heart leaps as fond for thee,

As when, beneath Arbigland tree,

We stay'd and woo'd, and thought the moon

Set on the sea an hour too soon,

Or linger'd 'mid the falling dew,

When looks were fond, and words were few.

Though I see smiling at my feet

Five sons and one fair daughter sweet,

And time and care and birthtime woes

Have dimm'd thine eye, and touch'd thy rose, 
To thee, and thoughts of thee, belong Whate'er charms me in tale or song. When words descend, like dews unsought, With gleams of deep enthusiast thought, And Fancy in her heaven flies free, They come, my love, they come from thee.

Oh, when more thought we gave, of old, To silver, than some give to gold, 'Twas sweet to sit and ponder o'er How we should deck our humble bower; 'Twas sweet to pull, in hope, with thee, The golden fruit of Fortune's tree; And sweeter still to choose and twine A garland for that brow of thine:

A song-wreath which may grace my Jean, While rivers flow, and woods grow green.

At times there come, as come there ought, Grave moments of sedater thought, When Fortune frowns, nor lends our night One gleam of her inconstant light;

And Hope, that decks the peasant's bower, Shines like a rainbow through the shower, Oh then I see, while seated nigh, A mother's heart shine in thine eye, And proud resolve and purpose meek Speak of thee more than words can speak. I think this wedded life of mine The best of all things not divine. 


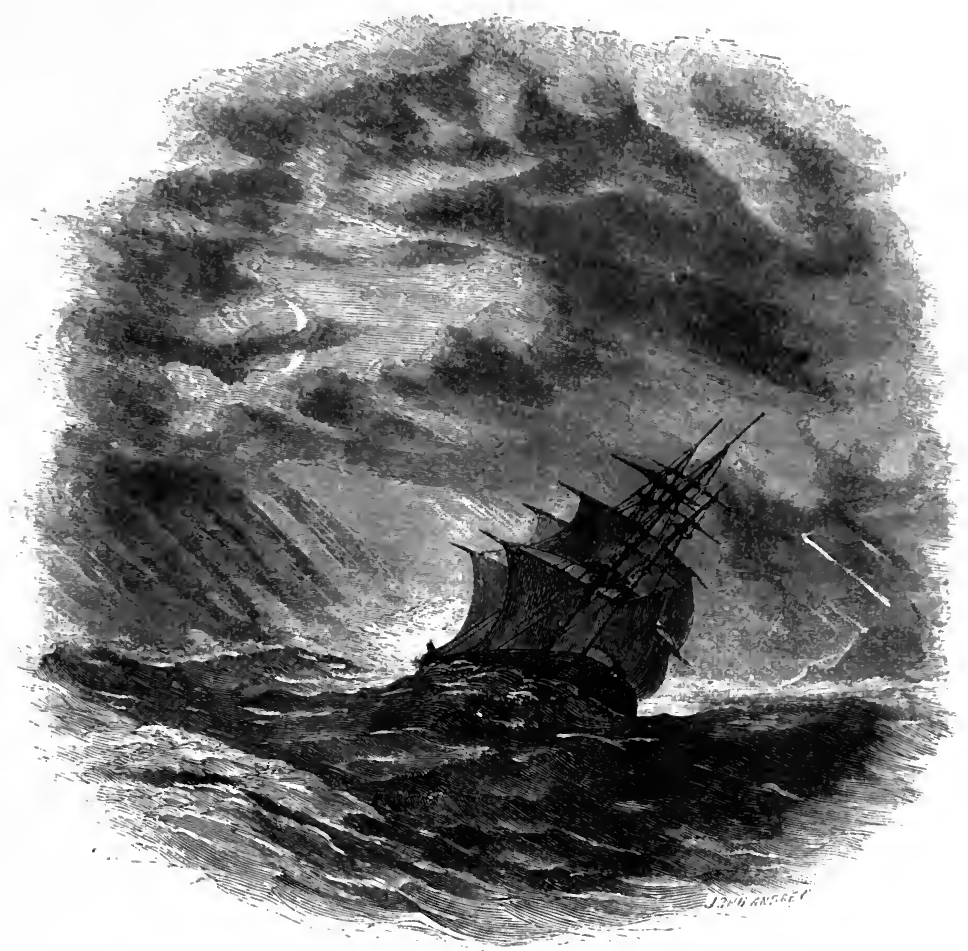

A WET SHEET AND A FLOWING SEA.

A wer sheet and a flowing sea,

A wind that follows fast,

And fills the white and rustling sail, And bends the gallant mast;

And bends the gallant mast, my boys,

While, like the eagle free, 


\section{A WET SHEET AND A FLOWING SEA.}

A way the good ship flies, and leaves

Old England on the lee.

"Oh for a soft and gentle wind!"

I heard a fair one cry;

But give to me the snoring breeze, And white waves heaving high;

And white waves heaving high, my boys, The good ship tight and free.'The world of waters is our lome, And merry men are we.

There's tempest in yon hornèd moon, And lightning in yon cloud;

And hark the music, mariners!

The wind is piping loud;

The wind is piping loud, my boys, The lightning flashing free-

While the hollow oak our palace is, Our heritage the sea. 


\section{WALKER.}

\section{TO A GIRL IN HER THIRTEENTH YEAR.}

THY smiles, thy talk, thy aimless plays,

So beantiful approve thee,

So winning light are all thy ways,

I cannot choose but love thee.

'Thy balmy breath upon my brow

Is like the summer air,

As o'er my cheek thou leanest now,

To plant a soft kiss there.

Thy steps are dancing toward the bound

Between the child and woman,

And thoughts and feelings more profound,

And other years are coming:

And thou shalt be more deeply fair,

More precious to the heart,

But never canst thou be again

That lovely thing thou art!

And youth shall pass, with all the brood

Of fancy-fed affection;

And grief shall come with womanhood,

And waken cold reflection.

'Thou'lt learn to toil, and watch, and weep

O'er pleasures unreturning,

like one who wakes from pleasant sleep

Unto the cares of morning.

Nay, say not so! nor cloud the sun

Of joyous expectation,

Ordain'd to bless the little one,

The freshling of creation! 


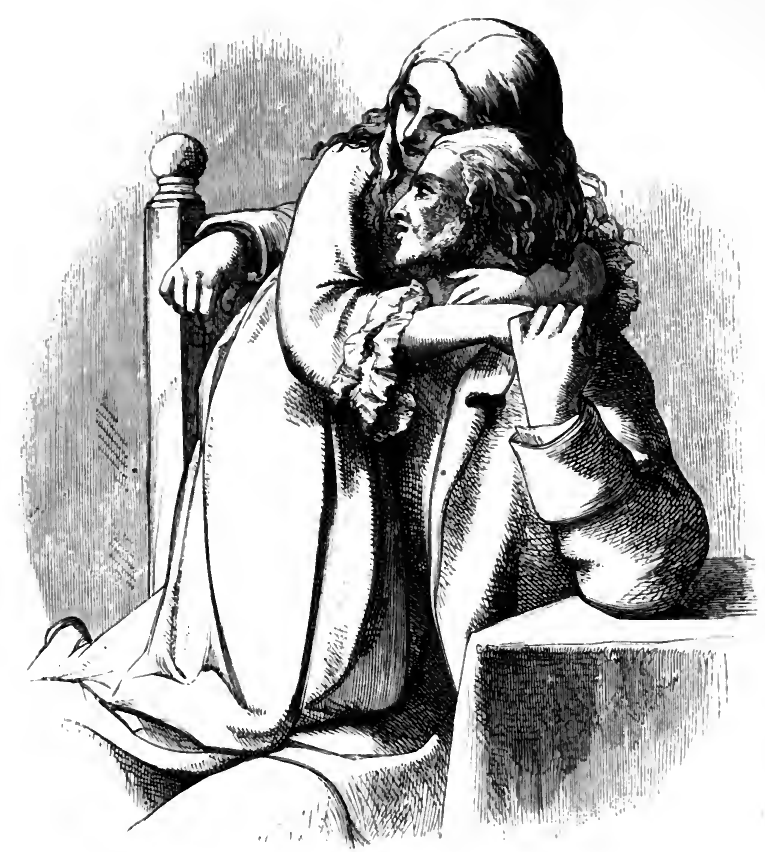

Nor doubt that He who thus doth feed

Her early lamp with gladness, Will be her present Help in need, Her Comforter in sadness.

Smile on, then, little winsome thing?

All rich in Nature's treasure,

Thou hast within thy heart a spring Of self-renewing pleasure.

Smile on, fair child, and take thy fill

Of mirth, till time shall end it;

"Tis Nature's wise and gentle will-

And who shall reprehend it? 


\section{HOGG.}

\section{THE RAPTURE OF KILMENY.}

Bonvy Kilmeny gaed up the glen;

But it wasna to meet Duneira's men,

Nor the rosy monk of the isle to see,

For Kilmeny was pure as pure could be.

It was only to hear the Yorlin sing,

And pu' the cress-flower round the spring;

The scarlet hypp and the hindberrye,

And the nut that hangs frae the hazel-tree;

For Kilmeny was pure as pure could be.

But lang may her minny look o'er the wa',

And lang may she seek $i$ the green-wood shaw;

Lang the laird of Duneira blame,

And lang, lang greet, or Kilmeny come hame!

When many a day had come and fled,

When grief grew calm, and hope was dead,

When mass for Kilmeny's soul had been sung,

When the bedesman had pray'd, and the dead-bell runer,

Late, late in a gloamin' when all was still,

When the fringe was red on the westlin' hill,

'The wood was sere, the moon i' the wane,

'The reek o' the cot hung over the plain,

Like a little wee cloud in the world its lane;

When the ingle low'd with an eiry leme, 
Late, late in the gloamin' Kilmeny came hame!

"Kilmeny, Kilmeny, where have you been?

Lang hae we sought baith holt and den;

By linn, by ford, by green-wood tree,

Yet you are halesome and fair to see.

Where gat you that joup o' the lily scheen?

'That bonny snood o' the birk sae green?

And these roses, the fairest that ever were seen?

Kilmeny, Kilmeny, where have you been?"

Kilmeny look'd up with a lovely grace,

But nae smile was seen on Kilmeny's face;

As still was her look, and as still was her e'e,

As the stillness that lay on the emerant lea,

Or the mist that sleeps on a waveless sea.

For Kilmeny had been she knew not where,

And Kilmeny had seen what she could not declare;

Kilmeny had been where the cock never crew,

Where the rain never fell, and the wind never blew;

But it seem'd as the harp of the sky had rung,

And the airs of heaven play'd round her tongue,

When she spake of the lorely forms she had seen,

And a land where sin had never been;

$A$ land of love and a land of light,

Withouten sun, or moon, or night;

Where the river swa'd a living stream,

And the light a pure celestial beam:

The land of vision it would seem,

A still, an everlasting dream.

In yon green-wood there is a waik,

And in that waik there is a wene,

And in that wene there is a maike,

'That neither has flesh, blood, nor bane;

And down in yon green-wood he walks his lane.

In that green wene Kilmeny lay, Iler bosom happ'd wi' the flowerets gay; 


\section{HOGG.}

But the air was soft, and the silence deep, And bonny Kilmeny fell sound asleep;

She kend nae mair, nor open'd her e'e,

'Till waked by the hymns of a far countrye.

She 'waken'd on a couch of the silk sae slim,

All striped wi' the bars of the rainbow's rim;

And lovely beings round were rife,

Who erst had travelled mortal life;

And aye they smiled, and 'gan to speer,

"What spirit has brought this mortal here?"-

They clasped her waist and her hands sae fair,

They kissed her cheek, and they kemed her hair,

And round came many a blooming fere,

Saying, "Bonny Kilmeny, ye're welcome here!

"Oh, would the fairest of mortal kind

Aye keep the holy truths in mind

That kindred spirits their motions see,

Who wateh their ways with anxious e'e,

And grieve for the guilt of humanitye!

Oh, sweet to Heaven the maiden's prayer,

And the sigh that heaves a bosom sae fair!

And dear to Heaven the words of truth,

And the praise of virtue frae beanty's mouth!

And dear to the viewless forms of air,

The minds that kythe as the body fair!

O bonny Kilmeny! free frae stain,

If ever you seek the world again-

That world of sin, of sorrow, and fear-

Oh, tell of the joys that are waiting here;

And tell of the signs you shall shortly see;

Of the times that are now, and the times that shall be."

They lifted Kilmeny, they led her away,

And she walk'd in the light of a sunless day:

The sky was a dome of crystal bright, 


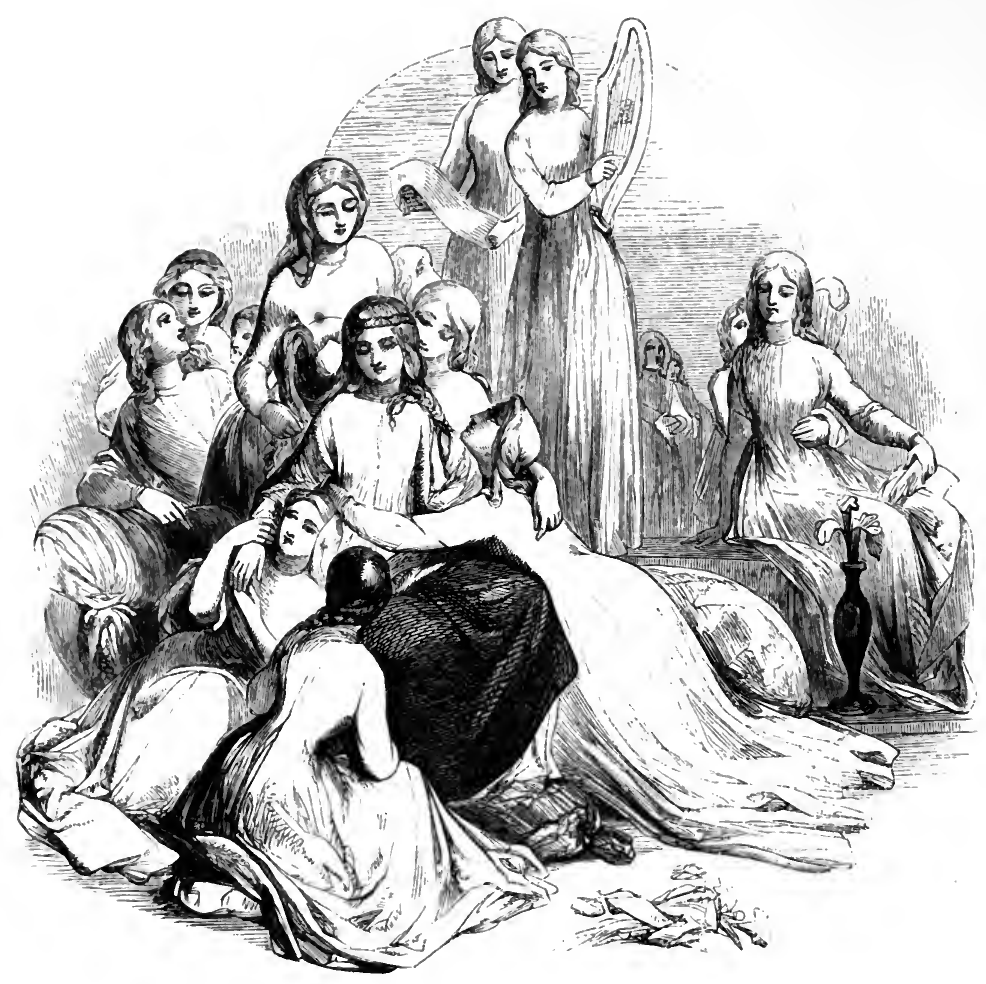

The fountain of vision, and fountain of light ; The emerald fields were of dazzling glow, And the flowers of everlasting blow.

Then deep in the stream her body they laid, 'That her youth and beauty never might fade: And they smiled on heaven, when they saw her lie In the stream of life that wander'd by. And she heard a song, she heard it sung, She kend not where; but sae sweetly it rung, It fell on her ear like a dream of the morn, 
"Oh! blest be the day Kilmeny was born!

Now shall the land of the spirits see,

Now shall it ken what a woman may be!

The sun that shines on the world sae bright,

A borrow'd gleid of the fountain of light;

And the moon that sleeks the sky sae dun,

Like a gouden bow, or a beamless sun,

Shall wear away, and be seen nae mair,

And the angels shall miss them travelling the air.

But lang, lang after baith night and day,

When the sun and the world have elyed away;

When the sinner has gane to his waesome doom,

Kilmeny shall smile in eternal bloom!"

Then Kilmeny begg'd again to see

The friends she had left in her own countrye,

To tell of the place where she had been,

And the glories that lay in the land unseen;

To warn the living maidens fair,

The loved of Heaven, the spirits' care,

That all whose minds unmeled remain

Shall bloom in beauty when time is gane.

With distant music, soft and deep,

They lull'd Kilmeny sound asleep;

And when she awakened, she lay her lane,

All happed with flowers in the green-wood wene.

When seven long years were come and fled;

When grief was calm, and hope was dead;

When scarce was remember'd Kilmeny's name,

Late, late in a gloamin' Kilmeny came hame!

And oh, her beauty was fair to see,

But still and steadfast was her e'e!

Such beauty bard may never declare,

For there was no pride nor passion there;

And the soft desire of maiden's een 
In that mild face could never be seen.

Her seymar was the lily flower,

And her cheek the moss-rose in the shower,

And her voice like the distant melodye,

That floats along the twilight sea.

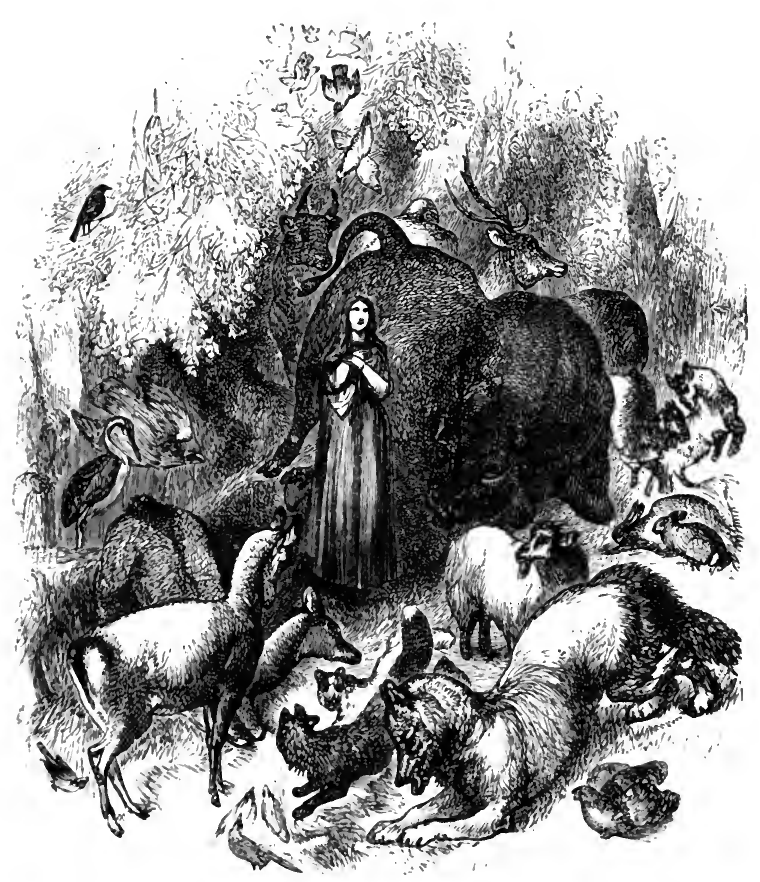

But she loved to raike the lanely glen, And keeped afar frae the haunts of men; Ifer lioly hymus mheard to sing, 'To suck the flowers, and drink the spring. But wherever her peaceful form appear'd, The wild beasts of the hill were cheer'd; 
The wolf play'd blithely round the field,

The lordly bison low'd and kneel'd;

The dun deer woo'd with manner bland,

And cower'd aneath her lily hand.

And when at even the woodlands rung,

When hymns of other worlds she sung

In ecstasy of sweet devotion,

$\mathrm{Oh}$, then the glen was all in motion!

'The wild beasts of the forest came,

Broke from their bughts and faulds the tame,

And goved around, charmed and amazed;

Even the dull cattle crooned and gazed,

And murmur'd, and look'd with anxious pain

For something the mystery to explain.

The buzzard came with the throstle-cock;

The corby left her houf in the rock;

The blackbird alang wi' the eagle flew;

The hind came tripping $0^{\circ}$ er the dew;

The wolf and the kid their raike began,

And the tod, and the lamb, and the leveret ran;

The hawk and the hern attour them hung,

And the merl and the mavis forhooyed their young;

And all in a peaceful ring were hurl'd;-

It was like an eve in a sinless world!

When a month and a day had come and gane,

Kilmeny sought the green-wood wene;

There laid her down on the leaves sae green,

And Kilmeny on earth was never mair seen.

But $\mathrm{O}$, the words that fell from her mouth,

Were words of wonder, and words of truth!

But all the land were in fear and dread,

For they kendna whether she was living or dead;

It wasna her hame, and she couldna remain;

She left this world of sorrow and pain,

And return'd to the Land of Thought again. 


\section{SPRAGUE.}

THE WINGED WORSHIPPERS.

ADDRESSED TO TWO SWALLOWS THAT FLEW INTO THE CHAUNCEY

PLACE CHURCH DURING DIVINE SERVICE.

GAY, guiltless pair,

What seek ye from the fields of heaven?

Ye have no need of prayer,

Ye have no sins to be forgiven.

Why perch ye here,

Where mortals to their Maker bend?

Can your pure spirits fear

The God ye never could offend?

Ye never knew

The crimes for which we come to weep.

Penance is not for you,

Blessed wanderers of the upper deep.

To you 'tis given

To wake sweet Nature's untaught lays;

Beneath the arch of heaven

To chirp away a life of praise.

Then spread each wing,

Far, far above, o'er the lakes and lands,

And join the choirs that sing

In yon blue dome not reared with hands.

Or, if ye stay,

To note the consecrated hour,

Toach me the airy way,

And let me try your envied power. 
Above the crowd,

On upward wings could I but fly,

I'd bathe in yon bright cloud,

And seek the stars that gem the sky.

'Twere Heaven indeed

Through fields of trackless light to soar,

On Nature's charms to feed,

And Nature's own great God adore.

\section{THE BROTHERS.}

WE are but two-the others sleep

Through Death's untroubled night;

We are but two-O, let us keep

The link that binds us bright !

Heart leaps' to heart-the sacred flood

That warms us is the same;

That good old man-his honest blood

Alike we fondly claim.

We in one mother's arms were lockedLong be her love repaid;

In the same cradle we were rocked,

Round the same hearth we played.

Our boyish sports were all the same,

Each little joy and woe;-

Let manhood keep alive the flame,

Lit up so long ago.

We are but two-be that the band

To hold us till we die;

Shoulder to shoulder let us stand,

Till side by side we lie. 


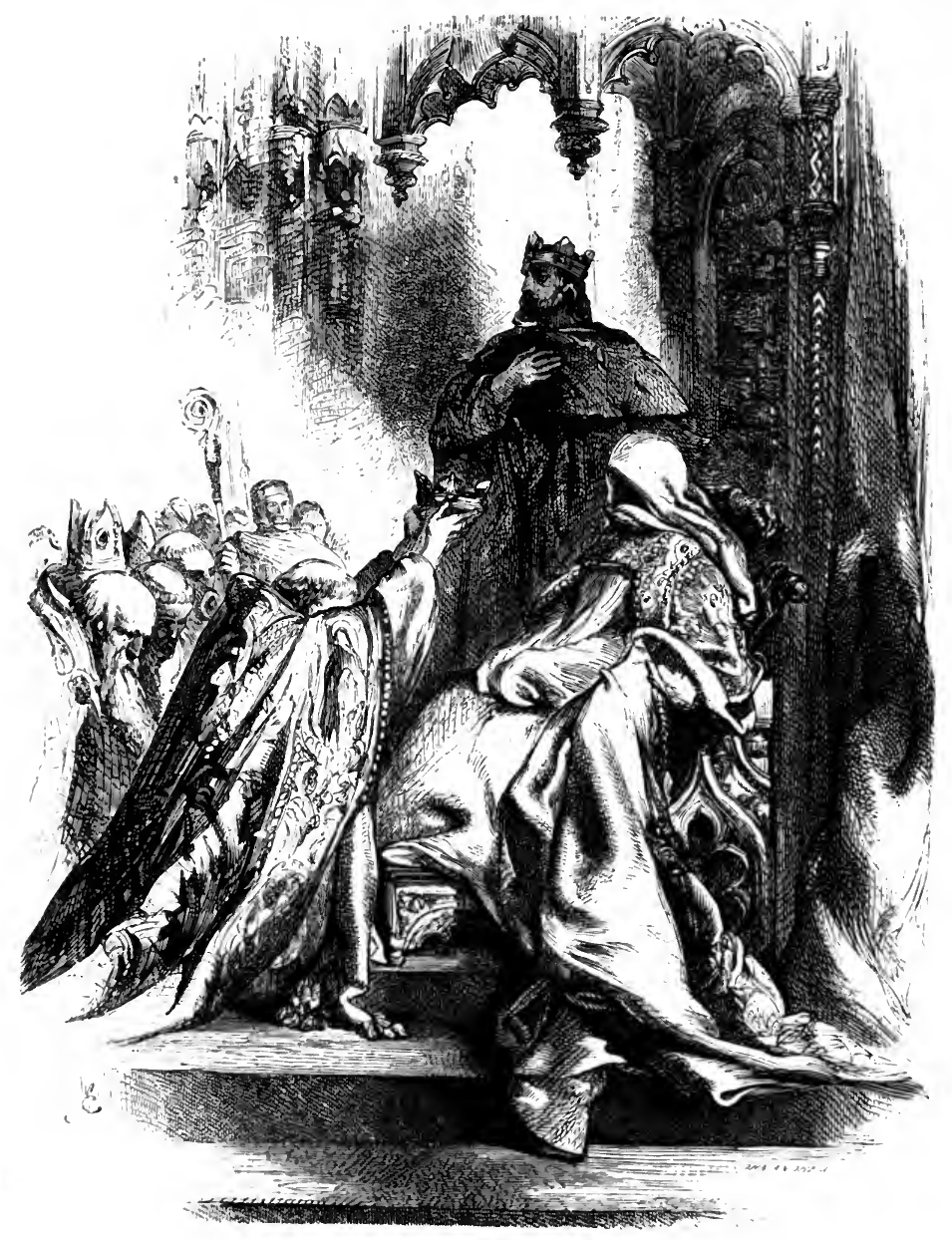

HEMANS.

THE CORONATION OF INEZ DE CASTRO.

Them: was music on the midnight:

From a royal fane it rolld ; 
And a mighty bell, each pause between, Sternly and slowly toll'd.

Strange was their mingling in the sky,

It hush'd the listener's breath;

For the music spoke of triumph high, The lonely bell, of death!

There was hurrying through the midnight,

A sound of many feet;

But they fell with a muffled fearfulness

Along the shadowy street:

And softer, fainter grew their tread, As it near'd the minster gate,

Whence a broad and solemn light was shed

From a scene of royal state.

Full glow'd the strong red radiance

In the centre of the nave,

Where the folds of a purple canopy

Swept down in many a wave;

Loading the marble pavement old

With a weight of gorgeous gloom;

For something lay 'midst their fretted gold,

Like a shadow of the tomb.

And within that rich pavilion,

High on a glittering throne,

A woman's form sat silently,

'Midst the glare of light alone.

Her jewell'd robes fell strangely still-

The drapery on her breast

Seem'd with no pulse beneath to thrill,

So stonelike was its rest!

But a peal of lordly music

Shook e'en the dust below, 
When the burning gold of the diadem

Was set on her pallid brow!

Then died away that haughty sound,

And from the encireling band

Stepp'd prinee and chief, 'midst the hush profound,

With homage to her hand.

Why pass'd a faint, cold shuddering

Over each martial frame,

As one by one, to touch that hand,

Noble and leader came?

Was not the settled aspect fair?

Did not a queenly grace,

Under the parted ebon hair,

Sit on the pale, still face?

Death! death! canst thou be lovely

Unto the eye of life?

Is not each pulse of the quick ligh breast

With thy cold mien at strife?-

It was a strange and fearful sight,

The crown upon that head,

The glorious robes, and the blaze of light,

All gather'd round the Dead!

And beside her stood in silence

One with a brow as pale,

And white lips rigidly compress'd,

Lest the strong heart should fail:

King Pedro, with a jealous eye,

Watching the homage done

By the land's flower and ehivalry

'To her, his martyr'd one.

But on the face he looked not,

Which once his star had been; 


\section{HEMANS.}

To every form his glance was turn'd,

Save of the breathless queen:

Though something, won from the grave's embrace,

Of her beauty still was there,

Its hues were all of that shadowy place,

It was not for hin to bear.

Alas! the crown, the sceptre,

The treasures of the earth,

And the priceless love that pour'd those gifts,

Alike of wasted worth!

The rites are closed:-bear back the dead

Unto the chamber deep!

Lay down again the royal head,

Dust with the dust to sleep!

There is music on the midnight-

A requiem sad and slow,

As the mourners through the sounding aisle

In dark procession go;

And the ring of state, and the starry crown,

And all the rich array,

Are borne to the house of silence down,

With her, that queen of clay!

And tearlessly and firmly

King Pedro led the train;

But his face was wrapt in his folding robe,

When they lower'd the dust again.

'Tis hush'd at last the tomb above-

Hymns die, and steps depart:

Who call'd thee strong as Death, O Love?

Mightier thou wast and art. 
THE MESSAGE TO THE DEAD.

THE MESSAGE TO THE DEAD.

Tноч 'rt passing hence, my brother!

O my earliest friend, farewell!

Thou 'rt leaving me, without thy voice,

In a lonely home to dwell;

And from the hills, and from the hearth,

And from the household tree,

With thee departs the lingering mirth,

The brightness goes with thee.

But thou, my friend, my brother!

Thou 'rt speeding to the. shore

Where the dirge-like tone of parting words

Shall smite the soul no more!

And thou wilt see our holy dead,

'The lost on earth and main:

Into the sheaf of kindred hearts

Thou wilt be bound again!

Tell, then, our friend of boyhood

That yet his name is heard

On the blue mountains, whence his youth

Pass'd like a swift, bright bird.

The light of his exulting brow,

'The vision of his glee,

Are on me still-Oh! still I trust

That smile again to see.

And tell our fair young sister,

The, rose eut down in spring,

'That yet my gushing soul is fill'd

With lays she lov'd to sing. 


\section{HEMANS.}

Her soft deep eyes look through my dreams,

Tender and sadly sweet;-

Tell her my heart within me burns

Once more that gaze to meet.

And tell our white-hair'd father,

That in the paths he trod,

The child he lov'd, the last on earth,

Yet walks and worships God.

Say, that his last fond blessing yet

Rests on my soul like dew,

And by its hallowing might $I$ trust

Once more his face to view.

An tell our gentle mother,

That on her grave I pour

The sorrows of my spirit forth,

As on her breast of yore.

Happy thou art that soon, how soon,

Our good and bright will see!

O brother, brother! may I dwell,

Erelong, with them and thee!

\section{THE RETURN.}

"HAST thou come with the heart of thy childhood back?

The free, the pure, the kind?"

-So murmur'd the trees in my homeward track,

As they play'd to the mountain-wind.

"Hath thy soul been true to its early love?"

Whisper'd my native streams; 
"Hath the spirit, nursed amidst hill and grove, Still revered its first high dreams?"

"Hast thou borne in thy bosom the holy prayer Of the child in his parent-halls?"

'Thus breath'd a voice on the thrilling air, From the old ancestral walls.

"Hast thou kept thy faith with the faithful dead, Whose place of rest is nigh?

With the father's blessing o'er thee shed, With the mother's trusting eye?"

Then my tears gush'd forth in sudden rain, As I answer'd-" $\mathrm{O}$ ye shades!

I bring not my childhood's heart again To the freedom of your glades.

"I have turn'd from my first pure love aside, $\mathrm{O}$ bright and happy streams!

Light after light, in my soul have died The day-spring's glorious dreams.

"And the holy prayer from my thoughts hath pass'dThe prayer at my mother's knee; Darken'd and troubled I come at last, Home of my boyish glee!

"But I bear from my childhood a gift of tears, 'To soften and atone; And oh! ye scenes of those bless'd years, They shall make me again your own." 


\section{MITFORD.}

\section{RIENZI AND HIS DAUGHTER.}

Rienzi. Claudia-nay, start not! Thou art sad; to-day

I found thee sitting idly, 'midst thy maids,

A pretty, laughing, restless band, who plied

Quick tongue and nimble finger, mute and pale

As marble; those unseeing eyes were fix'd

On vacant air; and that fair brow was bent

As sternly, as if the rude stranger, Thought-

Age-giving, mirth-destroying, pitiless Thought-

Had knock'd at thy young giddy brain.

Claudia.

Nay, father,

Mock not thine own poor Claudia.

Rien. Claudia used

To bear a merry heart, with that clear voice,

Prattling; and that light busy foot astir

In her small housewifery, the blithest bee

That ever wrought in hive.

Cla. Oh! mine old home!

Rien. What ails thee, lady-bird?

Cla. Mine own dear home!

Father, I love not this new state; these halls,

Where comfort dies in vastness; these trim maids,

Whose service wearies me. Oh! mine old home!

My quiet, pleasant chamber, with the myrtle

Woven round the casement; and the cedar by,

Shading the sun; my garden overgrown

With flowers and herbs, thick-set as grass in fields; 


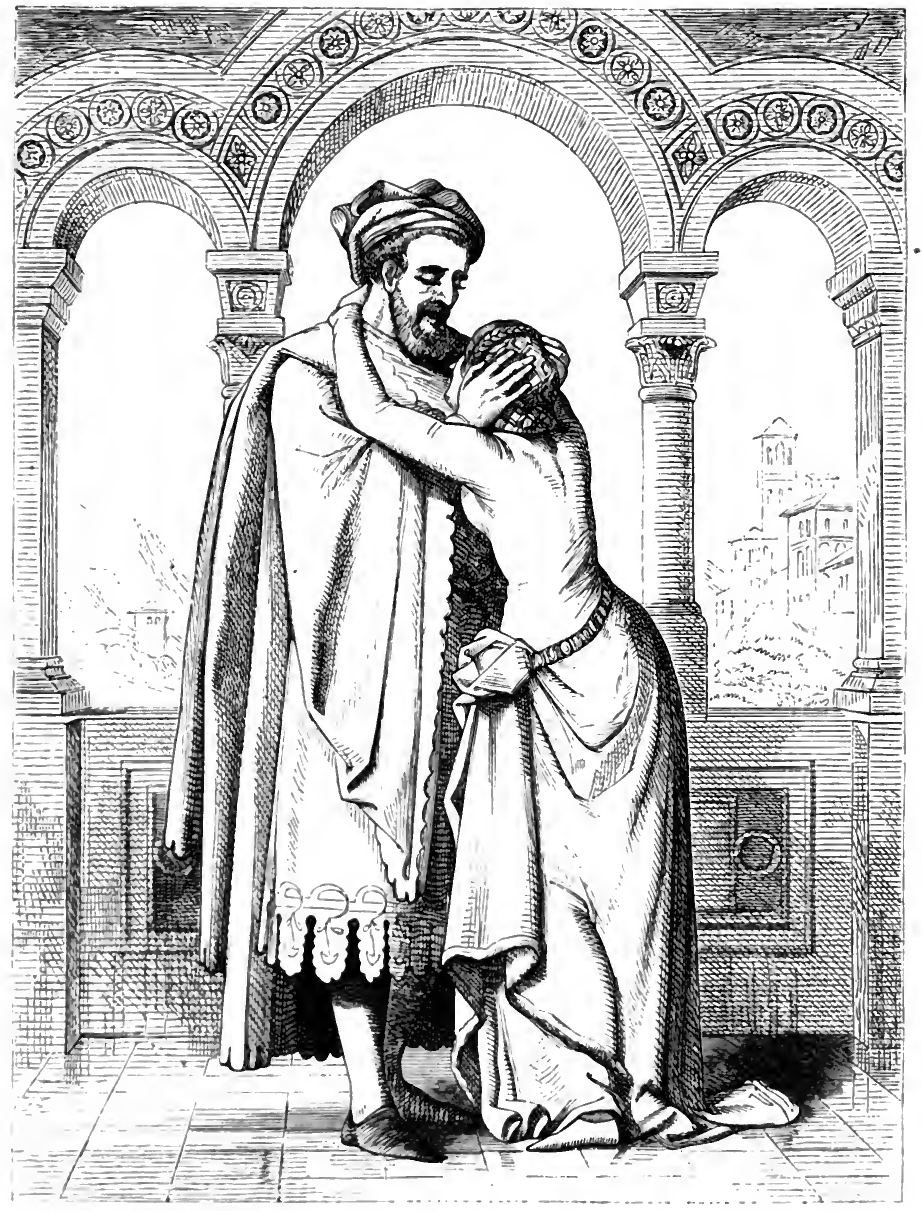

My pretty snow-white doves; my kindest nurse; And old Camillo. Oh! mine own dear home!

Rien. Why, simple child, thou hast thine old, fond nurse, And good Camillo, and shalt have thy doves, Thy myrtle flowers, and cedars; a whole province 


\section{MITFORD.}

Laid in a garden, an' thou wilt. My Claudia, Hast thou not learnt thy power? Ask Orient gems,

Diamonds and sapphires, in rich caskets, wrought

By cunning goldsmiths; sigh for rarest birds

Of farthest Ind, like winged flowers, to flit

Around thy stately bower; and, at a wish,

The precious toys shall wait thee. Old Camillo!

'Thou shalt have nobler servants, emperors, kings,

Electors, princes! not a bachelor

In Christendom but would right proudly kneel

To my fair daughter.

Cla. Oh! mine own dear home!

liven. Wilt have a list to choose from?

Listen, sweet!

If the tall cedar, and the branchy myrtle,

And the white doves, were tell-tales, I would ask them

Whose was the shadow on the sunny wall?

And if, at eventide, they heard not oft

A tuneful mandoline, and then a voice,

Clear in its manly depth, whose tide of song

O'erwhelm'd the quivering instruments; and then

A world of whispers, mix'd with low response,

Sweet, short, and broken, as divided strains

Of nightingales.

Cla.

Oh, father! father!

Rien.

Well!

Dost love him, Claudia?

Cla. Father!

Rien. Dost thou love

Young Angelo? Yes? Saidst thou yes? That heart, That throbbing heart of thine, keeps such a coil,

I cannot hear thy words. He is return'd

'To Rome; he left thee on mine errand, dear one.

And now-Is there no casement myrtle-wreath'd,

No cedar in our courts, to shade to-night

The lover's song? 
SONG.

Cla. Oh, father! father!

Rien. Now,

Back to thy maidens, with a lighten'd heart, Mine own beloved child. 'Thou shalt be first In Rome, as thou art fairest; never princess Brought to the proud Colonna such a dower As thou. Young Angelo hath chosen his mate From out an eagle's nest.

Cla. Alas! alas!

I tremble at the height. Whene'er I think

Of the hot barons, of the fickle people, And the inconstancy of power, I tremble For thee, dear father.

Rien. Tremble! let them tremble:

I am their master, Claudia! whom they scorn'd, Endured, protected.-Sweet, go dream of love!

I am their master, Claudia!

\section{SONG.}

HaIr to the gentle bride! the dove

High nested in the column's erest!

Oh, welcome as the bird of love,

Who bore the olive-sign of rest!

Hail to the gentle bride! the flower

Whose garlands round the column twine!

Oh, fairer than the eitron bower,

More fragrant than the blossom'd vine!

Hail to the gentle bride! the star

Whose radiance o'er the column beams

Oh, soft as moonlight seen afur-

A silver shine on trembling streams! 


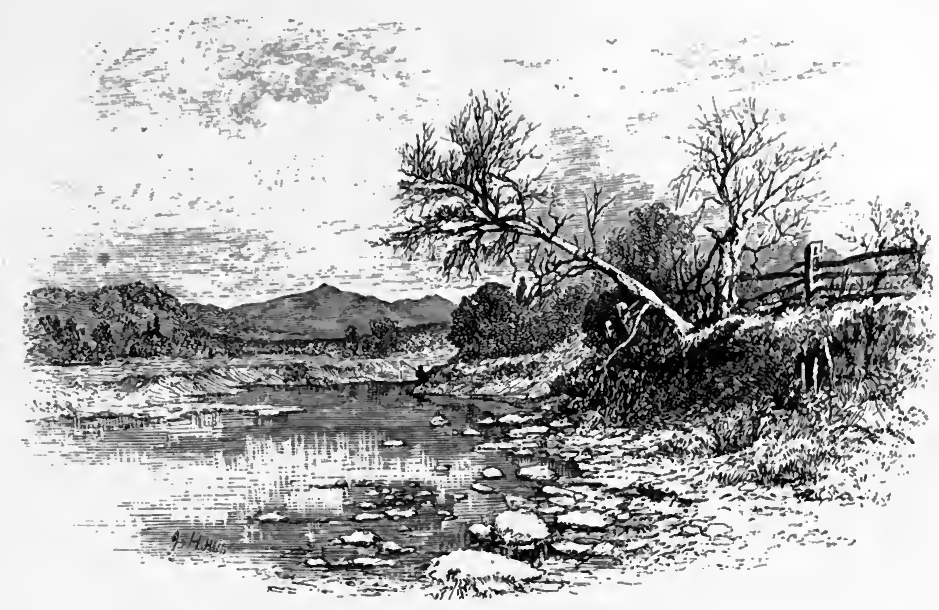

SIGOURNEY.

THE INDIAN SUMMER.

WHEN was the red man's summer?

When the rose

Hung its first banner out? When the gray rock,

Or the brown heath, the radiant kalmia clothed?

Or when the loiterer by the reedy brooks

Started to see the proud lobelia glow

Like living flame? When through the forest gleam'd

The rhododendron? or the fragrant breath

Of the magnolia swept deliciously

O'er the half laden nerve?

No. When the groves

In fleeting colors wrote their own decay, And leaves fell eddying on the sharpen'd blast That sang their dirge; when o'er their rustling bed 


\section{THE INDIAN SUMMER.}

The red deer sprang, or fled the shrill-voiced quail, Heavy of wing and fearful; when, with heart

Foreboding or depress'd, the white man mark'd

The signs of coming winter: then began

The Indian's joyous season. Then the haze,

Soft and illusive as a fairy dream,

Lapp'd all the landscape in its silvery fold.

The quiet rivers that were wont to hide

'Neath shelving banks, beheld their course betray'd

By the white mist that o'er their foreheads crept,

While wrapp'd in morning dreams, the sea and sky

Slept 'neath one curtain, as if both were merged

In the same element. Slowly the sun,

And all reluctantly, the spell dissolved

And then it took upon its parting wing

A rainbow glory.

Gorgeous was the time,

Yet brief as gorgeous. Beautiful to thee,

Our brother hunter, but to us replete

With musing thoughts in melancholy train.

Our joys, alas! too oft were woe to thee,

Yet ah, poor Indian! whom we fain would drive

Both from our hearts, and from thy father's lands,

The perfect year doth bear thee on its crown,

And when we would forget, repeat thy name. 
SIGOURNEY.

\section{THE HOLY DEAD.}

"Wherefore I praised the dead who are already dead, more than the living who are yet alive."-SoLoxos.

They dread no storm that lowers,

No perish'd joys bewail ;

They pluck no thorn-clad flowers,

Nor drink of streams that fail:

There is no tear-drop in their eye,

No change upon their brow;

Their placid bosom heaves no sigh,

Though all earth's idols bow.

Who are so greatly blest?

From whom hath sorrow fled?

Who share such deep, unbroken rest

Where all things toil? The dead?

The holy dead. Why weep ye so

Above yon sable bier?

Thrice blessed! they have done-with woe,

The living claim the tear.

Go to their sleeping bowers,

Deck their low couch of clay

With earliest spring's soft breathing flowers;

And when they fade away,

Think of the amaranthine wreath,

The garlands never dim,

And tell me why thou fly'st from death,

Or hid'st thy friends from him. 
We dream, but they awake;

Dread visions mar our rest;

Through thorns and snares our way we take,

And yet we mourn the blest!

For spirits round the Eternal Throne

How vain the tears we shed!

They are the living, they alone,

Whom thus we call the dead.

TALK WITH THE SEA.

I sAID with a moan, as I roamed alone,

By the side of the solemn sea,-

"Oh cast at my feet, which thy billows meet,

Some token to comfort me.

'Nid thy surges cold, a ring of gold

I have lost, with an amethyst bright,

'Thou hast locked it so long, in thy casket strong,

That the rust must have quenched its light.

"Send a gift, I pray, on thy sheeted spray,

To solace my drooping mind,

For I'm sad and grieve, and erelong must leave

This rolling globe behind."

Then the Sea answered, "Spoils are mine,

From many an argosy,

And pearl-drops sleep in my bosom deep,

But natught have I there for thee!" 


\section{SIGOURNEY.}

"When I mused before, on this rock-bound shore,

The beautiful walked with me,

She hath gone to her rest in the churchyard's breast

Since I saw thee last, thou Sea!

Restore! restore! the smile she wore,

When her cheek to mine was pressed,

Give back the voice of the fervent soul

That could lighten the darkest breast!"

But the haughty Sea, in its majesty

Swept onward as before,

Though a surge in wrath from its rocky path,

Shrieked out to the sounding shore-

"Thou hast asked of our king a harder thing

Than mortal e'er claimed before,

For never the wealth of a loving heart,

Could Ocean or Earth restore." 


\section{HEBER.}

THE PASSAGE OF THE RED SEA.

Wiтn heat o'erlabour'd and the length of way,

On Ethan's beach the bands of Israel lay.

'Twas silence all, the sparkling sands along;

Save where the locust trill'd her feeble song,

Or blended soft in drowsy cadence fell

The wave's low whisper, or the camel's bell.-

'Twas silence all!-the flocks for shelter fly

Where, waving light, the acacia shadows lie;

Or where, from far, the flattering vapours make

The noontide semblance of a misty lake:

While the mute swain, in careless safety spread,

With arms enfolded, and dejected head,

Dreams o'er his wondrous call, his lineage high,

And, late reveal'd, his children's destiny.-

For, not in vain, in thraldom's darkest hour,

Had sped from Amram's sons the word of power;

Nor fail'd the dreadful wand, whose godlike sway

Could lure the locust from her airy way;

With reptile war assail their proud abodes,

And mar the giant pomp of Egypt's gods.

Oh, helpless gods! who nought avail'd to shield

From fiery rain your Zoan's favour'd field:- 
HEBER.

Oh, helpless gods! who saw the curdled blood Taint the pure lotus of your ancient flood, And four-fold night the wondering earth enchain, While Memnon's orient harp was heard in vain!Such musings held the tribes, till now the west With milder influence on their temples prest; And that portentous cloud, which all the day Hung its dark curtain o'er their weary way, (A cloud by day, a friendly flame by night,) Roll'd back its misty veil, and kindled into light!Soft fell the eve:-But, ere the day was done, Tall waving banners streak'd the level sun; And wide and dark along the horizon red, In sandy surge the rising desert spread."Mark, Israel, mark !"-On that strange sight intent, In breathless terror, every eye was bent; And busy faction's fast-increasing hum, And female voices shriek, "They come! they come!" They come, they come, in scintillating show O'er the dark mass the brazen lances glow; And sandy clouds in countless shapes combine, As deepens or extends the long tumultuous line;And fancy's keener glance e'en now may trace The threatening aspects of each mingled race: For many a coal-black tribe and cany spear, The hireling guards of Misraim's throne, were there. From distant Cush they troop'd, a warrior train, Siwah's green isle and Sennaar's marly plain : On either wing their fiery coursers check The parch'd and sinewy sons of Amalek: While close behind, inured to feast on blood, Deck'd in Behemoth's spoils, the tall Shangalla strode. 'Mid blazing helms and bucklers rough with gold, Saw ye how swift the scythed chariots roll'd? Lo, these are they whom, lords of Afric's fates, Old Thebes hath pour'd through all her hundred gates, 
Mother of armies!-How the emeralds glow'd, Where, flushed with power and vengeance, Pharaoh rode!

And stoled in white, those brazen wheels before,

Osiris' ark his swarthy wizards bore;

And, still responsive to the trumpet's cry,

The priestly sistrum murmur'd-Victory!-

Why swell these shouts that rend the desert's gloom?

Whom come ye forth to combat?-warriors, whom?

These flocks and herds-this faint and weary train-

Red from the scourge and recent from the chain?-

God of the poor, the poor and friendless save!

Giver and Lord of freedom, help the slave :-

North, south, and west, the sandy whirlwinds fly,

'The circling horns of Egypt's chivalry.

On earth's last margin throng the weeping train:

Their cloudy guide moves on :- "And must we swim the main?"

'Mid the light spray their snorting camels stood,

Nor bath'd a fetlock in the nauseous flood-

He comes-their leader comes! - the man of God

O'er the wide waters lifts his mighty rod,

And onward treads.-The cireling waves retreat,

In hoarse deep murmurs, from his holy feet;

And the chased surges, inly roaring, show

The hard wet sand, and coral hills below.

With limbs that falter, and with hearts that swell, Down, down they pass-a steep and slippery dell-

Around them rise, in pristine chaos hurl'd,

The ancient rocks, the secrets of the world;

And flowers that blush beneath the ocean green,

And caves, the sea-calves' low-roof'd haunt, are seen.

Down, safely down the narrow pass they tread;

The beetling waters storm above their head:

While fur behind retires the sinking day,

And fades on Fdom's hills its latest ray.

Yet not from Israel fled the friendly light,

Or dark to them, or cheerless came the night. 
Still in their van, along that dreadful road, Blazed broad and fierce the brandish'd toreh of God.

Its meteor glare a ten-fold 'lustre gave,

On the long mirror of the rosy wave:

While its blest beams a sun-like heat supply,

Warm every cheek, and dance in every eye-

'To them alone-for Misraim's wizard train

Invoke for light their monster-gods in vain:

Clouds heap'd on clouds their struggling sight confine, And ten-fold darkness broods above their line.

Yet on they fare, by reckless vengeance led, And range unconscious through the ocean's bed: Till midway now-that strange and fiery form Show'd his dread visage lightening through the storm; With withering splendour blasted all their might, And break their chariot-wheels, and marr'd their coursers' flight. "Fly, Misraim, fly!"-The ravenous floods they see, And, fiercer than the floods, the Deity. "Fly, Misraim, fly!"-From Edom's coral strand Again the prophet stretch'd his dreadful wand:With one wild crash the thundering waters sweep, And all is waves-a dark and lonely deepYet o'er those lonely waves such murmurs past, As mortal wailing swell'd the nightly blast; And strange and sad the whispering breezes bore The groans of Egypt to Arabia's shore.

Oh! welcome came the morn, where Israel stood In trustless wonder by th' avenging flood!

Oh! welcome came the cheerful morn, to show The drifted wreck of Zoan's pride below;

The mangled limbs of men-the broken carA few sad relics of a nation's war: Alas, how few!-Then, soft as Elim's well, The precious tears of new-born freedom fell. And he, whose harden'd heart alike had borne The house of bondage and th' oppressor's scorn, 
The stubborn slave, by hope's new beams subdued,

In faltering accents sobb'd his gratitude-

'Till, kindling into warmer zeal, around

The virgin timbrel waked its silver sound:

And in fierce joy, no more by doubt supprest,

'The struggling spirit throbb'd in Miriam's breast.

She, with bare arms, and fixing on the sky

The dark transparence of her lucid eye,

Pour'd on the winds of heaven her wild sweet harmony.

"Where now," she sang, "the tall Egyptian spear?

On's sun-like shield, and Zoan's chariot, where?

Above their ranks the whelming waters spread.

Shout, Israel, for the Lord hath triumphèd!"-

And every pause between as Miriam sang,

From tribe to tribe the martial thunder rang,

And loud and far their stormy chorus spread,-

"Shout, Israel, for the Lord hath triumphèd!"

LINES ADDRESSED TO MRS. HEBER.

If thou wert by my side, my love,

How fast would evening fail,

In green Bengola's palmy grove,

Listening the nightingale!

If thou, my love, wert by my side,

My babies at my knee,

How gayly would our pinnace glide

O'er Gunga's mimic sea! 


\section{HEBER.}

I miss thee at the dawning gray, When, on our deck reclined, In careless ease my limbs I lay And woo the cooler wind.

I miss thee when by Gunga's stream My twilight steps I guide,

But most beneath the lamp's pale beam I miss thee from my side.

I spread my books, my pencil try The lingering noon to cheer, But miss thy kind approving eye, Thy meek attentive ear.

But when of morn and eve the star Beholds me on my knee, I feel, though thou art distant far, Thy prayers ascend for me.

Then on! then on! where duty leads, My course be onward still, O'er broad Hindostan's sultry mead, O'er bleak Almorah's hill.

That eourse nor Delhi's kingly gates, Nor wild Malwah detain;

For sweet the bliss us both awaits

By yonder western main.

Thy towers, Bombay, gleam bright, they say, Across the dark blue sea, But ne'er were hearts so light and gay As then shall meet in thee! 


\section{LINES.}

\section{LINES}

WRITTEN TO A MARCH COMPOSED IN IMITATION OF A MILITARY BAND.

I SEE them on their winding way, Above their ranks the moon-beams play, And nearer yet, and yet more near, The martial chorus strikes the ear.

They're lost and gone,- the moon is : past, The wood's dark shade is o'er them cast, And fainter, fainter, fainter still, The dim march warbles up the hill.

Again, again,- - the pealing drum, The clashing horn-they come! they come! And lofty deeds and daring high, Blend with their notes of victory.

Forth, forth, and meet them on their way, The trampling hoof brooks no delay;

The thrilling fife, the pealing drum, How late-but oh, how loved they come! 


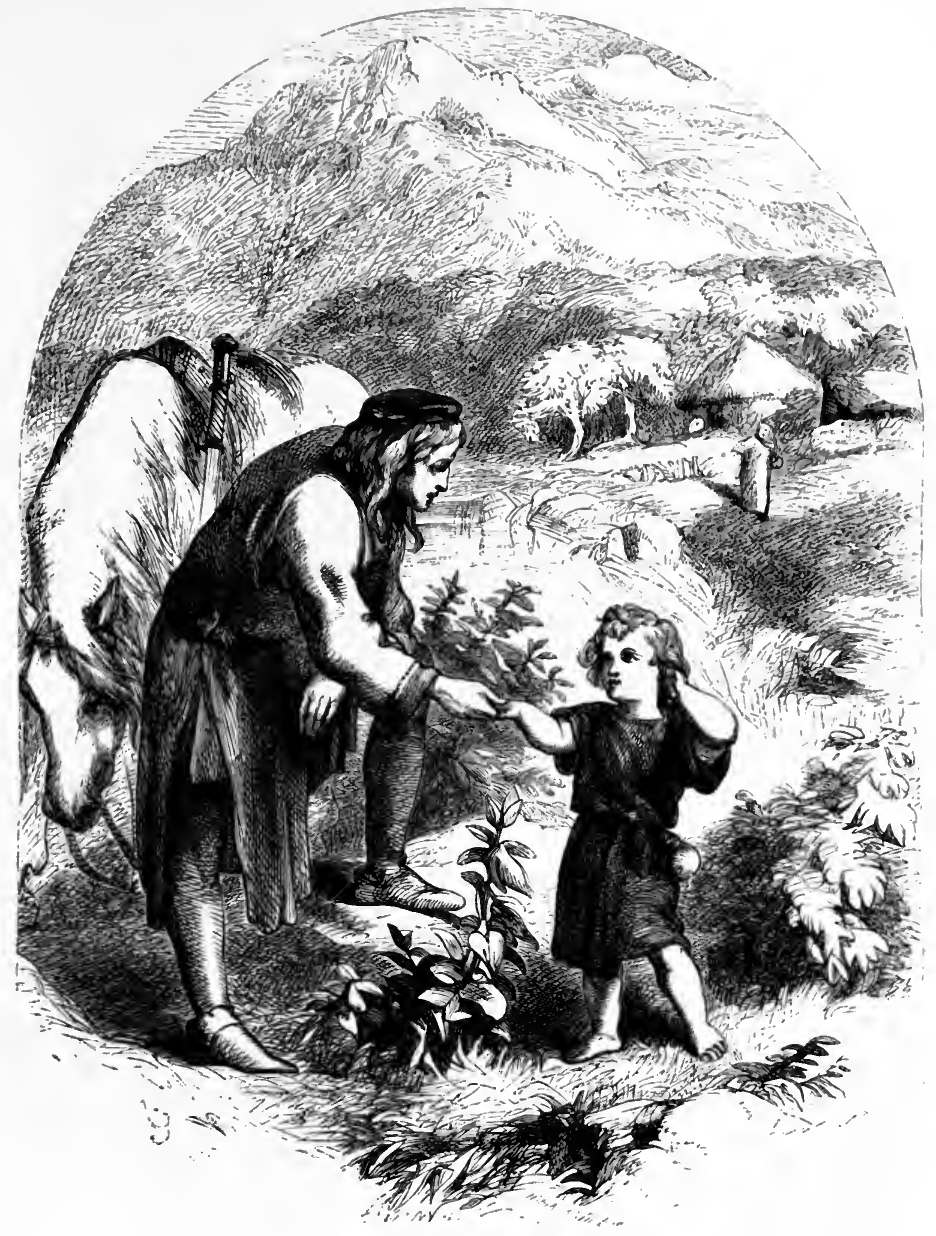

SOUTHEY.

THE VISIT OF MADOC.-A SCENE AMONG THE WELSH HILLS.

Now hath Prince Madoc left the holy Isle, And homeward to Aberfraw, through the wilds Of Arvon, bent his course. A little way 
He turned aside, by natural impulses

Moved, to behold Cadwallon's lonely hut.

That lonely dwelling stood among the hills

By a grey mountain-stream; just elevate

Above the winter torrents did it stand,

Upon a craggy bank; an orchard slope Arose behind, and joyous was the scene

In early summer, when those antic trees

Shone with their blushing blossoms, and the flax

'Twinkled beneath the breeze its liveliest green.

But save the flax-field and that orchard slope,

All else was desolate, and now it wore

One sober hue; the narrow vale, which wound

Among the hills, was grey with rocks, that peer'd .

Above its shallow soil; the mountain side

Was loose with stones bestrewn, which oftentimes

Clatter'd adown the steep, beneath the foot

Of straggling goat dislodged; or lower'd with crags,

One day, when winter's work hath loosen'd them,

To thunder down. All things assorted well

With that grey mountain hue; the low stone lines,

Which scarcely seem'd to be the work of man,

The dwelling rudely rear'd with stones unhewn,

The stubble flax, the crooked apple-trees,

Grey with their fleecy moss and mistletoe,

'The white-bark'd birch, now leafless, and the ash

Whose knotted roots were like the drifted rock

Through which they forced their way. Adown the vale, broken by stones, and o'er a stony bed,

Roll'd the loud mountain-stream-

\section{When Madoc came,}

A little child was sporting by the brook, Floating the fallen leaves, that he might sce them

Whirl in the edly now, and now be driven

Down the descent, now on the smoother stream 


\section{SOUTHEY.}

Sail onwaid far away. But when he heard The horse's tramp, he raised his head and wateh'd 'The Prince, who now dismounted and drew nigh. 'The little boy still fix'd his eyes on him,

His bright. blue eyes; the wind just moved the curls That cluster'd round his brow; and so he stood, His rosy cheeks still lifted up to gaze In innocent wonder. Madoc took his hand, And now had ask'd his name, and if he dwelt There in the hut; when from that cottage-door A woman came, who, seeing Madoc, stopt With such a fear-for she had cause to fearAs when a bird, returning to her nest, Turns to a tree beside, if she behold

Some prying boy too near the dear retreat. Howbeit, advancing, soon she now approach'd The approaching Prince, and timidly inquired If on his wayfare he had lost the track, That thither he had stray'd. "Not so," replied The gentle Prince; "but having known this place, And its old inhabitants, I came once more 'To see the lonely hut among the hills."

\section{THE WORLD OF WOE.}

WHOE'ER hath loved with venturous step to tread

The chambers dread

Of some deep' cave, and seen his taper's beam

Lost in the areh of darkness overhead,

And mark'd its gleam

Playing afar upon the sunless stream, Where from their secret bed, And course unknown, and inaccessible,

The silent waters well; 


\section{THE WORLD OF WOE.}

Whoe'er hath trod such caves of endless night, He knows, when measuring back the gloomy way,

With what delight refresh'd his eye

Perceives the shadow of the light of day,

Through the far portal slanting, where it falls

Dimly reflected on the watery walls:

How heavenly seems the sky;

And how, with quicken'd feet, he hastens up,

Eager again to greet

The living world and blessed sunshine there,

And drink, as from a cup

Of joy, with thirsty lips, the open air.

Far other light than that of day there shone

Upon the travellers, entering Padalon.

They too in darkness enter'd on their way;

But far before the car,

A glow, as of a fiery furnace light,

Fill'd all before them. 'Twas a light which made

Darkness itself appear

A thing of comfort, and the sight, dismay'd,

Shrunk inward from the molten atmosphere.

Their way was through the adamantine roek

Which girt the World of Woe; on either side

Its massive walls arose, and overhead

Areh'd the long passage; onward as they ride,

With stronger glare the light around them spread;

And lo! the regions dread,

The World of Woe before them, opening wide.

There rolls the fiery flood,

Girding the realms of Padalon around.

A sea of flame it seem'd to be,

Sea without bound;

For neither mortal nor immortal sight

Could pierce across through that intensest light. 


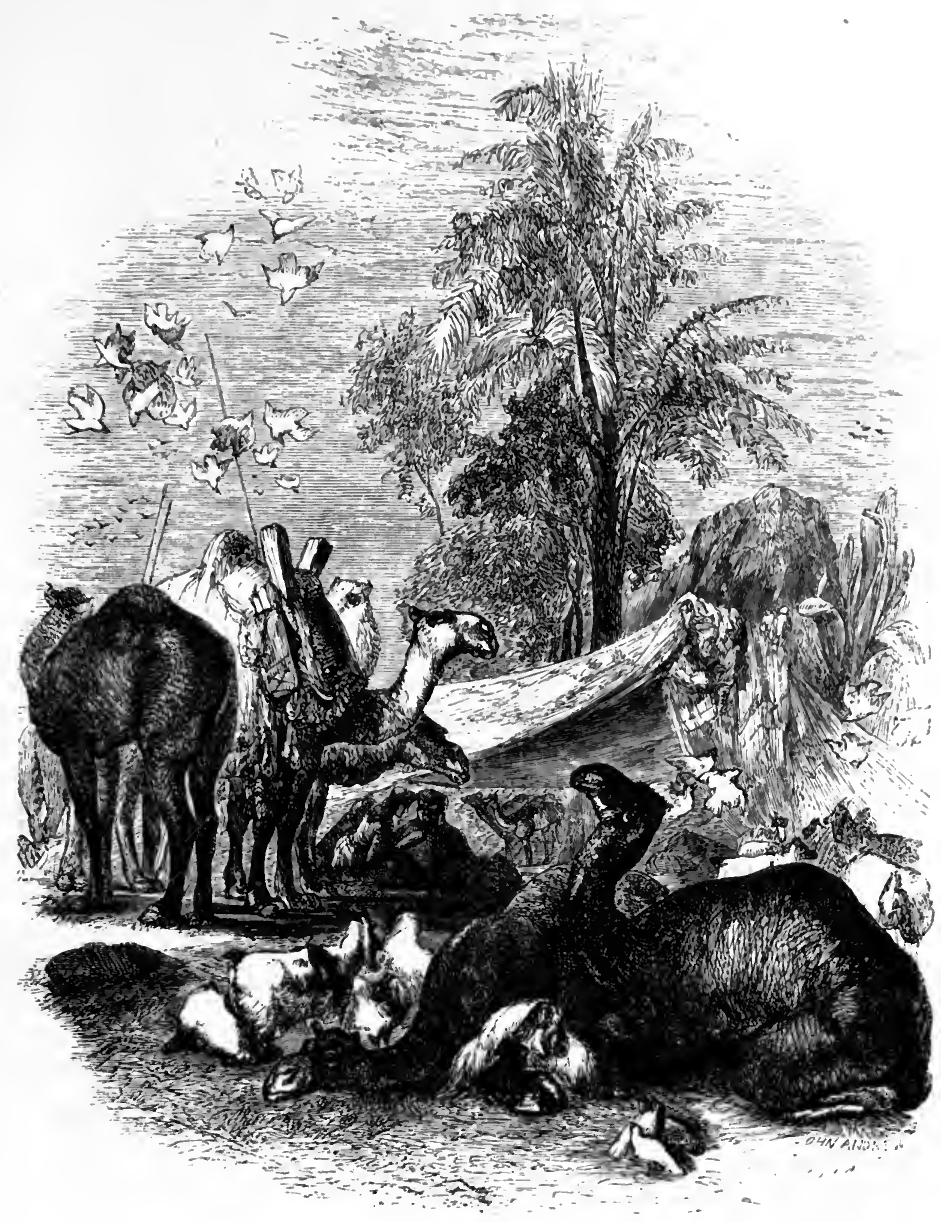

THALABA IN THE TENT OF MOATH.

IT was the wisdom and the will of Heaven,

That in a lonely tent had cast

The lot of Thalaba;

'There might his soul develop best

Its strengthening energies;

There might he from the world 
Keep his heart pure and uncontaminate, Till at the written hour he should be found

Fit servant of the Lord, without a spot.

Years of his youth, how rapidly ye fled

In that beloved solitude!

Is the morn fair, and doth the freshening breeze

Flow with cool current o'er his cheek?

Lo! underneath the broad-leaved sycamore,

With lids half-closed, he lies,

Dreaming of days to come.

His dog beside him, in mute blandishment,

Now licks his listless hand;

Now lifts an anxious and expectant eye,

Courting the wonted caress.

Or comes the Father of the Rains

From his caves in the uttermost West,

Comes he in darkness and storms?

When the blast is loud; •

When the waters fill

'The traveller's tread in the sands;

When the pouring shower

Streams adown the roof;

When the door-curtain hangs in heavier folds;

When the out-strain'd tent flags loosely:

Within there is the ember's cheerful glow,

The sound of the familiar voice,

The soner that lightens toil,-

Domestic Peace and Comfort are within

Under the common shelter, on dry sand,

The quiet camels ruminate their food;

The lengthening cord from Moath falls,

As patiently the old man

Entwines the strong palm-fibres; by the hearth

The damsel shakes the coffee-grains, 


\section{SOU'THEY.}

That with warm fragrance fill the tent;

And while, with dexterous fingers, 'Thalaba

Shapes the green basket, haply at his feet

Her favourite kidling gnaws the twig,

Forgiven plunderer, for Oneiza's sake.

Or when the winter torrent rolls

Down the deep-channell'd rain-course, foamingly,

Dark with its mountain spoils,

With bare feet pressing the wet sand,

There wanders Thalaba,

The rushing flow, the flowing roar,

Filling his yielded faculties,

A vague, a dizzy, a tumultuous joy.

Or lingers it a vernal brook

Gleaming o'er yellow sands?

Beneath the lofty bank reelined,

With idle eye he views its little waves,

Quietly listening to the quiet flow;

While in the breathings of the stirring gale,

The tall canes bend above,

Floating like streamers in the wind

Their lank uplifted leaves.

Nor rich, nor poor, was Moath; God hath given

Enough, and blest him with a mind content.

No hoarded gold disquieted his dreams;

But ever round his station he beheld

Camels that knew his voice,

And home-birds, grouping at Oneiza's call,

And goats that, morn and eve,

Came with full udders to the damsel's hand.

Dear child! the tent beneath whose shade they dwelt,

It was her work; and she had twined

His girdle's many hues;

And he had seen his robe 
Grow in Oneiza's loom.

How often, with a memory-mingled joy

Which made her mother live before his sight,

He watch'd her nimble fingers thread the woof!

Or at the hand-mill, when she knelt and toil'd, Toss'd the thin cake on spreading palm,

Or fix'd it on the glowing oven's side

With bare wet arm, and safe dexterity.

'Tis the cool evening hour:

The tamarind from the dew

Sheathes its young fruit, yet green.

Before their tent the mat is spread;

The old man's solemn voice

Intones the holy book.

What if beneath no lamp-illumined dome,

Its marble walls bedeck'd with flourish'd truth,

Azure and gold adornment? Sinks the word

With deeper influence from the Imam's voice

Where in the day of congregation crowds

Perform the duty-task?

Their Father is their Priest,

The Stars of Heaven their point of prayer,

And the blue Firmament

The glorious Temple, where they feel

'The present Deity.

Yet through the purple glow of eve

Shines dimly the white moon.

'The slacken'd bow, the quiver, the long lance,

Rest on the pillar of the tent.

Knitting light palm-leaves for her brother's brow,

The dark-eyed damsel sits;

The old man tranquilly

Up his curl'l pipe inhales

The tranquillising herb.

So listen they the reed of Thalaba, 


\section{SOUTHEY.}

While his skill'd fingers modulate

The low, sweet, soothing, melancholy tones.

Or if he strung the pearls of poesy, Singing with agitated face

And eloquent arms, and sobs that reach the heart,

A tale of love and woe;

Then, if the brightening moon that lit his face,

In darkness favour'd hers,

Oh! even with such a look, as fables say,

The Mother Ostrich fixes on her egg,

Till that intense affection

Kindle its light of life,

Even in such deep and breathless tenderness

Oneiza's soul is centred on the youth,

So motionless, with such an ardent gaze,

Save when from her full eyes

She wipes away the swelling tears

That dim his image there.

She call'd him Brother; was it sister-love

For which the silver rings,

Round her smooth ankles and her tawny arms,

Shone daily brighten'd? for a brother's eye

Were her long fingers tinged,

As when she trimm'd the lamp,

And through the veins and delicate skin

The light shone rosy? that the darken'd lids

Gave yet a softer lustre to her eye?

That with such pride she trick'd

Her glossy tresses, and on holy-day

Wreath'd the red flower-crown round

Their waves of glossy jet?

How happily the days

Of Thalaba went by !

Years of his youth, how rapidly ye fled! 
To Bardsey was the Lord of Ocean bound;

Bardsey, the holy Islet, in whose soil

Did many a Chief and many a Saint repose,

His great progenitors. He mounts the skiff;

The canvas swells before the breeze, the sea

Sings round her sparkling keel, and soon the Lord

Of Ocean treads the venerable shore.

There was not, on that day, a speck to stain

The azure heaven; the blessed Sun alone

In unapproachable divinity

Career'd, rejoicing in his fields of light.

How beautiful beneath the bright blue sky

The billows heave! one glowing green expanse,

Save where along the bending line of shore

Such hue is thrown, as when the peacock's neck

Assumes its proudest tint of amethyst,

Embathed in emerald glory. All the flocks

Of Ocean are abroad; like floating foam

The sea-gulls rise and fall upon the waves;

With long protruded neck the cormorants

Wing their far flight aloft, and round and round

The plovers wheel, and give their note of joy.

It was a day that sent into the heart

A summer feeling; even the insect swarms

From their dark nooks and coverts issued forth,

'T'o sport through one day of existence more;

The solitary primrose on the bank

Seem'd now as though it had no cause to mourn

Its bleak autumnal birth; the rocks and shores,

'The forest and the everlasting hills,

Smiled in that joyful sunshine, . . . they partook

The universal blessing. 


\title{
CAROLINE BOWLES (MRS. SOUTHEY).
}

\author{
SUNDAY EVENING.
}

I sAT last Sunday evening, From sunset even till night, At the open casement watching The day's departing light.

Such hours to me are holy,

Holier than tongue can tell, They fall on my heart like dew

On the parchèd heather-bell.

The Sun had shone bright all day-

His setting was brighter still, But there sprang up a lovely air

As he dropt down the western hill.

The fields and lanes were swarming

With holy-day folks in their best,

Released from their six days' cares

By the seventh day's peace and rest.

I heard the light-hearted laugh,

The trampling of many feet-

I saw them go merrily by,

And to me the sight was sweet. 


\section{SUNDAY EVENING.}

There's a sacred soothing sweetness,

A pervading spirit of bliss,

Peculiar from all other times,

In a Sabbath eve like this.

Methinks, though I knew not the day, Nor beheld those glad faces, yet all

Would tell me that Nature was keeping Some solemn festival.

The steer and the steed in their pastures Lie down with a look of peace, As if they knew 'twas commanded That this day their labours should cease.

The lark's vesper song is more thrilling

As he mounts to bid Heaven good-night;

The brook sings a quieter tune-

The sun sets in lovelier light-

The grass, the green leares, and the flowers

Are tinged with more exquisite hues,

More odorous incense from out them

- Steams up with the evening dews.

So I sat last Sunday evening

Musing on all these things,

With that quiet gladness of spirit

No thought of this world brings -

I watched the departing glory,

'Till its last red streak grew pale,

And Earth and Heaven were woven

In 'Twilight's dusky veil. 
'Then the lark dropt down to his mate

By her nest on the dewy ground;

And the stir of human life

Died away to a distant sound-

All sounds died away - the light laugh-

The far footstep-the merry call-

To such stillness, the pulse of one's heart

Might have echoed a rose-leaf's fall-

And, by little and little, the darkness

Waved wider its sable wings,

Till the nearest objects and largest

Became shapeless confused things-

And, at last, all was dark-then I felt

A cold sadness steal over my heart,

And I said to myself, "Such is life!

So its hopes and its pleasures depart!

"And when night comes-the dark night of age,

What remaineth beneath the sun

Of all that was lovely and loved?

Of all we have learnt and done?

"When the eye waxeth dim, and the ear To sweet music grows dull and cold, And the fancy burns low, and the heartOh, Heavens! can the heart grow old?

"Then, what remaineth of life

But the lees with. bitterness fraught?

What then?"-But I check'd as it rose,

And rebuked that weak, wicked thought. 
And I lifted mine eyes up, and, lo: An answer was written on high By the finger of God himself, In the depths of the dark blue sky.

There appeared a sign in the eastA bright, beautiful, fixed star!-And I look'd on its steady light Till the evil thoughts fled afar-

And the lesser lights of Heaven

Shone out with their pale soft rays, Like the calm unearthy comforts Of a good man's latter days-

And there came up a sweet perfume From the unseen flowers below, Like the savour of virtuous deeds, Of deeds done long ago;

Like the mem'ry of well-spent timeOf things that were holy and dear-. Of friends, "departed this life In the Lord's faith and fear."

So the burthen of darkness was taken From my soul, and my heart felt light; And I laid me down to slumber

With peaceful thoughts that night. 


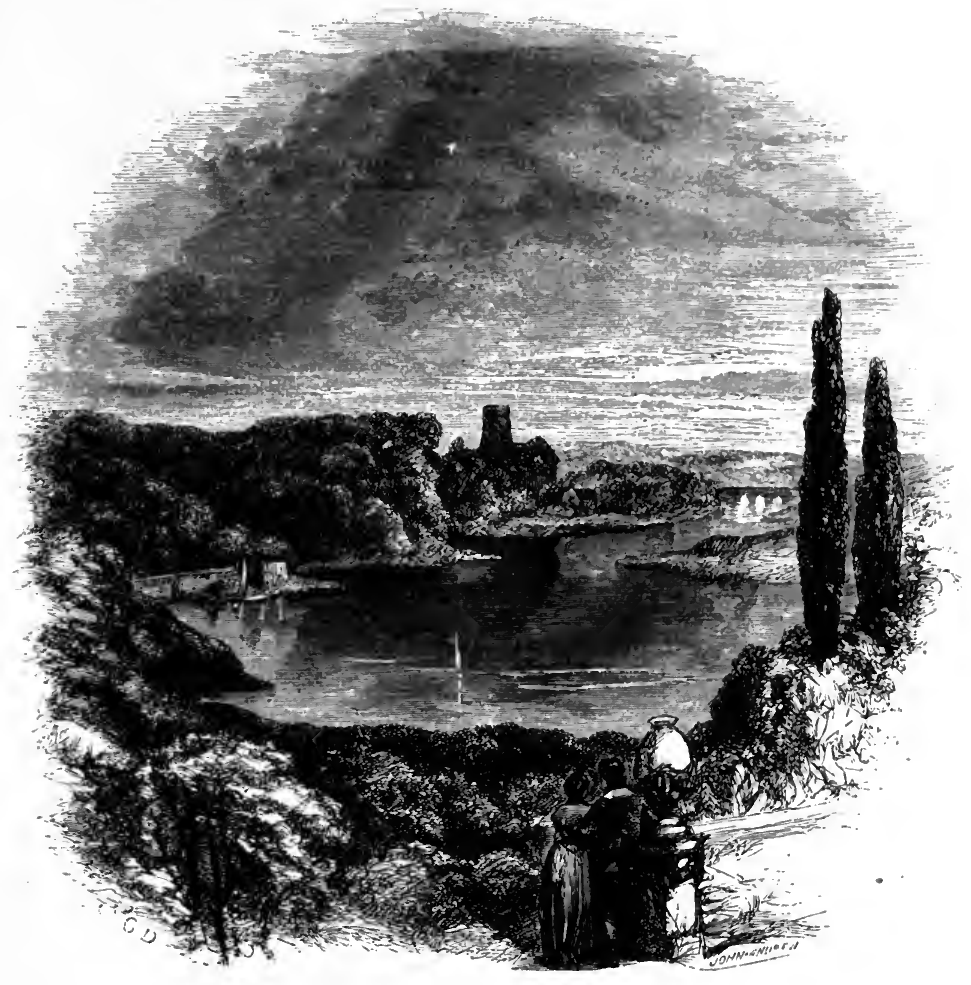

LEYDEN.

TO THE EVENING STAR.

How sweet thy modest light to view, Fair Star, to love and lovers dear! 
While trembling on the falling dew

Like beauty shining through a tear.

Or, hanging o'er that mirror-stream,

To mark that image trembling there,

Thou seem'st to smile with softer gleam,

To see thy lovely face so fair.

Though, blazing on the arch of night,

The moon thy timid beams outshine

As far as thine each starry light;-

Her rays can never vie with thine

Thine are the soft enchanting hours

When twilight lingers on the plain, And whispers to the closing flowers,

That soon the sun will rise again.

Thine is the breeze that, murmuring bland As music, wafts the lover's sigh, And bids the yielding heart expand

In love's delicious ecstasy.

Fair Star! though I be doom'd to prove

That rapture's tears are mix'd with pain, Ah ! still I feel 'tis sweet to love!

But sweeter to be lov'd again! 
LEYDEN.

TO AN INDIAN GOLD COIN.

Slave of the dark and dirty mine!

What vanity has brought thee here?

How can I love to see thee shine

So bright, whom I have bought so dear?-

The tent-ropes flapping lone I hear

For twilight converse, arm in arm;

The jackal's shriek bursts on mine ear

When mirth and music wont to charm.

By Chéricál's dark wandering streams,

Where cane-tufts shadow all the wild,

Sweet visions haunt my waking dreams

Of Teviot lov'd, chill, still, and mild,

Of castled rocks stupendous pil'd

By Esk or Eden's classic wave,

Where loves of youth and friendship smil'd,

Uncurs'd by thee, vile yellow slave!

Fade, day-dreams sweet, from memory fade!

The perish'd bliss of youth's first prime,

That once so bright on fancy play'd,

Revives no more in after time.

Far from my sacred natal clime,

I haste to an untimely grave;

The daring thoughts that soar'd sublime

Are sunk in ocean's southern wave.

Slave of the mine! thy yellow light

Gleams baleful on the tomb-fire drear-

A gentle vision comes by night

My lonely widow'd heart to cheer; 
Her eyes are dim with many a tear,

That once were guiding stars to mine:

Her fond heart throbs with many a fear!-

I cannot bear to see thee shine.

For thee, for thee, vile yellow slave,

I left a heart that lov'd me true!

I cross'd the tedious ocean-wave,

To roam in climes unkind and new :

The cold wind of the stranger blew

Chill on my wither'd heart:- the grave

Dark and untimely met my view-

And all for thee, vile yellow slave!

Ha! com'st thou now so late to mock

A wanderer's banish'd heart forlorn,

Now that his frame the lightning shock

Of sun-rays tipt with death has borne?

From love, from friendship, country, torn,

To memory's fond regrets the prey,

Vile slave, thy yellow dross I scorn!

Go mix thee with thy kindred clay! 
CLARE.

\section{CLARE.}

MARY LEE.

I HAve traced the valleys fair

In May morning's dewy air, My bonny Mary Lee!

Wilt thou deign the wreath to wear,

Gather'd all for thee?

They are not flowers of Pride,

For they graced the dingle-side;

Yet they grew in Heaven's smile, My gentle Mary Lee!

Can they fear thy frowns the while,

Though offered by me?

Here's the lily of the vale, That perfumed the morning gale,

My fairy Mary Lee!

All so spotless and so pale,

Like thine own purity.

And might I make it known,

'Tis an emblem of my own

Love-if I dare so name

My esteem for thee.

Surely flowers can bear no blame,

My bonny Mary Lee! 
Here's the violet's modest blue, 'That 'neath hawthorns hides from view,

My gentle Mary Lee,

Would show whose heart is true,

While it thinks of thee.

While they choose each lowly spot,

The sun disdains them not;

I'm as lowly too, indeed,

My charming Mary Lee;

So I've brought the flowers to plead,

And win a smile from thee.

Here's a wild rose just in bud;

Spring's beauty in its hood,

My bonny Mary Lee!

'Tis the first in all the wood

I could find for thee.

Though a blush is scarcely seen,

Yet it hides its worth within,

Like my love; for I've no power,

My angel, Mary Lee,

To speak unless the flower

Can make excuse for me.

Though they deck no princely halls,

In bouquets for glittering balls,

My gentle Mary Lee!

Richer hues than painted walls

Will make them dear to thee;

For the blue and laughing sky

spreads a grander canopy

Than all wealth's golden skill,

My charming Mary Lee!

Love would make them dearer still,

'That offers them to thee. 
CLARE.

My wreathed flowers are few; Yet no fairer drink the dew, My bonny Mary Lee!

They may seem as trifles too-

Not, I hope, to thee.

Some may boast a richer prize

Under pride and wealth's disguise;

None a fonder offering bore

Than this of mine to thee;

And can true love wish for more?

Surely not, Mary Lee! 


\section{BRAINARD.}

\section{SALMON RIVER.}

Hic viridis tenera pratexit arundine ripas Mincius.-VIRgIL.

'Tis a sweet stream-and so, 'tis true, are all That undisturbed, save by the harmless brawl Of mimic rapid or slight waterfall, Pursue their way

By mossy bank, and darkly waving wood, By rock, that since the Deluge fixed has stood, Showing to sun and moon their erisping flood By night and day.

But yet there's something in its humble rank, Something in its pure wave and sloping bank, Where the deer sported, and the young fawn drank With unseared look:

There's much in its wild history, that tcems With all that's superstitious-and that seems To match our fancy and eke out our dreams, In that small brook.

Havoc has been upon its peaceful plain, And blood has dropped there, like the drops of rain; 'The corn grows o'er the still graves of the slainAnd many a quiver, 
Filled from the reeds that grew on yonder hill, Has spent itself in carnage. Now 'tis still, And whistling ploughboys oft their runlets fill From Salmon River.

Here, say old men, the Indian Magi made Their spells by moonlight; or beneath the shade That shrouds sequestered rock, or darkening glade, Or tangled dell.

Here Philip eame, and Miantonimo, And asked about their fortunes long ago, As Saul to Endor, that her witch might show Old Samuel.

And here the black fox roved, and howled, and shook His thick tail to the hunters, by the brook Where they pursued their game, and him mistook For earthly fox;

Thinking to shoot him like a shaggy bear, And his soft peltry, stript and dressed, to wear,

Or lay a trap, and from his quiet lair Transfer him to a box.

Such are the tales they tell. 'Tis hard to rhyme About a little and unnoticed stream, That few have heard of-but it is a theme I chance to love; And one day I may tune my rye-straw reed, And whistle to the note of many a deed Done on this river-which, if there be need, I'll try to prove. 
THE BLACK FOX OF SALMON RIVER.

How cold, how beautiful, how bright,

The cloudless heaven above us shines;

But 'tis a howling winter's night,

'Twould freeze the very forest pines!

"The winds are up, while mortals sleep;

The stars look forth when eyes are shut;

The bolted snow lies drifted deep

Around our poor and lonely hut.

"With silent step and listening ear,

With bow and arrow, dog and gun,

We'll mark his track, for his prowl we hear,

Now is our time!-come on, come on!"

O'er many a fence, through many a wood,

Following the dog's bewildered scent,

In anxious haste and earnest mood,

The Indian and the white man went.

The gun is eocked, the bow is bent, The dog stands with uplifted paw, And ball and arrow swift are sent,

Aimed at the prowler's very jaw.

The hall, to kill that fox, is run

Not in a mould by mortals made !

'The arrow which that fox should shum

Was never shaped from earthly reed!

'The Indian Druids of the wood

Know where the fatal arrows grow--

'They spring not by the summer flood,

They pierce not through the winter snow! 
Why cowers the dog, whose snuffing nose

Was never once deceived till now?

And why, amid the chilling snows,

Does either hunter wipe his brow?

For once they see his fearful den,

'Tis a dark cloud that slowly moves

By night around the homes, of men,

By day-along the stream it loves.

Again the dog is on his track,

'The hunters chase o'er dale and hill,

They may not, though they would, look back,

They must go forward-forward still.

Onward they go, and never turn,

Spending a night that meets no day;

For them shall never morning sun

Light them upon their endless way.

The hut is desolate, and there

The famished dog alone returns;

On the cold steps he makes his lair,

By the shut door he lays his bones.

Now the tired sportsman leans his gun

Against the ruins of the site,

And ponders on the hunting done

By the lost wanderers of the night.

And there the little country girls

Will stop to whisper, and listen, and look, And tell, while dressing their sunny curls,

Of the Black Fox of Salmon Brook. 


\section{EDWARD COATE PINKNEY.}

\section{A HEALTH.}

I FILL this cup to one made up of loveliness alone, A woman, of her gentle sex the seeming paragon; 'To whom the better elements and kindly stars have given A form so fair, that, like the air, 'tis less of earth than heaven.

Her every tone is music's own, like those of morning birds, And something more than melody dwells ever in her words; The coinage of her heart are they, and from her lips each flows As one may see the burthened bee forth issue from the rose.

Affections are as thoughts to her, the measures of her hours; Her feelings have the fragrancy, the freshness of young flowers; And lovely passions, changing oft, so fill her, she appears The image of themselves by turns,-the idol of past years.

Of her bright face one glance will trace a picture on the brain, And of her voice in echoing hearts a sound must long remain; But memory such as mine of her so very much endears, When death is nigh my latest sigh will not be life's but hers.

I filled this cup to one made up of loveliness alone,

A woman, of her gentle sex the seeming paragon-

Her health! and would on earth there stood some more of such a frame,

That life might be all poetry, and weariness a name. 


\section{A PICTURE-SONG.}

How may this little tablet feign the features of a face, Which o'er-informs with loveliness its proper share of space; Or human hands on ivory enable us to see The charms that all must wonder at, thou work of gods, in thee!

But yet, methinks, that sunny smile familiar stories tells, And I should know those placid eyes, two shaded crystal wells; Nor can my soul, the limner's art attesting with a sigh, Forget the blood that decked thy cheek, as rosy clouds the sky.

'They. could not semble what thou art, more excellent than fair, As soft as sleep or pity is, and pure as mountain air;

But here are common, earthly hues, to such an aspect wrought, That none, save thine, can seem so like the beautiful of thought.

The song I sing, thy likeness like, is painful mimicry Of something better, which is now a memory to me, Who have upon life's frozen sea arrived the icy spot, Where men's magnetic feelings show their guiding task forgot.

The sportive hopes, that used to chase their shifting shadows on, Like children playing in the sun, are gone-for ever gone; And on a careless, sullen peace, my double-fronted mind, Like Janus when his gates were shut, looks forward and behind.

Apollo placed his harp, of old, awhile upon a stone,

Which has resounded since, when struck, a breaking harpstring's tone ;

And thus my heart, though wholly now from early softness free, If touched, will yield the music yet it first received of thee. 


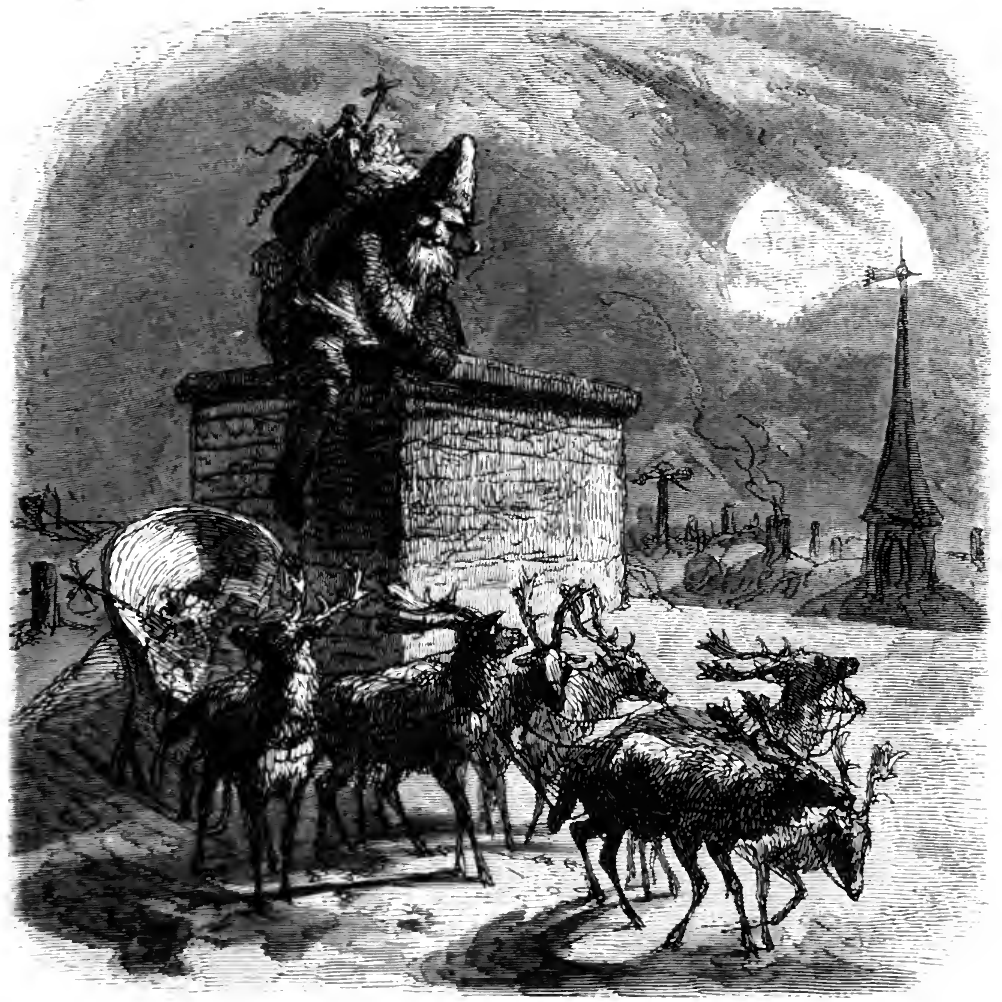

\section{CLEMENT' C. MOORE.}

I VISI'T FROM ST. NICHOLAS.

"Twas the night before Christmas, when all through the house

Not a creature was stirring, not even a mouse; 
The stockings were hung by the chimney with care,

In hopes that St. Nicholas soon would be there;

The children were nestled all snug in their beds,

While visions of sugar-plums danced in their heads;

And Mamma in her 'kerchief, and I in my cap,

Had just settled our brains for a long winter's nap;

When out on the lawn there arose such a clatter,

I sprang from the bed to see what was the matter.

Away to the window I flew like a flash,

Tore open the shutters and threw up the sash.

The moon on the breast of the new-fallen snow,

Gave the lustre of mid-day to objects below,

When, what to my wondering eyes should appear,

But a miniature sleigh, and eight tiny rein-deer,

With a little old driver, so lively and quick,

I knew in a moment it must be St. Nick.

More rapid than eagles his coursers they came,

And he whistled, and shouted, and called them by name;

"Now, Dasher! now, Dancer! now, Prancer! and Vixen!

On, Comet! on, Cupid! on, Donder and Blitzen!

To the top of the porch! to the top of the wall!

Now dash away! dash away! dash away all !"

As dry leaves that before the wild hurricane fly,

When they meet with an obstacle, mount to the sky;

So up to the house-top the coursers they flew,

With the sleigh full of toys, and St. Nicholas too.

And then, in a twinkling, I heard on the roof,

The prancing and pawing of each little hoof-

As I drew in my head, and was turning around,

Down the chimney St. Nicholas came with a bound.

Ile was dressed all in fur from his head to his foot,

And his clothes were all tarnished with ashes and soot;

A bundle of toys he had flung on his back,

And he looked like a pedlar just opening his pack.

His eyes-how they twinkled! his dimples how merry!

His cheeks were like roses, his nose like a cherry! 
His droll little mouth was drawn up like a bow, And the beard of his chin was as white as the snow; 'The stump of a pipe he held tight in his teeth, And the smoke it encireled his head like a wreath. He had a broad face and a little round belly, That shook, when he laughed, like a bowlful of jelly. He was chubby and plump, a right jolly old elf, And I laughed when I saw him, in spite of myself; A wink of his eye and a twist of his head, Soon gave me to know . I had nothing to dread; He spoke not a word, but went straight to his work, And filled all the stoekings; then turned with a jerk, And laying his finger aside of his nose, And giving a nod, up the chimney he rose; He sprang to his sleigh, to his team gave a whistle, And away $t_{2}, y$ all flew like the down of a thistle. But I heard him exclaim, ere he drove out of sight, "Happy Christ nas to all, and to all a good-night!" 

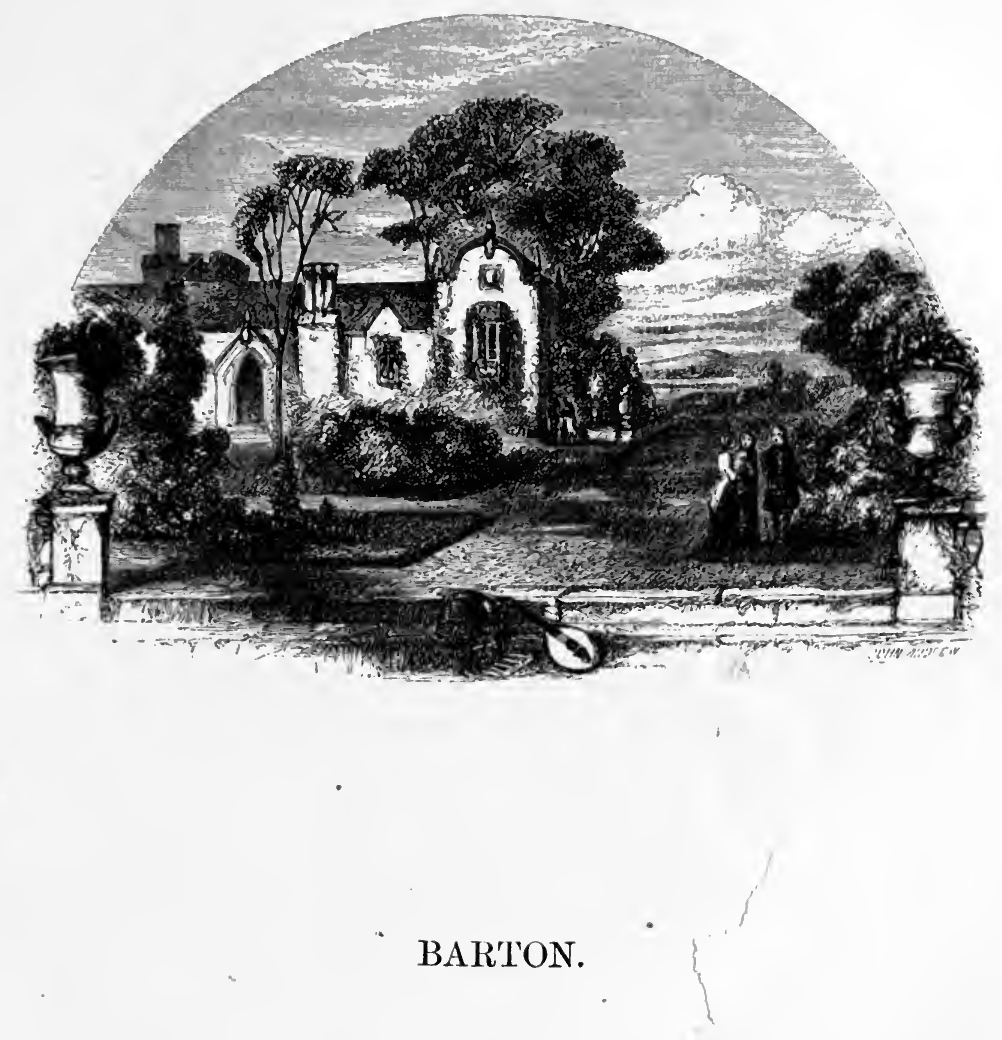

TO THE EVENING PRIMR! E.

FaIR flower, that shunn'st the $\varepsilon$ re of day;

Yet lov'st to open, meekly bol

To evening's hues of silver grey

Thy cup of paly gold;-

Be thine the offering, owing long

To thee, and to this pensive hour,

Or one brief tributary song,

Though transient as thy flower. 
I love to watch at silent eve Thy scatter'd blossoms' lonely light, And have my inmost heart receive The influence of that sight.

I love at such an hour to mark Their beauty greet the night-breeze chill, And shine, 'mid shadows gathering dark, The garden's glory still.

For such 'tis sweet to think the while,

When cares and griefs the breast invade, Is friendship's animating smile In sorrow's dark'ning shade.

'Thus it bursts forth, like thy pale cupGlist'ning amid its dewy tears, And bears the sinking spirit up

Amid its chilling fears-

But still more animating far,

If meek Religion's eye may trace

Even in thy glimm'ring, earth-born'star, The holier hope of Grace.

The hope, that as thy beauteous bloom

Expands to glad the close of day, So through the shadows of the tomb

May break forth Mercy's ray. 


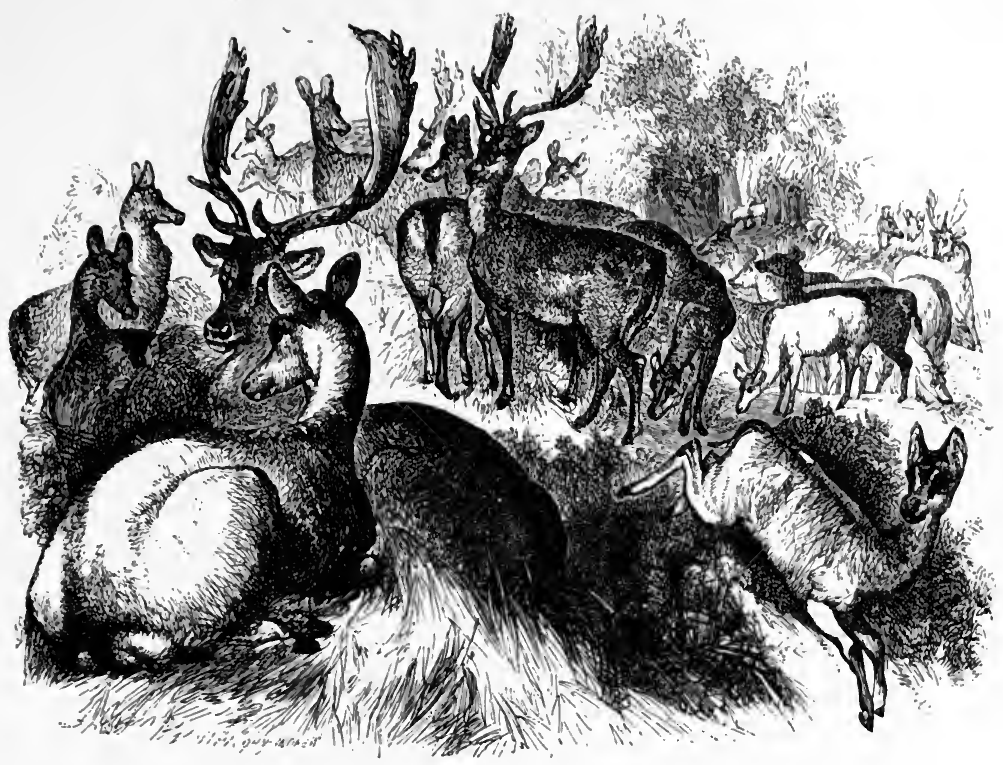

\section{SOTHEBY.}

RHINEFIELD,-A LODGE IN THE NEW FOREST.

RHinefield! as through thy solitude I rove,

Now lost amid the deep wood's gloomy night,

Doubtful I trace a ray of glimmering light;

Now where some antique oak, itself a grove,

Spreads its soft umbrage o'er the sunny glade, Stretched on its mossy roots at early dawn While o'er the furze with light bound leaps the fawn,

I count the herd that crops the dewy blade:

Frequent at eve list to the hum profound

That all around upon the chill breeze floats,

Broke by the lonely keeper's wild, strange notes,

At distance followed by the browsing deer;

Or the bewilder'd stranger's plaintive sound

That dies in lessening murmurs on the ear. 
ON CROSSING THE ANGLESEY STRAIT.

\section{SKIRID,}

A HILL NEAR ABERGAVENNY.

SkIRID! remembrance thy loved scene renews;

Fancy, yet lingering on thy shaggy brow,

Beholds around the lengthened landscape glow,

Which charmed, when late the day-beam's parting hues

Purpled the distant cliff. The erystal stream

Of Usk bright winds the verdant meads among;

'The dark heights lower with wild woods o'erhung;

Pale on the grey tower falls the twilight glean. And frequent I recal the sudden breeze,

Which, as the sun shot up his last pale flame, - Shook every light leaf shivering on the trees:

Then, bathed in dew, meek evening silent came, While the low wind, that faint and fainter fell, Soft murmured to the dying day-F AREweLr!

\section{ON CROSSING THE ANGLESEY STRAIT TO BANGOR AT} MIDNIGHT.

'Twas night, when from the Druid's gloomy cave,

Where I had wander'd, tranced in thought, alone

'Mid Cromlech's and the Carnedd's funeral stone, Pensive and slow I sought the Menai's wave:

Lulled by the scene, a soothing stillness laid Wach pang to rest. O'er Snowdon's cloudless brow The moon, that full orb'd rose, with peaceful glow

Beamed on the rocks; with many a star arrayed, Gilitter'd the broad blue sky; from shore to shore

O'er the smooth current streamed a silver light,

Save where along the flood the lonely height

Of rocky Penmaenmaur deep darkness spread;

And all was silence, save the ceaseless roar

Of Conway bursting on the ocean's bed. 


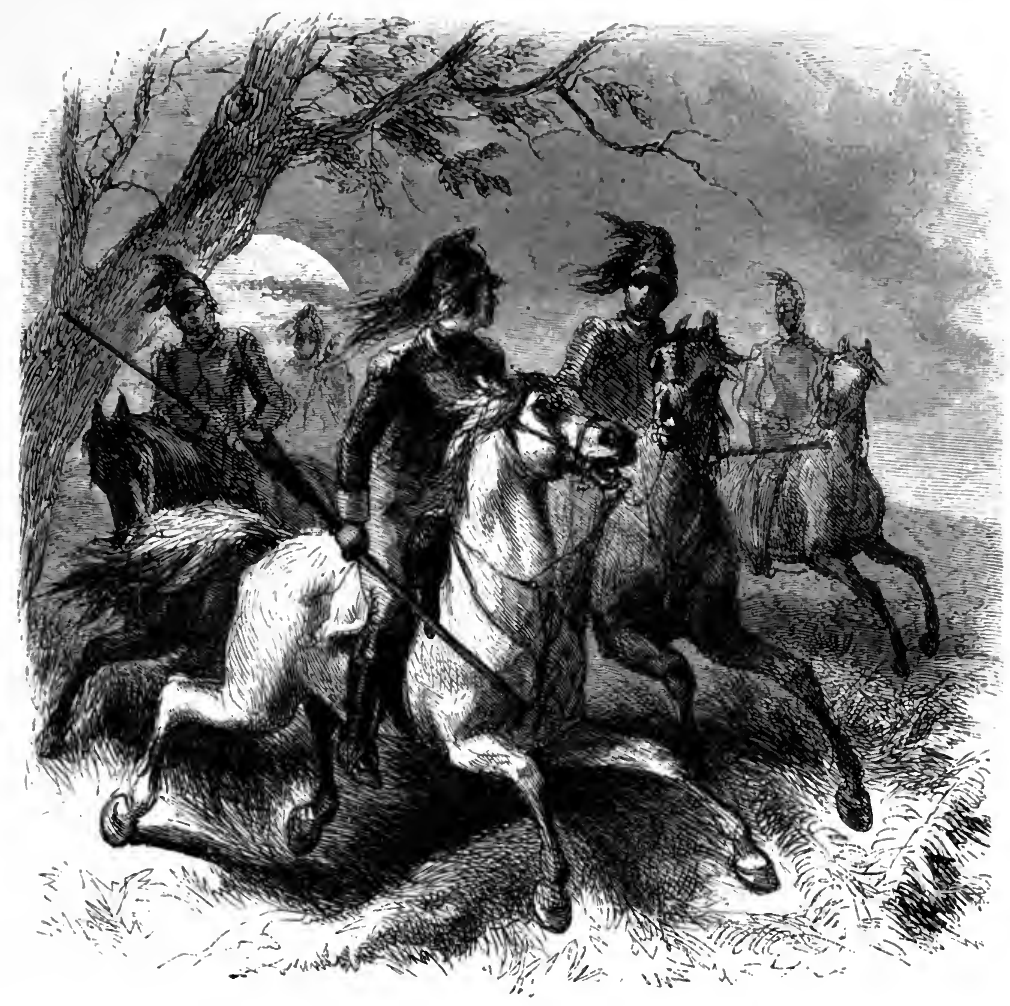

\section{BRYANT.}

SONG OF MARION'S MEN.

Our band is few, but true and tried, Our leader frank and bold;

The British soldier trembles

When Marion's name is told.

Our fortress is the good greenwood,

Our tent the cypress-tree;

We know the forest round us,

As seamen know the sea. 
We know its walls of thorny vines,

Its glades of reedy grass,

Its safe and silent islands

Within the dark morass.

Wo to the English soldiery, That little dread us near! On them shall light at midnight

A strange and sudden fear:

When, waking to their tents on fire,

They grasp their arms in vain,

And they who stand to face us

Are beat to earth again.

And they who fly in terror deem

A mighty host behind,

And hear the tramp of thousands

Upon the hollow wind.

Then sweet the hour that brings release

From danger and from toil :

We talk the battle over,

And share the battle's spoil.

The woodland rings with laugh and shout,

As if a hunt were up,

And woodland flowers are gathered

'To erown the soldier's cup.

With merry songs we mock the wind

That in the pine-top grieves,

And slumber long and sweetly

On beds of oaken leaves.

Well knows the fair and friendly moon

'The band that Marion leads-

'The glitter of their rifles,

The scampering of their steeds.

'Tis life to guide the fiery barb

Across the moonlight plain; 


\section{BRYAN'T}

'Tis life to feel the night-wind That lifts his tossing mane.

A moment in the British camp-

A moment-and away

Back to the pathless forest, Before the peep of day.

Grave men there are by broad Santee, Grave men with hoary hairs, Their hearts are all with Marion, For Marion are their prayers. And lovely ladies greet our band With kindliest welcoming, With smiles like those of summer, And tears like those of spring. For them we wear these trusty arms, And lay them down no more Till we have driven the Briton, For ever, from our shore. 


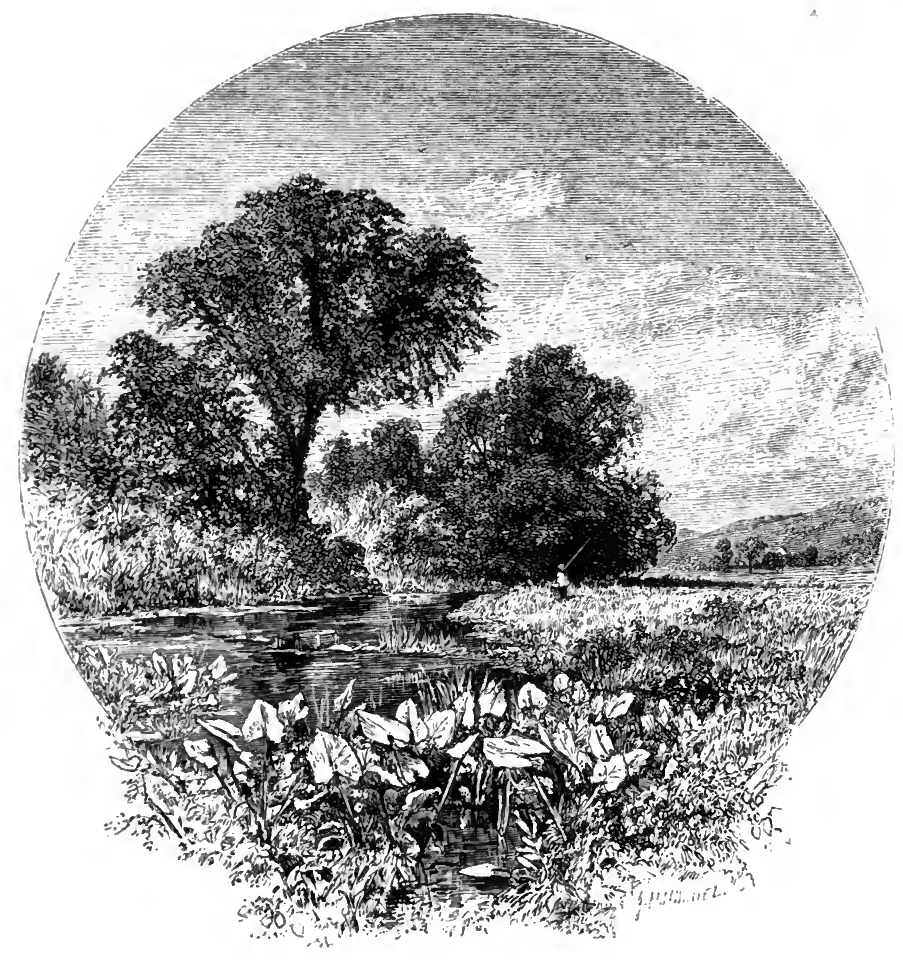

GREEN RIVER.

WHes breezes are soft and skies are fair, I steal an hour from study and care, And hie me away to the woodland scene, Where wanders the stream with waters of green, $\Lambda s$ if the bright fringe of herbs on its brink IIal given their stain to the wave they drink; And they, whose meadows it murmurs through, IIare named the stream from its own fair hue.

Yot pure its waters-its shallows are bright With colored pebbles and sparkles of light, And elear the depths where its eddies play, And dimples deepen and whirl away, 
And the plane-tree's speckled arms o'ershoot

The swifter current that mines its root,

Through whose shifting leaves, as you walk the hill,

The quivering glimmer of sun and rill

With a sudden flash on the eye is thrown,

Like the ray that streams from the diamond-stonc

Oh, loveliest there the spring days come,

With blossoms, and birds, and wild bees' hum;

'The flowers of summer are fairest there,

And freshest the breath of the summer air;

And sweetest the golden autumn day

In silence and sunshine glides away.

Yet, fair as thou art, thou shunnest to glide,

Beautiful stream! by the village side;

But windest away from haunts of men,

To quiet valley and shaded glen;

And forest, and meadow, and slope of hill,

Around thee, are lonely, lovely, and still.

Lonely, save when, by thy rippling tides,

From thicket to thicket the angler glides;

Or the simpler comes with basket and book,

For herbs of power on thy banks to look;

Or haply, some idle dreamer, like me,

To wander, and muse, and gaze on thee.

Still-save the chirp of birds that feed

On the river cherry and seedy reed,

And thy own wild music gushing out

With mellow murmur and fairy shout,

From dawn to the blush of another day

Like traveller singing along his way.

That fairy music I never hear,

Nor gaze on those waters so green and clear,

And mark them winding away from sight,

Darkened with shade or flashing with light, 


\section{GREEN RIVER.}

While o'er them the vine to its thicket clings, And the zephyr stoops to freshen his wings, But I wish that fate had left me free To wander these quiet haunts with thee, 'Till the eating cares of earth should depart, And the peace of the scene pass into my heart; And I envy thy stream as it glides along, 'Through its beautiful banks in a trance of song.

Though forced to drudge for the dregs of men, And scrawl strange words with the barbarous pen, And mingle among the jostling crowd, Where the sons of strife are subtle and loudI often come to this quiet place, To breathe the airs that ruffle thy face, And gaze upon thee in silent dream, For in thy lonely and lovely stream An image of that calm life appears That won my heart in my greener years. 
BRYANT.

\section{THE DEATH OF THE FLOWERS.}

The melancholy days are eome, the saddest of the year, Of wailing winds, and naked woods, and meadows brown and sere. Heaped in the hollows of the grove, the autumn leaves lie dead; They rustle to the eddying gust, and to the rabbit's tread. The robin and the wren are flown, and from the shrubs the jay, And from the wood-top calls the crow through all the gloomy day.

Where are the flowers, the fair young flowers, that lately sprang and stood In brighter light, and softer airs, a beauteous sisterhood? Alas! they all are in their graves, the gentle race of flowers Are lying in their lowly beds, with the fair and good of ours. The rain is falling where they lie, but the cold November rain

Calls not from out the gloomy earth the lovely ones again.

The wind-flower and the violet, they perished long ago, And the brier-rose and the orchis died amid the summer glow; But on the hill the golden-rod, and the aster in the wood, And the yellow sun-flower by the brook in autumn beauty stood, Till fell the frost from the clear cold heaven, as falls the plague $\mathrm{cn}$ men, And the brightness of their smile was gone, from upland, glade, and glen.

And now, when comes the calm mild day, as still such days will come, To call the squirrel and the bee from out their winter home; When the sound of dropping nuts is heard, though all the trees are still, And twinkle in the smoky light the waters of the rill, The south wind searches for the flowers whose fragrance late he bore, And sighs to find them in the wood and by the stream no more

And then I think of one who in her youthful beauty died, The fair meek blossom that grew up and faded by my side: In the cold moist earth we laid her, when the forests cast the leaf, And we wept that one so lovely should have a life so brief: Yet not unmeet it was that one, like that young friend of ours, So gentle and so beautiful, should perish with the flowers. 


\section{THE LAND OF DREAMS.}

A Mighty realm is the Land of Dreams,

With steeps that hang in the twilight sky, And weltering oceans and trailing streams,

That gleam where the dusky valleys lie.

But over its shadowy border flow

Sweet rays from the world of endless morn, And the nearer mountains catch the glow, And flowers in the nearer fields are born.

The souls of the happy dead repair,

From their bowers of light, to that bordering land, And walk in the fainter glory there,

With the souls of the living hand in hand.

One calm sweet smile, in that shadowy sphere, From eyes that open on earth no moreOne warning word from a voice once dear-

How they rise in the memory o'er and o'er!

Far off from those hills that shine with day, And fields that bloom in the heavenly gales, The Land of Dreams goes stretching away

To dimmer mountains and darker vales.

There lie the chambers of guilty delight,

There walk the spectres of guilty fear, And soft low voices, that float through the night,

Are whispering $\sin$ in the helpless ear. 


\section{BRYANT.}

Dear maid, in thy girlhood's opening flower, Searce weaned from the love of childish play! 'The tears on whose cheeks are but the shower That freshens the early blooms of May!

Thine eyes are closed, and over thy brow Pass thoughtful shadows and joyous gleams, And I know, by thy moving lips, that now Thy spirit strays in the Land of Dreams.

Light-hearted maiden, oh, heed thy feet!

O keep where that beam of Paradise falls, And only wander where thou may'st meet The blessed ones from its shining walls.

So shalt thou come from the Land of Dreams, With love and peace to this world of strife; And the light that over that border streams Shall lie on the path of thy daily life. 


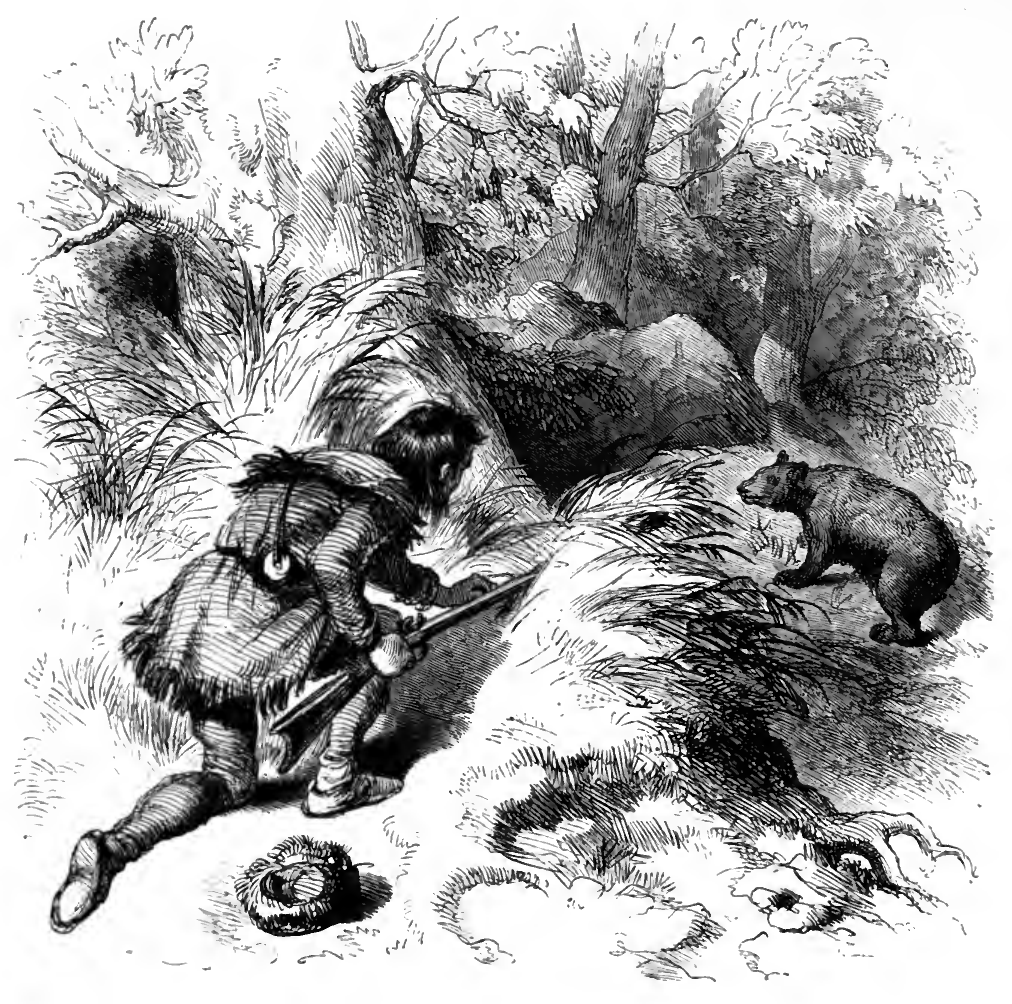

THE HUNTER OF THE PRAIRIES.

Ar, this is freedom!-these pure skies

Were never stained with village smoke:

The fragrant wind, that through them flies,

Is treathed from wastes by plough unbroke.

IIere, with my rifle and my steed,

And her who left the world for me,

I plant me where the red deer feed

In the green desert—and am free. 
For here the fair savannas know

No barriers in the bloomy grass;

Wherever breeze of heaven may blow,

Or beam of heaven may glance, I pass.

In pastures, measureless as air,

The bison is my noble game;

The bounding elk, whose antlers tear

The branches, falls before my aim.

Mine are the river-fowl that scream

From the long stripe of waving sedge;

The bear that marks my weapon's gleam,

Hides vainly in the forest's edge;

In vain the she-wolf stands at bay;

The brinded catamount, that lies

High in the boughs to watch his prey,

Even in the act of springing, dies.

With what free growth the elm and plane

Fling their huge arms across my way,

Gray, old, and cumbered with a train

Of vines, as huge, and old, and gray!

Free stray the lucid streams, and find

No taint in these fresh lawns and shades;

Free spring the flowers that scent the wind

Where never scythe has swept the glades.

Alone the Fire, when frost-winds sere

The heavy herbage of the ground,

Gathers his annual harvest here,

With roaring like the battle's sound, And hurrying flames that sweep the plain,

And smoke-streams gushing up the sky:

I meet the flames with flames again, And at my door they cower and die. 
Here, from dim woods, the aged past Speaks solemnly; and I behold

The boundless future in the vast And lonely river, seaward rolled. Who feeds its founts with rain and dew; Who moves, I ask, its ' gliding mass, And trains the bordering vines, whose blue Bright clusters tempt me as I pass?

Broad are these streams-my steed obeys, Plunges, and bears me through the tide. Wide are these woods-I thread the maze Of giant stems, nor ask a guide.

I hunt till day's last glimmer dies O'er woody vale and grassy height; And kind the voice and glad the eyes That welcome my return at night. 


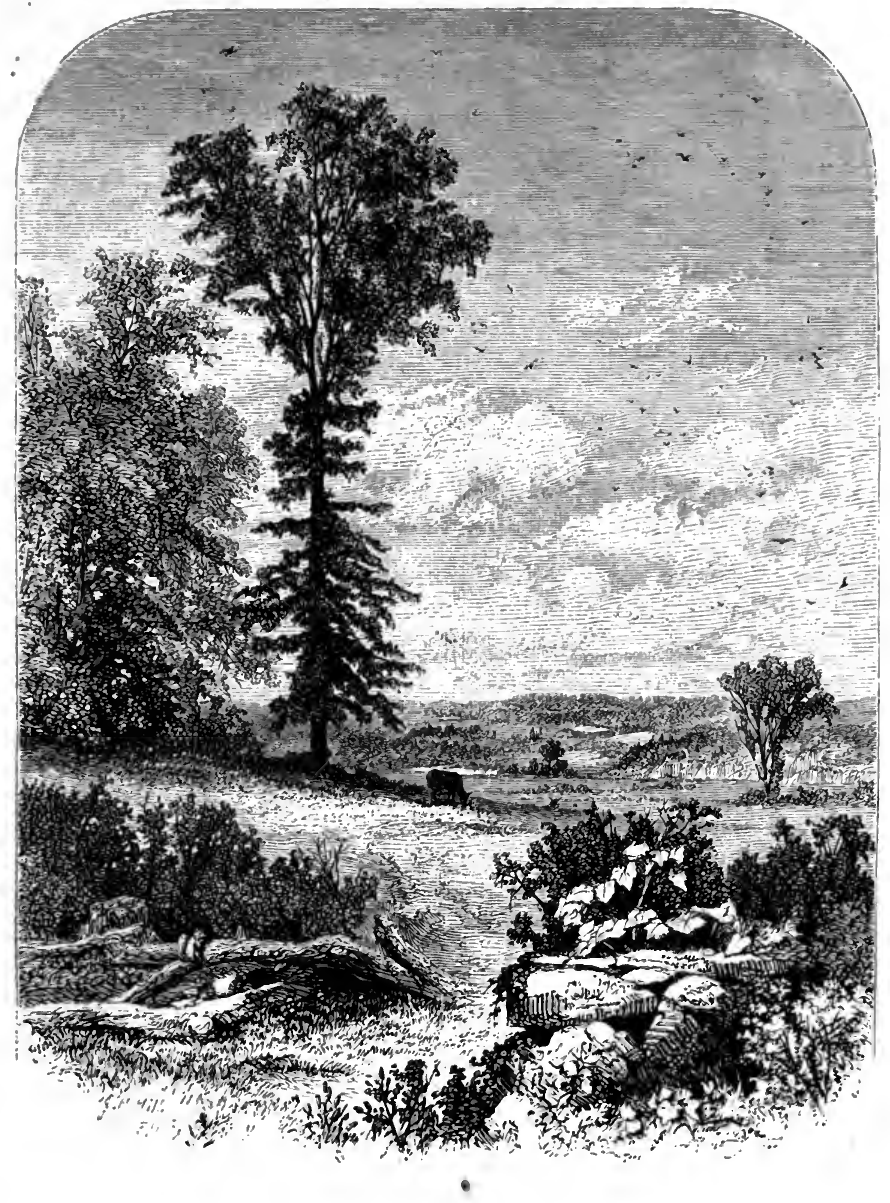

THE GLADNESS OF NATURE.

Is this a time to be cloudy and sad,

When our mother Nature laughs around;

When even the deep blue heavens look glad, And gladness breathes from the blossoming ground? 
There are notes of joy from the hang-bird and wren, And the gossip of swallows through all the sky; The ground-squirrel gayly chirps by his den, And the wilding bee hums merrily by.

The clouds are at play in the azure space, And their shadows at play on the bright green vale, And here they stretch to the frolic chase,

And there they roll on the easy gale.

There's a dance of leaves in that aspen bower, There's a titter of winds in that beechen tree, There's a smile on the fruit and a smile on the flower, And a laugh from the brook that runs to the sea.

And look at the broad-faced sun, how he smiles

On the dewy earth that smiles in his ray, On the leaping waters and gay young isles; Ay, look, and he'll smile thy gloom away.

\section{WILLIAM TELL.}

Cruars may subdue the feeble spirit, but thee, TeLL, of the iron heart! they could not tame! For thou wert of the mountains; they proclaim 'The everlasting ereed of liberty.

That ereed is written on the untrampled snow, Thundered by torrents which no power can hold, Save that of God, when he sends forth his cold, And breathed by winds that through the free heaven blow.

'Thou, while thy prison walls were dark around, Didst meditate the lesson Nature taught, And to thy brief captivity was brought

$A$ vision of thy Switzerland unbound.

The bitter eup they mingled, strengthened thee For the great work to set thy country free. 
BRYANT.

\section{AN INVITATION TO THE COUNTRY.}

ALL day, from shrubs by our summer dwelling,

The Easter-sparrow repeats his song,

A merry warbler, he chides the blossoms,

The idle blossoms, that sleep so long.

The blue-bird chants, from the elm's long branches,

A hymn to welcome the budding year;

The south-wind wanders from field to forest,

And softly whispers, The spring is here!

Come, daughter mine, from the gloomy city,

Before these lays from the elm have ceased;

The violet breathes by our door as sweetly

As in the air of her native East.

Though many a flower in the wood is waking,

The daffodil is our door-side queen;

She pushes upward the sward already,

To spot with sunshine the early green.

No lays so joyous as these are warbled

From wiry prison in maiden's bower;

No pampered bloom of the green-house chamber

Has half the charm of the lawn's first flower.

Yet these sweet lays of the early season

And these fair sights of its sunny days,

Are only sweet when we fondly listen,

And only fair when we fondly gaze. 
AN INVITATION TO THE COUNTRY.

There is no glory in star or blossom Till looked upon by a loving eye;

There is no fragrance in April breezes

Till breathed with joy as they wander by.

Come, Julia dear, for the sprouting willows, The opening flowers, and the gleaming brooks, And hollows green in the sun are waiting Their dower of beauty from thy glad looks. 


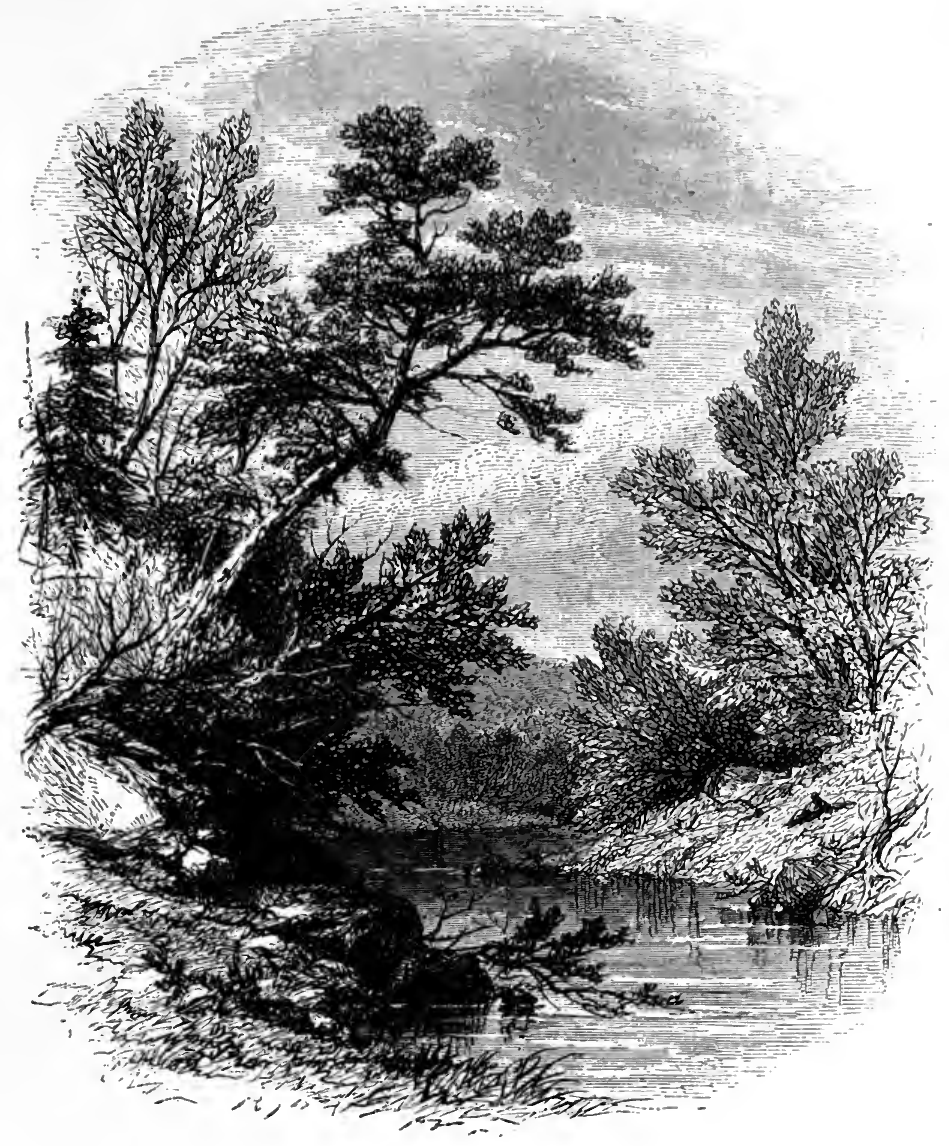

D R A K E.

\section{BRONX.}

I saT me down upon a green bank-side,

Skirting the smooth edge of a gentle river,

Whose waters seemed unwillingly to glide,

Like parting friends who linger while they sever;

Enforced to go, yet seeming still unready,

Backward they wind their way in many a wistful eddy. 


\section{BRONX.}

Gray o'er my head the yellow-vested willow Ruffled its hoary top in the fresh breezes, Glancing in light, like spray on a green billow,

- Or the fine frostwork which young winter freezes, When first his power in infant pastime trying, Congeals sad autumn's tears on the dead branches lying.

From rocks around hung the loose ivy dangling, And in the clefts sumach of liveliest green, Bright ising-stars the little beach was spangling,

The gold-cup sorrel from his gauzy screen

Shone like a fairy crown, enchased and beaded, Left on some morn, when light flashed in their eyes unleeded.

The humbird shook his sun-touched wings around,

'The bluefinch caroll'd in the still retreat;

The antic squirrel capered on the ground

Where lichens made a carpet for his feet:

Through the transparent waves, the ruddy minkle

shot up in glimmering sparks his red fin's tiny twinkle.

There were dark cedars with loose mossy tresses,

White powdered dog-trees, and stiff hollies flaunting

Gaudy as rustics in their May-day dresses,

Blue pelloret from purple leaves upslanting

$\Lambda$ modest gaze, like eyes of a young maiden

shining beneath dropt lids the evening of her wedding.

The breeze fresh springing from the lips of morn,

Kissing the leaves, and sighing so to lose 'em, The winding of the merry locust's horn,

The glad spring gushing firom the rock's bare bosom: Sweet sights, sweet sounds, all sights, all sounds excelling, Oh! 'twas a ravishing spot formed for a poet's dwelling. 
And did I leave thy loveliness, to stand

Again in the dull world of earthly blindness?

Pained with the pressure of unfriendly hands,

Sick of smooth looks, agued with iey kindness?

Left I for this thy shades, where none intrude, To prison wandering thought and mar sweet solitude?

Yet I will look upon thy face again,

My own romantic Bronx, and it will be

A face more pleasant than the face of men.

Thy waves are old companions, I shall see

A well-remembered form in each old tree,

And hear a voice long loved in thy wild minstrelsy.

\section{SONNET.}

Is thy heart weary of -unfeeling men,

And chilled with the world's ice? Then come with me,

And I will bring thee to a pleasant glen

Lovely and lonely. There we'll sit, unviewed

By scoffing eye; and let our hearts beat free

With their own mutual throb. For wild and rude

The access is, and none will there intrude,

To poison our free thoughts, and mar our solitude!

Such scenes move not their feelings-for they hold

No fellowship with nature's loneliness;

The frozen wave reflects not back the gold

And crimson flushes of the sun-set hour;

The roek lies cold in sunshine-not the power

Of heaven's bright orb can clothe its barrenness. 


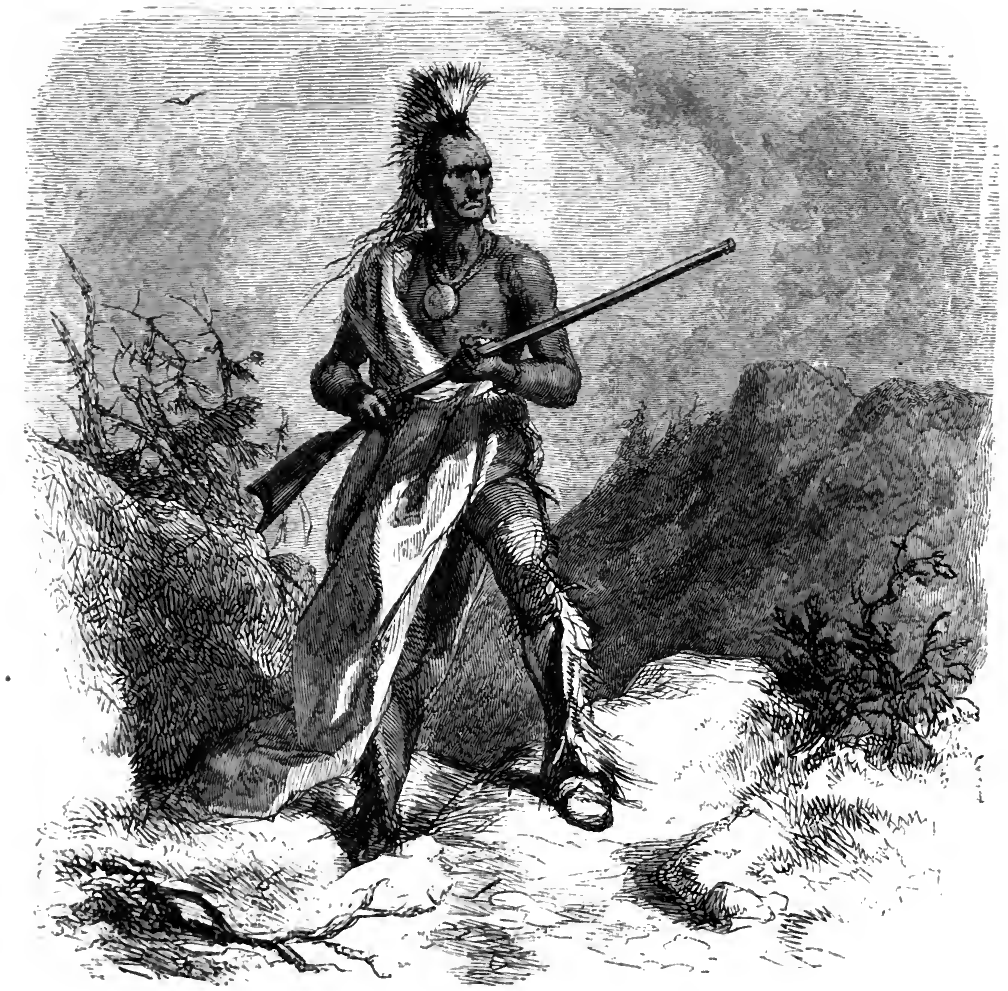

\section{HALIECK.}

\section{R E D J A C K E T.}

\section{A CHIEF OF THE INDIAN TRIBES, THE TUSCARORAS.}

ON LOOKIYG AT HIS PORTRAIT HY WEIR.

Coorer, whose name is with his country's woven, First in her files, her Pronese of mind-

$\Lambda$ wanderer now in other climes, has proven

His love for the young land he left behind; 


\section{HALLECK.}

And throned her in the senate-hall of nations,

Robed like the deluge rainbow, heaven-wrought;

Magnificent as his -own mind's creations,

And beautiful as its green world of thought:

And faithful to the Act of Congress, quoted

As law authority, it passed nem. con.:

He writes that we are, as ourselves have voted, The most enlightened people ever known.

That all our week is happy as a Sunday

In Paris, full of song, and dance, and laugh;

And that, from Orleans to the Bay of Fundy,

There's not a bailiff or an epitaph.

And furthermore-in fifty years, or sooner,

We shall export our poetry and wine;

And our brave fleet, eight frigates and a schooner,

Will sweep the seas from Zembla to the Line.

If he were with me, King of Tuscarora!

Gazing, as I, upon thy portrait now,

In all its medalled, fringed, and beaded glory,

Its eye's dark beauty, and its thoughtful brow-

Its brow, half martial and half diplomatic,

Its eye, upsoaring like an eagle's wings;

Well might he boast that we, the Democratic,

Outriyal Europe, even in our Kings!

For thou wast monarch born. Tradition's pages

Tell not the planting of thy parent tree,

But that the forest tribes have bent for ages

To thee, and to thy sires, the subject knee.

Thy name is princely-if no poet's magic

Could make Red JACKeT grace an English rhyme,

Though some one with a genius for the tragic

Hath introduced it in a pantomime, 


\section{RED JACKET.}

Yet it is music in the language spoken

Of thine own land; and on her herald roll; As bravely fought for, and as proud a token

As Cœur de Lion's of a warrior's soul.

Thy garb-though Austria's bosom-star would frighten

That medal pale, as diamonds the dark mine, And George the Fourth wore, at his court at Brighton,

A more becoming evening dress than thine;

Yet 'tis a brave one, scorning wind and weather, And fitted for thy couch, on field and flood, As Rob Roy's tartan for the Highland heather,

Or forest green for England's Robin Hood.

Is strength a monarch's merit, like a whaler's ?

Thou art as tall, as sinewy, and as strong As earth's first kings-the Argo's gallant sailors, Heroes in history, and gods in song.

Is beauty?-Thine has with thy youth departed; But the love-legends of thy manhood's years, And she who perished, young and broken-hearted, Are-but I rhyme for smiles and not for tears.

Is eloquence?-Her spell is thine that reaches The heart, and makes the wisest head its sport; And there's one rare, strange virtue in thy speeches, The secret of their mastery-they are short.

The monarch mind, the mystery of commanding, 'The birth-hour gift, the art Napoleon, Of wiming, fettering, moulding, wielding, banding The hearts of millions till they move as one:

'Thou hast it. $\Lambda$ t thy bidding men have crowded The roarl to death as to a festival; And minstrels, at their sepulchres, have shrouded

With banner-folds of glory the dark pall. 


\section{HALLECK.}

Who will belicve? Not I-for in deceiving Lies the dear charm of life's delightful dream;

I cannot spare the luxury of believing That all things beautiful are what they seem;

Who will believe that, with a smile whose blessing Would, like the Patriarch's, soothe a dying hour, With voice as low, as gentle, and caressing, As e'er won maiden's lip in moonlit bower;

With look, like patient Job's, eschewing evil; With motions graceful as a bird's in air; Thou art, in sober truth, the veriest devil That e'er clenched fingers in a captive's hair!

That in thy breast there springs a poison fountain, Deadlier than that where bathes the Upas-tree; And in thy wrath, a nursing cat-o'-mountain Is calm as her babe's sleep compared with thee!

And underneath that face, like summer ocean's, Its lip as moveless, and its cheek as clear, Slumbers a whirlwind of the heart's emotions, Love, hatred, pride, hope, sorrow-all save fear.

Love-for thy land, as if she were thy daughter, Her pipe in peace, her tomahawk in wars; Hatred-of missionaries and cold water; Pride-in thy rifle-trophies and thy scars;

Hope-that thy wrongs may be, by the Great Spirit, Remembered and revenged when thou art gone; Sorrow-that none are left thee to inherit Thy name, thy fame, thy passions, and thy throne! 


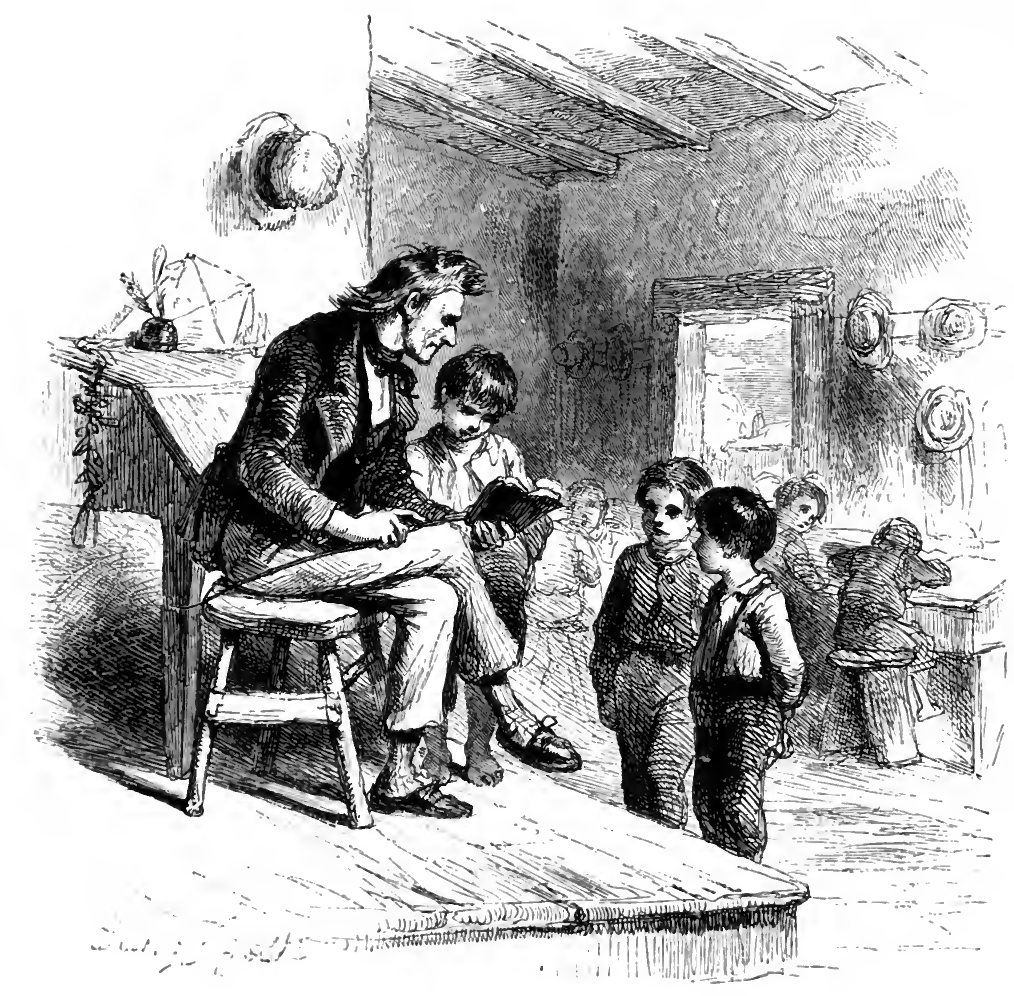

C O N N C TIC UT.

(FROM AN UNPUBLISHED POEM.)

- still her gray rocks tower above the sea

'That crouches at their feet, a conquered wave;

Tis a rough land of earth, and stone, and tree,

Where breathes no castled lord or cabined slave;

Where thoughts, and tongues, and hands are bold and free,

And friends will find a welcome, foes a grave;

And where none kneel, save when to heaven they pray,

Nor even then, unless in their own way. 
Theirs is a pure republic, wild, yet strong,

A "fierce democracie," where all are true

To what themselves have voted-right or wrong-

And to their laws denominated blue;

(If red, they might to Draco's code belong;)

A vestal state, which power could not subdue,

Nor promise win-like her own eagle's nest,

Sacred-the San Marino of the West.

A justice of the peace, for the time being, They bow to, but may turn him out next year;

They reverence their priest, but disagreeing

In price or creed, dismiss him without fear;

They have a natural talent for foreseeing

And knowing all things; and should Park appear

From his long tour in Africa, to show

The Niger's source, they'd meet him with-“We know."

They love their land, because it is their own, And scorn to give aught other reason why;

Would shake hands with a king upon his throne,

And think it kindness to his majesty;

A stubborn race, fearing and flattering none.

Such are they nurtured, such they live and die:

All-but a few apostates, who are meddling

With merchandise, pounds, shillings, pence, and peddling;

Or wandering through the southern countries, teaching

The A B C from Webster's spelling-book;

Gallant and godly, making love and preaching, .

And gaining by what they call "hook and crook,"

And what the moralists call overreaching,

A decent living. The Virginians look

Upon them with as favourable eyes

As Gabriel on the devil in Paradise. 
But these are but their outcasts. View them near

At home, where all their worth and pride is placed;

And there their hospitable fires burn clear,

And there the lowliest farmhouse hearth is graced

With manly hearts, in piety sincere,

Faithful in love, in honour stern and chaste,

In friendship warm and true, in danger brave,

Beloved in life, and sainted in the grave.

And minds have there been nurtured, whose control

Is felt even in their nation's destiny;

Men who swayed senates with a statesman's soul,

And looked on armies with a leader's eye;

Names that adorn and dignify the scroll,

Whose leaves contain their country's history,

And tales of love and war-listen to one

Of the Green-Mountaineer-the Stark of Bennington.

When on that field his band the Hessians fought,

Briefly he spoke before the fight began:

"Soldiers! those German gentlemen are bought

For four pounds eight and sevenpence per man,

By England's king; a bargain, as is thought.

Are we worth more? Let's prove it now we can;

For we must beat them, boys, ere set of sun,

Or Mary Stank's a widow!" It was done.

Ifers are not 'Tempe's nor Arcadia's spring,

Nor the long summer of Cathayan vales,

The vines, the flowers, the air, the skies, that fling

Such wild enchantment o'er Boccaccio's tales

Of Florence and the Arno; yet the wing

Of life's best angel, Health, is on her gales

Through sun and snow; and in the autumn time

Earth has no purer and no lovelier clime. 


\section{HALLECK.}

Her clear, warm heaven at noon-the mist that shrouds

Her twilight hills-her cool and starry eves,

'The glorious splendour of her sunset clouds,

The rainbow beauty of her forest leaves,

Come o'er the eye, in solitude and crowds,

Where'er his web of song her poet weaves;

And his mind's brightest vision but displays

The autumn scenery of his boyhood's days.

And when you dream of woman, and her love;

Her truth, her tenderness, her gentle power;

The maiden listening in the moonlight grove,

The mother smiling in her infant's bower;

Forms, features, worshipped while we breathe or move,

Be by some spirit of your dreaming hour

Borne, like Loretto's chapel, through the air

To the green land I sing, then wake, you'll find them there.

ON THE DEATH OF

JOSEPH RODMAN DRAKE,

OF NEW YORK, SEPT., 1820.

"The good die first, And they, whose hearts are dry as summer dust, Burn to the socket."-Wordsworti.

Green be the turf above thee, Friend of my better days!

None knew thee but to love thee,

Nor named thee but to praise.

Tears fell, when thou wert dying, From eyes unused to weep, And long where thou art lying,

Will tears the cold turf steep. 
ON THE DEATH OF JOSEPH RODMAN DRAKE.

When hearts, whose truth was proven,

Like thine, are laid in earth, There should a wreath be woven

To tell the world their worth;

And I, who woke each morrow

To clasp thy hand in mine,

Who shared thy joy and sorrow,

Whose weal and woe were thine:

It should be mine to braid it

Around thy faded brow,

But I've in vain essayed it,

And feel I cannot now.

While memory bids me weep thec,

Nor thoughts nor words are free,

The grief is fixed too deeply

That.mourns a man like thee. 


\section{HORACE SMITH.}

\section{THE FIRST OF MARCH.}

THE bud is in the bough, and the leaf is in the bud, And Earth's beginning now in her veins to feel the blood, Which warm'd by summer suns in th' alembic of the vine, From her founts will over-run in a ruddy gush of wine.

The perfume and the bloom that shall decorate the flower, Are quickening in the gloom of their subterranean bower; And the juices meant to feed trees, vegetables, fruits, "Unerringly proceed to their pre-appointed roots.

How awful is the thought of the wonders underground, Of the mystic changes wrought in the silent, dark profound; How each thing upward tends by necessity decreed, And a world's support depends on the shooting of a seed!

The summer's in her ark, and this sunny-pinion'd day

Is commission'd to remark whether Winter holds her sway: Go back, thou dove of peace, with the myrtle on thy wing. Say that floods and tempests cease, and the world is ripe for spriug.

'Thou hast fann'd the sleeping Earth till her dreams are all of flowers, And the waters look in mirth for their overhanging bowers; The forest seems to listen for the rustle of its leaves, And the very skies to glisten in the hope of summer eves.

Thy vivifying spell has been felt beneath the wave, By the dormouse in its cell, and the mole within its cave; And the summer tribes that creep, or in air expand their wing, Have started from their sleep at the summons of the Spring. 
'The cattle lift their voices from the valleys and the hills, And the feather'd race rejoices with a gush of tuneful bills; And if this cloudless arch fills the poet's song with glee, $\mathrm{O}$ thou sunny first of March, be it dedicate to thee.

\section{DARLEY.}

\section{HARVEST HOME.}

Dows the dimpled green-sward dancing Bursts a flaxen-headed bevy, Bud-lipt boys and girls advaneing, Love's irregular little levy.

Rows of liquid eyes in laughter,

IIow they glimmer, how they quiver! Sparkling one another after,

Like bright ripples on a river.

Tipsy band of rubious faces, Flushed with joy's ethereal spirit, Make your mocks and sly grimaces

At Love's self, and do not fear it. 


\section{PRAED.}

\section{CHILDHOOD AND HIS VISITORS.}

Orce on a time, when sunny May

Was kissing up the April showers,

I saw fair Childhoon hard at play

Upon a bank of blushing flowers;

Happy,-he knew not whence or how;

And smiling,-who could choose but love him?

For not more glad than CHIldHood's brow,

Was the blue heaven that beamed above him.

Old Tine, in most appalling wrath, That valley's green repose invaded;

The brooks grew dry upon his path,

The birds were mute, the lilies faded;

But 'Time so swiftly winged his flight,

In haste a Grecian tomb to batter,

That CHildroon watehed his paper kite,

And knew just nothing of the matter.

With curling lip, and glancing eye,

Guilt gazed upon the scene a minute,

But Cirmbuood's glance of purity

Had such a holy spell within it,

That the dark demon to the air

Spread forth again his baffled pinion,

And hid his envy and despair,

Self-tortured, in his own dominion. 
Then stepped a gloomy phantom up,

Pale, cypress-crowned, Night's awful daughter, And proffered him a fearful cup,

Full to the brim of bitter water:

Poor Cullunoon bade her tell her name,

And when the beldame muttered "Sonrow," He said,-" Don't interrupt my game;

I'll taste it, if I must, to-morrow."

The Mcse of Pindus thither came,

And wooed him with the softest numbers

That ever scattered wealth and fame

Upon a youthful poet's slumbers;

Though sweet the music of the lay,

To Cnnwmoon it was all a riddle, And "Oh," he cried, "do send away

That noisy woman with the fiddle."

Then Wisporr stole his bat and ball,

And taught him with most sage endearour,

Why bubbles rise, and acorns fall,

And why no toy may last for ever:

She talked of all the wondrous laws

Which Nature's open book discloses,

Ind Curbnoon, ere she made a pause,

Was fast asleep among the roses.

Sleep on, sleep on!-Oh! Mavmoon's dreams

Are all of earthly pain, or pleasure,

Of Giory's toils, Ambirion's schemes,

Of cherished love, or hoarded treasure:

But to the couch where Cunburoov lies

A more delicious trance is given,

Lit up by rays from Seraph-eyes,

And glimpses of remembered hearen! 


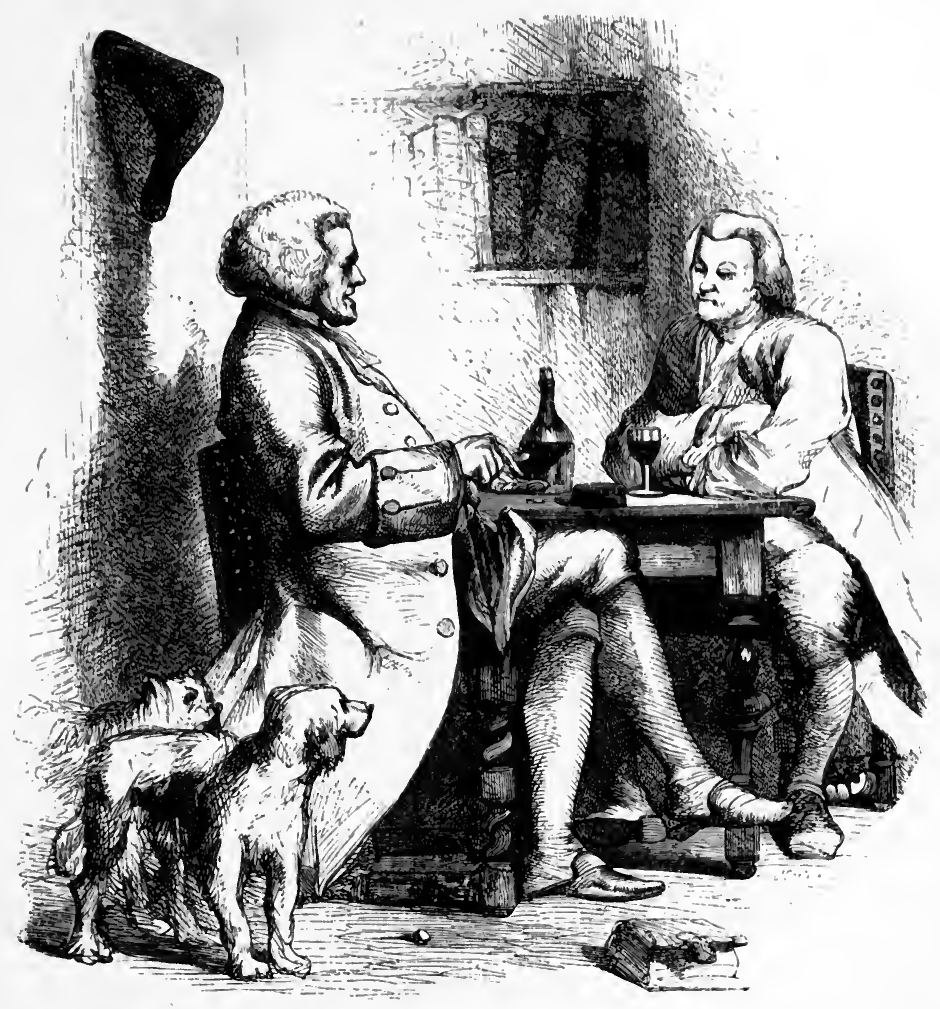

THE VICAR.

Some years ago, ere Time and Taste

Had turn'd our Parish topsy-turvy.

When Darnel Park was Darnel Waste,

And roads as little known as scurvy,

The man, who lost his way between

St. Mary's Hill and Sandy Thicket,

Was always* shown across the Green,

And guided to the Parson's wicket. 
Back flew the bolt of lissom lath;

Fair Margaret, in her tidy kirtle,

Led the lorn traveller up the path,

Through clean-clipt rows of box and myrtle;

And Don and Sancho, Tramp and Tray,

Upon the parlour steps collected,

Wagged all their tails, and seemed to say,

"Our master knows you ; you 're expected."

Up rose the Reverend Doctor Brown,

Up rose the Doctor's "winsome marrow;"

The lady laid her knitting down,

Her husband clasped his ponderous Barrow :

Whate'er the stranger's caste or creed,

Pundit or Papist, saint or sinner,

He found a stable for his steed,

And welcome for himself, and dinner.

If, when he reached his journey's end,

And warmed himself in court or college,

He had not gained an honest friend,

And twenty curious scraps of knowledge ;-

If he departed as he came,

With no new light on love or liquor,-

Good sooth, the traveller was to blame,

And not the Vicarage, or the Vicar.

Ilis talk was like a stream which runs

With rapid change from rocks to roses;

It slipped from politics to puns;

It passed from Mahomet to Moses;

lBegimning with the laws which keep

The plinets in their radiant courses,

And ending with some precept deep.

For dressing eels, or shoeing horses. 
He was a shrewd and sound divine, Of loud Dissent the mortal terror; And when, by dint of page and line, He 'stablished Truth, or started Error,

The Baptist found him far too deep;

The Deist sighed with saving sorrow;

And the lean Levite went to sleep,

And dreamed of tasting pork to-morrow.

His sermon never said nor show'd

That Earth is foul, that Heaven is gracious,

Without refreshment on the road

From Jerome, or from Athanasius;

And sure a righteous zeal inspired

The hand and heart that penn'd and plann'd them,

For. all who understood admired,

And some who did not understand them.

And he was kind, and loved to sit

In the low hut, or garnished cottage,

And praise the farmer's homely wit,

And share the widow's homelier pottage;

At his approach complaint grew mild,

And when his hand unbarred the shutter,

The clammy lips of Fever smiled

The welcome, which they could not utter.

He always had a tale for me

Of Julius Cæsar, or of Venus :

From him I learned the Rule of Three,

Cat's-cradle, leap-frog, and Quæ genus ;

I used to singe his powder'd wig,

To steal the staff he put such trust in;

And make the puppy dance a jig,

When he began to quote Augustin. 
Alack the change! in vain I look

For haunts in which my boyhood trifled.The level lawn, the trickling brook,

The trees I climbed, the beds I rifled:

The ehurch is larger than before;

You reach it by a carriage entry;

It holds three hundred people more;

And pews are fitted up for gentry.

Sit in the Vicar's seat: you 'll hear

The doetrine of a gentle Johnian,

Whose hand is white, whose tone is clear,

Whose style is very Ciceronian.

Where is the old man laid? Look down,

And construe on the slab before you,

"Hic jacet Gulielunus Brown,

Vir nulla non donandus lauro."

\section{A CHARADE.}

(THE WORD IS "CAMPBELL," THE POET.)

Cone from my First, ay, come!

The battle-dawn is nigh;

And the screaming trump and the thund'ring drum!

Are calling thee to die!

Fight as thy fathers fought,

Fall as thy fathers fell!

Thy task is taught, thy shroud is wrought;-

So-forward! and farewell ! 
PRAED.

Toll ye, my Second! toll !

Fling high the flambeaux' light;

And sing the hymn for a parted soul,

Beneath the silent night!

The wreath upon his head,

The cross upon his breast,

Let the prayer be said, and the tear be shed:-

So-take him to his rest!

Call ye, my Whole, ay, call !

The lord of lute and lay;

And let him greet the sable pall

With a noble song to-day;

Go, call him by his name;

No fitter hand may crave

To light the flame of a soldier's fame,

On the turf of a soldier's grave. 


\section{HOOD.}

\section{THE ELM TREE.-A DREAM IN THE WOODS.}

"And this our life, exempt from public haunt, Finds tongues in trees!"-As you like it.

\section{Part I.}

'Twas in a shady Avenue,

Where lofty Elms abound-

And from a 'Tree

There came to me

A sad and solemn sound,

'That sometimes murmur'd overhead,

And sometimes underground.

Amongst the leaves it seemed to sigh,

Amid the boughs to moan;

It mutter'd in the stem, and then

The roots took up the tone;

As if beneath the dewy grass

The dead began to groan.

No breeze there was to stir the leaves;

No bolts that tempests launch,

To rend the trunk or rugged bark;

No gale to bend the branch;

No quake of earth to heave the roots,

That stood so stiff and staunch. 


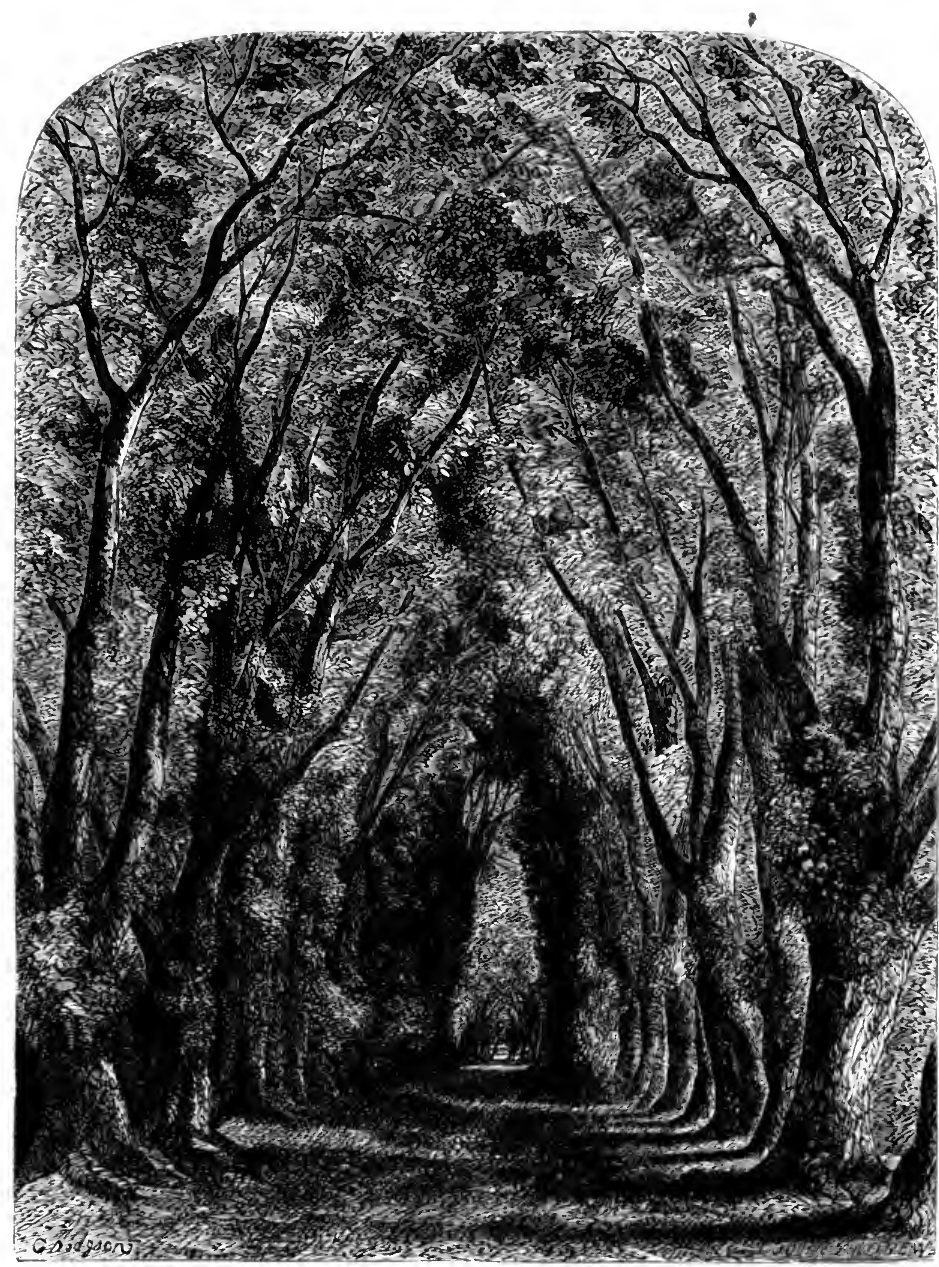

But still the sound was in my ear, A sad and solemn sound,

That sometimes murmur'd overhead, 
And sometimes underground-

'Twas in a shady Avenue,

Where lofty Elms abound.

From poplar, pine, and drooping birch,

And fragrant linden trees;

No living sound

E'er hovers round,

Unless the vagrant breeze,

The music of the merry bird,

Or hum of busy bees.

But busy bees forsake the Elm

That bears no bloom aloft-

The finch was in the hawthorn-bush,

The blackbird in the croft;

And among the firs the brooding dove,

That else might murmur soft.

Yet still I heard that solemn sound,

And sad it was to boot,

From ev'ry overhauging bough,

And each minuter shoot;

From rugged trunk and mossy rind,

And from the twisted root.

From these,-a melancholy moan;

From those,-a dreary sigh;

As if the boughs were wintry bare,

And wild winds sweeping by,-

Whereas the smallest fleecy cloud

Was steadfast in the sky.

No sign $o^{*}$ touch of stirring air

Could either sense observe-

The zephyr had not breath enough 
The thistle-down to swerve, Or force the filmy gossamers 'To take another curve.

In still and silent slumber hush'd

All Nature seemed to be:

From heaven above, or earth beneath, No whisper came to me-

Except the solemn sound and sad From that Mrstenious 'Tree!

A hollow, hollow, hollow sound, As is that dreamy roar

When distant billows boil and bound Along a shingly shore-

But the ocean brim was far aloof, A hundred miles or more.

No murmur of the gusty sea, No tumult of the beach, However they may foam and fret, The bounded sense could reachMethought the trees in mystic tongue Were talking each to each!-

Mayhap, rehearsing ancient tales Of greenwood love or guilt, Of whisper'd vows Beneath their boughs; Or blood obseurely spilt; Or of that near-hand Mansion House A royal 'Tudor built.

With wary eyes, and ears alert, As one who walks afraid,

I wander'd down the dappled path 
Of mingled light and shade-

How sweetly gleam'd that arch of blue

Beyond the green arcade!

How cheerly shone the glimpse of Heav'n

Beyond that verdant aisle!

All overarch'd with lofty elms,

That quench'd the light, the while,

As dim and chill

As serves to fill

Some old Cathedral pile!

And many a gnarlèd trunk was there,

That ages long had stood,

Till Time had wrought them into shapes

Like Pan's fantastic brood;

Or still more foul and hideous forms

That Pagans carve in wood!

A crouching Satyr lurking here,

And there a Goblin grim-

As staring full of demon life

As Gothic sculptor's whim;

A marvel it had scarcely been

To hear a voice from him !

Some whisper from that horrid mouth,

Of strange, unearthly tone;

Or wild infernal laugh, to chill

One's marrow in the bone.

But no-it grins like rigid Death,

And silent as a stone!

As silent as its fellows be,

For all is mute with them,-

The branch that elimbs the leafy roof- 
HOOD.

The rough and mossy stem-

The crooked root-

And tender shoot

Where hangs the dewy gem.

One mystic Tree alone there is,

of sad and solemn sound-

That sometimes murmurs overhead,

And sometimes underground-

In all that shady Avenue,

Where lofty Elms abound.

\section{Part II.}

The Scene is changed! No green Arcade,

No trees all ranged a-row-

But scatter'd like a beaten host,

Dispersing to and fro;

With here and there a sylvan corse,

That fell before the foe.

The Foe that down in yonder dell

Pursues his daily toil;

As witness many a prostrate trunk,

Bereft of leafy spoil,

Hard by its wooden stump, whereon

The adder loves to coil.

Alone he works-his ringing blows

Have banish'd bird and beast;

The hind and fawn have canter'd off

A hundred yards at least;

And on the maple's lofty top,

'The linnet's song has ceased. 
No eye his labour overlooks,

Or when he takes his rest;

Except the timid thrush that peeps

Above her secret nest,

Forbid by love to leave the young

Beneath her speckled breast.

The Woodman's heart is in his work,

His axe is sharp and good:

With sturdy arm and steady aim

He smites the gaping wood;

From distant rocks

His lusty knocks

Re-echo many a rood.

Aloft, upon his poising steel

The vivid sunbeams glance-

About his head and round his feet

The forest shadows dance;

And bounding from his russet coat

The acorn drops askance.

His face is like a Druid's face,

With wrinkles furrow'd deep,

And, tann'd by scorching suns, as brown

As corn that's ripe to reap;

But the hair on brow, and cheek, and chin,

Is white as wool of sheep.

IIis frame is like a giant's frame;

His legs are long and stark;

Ilis arms like limbs of knotted yew;

His hands like rugged bark;

So he felleth still

With right good will,

As if to build an ark: 


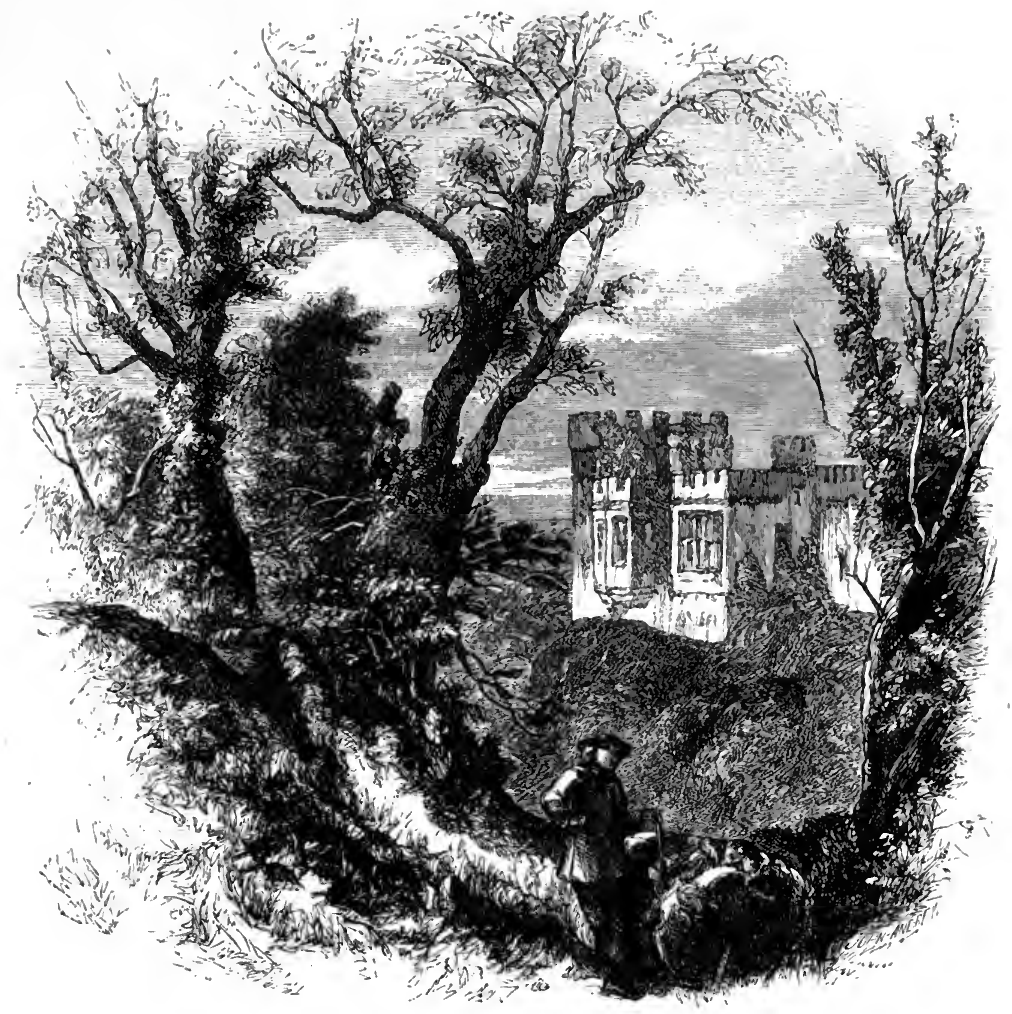

Oh! well to him the tree might breathe

A sad and solemn sound,

A sigh that murmur'd overhead, And groans from underground;

As in that shady Avenue,

Where lofty Elms abound!

But calm and mute the maple stands, The plane, the ash, the fir, 
'The elm, the beech, the drooping birch, Without the least demur; And e'en the aspen's hoary leaf Makes no unusual stir.

The pines-those old gigantic pines,

That writhe-recalling soon

The famous human group that writhes

With snakes in wild festoon-

In ramous wrestlings interlaced,

A Forest Läocoon-

Like Titans of primeval girth

By tortures overeome,

Their brown enormous limbs they twine,

Bedew'd with tears of gum-

Fieree agonies that ought to yell,

But, like the marble, dumb.

Nay, yonder blasted Elm that stands

So like a man of sin,

Who, frantic, flings his arms abroad

To feel the worm within-

For all that gesture, so intense,

It makes no sort of din!

An universal silence reigns

In rugged bark or peel,

Except that very trunk which rings

Beneath the biting steel-

Neanwhile, the Woodman plies his axe

With unrelenting zeal!

No rustic song is on his tongue,

No whistle on lis lips ;

But with a quiet thoughtfulness 
His trusty tool he grips, And, stroke on stroke, keeps hacking out

The bright and flying chips.

Stroke after stroke, with frequent dint

He spreads the fatal gash;

Till, lo! the remnant fibres rend,

With harsh and sudden crash, And on the dull resounding turf

The jarring branches lash!

Oh! now the Forest Trees may sigh,--

The ash, the poplar tall, The elm, the birch, the drooping beech,

The aspens-one and all,

With solemn groan

And hollow moan,

Lament a comrade's fall!

A goodly Elm, of noble girth,

That thrice the human span-

While on their variegated course

The constant Seasons ran,

Through gale, and hail, and fiery bolt-

Had stood erect as Man.

But now, like mortal Man himself,

Struck down by hand of God,

Or heathen idol tumbled prone

Beneath th' Eternal's nod,

In all its giant bulk and length

It lies along the sod!-

The echo sleeps: the idle axe,

A disregarded tool,

Lies crusling with its passive weight 
The toad's reputed stool;

The Woodman wipes his dewy brow

Within the shadows cool.

No zephyr stirs: the ear may catch

The smallest insect-hum;

But on the disappointed sense

No mystic whispers come;

No tone of sylvan sympathy-

The Forest Trees are dumb.

No leafy noise, nor inward voice,

No sad and solemn sound,

That sometimes murmurs overhead,

And sometimes underground-

As in that shady Avenue,

Where lofty Elms abound!

\section{PART III.}

The deed is done: the Tree is low

That stood so long and firm;

The Woodman and his axe are gone,

His toil has found its term;

And where he wrought the speckled thrush

Securely hunts the worm.

The cony from the sandy bank

Has run a rapid race,

Through thistle, bent, and tangled fern,

To seek the open space;

And on its haunches sits erect

To clean its furry face. 
HOOD.

The dappled fawn is close at hanil,

'The lind is browsing near,-

And on the larch's lowest bough

The ousel whistles clear;

But checks the note

Within its throat,

As choked with sudden fear?

With sudden fear her wormy quest

The thrush abruptly quits;

Through thistle, bent, and tangled fern

The startled cony flits;

And on the larch's lowest bough

No more the ousel sits.

With sudden fear,

The dappled deer

Effect a swift escape;

But well might bolder creatures start

And fly, or stand agape,

With rising hair, and curdled blood,

To see so grim a Shape!

The very sky turns pale above,

The earth grows dark beneath;

The human Terror thrills with cold,

And draws a shorter breath-

An universal panic owns

The dread approach of Deatn!

With silent pace, as shadows come,

And dark as shadows be,

The grisly Phantom takes his stand

Beside the fallen Tree,

And scans it with his gloomy eyes,

And laughs with horrid.glee- 
A dreary laugh and desolate, Where mirth is void and null, As hollow as its echo sounds

Within the hollow skull:

"Whoever laid this 'Tree along, His hatchet was not dull!

The human arm and human tool

Have done their duty well! But after sound of ringing axe Must sound the ringing knell;

When elm or oak Have felt the stroke, My turn it is to fell!

No passive unregarded tree,

A senseless thing of wood, Wherein the sluggish sap ascends

'To swell the vernal budBut conscious, moving, breathing trunks That throb with living blood!

Ah! little recks the Royal mind, Within his Banquet-Hall, While tapers shine, and music breathes, And Beauty leads the ball,IIe little recks the oaken plank Shall be his palace wall!

Ah! little dreams the haughty Peer,

The while his falcon flies-

Or on the blood-bedabbled turf

'The antler'd quarry diesThat in his own ancestral Park

The narrow dwelling lies! 
But haughty Peer and mighty King

One doom shall overwhelm!

'The oaken cell

Shall lodge him well

Whose sceptre ruled a realm-

While he who never knew a home

Shall find it in the Elm!

The tall abounding Elm that grows

In hedgerows up and down,

In field and forest, copse and park,

And in the peopled town,

With colonies of noisy rooks

That nestle on its crown.

And well th' abounding Elm may grow

In field and hedge so rife,

In forest, copse, and wooded park,

And 'mid the city's strife,-

For every hour that passes by

Shall end a human life!"

The Phantom ends: the shade is gone;

The sky is clear and bright;

On turf, and moss, and fallen Tree,

There glows a ruddy light;

And bounding through the golden fern

The rabbit comes to bite.

The thrush's mate beside her sits,

And pipes a merry lay;

The dove is in the evergreens;

And on the larch's spray

The fly-bird flutters up and down,

To catch its tiny prey. 
The gentle hind and dappled fawn

Are coming up the glade;

Each harmless furr'd and feather'd thing

Is glad, and not afraid-

But on my sadden'd spirit still

The Shadow leaves a shade:

A secret, rague, prophetic gloom, As though by certain mark

I knew the fore-appointed Tree,

Within whose rugged bark

This warm and living frame shall find

Its narrow house and dark.

That mystic Tree which breathed to me

A sad and solemn sound,

That sometimes murmur'd overhead,

And sometimes underground-

Within that shady Avenue,

Where lofty Elms abound. 


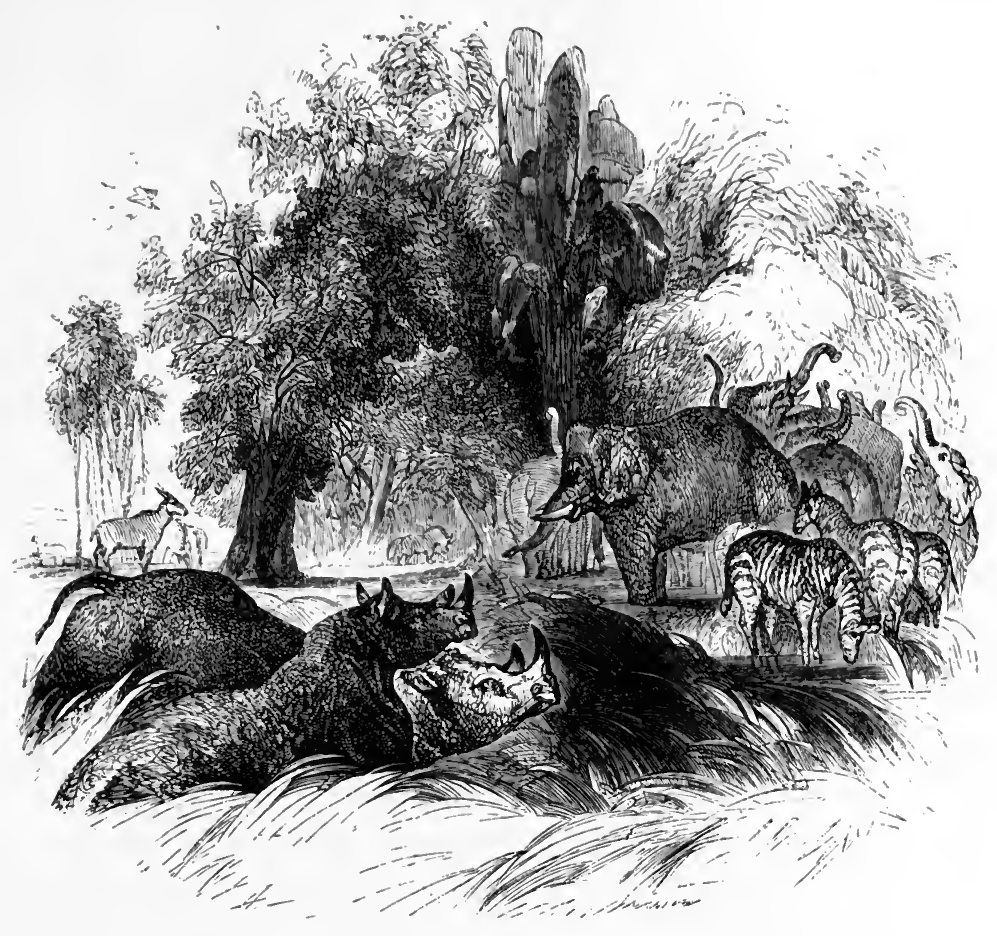

\section{PRINGLE.}

AFAR IN THE DESERT.

Afar in the Desert I love to ride,

With the silent Bush-boy alone by my side:

When the sorrows of life the soul o'ercast,

And, sick of the Present, I cling to the Past;

When the eye is suffused with regretful tears,

From the fond recollections of former years; 
And shadows of things that have long since fled Flit over the brain like the ghosts of the dead; And my Native Land, whose magical name Thrills to my heart like electric flame;

The home of my childhood; the haunts of my prime; All the passions and seenes of that rapturous time, When the feelings were young, and the world was new, Like the fresh bowers of Eden unfolding to view;All-all now forsaken, forgotten, foregone!

And I, a lone exile, remembered of none;

My high aims abandoned, my good acts undone, Aweary of all that is under the sun,With that sadness of heart which no stranger may sean, I fly to the Desert, afar from man!

Afar in the Desert $I$ love to ride, With the silent Bush-boy alone by my side: When the wild turmoil of this wearisome life, With its scenes of oppression, corruption, and strife,The proud man's frown, and the base man's fear, The scorner's laugh, and the sufferer's tear,And malice, and meanness, and falsehood, and folly, Dispose me to musing and dark melancholy; When my bosom is full, and my thoughts are high, And my soul is sick with the bondman's sigh; Oh! then there is freedom, and joy, and pride, Afar in the Desert alone to ride!

There is rapture to vault on the champing steel, And to bound away with the eagle's speed, With the death-fraught firelock in my hand,The only law of the Desert Land.

Afar in the Desert I love to ride, With the silent Bush-boy alone by my side; Away, away from the dwellings of men, By the wild-deer's haunt, by the buffalo's glen; 


\section{PRINGLE.}

By valleys remote, where the Oribi plays, Where the gnu, the gazelle, and the hartèbeest graze, And the kùdu and eland unhunted recline By the skirts of grey forests o'erhung with wild vine; Where the elephant browses at peace in his wood, And the river-horse gambols unscared in the flood, And the mighty rhinoceros wallows at will In the fen where the wild-ass is drinking his fill.

Afar in the Desert I love to ride, With the silent Bush-boy alone by my side; O'er the brown Karroo, where the bleating cry Of the springbok's fawn sounds plaintively; And the timorous quagga's shrill whistling neigh Is heard by the fountain at twilight grey; Where the zebra wantonly tosses his mane, With wild hoof scouring the desolate plain; And the fleet-footed ostrich over the waste Speeds like a horseman who travels in haste, Hieing away to the home of her rest, Where she and her mate have scoop'd their nest, Far hid from the pitiless plunderer's view In the pathless depths of the parch'd Karroo.

Afar in the Desert I love to ride, With the silent Bush-boy alone by my side; Away, away in the Wilderness vast Where the White Man's foot hath never pass'd, And the quiver'd Coránna or Bechuán Hath rarely cross'd with his roving clan: A region of emptiness, howling and drear, Which Man hath abandon'd from famine and fear;

Which the snake and the lizard inhabit alone, With the twilight bat from the yawning stone; Where grass, nor herb, nor shrub takes root, Save poisonous thorns that pierce the foot; 
And the bitter melon, for food and drink, Is the pilgrim's fare by the salt lake's brink: A region of drought, where no river glides, Nor rippling brook with osiered sides; Where sedgy pool, nor bubbling fount, Nor tree, nor cloud, nor misty mount, Appears, to refresh the aching eye; But the barren earth and the burning sky, And the blank horizon, round and round, Spread-void of living sight or sound.

And here, while the night winds round me sigh, And the stars burn bright in the midnight sky; As I sit apart by the desert stone, Like Elijah at Horeb's cave alone; "A still small voice" comes through the wild (Like a father consoling his fretful child), Which banishes bitterness, wrath, and fear, Saying-"Man is distant, but GoD is near!" 


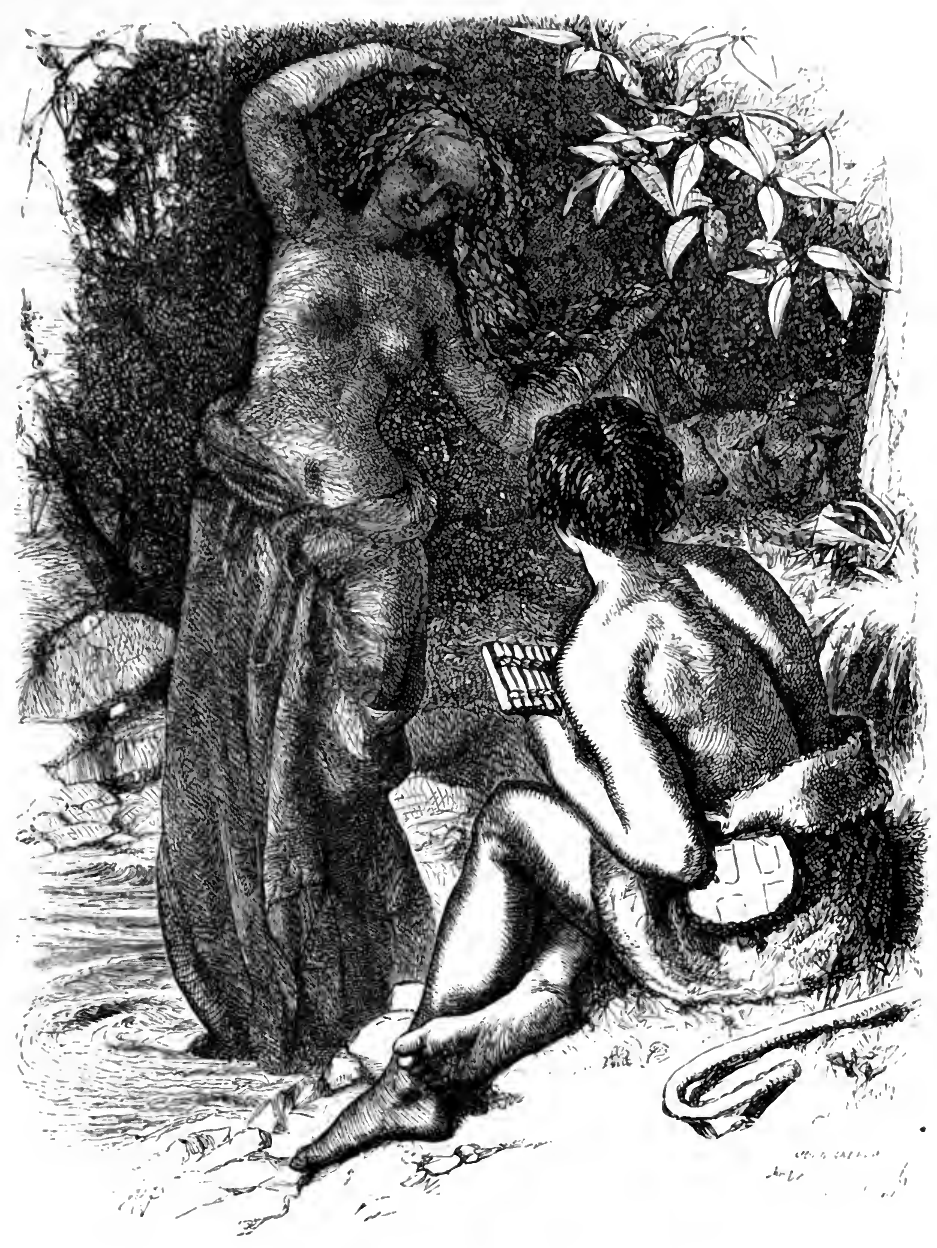

\section{LANDOR.}

THE WATER-NYMPH APPEARING TO THE SHEPHERD.

'Twas evening, though not sunset, and the tide,

Level with these green meadows, seem'd yet higher: 
'Twas pleasant; and I loosen'd from my neck The pipe you gave me, and began to play. Oh that I ne'er had learnt the tuneful art! It always brings us enemies or love. Well, I was playing, when above the waves Some swimmer's head methought I saw ascend; I, sitting still, survey'd it, with my pipe Awkwardly held before my lips half-closed,Gebir! it was a Nymph! a Nymph divine! I cannot wait describing how she came, How I was sitting, how she first assum'd The sailor; of what happen'd there remains Enough to say, and too much to forget. The sweet deceiver stept upon this bank Before I was aware; for with surprise Moments fly rapid as with love itself. Stooping to tune afresh the hoarsen'd reed, I heard a rustling, and where that arose My glance first lighted on her nimble feet. Her feet resembled those long shells explored By him who to befriend his steed's dim sight Would blow the pungent powder in the eye.

Even her attire

Was not of wonted woof nor vulgar art; Her mantle show'd the yellow samphire-pod, Her girdle the dove-colour'd wave serene. "Shepherd," said she, "and will you wrestle now, And with the sailor's harciicr race engage?" I was rejoiced to hear it, and contrived How to keep up contention; could I fail, By pressing not too strongly, yet to press? "Whether a shepherd, as indeed you seem, Or whether of the hardier race you boast, I am not daunted; no, I will engage!"

"But first," said she, "what wager will you lay?" "A sheep," I answered; "ald whate'er you will.". 


\section{L.ANDOR.}

"I cannot," she replied, "make that return;

Our hided vessels in their pitchy round

Seldom, unless from rapine, hold a sheep.

But I have sinuous shells of pearly hue

Within, and they that lustre have imbibed

In the sun's palace-porch, where when unyoked

His chariot-wheel stands midway in the wave:

Shake one and it awakens; then apply

Its polisht lips to your attentive ear,

And it remembers its august abodes,

And murmurs as the ocean murmurs there.

And I have others given me by the nymphs,

Of sweeter sound than any pipe you have.

But we, by Neptune! for no pipe contend,-

This time a sheep I win, a pipe the next."

\section{RODERIGO AND JULIAN.}

THE REPROACH OF THE BEREAVED.

Rod. Julian, thy gloomy soul still meditates-

Plainly I see it-death to me: pursue The dictates of thy leaders; let revenge

Have its full sway; let Barbary prevail, And the pure creed her elders have embraced:

Those placid sages hold assassination

A most compendious supplement to law.

Jul. Thou knowest not the one, nor I the other. Torn hast thou from me all my soul held dear;

Her form, her voice, all hast thou banisht from me, 
Nor dare I, wretched as I am! recal Those solaces of every grief erewhile.

I stand abased before insulting crime,

I falter like a criminal myself;

'The hand that hurl'd thy chariot o'er its wheels, That held thy steeds erect and motionless

As molten statues on some palace-gate, Shakes as with palsied age before thee now. Gone is the treasure of my heart for ever, Without a father, mother, friend, or name. Daughter of Julian!- Such was her delightSuch was mine too! what pride more innocent, What surely less deserving pangs like these, Than springs from filial and parental love! Debarr'd from every hope that issues forth To meet the balmy breath of early life, Her sadden'd days, all cold and colourless, Will stretch before her their whole weary length Amid the sameness of obscurity.

She wanted not seclusion to unveil

Her thoughts to heaven, cloister, nor midnight bell; She found it in all places, at all hours:

While to assuage my labours, she indulged

A playfulness that shunn'd a mother's eye, Still to avert my perils there arose

$A$ piety that even from me retired. 


\title{
JOSEPH BLANCO WHITE.
}

\author{
NIGHT AND DEATH.
}

Mrsteriods night! when our first parent knew

Thee from report Divine, and heard thy name,

Did he not tremble for this lovely frame, This glorious canopy of light and blue?

Yet, 'neath a curtain of translucent dew, Bathed in the rays of the great setting flame, Hesperus, with the host of hearen, came, And lo! creation widen'd in man's view.

Who could have thought such darkness lay concealed Within thy beams, $O$ sun! or who could find, Whilst fly, and leaf, and insect stood revealed, That to such countless orbs thou mad'st us blind? Why do we, then, shun death with anxious strife? If light can thus deceive, wherefore not life? 


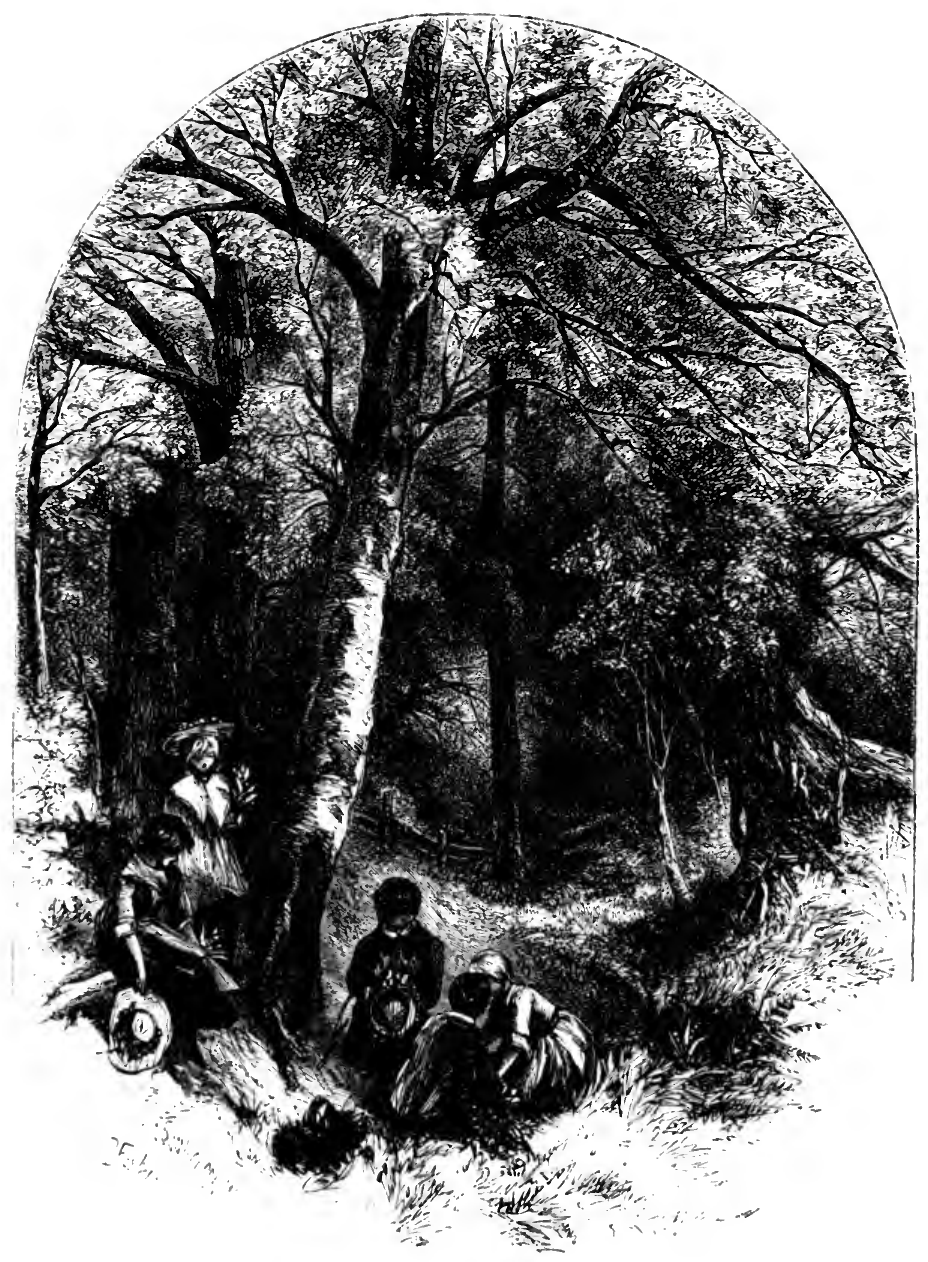

\section{KEBLE.}

"Consider the lilies of the field, how they grow."

SwEET nurslings of the vernal skies,

Bath'd in soft airs, and fed with dew, 
KEBLE.

What more than magic in you lies,

'To fill the heart's fond view?

In childhood's sports, companions gay,

In sorrow, on Life's downward way,

How soothing! in our last decay,

Memorials prompt and true.

Relics ye are of Eden's bowers,

As pure, as fragrant, and as fair,

As when ye crown'd the sunshine hours

Of happy wanderers there.

Fall'n all beside-the world of life, How is it stain'd with fear and strife !

In Reason's world what storms are rife,

What passions range and glare!

But cheerful and unchang'd the while

Your first and perfect form ye show, The same that won Eve's matron smile

In the world's opening glow.

The stars of heaven a course are taught

'Too high above our human thought;

Ye may be found if ye are sought,

And as we gaze, we know.

Ye dwell beside our paths and homes,

Our paths of sin, our homes of sorrow-

And guilty man, where'er he roams,

Your innocent mirth may borrow.

The birds of air before us fleet,

They cannot brook our shame to mẹt-

But we may taste your solace sweet,

And come again to-morrow.

Ye fearless in your nests abide-

Nor may we scorn, too proudly wise, 


\section{CHILDREN'S THANKFULNESS.}

Your silent lessons, undescried

By all but lowly eyes:

For ye could draw th' admiring gaze

Of Him who worlds and hearts surveys:

Your order wild, your fragrant maze,

He taught us how to prize.

Ye felt your Maker's smile that hour,

As when He paused and own'd you good;

His blessing on earth's primal bower,

Ye felt it all renew'd.

What care ye now, if winter's storm

Sweep ruthless o'er each silken form?

Christ's blessing at your heart is warm,-

Ye fear no vexing mood.

Alas! of thousand bosoms kind,

That daily court you and caress,

How few the happy secret find

Of your calm loveliness!

"Live for to-day! to-morrow's light

To-morrow's cares shall bring to sight;

Go sleep, like closing flowers, at night,

And Heaven thy morn will bless."

\section{CHILDREN'S THANKFULNESS.}

" $\perp$ joyful and a pleasant thing it is to be thankful."

Wir so stately, maiden fair,

Rising in thy nurse's arms

With that condescending air;

(iathering up thy queenly charms, 
Like some gorgeous Indian bird, Which, when at eve the balmy copse is stirr'd,

Turns the glowing neck to chide

Th' irreverent foot-fall, then makes haste to hide

Again its lustre deep

Under the purple wing, best home of downy sleep?

Not as yet she comprehends

How the tongues of men reprove,

But a spirit o'er her bends,

Train'd in heaven to courteous love,

And with wondering grave rebuke

Tempers, to-day, shy tone and bashful look.--

Graceless one, 'tis all of thee,

Who for her maiden bounty, full and free,

The violet from her gay

And guileless bosom, didst no word of thanks repay.

Therefore, lo, she opens wide

Both her blue and wistful eyes,-

Breathes her grateful chant, to chide

Our too tardy sympathies.

Little babes and angels bright-

They muse, be sure, and wonder, day and night,

How th' all-holy Hand should give,

The sinner's hand in thanklessness receive.

We see it and we hear,

But wonder not: for why? we feel it all too near.

Not in vain, when feasts are spread,

To the youngest at the board

Call we to incline the head,

And pronounce the solemn word.

Not in vain they clasp and raise

The soft, pure fingers in unconscious praise,-

'Taught, perchance, by pictur'd wall 


\section{CHILDREN'S THANKFULNESS.}

How little ones before the Lord may fall,

How to His lov'd caress

Reach out the restless arm, and near and nearer press.

Children in their joyous ranks,

As you pace the village street,

Fill the air with smiles and thanks

If but once one babe you greet.

Never weary, never dim,

From thrones seraphic mounts th' eternal hymn.

Babes and angels grudge no praise:-

But elder souls, to whom His saving ways

Are open, fearless take

'Their portion, hear the Grace, and no meek answer make.

Save our blessings, Master, save

From the blight of thankless eye:

Teach us for all joys to crave

Benedietion pure and high,

Own them given, endure them gone,

shrink from their hardening touch, yet prize them won:

Prize them as rich odours, meet

For Love to lavish on His sacred feet;-

Prize them as sparkles bright

Of heavenly dew, from yon o'erflowing well of light. 


\section{MILMAN.}

\section{THE HEBREW WEDDING.}

To the sound of timbrels sweet, Moving slow our solemn feet, We have borne thee on the road, To the virgin's blest abode; With thy yellow torches gleaming, And thy scarlet mantle streaming, And the canopy above

Swaying as we slowly move.

Thou hast left the joyous feast, And the mirth and wine have ceast;

And now we set thee down before The jealously-unclosing door;

That the favour'd youth admits, Where the veilèd virgin sits In the bliss of maiden fear, Waiting our soft tread to hear, And the music's brisker din, At the bridegroom's entering in: Entering in a welcome guest To the chamber of his rest.

\section{Chorus of Maidens.}

Now the jocund song is thine, Bride of David's kingly line; How thy dove-like bosom trembleth, And thy shrouded eye resembleth Violets, when the dews of eve A moist and tremulous glitter leave 


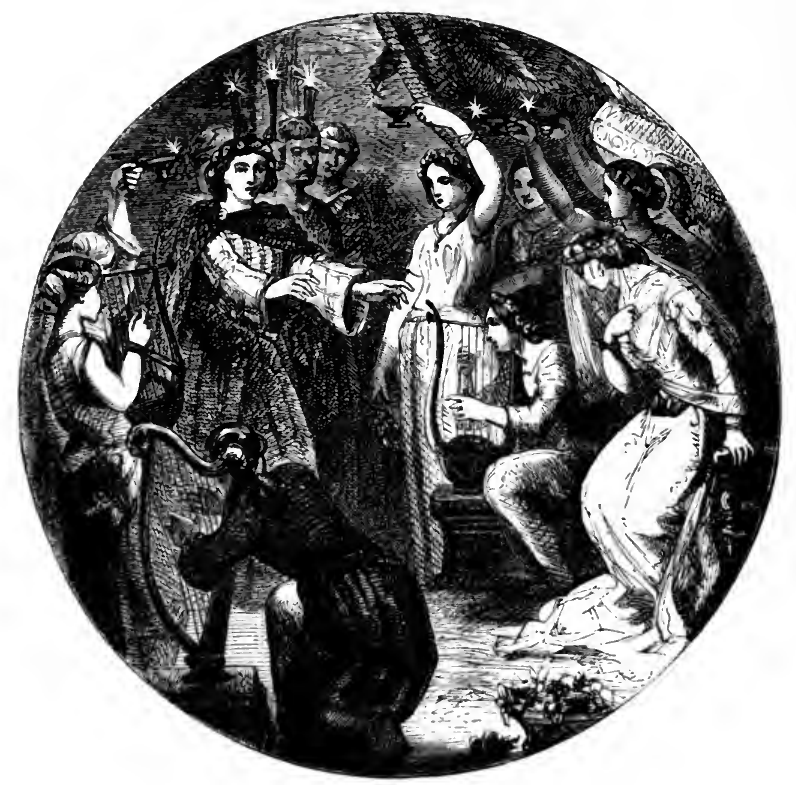

On the bashful sealèd lid!

Close within the bride-veil hid, Motionless thou sitt'st and muto;

Save that at the soft salute

Of each entering maiden friend,

Thou dost rise and softly bend.

Hark ! a brisker, merrier glee!

The door unfolds,-, tis he! 'tis he!

Thus we lift our lamps to meet him,

Thus we touch our lutes to greet him.

Thou shalt give a fonder meeting,

Thou shalt give a tenderer greeting. 
Even thus, amid thy pride and luxury,

O Earth! shall that last coming burst on thee, That secret coming of the Son of Man.

When all the eherub-throning clouds shall shine,

Irradiate with his bright advancing sign :

- When that Great Husbandman shall wave his fan, Sweeping, like ehaff, thy wealth and pomp away:

Still, to the noontide of that nightless day,

Shalt thou thy wonted dissolute course maintain.

Along the busy mart and crowded street, The buyer and the seller still shall meet,

And marriage-feasts begin their jocund strain:

Still to the pouring out the Cup of Wor;

Till Earth, a drunkard, reeling to and fro, And mountains molten by his burning feet, And Heaven his presence own, all red with furnace heat.

The hundred-gated Cities then,

The Towers and Temples, nam'd of men

Eternal, and the Thrones of Kings;

The gilded summer Palaces,

The courtly bowers of love and ease,

Where still the Bird of Pleasure sings:-

Ask ye the destiny of them?

Go, gaze on fallen Jerusalem!

Yea, mightier names are in the fatal roll,

'Gainst earth and heaven God's standard is unfurl'd ;

The skies are shrivell'd like a burning seroll,

And the vast common doom ensepulchres the world.

Oh! who shall then survive?

Oh! who shall stand and live? 
When all that hath been is no more:

When for the round earth hung in air,

With all its eonstellations fair

In the sky's azure canopy;

When for the breathing Earth, and sparkling Sea,

Is but a fiery deluge without shore,

Heaving along the abyss profound and dark,

A fiery deluge, and without an ARk.

Lord of all power, when thou art there alone

On thy eternal fiery-wheeled throne,

That in its high meridian noon

Needs not the perish'd sun nor moon:

When thou art there in thy presiding state,

Wide-sceptred Monareh o'er the realm of doom;

When from the sea-depths, from earth's darkest womb,

The dead of all the ages round thee wait:

And when the tribes of wickedness are strown

Like forest-leaves in th' autumn of thine ire:

Faithful and 'True! thou still wilt save thine own!

The Saints shall dwell within th' unharming fire:

bach white robe spotless, blooming every palm.

Even safe as we by this still fountain's side,

So shall the Chureh, thy bright and mystic Bride, sit on the stormy gulf a haleyon bird of calm.

Yes, 'mid yon angry and destroying signs,

O'er us the rainbow of thy merey shines;

We hail, we bless the covenant of its beam, Almighty to avenge, Almightiest to redeem. 


\section{LEIGH HUNT.}

\section{AN ITALIAN GARDEN.}

$\Lambda$ Noble range it was, of many a rood, Wall'd round with trees, and ending in a wood:

Indeed, the whole was leafy; and it had

A winding stream about it, clear and glad,

That danced from shade to shade, and on its way

Seem'd smiling with delight to feel the day.

There was the pouting rose, both red and white,

The flamy heart's-ease, flush'd with purple light,

Blush-hiding strawberry, sunny-colored box,

Hyacinth, handsome with his clustering locks,

The lady lily, looking gently down,

Pure lavender, to lay in bridal-gown,

The daisy, lovely on both sides, -in short,

All the sweet cups to which the bees resort,

With plots of grass, and perfum'd walks between

Of sweetbrier, honeysuckle, and jessamine,

With orange, whose warm leaves so finely suit,

And look as if they shade a golden fruit;

And 'midst the flowers, turf'd round beneath a shade

Of circling pines, a babbling fountain play'd,

And 'twixt their shafts you saw the water bright,

Which through the darksome tops glimmer'd with showering light.

So now you walk'd beside an odorous bed

Of gorgeous hues, purple, and gold, and red;

And now turn'd off into a leafy walk,

Close and continuous, fit for lovers' talk; 


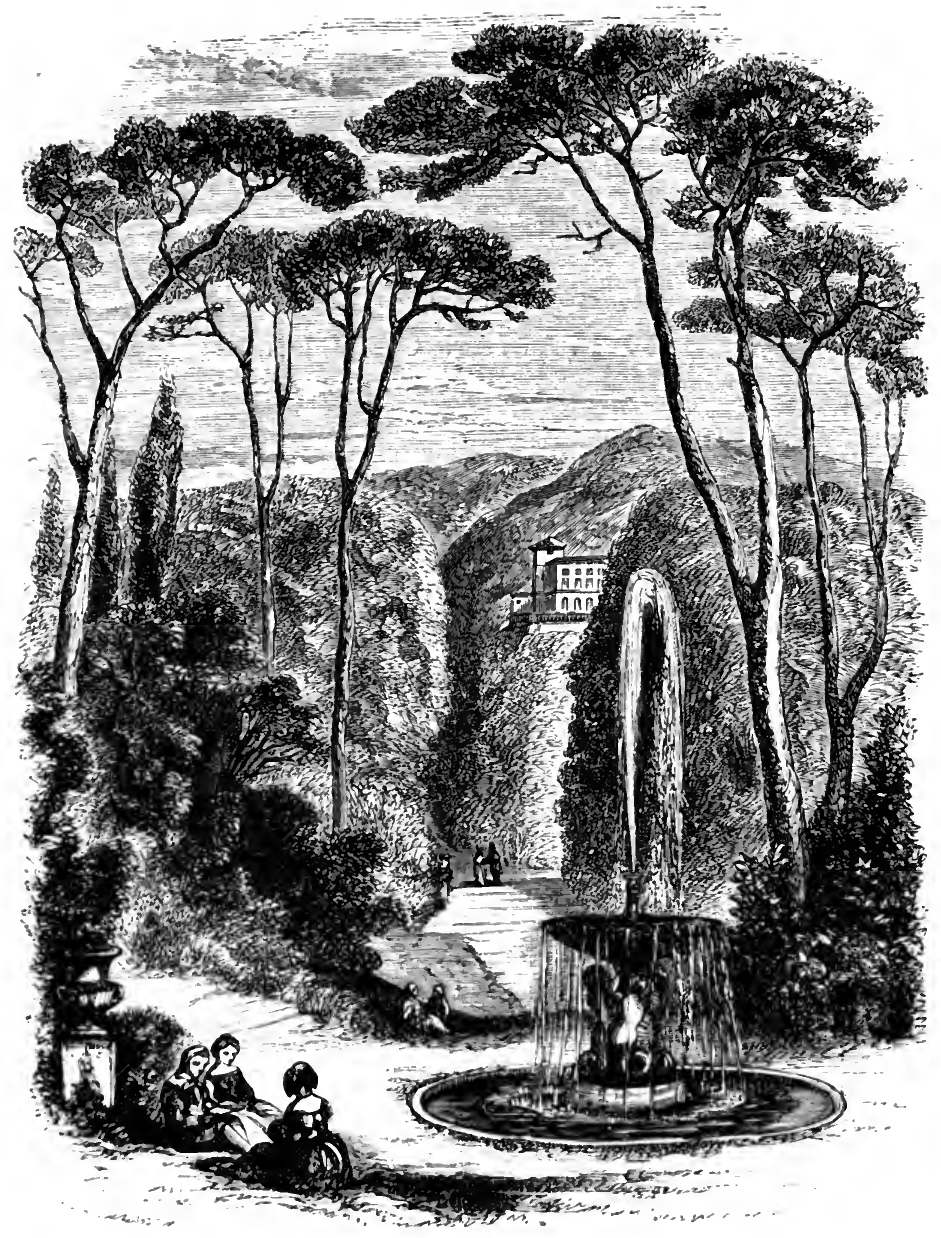

And now pursued the stream, and as you trod

Onward and onward o'er the velvet sod,

Felt on your fare an air, watery and sweet,

Aurl a new sense in your soft-lighting feet; 


\section{LEIGH HUN'T.}

And then, perhaps, you enter'd upon shades, Pillow'd with dells and uplands 'twixt the glades, 'Through which the distant palace, now and then, Look'd lordly forth with many-window'd ken,-

A land of trees, which reaching round about, In shady blessing streteh'd their old arms out, With spots of sunny opening, and with nooks 'To lie and read in, sloping into brooks, Where at her drink you startled the slim deer, Retreating lightly with a lovely fear. And all about, the birds kept leafy house, And sung and darted in and out the boughs; And all about, a lovely sky of blue Clearly was felt, or down the leaves laugh'd through; And here and there, in every part, were seats, Some in the open walks, some in retreats With bowering leaves o'erhead, to which the eye Look'd up half sweetly and half awfully,Places of nestling green, for poets made, Where, when the sunshine struck a yellow shade, The rugged trunks, to inward-peeping sight, Throng'd in dark pillars up the gold green light.

But 'twixt the wood and flowery walks, half-way, And form'd of both, the loveliest portion lay, A spot that struck you like enchanted ground:

It was a shallow dell, set in a mound Of sloping shrubs, that mounted by degreesThe birch and poplar mixed with heavier trees;

Down by whose roots, descending darkly still, (You saw it not, but heard) there gush'd a rill, Whose low sweet talking seem'd as if it said Something eternal to that happy shade.

The ground within was lawn, with plots of flowers Heap'd towards the centre, and with citron bowers; And in the midst of all, cluster'd with bay And myrtle, and just glancing to the day, 
Lurk'd a pavilion,-a delicious sight,Small, marble, well-proportion'd, mellowy white, With yellow vine-leaves sprinkled,-but no more,And a young orange either side the door. 'The door was to the wood, forward and square;

The rest was domed at top, and circular;

And through the dome the only light came in, 'Tinged, as it enter'd, with the vine-leaves thin.

\section{ABOU BEN ADHEM.}

Abou Bex Adnem (may his tribe increase!)

A woke one night from a deep dream of peace, And saw, within the moonlight in his room, Making it rich, and like a lily in bloom, An Angel writing in a book of gold:Exceeding peace had made Ben Adhem bold, And to the Presence in the room he said, "What writest thou?"-The Vision rais'd its head, And with a look made of all sweet accord, Answer'd, "The names of those who love the Lord." "And is mine one?" said Abou. "Nay, not so," Replied the Angel. Abou spoke more low, But cheerly still; and said, "I pray thee then, Write me as one that loves his fellow-men."

'The Angrel wrote, and ranish'd. The next night It came again with a great wakening light, And show'd the names whom love of God had bless'd, And, lo! ben Adhem's name led all the rest. 


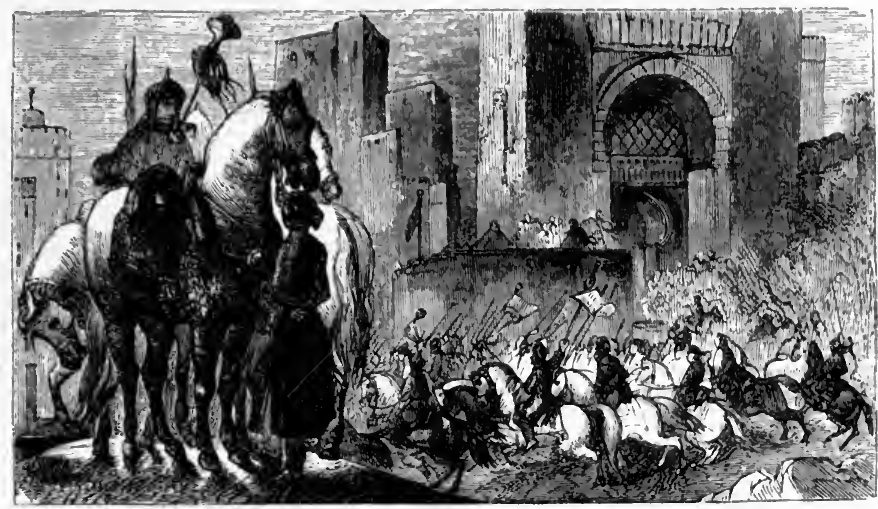

CROLY.

THE ALHAMBRA.

Palace of Beauty! where the Moorish Lord, King of the bow, the bridle, and the sword, Sat like a Genie in the diamond's blaze. $\mathrm{Oh}$ ! to have seen thee in the ancient days, When at thy morning gates the coursers stood, The "thousand" milk-white, Yemen's fiery blood, In pearl and ruby harness'd for the King; And through thy portals pour'd the gorgeous flood Of jewell'd Sheik and Emir, hastening, Before the sky the dawning purple show'd, Their turbans at the Caliph's feet to fling. Lovely thy morn-thy evening lovelier still, When at the waking of the first blue star That trembled on the Atalaya hill, The splendours of the trumpet's voice arose, 
Brilliant and bold, and yet no sound of war;

But summoning thy beauty from repose,

The shaded slumber of the burning noon.

Then in the slant sun all thy fountains shone,

Shooting the sparkling column from the vase

Of crystal cool, and falling in a haze

Of rainbow hues on floors of porphyry,

And the rich bordering beds of every bloom

That breathes to African or Indian sky,

Carnation, tuberose, thick anemone;

Then was the harping of the minstrels heard,

In the deep arbours, or the regal hall,

Hushing the tumult of the festival,

When the pale bard his kindling eye-ball rear'l,

And told of Eastern glories, silken hosts,

'Tower'd elephants, and chiefs in topaz arm'd;

Or of the myriads from the cloudy coasts

Of the far Western sea,- - the sons of blood,

The iron men of tournament and feud,

That round the bulwarks of their father swarm'd,

Doom'd by the Moslem scimitar to fall,

Till the Red Cross was hurl'd from Salem's wall.

Where are thy pomps, Alhambra, earthly sun,

That had no rival, and no second?-gone!

Thy glory down the arch of time has roll'd, Like the great day-star to the ocean dim, The billows of the ages o'er thee swim,

Gloomy and fathomless; thy tale is told.

Where is thy horn of battle? that, but blown, Brought every chief of $\Lambda$ fric from his throne;

Brought every spear of Afric from the wall;

Brought every charger barbed from the stall,

Till all its tribes sat mounted on the shore;

Waiting the waving of thy torch to pour

The living deluge on the fields of Spain.

Queen of Eartl's loveliness, there was a stain 


\section{CROLY.}

Upon thy brow-the stain of guilt and gore:

Thy course was bright, bold, treach'rous-and 'tis $0^{\circ} \mathrm{er}$.

The spear and diadem are from thee gone;

Silence is now sole monarch of thy throne!

FLORA.

The flowers are Nature's jewels, with whose wealth

She decks her Summer beauty; Primrose sweet,

With blossoms of pure gold; enchanting Rose,

That, like a virgin queen, salutes the Sun,

Dew-diadem'd; the perfumed Pink, that studs

The earth with clustering ruby; Hyacinth,

The hue of Venus' tresses; Myrtle green,

That maidens think a charm for constant love,

And give night-kisses to it, and so dream;

Fair Lily! woman's emblem, and oft twined

Round bosoms, where its silver is unseen,

Such is their whiteness; downcast Violet,

Turning away its sweet head from the wind,

As she her delicate and startled ear

From passion's tale! 


\section{FERGUSON.}

\section{THE FORGING OF THE ANCHOR.}

Cove, see the Dolphin's Anchor forged; 'tis at a white heat now: The bellows ceased, the flames decreased; though on the forge's brow; The little flames still fitfully play through the sable mound; And fitfully you still may see the grim smiths ranking round, All clad in leathern panoply, their broad hands only bare; Some rest upon their sledges here, some work the windlass there.

The windlass strains the tackle chains, the black mound heaves below; And red and deep, a hundred veins burst out at every throe: It rises, roars, rends all outright-O, Vulcan, what a glow ! 'Tis blinding white, 'tis blasting bright; the high sun shines not so! The high sun sees not, on the earth, such fiery fearful show; The roof-ribs swarth, the candent hearth, the ruddy lurid row Of smiths, that stand, an ardent band, like men before the foe; As, quivering through his fleece of flame, the sailing monster, slow Sinks on the anvil-all about the faces fiery grow"Hurrah!" they shout, "leap out-leap out ;" bang, bang, the sledges go: Hurrah! the jetted lightnings are hissing high and low;

A hailing fount of fire is struck at every squashing blow; The leathern mail rebounds the hail; the rattling einders strow The ground around; at every bound the sweltering fountains flow; And thick and loud the swinking crowd, at every stroke, pant "ho?"

Leap out, leap out, my masters; leap out and lay on load!

Let's forge a goodly anchor; a Bower, thick and broad:

For a heart of oak is hanging on every blow I bode; And I see the good ship riding all in a perilous road, 


\section{FERGUSON.}

The low reef rolling on her lee; the roll of ocean poured From stem to stern, sea after sea; the mainmast by the board; 'The bulwarks down; the rudder' gone; the boats stove at the chains; But courage still, brave mariners - the Bower yet remains, And not an inch to flinch he deigns save when ye pitch sky high, 'Then moves his head, as though he said, "Fear nothing-here am I!"

Swing in your strokes in order; let foot and hand keep time, Your blows make music sweeter far than any steeple's chime; But while ye swing your sledges, sing; and let the burden be, The anchor is the anvil king, and royal craftsmen we!

Strike in, strike in-the sparks begin to dull their rustling red; Our hammers ring with sharper din, our work will soon be sped: Our anchor soon must change his bed of fiery rich array For a hammock at the roaring bows, or an oozy couch of clay; Our anchor soon must change the lay of merry craftsmen here, For the yeo-heave-o', and the heave-away, and the sighing seaman's cheer ; When, weighing slow, at eve they go, far, far from love and home; And sobbing sweethearts, in a row, wail o'er the ocean foam.

In livid and obdurate gloom he darkens down at last;

A shapely one he is, and strong, as e'er from cat was cast.-

$\mathrm{O}$ trusted and trustworthy guard, if thou hadst life like me, What pleasures would thy toils reward beneath the deep green sea' $\mathrm{O}$ deep sea-diver, who might then behold such sights as thou? The hoary monsters' palaces! methinks what joy 'twere now To go plumb plunging down amid the assembly of the whales, And feel the churned sea round me ioil beneath their scourging tails! Then deep in tangle-woods to fight the fierce sea unicorn, And send him foiled and bellowing back, for all his ivory horn; To leave the subtle sworder-fish of bony blade forlorm; And for the ghastly-grinning shark to laugh his jaws to scorn; 'To leap down on the kraken's back, where 'mid Norwegian isles He lies, a lubber anchorage for sudden shallowed miles; 'Iill snorting, like an under-sea volcano, off he rolls; Meanwhile to swing, a-buffeting the far-astonished shoals 
Of his back-browsing ocean calves; or, haply in a cove, Shell-strown, and consecrate of old to some Undine's love, To find the long-haired mermaidens; or, hard by iey lands, To wrestle with the sea-serpent, upon cerulean sands.

O broad-armed fisher of the deep, whose sports can equal thine? The Dolphin weighs a thousand tons that tugs thy cable line; And night by night 'tis thy delight, thy glory day by day, 'Through sable sea and breaker white, the giant game to play; But, shamer of our little sports! forgive the name I gave,

A fisher's joy is to destroy-thine office is to save.

$O$ lodger in the sea-king's halls, couldst thou but understand Whose be the white bones by thy side, or who that dripping band, Slow swaying in the heaving waves that round about thee bend, With sounds like breakers in a dream blessing their ancient friend: Oh, couldst thou know what heroes glide with larger steps round thee, Thine iron side would swell with pride; thou'dst leap within the sea!

Give honour to their memories who left the pleasant strand, 'To shed their blood so freely for the love of fatherland.

Who left their chance of quiet age and grassy churehyard grave, So freely, for a restless bed amid the tossing wave: Oh, though our anchor may not be all I have fondly sung, Honour him for their memory, whose bones he goes among: 


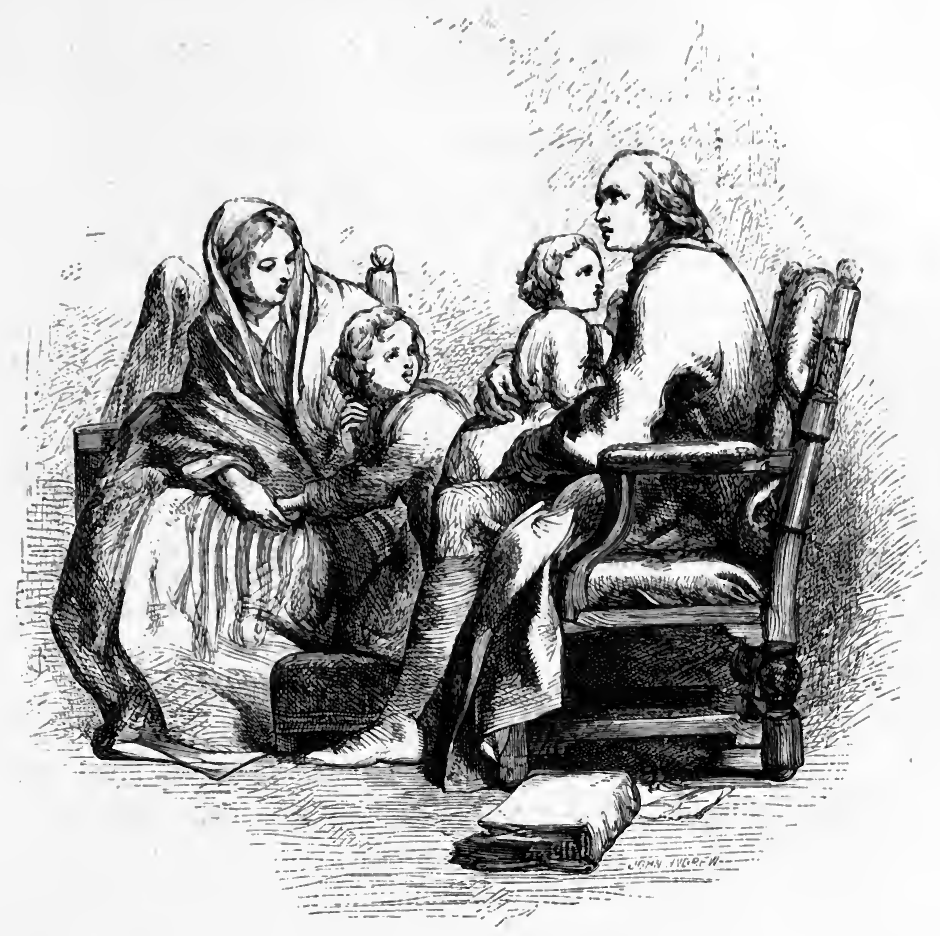

\section{MOULTRIE.}

THE THREE SONS.

I have a son, a little son, a boy just five years old, With eyes of thoughtful earnestness, and mind of gentle mould; They tell me that unusual grace in all his ways appears, That my child is grave and wise of heart beyond his childish years.

I cannot say how this may be,-I know his face is fair, And yet his chiefest comeliness is his sweet and serious air: I know his heart is kind and fond, I know he loveth me, But loveth yet his mother more with grateful fervency. 
But that which others most admire is the thought which fills his mind; The food for grave inquiring speech he everywhere doth find: Strange questions doth he ask of me, when we together walk; He scarcely thinks as children think, or talks as children talk; Nor cares he much for childish sports, dotes not on bat or ball, But looks on manhood's ways and works, and aptly mimies all. His little heart is busy still, and oftentimes perplext With thoughts about this world of ours, and thoughts about the next; He kneels at his dear mother's knee, she teaches him to pray, And strange, and sweet, and solemn then are the words which he will say. Oh, should my gentle child be spared to manhood's years like me, $A$ holier and a wiser man I trust that he will be: And when I look into his eyes, and stroke his thoughtful brow, I dare not think what I should feel, were I to lose him now.

I have a son, a second son, a simple child of three; I'll not declare how bright and fair his little features be, How silver sweet those tones of his when he prattles on my knee. I do not think his light-blue eye is, like his brother's, keen, Nor his brow so full of childish thought as his hath ever been; But his little heart's a fountain pure of kind and tender feeling, And his every look's a gleam of light, rich depths of love revealing. When he walks with me, the country folk, who pass us in the street, Will shout with joy, and bless my boy, he looks so mild and sweet.

A playfellow is he to all, and yet, with cheerful tone, Will sing his little song of love, when left to sport alone. His presence is like sunshine sent to gladden home and hearth, To comfort us in all our griefs, and sweeten all our mirth. Should he grow up to riper years, God grant his heart may prove As sweet a home for heavenly grace as now for earthly love. And if, beside his grave, the tears our aching eyes must dim, God confort us for all the love which we shall lose in him.

I have a son, a third sweet son; his age I can not tell, For they reckon not by years or months where he is gone to dwell. 'To us, for fourteen anxious months, his infant smiles were given, And then he bade farewell to Earth, and went to live in Heaven. 


\section{MOULTRIE.}

I cannot tell what form is his, what looks he weareth now, Nor guess how bright a glory crowns his shining seraph brow. The thoughts that fill his sinless soul, the bliss which he doth feel, Are number'd with the seeret things which God will not reveal. But I know (for God hath told me this) that he is now at rest, Where other blessed infants be, on their Saviour's loving breast.

I know his spirit feels no more this weary load of flesh, But his sleep is bless'd with endless dreams of joy for ever fresh.

I know the angels fold him close beneath their glittering wings, And soothe him with a song that breathes of Heaven's divinest things. I know that we shall meet our babe, (his mother dear and I,) When God for aye shall wipe away all tears from every eye. Whate'er befalls his brethren twain, his bliss can never cease; Their lot may here be grief and fear, but his is certain peace. It may be that the tempter's wiles their souls from bliss may sever, But if our own poor faith fail not, he must be ours for ever. When we think of what our darling is, and what we still must be,When we muse on that world's perfect bliss, and this world's misery,When we groan beneath this load of sin, and feel this grief and pain,Oh! we'd rather lose our other two, than have him here again. 
"FORGET THEE?"

"Forget thee?" if to dream by night, and muse on thee by day, If all the worship deep and wild a poet's heart can pay,

If prayers in absence breathed for thee to Heaven's protecting power, If winged thoughts that flit to thee, - a thousand in an hour, If' busy 'Fancy blending thee with all my future lot,If this thou call'st "forgetting," thou, indeed, shalt be forgot!

"Forget thee?" Bid the forest-birds forget their sweetest tune; "Forget thee?" Bid the sea forget to swell beneath the moon; Bid the thirsty flowers forget to drink the eve's refreshing dew; Thyself forget thine own "dear land" and its "mountains wild and bluc." Forget each old familiar face, each long-remember'd spot,When these things are forgot by thee, then thou shalt be forgot!

Keep, if thou wilt, thy maiden peace, still calm and fancy-free, For God forbid thy gladsome heart should grow less glad for me; Yet, while that heart is still unwon, oh! bid not mine to rove, But let it nurse its humble faith, and uncomplaining love;If these, preserved for patient years, at last avail me not, Forget me then;-but ne'er believe that thou canst be forgot! 


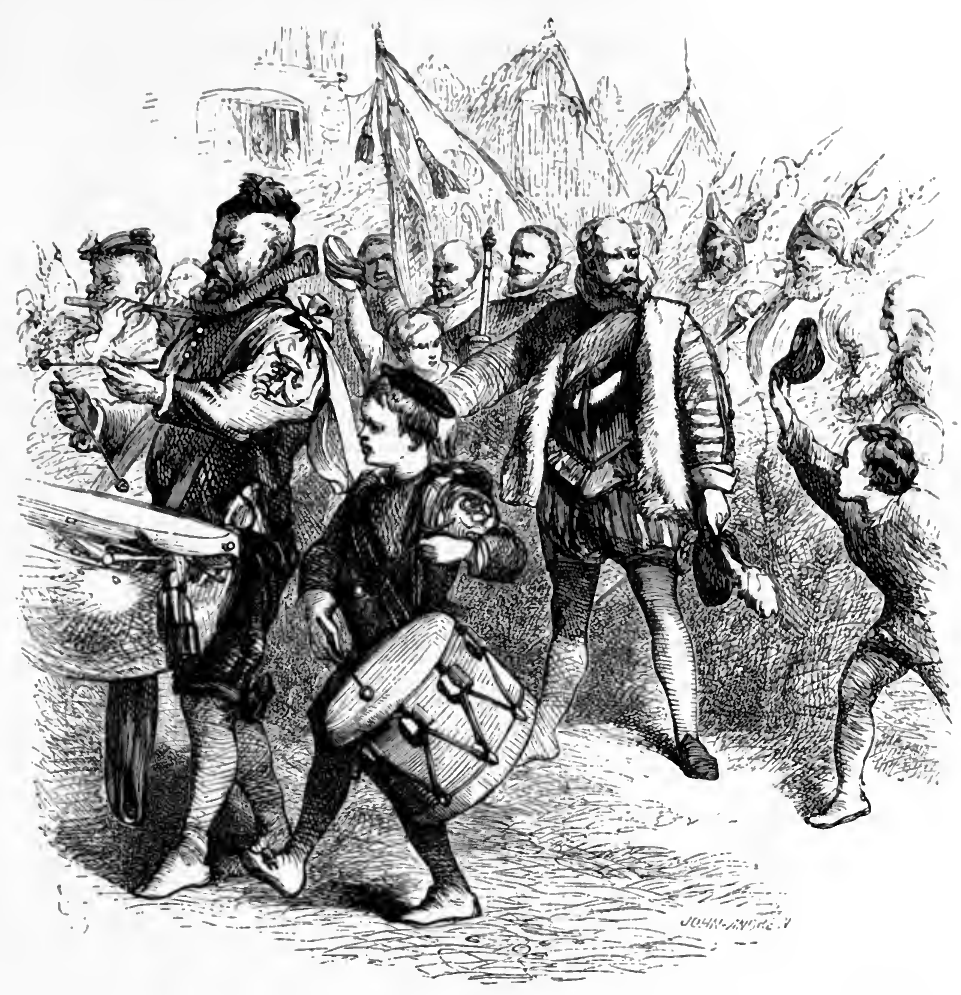

\section{MACAULAY.}

\section{THE SPANISH ARMADA.}

Atrend, all ye who list to hear our noble England's praise; I tell of the thrice-famous deeds she wrought in ancient days, When that great Fleet Invincible against her bore in vain The richest spoils of Mexico, the stoutest hearts of Spain. It was about the lovely close of a warm summer day, There came a gallant merchant-ship full sail to Plymouth Bay; 
Her crew hath seen Castile's black fleet, beyond Aurigny's isle, At earliest twilight, on the waves lie heaving many a mile; At sunrise she escaped their van, by God's especial grace; And the tall Pinta, till the noon, had held her close in chase. Forthwith a guard at every gun was placed along the wall; The beacon blazed upon the roof of Edgecumbe's lofty hall; Many a light fishing-bark put out to pry along the coast; And with loose rein and bloody spur rode inland many a post. With his white hair unbonneted, the stout old sheriff comes; Behind him march the halberdiers; before him sound the drums; His yeomen round the market-cross make clear an ample space, For there behoves him to set up the standard of Her Grace. And haughtily the trumpets peal, and gaily dance the bells, As slow upon the labouring wind the royal blazon swells. Look how the Lion of the sea lifts up his ancient crown, And underneath his deadly paw treads the gay lilies down. So stalked he when he turned to flight, on that famed Picard field, Bohemia's plume, and Genoa's bow, and Cæsar's eagle shield: So glared he when at Agincourt in wrath he turned to bay, And crushed and torn beneath his claws the princely hunters lay. Ho! strike the flagstaff deep, Sir Knight: ho! scatter flowers, fair maids: Ho! gunners, fire a loud salute: ho! gallants, draw your blades: Thou sun, shine on her joyously-ye breezes, waft her wide; Our glorious Semper Eadem, the banner of our pride.

The freshening breeze of eve unfurl'd that banner's massy fold, The parting gleam of sunshine kissed that haughty scroll of gold; Night sunk upon the dusky beach, and on the purple sea, Such night in England ne'er had been, nor e'er again shall be. From Eddystone to Berwick bounds, from Lynn to Milford Bay, That time of slumber was as bright and busy as the day; For swift to east and swift to west the ghastly war-flame spread; High on St. Michael's Mount it shone: it shone on Beachy Head. Far on the deep the Spaniard saw, along each southern shire, Cape beyond cape, in endless range, those twinkling points of fire; The fisher left his skiff to rock on Tamar's glittering waves: The rugged miners poured to war from Mendip's sunless caves: O'er Longleat's towers, o'er Cranbourne's oaks, the fiery herald flew : 


\section{MACAULAY.}

He roused the shepherds of Stonehenge, the rangers of Beaulieu: Right sharp and quick the bells all night rang out from Bristol town; And ere the day three hundred horse had met on Clifton down; The sentinel on Whitehall Gate looked forth into the night, And saw o'erhanging Richmond Hill the streak of blood-red light. Then bugle's note and cannon's roar the death-like silence broke, And with one start, and with one cry, the royal city woke. At once on all her stately gates arose the answering fires; At once the wild alarum clashed from all her reeling spires; From all the batteries of the Tower pealed loud the voice of fear; And all the thousand masts of Thames sent back a louder cheer; And from the farthest wards was heard the rush of hurrying feet, And the broad streams of flags and pikes dashed down each roaring street: And broader still became the blaze, and louder still the din, As fast from every village round the horse came spurring in: And eastward straight from wild Blackheath the warlike errand went, And roused in many an ancient hall the gallant squires of Kent. Southward from Surrey's pleasant hills flew those bright couriers forth; High on bleak Hampstead's swarthy moor they started for the north; And on, and on, without a pause, untired they bounded still,All night from tower to tower they sprang; they sprang from hill to hill : Till the proud peak unfurl'd the flag o'er Darwin's rocky dales, Till like volcanoes flared to heaven the stormy hills of Wales, 'Till twelve fair counties saw the blaze on Malvern's lonely height, 'Till streamed in'crimson on the wind the Wrekin's crest of light, 'Till broad and fierce the star came forth on Ely's stately fane, And tower and hamlet rose in arms o'er all the boundless plain; Till Belvoir's lordly terraces the sign to Lincoin sent, And Iincoln sped the message on o'er the wide vale of Trent; Till Skiddaw saw the fire that burned on Gaunt's embattled pile, And the red glare on Skiddaw roused the burghers of Carlisle. 


\section{MOTHERWELL.}

\section{JEANIE MORRISON.}

I've wandered east, I've wandered west, Through mony a weary way;

But never, never can forget

The luve o' life's young day!

The fire that's blawn on Beltane e'en,

May weel be black gin Yule;

But blacker fa' awaits the heart

Where first fond luve grows cule.

O dear, dear Jeanie Morrison,

The thochts o' bygane years

Still fling their shadows ower my path,

And blind my een wi' tears :

They blind my een wi' saut, saut tears,

And sair and sick I pine,

As memory idly summons up

The blithe blinks o' langsyne.

'Twas then we luvit ilk ither weel,

'Twas then we twa did part;

Sweet time-sad time! twa bairns at seule,

'Twa bairns, and but ae heart!

'Twas then we sat on ae laigh bink,

'To leir ilk ither lear;

And tones, and looks, and smiles were shed,

Remembered evermair. 
I wonder, Jeanie, aften yet,

When sitting on that bink,

Cheek touchin' cheek, loof lock'd in loof,

What our wee heads could think?

When baith bent doun ower ae braid page,

Wi' ae buik on our knee,

Thy lips were on thy lesson, but

My lesson was in thee.

Oh, mind ye how we hung our heads,

How cheeks brent red wi' shame,

Whene'er the scule-weans laughin' said,

We cleek'd thegither hame?

And mind ye o' the Saturdays,

(The scule then skail't at noon,)

When we ran aff to speel the braes-

The broomy braes o' June?

My head rins round and round about, My heart flows like a sea,

As ane by ane the thochts rush back

$O^{\prime}$ scule-time and o' thee.

Oh, mornin' life! oh, mornin' luve!

Oh lichtsome days and lang,

When hinnied hopes around our hearts

Like simmer blossoms sprang!

Oh mind ye, luve, how aft we left

'The deavin' dinsome toun,

To wander by the green burnside,

And hear its waters croon?

The simmer leaves hung ower our heads,

The flowers burst round our feet,

And in the gloamin' o' the wood,

The throssil whusslit sweet; 
The throssil whusslit in the wood, The burn sang to the trees, And we with Nature's heart in tune, Concerted harmonies;

And on the knowe abune the burn,

For hours thegither sat

In the silentness o' joy, till baith

Wi' very gladness grat.

Aye, aye, dear Jeanie Morrison, Tears trinkled doun your cheek, Like dew-beads on a rose, yet nane

Had ony power to speak!

That was a time, a blessed time, When hearts were fresh and young, When freely gushed all feelings forth, Unsyllabled-unsung !

I marvel, Jeanie Morrison, Gin I hae been to thee

As closely twined wi' earliest thochts,

As ye hae been to me?

Oh! tell me gin their music fills

Thine ear as it does mine;

Oh! say gin e'er your heart grows grit

Wi' dreamings o' langsyne?

I've wandered east, I've wandered west, I've borne a weary lot;

But in my wanderings, far or near,

Ye never were forgot.

The fount that first burst frae this heart,

Still travels on its way;

And channels deeper as it rins,

The luve o' life's young day. 


\section{MOTHERWELL.}

O dear, dear Jeanie Morrison,

Since we were sindered young,

I've never seen your face, nor heard

The music o' your tongue;

But I could hug all wretchedness,

And happy could I die,

Did I but ken your heart still dreamed

O' bygane days and me!

\section{THEY COME! THE MERRY SUMMER MONTHS.}

THey come! the merry summer months of Beauty, Song, and Flowers; They come! the gladsome months that bring thick leafiness to bowers. Up, up, my heart, and walk abroad, fling cark and care aside, Seek silent hills, or rest thyself where peaceful waters glide;

Or, underneath the shadow vast of patriarchal tree, Scan through its leaves the cloudless sky in rapt tranquillity.

The grass is soft, its velvet touch is grateful to the hand, And like the kiss of maiden love, the breeze is sweet and bland;

The daisy and the buttercup are nodding courteously, It stirs their blood with kindest love, to bless and welcome thee: And mark how with thine own thin locks, - they now are silvery grey,That blissful breeze is wantoning, and whispering "Be gay!"

There is no cloud that sails along the ocean of yon sky, But hath its own winged mariners to give it melody: Thou seest their glittering fans outspread all gleaming like red gold; And hark! with shrill pipe musical, their merry course they hold. 


\section{A SOLEMN CONCEIT.}

God bless them all, these little ones, who far above this earth, Can make a scoff of its mean joys, and vent a nobler mirth.

But soft! mine ear upcaught a sound; from yonder wood it eame; The spirit of the dim green glade did breathe his own glad name;Yes, it is he! the hermit bird, that apart from all his kind Slow spells his beads monotonous to the soft western wind; Cuckoo! Cuckoo! he sings again,- - his notes are void of art, But simplest strains do soonest sound the deep founts of the heart!

Grood Lord! it is a gracious boon for thought-erazed wight like me, To smell again these summer flowers beneath this summer tree!

'To suck onee more in every breath their little souls away, And feed my fancy with fond dreams of youth's bright summer day, When rushing forth like untamed eolt, the reckless truant boy Wandered through green woods all day long, a mighty heart of joy!

I'm sadder now, I have had eause; but O! I'm proud to think That each pure joy-fount loved of yore, I yet delight to drink ;Leaf, blossom, blade, hill, valley, stream, the calm unclouded sky, Still mingle music in my dreams as in the days gone by.

When summer's loveliness and light fall round me dark and cold, I'll bear indeed life's heariest curse, -a heart that hath waxed old:

\section{A SOLEMN CONCEIT.}

Stately trees are growing, Lusty winds are blowing, And mighty rivers flowing

On, for ever on.

As stately forms were growing,

As lusty spirits blowing,

As mighty fancies flowing

On, for ever on ; 


\section{MOTHERWELL.}

But there has been leave-taking,

Sorrow and heart-breaking,

And a moan, pale Echo's making,

For the gone, for ever gone!

Lovely stars are gleaming,

Bearded lights are streaming,

And glorious suns are beaming

On, for ever on.

As lovely eyes were gleaming,

As wondrous lights were streaming,

As glorious minds were beaming

On, for ever on ;-

But there has been soul-sundering,

Wailing, and sad wondering;

For graves grow fat with plundering

The gone, for ever gone!

We see great eagles soaring,

We hear deep oceans roaring,

And sparkling fountains pouring

On, for ever on.

As lofty ones were soaring,

As sonorous voices roaring,

And as sparkling wits were pouring

On, for ever on ;-

But, pinions have been shedding,

And voiceless darkness spreading,

Since a measure Death's been treading

O'er the gone, for ever gone!

Every thing is sundering,

Every one is wondering,

And this huge globe goes thundering

On, for ever on.

But, 'mid this weary sundering,

Heart-breaking and sad wondering, 


\section{A SOLEMN CONCEIT.}

And this huge globe's rude thundering

On, for ever on,

I would that I were dreaming

Where little flowers are gleaming,

And the long green grass is streaming

O'er the gone, for ever gone! 


\section{TAYLOR.}

\section{ARTEVELDE IN GHENT.}

THE PLATform AT THE TOP OF THE STEEPLe OF ST. NICHOLA' CHURCH. -TIME-DAY-BREAK.

ARTEVELDE (alone).

There lies a sleeping city. God of dreams!

What an unreal and fantastic world

Is going on below!

Within the sweep of yon encircling wall,

How many a large creation of the night,

Wide wilderness and mountain, rock and sea,

Peopled with busy transitory groups,

Finds room to rise, and never feels the crowd!

-If when the shows had left the dreamers' eyes

They should float upward visibly to mine,

How thick with apparitions were that void!

But now the blank and blind profundity

Turns my brain giddy with a sick aversion.

-I have not slept. I am to blame for that.

Long vigils, join'd with seant and meagre food,

Must needs impair that promptitude of mind,

And cheerfulness of spirit, which, in him

Who leads a multitude, is past all price.

I think I could redeem an hour's repose

Out of the night that I have squander'd, yet.

The breezes, launch'd upon their early voyage,

Play with a pleasing freshness on my face.

I will enfold my cloak about my limbs,

And lie where I shall front them;-here, I think.

[He lies dowit. 
If this were over-blessed be the calm

'That comes to me at last! A friend in need

Is nature to us, that, when all is spent,

Brings slumber-bountifully - whereupon

We give her sleepy welcome-if all this

Were honourably over-Adrianna-

[Falls asleep, but starts up almost instantly.

I heard a hoof, a horse's hoof I'll swear,

Upon the road from Bruges,-or did I dream?

No! 'tis the gallop of a horse at speed.

VAN DEN BOSCH (without).

What ho! Van Artevelde!

ARTEVELDE.

$$
\begin{aligned}
& \text { Who calls? } \\
& \text { VAN DEN BOSCH (entering). }
\end{aligned}
$$

'Tis $\mathbf{I}$.

'Thou art an early riser, like myself;

Or is it that thou hast not been to bed?

ARTEVELDE.

What are thy tidings?

\section{VAN DEN BOSCH.}

Nay, what can they be?

A page from pestilence and famine's day-book;

So many to the pest-house carried in,

So many to the dead-house carried out.

The same dull, dismal, damnable old story.

ARTEVELDE.

Be quiet; listen to the westerly wind,

And tell me if it bring thee nothing new.

VAN DEN BOSCH.

Nought to my car, save howl of hungry dog

'That hears the house is stirring-nothing else.

ARTEVELDE.

No,-now-I hear it not myself-no-nothing.

The city's hum is up-but ere you came

'Twas audible enough. 
TAYLOR.

VAN DEN BOSCH.

In God's name what?

ARTEVELDE.

A horseman's tramp upon the road from Bruges.

VAN DEN BOSCH.

Why, then, be certain 'tis a flag of truce!

If once he reach the eity we are lost.

Nay, if he be but seen, our danger's great.

What terms so bad they would not swallow now?

Let's send some trusty varlets forth at once

To cross his way.

ARTEVELDE.

And send him back to Bruges?

VAN DEN BOSCH.

Send him to hell-and that's a better place.

ARTEVELDE.

Nay, softly, Van den Boseh; let war be war,

But let us keep its ordinances.

VAN DEN BOSCH.

Tush !

I say, but let them see him from afar,

And in an hour shall we, bound hand and foot,

Be on our way to Bruges.

ARTEVELDE.

Not so, not so;

My rule of governance has not been such

As e'er to issue in so foul a close.

VAN DEN BOSCH.

What matter by what rule thou may'st have govern'd?

'Think'st thou a hundred thousand citizens

Shall stay the fury of their empty maws

Because thou'st ruled them justly?

ARTEVELDE.

That such a hope is mine.

It may be 


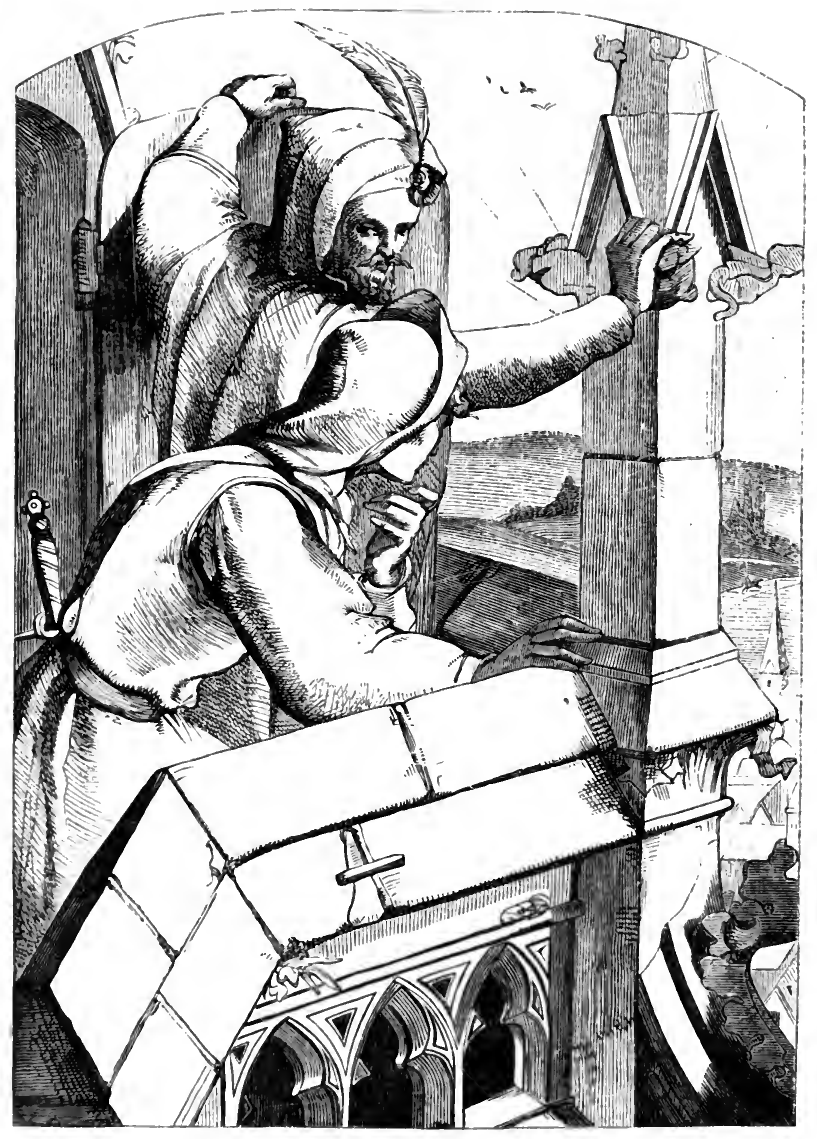

VAN DEN BOSCH.

Then thou art mad,

And I must take this matter on myself. [Is going. A RTEVEL,1)E.

Hold, Van den Bosch; I say this shall not be. 
I must be madder than I think I am

Ere I shall yield up my authority,

Which I abuse not, to be used by thee.

VAN DEN BOSCH.

This comes of lifting dreamers into power.

I tell thee, in this strait and stress of famine,

The people, but to pave the way for peace,

Would instantly despatch our heads to Bruges.

Once and again $I$ warn thee that thy life

Hangs by a thread.

ARTEVELDE.

Why, know I not it does?

What hath it hung by else since Utas' eve?

Did I not by mine own advised choice

Place it in jeopardy for certain ends?

And what were these? To prop thy tottering state?

To float thee o'er a reef, and, that performed,

To cater for our joint security?

No, verily; not such my high ambition.

I bent my thoughts on yonder city's weal;

I looked to give it victory and freedom;

And working to that end, by consequence

From one great peril did deliver thee-

Not for the love of thee or of thy life,

Which I regard not, but the city's service;

And if for that same service it seem good,

I will expose thy life to equal hazard.

VAN DEN BOSCH.

Thou wilt?

ARTEVELDE.

I will.

VAN DEN BOSCH.

Oh, Lord! to hear him speak,

What a most mighty emperor of puppets

Is this that I have brought upon the board!

But how if he that made it should unmake? 


\section{ARTEVELDE IN GHEN'T.}

\section{ARTEVELDE.}

Unto His sovereignty who truly made me With infinite humility I bow!

Both, both of us are puppets, Van den Bosch; Part of the curious clock-work of this world, We scold, and squeak, and crack each other's crowns; And if by twitches moved from wires we see not, I were to toss thee from this steeple's top,

I should be but the instrument-no more-

The tool of that chastising Providence

Which doth exalt the lowly, and abase

The violent and proud: but let me hope

There's no such task appointed me to-day.

Thou passest in the world for worldly wise:

Then, seeing we must sink or swim together, What can it profit thee, in this extreme

Of our distress, to wrangle with me thus For my supremacy and rule? Thy fate, As of necessity bound up with mine, Must needs partake my cares: let that suffice To put thy pride to rest till better times. Contest-more reasonably wrong-a prize More precious than the ordering of a shipwreck.

VAN DEN BOSCH.

'Tush, tush, Van Artevelde; thou talk'st and talk'st, And honest burghers think it wondrous fine.

But thou might'st easilier with that tongue of thine Persuade yon smoke to fly i' th' face o' the wind, Than talk away my wit and understanding. I say yon herald shall not enter here.

ARTEVEIDE.

I know, sir, no man better, where my talk

Is serviceable singly, where it needs

'To be by acts enforced. I say, beware, And brave not mine authority too far. 


\section{TAYLOR.}

VAN DEN BOSCH.

Hast thou authority to take my life?

What is it else to let yon herald in

To bargain for our blood?

ARTEVELDE.

Thy life again!

Why, what a very slave of life art thou!

Look round about on this once populous town;

Not one of these innumerous house-tops

But hides some spectral form of misery,

Some peevish, pining child and moaning mother,

Some aged man that in his dotage scolds,

Not knowing why he hungers, some cold corse

That lies unstraightened where the spirit left it.

Look round, and answer what thy life can be

To tell for more than dust upon the balance.

I, too, would live-I have a love for life-

But rather than to live to charge my soul

With one hour's lengthening out of woes like these,

I'd leap this parapet with as free a bound

As e'er was schoolboy's o'er a garden wall.

$$
\text { VAN DEN BOSCH. }
$$

I'd like to see thee do it.

\section{ARTEVELDE.}

I know thou wouldst;

But for the present be content to see

My less precipitate descent; for lo:

'There comes the herald o'er the hill.

VAN DEN BOSCH.

Beshrew thee!

Thou shalt not have the start of me in this.

[He follows, and the scene closes. 
ERNESTO.

ERNESTO.

Thodghtfully by the side Ernesto sate

Of her whom, in his earlier youth, with heart

'Then first exulting in a dangerous hope,

Dearer for danger, he had rashly loved.

That was a season when the untravell'd spirit,

Not way-worn nor way-wearied, nor with soil

Nor stain upon it, lions in its path

Saw none-or seeing, with triumphant trust

In its resources and its powers, defied-

Perverse to find provocatives in warnings,

And in disturbance taking deep delight.

By sea or land he still saw rise the storm

With a gay courage, and through broken lights,

Tempestuously exalted, for a while

His heart ran mountains high, or to the roar

Of shatter'd forests sang superior songs

With kindling, and what might have seem'd to some,

Auspicious energy;-by land and sea

He was way-founder'd-trampled in the dust

His many-colour'd hopes-his lading rich

Of precious pictures, bright imaginations,

In absolute shipwreck to the wind and waves

Suddenly render'd-

By her side he sate:

But time had been between and wov'n a veil

Of seven years' separation; and the past

Was seen with soften'd outlines, like the face

Of Nature through a mist. What was so seen?

In a short hour, there sitting with his eyes

Fix'd on her face, observant though abstracted, 


\section{TAYLOR.}

Lost partly in the past, but mixing still

With his remembrances the life before him, He traced it all-the pleasant first accost, Agreeable acquaintance, growing friendship, Love, passion at the culminating point

When in a sleeping body through the night

The heart would lie awake, reverses next

Gnawing the mind with doubtfulness, and last

The affectionate bitterness of love refused.

- Rash had he been by choice-by wanton choice Deliberately rash; but in the soil

Where grows the bane, grows too the antidote;

The same young-heartedness which knew not fear

Renounced despondency, and brought at need

With its results, resources. In his day

Of utter condemnation, there remain'd

Appeal to that imaginative power

Which can commute a sentence of sore pain

For one of softer sadness, which can bathe

The broken spirit in the balm of tears.

And more and better to after days; for soon

Upsprang the mind within him, and he knew

The affluence and the growth which nature yiclds

After an overflow of loving grief.

Hence did he deem that he could freely draw

A natural indemnity. The tree

Sucks kindlier nurture from a soil enrich'd

By its own fallen leaves; and man is made

In heart and spirit from deciduous hopes

And things that seem to perish. 'Thro' the stress

And fever of his suit, from first to last,

His pride (to call it by no nobler name)

Had been to love with reason and with truth,

To carry clear thro' many a turbulent trial

A perspicacious judgment and true tongue,

And neither with fair word nor partial thought

To flatter whom he loved. If pride it was 


\section{ERNESTO.}

To love and not to flatter, by a breath

Of purer aspiration was he moved

To suffer and not blame, grieve, not resent;

And when all hopes that needs must knit with self

Their object, were irrevocably gone,

Cherish a mild commemorative love,

Such as a mourner might unblamed bestow

On a departed spirit-

\section{Once again}

He sate beside her-for the last time now.

And scarcely was she alter'd; for the hours

Had led her lightly down the vale of life,

Dancing and scattering roses, and her face

Seem'd a perpetual daybreak, and the woods,

Where'er she rambled, echoed through their aisles

The music of a laugh so softly gay

That spring with all her songsters and her songs

Knew nothing like it. But how changed was he!

Care and disease and ardours unrepress'd,

And labours unremitted, and much grief,

Had written their death-warrant on his brow.

Of this she saw not all-she saw but little-

That which she could not choose but see she saw;

And o'er her sunlit dimples and her smiles

A shadow fell-a transitory shade;

And when the phantom of a hand she clasped

At parting scarce responded to her touch,

She sigh'd-but hoped the best.

When winter came

She sigh'd again;-for with it came the word

That trouble and love had found their place of rest

And slept beneath Madeira's orange groves. 


\section{MOIR.}

\section{CASA WAPPY.*}

Axp hast thou sought thy heavenly home,

Our fond, dear boy-

The realms where sorrow dare not come,

Where life is joy?

Pure at thy death as at thy birth,

'Thy spirit caught no taint from earth;

Even by its bliss we mete our death,

Casa Wappy!

Despair was in our last farewell,

As closed thine eye;

Tears of our anguish may not tell

When thou didst die;

Words may not paint our grief for thee,

Sighs are but bubbles on the sea

Of our unfathomed agony,

\section{Casa Wappy!}

Thou wert a vision of delight

To bless us given;

Beauty embodied to our sight,

A type of heaven:

So dear to us thou wert, thou art

Even less thine own self than a part

Of mine and of thy mother's heart,

Casa Wappy!

* Casa Wappy was the self-conferred pet-name of an infant son of the poet, snatched away after a very brief illness. 
Thy bright brief day knew no decline, 'Twas cloudless joy;

Sunrise and night alone were thine

Beloved boy!

This morn beheld thee blithe and gay,

That found thee prostrate in decay,

And ere a third shone, clay was clay,

Casa Wappy!

Gem of our hearth, our household pride,

Earth's undefiled;

Could love have saved, thou hadst not died,

Our dear, sweet child!

Humbly we bow to Fate's decree;

Yet had we hoped that Time should see

Thee mourn for us, not us for thee, Casa Wappy!

Do what I may, go where I will,

Thou meet'st my sight;

There dost thou glide before me still-

A form of light!

I feel thy breath upon my cheek-

I see thee smile, I hear thee speak-

Till oh! my heart is like to break,

Casa Wappy!

Methinks thou smil'st before me now,

With glance of stealth;

The hair thrown back from thy full brow

In buoyant health :

I see thine eye's deep violet light,

Thy dimpled cheek carnationed bright,

Thy clasping arms so round and white,

Casa Wappy! 
The nursery shows thy pictured wall,

'Thy bat, thy bow,

'Thy cloak and bonnet, club and ball;

But where art thou?

A corner holds thine empty chair,

Thy playthings idly scattered there,

But speak to us of our despair,

Casa Wappy!

Even to the last thy every word-

To glad, to grieve-

Was sweet as sweetest song of bird

On summer's eve;

In outward beauty undecayed,

Death o'er thy spirit cast no shade, And like the rainbow thou didst fade,

Casa Wappy!

We mourn for thee when blind blank night

The chamber fills;

We pine for thee when morn's first light

Reddens the hills:

The sun, the moon, the stars, the sea, All, to the wall-flower and wild pea, Are changed-we saw the world through thee,

Casa Wappy!

And though, perchance, a smile may gleam

Of easual mirth,

It doth not own, whate'er may seem,

An inward birth:

We miss thy small step on the stair;

We miss thee at thine evening prayer!

All day we miss thee, everywhere,

Casa Wappy! 
Snows muffled earth when thou didst go, In life's spring bloom,

Down to the appointed house below,

The silent tomb.

But now the green leaves of the tree,

The cuckoo and "the busy bee"

Return-but with them bring not thee, Casa Wappy!

'Tis so; but can it be (while flowers Revive again)

Man's doom, in death that we and ours

For aye remain?

Oh! can it be, that o'er the grave

The grass renewed, should yearly wave,

Yet God forget our child to save?-

Casa Wappy !

It eannot be: for were it so

Thus man could die,

Life were a moekery, Thought were woe,

And Truth a lie;

Heaven were a coinage of the brain,

Religion frenzy, Virtue vain,

And all our hopes to meet again,

Casa Wappy:

Then be to us, O dear, lost child:

With beam of love,

A star, death's uneongenial wild

Smiling above;

Soon, soon thy little feet have trod

The skyward path, the seraph's roal,

That led thee back from man to God,

Casa Wappy: 
MOIR.

Yet 'tis sweet balm to our despair,

Fond, fairest boy,

That heaven is God's, and thou art there,

With him in joy:

'There past are death and all its woes,

There beauty's stream forever flows,

And pleasure's day no sunset knows,

Casa Wappy!

Farewell, then-for a while, farewell-

Pride of my heart!

It cannot be that long we dwell,

Thus torn apart:

Time's shadows like the shuttle flee:

And, dark howe'er life's night may be, Beyond the grave I'll meet with thee,

- Casa Wappy! 


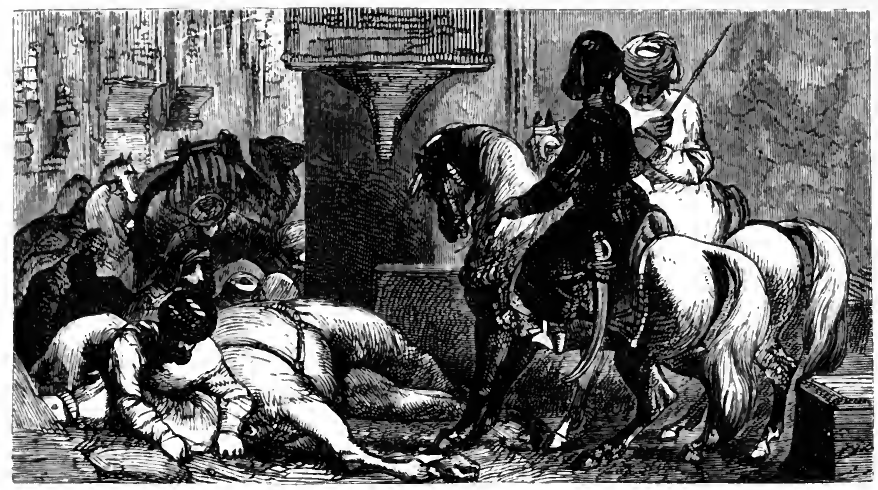

\section{TRENCH.}

THE SPILT PEARLS.

His courtiers of the Caliph crave,-

"Oh, say how this may be,

That of thy slaves, this Ethiop slave

Is best beloved by thee?

"For he is ugly as the Night;

But when has ever chose

A .nightingale, for its delight,

A hueless, scentless rose?"

The Caliph, then:- "No features fair,

Nor comely mien, are his;

Love is the beauty he doth wear,

And Love his glory is.

"When once a camel of my train

There fell in narrow street,

From broken casket roll'd amain

Rich pearls before my feet. 
"I winking to the slaves that I

Would freely give them these, At once upon the spoil they fly,

The costly boon to seize.

"One only at my side remained-

Beside this Ethiop none:

$\mathrm{He}$, moveless as the steed he reined, Behind me sat alone.

" "What will thy gain, good fellow, be,

Thus lingering at my side?'

'My king, that I shall faithfully

Have guarded thee,' he cried.

"True servant's title he may wear

He only who has not,

For his Lord's gifts, how rich soe'er,

His Lord himself forgot."

So thou alone dost walk before

Thy God with perfect aim,

From Him desiring nothing more

Beside Himself to claim.

For if thou not to Him aspire,

But to His gifts alone,

Not Love, but covetous desire,

Has brought thee to His throne.

While such thy prayer, it climbs above

In vain-the golden key

Of God's rich treasure-house of love,

Thine own will never be 


\section{EMERSON.}

THE HUMBLE-BEE.

Burly, dozing, humble-bee,

Where thou art is clime for me.

Let them sail for Porto Rique,

Far-off heats through seas to seek;

I will follow thee alone,

Thou animated torrid zone !

Zigzag steerer, desert cheerer,

Let me chase thy waving lines;

Keep me nearer, me thy hearer,

Singing over shrubs and vines.

Insect lover of the sun,

Joy of thy dominion!

Sailor of the atmosphere;

Swimmer through the waves of air;

Voyager of light and noon;

Epicurean of June;

Wait, I prithee, till I come

Within earshot of thy hum,-

All without is martyrdom.

When the south wind, in May days,

With a net of shining haze

Silvers the horizon wall,

And, with softness touching all,

'Tints the human countenance

With a colour of romance,

And, infusing subtle heats,

'Turns the sod to violets,

Thou, in sunny solitudes,

Rover of the underwoods, 


\section{EMERSON.}

The green silence dost displace

With thy mellow, breezy bass.

Hot midsummer's petted crone,

Sweet to me thy drowsy tone

Tells of countless sunny hours,

Long days, and solid banks of flowers;

Of gulfs of sweetness without bound

In Indian wildernesses found;

Of Syrian peace, immortal leisure,

Firmest cheer, and bird-like pleasure.

Aught unsavoury or unclean

Hath my insect never seen;

But violets and bilberry bells,

Maple-sap, and daffodels,

Grass with green flag half-mast high,

Succory to match the sky,

Columbine with horn of honey,

Scented fern and agrimony,

Clover, catch-fly, adder's-tongue,

And brier roses, dwelt among;

All beside was unknown waste,

All was picture as he passed.

Wiser far than human seer,

Yellow-breeched philosopher!

Seeing only what is fair,

Sipping only what is sweet,

Thou dost mock at fate and care,

Leave the chaff, and take the wheat.

When the fierce north-western blast

Cools sea and land so far and fast,

Thou already slumberest deep;

Woe and want thou canst outsleep;

Want and woe, which torture us,

Thy sleep makes ridiculous. 


\section{HOFFMANN.}

\section{SPARKLING AND BRIGHT.}

Sparklivg and bright in liquid light,

Does the wine our goblets gleam in, With hue as red as the rosy bed

Which a bee would choose to dream in.

Then fill to-night with hearts as light, To loves as gay and fleeting As bubbles that swim on the beaker's brim.

And break on the lips while meeting.

Oh! if Mirth might arrest the flight Of 'Time through Life's dominions, We here.awhile would now beguile

The grey-beard of his pinions

To drink to-night with hearts as light,

To loves as gay and fleeting

As bubbles that swim on the beaker's brim, And break on the lips while meeting.

But since delight can't tempt the wight,

Nor fond regret delay him,

Nor Love himself can hold the elf,

Nor sober Friendship stay him,

We'll drink to-night with hearts as light,

To loves as gay and fleeting

As bubbles that swim on the beaker's brim,

And break on the lips while meeting. 


\section{MORRIS.}

WOODMAN, SPARE THAT TREE.

Woodyan, spare that tree!

Touch not a single bough!

In youth it sheltered me,

And I'll protect it now.

'Twas my forefather's hand

That placed it near his cot;

There, woodman, let it stand,

Thy axe shall harm it not!

That old familiar tree,

Whose glory and renown

Are spread o'er land and sea,

And wouldst thou hew it down?

Woodman, forbear thy stroke!

Cut not its earth-bound ties;

$\mathrm{Oh}$, spare that aged oak,

Now towering to the skies!

When but an idle boy

I sought its grateful shade;

In all their gushing joy

Here too my sisters played.

My mother kissed me here;

My father pressed my hand-

Forgive this foolish tear,

But let that old oak stand!

My heart-strings round thee cling,

Close as thy bark, old friend!

Here shall the wild-bird sing,

And still thy branches bend. 


\section{POETRY.}

Old tree! the storm still brave!

And woodman, leave the spot;

While I've a hand to save, Thy axe shall harm it not.

\section{POETRY.}

To me the world's an open book, Of sweet and pleasant poetry;

I read it in the running brook That sings its way towards the sea.

It whispers in the leaves of trees, The swelling grain, the waving grass, And in the cool, fresh evening breeze That crisps the wavelets as they pass.

The flowers below, the stars above, In all their bloom and brightness given, Are, like the attributes of love, The poetry of earth and heaven. Thus Nature's volume, read aright, Attunes the soul to minstrelsy, 'Tinging life's clouds with rosy light, And all the world with poetry. 


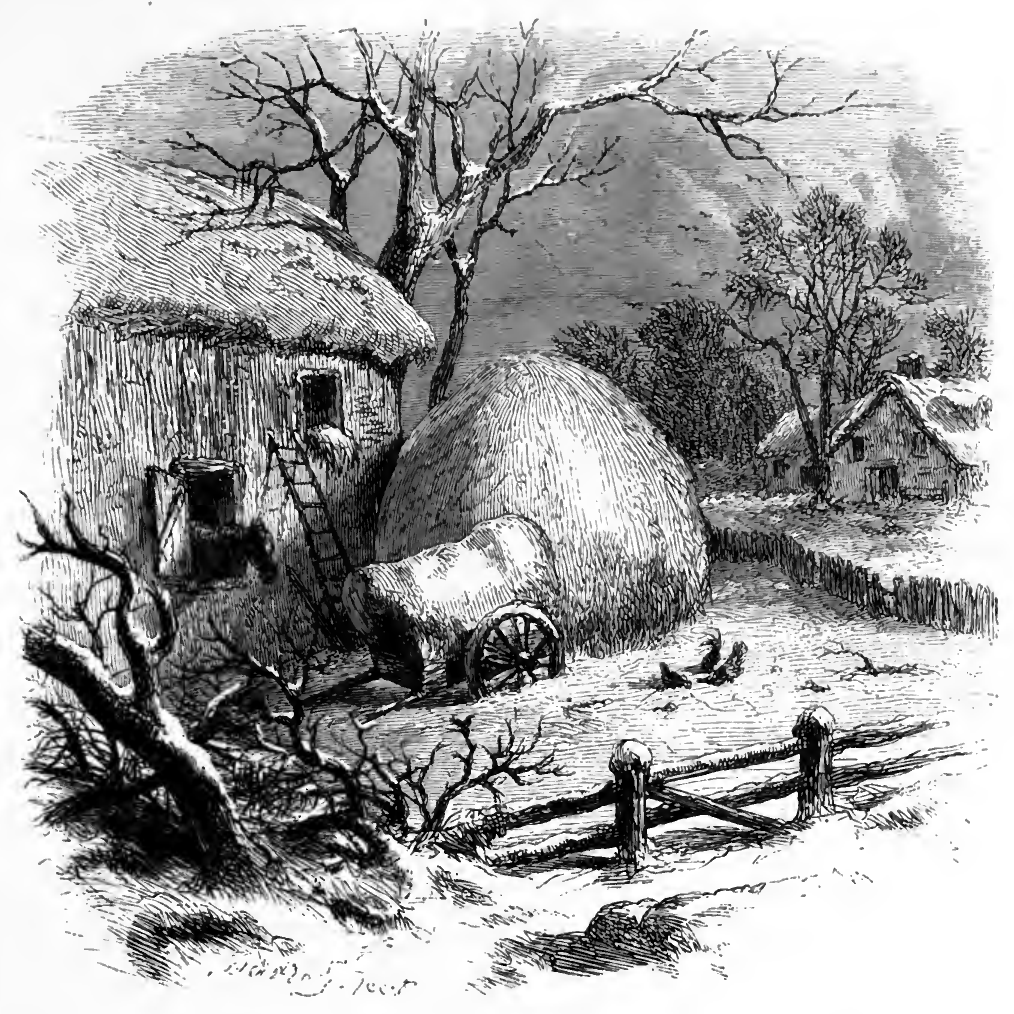

\section{HOYT.}

\section{SNOW-A WINTER SKETCH.}

THE blessed morn has come again;

The early gray

Taps at the slumberer's window pane,

And seems to say

Break, break from the enchanter's chain,

Away, away! 
'Tis winter, yet there is no sound

Along the air,

Of winds upon their battle-ground,

But gently there,

The snow is falling, -all around

How fair-how fair!

The jocund fields would masquerade;

Fantastic scene!

Tree, shrub, and lawn, and lonely glade

Have cast their green,

And joined the revel, all arrayed

So white and clean.

E'en the old posts, that hold the bars

And the old gate,

Forgetful of their wintry wars,

And age sedate,

High capped, and plumed, like white hussars,

Stand there in state.

The drifts are hanging by the sill,

The eaves, the door;

The hay-stack has become a hill;

All covered o'er

The waggon, loaded for the mill

The eve before.

Maria brings the water-pail,

But where's the well!

Like magic of a fairy tale,

Most strange to tell,

All vanished, curb, and crank, and rail!

How deep it fell! 
The wood-pile, too, is playing hide;

The axe, the log,

The kennel of that friend so tried,

('The old wateh-dog,)

The grindstone standing by its side, All now incog.

The bustling cock looks out aghast

From his high shed;

No spot to serateh him a repast

Up curves his head,

Starts the dull hamlet with a blast,

And back to bed.

Old drowsy dobbin, at the call, Amazed, awakes;

Out from the window of his stall

A view he takes;

While thick and faster seem to fall

The silent flakes.

The barn-yard gentry, musing, chime Their morning moan;

Like Memnon's music of old time

That voice of stone!

So marbled they-and so sublime

Their solemn tone.

Good Ruth has called the younker folk

To dress below;

Full welcome was the word she spoke,

Down, down they gc,

The cottage quietude is broke,-

The snow!-the snow! 
Now rises from around the fire

A pleasant strain;

Ye giddy sons of mirth, retire!

And ye profane!

A hymn to the Eternal Sire

Goes up again.

The patriarchal Book divine,

Upon the knee,

Opes where the gems of Judah shine,

(Sweet minstrelsie!)

How soars each heart with each fair line,

Oh God, to Thee!

Around the altar low they bend,

Devout in prayer ;

As snows upon the roof descend,

So angels there

Come down that household to defend

With gentle care.

Now sings the kettle o'er the blaze;

The buckwheat heaps;

Rare Mocha, worth an Arab's praise,

Sweet Susan steeps;

The old round stand her nod obeys,

And out it leaps.

Urierring presages declare

'The banquet near;

Soon busy appetites are there;

And disappear

The glories of the ample fare,

With thanks sincere. 
HOY'T.

Now tiny snow-birds venture nigh

From copse and spray,

(Sweet strangers! with the winter's sky

To pass away ;)

And gather crumbs in full supply,

For all the day.

Let now the busy hours begin:

Out rolls the churn;

Forth hastes the farm-boy, and brings in

The brush to burn;

Sweep, shovel, scour, sew, knit, and spin,

'Till night's return.

To delve his threshing John must hie;

His sturdy shoe

Can all the subtle damp defy;

How wades he through!

While dainty milkmaids slow and shy,

His track pursue.

Each to the hour's allotted care;

To shell the corn;

The broken harness to repair;

The sleigh t' adorn;

As cheerful, tranquil, frosty, fair,

Speeds on the morn.

While mounts the eddying smoke amain

From many a hearth,

And all the landscape rings again

With rustic mirth;

So gladsome seems to every swain

The snowy earth. 


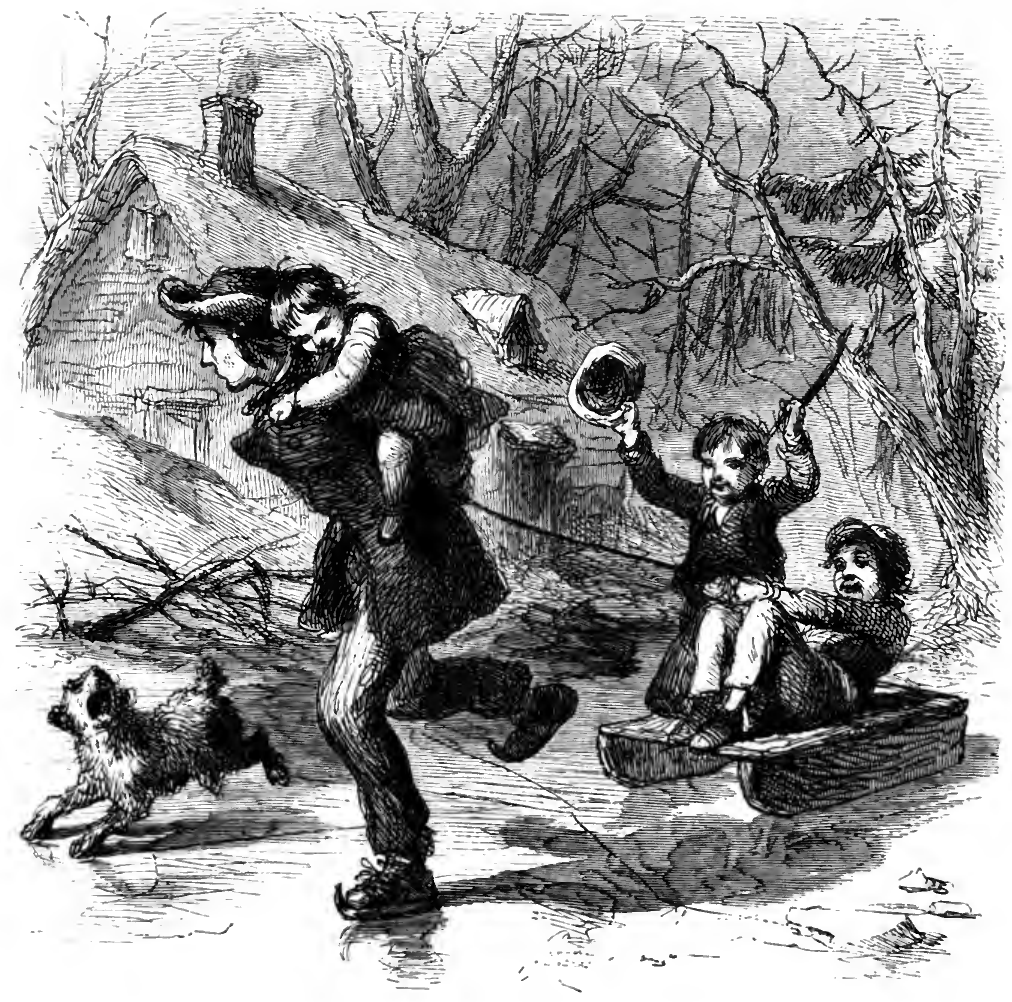

SIMLMS.

BLESSINGS ON CHILDREN.

Blessincs on the blessing ehildren, sweetest gifts of Heaven to eartl, Filling all the heart with gladness, filling all the house with mirth; Bringing with them native sweetness, pictures of the primal bloom Which the bliss for ever gladdens, of the region whence they come; Bringing with them joyous impulse of a state withouten care, And a buoyant faith in being, which makes all in nature fair; Not a doubt to dim the distance, not a grief to vex the nigh, And a hope that in existence, finds each hour a luxury; 
Going singing, bounding, brightening-never fearing as they go, That the innocent shall tremble, and the loving find a foe;

In the daylight, in the starlight, still with thought that freely flies, Prompt and joyous, with no question of the beauty in the skies; Genial fancies winning raptures, as the bee still sucks her store, All the present still a garden glean'd a thousand times before; All the future, but a region, where the happy serving thought, Still depiets a thousand blessings, by the wingéd hunter caught; Life a chase where blushing pleasures only seem to strive in fiight, Lingering to be caught, and yielding gladly to the proud delight; As the maiden, through the alleys, looking backward as she flies, Woos the fond pursuer onward, with the love-light in her eyes. Oh ! the happy life in children, still restoring joy to our's, Making for the forest music, planting for the wayside flowers; Back recalling all the sweetness, in a pleasure pure as rare, Back the past of hope and rapture bringing to the heart of eare. How, as swell the happy voices, bursting through the shady grove, Memories take the place of sorrows, time restores the sway to love! We are in the shouting comrades, shaking off the load of years, Thought forgetting, strifes and trials, doubts and agonies and tears; We are in the bounding urchin, as o'er hill and plain he darts, Share the struggle and the triumph, gladdening in his heart of hearts;

What an image of the vigour and the glorious grace we knew, When to eager youth from boyhood, at a single bound we grew! Even such our slender beauty, such upon our cheek the glow, In our eyes the life and gladness-of our blood the overflow. Bless the mother of the urchin! in his form we see her truth: He is now the very picture of the memories in our youth; Never can we doubt the forehead, nor the sunny flowing hair, Nor the smiling in the dimple speaking chin and cheek so fair: Bless the mother of the young one! he hath blended in his grace, All the hope and joy and beauty, kindling once in either face!

Oh! the happy faith of children! that is glad in all it sees, And with never need of thinking, pierces still its mysteries; In simplicity profoundest, in their soul abundance blest, Wise in value of the sportive, and in restlessness at rest; 


\section{BLESSINGS ON CHILDREN.}

Lacking every creed yet having faith so large in all they see, - That to know is still to gladden, and 'tis rapture but to be. What trim fancies bring them flowers; what rare spirits walk their wood, What a wondrous world the moonlight harbours of the gay and good! Unto them the very tempest walks in glories grateful still, And the lightning gleams, a seraph, to persuade them to the hill: 'Tis a sweet and loving spirit, that throughout the midnight rains, Broods beside the shutter'd windows, and with gentle love complains; And how wooing, how exalting, with the richness of her dyes, Spans the painter of the rainbow, her bright arch along the skies, With a dream like Jacob's ladder, showing to the fancy's sight, How 'twere easy for the sad one to escape to worlds of light! $\mathrm{Ah}$ ! the wisdom of such fancies, and the truth in every dream, 'That to faith confiding offers, cheering every gloom, a gleam! Happy hearts, still cherish fondly each delusion of your youth, Joy is born of well believing, and the fiction wraps the truth. 


\section{WILLIS.}

\section{UNSEEN SPIRITS.}

The shadows lay along Broadway-

'Twas near the twilight-tide-

And slowly there a lady fair

Was walking in her pride.

Alone walked she; but, viewlessly,

Walked spirits at her side.

Peace charmed the street beneath her feet, And Honour charmed the air;

And all astir looked kind on her, And called her good as fair-

For all God ever gave to her She kept with chary care.

She kept with care her beauties rare From lovers warm and true-

For her heart was cold to all but gold, And the rich came not to woo-

But honoured well are charms to sell If priests the selling do.

Now walking there was one more fair-

A slight girl, lily-pale;

And she had unseen company

To make the spirit quail-

'Twixt Want and Scorn she walked forlorn, And nothing could avail. 


\section{LITTLE FLORENCE GRAY.}

No mercy now can clear her brow

For this world's peace to pray;

For, as love's wild prayer dissolved in air,

Her woman's heart gave way!-

But the sin forgiven by Christ in heaven

By man is curst alway!

\section{LITTLE FLORENCE GRAY.}

I was in Greece. It was the hour of noon, And the Agean wind had dropped asleep

Upon Hymettus, and the thymy isles

Of Salamis and Agina lay hung

Like clouds upon the bright and breathless sea.

I had elimbed up th' Acropolis at morn,

And hours had fled as time will in a dream

Amid its deathless ruins-for the air

Is full of spirits in these mighty fanes,

And they walk with you! As it sultrier grew,

I laid me down within a shadow deep

Of a tall column of the Parthenon,

And in an absent idleness of thought

I scrawled upon the smooth and marble base.

Tell me, O memory, what wrote I there?

The name of a sucet clild I knew at Rome!

I was in $\Lambda$ sia. 'Twas a peerless night Lipon the plains of Sardis, and the moon, 'Touching my eyelids through the wind-stirred tent, Ilad witched me from my slumber. I arose, And silently stole forth, and by the brink 


\section{WILLIS:}

Of golden "Pactolus," where bathe his waters The bases of Cybele's columns fair,

I paced away the hours. In wakeful mood

I mused upon the storied past awhile,

Watching the moon, that with the same mild eye

Had looked upon the mighty Lybian kings

Sleeping around me-Crœsus, who had heaped

Within the mouldering portico his gold,

And Gyges, buried with his viewless ring

Beneath yon swelling tumulus-and then

I loitered up the valley to a small

And humbler ruin, where the undefiled*

Of the Apocalypse their garments kept

Spotless; and crossing with a conscious awe

The broken threshold, to my spirit's eye

It seemed as if, amid the moonlight, stood

"The angel of the church of Sardis" still!

And I again passed onward, and as dawn

Paled the bright morning star, I lay me down,

Weary and sad, beside the river's brink,

And 'twixt the moonlight and the rosy morn,

Wrote with my fingers in the golden "sands."

Tell me, O memory! what wrote I there?

The name of the sweet child I knew at Rome!

The dust is old upon my "sandal-shoon," And still I am a piigrim; I have roved From wild America to spicy Ind, And worshipped at innumerable shrines Of beauty, and the painter's art, to me, And sculpture, speak as with a living tongue, And of dead kingdoms, I recall the soul, Sitting amid their ruins. I have stored

* "Thou hast a few names even in Sardis which have not defiled their garments; and they shall walk with me in white; for they are worthy."-Rws. iii. 4. 


\section{LITTLE FLORENCE GRAY.}

My memory with thoughts that can allay Fever and sadness; and when life gets dim, And I am overladen in my years, Minister to me. But when wearily The mind gives over toiling, and, with eyes Open but seeing not, and senses all Lying awake within their chambers fine, Thought settles like a fountain, clear and calmFar in its sleeping depths, as 'twere a gem, Tell me, $\mathrm{O}$ memory! what shines so fair? The face of the sweet child I knew at Rome! 


\section{ALFORD.}

\section{HYMN TO THE SEA.}

Wно shall declare the secret of thy birth, Thou old companion of the circling earth?

And having marked with keen poetic sight

Ere beast or happy bird

Through the vast silence stirred,

Roll back the folded darkness of the primal night?

Corruption-like, thou teemedst in the graves

Of mouldering systems, with dark weltering waves

Troubling the peace of the first mother's womb;

Whose ancient awful form,

With inly tossing storm,

Unquiet heavings kept-a birth-place and a tomb.

Till the life-giving Spirit moved above

The face of the waters, with creative love

Warming the hidden seeds of infant light:

What time the mighty Word

Through thine abyss was heard,

And swam from out thy deeps the young day heavenly bright.

Thou and the earth, twin-sisters, as they say, In the old prime were fashioned in the day,

And therefore thou delightest evermore

With her to lie, and play

The summer hours away,

Curling thy loving ripples up her quiet shore.

She is married, a matron long ago,

With nations at her side; her milk doth flow 


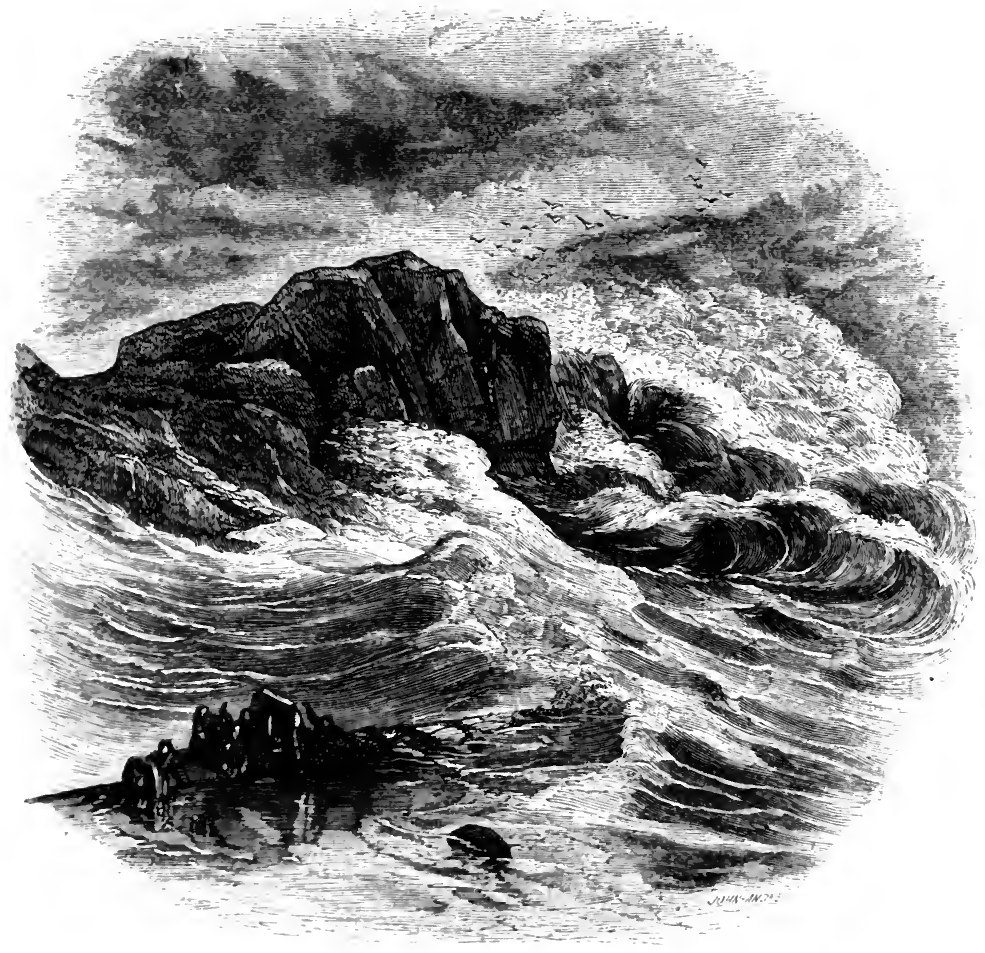

Eich year; but thee no husband dares to tame;

Thy wild will is thine own,

'Thy sole and virgin throne-

Thy mood is ever changing-thy resolve the same.

Sunlight and moonlight minister to thee;-

O'er the broul circle of the shoreless sea

Heaven's two great lights for ever set and rise;

While the round vault above,

In rast and silent love,

I. gazing down upon thee with his hundred eyes. 


\section{ALFORD.}

All night thou, utterest forth thy solemn moan,

Counting thy weary minutes all alone;

Then in the morning thou dost calmly lie,

Deep blue, ere yet the sun

His day-work hath begun,

Under the opening windows of the golden sky.

The spirit of the mountain looks on thee

Over an hundred hills; quaint shadows flee

Across thy marbled mirror; brooding lie

Storm-mists of infant cloud,

With a sight-baffling shroud

Mantling the grey-blue islands in the western sky.

Sometimes thou liftest up thine hands on high

Into the tempest-cloud that blurs the sky,

Holding rough dalliance with the fitful blast,

Whose stiff breath, whistling shrill,

Pierces with deadly chill

The wet crew feebly clinging to their shattered mast.

Foam-white along the border of the shore

Thine onward-leaping billows plunge and roar;

While o'er the pebbly ridges slowly glide

Cloaked figures, dim and grey,

Through the thick mist of spray,

Watching for some struck vessel in the boiling tide.

Daughter and darling of remotest eld-

'Time's childhood and Time's age thou hast beheld;

His arm is feeble and his eye is dim-

He tells old tales again-

He wearies of long pain;-

Thou art as at the first: thou journeyedst not with him. 


\section{THACKERAY.}

\section{THE BALLAD OF BOUILLABAISSE.}

A street there is in Paris famous,

For which no rhyme our language yields,

Rue Neuve des Petits Champs its name is-

The New Street of the Little Fields;

And here's an inn, not rich and splendid,

But still in comfortable case;

The which in youth $I$ oft attended,

To eat a bowl of Bouillabaisse.

This Bouillabaisse a noble dish is-

A sort of soup, or broth, or brew, Or hotchpotch of all sorts of fishes,

That Greenwich never could outdo;

Green herbs, red peppers, muscles, saffern,

Soles, onions, garlic, roach, and dace;

All these you eat at Terré's tavern,

In that one dish of Bouillabaisse.

Indeed, a rich and savoury stew 'tis;

And true philosophers, methinks,

Who love all sorts of natural beauties,

Should love good vietuals and good drinks.

And Cordelier or Benedictine

Might gladly, sure, his lot embrace,

Nor find a fast-day too afflicting,

Which served him up a Bonillabaisse. 


\section{THACKERAY.}

I wonder if the house still there is?

Yes, here the lamp is, as before;

The smiling, red-cheeked écaillère is

Still opening oysters at the door.

Is Terré still alive and able?

I recollect his droll grimace;

He'd come and smile before your table,

And hoped you liked your Bouillabaisse.

We enter; nothing's changed or older.

"How's Monsieur TERnÉ, waiter, pray?"

The waiter stares and shrugs his shoulder;-

"Monsieur is dead this many a day."

"It is the lot of saint and sinner.

So honest Terré's run his race?"

"What will Monsieur require for dinner?"

"Say, do you still cook Bouillabaisse?"

"Oh, oui, Monsieur," 's the waiter's answer;

"Quel vin Monsieur desire-t-il ?"

"Tell me a good one." "That I can, sir"

The Chambertin with yellow seal."

"So 'Terré's gone," I say, and sink in

My old accustomed corner-place ;

"He's done with feasting and with drinking,

With Burgundy and Bouillabaisse."

My old accustomed corner here is,

The table still is in the nook;

Ah! vanished many a busy year is,

This well-known chair since last I took.

When first I saw ye, Cari luoghi,

I'd scarce a beard upon my face,

And now a grizzled, grim old fogy,

I sit and wait for Bouillabaisse. 


\section{THE BALLAD OF BOUILLABAISSE.}

Where are you, old companions trusty Of early days, here met to dine?

Come, waiter! quick, a flagon crusty-

I'll pledge them in the good old wine.

The kind old voices and old faces

My memory can quick retrace;

Around the board they take their places, And share the wine and Bouillabaisse.

There's JACK has made a wondrous marriage;

'There's laughing Tox is laughing yet;

'There's brave Augustus drives his earriage;

There's poor old Fred in the Gazette;

On JAMEs's head the grass is growing:

Good Lord! 'The world has wagged apace

Since here we set the Claret flowing, And drank, and ate the Bouillabaisse.

Ah me! how quick the days are flitting!

I mind me of a time that's gone,

When lere I'd sit, as now I'm sitting,

In this same place-but not alone.

I fair young form was nestled near me,

A dear, dear face looked fondly up,

And sweetly spoke and smiled to cheer me

-There's no one now to share my cup.

I drink it as the Fates ordain it.

Come, fill it, and have done with rhymes;

Fill up the lonely glass, and drain it

In memory of dear old times.

Welcome the wine, whate'er the seal is;

And sit you down and say your grace

With thankful heart, whate' the meal is.

- Here romes the smoking Bouillabaisse. 


\section{THACKERAY.}

\section{THE END OF THE PLAY.}

The play is done; the curtain drops,

Slow falling to the prompter's bell:

A moment yet the actor stops,

And looks around to say farewell.

It is an irksome word and task;

And, when he's laughed and said his say,

He shows, as he removes the mask,

A face that's any thing but gay.

One word, ere yet the evening ends,

Let's close it with a parting rhyme,

And pledge a hand to all young friends,

As fits the merry Christmas time.

On life's wide scene you, too, have parts,

That Fate ere long shall bid you play;

Good-night! with honest gentle hearts

A kindly greeting go alway!

Good-night!-I'd say, the griefs, the joys,

Just hinted in this mimic page,

The triumphs and defeats of boys,

Are but repeated in our age.

I'd say, your woes were not less keen,

Your hopes more vain than those of men;

Your pangs or pleasures of fifteen

At forty-five played o'er again.

I'd say we suffer and we strive,

Not less nor more as men than boys;

With grizzled beards at forty-five,

As erst at twelve in corduroys, 
And if in time of sacred youth,

We learned at home to love and pray, Pray Heaven that early Love and 'Truth May never wholly pass away.

And in the world, as in the school,

I'd say, how fate may change and shift;

The prize be sometimes with the fool,

The race not always to the swift.

The strong may yield, the good may fall,

The great man be a vulgar clown,

The knave be lifted over all,

The kind cast pitilessly down.

Who knows the inscrutable design?

Blessed be $\mathrm{He}$ who took and gave! Why should your mother, Charles, not mine,

Be weeping at her darling's grave?

We bow to Heaven that willed it so,

That darkly rules the fate of all, 'That sends the respite or the blow,

That's free to give or to recall.

This crowns his feast with wine and wit:

Who brought him to that mirth and state?

His betters, see, below him sit,

Or hunger hopeless at the gate.

Who bade the mud from Dives' wheel

To spurn the rags of Lazarus?

Come, brother, in that dust we'll kneel,

Confessing Heaven that ruled it thus.

So each shall mourn, in life's advance,

Dear hopes, dear friends, untimely killed;

Shall grieve for many a forfeit chance,

And longing passion unfulfilled. 


\section{THACKERAY.}

Amen! whatever fate be sent,

Pray God the heart may kindly glow, Although the head with cares be bent, And whitened with the winter snow.

Come wealth or want, come good or ill, Let young and old accept their part, And bow before the Awful Will,

And bear it with an honest heart.

Who misses, or who wins the prize?

Go, lose or conquer as you can :

But if you fail, or if you rise,

Be each, pray God, a gentleman.

\section{A gentleman, or old or young !}

(Bear kindly with my humble lays ;)

The sacred chorus first was sung

Upon the first of Christmas days:

The shepherds heard it overhead-

The joyful angels raised it then :

Glory to Heaven on high, it said,

And peace on earth to gentle men.

My song, save this, is little worth ;

I lay the weary pen aside,

And wish you health, and love, and mirth,

As fits the solemn Christmas-tide.

As fits the holy Christmas birth,

Be this, good friends, our carol still-

Be peace on earth, be peace on earth,

To men of gentle will. 


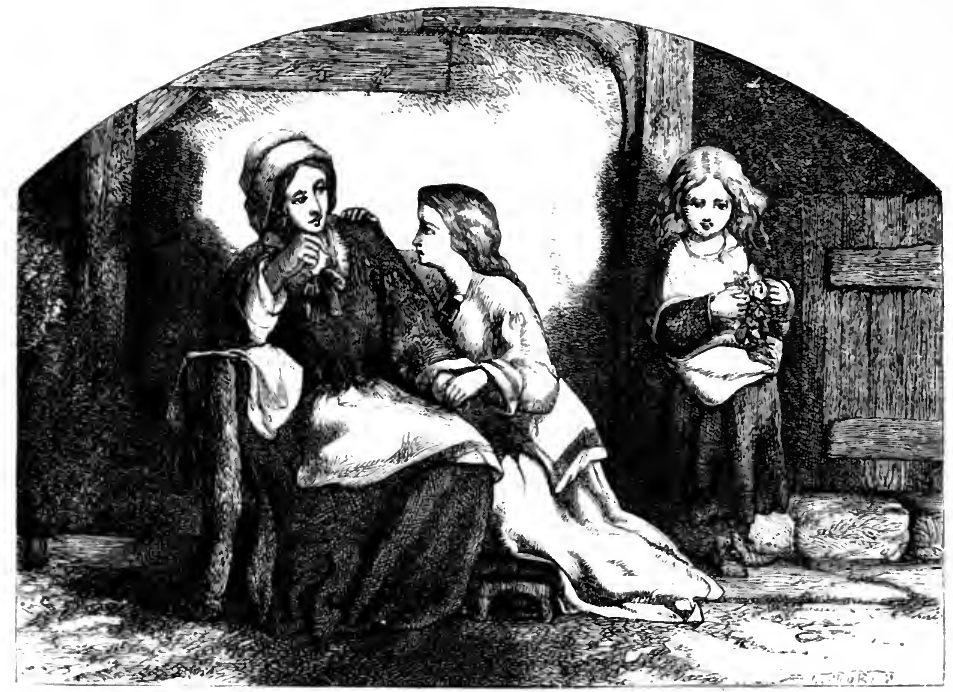

\section{TENNYSON.}

\section{THE MAY QUEEN.}

Yov must wake and call me early, call me early, mother dear:

T()-morrow 'ill be the happiest time of all the glad New-year;

Of' all the glad New-year, mother, the maddest merriest day;

For I'm to be Queen o' the May, mother, I'm to be Queen o' the May.

There's many a black black eye, they say, but none so bright as mine;

'There's Margatret and Mary, there's Kate and Caroline:

But none so fair as little Alice in all the land they say,

So I'm to be Queen o' the May, mother, I'm to be Queen o' the May.

I sleep so sound all night, mother, that I shall never wake,

If you do not call me loul when the day begins to break:

But I must gather knots of flowers, and buds and garlands gay,

For I'm to be Queen o' the May, mother, I'm to be Queen o' the May. 


\section{TENNYSON.}

As I came up the valley, whom think ye should I see,

But Robin leaning on the bridge beneath the hazel-tree?

He thought of that sharp look, mother, I gave him yesterday,-

But I'm to be Queen o' the May, mother, I'm to be Queen o' the May.

He thought I was a ghost, mother, for I was all in white, And I ran by him without speaking, like a flash of light. They call me cruel-hearted, but I care not what they say, For I'm to be Queen o' the May, mother, I'm to be Queen o' the May.

They say he's dying all for love, but that can never be: They say his heart is breaking, mother,-what is that to me?

There's many a bolder lad 'ill woo me any summer day, For I'm to be Queen o' the May; mother, I'm to be Queen o' the May.

Little Effie shall go with me to-morrow to the green, And you'll be there, too, mother, to see me made the Queen; For the shepherd-lads on every side 'ill come from far away, And I'm to be Queen o' the May, mother, I'm to be Queen o' the May.

'The honeysuckle round the porch has wov'n its wavy bowers, And by the meadow-trenches blow the faint sweet cuckoo-flowers; And the wild marsh-marigold shines like fire in swamps and hollows gray, And I'm to be Queen o' the May, mother, I'm to be Queen o' the May.

The night-winds come and go, mother, upon the meadow-grass, And the happy stars above them seem to brighten as they pass; There will not be a drop of rain the whole of the live-long day, And I'm to be Queen o' the May, mother, I'm to be Queen o' the May.

All the valley, mother, 'ill be fresh and green and still, And the cowslip and the crowfoot are over all the hill, And the rivulet in the flowery dale 'ill merrily glance and play, For I'm to be Queen o' the May, mother, I'm to be Queen o' the May.

So you must wake and call me early, call me early, mother dear, To-morrow 'ill be the happiest time of all the glad New-year;

To-morrow 'ill be of all the year the maddest merriest day, For I'm to be Queen o' the May, mother, I'm to be Queen o' the May. 


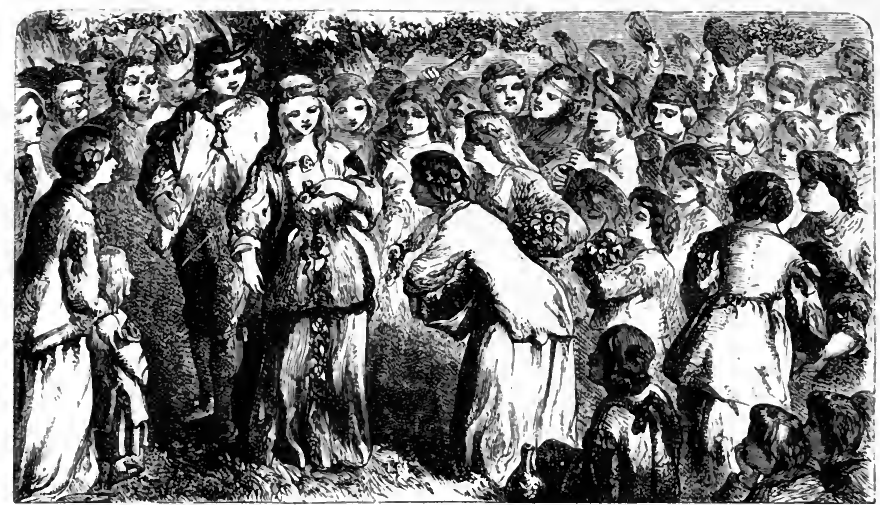

NEW-YEAR'S EVE.

If you're waking call me early, call me early, mother dear, For I would see the sun rise upon the glad New-year:

It is the last New-year that I shall ever see, Then you may lay me low i' the mould, and think no more of me.

To-night I saw the sun set: he set and left behind

- The good old year, the dear old time, and all my peace of mind; And the New-year's coming up, mother, but I shall never see The blossom on the blackthorn, the leaf upon the tree.

Last May we made a crown of flowers; we had a merry day: Beneath the hawthorn on the Green they made me Queen of May; And we danced about the May-pole and in the hazel copse, Till Charles's Wain eame out above the tall white chimney-tops.

There's not a flower on all the hills: the frost is on the pane:

I only wish to live till the snowdrops come again:

I wish the snow would melt, and the sun come out on high:

I long to see a flower so before the day I die.

The building rook 'ill eaw from the windy tall elm-tree, And the tufted plover pipe along the fallow lea, And the swallow 'ill come back again with summer o'er the wave,But I shall lie alone, mother, within the mouldering grave. 


\section{TENNYSON.}

Upon the chancel-casement, and upon that grave of mine, In the early early morning the summer sun 'ill shine, Before the red cock crows from the barn upon the hill, When you are warm asleep, mother, and all the world is still.

When the flowers come again, mother, beneath the waning light You'll never see me more in the long gray fields at night; When from the dry dark wold the summer airs blow cool On the oat-grass and the sword-grass, and the bulrush in the pool.

You'll bury me, my mother, just beneath the hawthorn shade, And you'll come sometimes and see me where I am lowly laid. I shall not forget you, mother; I shall hear you when you pass, With your feet above my head in the long and pleasant grass.

I have been wild and wayward, but you'll forgive me now; You'll kiss me, my own mother, upon my cheek and brow; Nay, nay, you must not weep, nor let your grief be wild, You should not fiet for me, mother,-you have another child.

If I can I'll come again, mother, from out my resting-place; Though you'll not see me, mother, I shall look upon your face; Though I cannot speak a word, I shall hearken what you say, And be often, often with you, when you think I'm far away.

Good-night, good-night, when I have said good-night for evermore, And you see me carried out from the threshold of the door; Don't let Effie come to see me till my grave be growing green: She'll be a better child to you than ever I have been.

She'll find my garden-tools upon the granary floor:

Let her take 'em: they are hers: I shall never garden more: But tell her, when I'm gone, to train the rose-bush that I set About the parlour-window and the box of mignonette.

Good-night, sweet mother: call me before the day is born. All night $I$ lie awake, but $I$ fall asleep at morn;

But I would see the sun rise upon the glad New-year, So, if you're waking, call me, call me early, mother dear. 


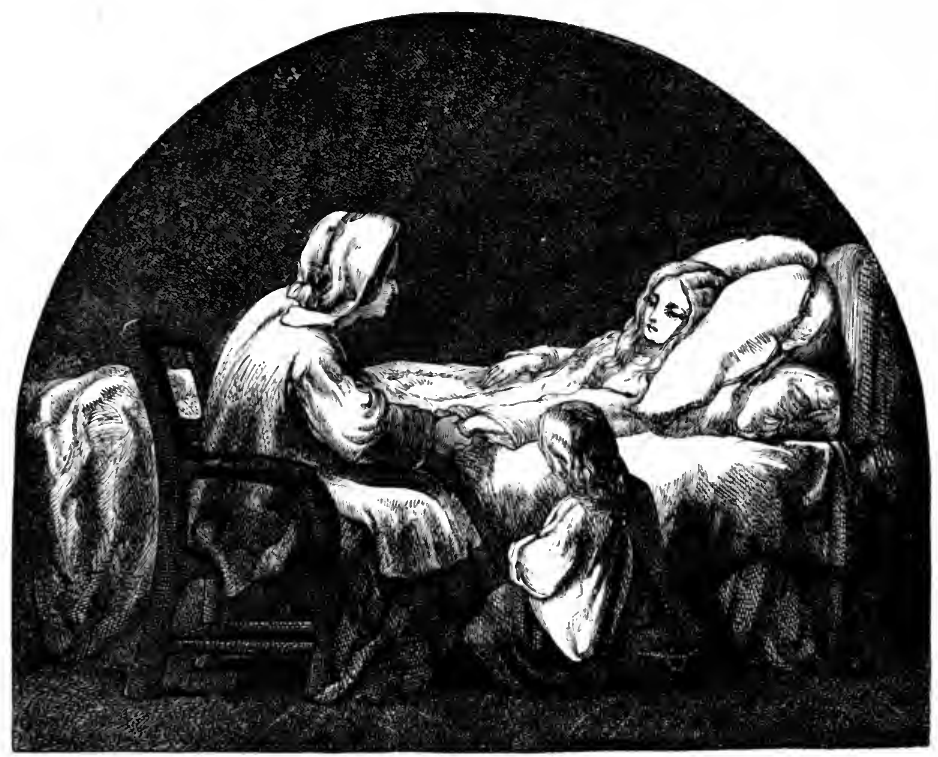

CONCLUSION.

I thought to pass away before, and yet alive I am;

And in the fields all round I hear the bleating of the lamb.

IIow sadly, I remember, rose the morning of the year!

'To die before the snowdrop came, and now the violet's here.

() sweet is the new violet, that comes beneath the skies, And sweeter is the young lamb's voice to me that cannot rise, And sweet is all the land about, and all the flowers that blow, And sweeter far is death than life to me that long to go.

It seemed so hard at first, mother, to leave the blessed sun, And now it seems as hard to stay, and yet His will be done!

lut still I think it can't be long before I find release;

And that good man, the clergyman, has told me words of peace.

O blessings on his kindly voice, and on his silver hair!

And blessings on his whole life long, until he meet me there!

O blessings on his kindly heart, and on his silver head!

I thousand times I blest him, as he knelt beside my bed. 
He show'd me all the mercy, for he tanght me all the sin:

Now, though my lamp was lighted late, there's One will let me in:

Nor would I now be well, mother, again, if that could be,

For my desire is but to pass to Him that died for me.

I did not hear the dog howl, mother, or the death-wateh beat,

There came a sweeter token when the night and morning meet:

But sit beside my bed, mother, and put your hand in mine,

And Effie on the other side, and I will tell the sign.

All in the wild March-morning I heard the angels call;

It was when the moon was setting, and the dark was over all;

The trees began to whisper, and the wind began to roll, And in the wild March-morning I heard them call my soul.

For lying broad awake I thought of you and Effie dear;

I saw you sitting in the house, and I no longer here;

With all my strength I prayed for both, and so I felt resign'd,

And up the valley came a swell of music on the wind.

I thought that it was fancy, and I listen'd in my bed,

And then did something speak to me-I know not what was said;

For great delight and shuddering took hold of all my mind,

And up the valley came again the music on the wind.

But you were sleeping; and I șaid, "It's not for them: it's mine."

And if it comes three times, I thought, I take it for a sign.

And once again it came, and close beside the window-bars;

Then seem'd to go right up to Heaven, and die among the stars.

So now I think my time is near. I trust it is. I know

The blessed music went that way my soul will have to go.

And for myself, indeed, I care not if I go to-day.

But, Effie, you must comfort her when I am past away.

And say to Robin a kind word, and tell him not to fret;

There's many worthier than I, would make him happy yet.

If I had lived-I cannot tell-I might have been his wife;

But all these things have ceased to be, with my desire of life. 
O look! the sun begins to rise, the heavens are in a glow; He shines upon a hundred fields, and all of them I know. And there I move no longer now, and there his light may shineWild flowers in the valley for other hands than mine.

$\mathrm{O}$ sweet and strange it seems to me, that ere this day is done The roice, that now is speaking, may be beyond the sunFor ever and for ever with those just souls and trueAnd what is life, that we should moan? why make we such ado?

For ever and for ever, all in a blessed homeAnd there to wait a little while till you and Effie come; 'To lie within the light of God, as I lie upon your breastAnd the wicked cease from troubling, and the weary are at rest.

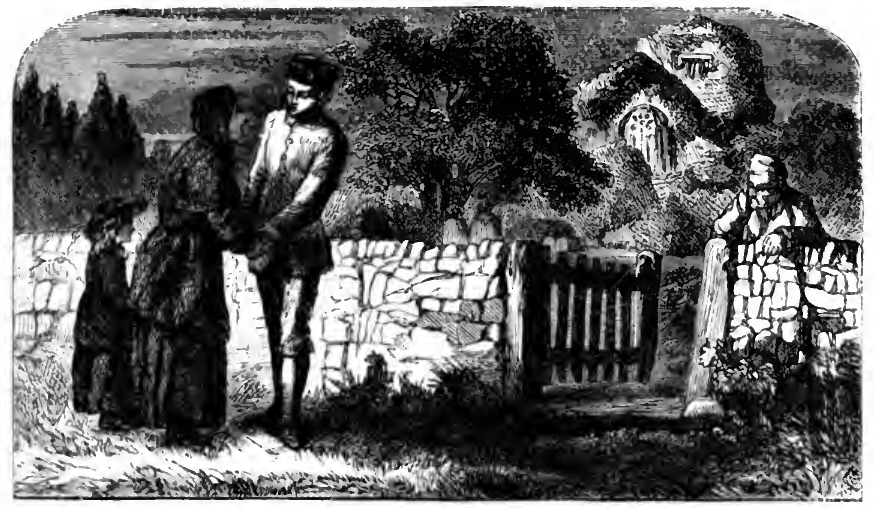




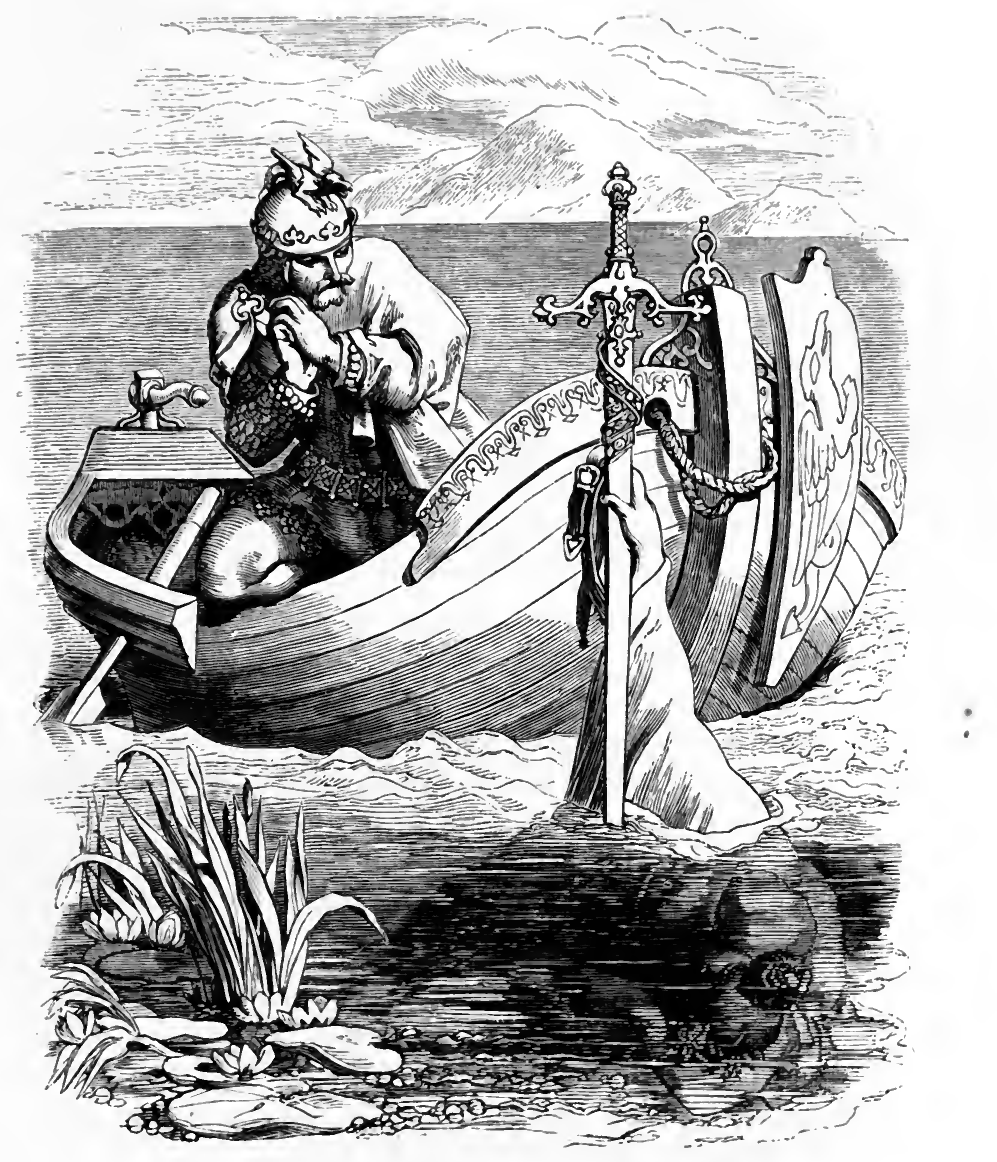

MORTE D'ARTHUR.

So all day long the noise of battle roll'd Among the mountains by the winter sea; 
Until King Arthur's table, man by man, Had fall'n in Lyonness about their Lord, King Arthur: then, because his wound was deep, The bold Sir Bedivere uplifted him, Sir Bedivere, the last of all his knights, And bore him to a chapel nigh the field, A broken chancel with a broken cross, That stood on a dark strait of barren land.

On one side lay the Ocean, and on one Lay a great water, and the moon was full.

Then spake King Arthur to Sir Bedivere : "The sequel of to-day unsolders all The goodliest fellowship of famous knights Whereof this world holds record. Such a sleep They sleep-the men I loved. I think that we Shall never more, at any future time, Delight our souls with talk of knightly deeds, Walking about the gardens and the halls Of Camelot, as in the days that were.

I perish by this people which I made,Tho' Merlin sware that $I$ should come again To rule once more-but let what will be, be, I am so deeply smitten thro' the helm 'That without help I cannot last till morn. Thou therefore take my brand Excalibur, Which was my pride: for thou rememberest how In those old days, one summer noon, an arm Rose up from out the bosom of the lake, Clothed in white samite, mystic, wonderful, Iolling the sword-and how I row'd across And took it, and have worn it, like a king: $\Lambda$ nd, wheresoever I am sung or told In aftertime, this also shall be known: But now delay not: take Excalibur, And fling him far into the middle mere:

Watch what thon seëst, and lightly bring me word."

To him replied the bold Sir Bedivere: 
"It is not meet, Sir King, to leave thee thus, Aidless, alone, and smitten thro' the helm.

A little thing may harm a wounded man.

Yet I thy hest will all perform at full,

Watch what I see, and lightly bring thee word."

So saying, from the ruin'd shrine he stept

And in the moon athwart the place of tombs,

Where lay the mighty bones of ancient men,

Old knights, and over them the sea-wind sang

Shrill, chill, with flakes of foam. He, stepping down

By zig-zag paths, and juts of pointed rock,

Came on the shining levels of the lake.

There drew he forth the brand Excalibur,

And o'er him, drawing it, the winter moon,

Brightening the skirts of a long cloud, ran forth

And sparkled keen with frost against the hilt:

For all the haft twinkled with diamond sparks,

Myriads of topaz-lights, and jacinth-work

Of subtlest jewellery. He gazed so long

That both his eyes were dazzled, as he stood,

This way and that dividing the swift mind,

In act to throw: but at the last it seem'd

Better to leave Excalibur conceal'd

There in the many-knotted waterflags,

That whistled stiff and dry about the marge.

So strode he back slow to the wounded King.

Then spake King Arthur to Sir Bedivere:

"Hast thou perform'd my mission which I gave?

What is it thou hast seen? or what hast heard?"

And answer made the bold Sir Bedivere:

"I heard the ripple washing in the reeds,

And the wild water lapping on the crag."

To whom replied King Arthur, faint and pale:

"Thou hast betray'd thy nature and thy name,

Not rendering true answer, as beseem'd

Thy fëalty, nor like a noble knight:

For surer sign had follow'd, either hand, 
Or voice, or else a motion of the mere. This is a shameful thing for men to lie. Yet now, I charge thee, quickly go again As thou art lief and dear, and do the thing I bad thee, watch, and lightly bring me word." Then went Sir Bedivere the second time Across the ridge, and paced beside the mere, Counting the dewy pebbles, fix'd in thought; But when he saw the wonder of the hilt, How curiously and strangely chased, he smote His palms together, and he cried aloud. "And if indeed I cast the brand away, Surely a precious thing, one worthy note, Should thus be lost for ever from the earth, Which might have pleased the eyes of many men. What good should follow this, if this were done?

What harm, undone? deep harm to disobey, Seeing obedience is the bond of rule.

Were it well to obey then, if a king demand An aet unprofitable, against himself?

The King is siek, and knows not what he does. What record, or what relic of my lord Should be to aftertime, but empty breath And rumours of a doubt? but were this kept, Stored in some treasure-house of mighty kings, Some one might show it at a joust of arms, Saying, 'King Arthur's sword, Exealibur, Wrought by the lonely maiden of the Lake. Nine years she wrought it, sitting in the deeps Upon the hidden bases of the hills.'

So might some old man speak in the aftertime To all the people, winning reverence.

But now much honour and much fame were lost."

So spake he, elouded with his own conceit, And hid Excalibur the seeond time, And so strode back slow to the wounded King. Then spoke King $\Lambda$ rthur, breathing heavily: 
"What is it thou hast seen? or what hast heard?" And answer made the bold Sir Bedivere:

"I heard the water lapping on the crag, And the long ripple washing in the reeds."

To whom replied King Arthur, much in wrath:

"Ah, miserable and unkind, untrue,

Unknightly, traitor-hearted! Woe is me !

Authority forgets a dying king,

Laid widow'd of the power in his eye

That bow'd the will. I see thee what thou art,

For thou, the latest-left of all my knights,

In whom should meet the offices of all,

Thou wouldst betray me for the precious hilt;

Either from lust of gold, or like a girl

Valuing the giddy pleasure of the eyes.

Yet, for a man may fail in duty twice,

And the third time may prosper, get thee hence:

But, if thou spare to fling Excalibur,

I will arise and slay thee with my hands."

Then quickly rose Sir Bedivere, and ran, And, leaping down the ridges lightly, plunged Among the bulrush-beds, and cluteh'd the sword, And strongly wheel'd and threw it. The great brand Made lightnings in the splendour of the moon, And flashing round and round, and whirl'd in an arch, Shot like a streamer of the northern morn, Seen where the moving isles of winter shock By night, with noises of the northern sea. So flash'd and fell the brand Excalibur:

But ere he dipt the surface, rose an arm

Clothed in white samite, mystic, wonderful, And caught him by the hilt, and brandish'd him Three times, and drew him under in the mere. And lightly went the other to the King.

Then spoke King Arthur, drawing thicker breath: "Now see I by thine eyes that this is done. Speak out: what is it thou hast heard, or seen?" 
And answer made the bold Sir Bedivere:

"Sir King, I closed mine eyelids, lest the gems

Should blind my purpose, for I never saw,

Nor shall see, here or elsewhere, till I die,

Not tho' I live three lives of mortal men,

So great a miracle as yonder hilt.

Then with both hands I flung him, wheeling him;

But when I look'd again, behold an arm,

Clothed in white samite, mystic, wonderful,

That caught him by the hilt, and brandish'd him

Three times, and drew him under in the mere."

And answer made King Arthur, breathing hard:

"My end draws nigh; 'tis time that $\mathrm{I}$ were gone.

Make broad thy shoulders to receive my weight,

And bear me to the margin; yet I fear

My wound hath taken cold, and I shall die."

So saying, from the pavement he half rose,

Slowly, with pain, reclining on his arm,

And looking wistfully with wide blue eyes

As in a pieture. Him Sir Bedivere

Remorsefully regarded thro' his tears,

And would have spoken, but he found not words,

Then took with eare, and kneeling on one knee,

O'er both his shoulders drew the languid hands,

And rising bore him thro' the place of tombs.

But, as he walk'd, King Arthur panted hard,

Like one that feels a nightmare on his bed

When all the house is mute. So sigh'd the King,

Muttering and murmuring at his ear "Quick, quick!

I fear it is too late, and I shall die."

But the other swiftly strode from ridge to ridge,

Clothed with his breath, and looking, as he walk'd,

Larger than human on the frozen hills.

He heard the deep behind him, and a cry

Before. His own thought drove him like a goad.

Dry claslid his harness in the icy eaves

And barren chasms, and all to left and right 


\section{TENNYSON.}

The bare black cliff clang'd round him, as he based

His feet on juts of slippery crag that rang

Sharp-smitten with the dint of armed heels-

And on a sudden, lo! the level lake,

And the long glories of the winter moon.

Then saw they how there hove a dusky barge,

Dark as a funeral scarf from stem to stern,

Beneath them; and descending they were ware

That all the decks were dense with stately forms

Black-stoled, black-hooded, like a dream-by these

Three Queens with crowns of gold-and from them rose

A cry that shiver'd to the tingling stars,

And, as it were one voice, an agony

Of lamentation, like a wind, that shrills

All night in a waste land, where no one comes,

Or hath come, since the making of the world.

Then murmur'd Arthur, "Place me in the barge,"

And to the barge they came. There those three Queens

Put forth their hands, and took the King, and wept.

But she, that rose the tallest of them all

And fairest, laid his head upon her lap,

And loosed the shatter'd casque, and chafed his hands,

And call'd him by his name, complaining loud,

And dropping bitter tears against his brow

Striped with dark blood: for all his face was white

And colourless, and like the wither'd moon

Smote by the fresh beam of the springing east;

And all his greaves and cuisses dash'd with drops

Of onset; and the light and lustrous curls-

That made his forehead like a rising sun

High from the däis-throne-were parch'd with dust;

Or, clotted into points and hanging loose,

Mix'd with the knightly growth that fringed his lips.

So like a shatter'd column lay the King;

Not like that Arthur who, with lance in rest,

From spur to plume a star of tournament, 
Shot thro' the lists at Camelot, and charged Before the eyes of ladies and of kings.

Then loudly cried the bold Sir Bedivere, "Ah! my Lord Arthur, whither shall I go? Where shall I hide my forehead and my eyes?

For now I see the true old times are dead, When every morning brought a noble chance, And every chance brought out a noble knight. Such times have been not since the light that led The holy Elders with the gift of myrrh.

But now the whole Round table is dissolved Which was an image of the mighty world;

And I, the last, go forth companionless, And the days darken round me, and the years, Among new men, strange faces, other minds." And slowly answer'd Aithur from the barge: "The old order changeth, yielding place to new, And God fulfils himself in many ways, Lest one good custom should corrupt the world. Comfort thyself: what comfort is in me? I have lived my life, and that which I have done May He within himself make pure! but thou, If thou shouldst never see my face again, Pray for my soul. More things are wrought by prayer Than this world dreams of. Wherefore, let thy voice Rise like a fountain for me night and day. For what are men better than sheep or goats That nourish a blind life within the brain, If, knowing God, they lift not hands of prayer Both for themselves and those who call them friend?

For so the whole round earth is every way Bound by gold chains about the feet of God.

But now farewell. I am going a long way

With these thou seëst-if indeed I go(For all my mind is clouded with a doubt) To the island-ralley of Avilion;

Where falls not hail, or rain, or any snow, 


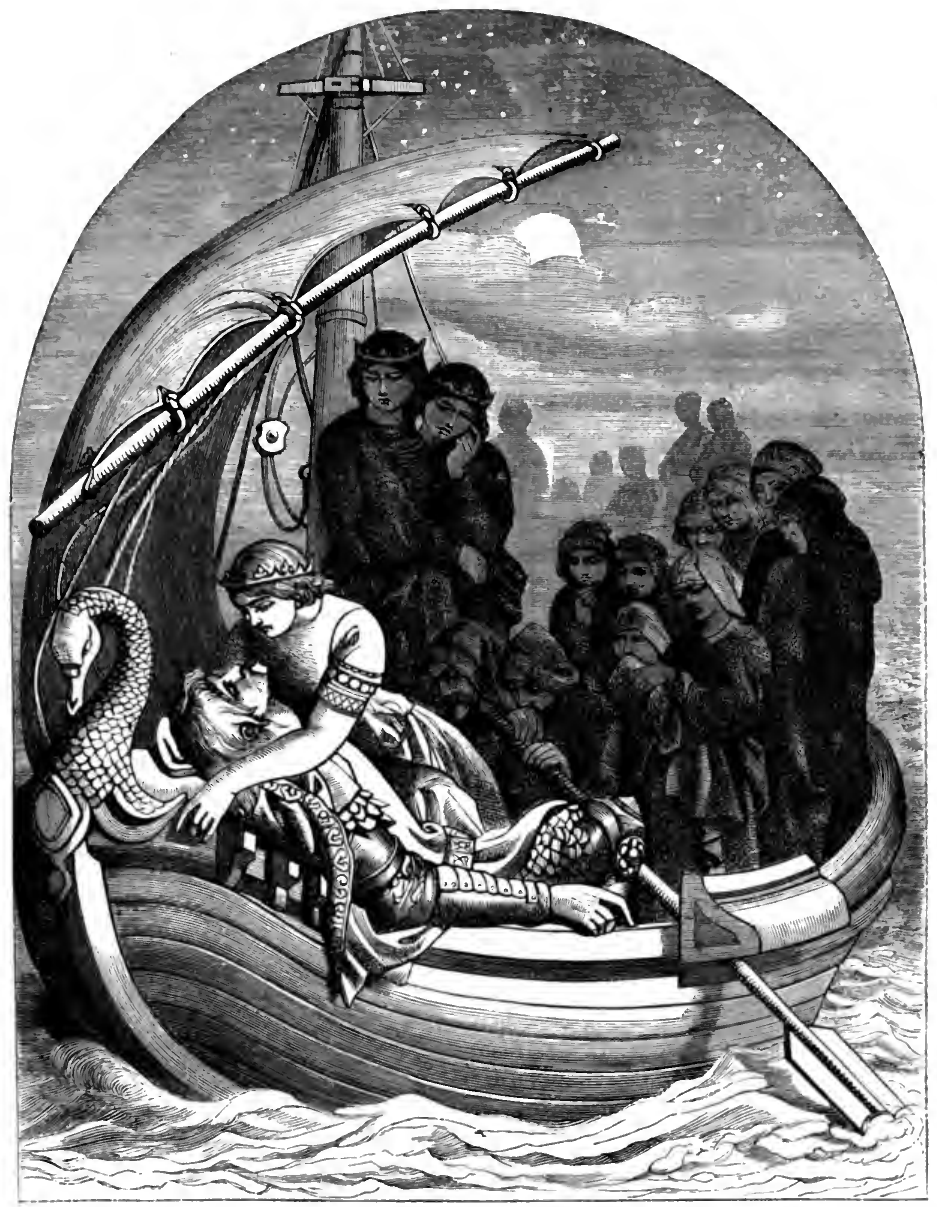

Nor ever wind blows loudly; but it lies Deep-meadow'd, happy, fair with orchard-lawns And bowery hollows crown'd with summer sea, Where I will heal me of my grievous wound." 
So said he, and the barge with oar and sail Moved from the brink, like some full-breasted swan That, fluting a wild carol ere her death, Ruffles her pure cold plume, and takes the flood With swarthy webs. Long stood Sir Bedivere Revolving many memories, till the hull Look'd one black dot against the verge of dawn, And on the mere the wailing died away. 


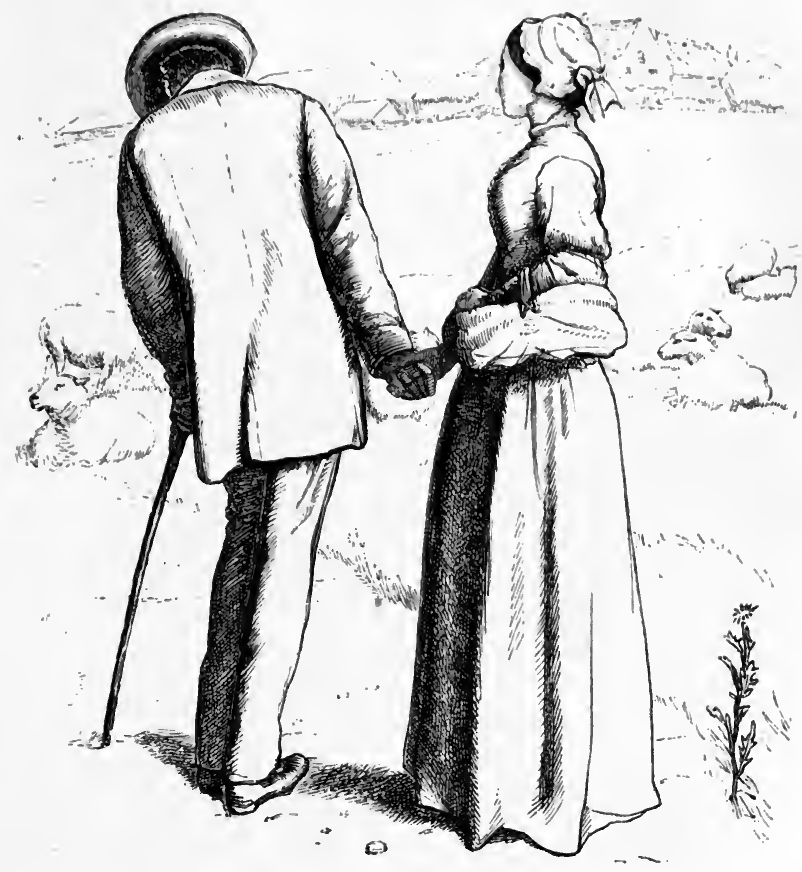

EDWARD GRAY

SweEt Emma Moreland of yonder town Met me walking on yonder way,

"And have you lost your heart?" she said; "And are you married yet, Edward Gray?"

Sweet Emma Moreland spoke to me:

Bitterly weeping I turn'd away:

"Sweet Emma Moreland, love no more

Can touch the heart of Edward Gray 
"Ellen Adair she loved me well,

Against her father's and mother's will:

'To-day I sat for an hour and wept,

By Ellen's grave, on the windy hill.

"Shy she was, and I thought her cold;

Thought her proud, and fled over the sea;

Fill'd I was with folly and spite,

When Ellen Adair was dying for me.

"Cruel, cruel the words I said!

Cruelly came they back to-day:

'You're too slight and fickle,' I said,

'To trouble the heart of Edward Gray.'

"There I put my face in the grass-

Whisper'd, 'Listen to my despair:

I repent me of all $I$ did:

Speak a little, Ellen Adair!'

"Then I took a pencil, and wrote

On the mossy stone, as I lay,

'Here lies the body of Ellen Adair;

And here the heart of Edward Gray!'

"Love may come, and love may go,

And fly, like a bird, from tree to tree:

But I will love no more, no more,

Till Ellen Adair come back to me.

"Bitterly wept I over the stone:

Bitterly weeping I turn'd away:

There lies the body of Ellen Adair !

And there the heart of Edward Gray!". 


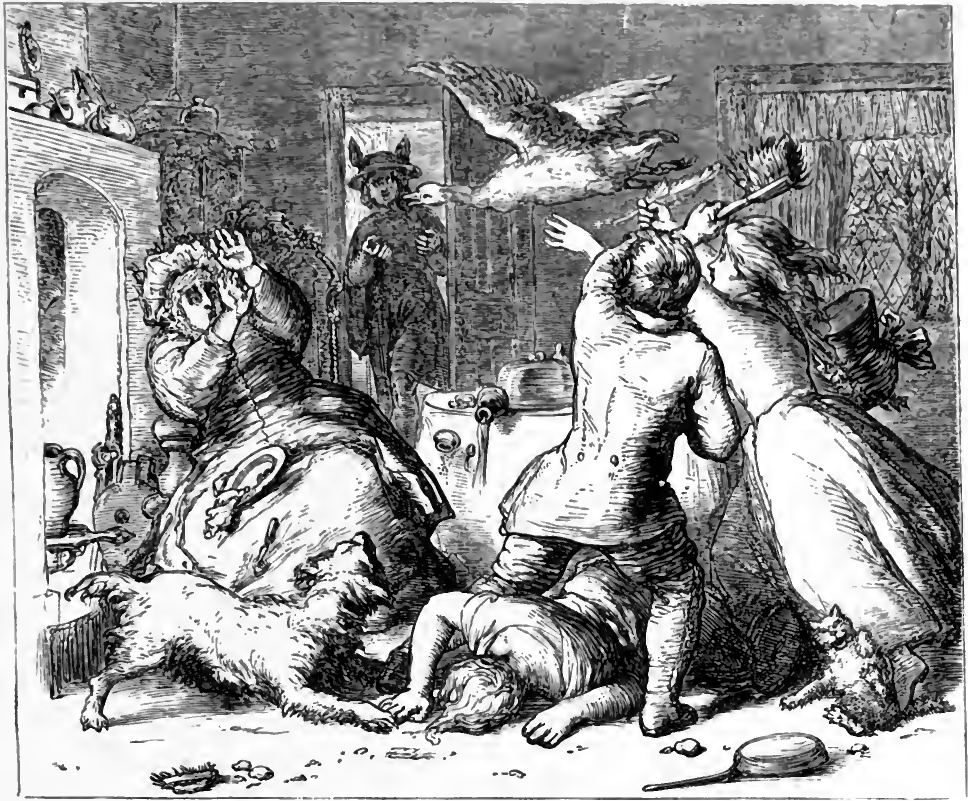

THE GOOSE.

I kNEw an old wife lean and poor,

Her rags scarce held together;

There strode a stranger to the door,

And it was windy weather.

He held a goose upon his arm,

He utter'd rhyme and reason,

"Here, take the goose, and keep you warm,

It is a stormy season."

She caught the white goose by the leg,

A goose-'twas no great matter.

The goose let fall a golden egg

With cackle and with clatter. 
THE GOOSE.

She dropt the goose, and caught the pelf, And ran to tell her neighbours; And bless'd herself, and cursed herself, And rested from her labours.

And feeding high, and living soft, Grew plump and able-bodied; Until the grave churchwarden doff'd, The parson smirk'd and nodded.

So sitting, served by man and maid, She felt her heart grow prouder : But ah! the more the white goose laid It clack'd and cackled louder.

It clutter'd here, it chuckled there; It stirr'd the old wife's mettle: She shifted in her elbow-chair, And hurl'd the pan and kettle.

"A quinsy choke thy cursed note!" Then wax'd her anger stronger.

"Go, take the goose, and wring her throat, I will not bear it longer."

Then yelp'd the cur, and yawl'd the cat;

Ran Gaffer, stumbled Gammer.

The goose flew this way and flew that, And fill'd the house with clamour.

As head and heels upon the floor

They flounder'd all together, There strode a stranger to the door, And it was windy weather: 


\section{TENNYSON.}

He took the goose upon his arm,

He utter'd words of scorning;

"So keep you cold, or keep you warm,

It is a stormy morning."

The wild wind rang from park and plain,

And round the attics rumbled,

Till all the tables danced again,

And half the chimneys tumbled.

The glass blew in, the fire blew out,

The blast was hard and harder.

Her cap blew off, her gown blew up, And a whirlwind clear'd the larder;

And while on all sides breaking loose

Her household fled the danger,

Quoth she, "The Devil take the goose,

And God forget the stranger !" 


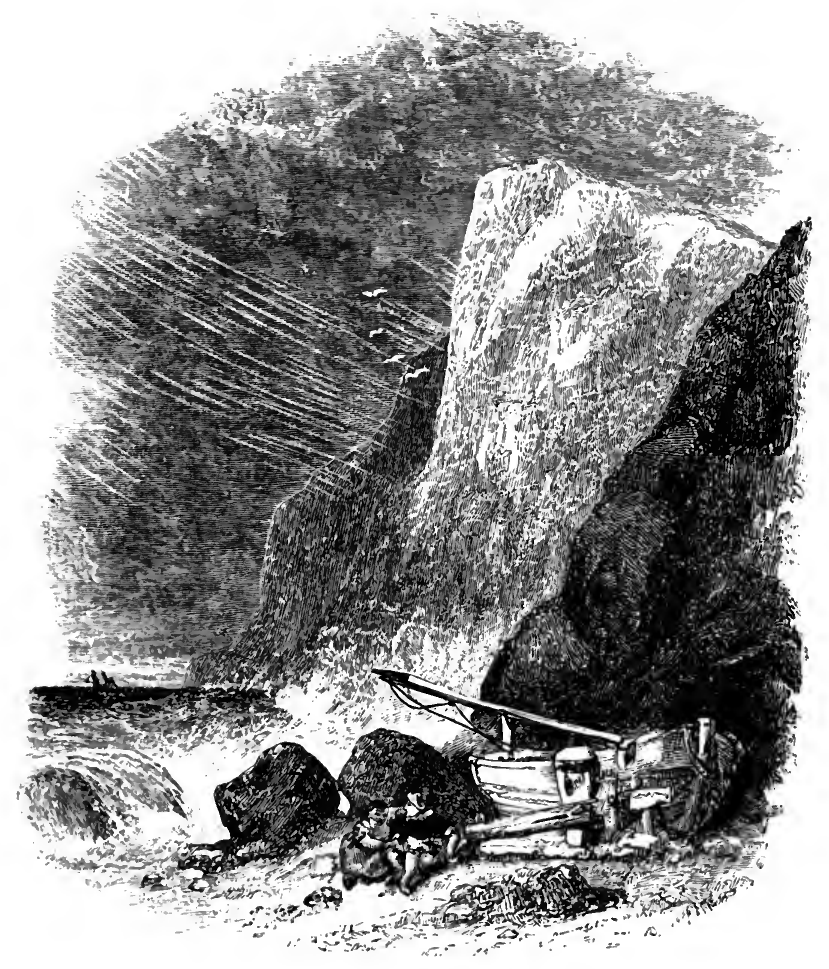

BREAK, break, break,

On thy cold gray stones, O Sea!

And I would that my tongue could utter

The thoughts that arise in me.

O well for the fisherman's boy,

That he shouts with his sister at play!

O well for the sailor lad,

That he sings in his boat on the bay! 


\section{TENNYSON.}

And the stately ships go on

'To their haven under the hill;

But $O$ for the touch of a vanish'd hand, And the sound of a voice that is still!

Break, break, break, At the foot of thy crags, O Sea!

But the tender grace of a day that is dead Will never come back to me. 


\section{COOKE.}

FLORENCE VANE.

I LOVED thee long and dearly, Florence Vane;

My life's bright dream, and early

Hath come again;

I renew in my fond vision, My heart's dear pain, My hope, and thy derision, Florence Vane.

The ruin lone and hoary,

The ruin old,

Where thou didst mark my story,

At even told,-

That spot-the hues Elysian

Of sky and plain-

I treasure in my vision, Florence Vane.

Thou wast lovelier than the roses

In their prime;

Thy voice excelled the closes

Of sweetest rhyme;

Thy heart was as a river

Without a main.

Would I had loved thee never,

Florence Vane!

But, fairest, coldest wonder !

Thy glorious clay

Lieth the green sod under-

Alas the day! 
COOKE.

And it boots not to remember

Thy disdain-

To quicken love's pale ember, Florence Vane.

The lilies of the valley

By young graves weep,

The pansies love to dally

Where maidens sleep;

May their bloom, in beauty vying,

Never wane

Where thine earthly part is lying, Florence Vane!

\section{YOUNG ROSALIE LEE.}

I LOVE to forget ambition,

And hope, in the mingled thought

Of valley, and wood, and meadow,

Where, whilom, my spirit caught

Affection's holiest breathings-

Where under the skies, with me

Young Rosalie roved, aye drinking

From joy's bright Castaly.

I think of the valley and river, Of the old wood bright with blossoms;

Of the pure and chastened gladness

Upspringing in our bosoms.

I think of the lonely turtle

So tongued with melancholy;

Of the hue of the drooping moonlight,

And the starlight pure and holy. 
Of the beat of a heart most tender,

The sigh of a shell-tinct lip

As soft as the land-tones wandering

Far leagues over ocean deep;

Of a step as light in its falling

On the breast of the beaded lea

As the fall of the faery moonligint

On the leaf of yon tulip tree.

I think of these-and the murmur

Of bird, and katydid,

Whose home is the grave-yard cypress,

Whose goblet the honey-reed.

And then I weep! for Rosalie

Has gone to her early rest;

And the green-lipped reed and the daisy

Suck sweets from her maiden breast. 


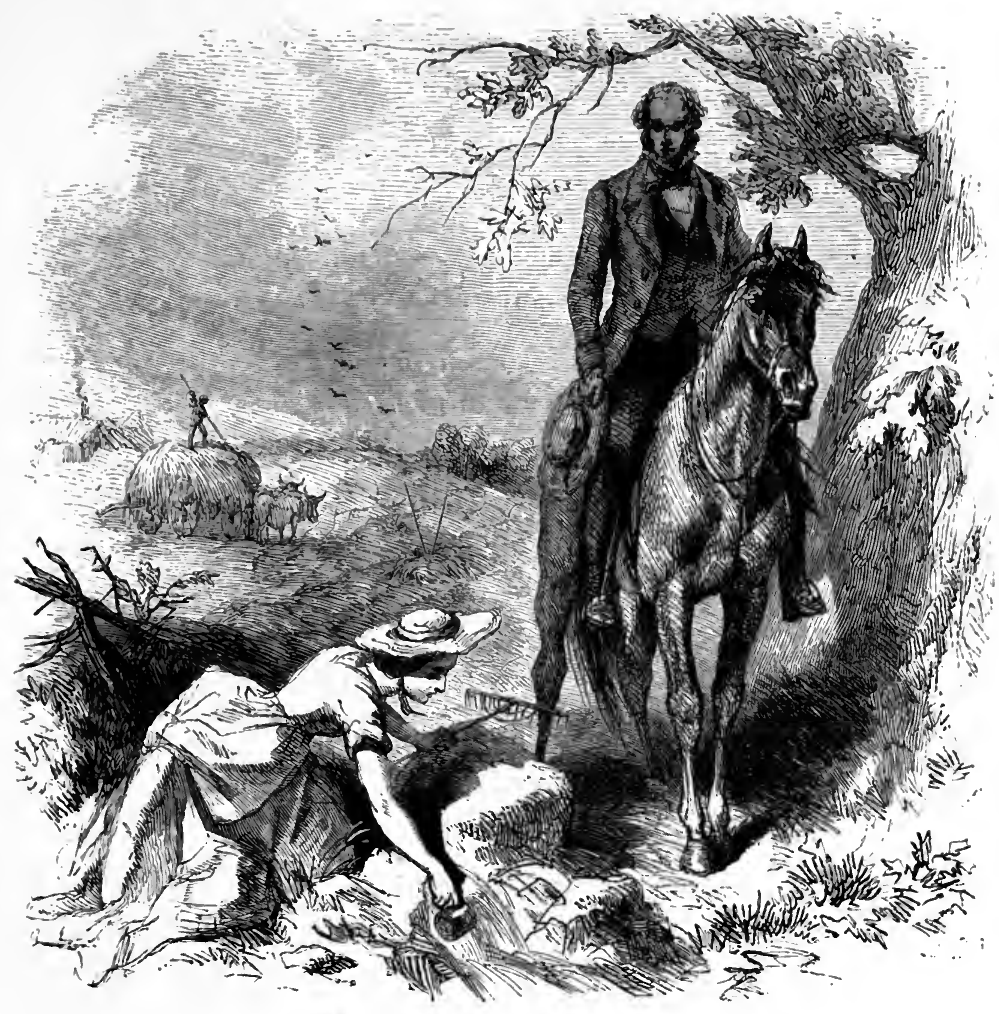

WHITTIER.

M A U D M L L E.

Maud Mulder, on a summer's day, Raked the meadow, sweet with hay.

Beneath her torn hat glowed the wealth Of simple beauty and rustic health. 
Singing, she wrought, and her merry glee The mock-bird echoed from his tree.

But, when she glanced to the far-off town, White from its hill-slope looking down,

The sweet song died, and a vague unrest And a nameless longing filled her breast-

A wish, that she hardly dared to own, For something better than she had known.

The Judge rode slowly down the lane, Smoothing his horse's chestnut mane.

He drew his bridle in the shade Of the apple-trees, to greet the maid, And ask a draught from the spring that flowed Through the meadow across the road.

She stooped where the cool spring bubbled up, And filled for him her small tin cup,

And blushed as she gave it, looking down On her feet so bare, and her tattered gown.

"Thanks!" said the Judge, "a sweeter draught From a fairer hand was never quaffed."

He spoke of the grass and flowers and trees, Of the singing birds and the humming bees;

Then talked of the haying, and wondered whether The cloud in the west would bring foul weather.

And Maud forgot her brier-torn gown, And her graceful ankles bare and brown;

And listened, while a pleased surprise Looked from her long-lashed hazel eyes.

At last, like one who for delay Seeks a vain excuse, he rode away. 


\section{WHITTIER.}

Maud Muller looked and sighed: " $\mathrm{Ah}$, me!

That I the Judge's bride might be!

"He would dress me up in silks so fine,

And praise and toast me at his wine.

"My father should wear a broadcloth coat;

My brother should sail a painted boat.

"I'd dress my mother so grand and gay,

And the baby should have a new toy each day.

"And I'd feed the hungry and clothe the poor, And all should bless me who left our door."

The Judge looked back as he climbed the hill, And saw Maud Muller standing still.

"A form more fair, a face more sweet, Ne'er hath it been my lot to meet.

"And her modest answer and graceful air Show her wise and good as she is fair.

"Would she were mine, and I to-day, Iike her, a harvester of hay:

"No doubtful balance of rights and wrongs, Nor weary lawyers with endless tongues;

"But low of cattle and song of birds, And health and quiet and loving words."

But he thought of his sisters proud and cold, And his mother vain of her rank and gold.

So, closing his heart, the Judge rode on, And Maud was left in the field alone.

But the lawyers smiled that afternoon, When he hummed in court an old love-tune;

And the young girl mused beside the well, Till the rain on the unraked clover fell. 
He wedded a wife of richest dower, Who lived for fashion, as he for power.

Yet oft, in his marble hearth's bright glow, He watched a picture come and go:

And sweet Maud Muller's hazel eyes

Looked out in their innocent surprise.

Oft when the wine in his glass was red, He longed for the way-side well instead;

And closed his eyes on his garnished rooms, To dream of meadows and clover-blooms.

And the proud man sighed, with a secret pain:

"Ah, that I were free again!

"Free as when I rode that day,

Where the barefoot maiden raked her hay."

She wedded a man unlearned and poor, And many children played round her door.

But care and sorrow, and childbirth pain, Left their traces on heart and brain.

And oft, when the summer sun shone hot On the new-mown hay in the meadow lot,

And she heard the little spring-brook fall Over the road-side, through the wall,

In the shade of the apple-tree again

She saw a rider draw his rein:

And, gazing down with timid grace,

She felt his pleased eyes read her face.

Sometimes her narrow kitchen walls

Stretched away into stately halls;

The weary wheel to a spinnet turned, The tallow candle an astral.burned, 


\section{WHITTIER.}

And for him who sat by the chimney lug, Dozing and grumbling o'er pipe and mug,

A manly form at her side she saw, And joy was duty and love was law.

Then she took up her burden of life again, Saying only, "It might have been."

Alas for maiden, alas for Judge, For rich repiner and household drudge:

God pity them both! and pity us all, Who vainly the dreams of youth recall.

For of all sad words of tongue or pen, The saddest are these: "It might have been!"

Ah, well! for us all some sweet hope lies Deeply buried from human eyes;

And, in the hereafter, angels may

Roll the stone from its grave away!

GONE.

Avother hand is beckoning us, Another call is given;

And glows once more with Angel-steps

The path which reaches Heaven.

Our young and gentle friend whose smile

Made brighter summer hours, Amid the frosts of autumn time

Has left us, with the flowers. 
GONE.

No paling of the cheek of bloom

Forewarned us of decay;

No shadow from the Silent Land

Fell round our sister's way.

The light of her young life went down,

As sinks behind the hill

The glory of a setting star-

Clear, suddenly, and still.

As pure and sweet, her fair brow seemed-

Eternal as the sky;

And like the brook's low song, her voice-

A sound which could not die.

And half we deemed she needed not

The changing of her sphere,

To give to Heaven a Shining One,

Who walked an Angel here.

The blessing of her quiet life

Fell on us like the dew;

And good thoughts, where her footsteps pressel,

Like fairy blossoms grew.

Sweet promptings unto kindest deeds

Were in her very look;

We read her face, as one who reads

A true and holy book:

The measure of a blessed hymn,

To which our hearts could move;

The breathing of an inward psalm;

A canticle of love.

We miss her in the place of prayer,

And by the hearth-fire's light;

We pause besile her door to hear

Once more her sweet "Good-night!" 


\section{WHITTIER.}

There seems a shadow on the day,

Her smile no longer cheers;

A dimness on the stars of night,

Like eyes that look through tears.

Alone unto our Father's will

One thought hath reconciled;

That He whose love exceedeth ours

Hath taken home His child.

Fold her, oh Father! in thine arms, And let her henceforth be

A messenger of love between

Our human hearts and Thee.

Still let her mild rebuking stand

Between us and the wrong,

And her dear memory serve to make

Our faith in Goodness strong.

And, grant that she who, trembling, here

Distrusted all her powers,

May welcome to her holier home

The well beloved of ours. 


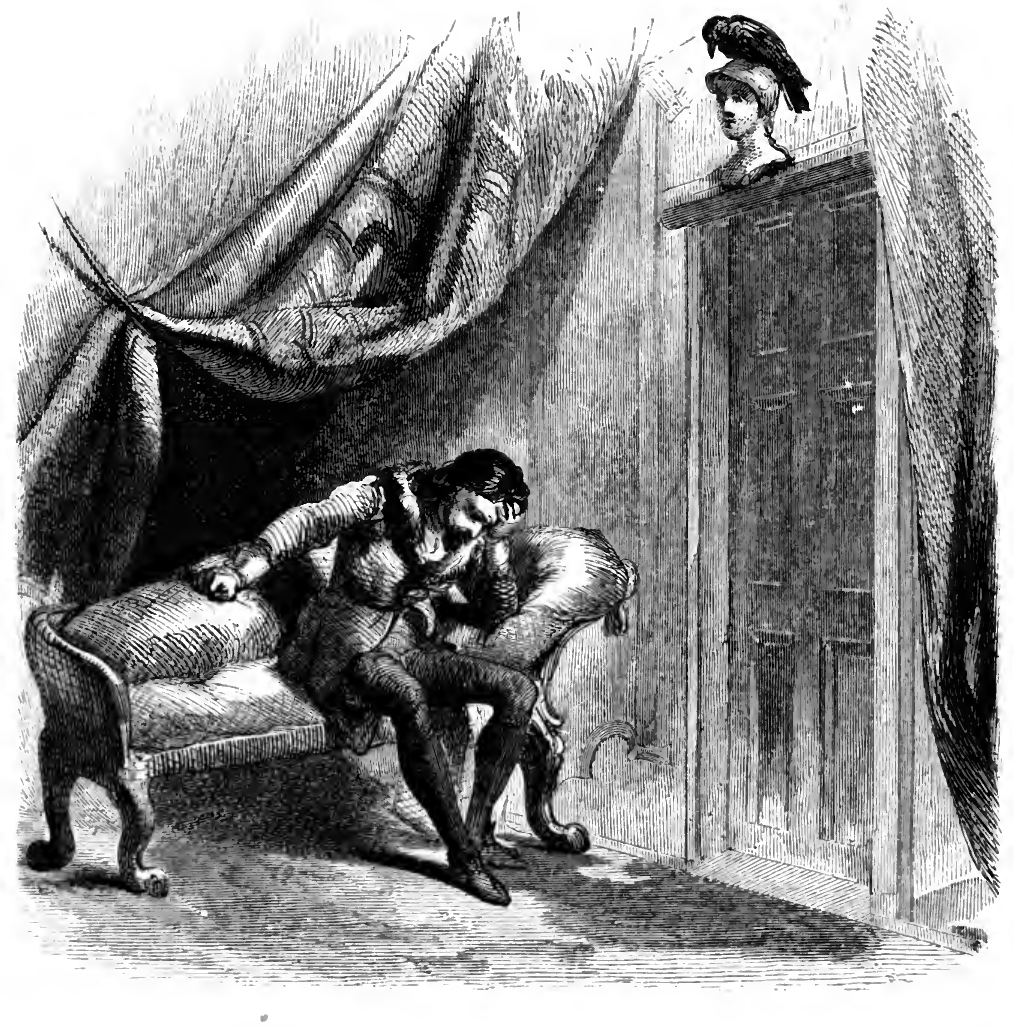

POE.

THE RAVEN.

Oxce upon a midnight dreary, while I pondered weak and weary, Over inany a quaint and curious volume of forgotten loreWhile I nodded, nearly napping, suddenly there came a tapping, $\Lambda \mathrm{s}$ of some one gently rapping, rapping at my chamber door. "Tis some visitor," I muttered, "tapping at my chamber doorOnly this and nothing more." 
POE.

$\mathrm{Ab}$, distinctly I remember it was in the bleak December,

And each separate dying ember wrought its ghost upon the floor.

Eagerly I wished the morrow;-vainly I had sought to borrow

From my books surcease of sorrow-sorrow for the lost Lenore-

For the rare and radiant maiden whom the angels name Lenore-

Nameless here for evermore.

And the silken sad, uncertain rustling of each purple curtain Thrilled me-filled me with fantastic terrors never felt before; So that now, to still the beating of my heart, I stood repeating "'Tis some visitor entreating entrance at my chamber doorSome late visitor entreating entrance at my chamber door;

This it is and, nothing more."

Presently my soul grew stronger; hesitating then no longer, "Sir," said I, "or Madam, truly your forgiveness I implore; But the fact is I was napping, and so gently you came rapping, And so faintly you came tapping, tapping at my chamber door, That I searce was sure I heard you"-here I opened wide the door;Darkness there and nothing more.

Deep into that darkness peering, long I stood there wondering, fearing, Doubting, dreaming dreams no mortals ever dared to dream before; But the silence was unbroken, and the stillness gave no token, And the only word there spoken was the whispered word, "Lenore?" This I whispered, and an echo murmured back the word, "Lenore!"Merely this and nothing more.

Back into the chamber turning, all my soul within me burning, Soon again I heard a tapping something louder than before. "Surely," said I, "surely that is something at my window lattice; Let me see, then, what thereat is and this mystery exploreLet my heart be still a moment and this mystery explore;'Tis the wind and nothing more."

Open here I flung the shutter, when, with many a flirt and flutter, In there stepped a stately Raven of the saintly days of yore. 


\section{THE RAVEN.}

Not the least obeisance made he; not a minute stopped or stayed he; But, with mien of lord or lady, perched above my chamber doorPerched upon a bust of Pallas just above my chamber door-

Perched, and sat, and nothing more.

Then this ebony bird beguiling my sad fancy into smiling, By the grave and stern decorum of the countenance it wore, "Though thy crest be shorn and shaven, thou," I said, "art sure no craven,

Ghastly grim and ancient Raven wandering from the Nightly shoreTell me what thy lordly name is on the Night's Plutonian shore!". Quoth the Raven, "Nevermore."

Much I marvelled this ungainly fowl to hear discourse so plainly, 'Though its answer little meaning-little relevancy bore; For we cannot help agreeing that no living human being Ever yet was blessed with seeing bird above his chamber doorBird or beast upon the sculptured bust above his chamber door,

With such name as "Nevermore."

But the Raven, sitting lonely on that placid bust, spoke only That one word, as if his soul in that one word he did outpour. Nothing farther then he uttered; not a feather then he flutteredTill I scarcely more than muttered "Other friends have flown beforeOn the morrow he will leave me, as my Hopes have flown before." Then the bird said "Nevermore."

Startled at the stillness broken by reply so aptly spoken, "Doubtless," said I, "what it utters is its only stock and store Caught from some unhappy master whom unmereiful Disaster Followed fast and followed faster till his songs one burden borcTill the dirges of his Hope that melancholy burden bore

Of 'Never-nevermore.",

But the Raven still beguiling all my sad soul into smiling, Straight I wheelerl a cushioned seat in front of bird and bust and door; Then, upon the velvet sinking, I betook myself to linking 
Fancy unto fancy, thinking what this ominous bird of yoreWhat this grim, ungainly, ghastly, gaunt, and ominous bird of yore Meant in croaking "Nevermore."

This I sat engaged in guessing, but no syllable expressing

To the fowl whose fiery eyes now burned into my bosom's core; This and more I sat divining, with my head at ease reclining On the cushion's velvet lining that the lamp-light gloated o'er, But whose velvet violet lining with the lamp-light gloating o'er She shall press, ah, nevermore!

Then, methought, the air grew denser, perfumed from an unseen censer Swung by Seraphim whose foot-falls tinkled on the tufted floor. "Wretch," I cried, "thy God hath lent thee-by these angels he hath sent thee

Respite-respite and nepenthe from thy memories of Lenore! Quaff, oh quaff this kind nepenthe and forget this lost Lenore!" Quoth the Raven, "Nevermore"

"Prophet!" said I, "thing of evil!-prophet still, if bird or devil!Whether Tempter sent, or whether tempest tossed thee here ashore, Desolate yet all undaunted, on this desert land enchantedOn this home by Horror haunted-tell me truly, I imploreIs there-is there balm in Gilead?-tell me-tell me, I implore!" Quoth the Raven, "Nevermore."

"Prophet!" said I, "thing of evil-prophet still, if bird or devil! By that Heaven that bends above us-by that God we both adoreTell this soul with sorrow laden if, within the distant Aidenn, It shall clasp a sainted maiden whom the angels name LenoreClasp a rare and radiant maiden whom the angels name Lenore." Quoth the Raven, "Nevermore."

"Be that word our sign of parting, bird or fiend!" I shrieked, upstarting-

"Get thee back into the tempest and the Night's Plutonian shore!

Leave no black plume as a token of that lie thy soul hath spoken! 


\section{THE RAVEN:}

Leave my loneliness unbroken!-quit the bust above my door!

Take thy beak from out my heart, and take thy form from off my door !"

Quoth the Raven, "Nevermore."

And the Raven, never flitting, still is sitting, still is sitting On the pallid bust of Pallas just above my chamber door; And his eyes have all the seeming of a demon's that is dreaming, And the lamp-light o'er him streaming throws his shadow on the floor; And my soul from out that shadow that lies floating on the floor Shall be lifted-nevermore! 


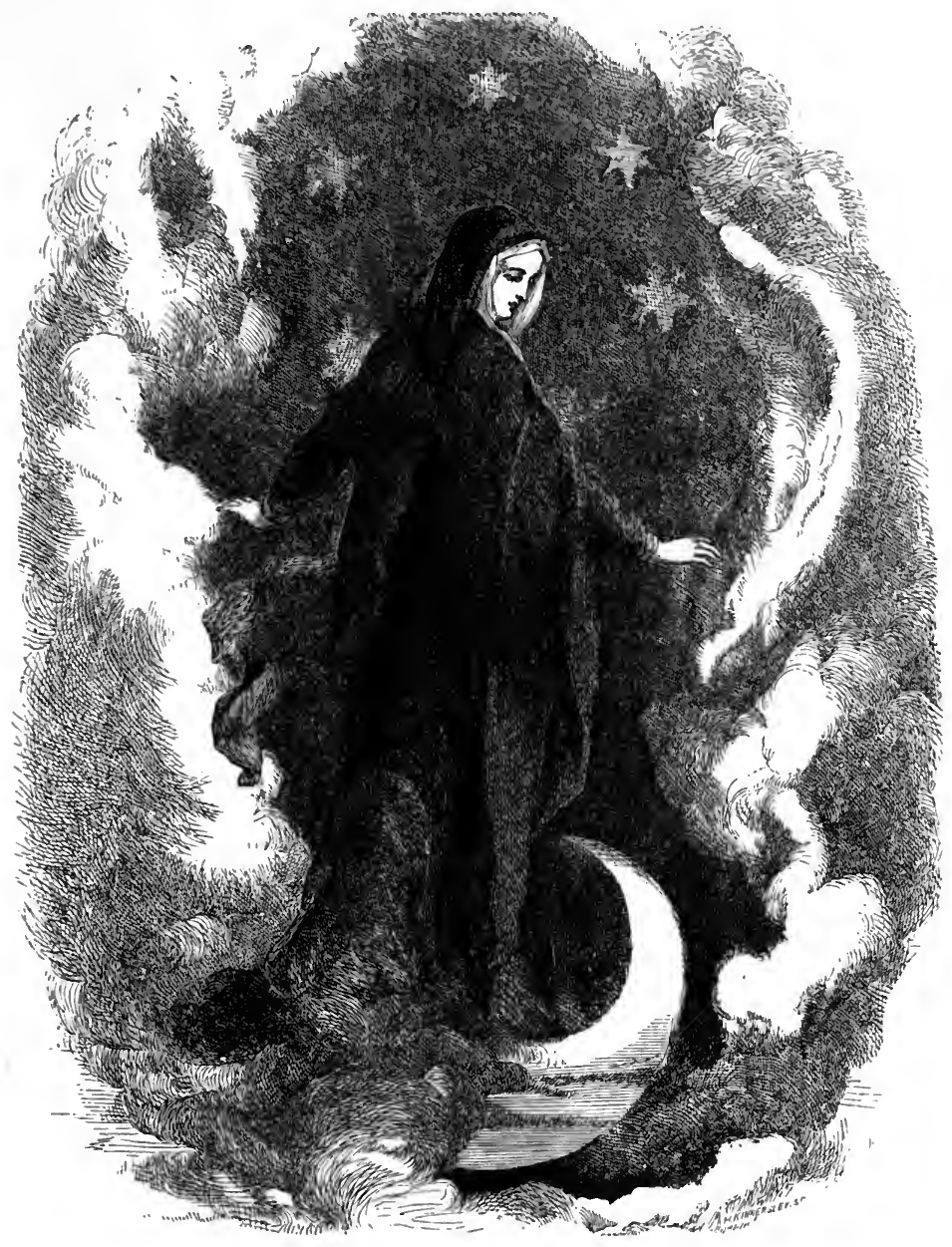

LONGFELLOW.

\section{HYMN TO THE NIGHT.}

'A $\sigma \pi a \sigma i ́ \eta, \tau \rho i \lambda \lambda \iota \sigma \tau o \varsigma$.

I HEARD the trailing garments of the Night Sweep through her marble halls!

I saw her sable skirts all fringed with light From the celestial walls! 
I felt her presence, by its spell of might, Stoop o'er me from above;

The calm, majestic presence of the Night, As of the one I love.

I heard the sounds of sorrow and delight, The manifold, soft chimes, That fill the haunted chambers of the Night, Like some old poet's rhymes.

From the cool cisterns of the midnight air My spirit drank repose;

The fountain of perpetual peace flows there, From those deep cisterns flows.

O holy Night! from thee I learn to bear What man has borne before; Thou layest thy finger on the lips of Care, And they complain no more.

Peace! Peace! Orestes-like I breathe this prayer!

Descend with broad-winged flight, The welcome, the thrice-prayed for, the most fair, The best-beloved Night! 


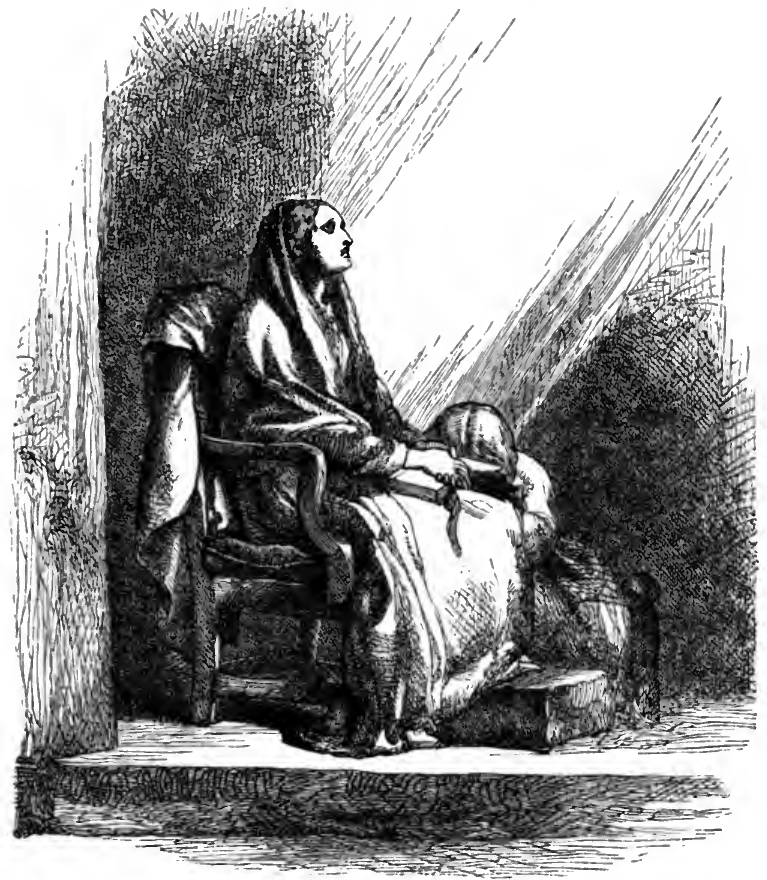

\section{RESIGNATION.}

There is no flock, however watched and tended,

But one dead lamb is there!

There is no fireside, howsoe'er defended,

But has one vacant chair!

The air is full of farewells to the dying, And mournings for the dead;

The heart of Rachel, for her children crying, Will not be comforted! 


\section{RESIGNATION.}

Let us be patient! These severe afflictions

Not from the ground arise, But oftentimes celestial benedictions

Assume this dark disguise.

We see but dimly through the mists and vapours, Amid these earthly damps;

What seem to us but sad, funereal tapers, May be heaven's distant lamps.

There is no Death! What seems so is transition; 'This life of mortal breath

Is but a suburb of the life elysian, Whose portal we call Death.

She is not dead,- the child of our affection,But gone unto that school

Where she no longer needs our poor protection, And Christ himself doth rule.

In that great cloister's stillness and seclusion, By guardian angels led, Safe from temptation, safe from sin's pollution, She lives, whom we call dead.

Day after day we think what she is doing In those bright realms of air;

Year after year her tender steps pursuing, Behold her grown more fair.

Thus do we walk with her, and keep unbroken 'The bond which nature gives, Thinking that our remembrance, though unspoken, May reach her where she lives. 


\section{LONGFELLOW.}

Not as a child shall we again behold her;

For when with raptures wild

In our embraces we again enfold her,

She will not be a child;

But a fair maiden, in her Father's mansion, Clothed with celestial grace;

And beautiful with all the soul's expansion Shall we behold her face.

And though at times impetuous with emotion And anguish long suppressed,

The swelling heart heaves moaning like the ocean,

That cannot be at rest,-

We will be patient, and assuage the feeling

We may not wholly stay;

But silence sanctifying, not concealing,

The grief that must have way. 


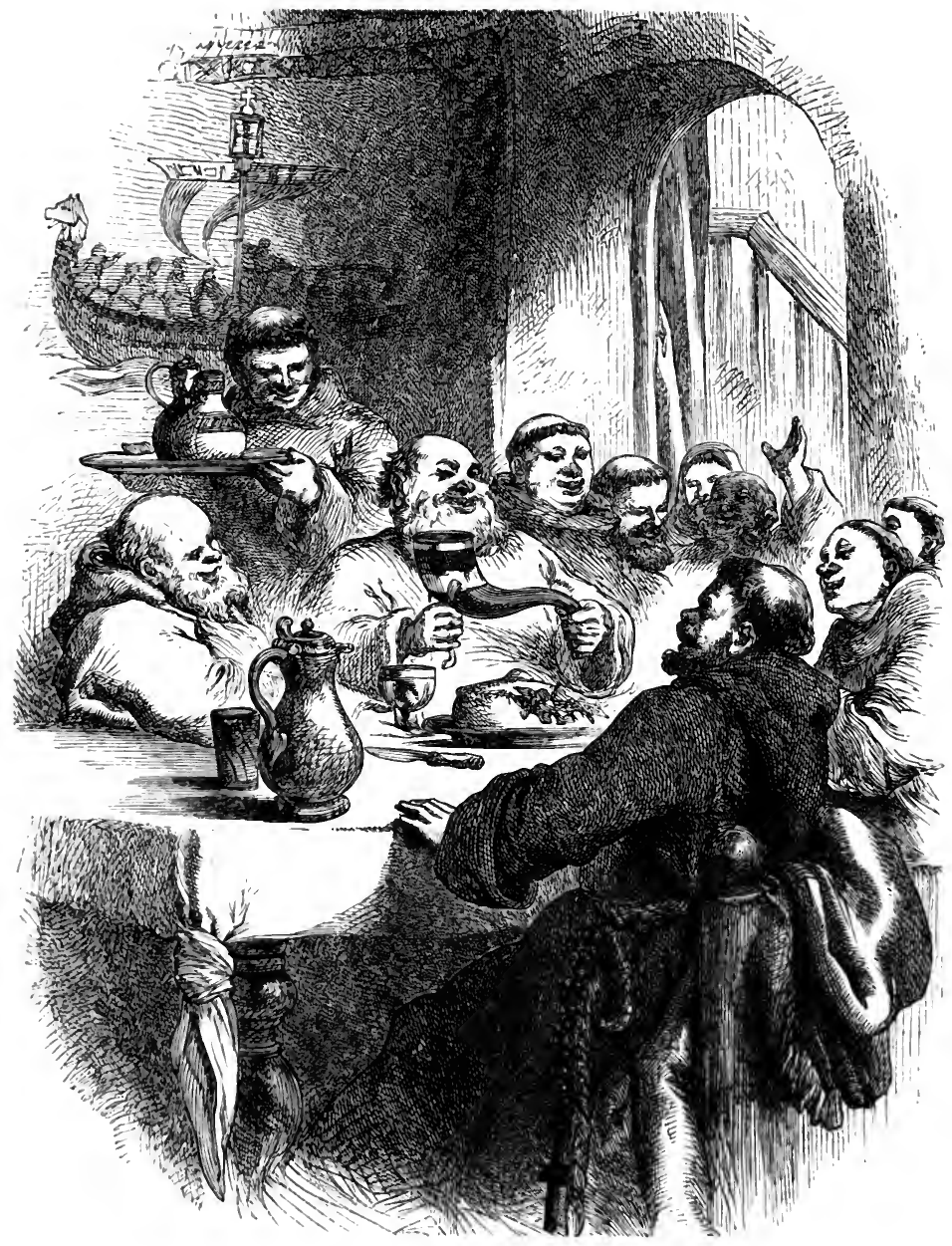

KING WITLAF'S DRINKING-HORN.

Witlaf, a king of the Saxons, Ere yet his last he breathed, To the merry monks of Croyland His drinking-horn bequeathed,- 


\section{IONGFELILOW.}

That, whenever they sat at their revels, And drank from the golden bowl, They miglit remember the donor, And breathe a prayer for his soul.

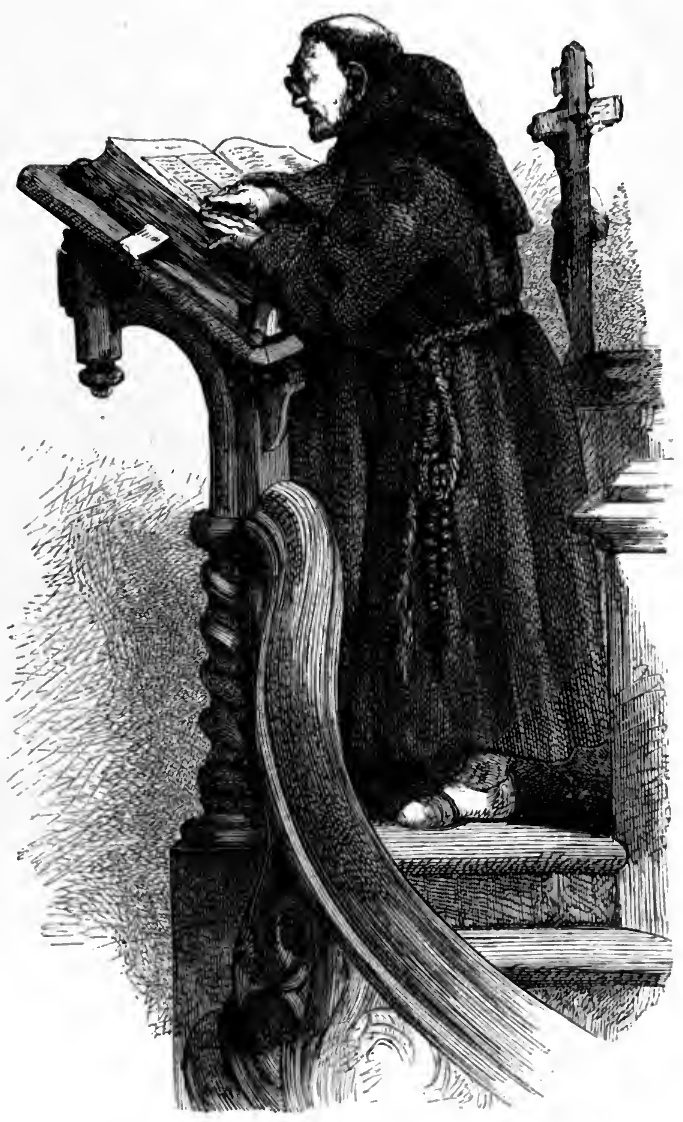

So sat they once at Christmas, And bade the goblet pass;

In their beards the red wine glistened Like dew-drops in the grass. 


\section{KING WITLAF'S DRINKING-HORN.}

They drank to the soul of Witlaf, They drank to Christ the Lord, And to each of the Twelve Apostles,

Who had preached his holy word.

They drank to the Saints and Martyrs

Of the dismal days of yore, And as soon as the horn was empty

'They remembered one Saint more.

And the reader droned from the pulpit,

Like the murmur of many bees, The legend of good Saint Guthlac, And Saint Basil's homilies;

'Till the great bells of the convent, From their prison in the tower, Guthlac and Bartholomæus,

Proclaimed the midnight hour.

And the Yule-log cracked in the chimney,

And the Abbot bowed his head, And the flamelets flapped and flickered,

But the Abbot was stark and dead.

Yet still in his pallid fingers

He clutched the golden bowl,

In which, like a pearl dissolving,

Had sunk and dissolved his soul.

But not for this their revels

'The jovial monks forbore, For they cried, "Fill high the goblet:

We must drink to one Saint more!" 


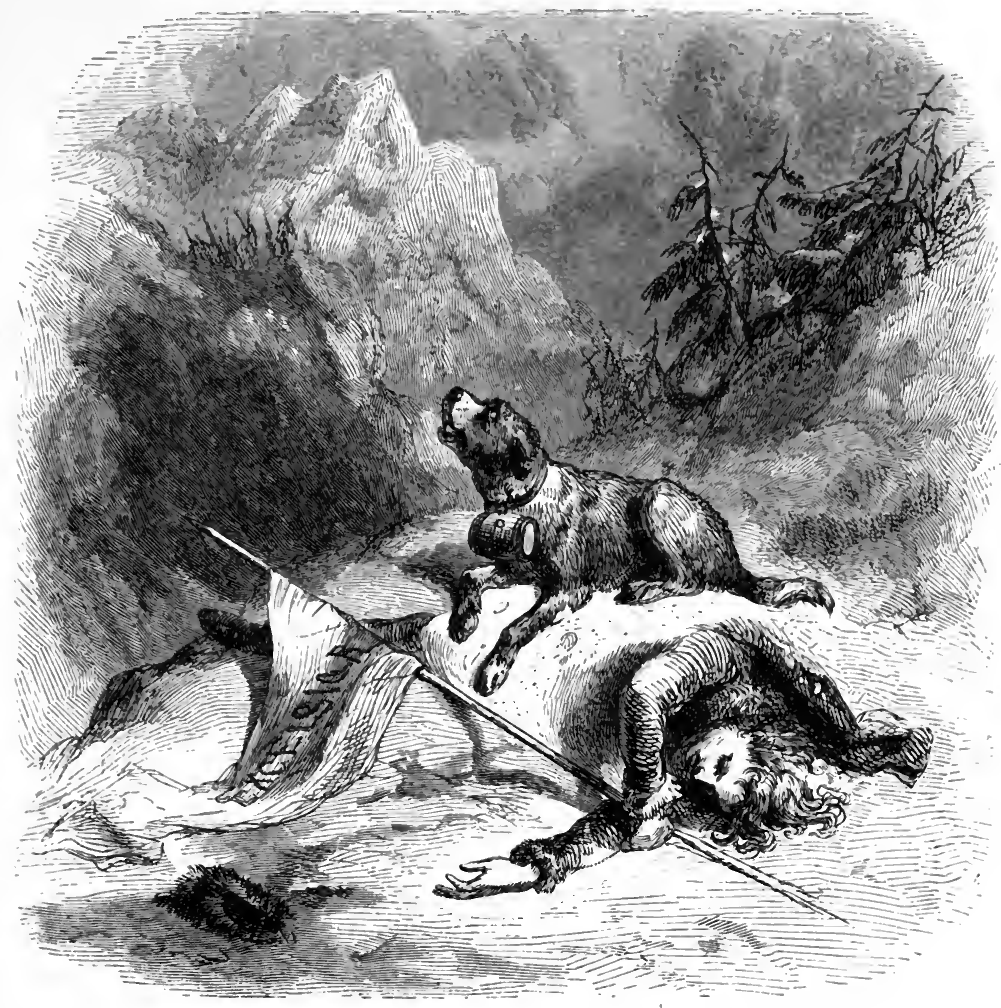

EXCELSIOR.

The shades of night were falling fast, As through an Alpine village passed

A youth, who bore, 'mid snow and ice,

A banner with the strange device, Excelsior!

His brow was sad; his eye beneath, Flashed like a falchion from its sheath, And like a silver clarion rung The accents of that unknown tongue, Excelsior! 


\section{EXCELSIOR.}

In happy homes he saw the light

Of household fires gleam warm and bright;

Above, the spectral glaciers shone, And from his lips escaped a groan, Excelsior!

"Try not the Pass!" the old man said;

"Dark lowers the tempest overhead, The roaring torrent is deep and wide!" And loud that clarion voice replied, Excelsior!

"O, stay," the maiden said, "and rest Thy weary head upon this breast!" A tear stood in his bright blue eye, But still he answered, with a sigh, Excelsior!

"Beware the pine-tree's withered branch!

Beware the awful avalanche!"

This was the peasant's last Good-night;

A voice replied, far up the height, Excelsior!

At break of day, as heavenward The pious monks of Saint Bernard Uttered the oft-repeated prayer, A voice cried through the startled air, Excelsior!

A traveller, by the faithful hound, Half-buried in the snow was found, Still grasping in his hand of ice That banner with the strange derice, Excelsior! 


\section{LONGFELLOW.}

There, in the twilight cold and gray, Lifeless, but beautiful, he lay, And from the sky, serene and far, A voice fell, like a falling star, Excelsior! 


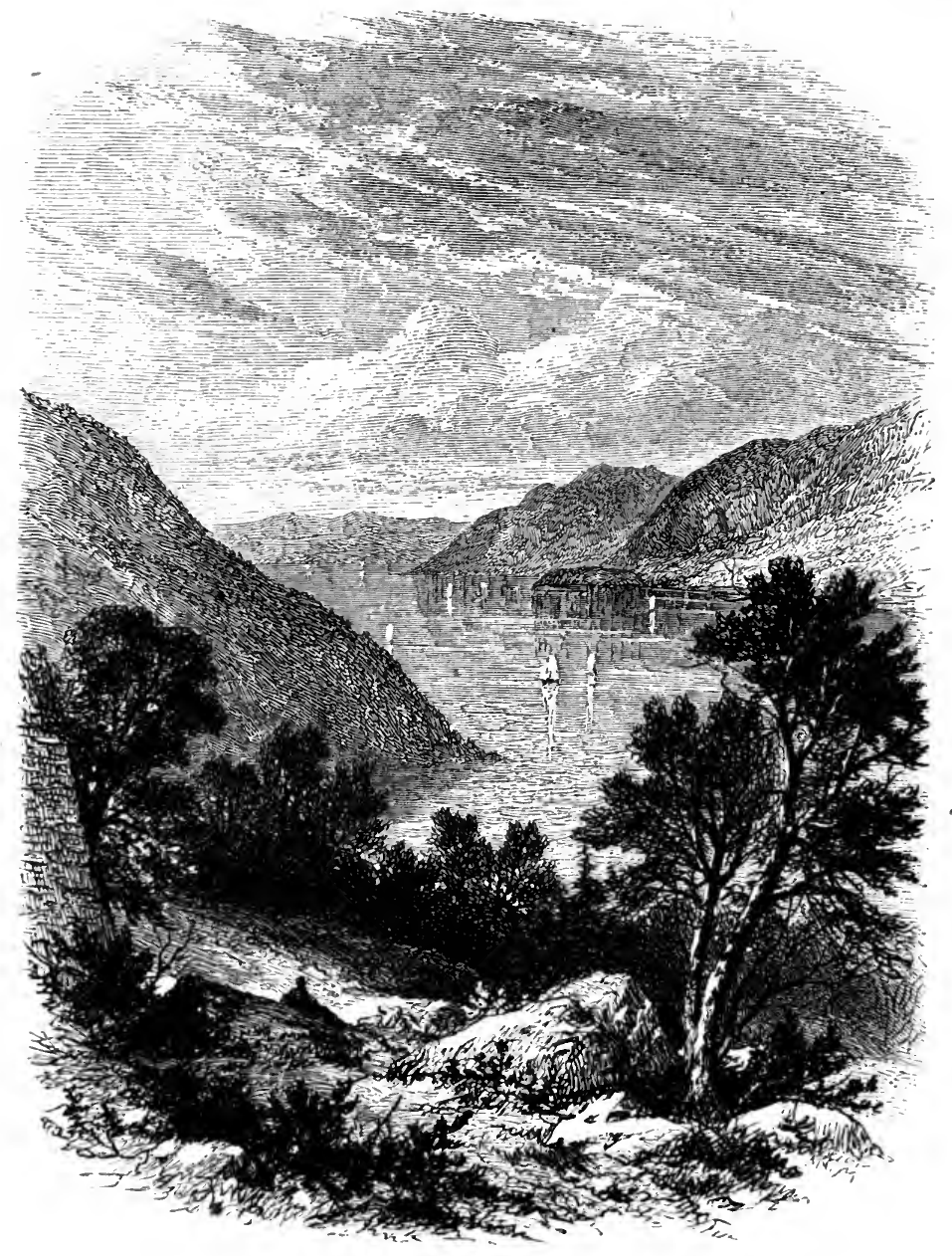

\section{TUCKERMAN.}

\section{WEST POIN T.}

WIII) umbrage far around me elings

To breesy knoll and hushed ravine, And ier each rocky headland flings

Its mantle of refreshing green. 


\section{'TUCKERMAN.}

The echoes that so boldly rung

When cannon flashed from steep to steep, And Freedom's airy challenge flung,

In each romantic valley sleep.

His counsels here our chieftain breathed,

Here roved his mild, undaunted eye, When yon lone fort with thickets wreathed, Held captive Britain's gallant spy.

Fit home to rear a nation's youth By self-control to nerve the will, Through knowledge gain expansive truth, And with high aims life's circle fill.

How grateful is the sudden change From arid pavements to the grass, From narrow streets that thousands range, To meadows where June's zephyrs pass!

Beneath the cliffs the river steals

In darksome eddies to the shore, But midway every sail reveals

Reflected on its crystal floor.

In tranquil mood the cattle walk Along the verdant marge to feed, While poised upon the mullein stalk The chirping red-bird pecks the seed.

Low murmurs in the foliage bred, 'The clear horizon's azure line, Fresh turf elastic to the tread, And leafy canopies are thine. 
White fleecy clouds move slowly by, How cool their shadows fall to-day!

A moment on the hills they lie, And then like spirits glide away.

Amid the herbage, yesternight

His web the cunning spider threw, And now, as sparkling diamonds bright,

It glistens with the pendent dew.

Gay butterflies dart on and sink

O'er the sweet blossoms of the pea, And from the clover's globe of pink

Contented hums the downy bee.

In all his varied beauty glows

Deep meaning for the thoughtful heart, As it were fain to teach repose; And lofty confidence impart.

How vivid to my fancy now,

Uprise the forms that life redeem:

The ardent eye-the open brow,

And tender smile beside me seem.

For Nature's presence gathers back

'The deeds that grace, the loves that cheer, And as her holy steps we track,

IIope's rainbow breaks through sorrow's tear. 


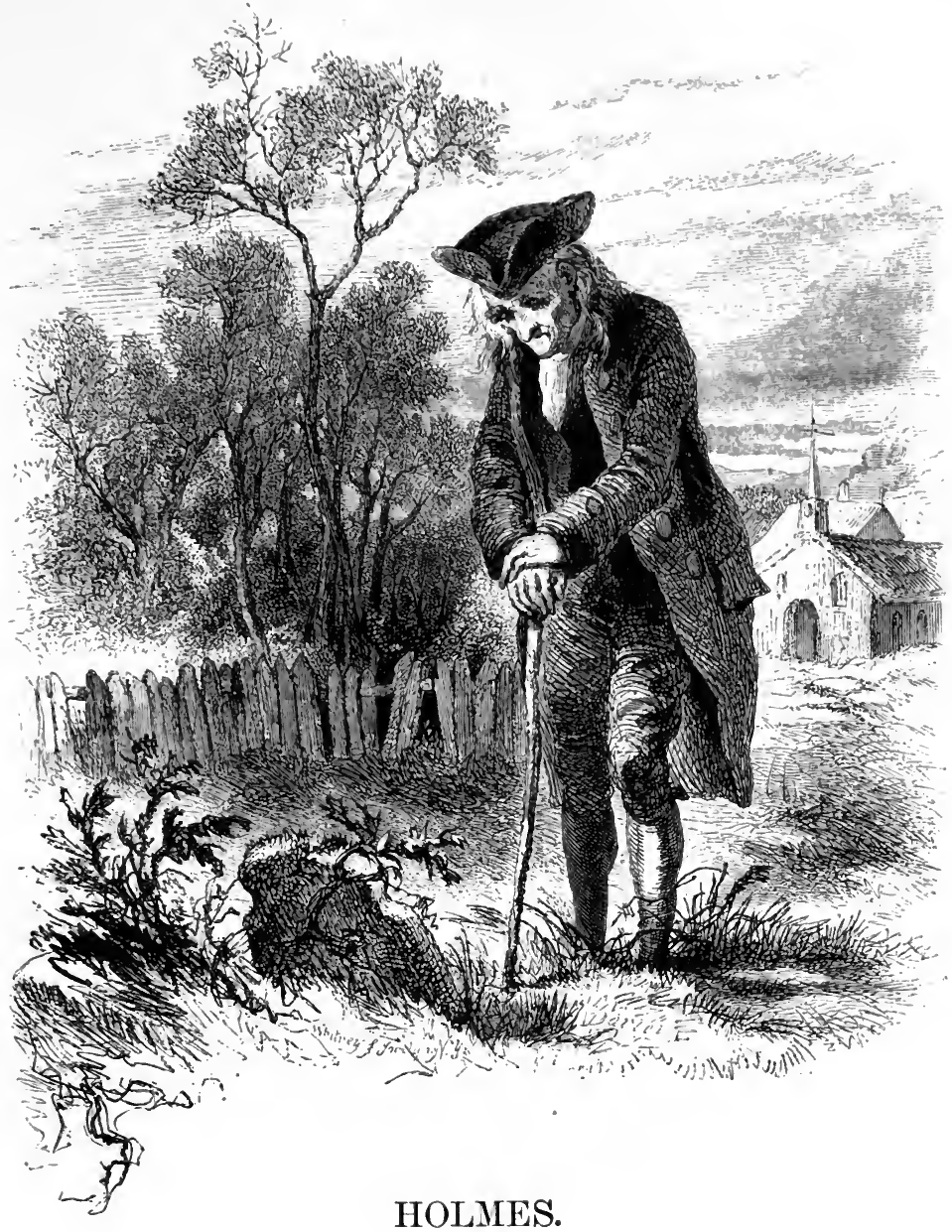

THE LAST LEAF.

I SAw him once before,

As he passed by the door,

And again

The pavement stones resound

As he totters o'er the ground

With his cane. 
They say that in his prime, Ere the pruning-knife of Time

Cut him down,

Not a better man was found

By the Crier on his round Through the town.

But now he walks the streets, And he looks at all he meets

Sad and wan,

And he shakes his feeble head,

That it seems as if he said,

"They are gone."

The mossy marbles rest

On the lips that he has prest

In their bloom,

And the names he loved to hear

Have been carved for many a year

On the tomb.

My grandmamma has said,-

Poor old lady, she is dead

Long ago,-

That he had a Roman nose,

And his eheek was like a rose

In the snow.

But now his nose is thin,

And it rests upon his chin

Like a staff,

And a crook is in his back,

And a melancholy erack

In his laugh.

I know it is a sin

For me to sit and grin

At him here; 


\section{HOLMES.}

But the old three-cornered hat, And the breeches, and all that, Are so queer!

And if I should live to be The last leaf upon the tree

In the spring,-

Let them smile, as I do now, At the old forsaken bough

Where I eling. 


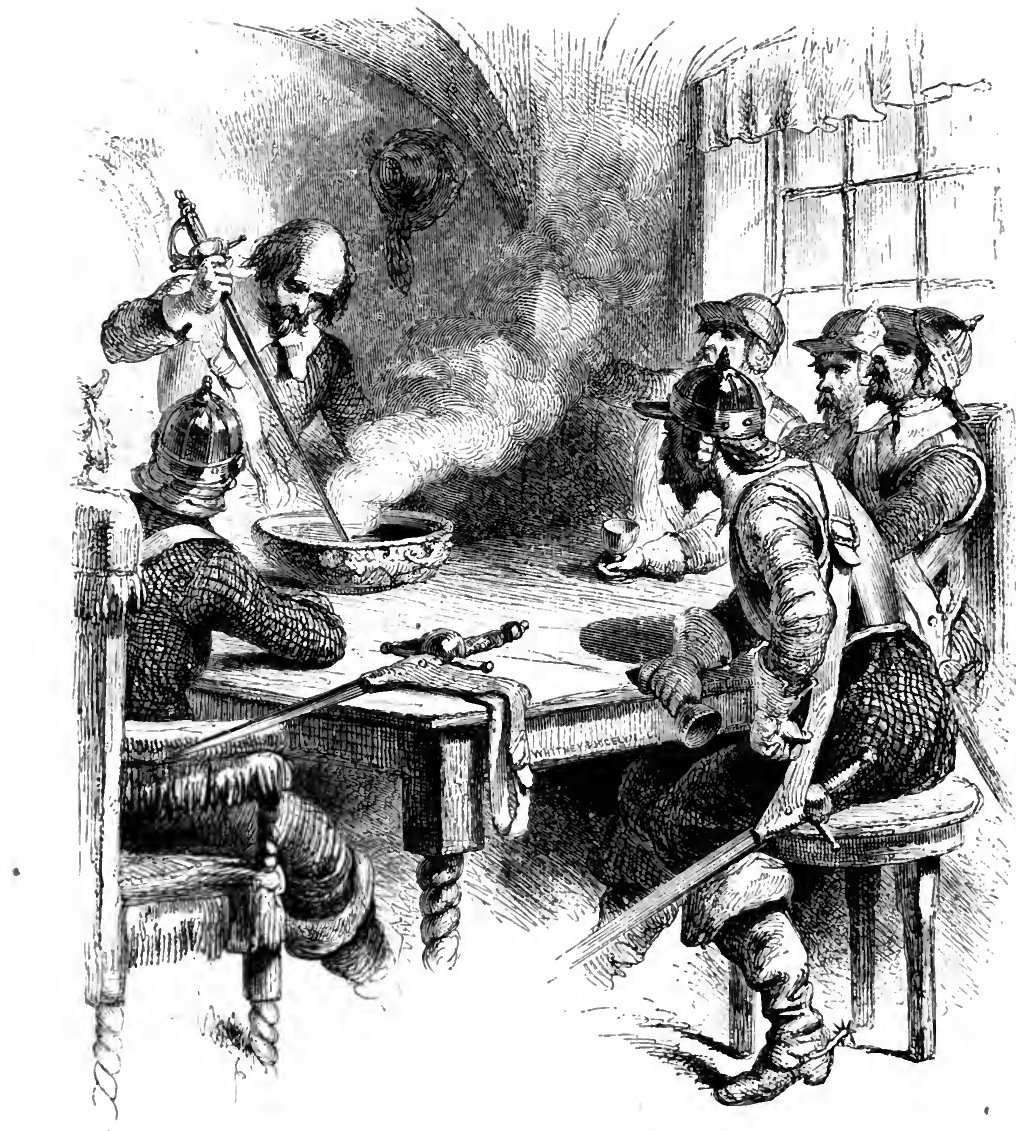

ON L.ENDING A PUNCH-BOWL.

Turs aneient silver bowl of mine-it tells of good old times, Of joyous days and jolly nights, and merry Christmas chimes; They were a free and jovial race, but honest, brave and true, That dipped their ladle in the punch when this old bowl was new. 
HOLMES.

A Spanish galleon brought the bar-so runs the ancient tale'Twas hammered by an Antwerp smith, whose arm was like a flail; And now and then between the strokes, for fear his strength should fail, He wiped his brow, and quaffed a cup of good old Flemish ale.

'Twas purchased by an English squire to please his loving dame, Who saw the cherubs, and conceived a longing for the same; And oft as on the ancient stock another twig was found, "Twas filled with caudle spiced and hot, and handed smoking round.

But, changing hands, it reached at length a Puritan divine, Who used to follow Timothy, and take a little wine, But hated punch and prelacy; and so it was, perhaps, He went to Leyden, where he found conventicles and schnaps.

And then, of course, you know what's next-it left the Dutchman's shore With those that in the Mayflower came,-a hundred souls and more,Along with all the furniture, to fill their new abodesTo judge by what is still on hand, at least a hundred loads.

'Twas on a dreary winter's eve, the night was closing dim, When old Miles Standish took the bowl, and filled it to the brim, The little Captain stood and stirred the posset with his sword, And all his sturdy men at arms were ranged about the board.

He poured the fiery hollands in-the man that never fearedHe took a long and solemn draught, and wiped his yellow beard; And one by one the musketeers, the men that fought and prayed, All drank as 'twere their mother's milk, and not a man afraid!

That night, affrighted from his nest, the screaming eagle flew, He heard the Pequot's ringing whoop, the soldier's wild halloo; And there the sachem learned the rule he taught to kith and kin, "Run from the white man when you find he smells of hollands gin!"

A hundred years, and fifty more had spread their leaves and snows, A thousand rubs had flattened down each little cherub's nose; When once again the bowl was filled, but not in mirth or joy, 'Twas mingled by a mother's hand to cheer her parting boy. 


\section{ON LENDING A PUNCH-BOWL.}

Drink, John, she said, 'twill do you good-poor child, you'll never bear' This working in the dismal trench, out in the midnight air, And if-God bless me-you were hurt, 'twould keep away the chill; So John did drink-and well he wrought that night at Bunker's Hill !

I tell you, there was generous warmth in good old English cheer; I tell you, 'twas a pleasant thought to bring its symbol here; 'Tis but the fool that loves excess-hast thou a drunken soul, Thy bane is in thy shallow skull, not in my silver bowl!

I love the memory of the past-its pressed yet fragrant flowersThe moss that clothes its broken walls-the ivy on its towersNay, this poor bauble it bequeathed-my eyes grow moist and dim, To think of all the vanished joys that danced around its brim.

Then fill a fair and honest cup, and bear it straight to me; The goblet hallows all it holds, whate'er the liquid be;

And may the cherubs on its face protect me from the sin, That dooms one to those dreadful words-"My dear, where have you been?" 


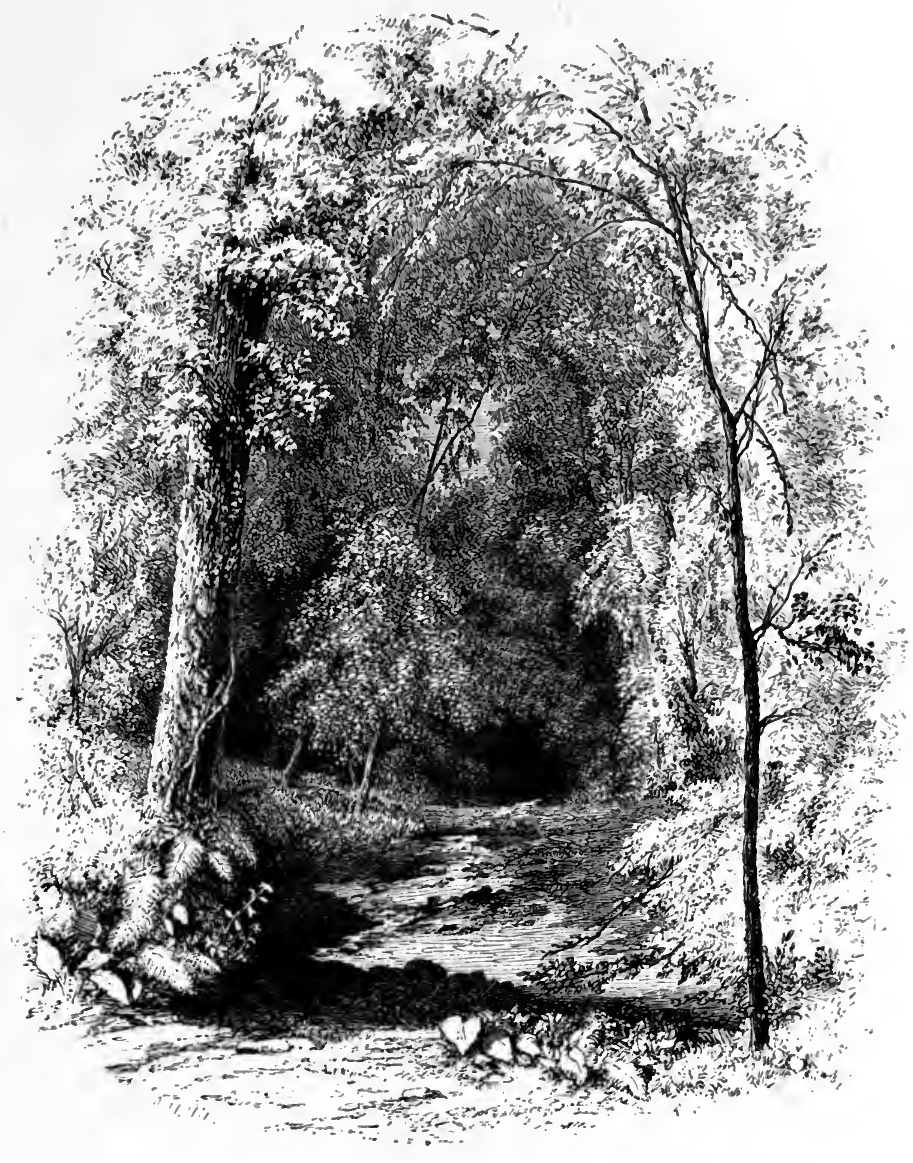

\section{STREET.}

\section{A FOREST NOOK.}

A rook within the forest; overhead

The branches arch, and shape a pleasant bower,

Breaking white clond, blue sky and sunshine bright,

Into pure ivory and sapphire spots, 


\section{A FOREST NOOK.}

And flecks of gold; a soft cool emerald tint Colours the air, as though the delicate leaves Emitted self-born light. What splendid walls And what a gorgeous roof carved by the hand Of glorious Nature! Here the spruce thrusts in Its bristling plume, tipp'd with its pale green points; 'The scallop'd beech leaf, and the birch's cut Into fine ragged edges, interlace:

While here and there, through clefts, the laurel lifts

Its snowy chalices half-brimm'd with dew, As though to hoard it for the haunting elves The moonlight calls to this their festal hall, A thick, rich, grassy carpet clothes the earth, Sprinkled with autumn leares. The fern displays

Its fluted wreath beaded beneath with drops Of richest brown; the wild-rose spreads its breast Of delicate pink, and the o'erhanging fir Has dropp'd its dark, long cone.

The scorching glare

Without, makes this green nest a grateful haunt

For summer's radiant things; the butterfly

Fluttering within and resting on some flower,

Fans his rich velvet form; the toiling bee

Shoots by, with sounding hum and mist-like wings;

The robin perehes on the bending spray

With shrill, quick chirp; and like a flake of fire

The redbird seeks the shelter of the leaves.

And now and then a flutter overhead

In the thick green, betrays some wandering wing Coning and going, yet conceal'd from sight.

A shrill, loud outery-on yon highest bough Sits the gray squirrel, in his burlesque wrath Stamping and chattering fiercely: now he drops

A hoarded nut, then at my smiling gaze

Buries himself within the foliage.

The inseet tribe are here; the ant toils on

With its white burthen; in its netted web 


\section{S'TREET.}

Gray glistening o'er the bush, the spider lurks, A close-crouch'd ball, out-darting as a hum Tells its trapp'd prey, and looping quick its threads, Chains into helplessness the buzzing wings. The wood-tick taps its tiny muffled drum To the shrill cricket-fife, and swelling loud, The grasshopper its swelling bugle winds. Those breaths of Nature, the light fluttering airs Like gentle respirations, come and go, Lift on its crimson stem the maple-leaf, Displaying its white lining underneath, And sprinkle from the tree-tops golden rain Of sunshine on the velvet sward below. Such nooks as this are common in the woods: And all these sights and sounds the commonest In Nature when she wears her summer prime. Yet by them pass not lightly: to the wise They tell the beauty and the harmony Of e'en the lowliest things that God hath made. That His familiar earth and sky are full Of His ineffable power and majesty; That in the humble objects, seen too oft To be regarded, is such wondrous grace, The art of man is vain to imitate;

That the low flower our careless foot treads down Is a rich shrine of incense delicate, And radiant beauty, and that God hath form'd All, from the cloud-wreath'd mountain, to the grain Of silver sand the bubbling spring casts up With deepest forethought and severest care. And thus these noteless lovely things are types Of his perfection and divinity. 


\section{ROBERT BROWNING.}

\section{TWO IN THE CAMPAGNA.}

I WONDER do you feel to-day

As I have felt, since, hand in hand,

We sat down on the grass, to stray

In spirit better through the land,

This morn of Rome and May?

For me, I touched a thought, I know,

Has tantalised me many times, (Like turns of thread the spiders throw

Mocking across our path,) for rhymes

'To catch at and let go.

Help me to hold it: first it left

The yellowing fennel, run to seed

There, branching from the brickwork's cleft,

Some old tomb's ruin: yonder weed

Took up the floating weft,

Where one small orange-cup amassed

Five beetles,-blind and green they grope

Among the honey-meal,-and last

Everywhere on the grassy slope

I traced it. Hold it fast!

The champaign with its endless fleece

Of feathery grasses everywhere!

Silence and passion, joy and peace,

An everlasting wash of air-

Rome's ghost since her decease. 


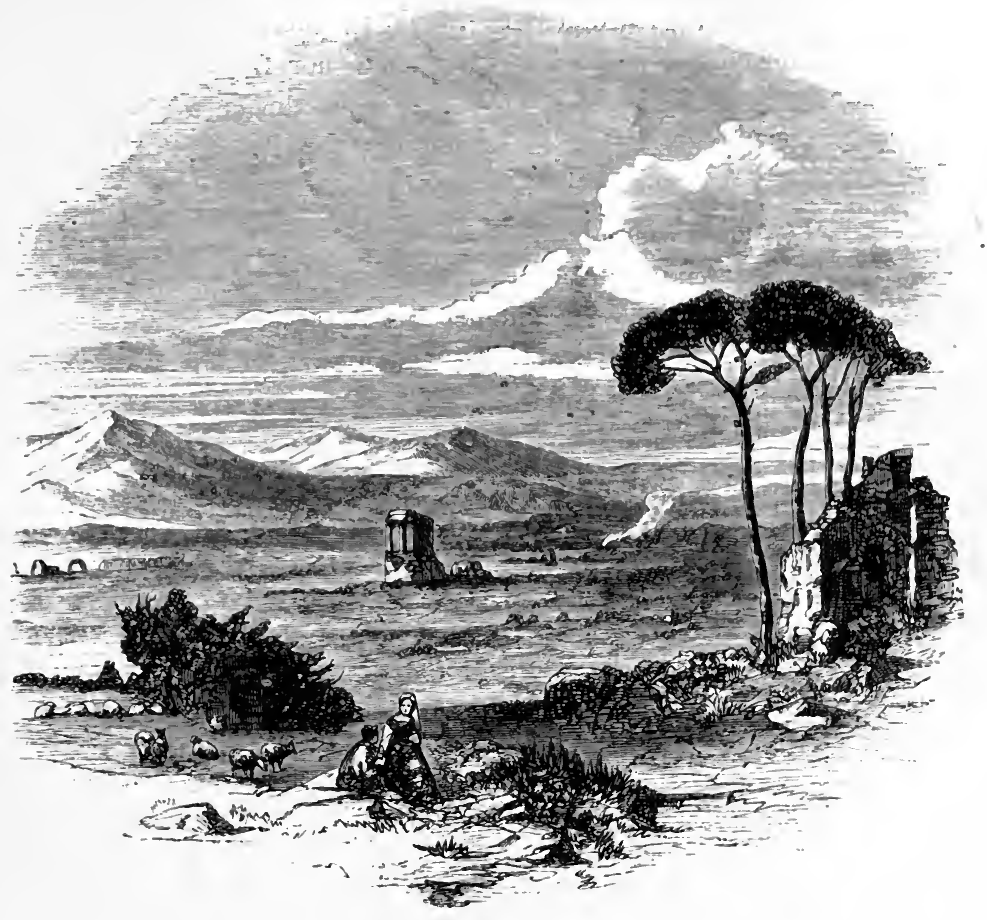

Such life there, through sueh lengths of hours,

Such miracles performed in play,

Such primal naked forms of flowers,

Such letting Nature have her way

While Heaven looks from its towers.

How say you? Let us, O my dove,

Let us be unashamed of soul,

As earth lies bare to heaven above.

How is it under our control

To love or not to love? 


\section{TWO IN THE CAMPAGNA.}

I would that you were all to me, You that are just so much, no moreNor yours, nor mine,-nor slave nor free!

Where does the fault lie? what the core Of the wound, since wound must be?

- I would I could adopt your will, See with your eyes, and set my heart - Beating by yours, and drink my fill

At your soul's springs,-your part, my part In life, for good and ill.

No. I yearn upward-touch you close, Then stand away. I kiss your cheek, Catch your soul's warmth,-I pluck the rose And love it more than tongue can speak,Then the good minute goes.

Already how am I so far

Out of that minute? Must I go Still like the thistle-ball, no bar, Onward, whenever light winds blow, Fixed by no friendly star?

Just when I seemed about to learn:-

Where is the thread now? Off again! The old trick! Only I discern-

Infinite passion and the pain Of finite hearts that yearn. 
ROBERT BROWNING.

\section{EVELYN HOPE.}

Beautiful Evelyn Hope is dead;

Sit and watch by her side an hour.

That is her book-shelf, this her bed;

She plucked that piece of geranium-flower,

Beginning to die too, in the glass.

Little has yet been changed, I think-

The shutters are shut, no light may pass

Save two long rays thro' the hinge's chink.

Sixteen years old when she died!

Perhaps she had scarcely heard my name-

It was not her time to love: beside,

Her life had many a hope and aim,

Duties enough and little cares,

And now was quiet, now astir-

Till God's hand beckoned unawares,

And the sweet white brow is all of her.

Is it too late, then, Evelyn Hope?

What, your soul was pure and true, The good stars met in your horoscope,

Made you of spirit, fire, and dew;

And just because I was thrice as old,

And our paths in the world diverged so wide,

Each was nought to each, must I be told?

We were fellow-mortals, nought beside?

No, indeed! for God above

Is great to grant, as mighty to make, And creates the love to reward the love,-

I claim you still, for my own love's sake! 
Delayed it may be for more lives yet, Through worlds I shall traverse, not a few-

Much is to learn and much to forget

Ere the time be come for taking you.

But the time will come, - at last it will,-

When, Evelyn Hope, what meant, I shall say,

In the lower earth, in the years long still,

That body and soul so pure and gay?

Why your hair was amber, I shall divine,

And your mouth of your own geranium's red-

And what you would do with me, in fine,

In the new life come in the old one's stead.

I have lived, I shall say, so much since then, Given up myself so many times,

Gained me the gains of various men,

Ransacked the ages, spoiled the climes;

Yet one thing, one, in my soul's full scope,

Either I missed or itself missed me-

And I want and find you, Evelyn Hope!

What is the issue? let us see!

I loved you, Evelyn, all the while;

My heart seemed full as it could hold-

There was place and to spare for the frank young smile,

And the red young mouth, and the hair's young gold.

So, hush,-I will give you this leaf to keep-

See, I shut it inside the sweet eold hand.

There, that is our secret! go to sleep;

You will wake, and remember, and understand. 


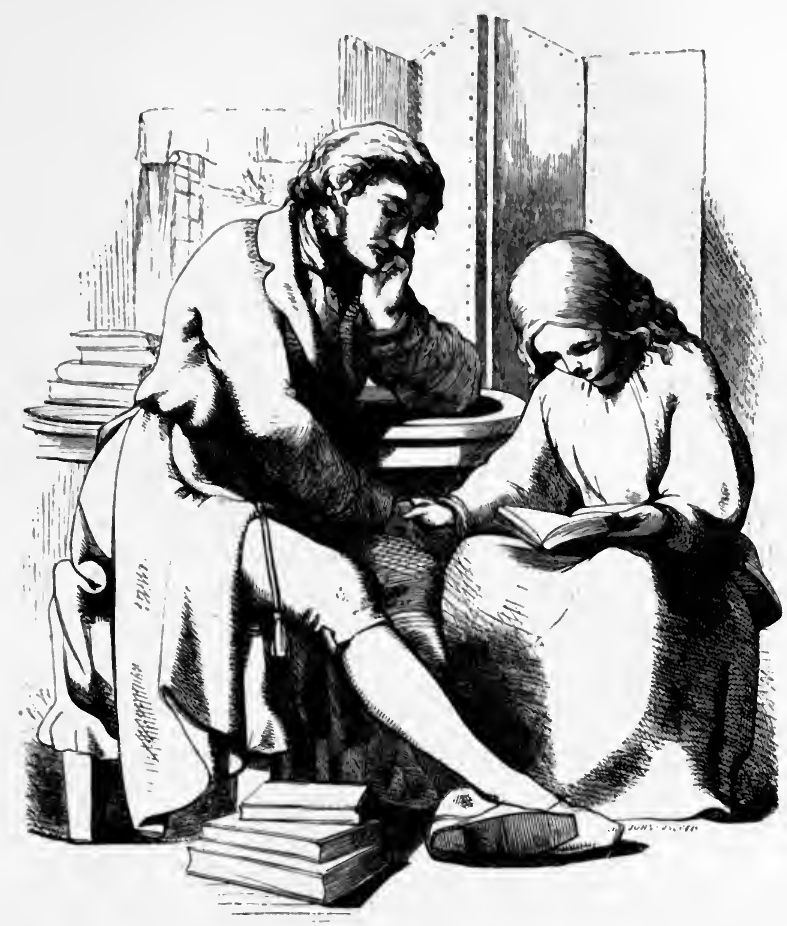

ELIZABETH BARRETT BROWNING.

WINE OF CYPRUS.

IF old Bacchus were the speaker,

He would tell you, with a sigh,

Of the Cyprus in this beaker

I am sipping like a fly,-

Like a fly or gnat on Ida

At the hour of goblet-pledge,

By queen Juno brushed aside, a

Full white arm-sweep, from the edge. 


\section{WINE OF CYPRUS.}

Sooth, the drinking should be ampler,

When the drink is so divine:

And some deep-mouthed Greek exampler

Would become your Cyprus wine!

Cyclop's mouth might plunge aright in,

While his one eye over-leered-

Not too large were mouth of Titan,

Drinking rivers down his beard.

Pan might dip his head so deep in,

That his ears alone pricked out,

Fauns around him, pressing, leaping,

Each one pointing to his throat:

While the Naiads, like Bacchantes

Wild, with urns thrown out to waste,

Cry,- "O earth, that thou wouldst grant us

Springs to keep, of such a taste!"

But for me, I am not worthy

After gods and Greeks to drink;

And my lips are pale and earthy

To go bathing from this brink.

Since you heard them speak the last time,

They have faded from their blooms,

And the laughter of my pastime

Has learnt silence at the tombs.

Ah, my friend! the antique drinkers

Crowned the cup, and crowned the brow.

Can I answer the old thinkers

In the forms they thought of, now?

Who will feteh from garden-closes

Some new garlands while I speak,

'That the forehead, crowned with roses,

May strike scarlet down the cheek? 
Do not mock me! with my mortal, Suits no wreath again, indeed!

I am sad-voiced as the turtle Which Anacreon used to feed; Yet as that same bird demurely Wet her beak in cup of his,, So, without a garland, surely

I may touch the brim of this.

Go!-let others praise the Chian!'This is soft as Muses' stringThis is tawny as Rhea's lion,

This is rapid as its spring,Bright as Paphia's eyes e'er met us, Light as ever trod her feet! And the brown bees of Hymettus Make their honey not so sweet.

Very copious are my praises, Though I sip it like a fly!$\mathrm{Ah}$-but, sipping,_times and places Change before me suddenlyAs Ulysses' old libation

Drew the ghosts from every part, So your Cyprus wine, dear Grecian, Stirs the Hades of my heart.

And I think of those long mornings Which my thought goes far to seek, When, betwixt the folio's turnings, Solemn flowed the rhythmic Greek. Past the pane, the mountain spreading, Swept the sheep-bell's tinkling noise, While a girlish voice was reading

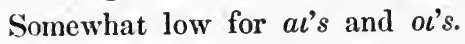


Then what golden hours were for us!-

While we sate together there,

How the white vests of the chorus

Seemed to wave up a live air!

How the cothurns trod majestic

Down the deep iambic lines;

And the rolling anapæstic

Curled like vapour over shrines!

Oh, our Aschylus, the thunderous!

How he drove the bolted breath

Through the cloud, to wedge it ponderous

In the gnarled oak beneath.

Oh, our Sophocles, the royal,

Who was born to monarch's place-

And who made the whole world loyal,

Less by kingly power than grace.

Our Euripides, the human-

With his droppings of warm tears;

And his touches of things common,

'Till they rose to touch the spheres!

Our Theocritus, our Bion,

And our Pindar's shining goals!-

These were cup-bearers undying

Of the wine that's meant for souls.

And my Plato, the divine one,-

If men know the gods aright

By their motions, as they shine on

With a glorious trail of light!-

And your noble Christian bishops,

Who mouthed grandly the last Greek:

Though the sponges on their hyssops

Were distent with wine-too weak. 
Yet, your Chrysostom, you praised him,

With his liberal mouth of gold;

And your Basil, you upraised him

To the height of speakers old:

And we both praised Heliodorus

For his secret of pure lies;-

Who forged first his linked stories

In the heat of ladies' eyes.

Do you mind that deed of Até

Which you bound me to so fast,-

Reading “De Virginitate,"

From the first line to the last?

How I said at ending, solemn,

As I turned and looked at you,

That St. Simeon on the column

Had had somewhat less to do?

For we sometimes gently wrangled;

Very gently, be it said,-

Since our thoughts were disentangled

By no breaking of the thread!

And I charged you with extortions

On the nobler fames of old-

Ay, and sometimes thought your Porsons

Stained the purple they would fold.

For the rest-a mystic moaning

Kept Cassandra at the gate,

With wild eyes the vision shone in-

And wide nostrils scenting fate.

And Prometheus, bound in passion

By brute force to the blind stone,

Showed us looks of invocation

Turned to ocean and the sun. 
And Medea we saw burning

At her nature's planted stake;

And proud (Edipus fate-scorning

While the cloud came on to break-

While the cloud came on slow-slower,

'Till he stood discrowned, resigned!-

But the reader's voice dropped lower

When the poet called him Busv !

Ah, my gossip! you were older,

And more learned, and a man !-

Yet that shadow-the enfolder

Of your quiet eyelids-ran

Both our spirits to one level,

And I turned from hill and lea,

And the summer-sun's green revel,-

To your eyes that could not see.

Now Christ bless you with the one light

Which goes shining night and day!

May the flowers which grow in sunlight

Shed their fragrance in your way!

Is it not right to remember

All your kindness, friend of mine,

When we two sate in the chamber

And the poets poured us wine?

So, to come back to the drinking

Of this Cyprus, - it is well-

But those memories, to my thinking,

Make a better onomel;

And whoever be the speaker,

None can murmur with a sigh-

That, in drinking from that beaker,

I am sipping like a fly. 


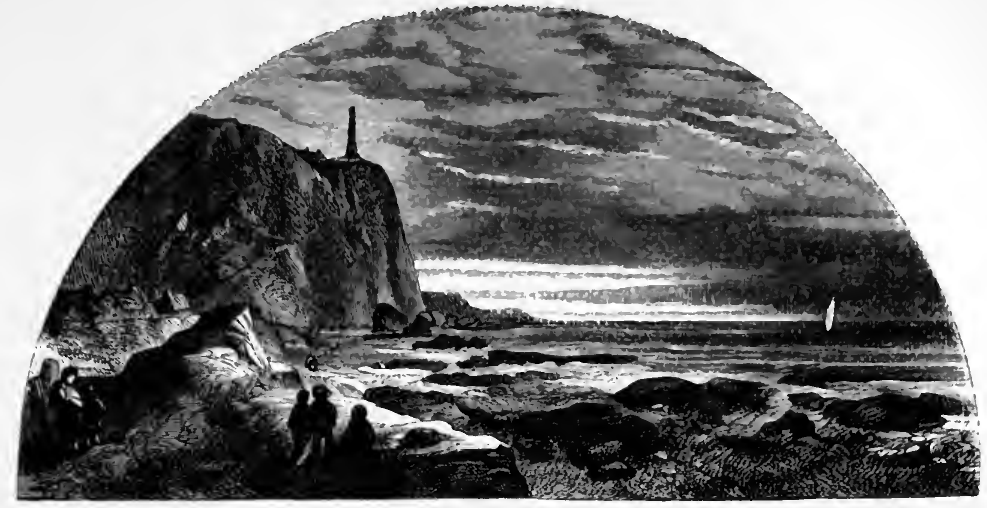

KINGSLEY.

THE THREE FISHERS.

Three fishers went sailing down to the west, Away to the west as the sun. went down;

Each thought of the woman who loved him the best, And the children stood watehing them out of the town:

For men must work, and women must weep, And here's little to earn, and many to keep, Though the harbour bar be moaning.

Three wives sat up in the lighthouse tower, And trimmed the lamps as the sun went down;

And they looked at the squall, and they looked at the shower, While the night rack came rolling up, ragged and brown;

But men must work, and women must weep, 'Though storms be sudden, and waters deep, And the harbour bar be moaning.

Three corpses lie out on the shining sands, In the morning gleam as the tide went down, And the women are weeping and wringing their hands, 


\section{THE SANDS OF DEE.}

For those who will never come home to the town.

But men must work, and women must weep,

And the sooner it's over, the sooner to sleep, And good-bye to the bar and its moaning.

\section{THE SANDS OF DEE.}

"OH, Mary, go and call the cattle home, And call the cattle home, And call the cattle home, Across the sands o' Dee ;"

'The western wind was wild and dank wi' foam, And all alone went she.

'The creeping tide came up along the sand, And o'er and o'er the sand, And round and round the sand, As far as eye could see;

The blinding mist came down and hid the landAnd never home came she.

"Oh, is it weed, or fish, or floating hair-

A tress o' golden hair,

O' drowned maiden's hair,

Above the nets at sea?

Was never salmon yet that shone so fair, Among the stakes on Dee."

They rowed her in across the rolling foan,

'The cruel, crawling foam,

The cruel, hungry foam, To her grave beside the sea:

But still the boatmen hear her eall the cattle home, Across the sands o' Dee. 
KINGSLEY.

\section{THE DAY OF THE LORD.}

The Day of the Lord is at hand, at hand:

Its storms roll up the sky:

$A$ nation sleeps starving on heaps of gold;

All dreamers toss and sigh;

The night is darkest before the dawn-

When the pain is sorest the child is born, And the Day of the Lord is at hand.

Gather you, gather you, angels of God-

Freedom, and Merey, and Truth ;

Come! for the Earth is grown coward and old-

Come down and renew us her youth.

Wisdom, Self-sacrifice, Daring, and Love,

Haste to the battle-field, stoop from above, To the Day of the Lord at hand.

Gather you, gather you, hounds of hell-

Famine, and Plague, and War;

Idleness, Bigotry, Cant, and Misrule,

Gather, and fall in the snare!

Hirelings and Mammonites, Pedants and Knaves,

Crawl to the battle-field-sneak to your graves, In the Day of the Lord at hand.

Who would sit down and sigh for a lost age of gold,

While the Lord of all ages is here?

True hearts will leap up at the trumpet of God,

And those who can suffer, can dare.

Each age of gold was an iron age too,

And the meekest of saints may find stern work to do,

In the Day of the Lord at hand. 


\section{AYTOUN.}

\section{THE BURIAL-MARCH OF DUNDEE.}

I.

Souvd the fife, and cry the slogan-

Let the pibroch shake the air

With its wild triumphal music,

Worthy of the freight we bear.

Let the ancient hills of Scotland

Hear once more the battle-song

Swell within their glens and valleys

As the clansmen march along!

Never from the field of combat,

Never from the deadly fray,

Was a nobler trophy carried

Than we bring with us to-day;

Never since the valiant Douglas

On his dauntless bosom bore

Good King Robert's heart-the priceless-.

To our dear Redeemer's shore!

Lo! we bring with us the hero-

Lo! we bring the conquering Grame,

Crowned as best beseems a victor

From the altar of his fame;

Fresh and bleeding from the battle

Whence his spirit took its flight,

Midst the erashing charge of squadrons,

And the thunder of the fight!

Strike, I say, the notes of triumph,

As we march o'er moor and lea:

Is there any here will venture

To bewail our dead Dundee? 


\section{AYTOUN.}

Let the widows of the traitors

Weep until their eyes are dim!

Wail ye may full well for Scotland-

Let none dare to mourn for him!

See! above his glorious body

Lies the royal banner's fold-

See! his valiant blood is mingled

With its crimson and its gold.

See how calm he looks and stately,

Like a warrior on his shield,

Waiting till the flush of morning

Breaks along the battle-field!

See-Oh never more, my comrades,

Shall we see that falcon eye

Redden with its inward lightning,

As the hour of fight drew nigh !

Never shall we hear the voice that,

Clearer than the trumpet's call,

Bade us strike for King and Country,

Bade us win the field, or fall!

II.

On the heights of Killiecrankie

Yester-morn our army lay:

Slowly rose the mist in columns

From the river's broken way;

Hoarsely roared the swollen torrent,

And the Pass was wrapped in gloom,

When the clansmen rose together

From their lair amidst the broom.

Then we belted on our tartans,

And our bonnets down we drew,

And we felt our broadswords' edges,

And we proved them to be true;

And we prayed the prayer of soldier,

And we cried the gathering-cry, 
And we clasped the hands of kinsmen,

And we swore to do or die!

Then our leader rode before us

On his war-horse black as night-

Well the Cameronian rebels

Knew that charger in the fight:-

And a cry of exultation

From the bearded warriors rose;

For we loved the house of Claver'se,

And we thought of good Montrose.

But he raised his hand for silence-

"Soldiers! I have sworn a vow:

Ere the evening star shall glisten

On Schehallion's lofty brow,

Either we shall rest in triumph,

Or another of the Græmes

Shall have died in battle-harness

For lis Country and King James!

Think upon the Royal Martyr-

Think of what his race endure-

Think on him whom butchers murder'd

On the field of Magus Muir:-

By his sacred blood I charge ye,

By the ruined hearth and shrine-

By the blighted hopes of Scotland,

By your injuries and mine-

Strike this day as if the anvil

Lay beneath your blows the while,

Be they Covenanting traitors,

Or the brood of false Argyle!

Strike! and drive the trembling rebels

Backwards o'er the stormy Forth;

Let them tell their pale Convention

IIow they fared within the North.

Iet them tell that Highland honour

Is not to be bought nor sold,

That we scorn their prince's anger 


\section{AYTOUN.}

As we loathe his foreign gold.

Strike! and when the fight is over,

If you look in vain for me,

Where the dead are lying thickest

Search for him that was Dundee!"

III.

Loudly then the hills re-echoed

With our answer to his call,

But a deeper echo sounded

In the bosoms of us all.

For the lands of wide Breadalbane,

Not a man who heard him speak

Would that day have left the battle.

Burning eye and flushing cheek

Told the clansmen's fierce emotion,

And they harder drew their breath;

For their souls were strong within them,

Stronger than the grasp of death.

Soon we heard a challenge-trumpet

Sounding in the Pass below,

And the distant tramp of horses,

And the voices of the foe;

Down we crouched amid the bracken,

Till the Lowland ranks draw near,

Panting like the hounds in summer,

When they scent the stately deer.

From the dark defile emerging,

Next we saw the squadrons come,

Leslie's foot and Leven's troopers

Marehing to the tuck of drum;

Through the scattered wood of birches,

O'er the broken ground and heath,

Wound the long battalion slowly,

Till they gained the field beneath;

Then we bounded from our covert. 
Judge how looked the Saxons then, When they saw the rugged mountain Start to life with arméd men! Like a tempest down the ridges Swept the hurricane of steel, Rose the slogan of MacdonaldFlashed the broadsword of Lochiel ! Vainly sped the withering volley

'Mongst the foremost of our bandOn we poured until we met them, Foot to foot, and hand to hand.

Horse and man went down like drift-wood

When the floods are black at Yule,

And their carcasses are whirling

In the Garry's deepest pool.

Horse and man went down before us-

Living foe there tarried none

On the field of Killiecrankie,

When that stubborn fight was done!

IV.

And the evening star was shining

On Schehallion's distant head,

When we wiped our bloody broadswords,

And returned to count the dead.

There we found him gashed and gory,

Stretched upon the cumbered plain,

$\Lambda \mathrm{s}$ he told us where to seek him,

In the thickest of the slain.

And a smile was on his visage,

For within his dying ear

Pealed the joyful note of triumph,

And the elansmen's elamorous cheer:

So, amidst the battle's thunder,

Shot, and steel, and scorching flame,

In the glory of his manhood

lassed the spirit of the Grame! 
AYTOUN.

v.

Open wide the vaults of Athol, Where the bones of heroes rest-

Open wide the hallowed portals

To receive another guest!

Last of Scots, and last of freemen-

Last of all that dauntless race

Who would rather die unsullied

Than outlive the land's disgrace!

$\mathrm{O}$ thou lion-hearted warrior!

Reck not of the after-time :

Honour may be deemed dishonour,

Loyalty be called a crime.

Sleep in peace with kindred ashes

Of the noble and the true,

Hands that never failed their country,

Hearts that never baseness knew.

Sleep!-and till the latest trumpet

Wakes the dead from earth and sea,

Scotland shall not boast a braver

Chieftain than our own Dundee! 


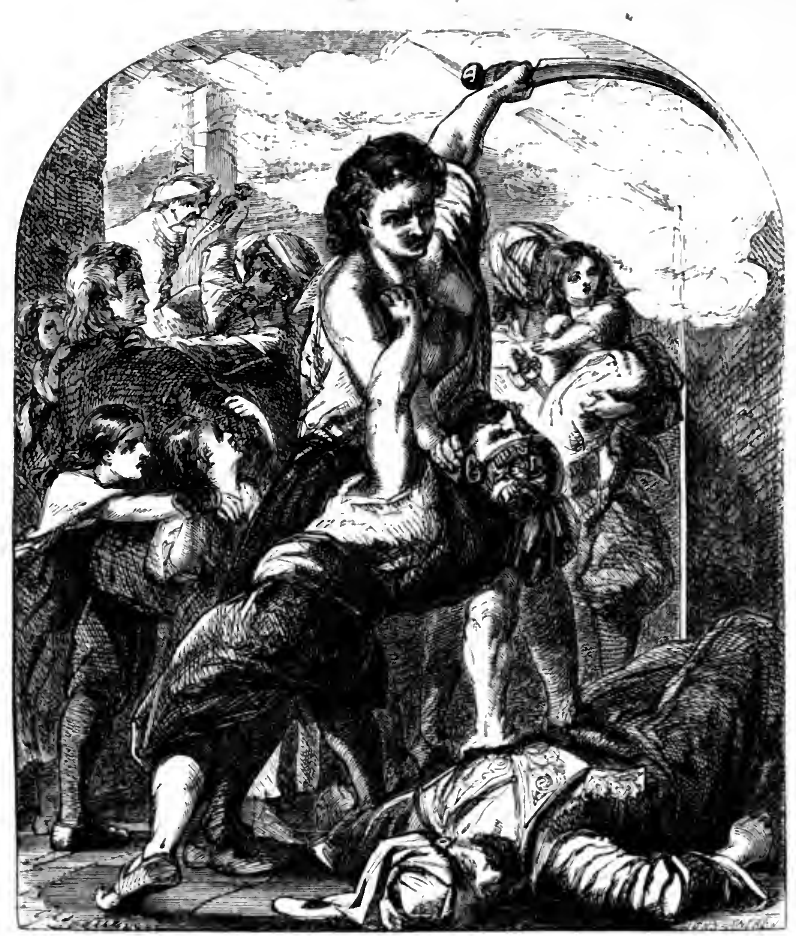

\section{DAVIS.}

THE SACK OF BALTIMORE.

Baltimore is a sea-port in South Munster, and was plundered by a band of Algerines in the night of June 20 th, 1631, under the guidance of Hackett, a Dungarvan fisherman.

True summer sun is falling soft on Carb'ry's hundred isles,

The summer sun is gleaming still through Gabriel's rough defiles:

Old Inisherkin's crumbled fane looks like a moulting bird, And in a calm and sleepy swell the ocean tide is heart. 


\section{DAVIS.}

The hookers lie upon the beach; the children cease their play;

The gossips leave the little inn; the households kneel to pray,And full of love, and peace, and rest-its daily labour o'erUpon that cosy creek there lay the town of Baltimore.

A deeper rest, a starry trance, has come with midnight there; No sound, except that throbbing wave, in earth, or sea, or air. The massive capes and ruined towers seem conscious of the ealm; The fibrous sod and stunted trees are breathing heavy balm. So still the night, these two long barques, round Dunashad that glide Must trust their oars, methinks not few, against the ebbing-tideOh! some sweet mission of true love must urge them to the shoreThey bring some lover to his bride, who sighs in Baltimore !

All, all asleep within each roof along that rocky street, And these must be the lover's friends, with gently gliding feetA stifled gasp! a dreamy noise !_ "The roof is in a flame!" From out their beds, and to their doors, rush maid, and sire, and dameAnd meet, upon the threshold stone, the gleaming sabre's fall, And o'er each black and bearded face the white or crimson shawlThe yell of "Allah" breaks above the prayer, and shriek, and roarOh, blessed God! the Algerine is lord of Baltimore!

Then flung the youth his naked hand against the shearing sword; Then sprung the mother on the brand with which her son was gor'd; Then sunk the grandsire on the floor, his grand-babes clutching wild; Then fled the maiden moaning faint, and nestled with the child; But see yon pirate.strangled lies, and crushed with splashing heel, While o'er him in an Irish hand there sweeps his Syrian steelThough virtue sink, and courage fail, and misers yield their store, There's one hearth well avengèd in the sack of Baltimore.

Midsummer morn, in woodland nigh, the birds begin to singThey see not now the milking maids, deserted is the spring! Midsummer day - this gallant rides from distant. Bandon's town, These hookers crossed from stormy Skull, that skiff from Affadown; 
'They only found the smoking walls, with neighbours' blood besprent, And on the strewed and trampled beach awhile they wildly went,Then dash'd to sea, and passed Cape Cleir, and saw five leagues before The pirate galleys vanishing that ravaged Baltimore.

Oh ! some must tug the galley's oar, and some must tend the steed,This boy will bear a Sheik's chibouk, and that a Bey's jerreed.

Oh! some are for the arsenals, by beauteous Dardanelles;

And some are in the caravan to Mecca's sandy dells. The maid that Bandon gallant sought is chosen for the DeyShe's safe-she's dead-she stabb'd him in the midst of his Serai. And, when to die a death of fire, that noble maid they bore, She only smiled-O'Driscoll's child-she thought of Baltimore.

'Tis two long years since sunk the town beneath that bloody band, And all around its trampled hearths a larger concourse stand, Where, high upon a gallows-tree, a yelling wretch is seen'Tis Hackett of Dungarvan,-he, who steered the Algerine! He fell amid a sullen shout, with scarce a passing prayer, For he had slain the kith and kin of many a hundred thereSome muttered of Mac Morrogh, who had brought the Norman o'erSome curs'd him with Iscariot, that day in Baltimore. 


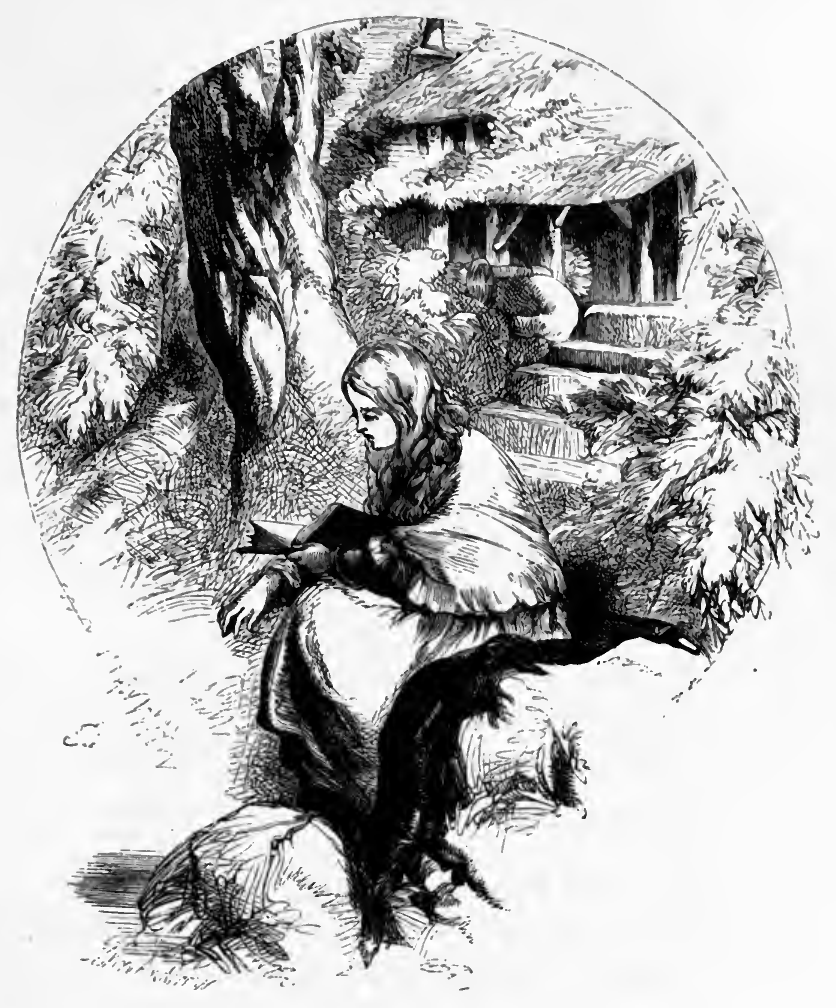

\section{BULWER LYTTON.}

EVA.

THE MAIDEN'S HOME.

A cotrage in a peaceful vale;

A jasmine round the door;

A hill to shelter from the gale;

A silver brook before. 
Oh, sweet the jasmine's buds of snow,

In mornings soft with May;

$\mathrm{Oh}$, silver-clear the waves that flow,

Reflecting heaven, away!

A sweeter bloom to Eva's youth

Rejoicing Nature gave;

And heaven was mirror'd in her truth

More clear than on the wave.

Oft to that lone sequester'd place

My boyish steps would roam,

There was a look in Eva's face

That seem'd a smile of home.

And oft I paused to hear at noon

A voice that sang for glee:

Or mark the white neck glancing down,

'The book upon the knee.

TIIE IDIOT BOY.

Who stands between thee and the sun?-

A cloud himself,-the Wandering One!

$A$ racant wonder in the eyes,-

The mind, a blank, unwritten scroll; -

The light was in the laughing skies,

And darkness in the Idiot's soul.

He touch'd the book upon her knee-

He look'd into her gentle face-

"Thou dost not tremble, maid, to see

Poor Arthur by thy dwelling-place.

I know not why, but where I pass

The aged turn away;

And if my shadow vex the grass,

The children cease from play.

My only playmates are the wind,

The blossom on the bough!

Why are thy looks so soft and kind?

Thou dost not tremble-thou !' 


\section{BULWER LYTTON.}

Though none were by, she trembled not,-

Too meek to wound, tqo good to fear him; And, as he linger'd on the spot,

She hid the tears that gush'd to hear him.

\section{THE YOUNG TEACHER.}

Of wonders on the land and deeps

She spoke, and glories in the sky-

The eternal life the Father keeps

For those, who learn from Him to die.

So simply did the maiden speak-

So simply and so earnestiy,

You saw the light begin to break,

And Soul the Heaven to see;

You saw how slowly, day by day,

The darksome waters caught the ray,

Confused and broken-come and gone--

The beams as yet uncertain are, But still the billows murmur on, And struggle for the star.

THE STRANGER-SUITOR.

There came to Eva's maiden home

A Stranger from a sunnier clime;

The lore that Hellas taught to Rome,

The wealth that Wisdom wins from 'Time, Which ever, in its ebb and flow,

Heaves to the seeker on the shore

The waifs of glorious wrecks below,

The argosies of yore;-

Each gem that in that dark profound

The Past the Student's soul can find,

Shone from his thought, and sparkled round

The Enchanted Palace of the Mind.

How trustful in the leafy June,

She roved with him the lonely vale; 


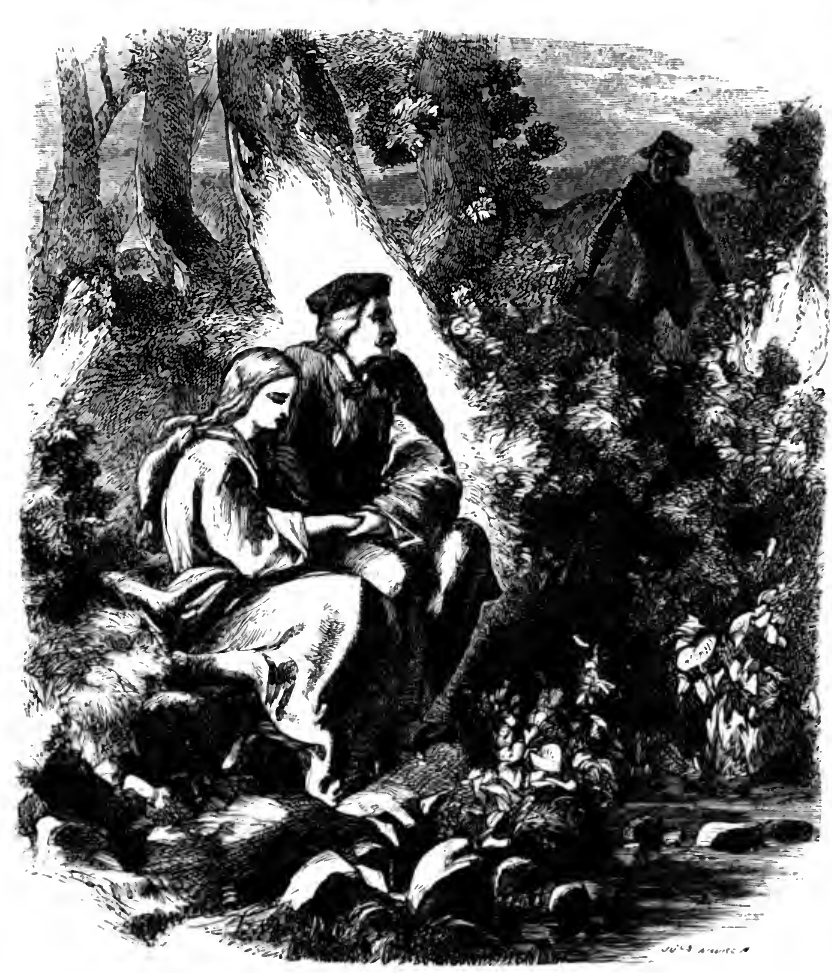

How trustful by the tender moon,

She blush'd to hear a tenderer tale.

O happy Earth! the dawn revives,

Day after day, each drooping flower-

Time to the heart once only gives

The joyous Morning-hour.

"To him-oh, wilt thou pledge thy youth,

For whom the world's false bloom is o'er? 


\section{BULWER LYTTON.}

My heart shall haven in thy truth, And tempt the faithless wave no more."

Her hand lay trembling on his arm, Averted glow'd the happy face;

A softer hue, a mightier charm, Grew mellowing o'er the hour-the place;

Along the breathing woodlands moved A presence dream-like and divineHow sweet to love and be beloved, To lean upon a heart that's thine! Silence was o'er the earth and skyBy silence Love is answer'd bestHer answer was the downcast eye, The rose-cheek pillow'd on his breast.

What rustles through the moonlit brake?

What sudden spectre meets their gaze? What face, the hues of life forsake,

Gleams ghost-like in the ghostly rays?

You might have heard his heart that beat, So heaving rose its heavy swellNo more the Idiot-at her feet

The Dark One, roused to reason, fell.

Loosed the last link that thrall'd the thought, The lightning broke upon the blindThe jealous love the cure had wrought, The Heart in waking woke the Mind.

\section{THE HERMIT.}

Years fly; beneath the yew-tree's shade, 'Thy father's holy dust is laid;

The brook glides on, the jasmine blows;

But where art thou, the wandering wife?

And what the bliss, and what the woes,

Glass'd in the mirror-sleep of life? 
For whether life may laugh or weep,

Death the true waking-life the sleep.

Who tenants thy forsaken cot-

Who tends thy childhood's favourite flowers-

Who wakes, from every haunted spot,

The Ghosts of buried Hours?

'Tis' He whose sense was doom'd to borrow

From thee the Vision and the Sorrow-

To whom the Reason's golden ray,

In storms that rent the heart, was given;

The peal that burst the elouds away

Left clear the face of heaven!

And wealth was his, and gentle birth,

A form in fair proportions cast;

But lonely still he walk'd the earth-

The Hermit of the Past.

It was not love-that dream was o'er!

No stormy grief, no wild emotion;

For oft, what once was love of yore,

The memory soothes into devotion!

He bought the cot:- The garden flowers-

The haunts his Eva's steps had trod,

Books-thought-beguiled the lonely hours,

That flow'd in peaceful waves to God.

\section{DESERTION.}

She sits, a Statue of Despair,

In that far land, by that bright sea;

She sits, a Statue of Despair,

Whose smile an Angel's seem'd to be.

she knows it all-the hideous tale-

The wrong, the perjury, and the shame;-

Before the bride had left her veil,

Another bore the nuptial name.

The infunt woke from feverish rest-

Its smile she sees, its voice she hears- 


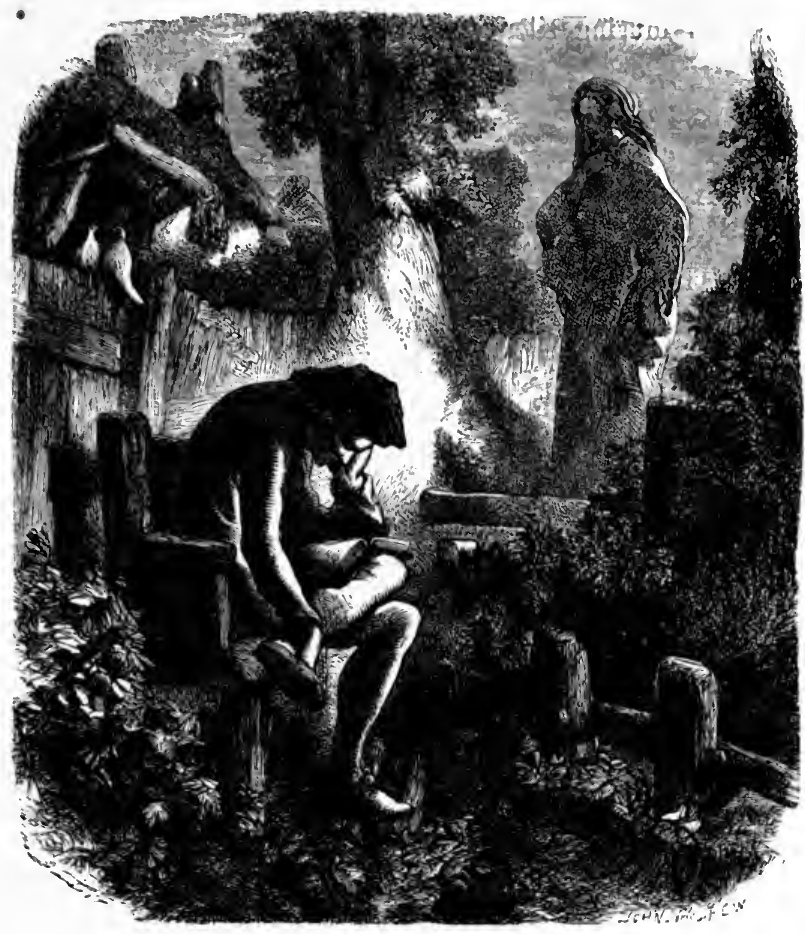

The marble melted from the breast, And all the Mother gush'd in tears.

THE RFTURN.

The cottage in the peaceful vale, The jasmine round the door, The hill still shelters from the gale, The brook still glides before. 
Without the porch, one summer noon, The Hermit-dweller see!

In musing silence bending down,

The book upon his knee.

Who stands between thee and the sun?-

A cloud herself,- the Wand'ring One!-

A vacant sadness in the eyes,

The mind a razed, defeatured scroll;

The light is in the laughing skies,

And darkness, Eva, in thy soul!

Yet still the native instinct stirr'd

The darkness of the breast-

She flies, as flies the wounded bird

Unto the distant nest;

O'er hill and waste, from land to land,

Her heart the faithful instinct bore;

And there, behold the Wanderer stand

Beside her Childhood's Home once more!

\section{LIGHT AND DARKNESS.}

When earth is fair, and winds are still,

When sunset gilds the western hill,

Oft by the porch, with jasmine sweet,

Or by the brook, with noiseless feet,

Two silent forms are seen;

So silent they-the place so lone-

They seem like souls, when life is gone,

That haunt where life has been:

And his to wateh, as in the past

Her soul had watch'd his soul.

Alas! her darkness waits the last,

The grave the only goal!

It is not what the leech can cure-

An erring chord, a jarring madness:

$\Lambda$ calm so deep, it must endure-

So deep, thou scarce canst call it sadness; 


\section{BULWER LY'TTON.}

A summer night, whose shadow falls

On silent hearths in ruin'd halls.

Yet, through the gloom, she seem'd to feel His presence like a happier air; Close by his side she loved to steal, As if no ill could harm her there!

And when her looks his own would seek, Some memory seem'd to wake the sigh, Strive for kind words she could not speak, And bless him in the tearful eye.

O sweet the jasmine's buds of snow, In mornings soft with May, And silver-clear the waves that flow To shoreless deeps away; But heavenward from the faithful heart

A sweeter incense stole;-

The onward waves their source desert, But Soul returns to Soul! 


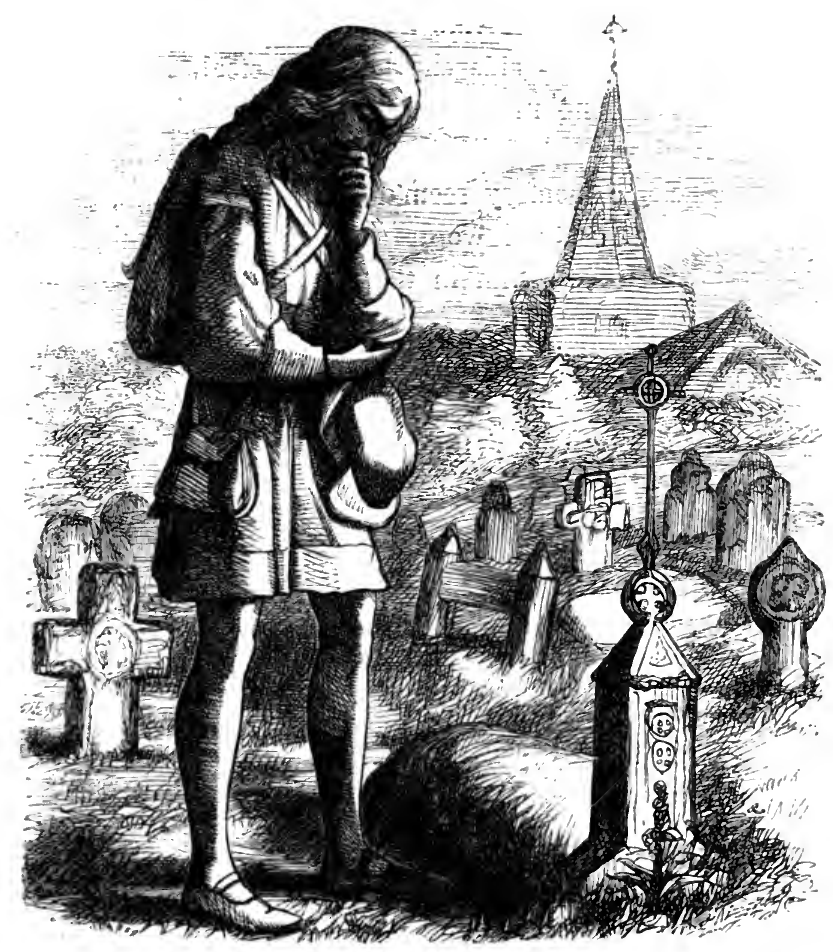

PROCTER.

THE HISTORY OF A LIFE.

1) AY dawned:-Within a curtained room, Filled to faintness with perfume, $A$ lady lay at point of doom. 
Day closed :-A Child had seen the light;

But for the lady, fair and bright,

She rested in undreaming night.

Spring rose:-'The lady's grave was green;

And near it oftentimes was seen

A gentle Boy, with thoughtful mien.

Years fled:--He wore a manly face, And struggled in the world's rough race, And won, at last, a lofty place.

And then-he died! Behold, before ye, Humanity's poor sum and story;

Life-Death, -and all that is of Glory.

\section{WITHIN AND WITHOUT.}

\section{WITHOUT.}

The winds are bitter; the skies are wild;

From the roof comes plunging the drowning rain:

Without,-in tatters, the world's poor child

Sobbeth abroad her grief, her pain!

No one heareth her, no one heedeth her:

But Hunger, her friend, with his bony hand

Grasps her throat, whispering huskily-

"What dost Thou in a Christian land?" 


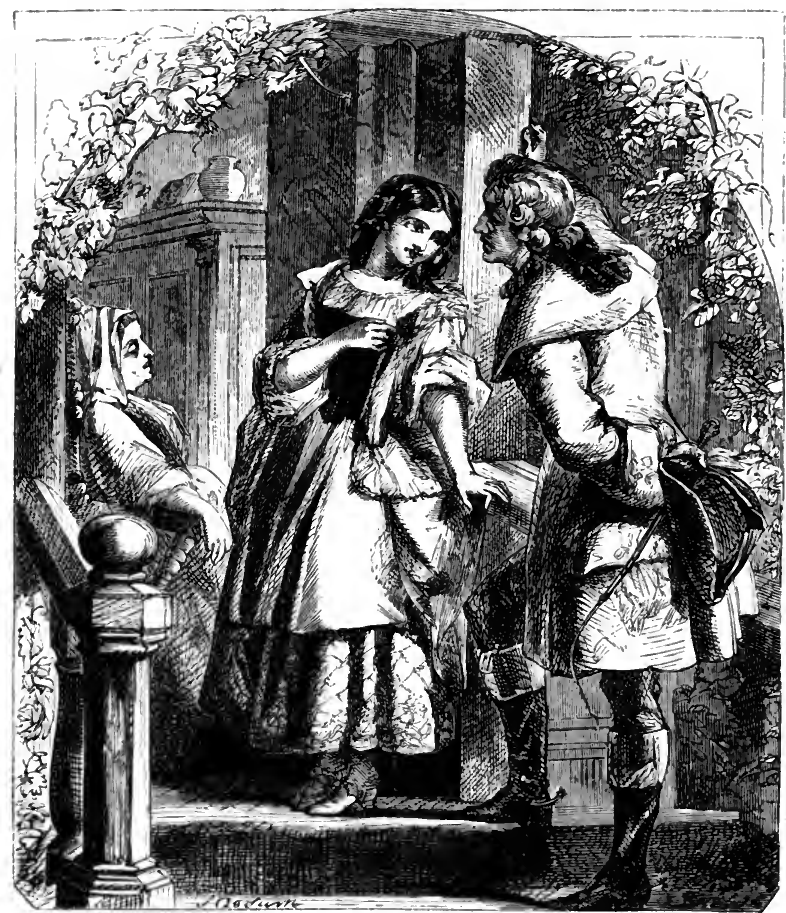

WITHIN.

The skies are wild, and the blast is cold;

Yet riot and luxury brawl within:

Slaves are waiting, in silver and gold,

Waiting the nod of a child of sin.

The fire is erackling, wine is bubbling

$\mathrm{U}_{\mathrm{p}}$ in each glass to its beaded brim:

The jesters are laughing, the parasites quaffing

"Happiness,"-" honour,"-and all for him! 


\section{PROCTER.}

WITHOUT.

She who is slain in the winter weather, $\mathrm{Ah}$ ! she once had a village fame;

Listened to love on the moonlit heather;

Had gentleness-vanity-maiden shame;

Now, her allies are the tempest howling;

Prodigals' curses; self-disdain ;

Poverty; misery: Well,-no matter;

There is an end unto every pain!

\section{WITHIN.}

He who yon lordly feast enjoyeth,

He who doth rest on his couch of down,

$\mathrm{He}$ it was, who threw the forsaken

Under the feet of the trampling town:

Liar-betrayer,-false as cruel,

What is the doom for his dastard sin?

His peers, they scorn?-high dames, they shun him?

- Unbar yon palace, and gaze within.

There,-yet his deeds are all trumpet-sounded, There, upon silken seats recline

Maidens as fair as the summer morning,

Watching him rise from the sparkling wine.

Mothers all proffer their stainless daughters;

Men of high honour salute him "Friend;"

Skies! oh, where are your cleansing waters?

World! oh, where do thy wonders end? 


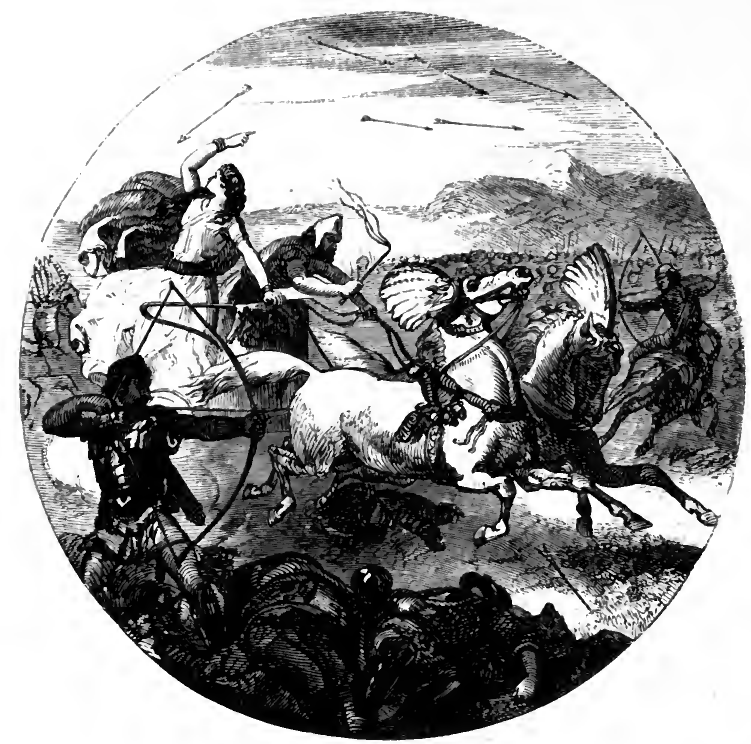

\section{ATHERS'TONE.}

BATTLE SCENES.

O'ER all the plain th' Assyrian camp-fires now Blaze high; and with the darkness a drear red Strangely commingle. Like a burning gulf, Sleeping till stirr'd by winds; the heaving mass Of warriors at the mountain's foot appears;

Breast-plates, and shields, and helms, and gonfalons, Glow blood-red here and there; but doubly dark Elsewhere the night. Now, toward the hills all haste: If Medes alone, or with Assyrians mixed, I cannot know; but rapid is the speed. The light increases: up the mountain's side, 


\section{ATHERSTONE.}

In the red darkness faintly I discern

The slumbering myriads; and toward its foot

Onward they come; like billows of dark fire.

But farther off, in one bright blaze, the camp.

Shines out: a countless multitude I see,

In flaming armour pouring o'er the plain.

Iike ocean glittering 'neath the ruddy sun,

The wide field flashes; like the ocean's roar

Their clamours rise.

Among the trees a crash

I hear,-a heaving of the branches. Lights

Are thickening near the hill. Ha! now I see

They rend the boughs for torches. In his hand

Each soldier bears a branch of blazing pine.

They speed toward the heights: they shake the toreh :

They wave the sword: like running flame they seem.

Now up the steep they urge. A cloud of darts

And arrows from the Medes upon them pours,-

A fiery cloud; and stones are hurled-and spears;-

Yet upward still they come. The watch-fires now

Are flaming on the hills: distinctly gleams

The battle forth. Their torches they cast down;

Not needed now. Ha! by his star-like helm,

Assyria's king appears. He shouts: he flies:

He points towards the rocks; -he waves them on.

A warrior meets him: sword with sword they fight-

Arabia's monarch, sure.-But both are lost,-

The waves of fight roll o'er them-

Meantime, along the sapphire bridge of heaven,

Far, far beyond the canopy of cloud

That mantled earth, the day-god's lightning steeds

'Through the pure ether rapt his chariot-wheels,

Sounding harmonious thunder. To the height

They had 'ascended; and the steep decline

Half-way had measured; yet the hard-fought field 
Still was contested; for, like men resolved

On that one day to peril all to come-

To die, perchance, but never to submit-

The Assyrian captains strove; and, with like fire,

'Their soldiers' hearts inflamed. Aid too had come-

Chariots, and horse, and foot; who, when the scale,

Charged with Assyria's doom, was sinking fast,

Twice had its fall arrested. Once again,

When seemed that utter ruin hovered nigh,

The chariot of Assyria's beauteous queen

From rank to rank flew on: and, as they saw,

The warriors' breasts, as with new soul infused,

Like beacons freshly kindled, burst at once

Into intensest flame. Unhelmed, unarmed,

Her ebon hair loose flying in the wind,

She raised aloft her arms, her voice uplift,

And bade them on to glory. As the star

Of morning, while the sun yet sleeps below,

And the grey mist is on the dewy earth,

Her face was pale and radiant. Like a shape

From heaven descended, and to mortal harm

Impassive, gloriously and fearlessly

Through the death-laden air she flew along.

Her spirit fired the host; with deafening shouts

Onward they bore; and, for a time, the Medes

Compelled, though slowly, backward. 


\section{MARY HOWITT.}

THE BALLAD OF RICHARD BURNELL.

\section{PART I.}

From his bed rose Richard Burnell

At the early dawn of day,

Ere the bells of London city

Welcomed in the morn of May.

Early on that bright May morning

Rose the young man from his bed,

He, the happiest man in London,

And thus to himself he said :-

" When the men and maids are dancing, And the folk are mad with glce,

In the Temple's shady gardens

Let me walk and talk with thee!'

"Thus my Alice spake last even, Thus with trembling lips she spake, And those blissful words have kept me

Through the live-long night awake.

"'Tis a joy beyond expression, When we first, in truth, perceive

That the love we long have cherished

Will not our fond hearts deceive! 


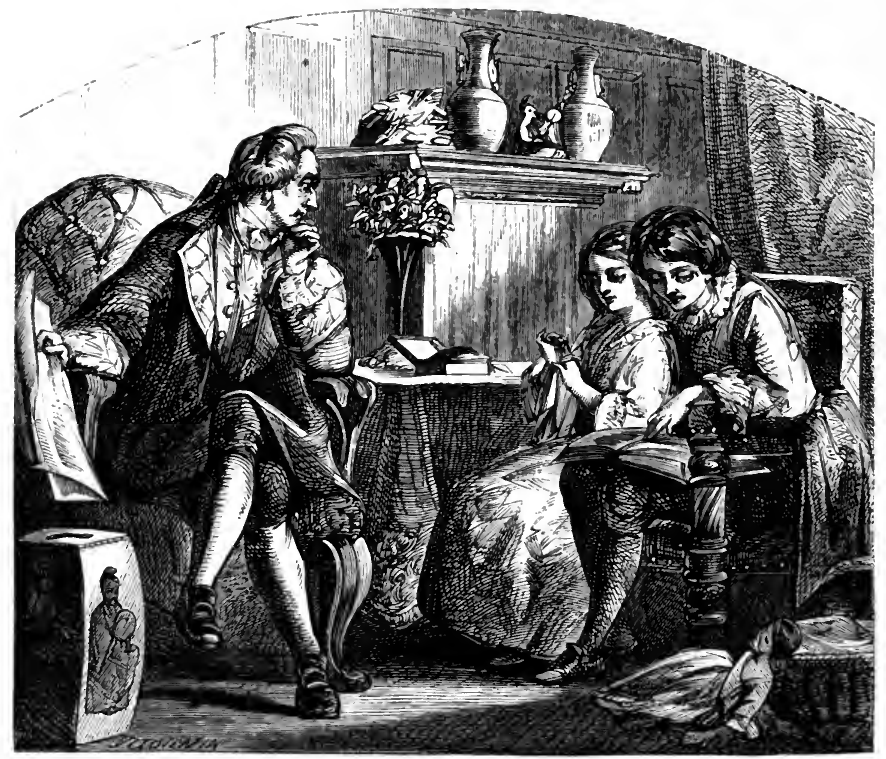

"Never dared I to confess it-

Deeds of homage spoke instead;

True love is its own revealer, She must know it! oft I said.

"All my words, and all my actions, But one meaning could impart; Love ean love's least sign interpret, And she reads my inmost heart.

"And her good old merehant father,Father he has been to me-

Saw the love grow up between us, Saw-and was well pleased to see. 


\section{MARY HOWITT.}

"Seven years I truly served him,

Now my time is at an end;

Master is he now no longer:

Father will be-has been friend.

"I was left betimes an orphan,

Heir unto great merchant-wealth,

But the iron rule of kinsfolk

Dimmed my youth, and sapped my health.

"Death had been my early portion

Had not my good guardian come;

He, the father of my Alice,

And conveyed me to his home.

"Here began a new existence,-

Then how new the love of friends!

And for all the child's afflictions

Each one strove to make amends.

"Late my spring-time came, but quickly

Youth's rejoicing currents run,

And my inner life unfolded

Like a flower before the sun.

"Hopes, and aims, and aspirations

Grew within the growing boy;

Life had new interpretation;

Manhood brought increase of joy.

"In and over all was Alice,

Life-infusing, like the spring;

My soul's soul! even joy without her

Was a poor and barren thing! 
"And she spoke last eve at parting, 'When the folk are mad with glee, In the Temple's pleasant gardens

Let me walk and talk with thee!'

"As she spoke, her sweet voice trembled,Love such tender tones can teach! And those words have kept me waking, And the manner of her speech!

"For such manner has deep meaning," Said young Burnell, blithe and gay;And the bells of London city Pealed a welcome to the May.

PART II.

Whilst the folk were mad with pleasure, 'Neath the elm-tree's vernal shade, In the Temple's quiet gardens Walked the young man and the maid.

On his arm her hand was resting,

And her eyes were on the ground; She was speaking, he was silent; Not a word his tongue had found.

"Friend beloved," she thus addressed him,

"I have faith and hope in thee!

Thou eanst do what no one clse can-

Thou canst be a friend to me! 
"Richard, we have lived together All these years of happy youth ; Have, as sister and as brother, Lived in confidence and truth.

"Thou from me hast hid no feelings, Thy whole heart to me is known; I-I only have kept from thee One dear, little thought alone.

"Have I wronged thee in so doing? Then forgive me! But give ear; 'Tis to bare my heart before thee That I now am with thee here.

"Well thou know'st my father loves thee; 'Tis his wish that we should wed,-

I shame not to speak thus franklyWish, or will more justly said.

"But this cannot be, my brother, Cannot be-'twere nature's wrong !I have said so to my father; But thou know'st his will is strong."

Not a word spake Richard Burnell:

Not a word came to his lips;

Like one tranced he stood and listened;

Life to him was in eclipse.

In a lower tone she murmured, Murmured like a brooding dove,

"Know thou,-Leonard Woodvil loves me,And-that he has won my love." 
-Came a pause. The words she uttered Seemed to turn him into stone; Pale he stood and mute beside her, And with blushes she went on.

"This is known unto my father;Leonard is well known to thee, Thou hast praised him, praised him often$\mathrm{Oh}$, how dear such praise to me!

"But my father, stern and steadfast, Will not list to Leonard's prayer;And 'tis only thou canst move him,Only thou so much canst dare.

"Tell my father firmly, freely, That we only love each other-

'Tis the truth, thou know'st it, Richard,As a sister and a brother!

"'Tell my father, if we wedded, Thou and I, it would be guilt! Thus it is that thou canst aid usAnd thou wilt-I know thou wilt!

"Yes, 'tis thus that thou must aid us, And thou wilt! I say no more!We've been friends, but this will make us Better friends than heretofore!"

Yet some moments he was silent;

His good heart was well-nigh broke;

She was blinded to his anguish;-

And “I will!" at length he spoke. 


\section{MARY HOWITT.}

\section{Part III.}

They were wedded. 'Twas a wedding

That had far and high renown, And from morning until even

Rang the bells of London town.

Time went on: the good old merchant

Wore a cloud upon his brow:

"Wherefore thus?" his friends addressed him,

"No man should be blithe as thou!"

"In my old age I am lonely," Said the merchant, "she is gone;And young Burnell, he I nurtured, He who was to me a son;

"He has left me!-I'm desertedE'en an old man feels such woe!

'Twas but natural she should marry, But he should not have served me so.

"'Twas not that which I expected!

He was very dear to me,-

And I thought no London merchant

Would have stood as high as he!

"He grew very strange and moody, What the cause I cannot say ; And he left me when my daughter, My poor Alice, went away! 


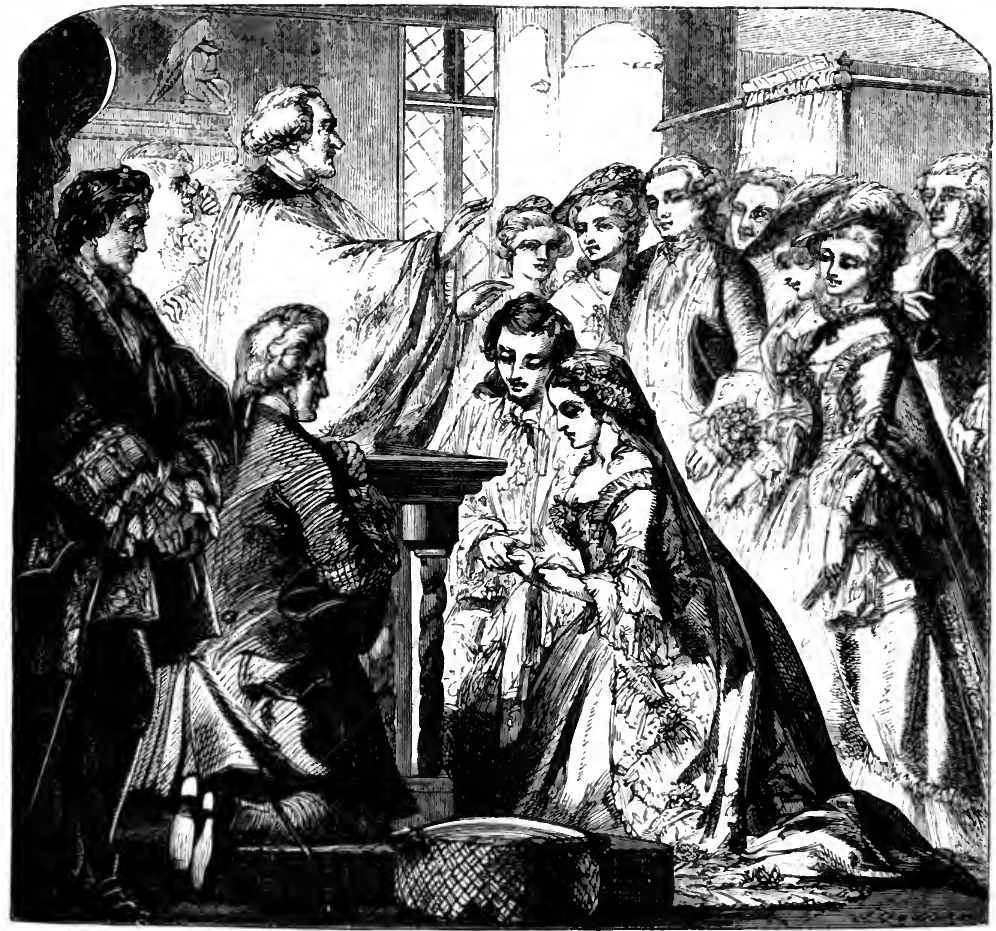

"I had been a father to him,

He to me was like a son:

Young folks should have more reflection,-

'Twas what $I$ could not have done!

"True, he writes me duteous letters;

Calls me father, tells me all

That in foreign parts is doing,-

But young people write so small, 


\section{MARY HOWIT'T.}

"'That I'm often forced to leave them, Pleasant letters though they be, Until Alice comes from Richmond, Then she reads them out to me.

"Alice fain would have me with her;

- Leonard well deserves my praiseBut he's not my Richard Burnell, Knows not my old wants and ways!

“No, my friends, I'll not deny it, It has cut me to the heart, That the son of my adoption

Thus has played a cruel part!"

So the merchant mourned and murmured;

And all foreign charms unheeding,

Dwelt the lonely Richard Burnell,

With his bruisèd heart still bleeding.

\section{Part IV.}

Time went on, and in the spring-tide, When the birds began to build, And the heart of all creation With a vast delight was filled,

Came a letter unto Alice-

Then a babe lay on her breast-

'Twas the first which Richard Burnell

Unto Alice had addressed. 
Few the words which it contained,

But each word was like a sigh;

"I am sick and very lonely;-

Let me see thee ere I die!

"In this time of tribulation

Thou wilt be a friend to me:

Therefore in the Temple Gardens

Let me once more speak with thee."

Once more in the Temple Gardens

Sat they 'neath the bright blue sky,

With the leafage thick around them,

And the river rolling by.

Pale and weak was Richard Burnell,

Gone all merely outward grace,

Yet the stamp of meek endurance

Gave sad beauty to his face.

Silent by his side sat Alice,

Now no word her tongue could speak,

All her soul was steeped in pity,

And large tears were on her cheek.

Burnell spake: "Within these Gardens

'Thy commands on me were laid, And, although my heart was breaking,

Yet were those commands obeyed.

"What I suffered no one knoweth, Nor shall know, I proudly said, And, when grew the grief too mighty,

Then-there was no help-I fled. 


\section{MARY HOWITT.}

"Yes, I loved thee, long had loved thee, And alone the God above, $\mathrm{He}$, who at that time sustained me, Knows the measure of my love!

"Do not let these words displease thee; Life's sore battle soon will cease;

I have fallen amid the conflict, But within my soul is peace.

"It has been a fiery trial, But the fiercest pang is past; Once more I am come amongst youOh! stand by me at the last!

"Leonard will at times come to me, And thy father. I will try To be cheerful in his presence, As I was in days gone by.

"Bitter has it been to leave him; But in all my heart's distress, The great anguish which consumed me Seemed to swallow up the less.

"Let me go! my soul is wearied, No fond heart of me has need, Life has no more duties for me;I am but a broken reed!

"Let me go, ere courage faileth, Gazing, gazing thus on thee!But in life's last awful moment, Alice! thou wilt stand by me!" 
THE BALLAD OF RICHARD BURNELL.

From her seat rose Alice Woodvil, And in steadfast tones began, Like a strong consoling angel, To address the dying man.

"Not in death alone, my brother, Would I aid thee in the strife;

I would fain be thy sustainer In the fiercer fight of life.

"With the help of God, thy spirit Shall not in this conflict yield; Prayer, the key which opens heaven, Is the Christian's sword and shield.

"God will aid thee! We will hold thee By our love!-thou shalt not go!And from out thy wounded spirit, We will pluck the thorns of woe.

"Say not life has no more duties

Which can claim thee! Where are then All the sinners; the neglected;

All the weeping sons of men?

" $\mathrm{Ah}$, my friend, hast thou forgotten All our dreams of early days?

How we would instruct poor children, How we would the fallen raise!

"God has not to me permitted Such great work of human love; He has marked me out a lower Path of duty where to move. 


\section{MARY HOWITT.}

"But to thee, Ilis chosen servant, Is this higher lot allowed;

He has brought thee through deep waters, Through the furnace, through the cloud;

"He has made of thee a mourner, Like the Christ, that thou may'st rise To a purer height of glory, Through the pangs of sacrifice!

"'Tis alone of His appointing, That thy feet on thorns have trod; Suffering, woe, renunciation, Only bring us nearer God.

"And when nearest Him, then largest The enfranchised heart's embrace:It was Christ, the Man rejected, Who redeemed the human race.

"Say not, then, thou hast no duties;Friendless outeasts on thee call, And the sick and the afflicted, And the children, more than all.

"Oh, my friend, rise up, and follow Where the hand of God shall lead; He has brought thee through affliction, But to fit thee for His need!"

Thus she spoke; and as from midnight Springs the opal-tinted morn, So, within his dreary spirit,

A new day of life was born. 


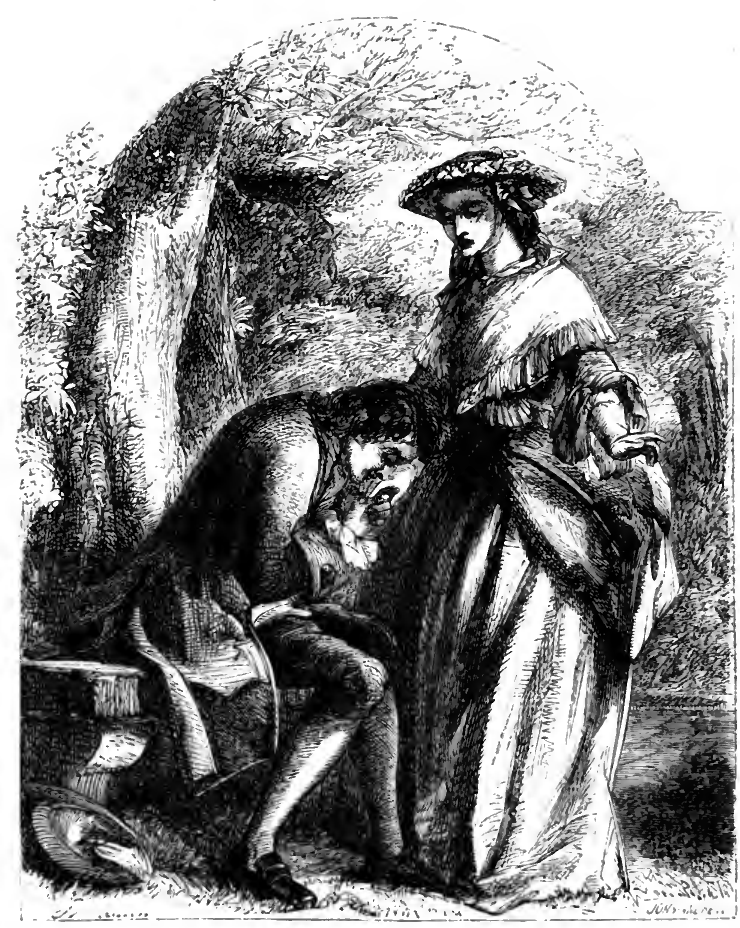

Strength sublime may rise from weakness, Groans be turned to songs of praise, Nor are life's divinest labours Only told by length of days.

Young he died: but deeds of mercy

Beautified his life's short span, And he left his worldly substance

To complete what he began. 


\title{
ARNOLD.
}

\section{TO A GIPSY CHILD BY THE SHORE.}

\author{
DOUGLAS, ISLE OF MAN.
}

WHo taught this pleading to unpractis'd eyes?

Who hid such import in an infant's gloom?

Who lent thee, child, this meditative guise?

What clouds thy forehead, and fore-dates thy doom?

Lo! sails that gleam a moment and are gone;

The swinging waters, and the cluster'd pier.

Not idly Earth and Ocean labour on,

Nor idly do these sea-birds hover near.

But thou whom superfluity of joy

Wafts not from thine own thoughts, nor longings vain,

Nor weariness, the full fed soul's annoy;

Remaining in thy hunger and thy pain:

Thou, drugging pain by patience; half averse

From thine own mother's breast, that knows not thee;

With eyes that sought thine eyes thou didst converse,

And that soul-searching vision fell on me.

Glooms that go deep as thine I have not known:

Moods of fantastic sadness, nothing worth.

Thy sorrow and thy calmness are thine own:

Glooms that enhance and glorify this earth.

What mood wears like complexion to thy woe?-

His, who in mountain glens, at noon of day, Sits rapt, and hears the battle break below?-

Ah! thine was not the shelter, but the fray. 
What exile's, cllanging bitter thoughts with glad?

What seraph's, in some alien planet born?No exile's dream was ever half so sad,

Nor any angel's sorrow so forlorn.

Is the calm thine of stoic souls, who weigh

Life well, and find it wanting, nor deplore:

But in disdainful silence turn away,

Stand mute, self-centred, stern, and dream no more?

Or do I wait, to hear some gray-hair'd king

Unravel all his many-colour'd lore:

Whose mind hath known all arts of governing,

Mus'd much, lov'd life a little, loath'd it more?

Down the pale cheek long lines of shadow slope,

Which years, and eurious thought, and suffering give-

'Thou hast foreknown the vanity of hope,

Foreseen thy harvest-yet proceed'st to live.

O meek anticipant of that sure pain

Whose sureness gray-hair'd scholars hardly learn!

What wonder shall time breed, to swell thy strain?

What heavens, what earth, what suns shalt thou discern?

Ere the long night whose stillness brooks no star,

Match that funereal aspect with her pall,

I think, thou wilt have fathom'd life too far,

IIave known too mueh-or else forgotten all.

The Guide of our dark steps a triple veil

Betwixt our senses and our sorrow keeps:

IIath sown with cloudless passages the tale

Of grief, and eas'd us with a thousand sleeps.

Ah! not the nectarous poppy lovers use,

Not daily labour's dull, Lethean spring,

Oblivion in lost angels can infuse

Of the soil'd glory, and the trailing wing; 


\section{ARNOLD.}

And though thou glean, what strenuous gleaners may,

In the throng'd fields where winning comes by strife;

And though the just sun gild, as all men pray,

Some reaches of thy storm-vext stream of life;

Though that blank sunshine blind thee; though the cloud

That sever'd the world's march and thine is gone:

Though ease dulls grace, and Wisdom be too proud

To halve a lodging that was all her own:

Once ere the day decline, thou shalt discern, Oh once, ere night, in thy success, thy chain:

Ere the long evening close, thou shalt return, And wear this majesty of grief again. 


\section{BENNETT.}

\section{B A B Y'S S H O E S.}

Or, those little, those little blue shoes!

Those shoes that no little feet use.

$\mathrm{Oh}$, the price were high

That those shoes would buy,

Those little blue unused shoes!

For they hold the small shape of feet

That no more their mother's eyes meet,

'That, by God's good will,

Years since grew still,

And ceased from their totter so sweet.

And oh, since that baby slept,

So hushed, how the mother has kept,

With a tearful pleasure,

That little dear treasure,

And over them thought and wept!

For they mind her for evermore

Of a patter along the floor;

And blue eyes she sees

Look up from her knees

With the look that in life they wore.

As they lie before her there,

There babbles from chair to ehair

A little sweet face

'That's a gleam in the place,

With its little gold curls of hair. 


\section{BENNETT.}

Then, oh, wonder not that her heart

From all else would rather part

Than those tiny blue shoes

That no little feet use,

And whose sight makes such fond tears start!

\section{LILIAN'S EPITAPH.}

THou hast been and thou hast fled,

Rose, sweet rose;

Budded, flushed, and, ah! art dead,

Rose, sweet rose;

Yet oblivion may not kill

Dreams of thee, our thoughts that fill, And for us thou'rt blooming still, Rose, sweet rose.

Breathing rose, nor might'st thou stay,

Rose, sweet rose;

Thou too, woe! hast passed away,

Rose, sweet rose;

Yet though death had heart to sever

Life and thee, thou'rt from us never;

No, in thought thou'rt with us ever,

Rose, sweet rose. 


\title{
ALEXANDER SMITH.
}

\author{
SCENE-THE BANKS OF A RIVER.
}

\section{_ 'Tis that loveliest stream.}

I've learned by heart its sweet and devious course By frequent tracing, as a lover learns The features of his best beloved's face.

In memory it runs, a shining thread,

With sunsets strung upon it thick, like pearls.

From yonder trees I've seen the western sky

All 'washed with fire, while, in the midst, the sun

Beat like a pulse, welling at ev'ry beat

A spreading wave of light. Where yonder church

Stands up to heaven, as if to intercede

For sinful hamlets scatter'd at its feet,

I saw the dreariest sight. The sun was down,

And all the west was paved with sullen fire.

I cried, "Behold! the barren beach of hell

At ebb tide." The ghost of one bright hour

Comes from its grave and stands before me now.

'Twas at the close of a long summer day,

As we were sitting on yon grassy slope,

The sunset hung before us like a dream

That shakes a demon in his fiery lair;

The clouds were standing round the setting sun

Like gaping caves, fantastic pinnacles,

Citadels throbbing in their own fieree light,

Tall spires that came and went like spires of flame,

Cliffs quivering with fire-snow, and peaks

Of pilèl gorgeousness, and rocks of fire

A-tilt and poised, bare beaches, erimson seas-

All these were huddled in that dreadful west,

All shook and trembled in unsteadfast light, 


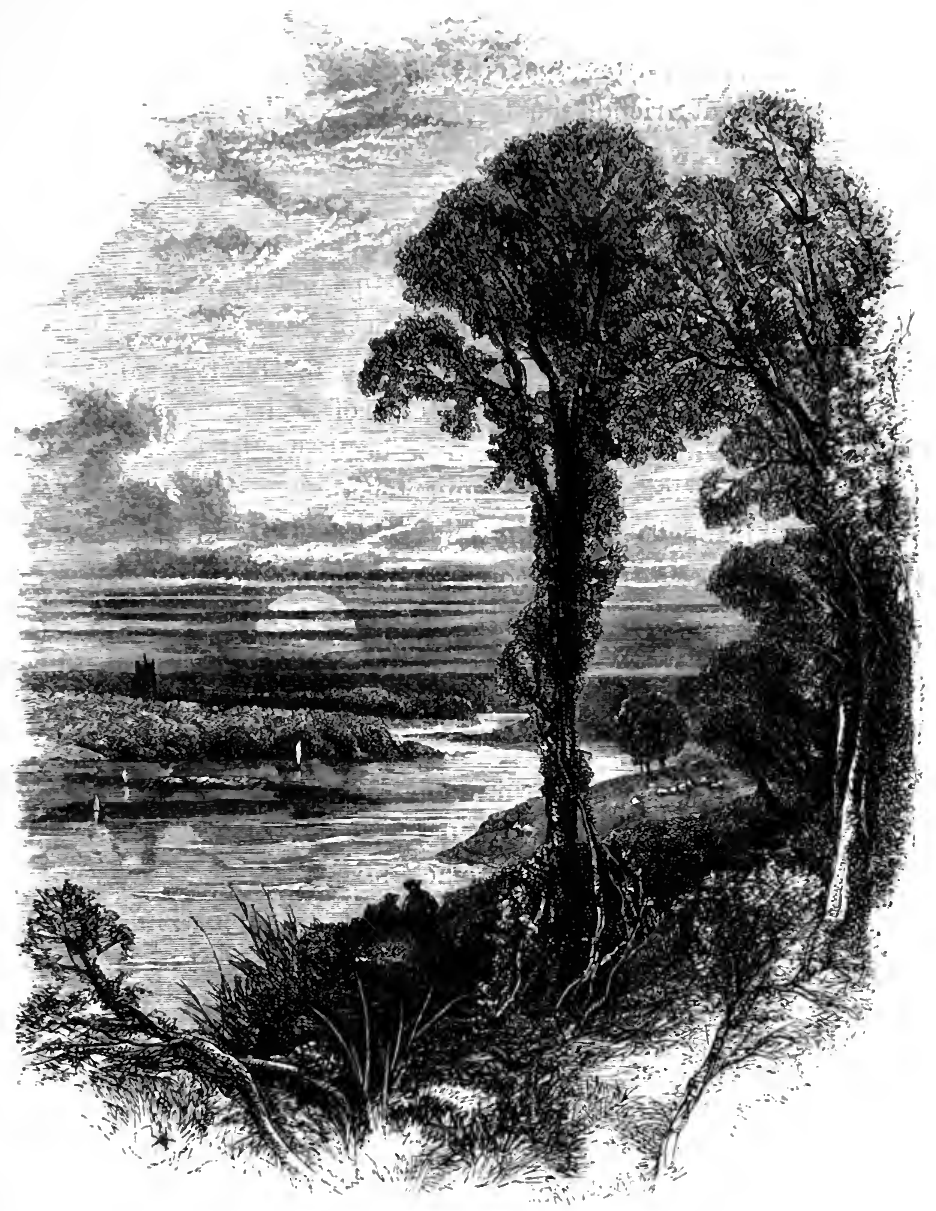

And from the centre blazed the angry sun,

Stern as the unlash'd eye of God a-glare

O'er evening city with its boom of sin.

I do remember, as we journeyed home,

(That dreadful sunset burnt into our brains,)

With what a soothing came the naked moon.

She, like a swimmer who has found his ground,

Came rippling up a silver strand of cloud, 
And plunged from the other side into the night.

$I$ and that friend, the feeder of my soul,

Did wander up and down these banks for years,

Talking of blessed hopes and holy faiths,

How sin and weeping all should pass away

In the calm sunshine of the earth's old age.

Breezes are blowing in old Chaucer's verse;

'Twas here we drank them. Here for hours we liung

O'er the fine pants and trembles of a line.

Oft, standing on a hill's green head, we felt

Breezes of love, and joy, and melody,

Blow through us, as the winds blow through the sky.

Oft with our souls in our eyes all day we fed

On summer landscapes, silver-veined with streams,

O'er which the air hung silent in its joy;

With a great city lying in its smoke,

A monster sleeping in its own thick breath;

And surgy plains of wheat, and ancient woods

In the calm evenings cawed by clouds of rooks,

Acres of moss, and long black strips of firs,

And sweet cots dropt in green, where children played,

To us unheard; till, gradual, all was lost

In distance-haze to a blue rim of lills,

Upon whose heads came down the closing sky.

\section{P I C T U R E S.}

TIIE lark is singing in the blinding sky,

Hedges are white with May. The bridegroom sea

Is toying with the shore, his wedded bride,

And, in the fulness of his marriage joy,

He decorates her tawny brow with shells, 


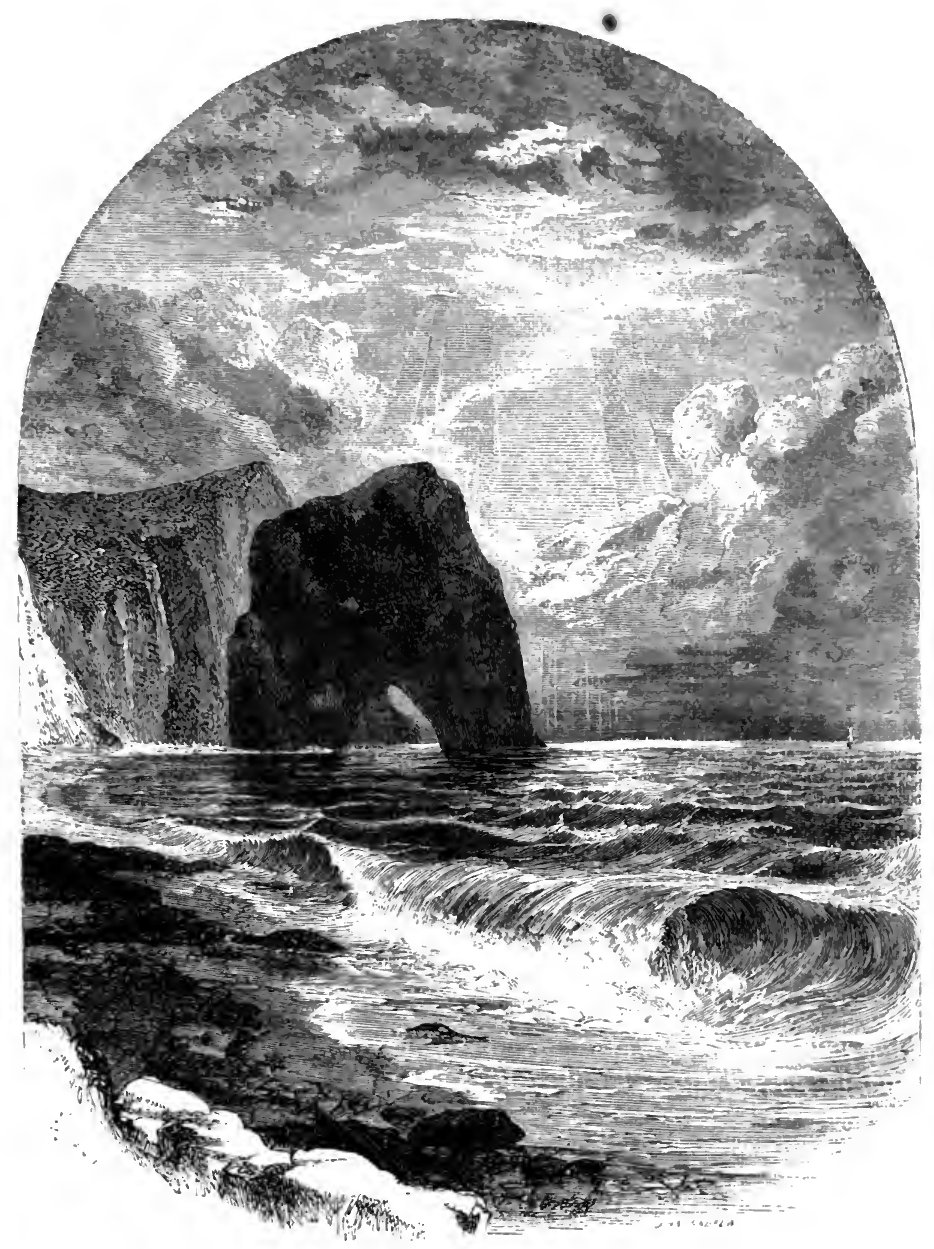

Retires a space, to see how fair she looks, Then, proud, runs up to kiss her. All is fairAll glad, from grass to sun 


\section{PICTURES.}

-One nymph slumbering lay,

A sweet dream 'neath her eyelids, her white limbs Sinking full softly in the violets dim;

When timbrelled troops rushed past with branches green.

One in each fountain, riched with golden sands,

With her delicious face a moment seen,

And limbs faint gleaming through their watery veil.

- A grim old king,

Whose blood leapt madly when the trumpets brayed

'To joyous battle 'mid a storm of steeds,

Won a rich kingdom on a battle-day;

But in the sunset he was ebbing fast,

Ringed by his weeping lords. His left hand held

His white steed, to the belly splashed with blood,

That seemed to mourn him with his drooping head;

His right, his broken brand; and in his ear

Ilis old victorious banners flap the winds.

He called his faithful herald to his side-

"Go! tell the dead I come!" With a proud smile,

The warrior with a stab let out his soul,

Which fled, and shrieked through all the other world,

"Ye dead! My master comes!" And there was pausc

'Till the great Shade should enter. 


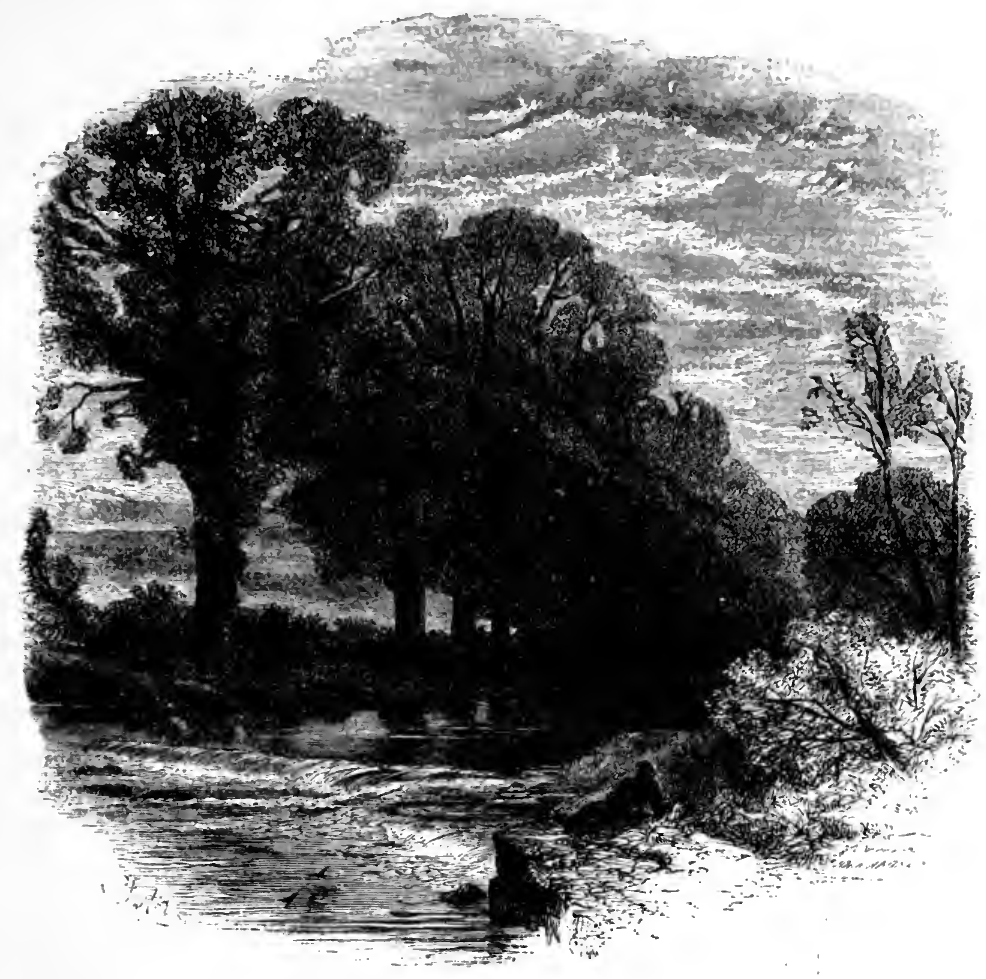

\section{BAILEY.}

\section{A SUMMER NIGHT.}

The last high upward slant of sun on the trees,

Like a dead soldier's sword upon his pall, Seems to console earth for the glory gone.

Oh! I could weep to see the day die thus;

The death-bed of a day, how beautiful!

Linger, ye clouds, one moment longer there;

Fan it to slumber with your golden wings!

Like pious prayers, ye seem to soothe its end. 
WORDS.

It will wake no more till the all-revealing day;

When, like a drop of water, greatened bright

Into a shadow, it shall show itself

With all its little tyrannous things and deeds,

Unhomed and clear. The day hath gone to God,-

Straight-like an infant's spirit, or a mocked

And mourning messenger of Grace to man.

Would it had taken me too on its wing!

My end is nigh. Would I might die outright,-

So o'er the sunset clouds of red mortality

The emerald hues of deathlessness diffuse

Their glory, heightening to the starry blue

Of all embosoming eternity.

Who that hath lain lonely on a high hill,

In the imperious silence of full noon,

With nothing but the clear dark sky about him,

Like GoD's HaND laid upon the head of earth,-

But hath expected that some natural spirit

Should start out of the universal air,

And, gathering his cloudy robe around him,

As one in act to teach mysterious things,

Explain that he must die?

\section{WORDS.}

Tin poet in his work reflects his soul,

As some lone nymph, beside a woodland well, Whose elear white limbs, like animated light, Make glad the heart and sanetify the sight, The soft and shadowy miracle of her form.

'The bard's aim is to give us thoughts; his art

Lieth in giving them as bright as may be. 
Words are the motes of thought, and nothing more. Words are like sea-shells on the shore; they show Where the mind ends, and not how far it has been. Let every thought, too, soldier-like, be stripped, And roughly looked over. The dress of words, Like to the Roman girl's enticing garb, Should let the play of limb be seen through it, And the round rising form. A mist of words, Like halos round the moon, though they enlarge 'The seeming size of thoughts, make the light less Doubly. It is the thought writ down we want, Not its effect,- - not likenesses of likenesses. And such descriptions are not, more than gloves Instead of hands to shake, enough for us. As in the good the fair; simplicity Is Nature's first step, and the last of Art.

\section{PORTRAIT OF A LADY.}

- Her form was all humanity,

Her soul all God's; in spirit and in form, Like fair. Her cheek had the pale pearly pink Of sea-shells, the world's sweetest tint, as though She lived, one half might deem, on roses sopped In silver dew; she spake as with the voice Of spheral harmony, which greets the soul When at the hour of death the saved one knows His sister angels near; her eye was as 'The golden fane the setting sun doth just Imblaze; which shows, till Heaven comes down again, All other lights but grades of gloom; her dark, Long rolling locks were as a stream the slave Might search for gold, and, searching, find. 


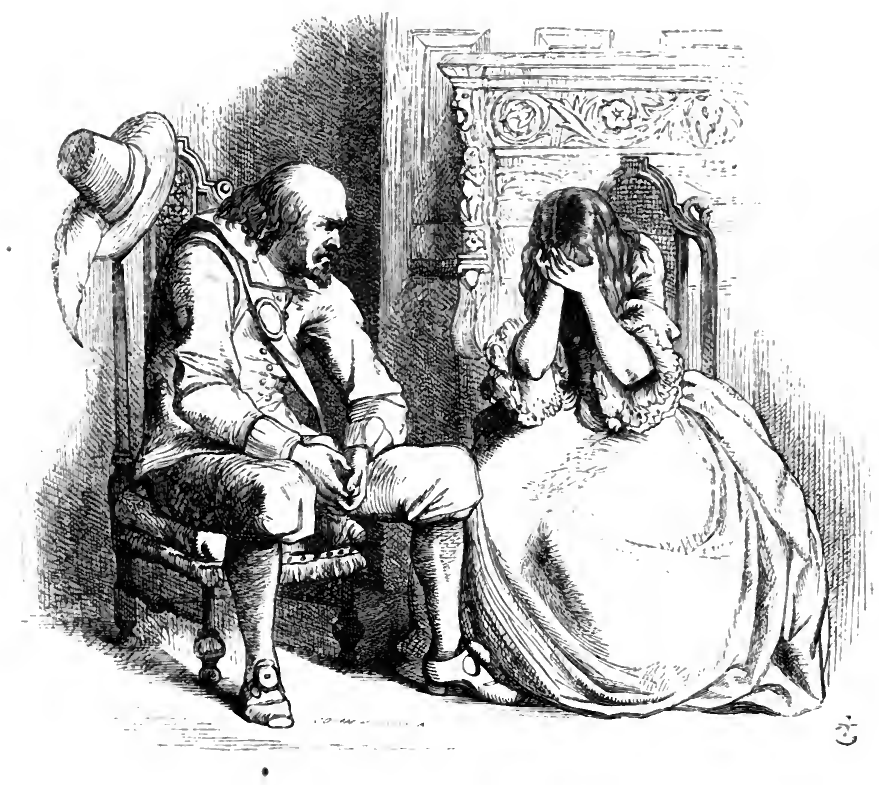

KNOWLES.

THE APPEAL AND THE REPROOF.

JULLIA AND MASTER WALTER.

Walter. What! run the waves so high? Not ready yet! Your lord will soon be here! 'The guests collect.

Julia. Show me some way to 'scape these nuptials! Do it! Some opening for avoidance or escape,-

Or to thy charge I'll lay a broken heart! 


\section{KNOWLES.}

It may be, broken vows, and blasted honour!

Or else a mind distraught!

Walter. What's this?

Julia. The strait

I'm fallen into my patience cannot bear!

It frights my reason-warps my sense of virtue!

Religion!-changes me into a thing

I look at with abhorring!

Walter. Iisten to me.

Julia. Listen to me, and heed me! If this contract Thou hold'st me to-abide thou the result!

Answer to Heaven for what I suffer!-act!

Prepare thyself for such calamity

To fall on me, and those whose evil stars

Have link'd them with me, as no past mishap,

However rare, and marvellously sad,

Can parallel! lay thy account to live

A smileless life, die an unpitied death-

Abhorr'd, abandon'd of thy kind, - as one

Who had the guarding of a young maid's peace,-

Look'd on and saw her rashly peril it;

And when she saw her danger, and confess'd

Her fault, compell'd her to complete her ruin!

Walter. Hast done?

Julia. Another moment, and I have.

Be warn'd! Beware how you abandon me

To myself! I'm young, rash, inexperienced! tempted

By most insufferable misery!

Bold, desperate, and reckless! Thou hast age,

Experience, wisdom, and collectedness,- 
Power, freedom,--everything that I have not,

Yet want, as none e'er wanted! Thou canst save me,

Thou ought'st! thou must! I tell thee, at his feet

I'll fall a corse-cre mount his bridal bed!

So choose betwixt my rescue and my grave;-

And quickly too! The hour of sacrifice

Is near! Anon the immolating priest

Will summon me! Devise some speedy means

To cheat the altar of its victim. Do it!

Nor leave the task to me!

Walter.

Julia.
Hast done?

I have.

Walter. Then list to me-and silently, if not

With patience.-

[Brings chairs for himself and her.

How I watch'd thee from thy childhood,

I'll not recall to thee. Thy father's wisdom-

Whose humble instrument I was-directed

Your nonage should be pass'd in privacy,

From your apt mind, that far outstripp'd your years,

Fearing the taint of an infected world ; -

For in the rich ground, weeds, once taking root,

Grow strong as flowers. He might be right or wrong!

I thought him right; and therefore did his bidding.

Most certainly he loved you-so did I;

Ay! well as I had been myself your father!

[His hand is resting upon his knee. Julia attempts to take it. IIe withdraws it; looks at her. She hangs her hect.

Well; you may take my hand! I need not say

How fast you grew in knowledge, and in goodness,-

That hope could searce enjoy its golden dreams,

so soon fulfilment realized them all! 


\section{KNOWLES.}

Enough. You came to womanhood. Your heart Pure as the leaf of the consummate bud, That's new unfolded by the smiling sun, And ne'er knew blight nor canker! When a good woman Is fitly mated, she grows doubly good, How good soe'er before! I found the man I thought a match for thee; and, soon as found, Proposed him to thee. 'Twas your father's will, Occasion offering, you should be married Soon as you reach'd to womanhood. You liked My choice-accepted him. We came to town ; Where, by important matters, summon'd thence, I left you, an affianced bride!
Julia.
You did!

You did!

Walter. Nay, check thy tears! Let judgment now, Not passion, be awake. On "my return, I found thee-what? I'll not describe the thing I found thee then! I'll not describe my pangs To see thee such a thing! The engineer Who lays the last stone of his sea-built tower It cost him years and years of toil to raise, And, smiling at it, tells the winds and waves To roar and whistle now-but, in a night, Beholds the tempest sporting in its placeMay look aghast, as I did! 


\section{MASSEY.}

OUR WEE WHITE ROSE.

ALL in our marriage garden Grew, smiling up to God, A bonnier flower than ever Suckt the green warmth of the sod;

$O$ beautiful unfathomably Its little life unfurled; And crown of all things was our wee White Rose of all the world.

From out a balmy bosom,

Our bud of beauty grew :

It fed on smiles for sunshine;

On tears for daintier dew :

Aye nestling warm and tenderly,

Our leaves of love were curled, So close and close, about our wee

White Rose of all the world.

With mystical faint fragrance

Our house of life she filled-

Revealed each hour some fairy tower

Where winged hopes might build!

We saw-though none like us might seeSuch precious promise pearled

Upon the petals of our wee

White Rose of all the world. 


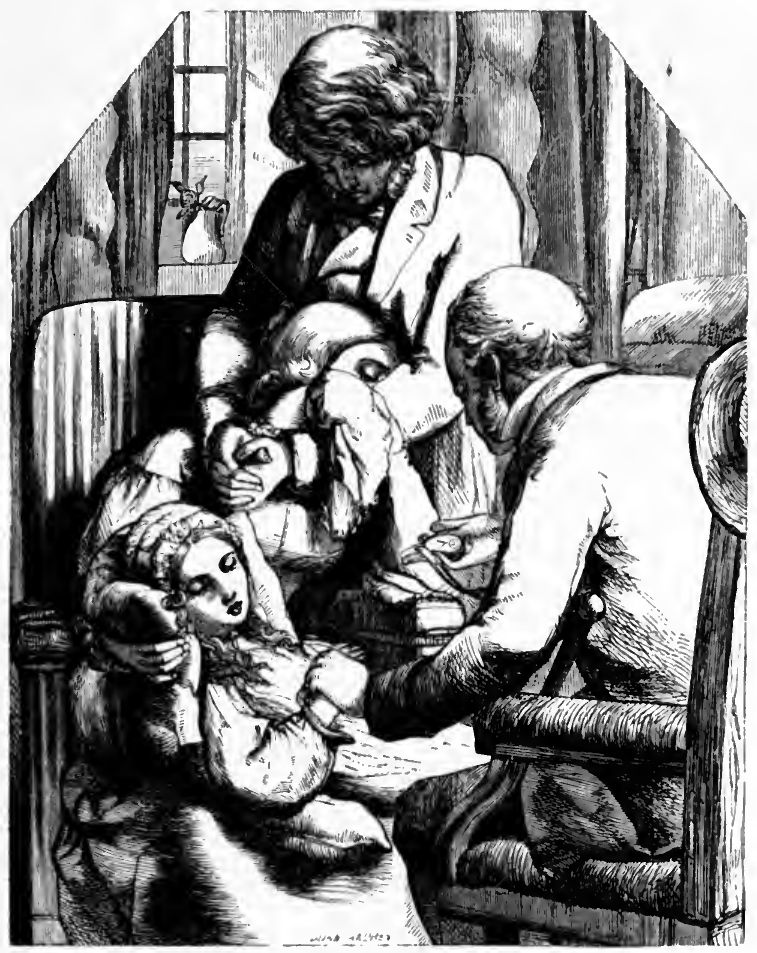

But, evermore the halo

Of Angel-light increased,

Like the mystery of moonlight

That folds some fairy feast.

Snow-white, snow-soft, snow-silently

Our darling bud up-curled,

And dropt i' the grave-God's lap-our wee

White Rose of all the world. 
Our Rose was but in blossom;

Our life was but in spring;

When down the solemn midnight

We heard the Spirits sing-

"Another bud of infaney

With holy dews impearled!"

And in their hands they bore our wee

White Rose of all the world.

You scarce could think so small a thing

Could leave a loss so large;

Her little light such shadow fling

From dawn to sunset's marge.

In other springs our life may be

In bannered bloom unfurled, But never, never match our wee

White Rose of all the world.

THAT MERRY, MERRY MAY.

ArI ! 'tis like a tale of olden

Time, long, long ago;

When the world was in its golden

Prime, and Love was lord below !

Every vein of Earth was dancing

With the Spring's new wine!

"Twas the pleasant time of flowers,

When I met you, love of mine !

Ah! some spirit sure was straying

Out of heaven that day,

When I met you, Sweet! a-Maying

In that merry, merry May! 


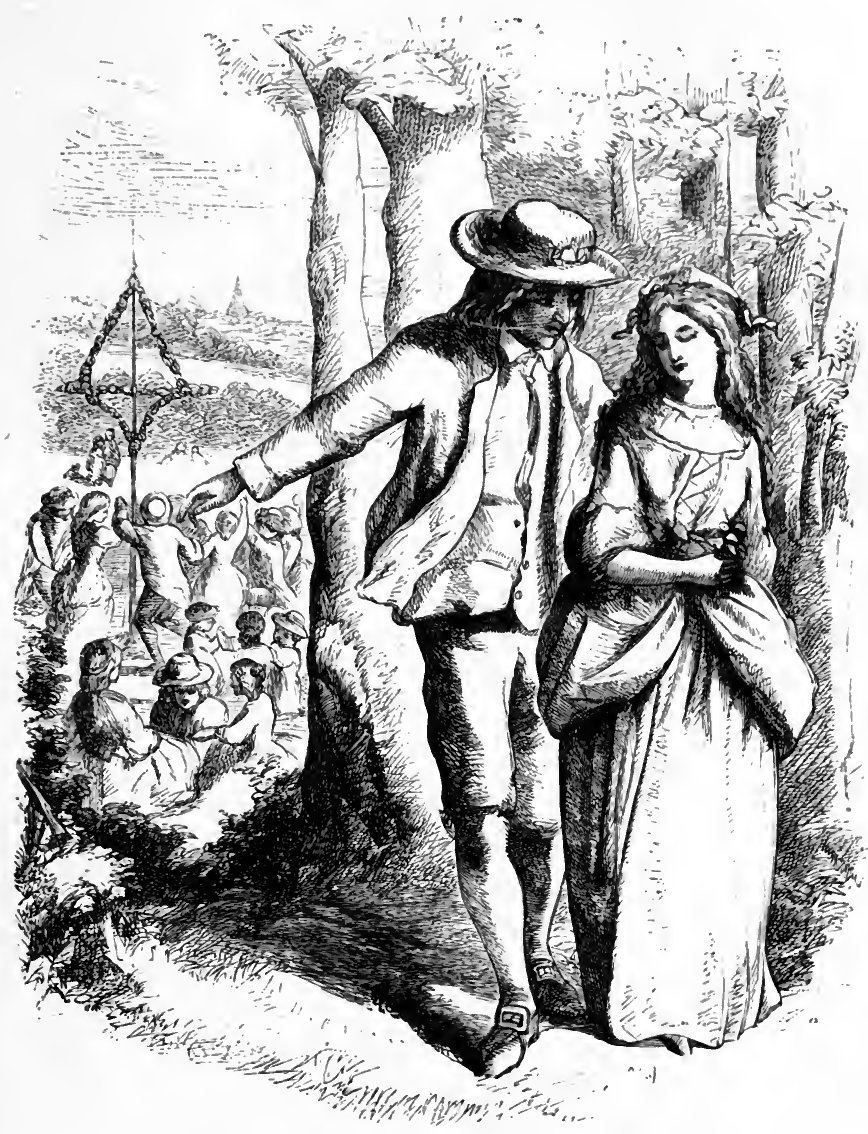

Little heart! it shyly open'd Its red leaves' love-lore, Like a rose that must be ripen'd To the dainty, dainty core. list its beauties daily brighten, And it blooms so dear,- 


\section{- Tho' a many Winters whiten,}

I go Maying all the year.

And my proud heart will be praying

Blessings on the day,

When I met you, Sweet, a-Maying,

In that merry, merry May.

\section{BABE CHRISTABEL.}

In this dim world of clouding cares,

We rarely know, till wildered eyes

See white wings lessening up the skies,

The Angels with us unawares.

And thou hast stolen a jewel, Death!

Shall light thy dark up like a Star,

A Beacon kindling from afar

Our light of love, and fainting faith.

'Thro' tears it gleams perpetually,

And glitters thro' the thickest glooms,

Till the eternal morning comes

To light us o'er the Jasper Sea.

With our best branch in tenderest leaf,

We've strewn the way our Lord doth come;

And, ready for the harvest-home,

His Reapers bind our ripest sheaf.

Our beautiful Bird of light hath fled:

A while she sat with folded wings-

Sing round us a few hoverings-

Then straightway into glory sped. 
And white-winged Angels nurture her;

With heaven's white radiance robed and crown'd,

And all Love's purple glory round,

She summers on the Hills of Myrrh.

'Thro' Childhood's morning-land serene

She walkt betwixt us twain, like Love;

While, in a robe of light above,

IIer better Angel walkt unseen,

Till Life's highway broke bleak and wild;

Then, lest her starry garments trail

In mire, heart bleed, and courage fail,

'The Angel's arms caught up the child.

Her wave of life hath backward roll'd

To the great ocean, on whose shore

We wander up and down, to store

Some treasures of the times of old:

And aye we seek and hunger on

For precious pearls and relics rare, Strewn on the sands for us to wear

At heart, for love of her that's gone.

O weep no more! there yet is balm

In Gilead! Love doth ever shed

Rich healing where it nestles,-spread

O'er desert pillows some green palm!

God's ichor fills the hearts that bleed;

The best fruit loads the broken bough;

And in the wounds our sufferings plough, Immortal Love sows sovereign seed. 


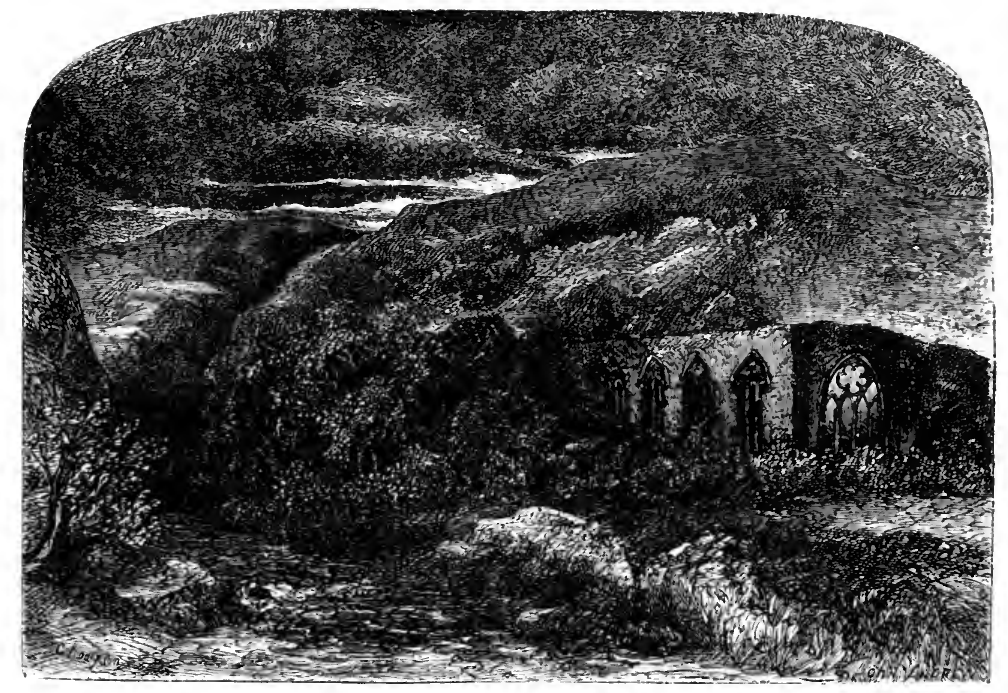

\section{ALLINGHAM.}

\section{AUTUMNAI, SONNET.}

Now Autumn's fire burns slowly along the woods, And day by day the dead leaves fall and melt, And night by night the monitory blast

Wails in the key-hole, telling how it pass'd

O'er empty fields, or upland solitudes,

Or grim wide wave; and now the power is felt

Of melancholy, tenderer in its moods

Than any joy indulgent summer dealt.

Dear friends, together in the glimmering eve,

Pensive and glad, with tones that recognise

'The soft invisible dew on each one's eyes,

It may be, somewhat thus we shall have leave

To walk with memory, when distant lies

Poor Earth, where we were wont to live and grieve. 


\section{MACKAY.}

\section{YOUTH AND SORROW.}

"GEr thee back, Sorrow, get thee back! My brow is smooth, mine eyes are bright, My limbs are full of health and strength, My cheeks are fresh, my heart is light. So, get thee back! oh, get thee back!

Consort with age, but not with me; Why shouldst thou follow on my track?

I am too young to live with thee."

"O foolish Youth, to seorn thy friend!

'To harm thee wherefore should I seek?

I would not dim thy sparkling eyes, Nor blight the roses on thy cheek.

I would but teach thee to be true; And should I press thee overmuch, Ever the flowers that I bedew

Yield sweetest fragrance to the touch."

"Get thee back, Sorrow, get thee back!

I like thee not; thy looks are chill.

The sunshine lies upon my heart, Thou showest me the shadow still. So, get thee back! oh, get thee back ! Nor touch my golden locks with grey; Why shouldst thou follow on my track? Let me be happy while I may."

"Good friend, thou needest sage advice; I'll keep thy heart from growing proud, I'll fill thy mind with kindly thoughts, And link thy pity to the crowd. 
Wouldst have a heart of pulseless stone?

Wouldst be too happy to be good?

Nor make a human woe thine own,

For sake of human brotherhood?"

"Get thee back, Sorrow, get thee back!

Why should I weep while I am young?-

I have not piped-I have not danced-

My morning songs $I$ have not sung:

The world is beautiful to me,

Why tarnish it to soul and sense?

Prithee begone! I'll think of thee

Some half a hundred wirters hence."

"O foolish Youth, thou know'st me not:

I am the mistress of the earth-

'Tis $I$ give tenderness to love;

Enhance the privilege of mirth;

Refine the human gold from dross;

And teach thee, wormling of the sod,

To look beyond thy present loss

To thy eternal gain with God."

"Get thee back, Sorrow, get thee back!

I'll learn thy lessons soon enough;

If virtuous pleasure smooth my way,

Why shouldst thou seek to make it rough?

No fruit can ripen in the dark,

No bud can bloom in constant cold-

So, prithee, Sorrow, miss thy mark,

Or strike me not till I am old."

"I am thy friend, thy best of friends;

No bud in constant heats can blow-

The green fruit withers in the drought,

But ripens where the waters flow. 


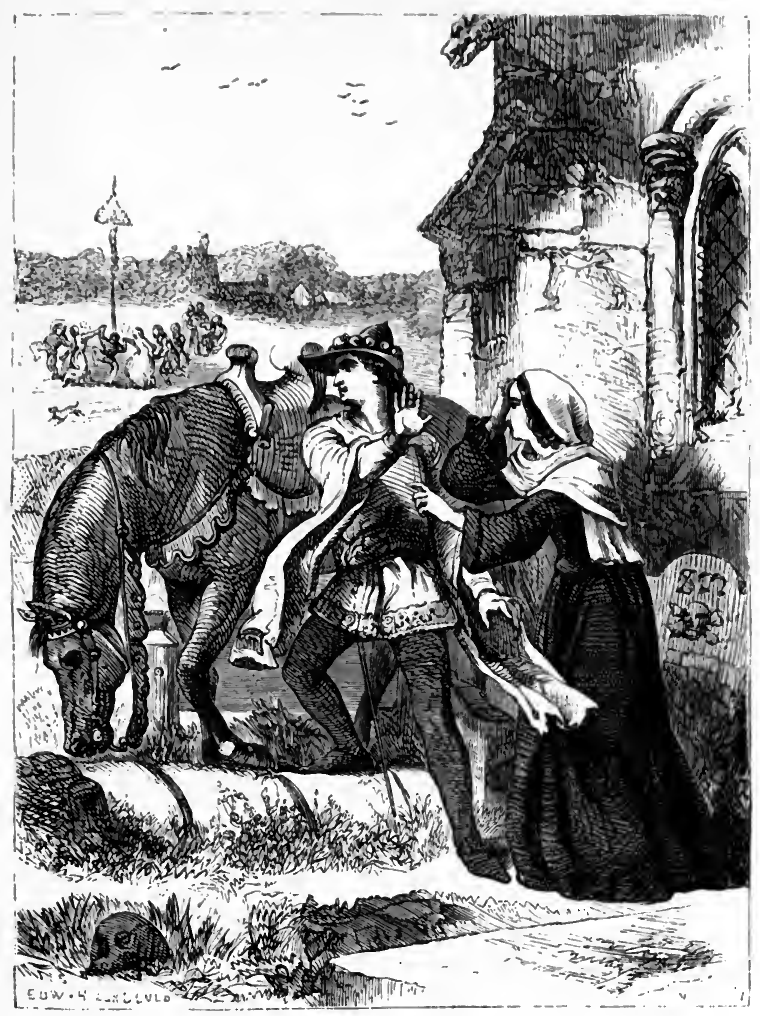

The sorrows of thy youthful day

Shall make thee wise in coming years;

The brightest rainbows ever play

Above the fountains of our tears."

Youth frowned, but Sorrow gently smiled;

Upon his heart her hand she.laid, And all its hidden sympathies

Throbbed to the fingers of the Maid.

And when his head grew grey with Time,

He owned that Sorrow spoke the truth,

And that the harvest of his prime

Was ripened by the rains of Youth. 


\section{FRANCES BROWN.}

\section{THE HOPE OF THE RESURRECTION.}

SUGGESTED BY THE REMARK OF AN AFRICAN CHIEF TO A MISSIONARY.

'TIY voice hath filled our forest shades,

Child of the sunless shore!

For never heard the ancient glades

Such wondrous words before.

Though bards our land of palms have filled

With tales of joy or dread,-

Yet thou alone our souls hast thrilled

With tidings of her dead.

The men of old, who slept in death

Before the forests grew,

Whose glory faded here beneath,

While yet the hills were new, -

The warriors famed in battles o'er,

Of whom our fathers spake,-

The wise, whose wisdom shines no more,Stranger, will they awake?

The foes who fell in thousand fights,

Beneath my conquering brand,-

Whose bones have strewn the Caffer's heights,

The Bushman's lonely land,- 


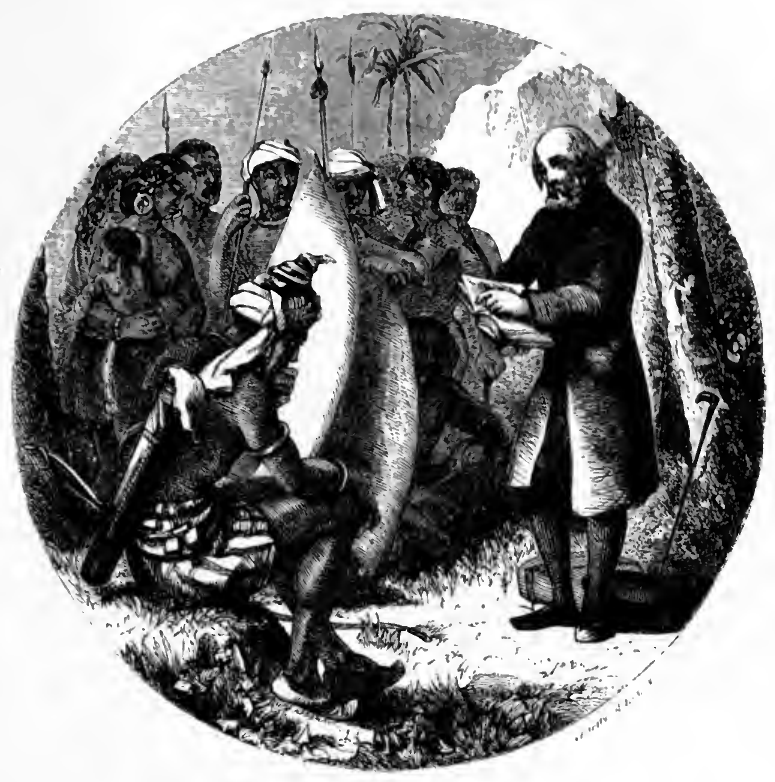

The young, who shared my warrior-way, But found an early urn,-

And the roses of my youth's bright dayStranger, will they return?

My mother's face was fair to see-

My father's glance was bright,-

But long ago the grave from me

Inath hid their blessed light;

Still sweeter was the sunshine shed

By my lost children's eyes,

That beam upon me from the dead,-

Stranger, will they arise? 


\section{ALL THINGS NEW.}

Was it some green grave's early guest,

Who loved thee long and well, That left the land of dreamless rest, Such blessed truths to tell?

For we have had our wise ones, too,

Who feared not death's abyss,-

The strong in hope, in love the true,-

But none that dreamed of this!

Yet, if the grave restore to life

Her ransomed spoils again,

And ever hide the hate and strife

That died with wayward men;-

How hath my spirit missed the star

That guides our steps above;-

Since only earth was given to war,-

That better land to love!

\section{ALL THINGS NEW.}

"And He that sat upon the Throne said, Behold, I make all things new."

New Heavens! for the stars grow pale

With the midnight scenes of time!

And the sun is weary of the wail

That meets him in every elime :-

And the sky grows dim with the mist of tears-

Bring back the blue of its first, bright years! 


\section{FRANCES BROWN.}

New Earth! for the land and waves

With a weight of evil groan;

And its dwellings stand in a soil of graves,

Which fearful things lave known:

From the touch of fire, from the battle-stain,

Gives us its Eden green again!

New Law! for 'tis the arm of wrong,

And great hath been the cry

When oppressors' hands in their might grew strong, And their deeds have pierced the sky:-

But the powers are shaken;-oh! requite

With the free, unchanging law of right.

New Faith! for a voice of blood

Hath been heard from every shrine,

And the world hath worshipped many a God

With rites it deemed divine:-

But the creeds grow old, and the fanes decay:-

Show us, at last, some better way!

New Hope! for it rose among

The thorns of a barren spot,

Where the bloom is brief and the labour long,

And the harvest cometh not:-

And hearts grow weary that watch and wait-

Give them a rainbow that fears not fate!

New Love! for it hath been cast

On the troubled waters, Iong,

And hoped in visions vain that passed

Away, like a night-bird's song:-

It may not be severed from the lost,-

But give us the young world's love uncross'd!

New Life! give the summers back

Whose glory passed in vain,- 
ALL THINGS NEW.

Redeem our days from the shadow black Of clouds without the rain,

And the wastes which bitter waters wore-

And our canker-eaten years restore!

New Light! for the lamps decay

Which shone on the old world's youth,

And the wise man watches for a ray

Of the undiscovered Truth :-

Long hath he looked through the midnight dim,-

Let the glorious Day-Spring visit him!

Must the Earth's last hope like a shadow flee?

Was the dream of ages vain?

$\mathrm{Oh}$ ! when will the bright restoring be,

And the glory come again

Of our promised spring, with its blessed dew-

And His Word, that maketh all things new! 


\section{PARSONS.}

S O R R E T O.

Midway betwixt the present and the past-

Naples and Prstum-look! Sorrento lies:

Ulysses built it, and the Sirens cast

Their spell upon the shore, the sea, the skies

If thou hast dreamed, in any dream of thine,

How Paradise appears, or those Elysian

Immortal meadows which the gods assign

Unto the pure of heart-behold thy vision!

These waters, they are blue beyond belief,

Nor hath green England greener fields than these:

The sun-'tis Italy's; here winter's brief

And gentle visit hardly chills the breeze.

Here 'Tasso dwelt, and here inhaled with spring

The breath of passion and the soul of song.

Here young Boceacio plumed his early wing,

Thenceforth to soar above the vulgar throng.

All charms of contrast-every nameless grace

That lives in outline, harmony, or hue-

So heighten all the romance of the place,

That the rapt artist maddens at the view,

And then despairs, and throws his pencil by,

And sits all day and looks upon the shore

And the calm ocean with a languid eye,

As though to labour were a law no more. 


\section{SORRENTO.}

Voluptuous coast! no wonder that the proud

Imperial Roman found in yonder isle

Some sunshine still to gild Fate's gathering cloud,

And lull the storm of conscience for a while.

What new Tiberius, tired of lust and life,

May rest him here to give the world a truce,-

A little truce from perjury and strife,

Justice adulterate and power's misuse?

Might the gross Bourbon-he that sleeps in spite

Of red Vesuvius ever in his eye,

Yet, if he wake, should tremble at its light

As 'twere Heaven's vengeance, promised from on high,-

Or that poor gamester, of so cunning play,

Who, up at last, in Fortune's fickle dance,

Aping the mighty in so mean a way,

Makes now his dice the destinies of France,-

Might they, or any of Oppression's band,

Sit here and learn the lesson of the scene,

Peace might return to many a bleeding land,

And men grow just again, and life serene. 
PARSONS.

SAIN T PERAY.

When to any saint I pray, It shall be to Saint Peray. He alone, of all the brood, Ever did me any good:

Many I have tried that are Humbugs in the calendar.

On the Atlantic faint and siek, Once I prayed Saint Dominick:

He was holy, sure, and wise;Was't not he who did devise Auto da Fès and rosaries? But for one in my condition This good saint was no physician.

Next in pleasant Normandie, I made a prayer to Saint Denis, In the great eathedral, where All the ancient kings repose; But, how I was swindled there At the "Golden Fleece,"-he knows !

In my wanderings, vague and various, Reaching Naples-as I lay Watching Vesuvius from the bay,

I besought Saint Januarius. But I was a fool to try him; Naught I said could liquefy him; And I swear he did me wrong, Keeping me shut up so long 
In that pest-house, with obscene

Jews and Greeks and things unclean-

What need had I of quaraatine?

In Sicily at least a score,-

In Spain about as many more,-

And in Rome almost as many

As the loves of Don Giovanni,

Did I pray to-sans reply;

Devil take the tribe!- said I.

Worn with travel, tired and lame,

'To Assisi's walls I came:

Sad and full of homesick fancies,

I addressed me to Saint Francis;

But the beggar never did

Anything as he was bid,

Never gave me aught but fleas,-

Plenty had I at Assise.

But in Pròvence, near Vaucluse,

Hard by the Rhone, I found a Saint

Gifted with a wondrous juice

Potent for the worst complaint.

'Twas at Avignon that first-

In the witching time of thirst-

To my brain the knowledge came

Of this blessed Catholic's name;

Forty miles of dust that day

Made me welcome Saint Peray.

'Though till then I had not heard

Aught about him, ere a third

Of a litre passed my lips,

All saints else were in eelipse.

For his gentle spirit glided

With such magic into mine, 
PARSONS.

That methought such bliss as I did Poet never drew from wine.

Rest he gave me and refection,-

Chastened hopes, calm retrospection,--

Softened images of sorrow,

Bright forebodings for the morrow,-

Charity for what is past,-

Faith in something good at last.

Now, why should any almanack

The name of this good creature lack?

Wherefore should the breviary

Omit a saint so sage and merry?

The Pope himself should grant a day

Especially to Saint Peray.

But, since no day hath been appointed,

On purpose, by the Lord's anointed,

Let us not wait-we'll do him right;

Send round your bottles, Hal-and set your night. 


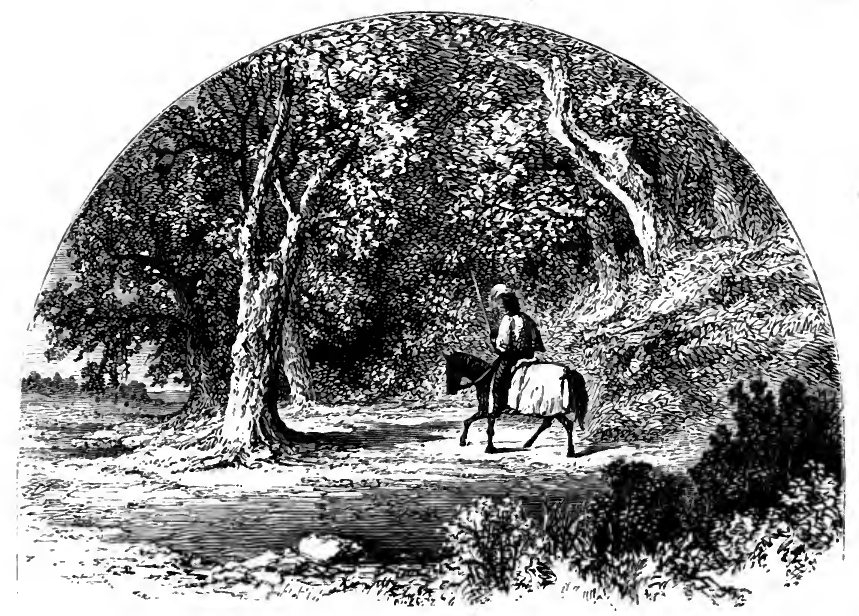

J. RUSSELL LOWELL.

THE SIN G I G LEAVES.

A BALLAD.

I.

"What fairings will ye that I bring?"

Said the king to his daughters three;

"For I to Vanity Fair am bound,

Now say what shall they be?".

Then up and spake the eldest daughter,

The lady tall and grand,

"Ye shall bring to me the diamonds great,

And gold rings for my hand." 


\section{J. RUSSELI, LOWELL.}

Thereafter spake the second daughter,

That was both white and red,

"For me bring silk that will stand alone

And a gold comb for my head."

Then lowly spake the least daughter,

That was whiter than thistle-down,

And among the gold of her blithesome hair

Dim shone the golden crown.

"There came a bird at sunrise And sang 'neath my bower-eaves,

And sent the sweet dream that bade me

To ask for the Singing Leaves."

The vein of his forehead reddened

In a ridge of angry scorn,

"Well have ye spoken, my two eldest,

And chosen as ye were born.

"But thou, like a thing of peasant blood, That is happy binding the sheaves!"-

Then he saw her dead mother in her face, And said, "Thou shalt have thy Ieaves."

II.

He bade farewell to the elder twain,

And touched his lips to their cheek,

But 'twas thrice he kiss'd the Princess Anne, And looked back and did not speak.

And he has ridden three days and nights,

Till he came to Vanity Fair;

And easy it was to buy gems and gold,

But no Singing Leaves were there. 


\section{THE SINGING LEAVES.}

Then deep in the greenwood rode he,

And asked of every tree :

"Oh, if ye have ever a singing leaf,

I pray you to give it me!"

But the trees all kept their counsel;

They said neither yea or nay;

Only there sighed from the pine-tops

A music of seas far away.

Only the aspen pattered

With a sound like growing rain,

That fell ever fast and faster,

Then faltered to silence again.

"Oh, where shall I find a little foot-page,

That would win both hose and shoon,

And will bring to me these Singing Leaves,

If they grow 'neath sun or moon?"

Then lightly turned him Walter, the page,

By the stirrup as he ran,

"Now pledge to me the truesome word

Of a knight and gentleman,

"That you will give me the first, first thing

You meet at your castle-gate;

And the princess shall get the Singing Leaves,

Or mine be the traitor's fate!"

'The king's head dropped on his bosom

A moment, as it might be-

'Twill be my hound, he thought, and he said,

"I pledge my word to thee."

Then Walter took from next his heart

$\Lambda$ packet small and thin;

"And give you this to the Princess Anne-

The Singing Leaves are therein." 


\section{J. RUSSELL LOWELL.}

III.

As the king rode in, o'er the loud draw-bridge

A maiden to meet him ran;

And, "Welcome, father !" she laughed and cried

'Together, the Princess Anne.

"Lo, here thy Singing Leaves," quoth he;

"And wo, but they cost me dear!"

She took the packet, and her smile

Deepened down beneath the tear.

It deepened down to her very heart, And then flushed back again, And lighted her tears as the sudden sun

Transfigures the summer rain.

And the first leaf, when she opened it, Sang, "I am Walter, the page, And the songs I sing 'neath thy window'

Are all my heritage!"

And the second leaf sang, "But in the land

That is neither on earth or sea,

My harp and I are lords of more

Than thrice this kingdom's fee!"

And the third leaf sang, "Be mine! be mine!" And still it sang, "Be mine!"

Then sweeter it sang and ever sweeter,

And said, "I am thine, thine, thine!"

At the first leaf she grew pale enough,

At the second she turned aside,

At the third, 'twas as if a lily flushed

With a rose's red heart's tide. 


\section{LONGING.}

"Good counsel gave the bird," she said;

"I have my wish thrice o'er;

For they sing to my very heart," she said,

"And it sings with them evermore."

\section{LONGING.}

OF all the myriad moods of mind

That through the soul come thronging,

Which one was e'er so dear, so kind,

So beautiful, as Longing?

The thing we long for, that we are

For one transcendent moment,

Before the Present poor and bare

Can make its sneering comment.

Still, through our paltry stir and strife,

Glows down the wished Ideal,

And Longing moulds in clay what Life

Carves in the marble Real;

To let the new life in, we know,

Desire must ope the portal ; -

Perhaps the longing to be so

Helps make the soul immortal.

Longing is God's fresh heavenward will,

With our poor earthward striving;

We quench it that we may be still

Content with merely living; 


\section{J. RUSSELL LOWELL.}

But would we learn that heart's full scope

Which we are hourly wronging,

Our lives must climb from hope to hope,

And realize our longing.

Ah ! let us hope that to our praise

Good God not only reckons

The moments when we tread his ways,

But when the spirit beckons,-

That some slight good is also wrought

Beyond self-satisfaction,

When we are simply good in thought,

Howe'er we fail in action.

\section{AUF WIEDERSEHEN !}

I.

SUMMER.

The little gate was reached at last, Half hid in lilacs down the lane; She pushed it wide, and as she passed A wistful look she backward cast, And said,-_"Auf Wiedersehen!"

With hand on latch, a vision white

Lingered, reluctant, and again

Half doubting if she did aright;

Soft as the dews that fell that night, She said,-"Auf Wiedersehen!" 


\section{PALINODE.}

The lamp's clear gleam flits up the stair;

I linger in delicious pain;

Ah! in that chamber, whose rich air

To breathe in thought I scarcely dare,

Thinks she,-“Auf Wiedersehen!"

'Tis thirteen years; once more $I$ press

The turf that silences the lane;

I hear the rustle of her dress,

I smell the lilacs, and-ah, yes,

I hear "Auf Wiedersehen!"

Sweet piece of bashful maiden art!

The English words had seemed too fain;

But these-they drew us heart to heart,

Yet held us tenderly apart,-

She said,-"Auf Wiedersehen!"

\section{P A L I NODE.}

II.

AUTUMN.

Still thirteen years: 'tis autumn now,

On field and hill, in heart and brain ;

The naked trees at evening sough,

The leaf to the forsaken bough

Sighs not,_-"We meet again!" 
Two watched yon oriole's pendent dome

That now is void, and dank with rain, And one-O, hope more frail than foam ! The bird to his deserted home

Sings not,-“We meet again!"

The loath gate swings with rusty creak;

Once, parting there, we played at pain ;

There came a parting, when the weak

And fading lips essayed to speak

Vainly,-"We meet again!"

Somewhere is comfort, somewhere faith, Though thou in outer dark remain; One sweet, sad voice ennobles death, And still, for eighteen centuries saith Softly,- "Ye meet again!"

If earth another grave must bear, Yet heaven hath won a sweeter strain, And something whispers to despair, That, from an orient chamber there, Floats down, "We meet again!" 


\section{MARIA LOWELL.}

\section{THE ALPINE SHEEP.}

ADDRESSED TO A FRIEND AFTER THE LOSS OF A CHILD.

When on my ear your loss was knelled, And tender sympathy upburst,

A little spring from memory welled,

Which once had quenched my bitter thirst,

And I was fain to bear to you

A portion of its mild relief,

That it might be as healing dew,

To steal some fever from your grief.

After our child's untroubled breath

Up to the Father took its way,

And on our home the shade of Death,

Like a long twilight haunting lay,

And friends came round, with us to weep

Her little spirit's swift remove,

The story of the Alpine sheep

Was told to us by one we love.

They, in the valley's sheltering care,

Soon crop the meadows' tender prime, And when the sod grows brown and bare,

The Shepherd strives to make them elimb

'To airy shelves of pasture green,

That hang along the mountain's side,

Where grass and flowers together lean,

And down through mist the sunbeams slide. 
But nought can tempt the timid things The steep and rugged path to try, Though sweet the shepherd calls and sings, And seared below the pastures lie,

Till in his arms his lambs he takes, Along the dizzy verge to go, Then, heedless of the rifts and breaks, They follow on o'er rock and snow.

And in those pastures, lifted fair, More dewy-soft than lowland mead, The shepherd drops his tender care, And sheep and lambs together feed.

This parable, by Nature breathed, Blew on me as the south-wind free O'er frozen brooks, that flow unsheathed From icy thraldom to the sea.

A blissful vision, through the night Would all my happy senses sway Of the Good Shepherd on the height, Or climbing. up the starry way,

Holding our little lamb asleep,

While, like the murmur of the sea, Sounded that voice along the deep, Saying, "Arise and follow me!" 


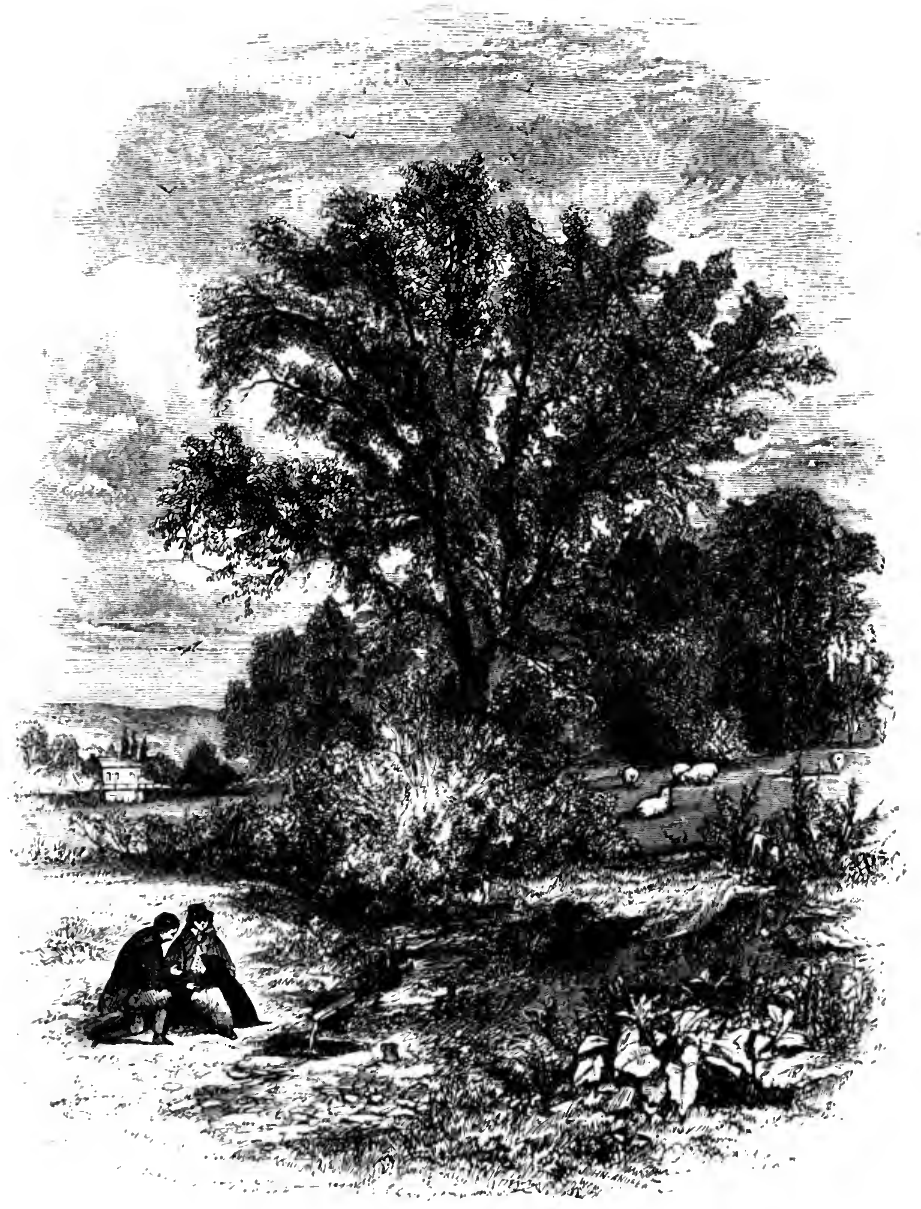

\section{READ.}

THE WAYSIDE SPRING.

FaIr dweller by the dusty way-

Bright saint within a mossy shrine, The tribute of a heart to-day

Weary and worn is thine. 
READ,

The earliest blossoms of the year,

The sweet-brier and the violet

The pious hand of Spring has here

Upon thy altar set.

And not alone to thee is given

The homage of the pilgrim's knee-

But oft the sweetest birds of Heaven

Glide down and sing to thee.

Here daily from his beechen cell

The hermit squirrel steals to drink, And flocks which cluster to their bell Recline along thy brink.

And here the waggoner blocks his wheels,

'To quaff the cool and generous boon;

Iere, from the sultry harvest fields

The reapers rest at noon.

And oft the beggar marked with tan,

In rusty garments grey with dust,

Here sits and dips his little can,

And breaks his seanty crust;

And, lulled beside thy whispering stream,

Oft drops to slumber unawares,

And sees the angel of his dream

Upon celestial stairs.

Dear dweller by the dusty way,

Thou saint within a mossy shrine,

The tribute of a heart to-day

Weary and worn is thine! 
THE CLOSING SCENE.

\section{THE CLOSING SCENE.}

Witurs this sober realm of leafless trees,

The russet year inhaled the dreamy air,

Like some tanned reaper in his hour of ease,

When all the fields are lying brown and bare.

The gray barns, looking from their hazy hills

O'er the dim waters widening in the vales, Sent down the air a greeting to the mills, On the dull thunder of alternate flails.

All sights were mellowed, and all sounds subdued,

The hills seemed farther, and the streams sang low;

As in a dream, the distant woodman hewed

His winter log with many a muffled blow.

'Th' embattled forests, erewhile armed in gold, Their banners bright with every martial hue, Now stood, like some sad beaten host of old, Withdrawn afar in Time's remotest blue.

On slumb'rous wings the vulture held his flight;

The dove searce heard his sighing mate's eomplaint;

And like a star slow drowning in the light,

The village church-vane seemed to pale and faint.

The sentinel cock upon the hill-side crew;

Crew thrice, and all was stiller than before-

Silent till some replying wanderer blew

His alien horn, and then was heard no more. 
Where erst the jay within the elm's tall crest

Made garrulous trouble round her unfledged young;

And where the oriole hung her swaying nest

By every light wind like a censer swung;

Where sang the noisy masons of the eves,

The busy swallows circling ever near,

Foreboding, as the rustic mind believes,

An early harvest and a plenteous year;

Where every bird which charmed the vernal feast

Shook the sweet slumber from its wings at morn,

To warn the reapers of the rosy east,

All now was songless, empty, and forlorn.

Alone, from out the stubble piped the quail,

And croaked the crow through all the dreary gloom;

Alone the pheasant, drumming in the vale,

Made echo to the distant cottage loom.

There was no bud, no bloom upon the bowers;

The spiders wove their thin shrouds night by night;

The thistle-down, the only ghost of flowers,

Sailed slowly by-passed noiseless out of sight.

Amid all this-in this most cheerless air,

And where the woodbine shed upon the porch

Its erimson leaves, as if the year stood there,

Firing the floor with his inverted torch-

Amid all this, the centre of the scene,

The white-haired matron, with monotonous tread

Plied her swift wheel, and with her joyless mien

Sat like a Fate, and watehed the flying thread. 
She had known sorrow. He had walked with her, Oft supped, and broke the bitter ashen crust, And in the dead leaves still she heard the stir Of his black mantle trailing in the dust.

While yet her cheek was bright with summer bloom, Her country summoned, and she gave her all, And twice War bowed to her his sable plume;

Re-gave the swords to rust upon her wall.

Re-gave the swords-but not the hand that drew, And struck for Liberty the dying blow; Nor him, who to his sire and country true Fell 'mid the ranks of the invading foe.

Long, but not loud, the droning wheel went on,

Like the low murmurs of a hive at noon;

Long, but not loud, the memory of the gone

Breathed through her lips a sad and tremulous tune.

At last the thread was snapped, her head was bowed:

Life dropped the distaff through his hands serene; And loving neighbours smoothed her careful shroud,

While Death and Winter closed the autumn scene. 


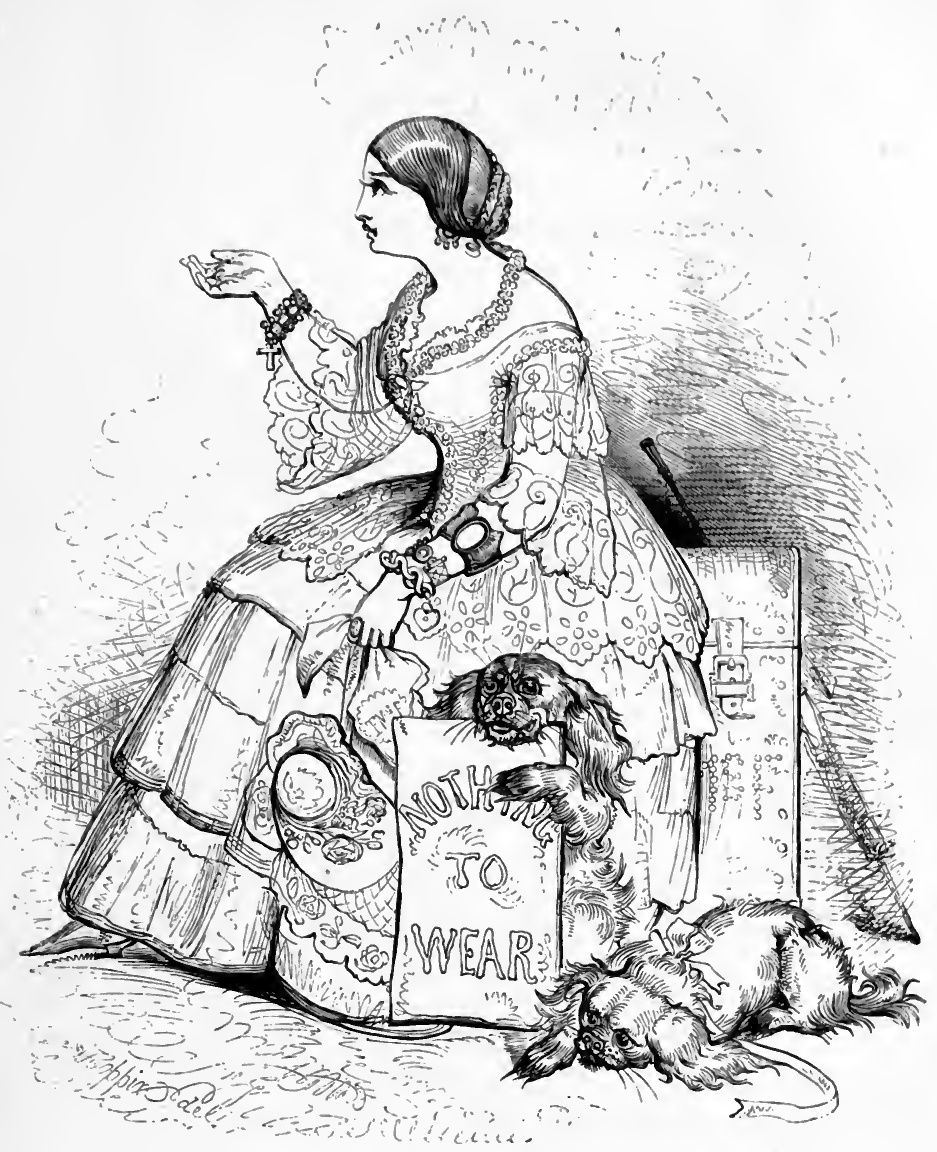

\section{BUTLER.}

\section{NOTHING TO WEAR.}

AN EPISODE OF CITY LIFE.

Miss Flora M'Fumsey, of Madison Square, Has made three separate journeys to Paris, And her father assures me, each time she was there, That she and her friend Mrs. Harris, 
(Not the lady whose name is so famous in history, But plain Mrs. H., without romance or mystery,) Spent six consecutive weeks without stopping, In one continuous round of shopping; Shopping alone, and shopping together, At all hours of the day, and in all sorts of weather; For all manner of things that a woman can put On the crown of her head or the sole of her foot, Or wrap round her shoulders, or fit round her waist, Or that can be sewed on, or pinned on, or laced, Or tied on with a string, or stitched on with a bow, In front or behind, above or below:

For bonnets, mantillas, capes, collars, and shawls;

Dresses for breakfasts, and dinners, and balls;

Dresses to sit in, and stand in, and walk in;

Dresses to dance in, and flirt in, and talk in;

Dresses in which to do nothing at all;

Dresses for winter, spring, summer, and fall ;

All of them different in colour and pattern,Silk, muslin, and lace, crape, velvet, and satin, Brocade, and broadcloth, and other material, Quite as expensive and much more ethereal; In short, for all things that could ever be thought of, Or milliner, modiste, or tradesman be bought of,

From ten-thousand-franc robes to twenty-sous frills; In all quarters of Paris, and to every store, While M'Flimsey in vain stormed, scolded, and swore, They footed the streets, and he footed the bills.

The last trip, their goods shipped by the steamer Arāgo Formed, M'Flimsey declares, the bulk of her cargo, Not to mention a quantity kept from the rest, Sufficient to fill the largest-sized chest, Which did not appear on the ship's manifest, But for which the ladies themselves manifested Such particular interest, that they invested 


\section{BUTLER.}

Their own proper persons in layers and rows Of muslins, embroideries, worked under-clothes, Gloves, handkerchiefs, scarfs, and such trifles as those; Then, wrapped in great shawls, like Circassian beauties, Gave good-by to the ship, and go-by to the duties.

Her relations at home all marvelled no doubt, Miss Flora had grown so enormously stout

For an actual belle and a possible bride;

But the miracle ceased when she turned inside out,

And the truth came to light, and the dry goods beside, Which, in spite of Collector and Custom-house sentry, Had entered the port without any entry.

And yet, though scarce three months have passed since the day This merchandise went, on twelve carts, up Broadway, This same Miss M'Flimsey, of Madison Square,

The last time we met, was in utter despair,

Because she had nothing whatever to wear!

Nothing to wear! Now, as this is a true ditty,

I do not assert-this, you know, is between usThat she's in a state of absolute nudity,

Like Powers' Greek Slave, or the Medici Venus; But I do mean to say, I have heard her declare, When, at the same moment, she had on a dress Which cost five hundred dollars, and not a cent less, And jewelry worth ten times more, I should guess, That she had not a thing in the wide world to wear!

I should mention just here, that out of Miss Flora's Two hundred and fifty or sixty adorers,

I had just been selected as he who should throw all The rest in the shade, by the gracious bestowal On myself, after twenty or thirty rejections, Of those fossil remains which she called her "affections," And that rather decayed, but well-known work of art, Which Miss Flora persisted in styling "her heart." 
So we were engaged. Our troth had been plighted, Not by moonbeam or starbeam, by fountain or grove, But in a front parlour, most brilliantly lighted, Beneath the gas-fixtures we whispered our love.

Without any romance, or raptures, or sighs,

Without any tears in Miss Flora's blue eyes,

Or blushes, or transports, or such silly actions,

It was one of the quietest business transactions,

With a very small sprinkling of sentiment, if any,

And a very large diamond imported by Tiffany.

On her virginal lips while I printed a kiss,

She exclaimed, as a sort of parenthesis,

And by way of putting me quite at my ease,

"You know, I'm to polka as much as I please,

And flirt when I like-now stop, don't you speak-.

And you must not come here more than twice in the week,

Or talk to me either at party or ball,

But always be ready to come when I call;

So don't prose to me about duty and stuff,

If we don't break this off, there will be time enough

For that sort of thing; but the bargain must be

That, as long as I choose, I am perfectly free,

For this is a sort of engagement, you see,

Which is binding on you but not binding on me."

Well, having thus wooed Miss M·Flimsey and gained her, With the silks, crinolines, and hoops that contained her,

I had, as I thought, a contingent remainder

At least in the property, and the best right

To appear as its escort by day and by night;

And it being the week of the STrckup's grand ball-

Their cards had been out a fortnight or so,

And set all the Avenue on the tip-toe-

I considered it only my duty to call,

And see if Miss Flora intended to go.

I found her-as ladies are apt to be found,

When the time intervening between the first sound 


\section{BUTILER.}

Of the bell and the visitor's entry is shorter Than usual-I found; I won't say-I caught herIntent on the pier-glass, undoubtedly meaning To see if perhaps it didn't need cleaning.

She turned as I entered-"Why, Harry, you sinner, I thought that you went to the Flashers' to dinner!" "So I did," I replied, "but the dinner is swallowed, And digested, I trust, for 'tis now nine and more, So being relieved from that duty, I followed

Inclination, which led me, you see, to your door. And now will your ladyship so condescend As just to inform me if you intend Your beauty, and graces, and presence to lend, (All which, when I own, I hope no one will borrow) 'To the Stuckup's, whose party, you know, is to-morrow?"

The fair Flora looked up with a pitiful air, And answered quite promptly, "Why Harry, mon cher, I should like above all things to go with you there; But really and truly-I've nothing to wear."

"Nothing to wear! go just as you are;

Wear the dress you have on, and you'll be by far, I engage, the most bright and particular star On the Stuckup horizon"-I stopped, for her eye, Notwithstanding this delicate onset of flattery, Opened on me at once a most terrible battery Of scorn and amazement. She made no reply, But gave a slight turn to the end of her nose (That pure Grecian feature), as much as to say, "How absurd that any sane man should suppose That a lady would go to a ball in the clothes, No matter how fine, that she wears every day!"

So I ventured again-"Wear your crimson brocade," (Second turn up of nose)—"That's too dark by a shade." 
"Your blue silk"- "That's too heavy;" "Your pink"—"That's too light." "Wear tulle over satin"- "I can't endure white."

"Your rose-coloured, then, the best of the batch"-

"I haven't a thread of point lace to match."

"Your brown moir antique"- "Yes, and look like a Quaker;"

"The pearl-coloured"- "I would, but that plaguy dress-makel

Has had it a week"- "Then that exquisite lilac,

In which you would melt the heart of a Shylock."

(Here the nose took again the same elevation)

"I wouldn't wear that for the whole of creation."

"Why not? It's my fancy, there's nothing could strike it

As more comme il faut_-" "Yes, but dear me, that lean .

Sophronia Stuckup has got one just like it,

And I won't appear dressed like a chit of sixteen."

"Then that splendid purple, that sweet Mazarine;

That superb point d'aiguille, that imperial green,

That zephyr-like tarleton, that rich grenadine"-

"Not one of all which is fit to be seen,"

Said the lady, becoming excited and flushed.

"Then wear," I exclaimed, in a tone which quite crushed

Opposition, "that gorgeous toilette which you sported

In Paris last spring, at the grand presentation,

When you quite turned the head of the head of the nation;

And by all the grand court were so very much courted."

The end of the nose was portentously tipped up,

And both the bright eyes shot forth indignation,

As she burst upon me with the fierce exelamation,

"I have worn it three times at the least calculation,

And that and the most of my dresses are ripped up!"

Here I ripped out something, perhaps rather rash,

Quite innocent, though; but, to use an expression

More striking than elassic, it "settled my hash,"

And proved very soon the last aet of our session.

"Fiddlesticks, is it, Sir? I wonder the ceiling

Doesn't fall down and erush you-oh, you men have no feeline,

You selfish, unnatural, illiberal creatures,

Who set yourselves up as patterns and preachers. 
Your silly pretence-why, what a mere guess it is!

Pray, what do you know of a woman's necessities?

I have told you and shown you I've nothing to wear,

And it's perfectly plain you not only don't care,

But you do not believe me" (here the nose went still higher).

"I suppose if you dared you would call me a liar.

Our engagement is ended, Sir-yes, on the spot;

You're a brute, and a monster, and-I don't know what."

I mildly suggested the words-Hottentot,

Pickpocket, and cannibal, Tartar, and thief,

As gentle expletives which might give relief;

But this only proved as spark to the powder,

And the storm I had raised came faster and louder,

It blew and it rained, thundered, lightened, and hailed

Interjections, verbs, pronouns, till language quite failed

To express the abusive, and then its arrears

Were brought up all at once by a torrent of tears,

And my last faint, despairing attempt at an obs-

Ervation was lost in a tempest of sobs.

Well, I felt for the lady, and felt for my hat, too,

Improvised on the crown of the latter a tattoo,

In lieu of expressing the feelings which lay

Quite too deep for words, as Wordsworth would say;

Then, without going through the form of a bow,

Found myself in the entry-I hardly knew how-

On door-step and sidewalk, past lamp-post and square,

At home and up stairs, in my own easy chair;

Poked my feet into slippers, my fire into blaze,

And said to myself, as I lit my cigar,

Supposing a man had the wealth of the Czar

Of the Russias to boot, for the rest of his days,

On the whole, do you think he would have much to spare If he married a woman with nothing to wear?

Since that night, taking pains that it should not be bruited Abroad in society, I've instituted

A course of inquiry, extensive and thorough, 
On this vital subject, and find, to my horror, 'That the fair Flora's case is by no means surprising,

But that there exists the greatest distress

In our female community, solely arising

From this unsupplied destitution of dress,

Whose unfortunate victims are filling the air

With the pitiful wail of "Nothing to wear."

Researches in some of the "Upper Ten" districts

Reveal the most painful and startling statistics,

Of which let me mention only a few:

In one single house, on the Fifth Avenue,

Three young ladies were found, all below twenty-two,

Who have been three whole weeks without any thing new

In the way of flounced silks, and thus left in the lurch

Are unable to go to ball, concert, or church.

In another large mansion near the same place

Was found a deplorable, heart-rending case

Of entire destitution of Brussels point lace.

In a neighbouring block there was found, in three calls,

'Total want, long continued, of camels'-hair shawls;

And a suffering family, whose case exhibits

The most pressing need of real ermine tippets;

One deserving young lady almost unable

'To survive for the want of a new Russian sable;

Another confined to the house, when it's windier

Than usual, because her shawl isn't India.

Still another, whose tortures have been most terrific

Ever since the sad loss of the steamer Pacific,

In which were ingulfed, not friend or relation, (For whose fate she perhaps might have found consolation,

Or borne it, at least, with serene resignation,)

But the choicest assortment of French sleeves and collars

Ever sent out from Paris, worth thousands of dollars,

And all as to style most recherché and rare,

The want of which leaves her with nothing to wear,

And renders her life so drear and dyspeptic

That she's quite a recluse, and almost a sceptic, 


\section{BUTI,ER.}

For she touchingly says that this sort of grief

Cannot find in Religion the slightest relicf, And Philosophy has not a maxim to spare

For the victims of such overwhelming despair.

But the saddest by far of all these sad features

Is the cruelty practised upon the poor creatures

By husbands and fathers, real Bluebeards and Timons,

Who resist the most touching appeals made for diamonds

By their wives and their daughters, and leave them for days

Unsupplied with new jewelry, fans, or bouquets,

Even laugh at their miseries whenever they have a chance,

And deride their demands as useless extravagance;

One case of a bride was brought to my view,

'Too sad for belief, but, alas! 'twas too true,

Whose husband refused, as savage as Charon,

'To permit her to take more than ten trunks to Sharon.

The consequence was, that when she got there,

At the end of three weeks she had nothing to wear,

And when she proposed to finish the season

At Newport, the monster refused out and out,

For his infamous conduct alleging no reason,

Except that the waters were good for his gout;

Such treatment as this was too shocking, of course,

And proceedings are now going on for divoree.

But why harrow the feelings by lifting the curtain

From these scenes of woe? Enough, it is certain,

Has here been disclosed to stir up the pity

Of every benevolent heart in the eity,

And spur up Humanity into a canter

To rush and relieve these sad cases instanter.

Won't somebody, moved by this touching deseription,

Come forward to-morrow and head a subscription?

Won't some kind philanthropist, seeing that aid is

So needed at once by these indigent ladies,

Take charge of the matter? or won't Peter Cooper

The eorner-stone lay of some splendid super- 
Structure, like that which to-day links his name In the Union unending of honour and fame; And found a new charity just for the care Of these unhappy women with nothing to wear, Which, in view of the cash which would daily be claimed, The Laying-out Hospital well might be named? Won't Stewart, or some of our dry-goods importers, Take a contract for clothing our wives and our daughters? Or, to furnish the cash to supply these distresses, And life's pathway strew with shawls, collars, and dresses, Ere the want of them makes it much rougher and thornier, Won't some one discorer a new California?

Oh ladies, dear ladies, the next sunny day Please trundle your hoops just out of Broadway, From its whirl and its bustle, its fashion and pride, And the temples of Trade which tower on each side, To the alleys and lanes, where Misfortune and Guilt Their children have gathered, their city have built; Where Hunger and Vice, like twin beasts of prey,

Have hunted their victims to gloom and despair;

Raise the rich, dainty dress, and the fine broidered skirt, Pick your delicate way through the dampness and dirt, Grope through the dark dens, climb the rickety stair To the garret, where wretches, the young and the old, Half-starved and half-naked, lie crouched from the cold. See those skeleton limbs, those frost-bitten feet, All bleeding and bruised by the stones of the street; Hear the sharp cry of childhood, the deep groans that swell

From the poor dying creature who writhes on the floor, Hear the curses that sound like the echoes of Hell,

$\Lambda$ s you sicken and shudder and fly from the door;

Then home to your wardrobes, and say, if you dareSpoiled children of Fashion-you've nothing to wear!

And oh, if perchance there should be a sphere, Where all is made right which so puzzles us here, 


\section{BUTTLER.}

Where the glare, and the glitter, and tinsel of Time Fade and die in the light of that region sublime, Where the soul, disenchanted of flesh and of sense, Unscreened by its trappings, and shows, and pretence, Must be elothed for the life and the service above, With purity, truth, faith, meekness, and love; Oh, daughters of Earth! foolish virgins, beware! Lest in that upper realm you have nothing to wear!

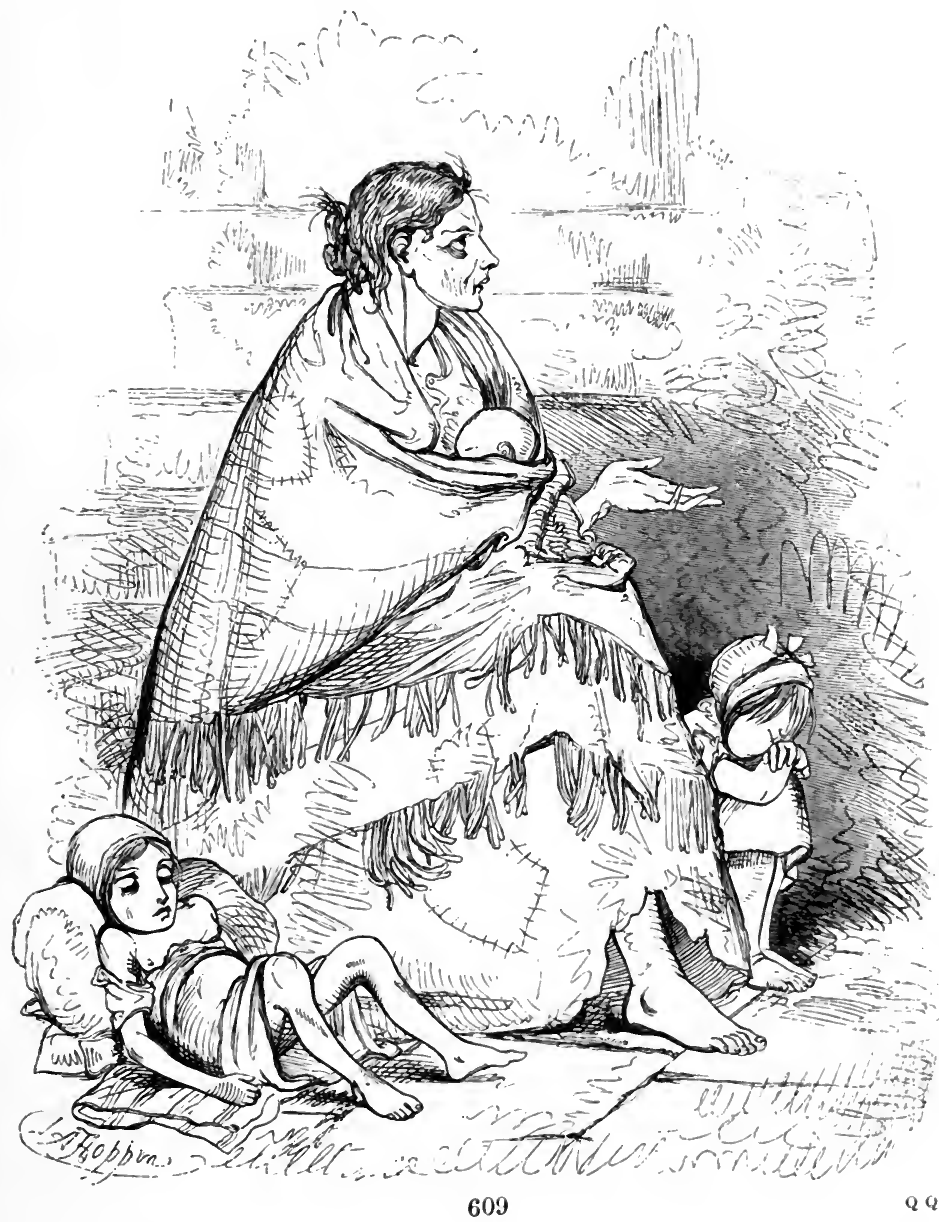




\section{BAYARD TAYLOR.}

DAUGHTER OF EGYPT.

Daughter of Egypt, veil thine eyes !

I cannot bear their fire;

Nor will I touch with sacrifice

Those altars of Desire.

For they are flames that shun the day,

And their unholy light

Is fed from natures gone astray

In passion and in night.

The stars of Beauty and of Sin,

They burn amid the dark,

Like beacons that to ruin win

The fascinated bark.

Then veil their glow, lest I forswear

The hopes thou canst not crown, And in the black waves of thy hail

My struggling manhood drown!

\section{ON THE SEA.}

Tue pathway of the sinking moon

Fades from the silent bay;

The mountain-isles loom large and faint,

Folded in shadows gray,

And the lights of land are setting stars

That soon will pass away. 
'Oh, boatman, cease thy mellow song! Oh, minstrel, drop thy. lyre!

Let us hear the voice of the midnight sea,

Let us speak as the waves inspire, While the plashy dip of the languid oar

Is a furrow of silver fire.

Day cannot make thee half so fair, Nor the stars of eve so dear:

The arms that elasp, and the breast that keeps,

They tell me thou art near,

And the perfect beauty of thy face

In thy murmured words I hear.

The lights of land have dropped below

The vast and glimmering sea;

The world we leave is a tale that is told-

A fable, that cannot be.

There is no life in the sphery dark

But the love in thee and me.

\section{BEDOUIN SONG.}

From the Desert I come to thee

On a stallion shod with fire;

And the winds are left behind

In the speed of my desire.

Under thy window I stand,

And the midnight hears my cry:

I love thee, I love but thee,

With a love that shall not die

Till the sun grows cold,

And the stars are old,

And the leaves of the Judgment

Book unfold! 


\section{BEDOUIN SONG.}

Look from thy window and see My passion and my pain;

I lie on the sands below, And I faint in thy disdain.

Let the night-winds touch thy brow With the heat of my burning sigh, And melt thee to hear the vow

Of a love that shall not die

Till the sun grows cold, And the stars are old, And the leaves of the Judgment Book unfold!

My steps are nightly driven, By the fever in my breast, To hear from thy lattice breathed

The word that shall give me rest. Open the door of thy heart, And open thy chamber door, And my kisses shall teach thy lips

The love that shall fade no more Till the sun grows cold, And the stars are old, And the leaves of the Judgment Book unfold! 


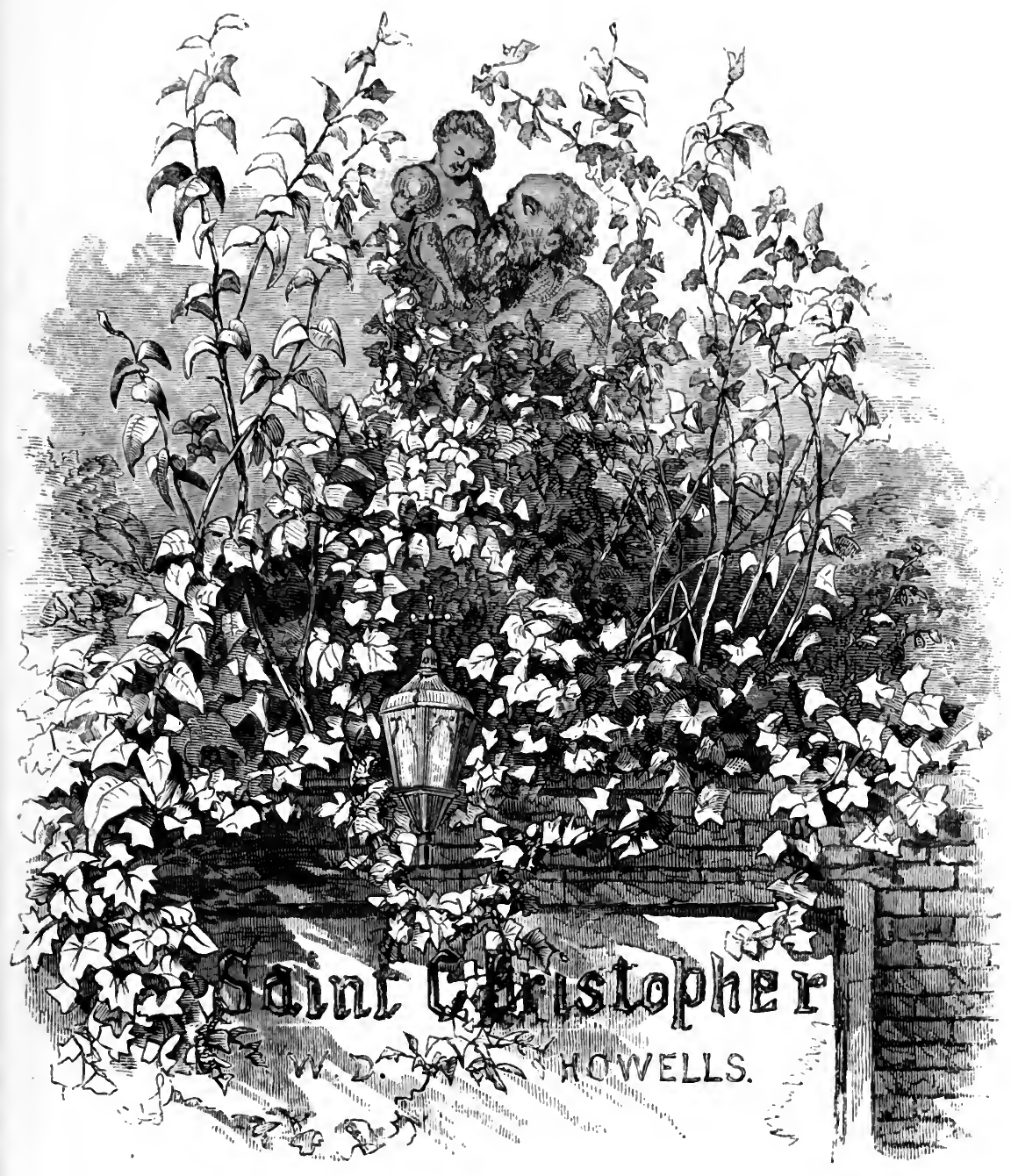

Is that narrow Venetian street,

On the wall above the garden-gate

(Within, the breath of the rose is sweet,

And the nightingale sings there, soon and late), 


\section{SAINT CHRISTOPHER.}

Stands Saint Christopher, carven in stone,

With the little child in his huge caress, And the arms of the baby Jesus thrown

About his gigantic tenderness;

And over the wall a wandering growth Of darkest and greenest ivy clings, And climbs around them, and holds them both

In its netted clasp of knots and rings,

Clothing the saint, from foot to beard,

In glittering leaves that whisper and dance

To the child, on his mighty arm upreared,

With a lusty, summer exuberance.

To the child on his arm the faithful saint

Looks up with a broad and tranquil joy,

His brows and his heavy beard aslant

Under the dimpled chin of the boy,

Who plays with the world upon his palm,

And bends his smiling looks divine

On the face of the giant, rapt and calm, .

And the glittering frolic of the vine.

He smiles on either with equal grace-

On the simple ivy's unconscious life,

And the soul in the giant's lifted face,

Strong from the peril and the strife;

For both are his own-the innocence

That climbs from the heart of earth to heaven,

And the virtue that greatly rises thence

Through trial sent and victory given.

Grow, ivy, up to his countenance !

But it cannot smile on my life as on thineLook, saint, with thy trustful, fearless glance,

Where I dare not lift these eyes of mine! 


\section{ALDEN.}

THE ANCIENT "LADY OF SORROW."

Her elosing eyelids mock the light;

Her cold, pale lips are sealèd quite;

Before her face of spotless white

A mystic veil is drawn.

Our Lady hides herself in night;

In shadows hath she her delight;

She will not see the dawn!

The morning leaps across the plain-

It glories in a promise vain;

At noon the day begins to wane,

With its sad prophecy;

At eve the shadows come again:

Our Lady finds no rest from pain,

No answer to her cry.

In Spring she doth her Winter wait;

The Autumn-shadoweth forth her fate;

Thus, one by one, years iterate .

Her mystic tragedy.

Before her pass in solemn state

All shapes that come, or soon or late,

Of this world's misery.

What is, or shall be, or hath been,

This Lady is; and she hath seen,

Like frailest leaves, the tribes of men

Come forth, and quickly die.

Therefore our Lady hath no rest;

For close beneath her snow-white breast

Her weary children lie. 
She taketh on her all our grief;

Her Passion passeth all relief;

In vain she holds the poppy leaf-

In vain her lotus crown.

Even fabled Lethe hath no rest,

No solace for her troubled breast,

And no oblivion.

"Childhood and youth are vain," she saith, "Since all things ripen unto death; The flower is blasted by the breath

That called it from the earth.

And yet," she saith, "this thing is sureThere is no life but shall endure,

And death is only birth.

"From death or birth no powers defend, And thus from grade to grade we tend, By resurrections without end,

Unto some final peace.

But distant is that peace," she saith;

Yet eagerly awaiteth Death,

Expecting her release.

"Oh Rest," she saith, "that will not come,

Not even when our lips are lumb,

Not evẹn when our limbs are numb,

And graves are growing green.

Oh Death, that, coming on apace,

Dost look so kindly in the face,

Thou wear'st a treach'rous mien."

But still she gives the shadow placeOur Lady, with the saddest grace, .

Doth yield her to his feigned embrace,

And to his treachery!

Ye must not draw aside her veil;

Ye must not hear her dying wail;

Ye must not see her die. 
ALDEN.

But, hark! from out the stillness rise Low-murmured myths and prophecies, And chants that tremble to the skiesMiserere Domine! They, trembling, lose themselves in rest, Soothing the anguish of her breastMiserere Domine! 


\section{STODDARD.}

THE SEA.

[THE LOVER.]

You stooped and picked a wreathèd shell

Beside the shining sea-

"This little shell, when I am gone,

Will whisper still of me."

I kissed your hands, upon the sands, For you were kind to me.

I hold the shell against my ear,

And hear its hollow roar;

It speaks to me about the sea,

But speaks of you no more.

I pace the sands, and wring my hands, For you are kind no more.

\section{ON THE PIER.}

Dow at the end of the long, dark street,

Years, years ago,

I sat with my sweetheart on the pier,

Watching the river flow. 
The moon was climbing the sky that night,

White as the winter's snow:

We kissed in its light, and swore to be true-

But that was years ago!

Once more I walk in the dark old street,

Wearily to and fro-

But I sit no more on the desolate pier,

Watching the river flow.

THE SKY IS THICK UPON THE SEA.

TuE sky is thick upon the sea,

The sea is sown with rain,

And in the passing gusts we hear

The clanging of the crane.

The cranes are flying to the Sonth;

We cut the northern foam;

The dreary land they leave behind

Must be our future home.

Its barren shores are long and dark, And gray its autumn sky;

But better these than this gray sea,

If but to land-and die ! 


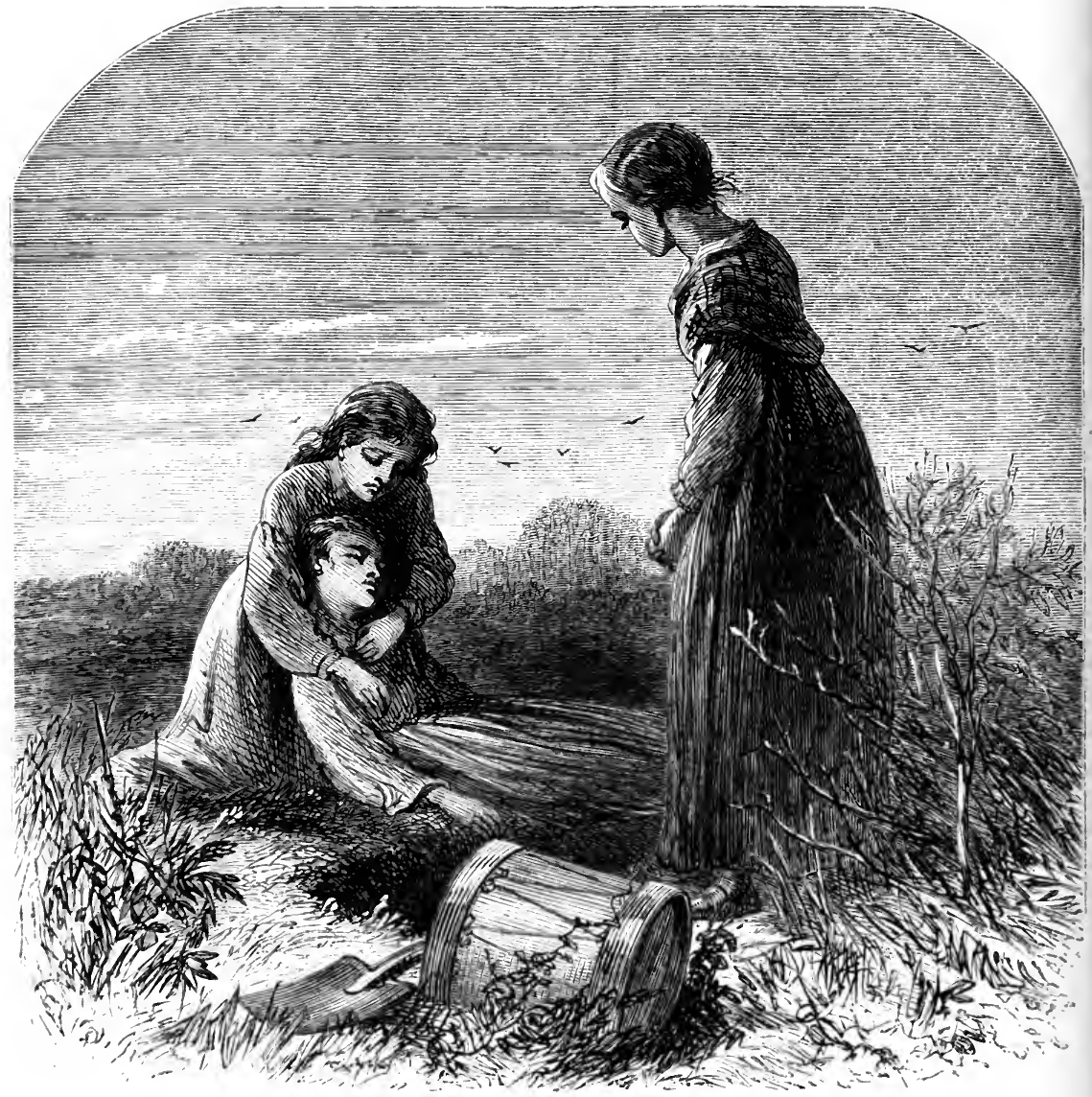

\section{DORR.}

THE DRUMIIER-BOY'S BURIAL.

AlL day long the storm of battle through the startled valley swept; All night long the star's in heav'n o'er the slain sad vigils kept.

Oh the ghastly upturned faces gleaming whitely through the night! Oh the heaps of mangled corses in that dim sepulchral light! 
DORR.

One by one the pale stars faded, and at length the morning broke; But not one of all the sleepers on that field of death awoke.

Slowly passed the golden hours of that long bright summer day, And upon that field of carnage still the dead unburied lay:

Lay there stark and cold, but pleading with a dumb, unceasing prayer, For a little dust to hide them from the staring sun and air.

But the foemen held possession of that hard-won battle-plain, In unholy wrath denying even burial to our slain.

Once again the night dropped round them-night so holy and so calm That the moonbeams hushed the spirit, like the sound of prayer or psalm.

On a couch of trampled grasses, just apart from all the rest, Lay a fair young boy, with small hands meekly folded on his breast

Death had touched him very gently, and he lay as if in sleepEven his mother scarce had shuddered at that slumber calm and deep;

For a smile of. wondrous sweetness lent a radiance to the face, And the hand of cunning sculptor could have added naught of grace

To the marble limbs so perfect in their passionless repose, Robbed of all save matchless purity by hard, unpitying foes.

And the broken drum beside him all his life's short story told: How he did his duty bravely till the death-tide o'er him rolled.

Midnight came with ebon garments and a diadem of stars, While right upward in the zenith hung the fiery planet Mars.

Hark! a sound of stealthy footsteps and of voices whispering lowWas it nothing but the young leaves, or the brooklet's murmuring flow?

Clinging closely to each other, striving never to look round As they passed with silent shudder the pale corses on the ground,

Came two little maidens-sisters-with a light and hasty tread, And a look upon their faces half of sorrow, half of dread. 
THE DRUMMER-BOY'S BURIAL.

And they did not pause nor falter till, with throbbing hearts, they . stood

Where the Drummer-boy was lying in that partial solitude.

They had brought some simple garments from their wardrobe's scanty store,

And two heavy iron shovels in their slender hands they bore.

Then they quickly knelt beside him, crushing back the pitying tears, For they had no time for weeping, nor for any girlish fears.

And they robed the icy body, while no glow of maiden shame Changed the pallor of their foreheads to a flush of lambent flame;

For their saintly hearts yearned o'er it in that hour of sorest need, And they felt that Death was holy, and it sanctified the deed.

But they smiled and kissed each other when their new, strange task was o'er,

And the form that lay before them its unwonted garments wore.

Then with slow and weary labour a small grave they hollowed out, And they lined it with the withered grass and leaves that lay about.

But the day was slowly breaking ere their holy work was done, And in crimson pomp the morning again heralded the sun.

And then those little maidens-they were children of our foesIaid the body of our Drummer-boy to undisturbed repose. 


\section{ROSSETTI.}

\section{THE SEA-LIMITS.}

Consider the sea's listless chime:

Time's self it is, made audible-

The murmur of the earth's own shell.

Secret continuance sublime

Is the sea's end. Our sight may pass

No furlong farther. Since time was,

This sound hath told the lapse of time.

No quiet, which is death's-it hath

The mournfulness of ancient life,

Enduring always at dull strife.

As the world's heart of rest and wrath,

Its painful pulse is in the sands.

Lost utterly, the whole sky stands,

Gray and not known, along its path.

Listen alone beside the sea-

Listen alone among the woods:

Those voices of twin solitudes

Shall have one sound alike to thee:

Hark where the murmurs of throngèd men

Surge, and sink back, and surge again-

Still the one voice of wave and tree.

Gather a shell from the strown beach,

And listen at its lips: they sigh

The same desire and mystery,

The echo of the whole sea's speech.

And all mankind is thus at heart

Not anything but what thon art;

And Earth, Sea, Man, are all in each. 


\section{CHRISTINA GABRIELLA ROSSETTI.}

\section{A BIRTHDAY.}

Mr heart is like a singing-bird

Whose nest is in a watered shoot;

My heart is like an apple-tree

Whose boughs are bent with thickset fruit;

My heart is like a rainbow shell

That paddles in a halcyon sea-

My heart is gladder than all these,

Because my love is come to me.

Raise me a dais of silk and down,

Hang it with vair and purple dyes,

Carve it in doves, and pomegranates,

And peacocks with a hundred eyes;

Work it in gold and silver grapes,

In leaves, and silver fleurs-de-lys,

Because the birthday of my life

Is come, my love is come to me.

SING NO SAD SONGS FOR ME.

Wuen I am dead, my dearest,

Sing no sad songs for me;

Plant thou no roses at my head,

Nor shady cypress-tree; 
CHRISTINA GABRIELLA ROSSLTTI.

Be the green grass above me

With showers and dew-drops wet, And if thou wilt, remember,

And if thou wilt, forget.

I shall not see the shadows, I shall not feel the rain;

I shall not hear the nightingale Sing on, as if in pain;

And dreaming through the twilight That doth not rise nor set, IAaply I may remember, And haply may forget. 


\section{SWINBURNE.}

\section{BEFORE PARTING.}

A мontu or twain to live on honeycomb

Is pleasant; but one tires of scented time,

Cold, sweet recurrence of aceepted rhyme,

And that strong purple under juice and foam

Where the wine's heart has burst,

Nor feel the latter kisses like the first.

Once yet, this poor one time; I will not pray

Even to change the bitterness of it-

The bitter taste ensuing on the sweet-

To make your tears fall where your soft hair lay

All blurred and heary in some perfumed wise

Over my face and eyes.

And yet, who knows what end the scythèd wheat

Makes of its foolish poppies' mouths of red?

These were not sown; these are not harvested;

They grow a month, and are cast under feet,

And none has care thereof,

As none has care of a divided love.

I know each shadow of your lips by rote,

Each change of love in eyelids and eyebrows;

The fashion of fair temples tremulous

With tender blood, and colour of your throat:

I know not how love is gone out of this,

seeing that all was his. 


\section{SWINBURNE.}

Love's likeness there endures upon all theseBut out of these one shall not gather love.

Day hath not strength, nor the night shade enough To make love whole, and fill his lips with ease, As some bee-builded cell

Feels at filled lips the honey swell.

I know not how this last month leaves your hair Less full of purple colour and hid spice, And that luxurious trouble of closed eyes Is mixed with meaner shadows and waste care; And love, kissed out by pleasure, seems not yet Worth patience to regret. 


\section{STEDMAN.}

THE DOOR-STEP.

The Conference-meeting through at last,

We boys around the vestry waited

To see the girls come tripping past

Like snow-birds willing to be mated.

Not braver he that leaps the wall

By level musket-flashes litten

Than I, who stepped before them all

Who longed to see me get the mitten.

But no; she blushed and took my arm!

We let the old folks have the highway, And started toward the Maple Farm

Along a kind of lovers' by-way.

I can't remember what we said-

'Twas nothing worth a song or story-

Yet that rude path by which we sped

seemed all transformed and in a glory.

The snow was crisp beneath our feet,

The moon was full, the fields were gleaming;

By hood and tippet sheltered sweet,

Her face with youth and health was beaming.

The little hand outside her muff

(Oh, sculptor, if you could but mould it !)

So lightly touched my jacket-enff,

To keep it warm I had to hold it. 
To have her with me there alone-

'Twas love, and fear, and triumph blended.

At last we reached the foot-wom stone

Where that delicious journey ended.

The old folks, too, were almost home;

Ier dimpled hand the latches fingered;

We heard the voices nearer come,

Yet on the door-step still we lingered.

She shook her ringlets from her hood,

And with a "Thank you, Ned," dissembled;

But yet I knew she understood

With what a daring wish I trembled.

A clond passed kindly orerhead, The moon was slyly peeping through it,

Yet hid its face, as if it said,

"Come, now or never-do it! do it!"

My lips till then had only known

The kiss of mother and of sister,

But somehow, full upon her own

Sweet, rosy, darling mouth, I kissed her !

Perhaps 'twas boyish love, yet still,

$\mathrm{Oh}$ listless woman, weary lover,

To feel once more that fiesh, wild thrill,

I'd give-but who can live youth orer? 
"DARKNESS AND THE SHADOW."

"DARKNESS AND THE SHADOW."

Waking, I have been nigh to Death-

Have felt the chillness of his breath

Whiten my cheek and numb my heart, And wondered why he stayed his dartYet quailed not, but could meet him so, As any lesser friend or foe.

But sleeping, in the dreams of night His phantom stifles me with fright. O God! what frozen horror's fall Upon me with bis visioned pallThe movelessness, the unknown dread, Fair life to pulseless silence wed!

And is the grave so darkly deep, So hopeless, as it seems in sleep? Can our sweet selves the coffin hold So dumb within its crumbling mould? And is the shroud so dank and drear A garl-the noisome worm so near?

Where, then, is Heaven's mercy fled, To quite forget the roiceless dead? 


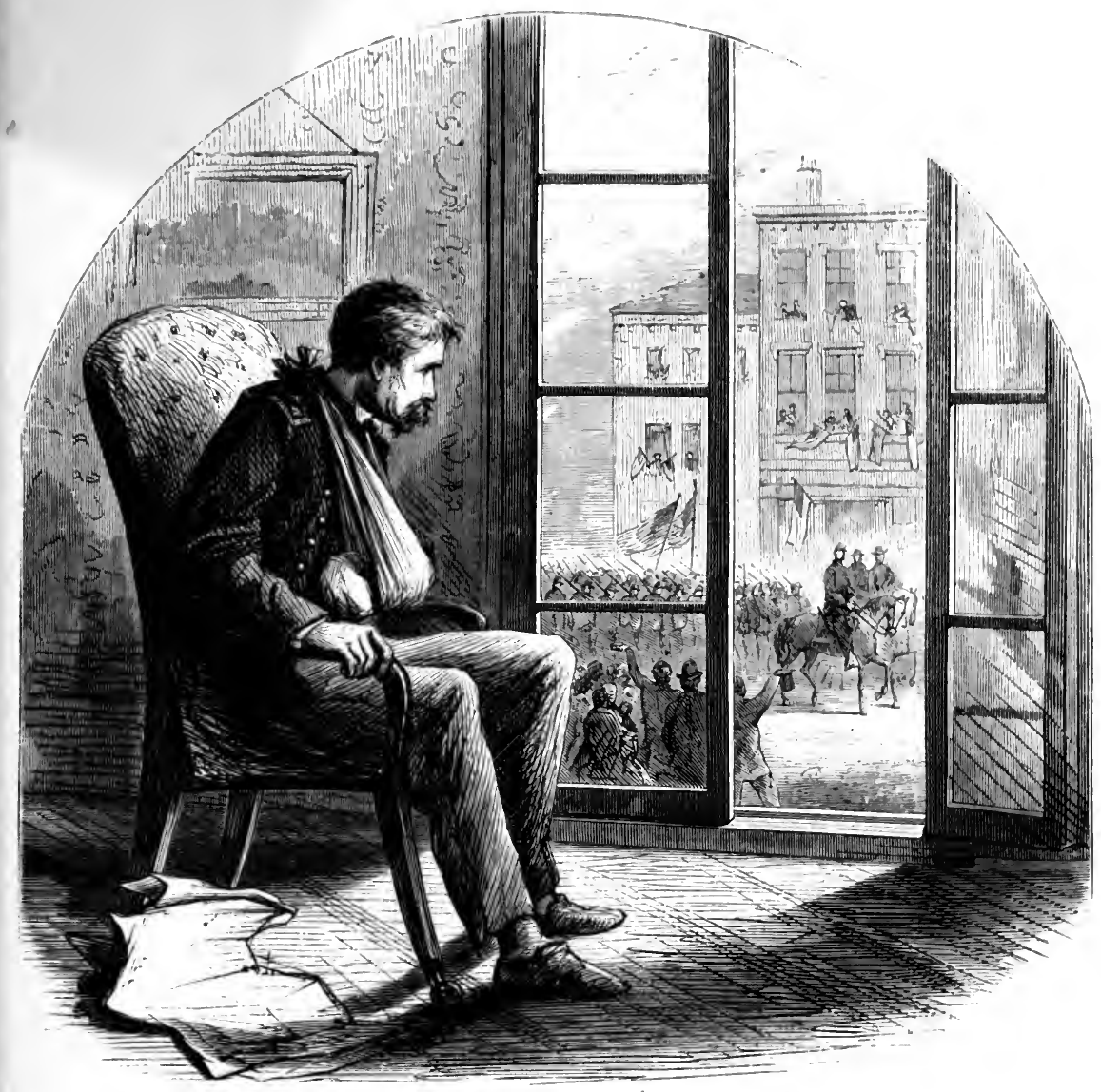

HALPINE (MILES O'PEILLY).

RES I G N E.

Never again on the shoulder

To see our knightly bars;

Nerer again on the shoulder

To see our lordly leaves;

Never again to follow

The flag of the Stripes and Stars;

Never again to dream the dream

That martial music weaves. 
Never again call "Comrade"

'To the men who were comrades for years;

Never to hear the bugles,

Thrilling, and sweet, and solemn;

Never again call "Brother"

To the men we think of with tears;

Never again to ride or march

In the dust of the marching columu.

Never again be a sharer

In the chilly hour of the strife

When, at dawn, the skirmish-rifles

In opening chorus rattle;

Never to feel our manhood

Kindle up into ruddy life

'Mid the hell of scenes and noises

In the hot hours of the battle.

Crippled, forlorn, and useless,

The glory of life grown dim,

Brooding alone o'er the memory

Of the bright, glad days gone by;

Nursing a bitter fancy,

And nursing a shattered limb;

Oh, comrades, resigning is harder-

We know it is easy to dic.

Never again on the jacket

To see our knightly bars;

Never again on the jacket

To see our lordly leaves;

Never again to follow

The flag of the Stripes and Stars;

Never again to dream the dream

That young ambition weaves. 


\section{GEORGE ELIOT.}

\section{DAY IS DYING.}

(FROM "THE SPANISH GYPSY.")

$\mathrm{D}_{\Lambda \mathrm{Y}}$ is dying! Float, $\mathrm{O}$ song,

Down the westward river, Requiems chanting to the DayDay, the mighty Giver.

Pierced by shafts of Time, he bleeds, Melted rubies sending Through the river and the sky,

Earth and heaven blending;

All the long-drawn earthy bauks

Up to cloud-land lifting;

Slow between them drifts the swan,

'Twixt two heavens drifting.

Wings half open, like a flow'r

July deeper flushing,

Neck and breast as virgin's pure-

Virgin proudly blushing.

Day is dying! Float, $\mathrm{O}$ swan,

Down the ruby river;

Follow, song, in requiem

To the mighty Giver. 
SPRING.

SPRING.

(FROM "THE SPANISI GYPSY.")

Sprixg comes hither, Buds the rose; Roses wither, Sweet Spring goes.

Ojalà, would she carry me!

Summer soars-

Wide-winged day

White light pours,

Flies away.

Ojali, would he carry me!

Soft winds blow,

Westward born,

Onward go

Toward the morn.

Ojalà, would they carry me!

Sweet birds sing

O'er the graves,

Then take wing

O'er the waves.

Ojali, would they carry me! 
GEORGE ELIO'T.

"IT WAS IN THE PRIME."

(FROM "TIE SPANISH GYPSY.")

IT was in the prime

Of the sweet Spring-time.

In the linnet's throat

Trembled the love-note, And the love-stirred air Thrilled the blossoms there.

Little shadows dancedEach a tiny elfHappy in large light And the thinnest self:

It was but a minute In a far-off Spring, But each gentle thingSweetly-wooing linnet, Soft-thrilled hawthorn-tree, Happy shadowy elf With the thinnest selfLive still on in me. $O$ the sweet, sweet prime Of the past Spring-time ! 


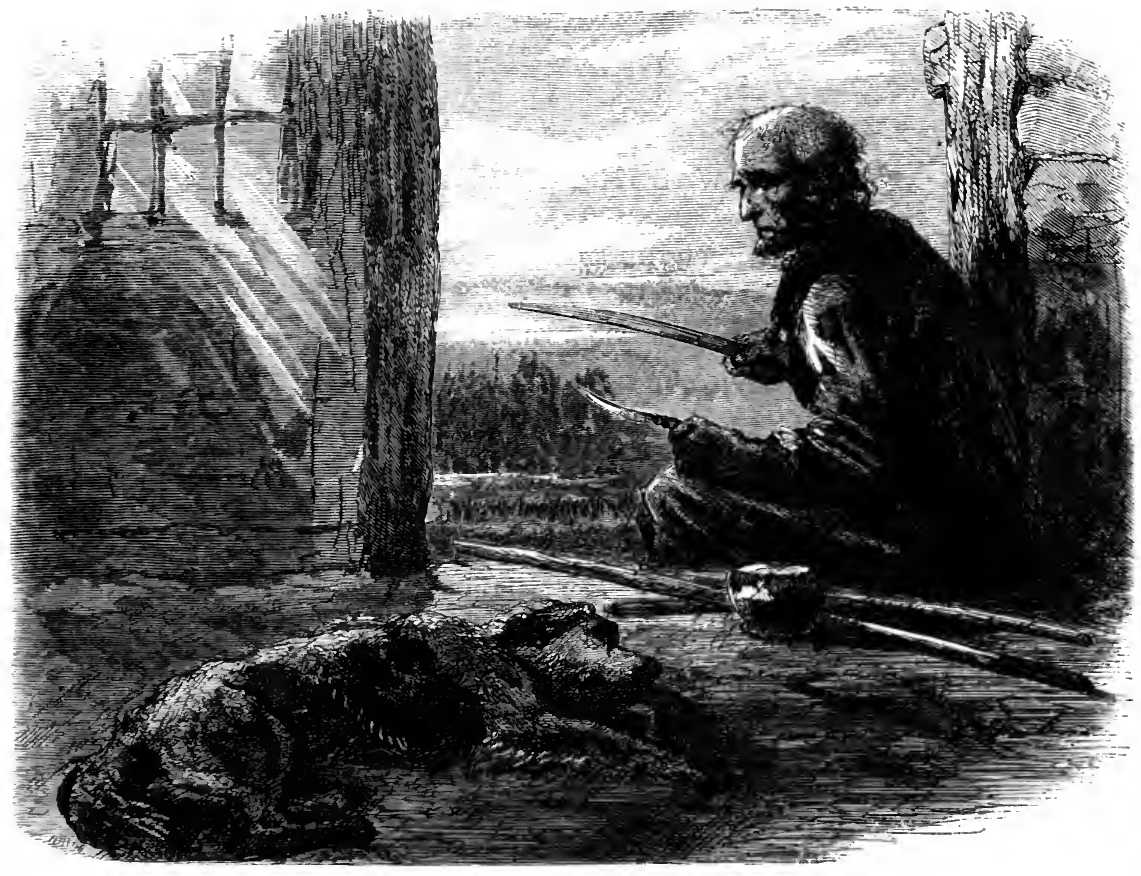

BEERS.

\section{A DOG'S DAY ENDED.}

I As only a dog, and I've had my day; So, idle and dreaming, stretched out I lay In the welcome warmth of the summer sum, A poor old hunter whose work is done.

Dream? Yes, indeed; though I am but a dogr, Don't I dream of the partridge I sprung by the log, Of the quivering have and her desperate flight, Of the nimble gray squirrel secure in his height, 
Far away in the top of the hickory-tree, Looking down safe and sancy at Matthew and me, Till the hand true and steady a messenger shot, And the creature upbounded, and fell, and was not?

Old Matthew was king of the wood-rangers then; And the quails in the stubble, the ducks in the fen, The hare on the eommon, the birds on the bough, Were afraid. They are safe enough now,

For all we ean harm them, old master and I. We have had our last hunt, the game must go by, While Matthew sits fashioning bows in the door For a living. We never hunt more.

For time, cold, and hardship have stiffened his knee; And since little Lottie died, often I see His hands tremble sorely, and go to his eyes For the lost baby-daughter so pretty and wise.

Oh! it's sad to be old, and to see the blue sky Look farther away to the dim fading eye; To feel the fleet foot growing weary and sore That in forest and hamlet shall lag evermore.

I am going-I hear the great wolf on my track; Already around me his shadow falls black. One hunting cry more! Oh, master! come nigh, And lay the white paw in your own as I die.

Oh come to me, master! the last hedge is passed; Our tramps in the wild wood are over at last; Stoop lower, and lay down my head on your knee. What! tears for a useless old hunter like me?

Yon will see little Lottie again by-and-by. I sha'n't. They don't have any dogs in the sky. 
Tell her, loving and trusty beside you I died, And-bury me, master, not far from her side;

For we loved little Lottie so well, you and I. Ha, master! the shadow ! fire low ! it is nigh! There was never a sound in the still morning heard, But the heart of the hunter his old jacket stirred

As he flung himself down on the brute's shaggy coat, And watched the faint life in its quivering throat Till it stopped quite at last. The black wolf had won, And the death-hunted hound into cover had run.

But long ere the snow over graves softly fell, Old Matthew was resting from labour as well; While the cottage stood empty, yet back from the hill The voice of the hound in the morn echoes still.

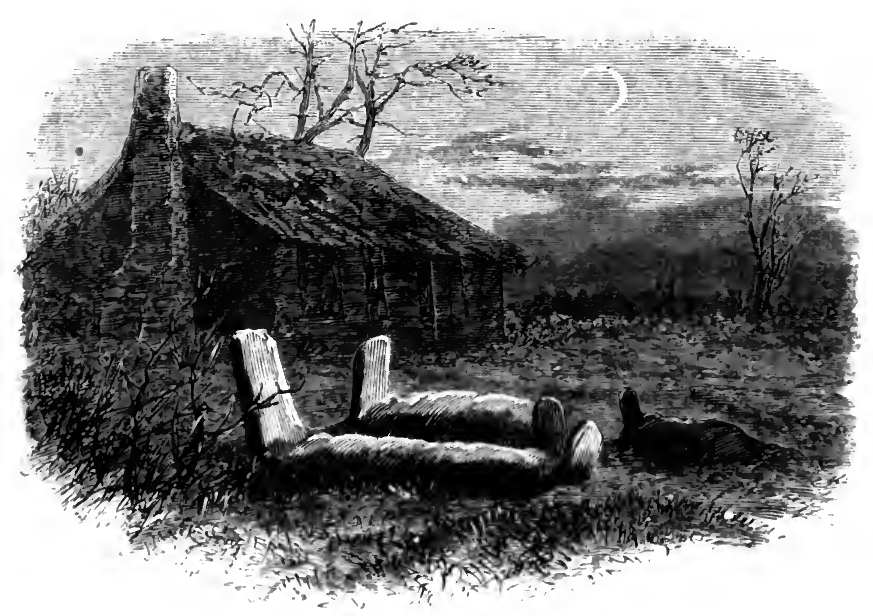




\section{LARCOM.}

\section{HANNAH BINDING SHOES.}

Poor lone Hannah,

Sitting at the window, binding shoes.

Faded, wrinkled,

Sitting, stitching, in a mournful muse.

Bright-eyed beauty once was she,

When the bloom was on the tree:

Spring and winter,

Hannah's at the window, binding shoes.

Not a neighbour

Passing nod or answer will refuse

To her whisper,

"Is there from the fishers any news?"

Oh, her heart's adrift with one

On an endless voyage gone!

Night and morning,

Hannah's at the window, binding shoes.

Fair young Hannah,

Ben, the sunburnt fisher, gayly woos;

Hale and clever,

For a willing heart and hand he sues.

May-day skies are all aglow,

And the waves are laughing so-

For her wedding

Hannah leaves her window and her shoes. 
May is passing:

'Mid the apple boughs a pigeon coos:

Hannah shudders,

For the mild southwester mischief brews.

Round the rocks of Marblehead,

Outward bound, a schooner sped-

Silent, lonesome,

IIannah's at the window, binding shoes.

'Tis November.

Now no tears her wasted cheek bedews.

From Newfoundland

Not a sail returning will she lose,

Whispering hoarsely, "Fishermen,

Have you-have you heard of Ben?"

Old with watching,

Hannah's at the window, binding shoes.

\section{Twenty winters}

Bleach and tear the ragged shore she views;

Twenty seasons-

Never one has brought her any news.

Still her dim eyes silently

Chase the white sails o'er the sea:

Hopeless, faithful,

Iannah's at the window, binding shoes. 


\section{ALICE CARY. \\ "THOU THAT DRAWEST ASIDE THE CURTAIN."}

(FROM "THE LOVER's DIARY.")

Tuov that drawest aside the curtain, Letting in the moon's broad beams, Give me back the sweet, th' uncertainGive, $O$ give me back my dreams.

Take the larger light and grander,

Piereing all things through and through;

Give me back the misty splendour,

Give me back the darling dew.

Take the harvest's ripe profusions,

Golden as the evening skies;

Give me back my soft delusions,

Give me back my wondering eyes.

Take the passionless caresses

All to waveless calm allied;

Give me back my heart's sweet guesses,

And my hopes unsatisfied.

Thou that mak'st the real too real, $\mathrm{O}, \mathrm{I}$ pray thee, get thee hence!

Give me back my old ideal,

Give me back my ignorance. 
"COME OUT TO THE SIDE OF THE SEA."

"COME OUT TO THE SIDE OF THE SEA."

(FROM "THE LOVER'S DIARY.")

Come out to the side of the sea, my love,

Come out to the side of the sea;

The sun is set, and the stars are met,

And the winds and the waves agree.

But star so bright, nor wave so ligbt,

Brings pleasure or peace to me.

O come, for I sit and wait, alone,

On the rocks by the side of the sea.

I am going down in my memory

To the blessed long ago,

When the golden ground of the buttereups

Was dashed with the daisies' snow;

And I'm thinking of all you said to me,

And if it were true or no,

While I wateh the tide as it runs away

From the beach so black and low.

If I should die, my love, my sweet,

Die of your smile forlorn,

Bury me here by the side of the sea,

Where all my joy was born;

Where the waves shall make my lullaby,

And the winds from night till morn

Shall say to the rocks, "He is gone to sleep

Where all his joy was born." 


\section{PHEBE CARY.}

\section{DREAMS AND REALITIES.}

O Rosamond, thou fair and good, And perfect flower of womanhood,

Thou royal rose of June, Why didst thou droop before thy time? Why wither in thy first sweet prime?

Why didst thou die so soon?

For, looking backward through my tears On thee and on my wasted years,

I cannot choose but say, If thou hadst lived to be my guide, Or thou hadst lived and I had died,

'Twere better far to-day.

$O$ child of light, $O$ golden headBright sunbeam for one moment shed

Upon life's lonely way-

Why didst thou vanish from our sight?

Could they not spare my little light

From heaven's unclouded day?

$O$ friend so true, $O$ friend so goodThou one dream of my maidenhood, That gave youth all its charmsWhat had I done, or what hadst thou, That through this lonesome world till now We walk with empty arms? 
And yet, had this poor soul been fed With all it loved and coveted-

Itad life been always fair-

Would these dear dreams that ne'er depart, That thrill with bliss my inmost heart,

Forever tremble there?

If still they kept their earthly place, The friends I held in my embrace,

And gave to death, alas!

Could I have learned that clear, calm faith

That looks beyond the bounds of death, And almost longs to pass?

Sometimes I think the things we see Are shadows of the things to be;

That what we plan we build;

That every hope that hath been crossed, And every dream we thought was lost,

In heaven shall be fulfilled;

That even the children of the brain Have not been born and died in vain,

Though here unclothed and dumb;

But on some brighter, better shore

They live, embodied evermore,

And wait for us to come.

And when on that last day we rise, Canght up between the earth and skies,

Then shall we hear our Lord

Say, Thou hast done with doubt and death; IIenceforth, according to thy faith, Shall be thy faith's reward. 


\section{$\mathrm{H} \Lambda \mathrm{Y}$.}

\section{MY CASTLE IN SPAIN.}

There was never a castle seen

So fair as mine in Spain :

It stands, embowered in green,

Crowning the gentle slope

Of a hill by the Xenil's shore,

And at eve its shade flaunts o'er

The storied Vega plain,

And its towers are hid in the mists of Hope;

And I toil through years of pain

Its glimmering gates to gain.

In visions wild and sweet

Sometimes its courts I greet;

Sometimes in joy its shining halls

I tread with favoured feet;

But never my eyes in the light of day

Were blest with its ivied walls,

Where the marble white and the granite gray

Turn gold alike when the sunbeams play,

When the soft day dimly falls.

I know in its dusky rooms

Are treasures rich and rare:

The spoil of Eastern looms,

And whatever of bright and fair

Painters divine have caught and ron

From the vault of Italy's air:

White gods in Phidian stone 
People the haunted glooms; And the song of immortal singers Like a fragrant memory lingers,

I know, in the echoing rooms.

But nothing of these, my soul!

Nor castle, nor treasures, nor skies, Nor the waves of the river that roll

With a cadence faint and sweet

In peace by its marble feetNothing of these is the goal

For which my whole heart sighs.

'Tis the pearl gives worth to the shell-

The pearl I would die to gain;

For there does my Lady dwell,

My love that I love so well-.

The Queen whose gracious reign

Makes glad my Castle in Spain.

Her crown of golden hair

Sheds light in the shaded places,

And the spell of her girlish graces

Makes glad the happy air.

A breath of purity

Forever before her flies, And ill things cease to be

In the glance of her honest eyes.

Around her pathway flutter,

Where her dear feet wander free,

In youth's pure majesty,

The wings of the vague desires;

But the thought that love would utter

In reverence expires.

Not yet! not yet shall I see

That face, which shines like a star

O'er my storm-swept life afar,

Transfigured with love for me. 
HAY.

Toiling, forgetting, and learning,

With labour, and vigils, and prayers, Pure heart and resolute will, At last I shall climb the hill, And breathe the enchanted airs

Where the light of my life is burning, Most lovely, and fair, and free;

Where alone in her youth and beauty, And bound by her fate's sweet duty, Unconscious she waits for me.

\section{WOMAN'S LOVE.}

A sentinel angel, sitting high in glory, Heard this shrill wail ring out from purgatory: "Have mercy, mighty angel! hear my story.

"I loved, and, blind with passionate love, I fell:

Love brought me down to death, and death to hell;

For God is just, and death for sin is well.

"I do not rage against his high decree, Nor for myself do ask that grace shall be, But for my love on earth, who mourns for me.

"Great spirit, let me see my love again, And comfort him one hour, and I were fain To pay a thousand years of fire and pain."

Then said the pitying.angel: "Nay, repent That wild vow. Look! the dial-finger's bent Down to the last hour of thy punishment." 


\section{WOMAN'S LOVE.}

But still she wailed: "I pray thee, let me go; I cannot rise to peace and leave him so! Oh, let me soothe him in his bitter woe!"

The brazen gates ground sullenly ajar, And upward, joyous, like a rising star She rose, and vanished in the ether far.

But soon adown the dying sunset sailing, And like a wounded bird her pinions trailing, She fluttered back with broken-hearted wailing.

She sobbed: "I found him by the summer sea Reclined, his head upon a maiden's knee;

She curled his hair and kissed him. Woe is me!"

She wept: "Now let my punishment begin:

I have been fond and foolish. Let me in To expiate my sorrow and my sin."

The angel answered: "Nay, sad sonl, go higher! To be deceived in your true heart's desire Was bitterer than a thousand years of fire!" 


\section{BRET HARTE.}

\section{"CICELY."}

\section{(ALKALI STATION.)}

Cicely says you're a poet; may be; I ain't much on rhyme:

I reckon you'd give me a hundred, and beat me every time.

Poetry! 'That's the way some chaps put's up an idee,

But I takes mine "straight, without sugar," and that's what's the matter with me.

Poetry! Just look around you-alkali, rock, and sage; Sage-brush, rock, and alkali-ain't it a pretty page? Sun in the east at mornin', sun in the west at night, And the shadow of this yer station the on'y thing moves in sight.

Poetry! Well, now-Polly! Polly, run to your mam; Run right away, my pooty! By-by! Ain't she a lamb? Poetry - that reminds me o' su'thin' right in that suit; Jest shet that door thar, will yer, for Cicely's ears is cute.

Ye noticed Polly-the baby? A month afore she was born, Cicely-my old woman-was moody-like and forlorn;

Out of her head and crazy, and talked of flowers and treesFamily man yourself, sir? Well, you know what a woman be's.

Narvous she was, and restless; said that she "couldn't stay." Stay-and the nearest woman seventeen miles away!

But I fixed it up with the doctor, and he said he would be on haml, And I kinder stuck by the shanty, and fenced in that bit o' land. 


\section{"CICELY."}

One night-the tenth of October-I woke with a chill and fright, For the door it was standing open, and Cicely warn't in sight,

- But a note was pinned on the blanket, which it said that she " couldn't stay,"

But had gone to visit her neighbor-seventeen miles away!

When and how she stampeded I didn't wait for to see,

For out in the road, next minit, I started as wild as she;

Running first this way and that way, like a hound that is off the scent,

For there warn't no track in the darkness to tell me the way she went.

I've had some mighty mean moments afore I kem to this spotLost on the Plains in '50, drowned almost, and shotBut out on this alkali desert, a-hunting a crazy wife, Was ra'ly as on-satis-factory as anything in my life.

"Cicely! Cicely! Cicely!" I called, and I held my breath; And "Cicely!" came from the eanyon-and all was as still as death; And "Cicely! Cicely! Cicely!" came from the rocks below, And jest but a whisper of "Cicely!" down from them peaks of snow.

I ain't what you call religious, but I jest looked up to the sky, And-this yer's to what I'm coming, and maybe ye think I lie; But up away to the east'ard, yaller, and big, and far, I saw of a suddent rising the singlerest kind of star.

Big, and yaller, and dancing, it seemed to beckon to me; Yaller, and big, and dancing, such as you never see; Big, and yaller, and dancing-I never saw such a star, And I thought of them sharps in the Bible, and I went for it then and thar. 
Over the brush and boulders I stumbled and pushed ahead; Keeping the star afore me, I went wherever it led;

It might hev been for an hour, when suddent, and peart, and nigh, Out of the yearth afore me thar riz up a baby's cry.

Listen! thar's the same music; but her lungs, they are stronger now Than the day I packed her and her mother-I'm derned if I jest know how.

But the doctor kem the next minit, and the joke o' the whole thing is, That Cis never knew what happened from that very night to this!

But Cicely says you're a poet, and maybe you might, some day, Jest sling her a rhyme 'bout a baby that was born in a curious wayAnd see what she says. And, old fellow, when you speak of the star, don't tell

As how the doctor's lantern-for maybe 'twon't sound so well. 


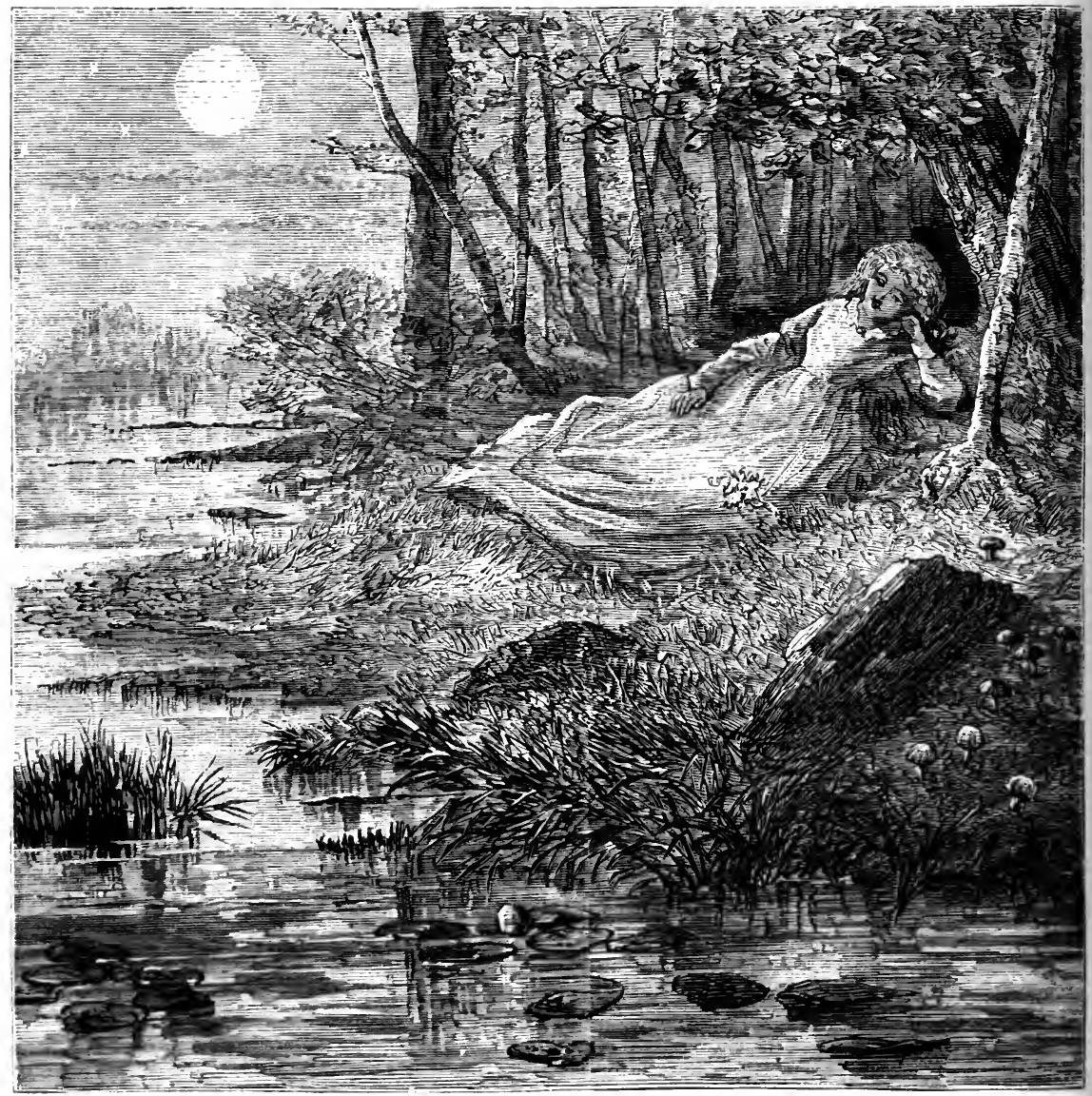

\section{CONANT.}

\section{A DREAM OF FAIRIES.}

IT was Summer-it was June;

Slept the sun in western bowers;

Le had risen the round moon:

Fainting with the breatl of flowers, IIushed the air its leafy tune. 
Faint gray clouds upon the sky, Where the failing zephyrs blew them,

Here and there hung, far and high;

And the stars were winking throngh them

With a dim and sleepy eye.

Everywhere, on every side, Quiet breathing, rest of Summer, And luxurious peace, denied Unto Spring, the riotous comer, Rashly wooing his coy bride.

Helen, sitting on the grass, Just within a grove of beeches (Like a Fairy kingdom 'twas), Gazed adown the sylvan reaches, Where the Fairy Queen may pass.

Mystic hollows, shadows gray, And a play of silvery shimmer; Rock and tree-trunk, leaf and spray, Seemed, in that uncertain glimmer, Ghosts of what they were by day.

By the great trees over-boughed, Flecked with shadows and moon-glanees, Sat she, still and thoughtful-browed, Dreaming a whole world of fanciesNot a word of them aloud!

In the shadow of the boughs Thus ran on her dim-eyed fancy (For the goddess of sweet vows With the subtlest necromancy Every lover's brain endows): 
"Fie, ye Fairies! So remiss!

Forty minutes have I waited

For those graceful courtesies

Done to straying folk, belated

In old time, beneath the trees.

"Have ye fled away from earth,

From our mountains and our valleys,

From the castle, from the hearth,

From the winding forest alleys,

'Taking all your tricksy mirth?

"Where is all the frolic crowd

Footed meadows in times olden,

When the air breathed not aloud,

And the moon, full-faced and golden,

Walked through heaven without a cloud?

"Whereto have ye fled and gone,

Since King Arthur's time, I wonder?

To the top of mountains flown?

To the dismal regions under,

Where the sunlight never shone?

"Whereto have ye disappeared?

Round the planets hiding, seeking?

Plucking comets by the beard?

Down yon pathway dancing, freaking,

Where no human step is feared?

"Wherefore have ye left our brooks,

Glens, and groves, and meadows, friendless?

Sigh ye not for those old nooks?

Have ye found, in regions endless,

Haunts with half so lovely looks? 
"Answer none! Ah! nevermore

In the woodlands shall we view them,

Nor on grassy meadow-floor;

Nor by falling waters woo them

To us, as in days of yore.

"Nevermore, in lonely wood,

Maids shall hear dim strains alluring,

Strains that cannot be withstood;

Something that's divine assuring

Nothing shall be met but good.

"Could we turn earth back again, And those olden days recover!

Some high lady were I then, And a glorious knight my lover,

Noblest, famousest of men ;

"Through the wide world nobly famed

For his gentleness and valour;

By the poor down-trodden claimed;

Wrong's dark cheek would turn to pallor

But to hear his scutcheon named!

"But his noble heart would be

Mine, though we were realms asunder;

And, when victory left him free,

He would come back, to sit under

The old oak-tree boughs with me.

"For a eastle should be ours,

Many-towered, high-walled, deep-moated

Ringed with groves, and lawns, and flowers;

Founts from marble basins spouted,

Falling back in silvery showers. 


\section{A DREAM OF FAIRIES.}

"Underneath the old oak-trees

With green chaplets I would crown him;

Do him dearer courtesies

Than a queen could smile upon him

For his famous victories;

"While my noble knight would tell

Hard adventures, wild and daring;

How the wizard-robber fell,

And the flames, the midnight scaring,

Shot up from his citadel;

"How the potent Fairy King

Was his Genius and his leaguer;

Of the wondrous Horn and Ring;

And the Goblet, to lips eager

With wine gushing, like a spring;

"How he passed through forests old,

Haunts of drear, mysterious dangers,

Where the Giants have their hold,

And the sealy Dragon-rangers

Guard enchanted heaps of gold;

"How the- Hush! what strains are those?

Some enchantment o'er me creeping?"

Soft and slow her eyelids close-

She droops sideways-she is sleeping,

While the music ebbs and flows;

Sleeping, cheek upon her arm,

IIer unknotted hair loose straying;

Naught can fall to her of harm

With the placid moonlight playing

On her eyelids like a charm. 


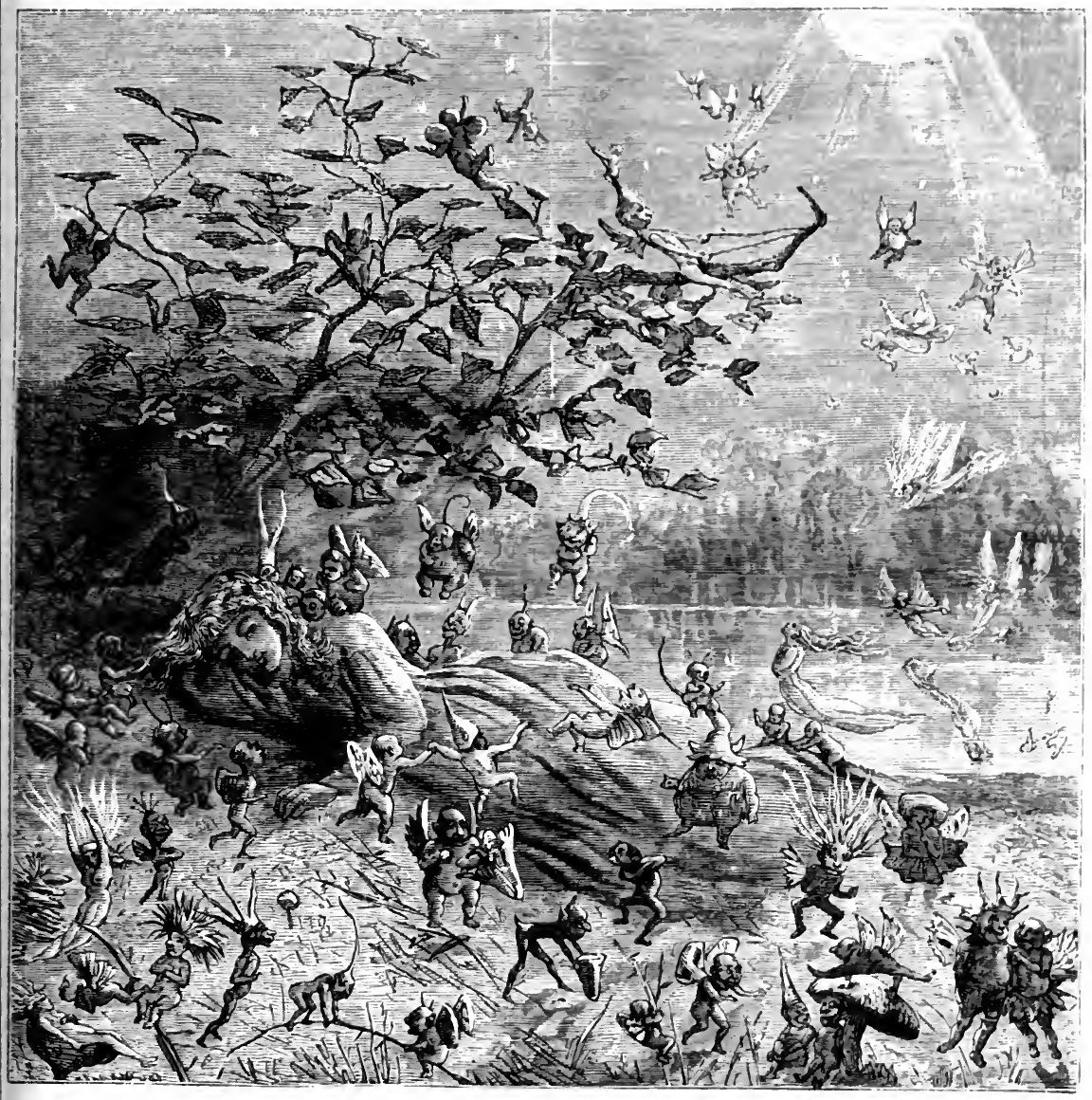

Lo, a thousand merry sprites,

Their lithe bodies sparkling, flashing,

Shower of animated lights,

Like the crystal rain a dashing

Wind from frosty branches smites;

Round about her, on the ground,

In the silvered air above her, 


\section{A DREAM OF FAIRIES.}

To the small, sweet, tinkling sound

Merrily skip, dance, and hover, Singing this fantastic round:

"Happy and free, Merrily we

Flit through the dells,

Sleep in the cells

Of flower-cups and bells.

Zephyr and Moonlight

Know where we bide, Hidden from noonlight, Snugly we hide!

Zephyr, Moonlight, never tell Where the Fairy people dweli !'

Tu whit, tu whoo! tu whit, tu whoo!

Sleep and Fairies fly together.

From the grove glides Helen, too,

Slowly, slowly, wondering whether

It was all a dream, or true. 


\section{BOKER.}

\section{DIRGE FOR A SOLDIER.}

Close his eyes-his work is done;

What to him is friend or foemall, Rise of moon, or set of sun,

Hand of man, or kiss of woman?

Lay him low, lay him low, In the clover or the snow;

What cares he? he cannot know:

Lay him low.

As man may, he fought his fight-

Proved his truth by his endeavour;

Let him sleep in solemn night,

Sleep forever and forever.

Lay him low, lay him low, In the clover or the snow;

What eares he? he cannot know:

Lay him low.

Fold him in his country's Stars,

Roll the drum and fire the volley;

What to him are all our wars-

What but Death bemocking Folly?

Lay him low, lay him low,

In the clover or the snow;

What eares he? he cannot know :

Lay him low. 
Leave him to God's watching eye, Trust him to the hand that made him. Mortal love weeps idly by-

God alone has power to aid him.

Lay him low, lay him low,

In the clover or the snow;

What cares he? he cannot know:

Lay him low.

SONNET.

$\mathrm{NAY}$, not to thee-to Nature will I tie

The gather'd blame of every pettish mood;

And when thou frown'st, I'll frown upon the wood, Saying, "How wide its gloomy shadows lie!" Or, gazing straight into the day's bright eye,

Predict ere night a second fatal flood;

Or vow the poet's sullen solitude

Has changed my vision to a darksome dye.

But when thou smil'st, I'll not look above

To wood or sky; my hand I will not lay

Upon the temple of my sacred love,

To blame its living fires with base decay;

But whisper to thee, as I nearer move,

"Love, thou dost add another light to day." 


\section{WHITMAN.}

\section{PROUD MUSIC OF THE STORM.}

${ }^{1}$ Proud music of the storm!

Blast that careers so free, whistling across the prairies!

Strong hum of forest tree-tops! wind of the mountains!

Personified dim shapes! you hidden orchestras!

You serenades of phantoms, with instruments alert,

Blending, with Nature's rhythmus, all the tongues of nations;

You chords left as by vast composers! you choruses!

You formless, free, religious dances! you from the Orient!

You undertone of rivers, roar of pouring cataracts;

You sounds from distant guns, with galloping cavalry!

Echoes of camps, with all the different bugle-calls!

Trooping tumultuous, filling the midnight late, bending me powerless, Entering my lonesome slumber-chamber-Why have you seiz'd me?

2

${ }^{2}$ Come forward, O my Soul, and let the rest retire;

Listen-lose not-it is toward thee they tend;

Parting the midnight, entering my slumber-chamber, For thee they sing and dance, $O$ Soul.

\section{${ }^{3}$ A festival song!}

The duet of the bridegroom and the bride-a marriage-march, With lips of love, and hearts of lovers, fill'd to the brim with love; The red-flush'd cheeks, and perfumes-the cortege swarming, full of friendly faces, young and old, To flutes' clear notes, and sounding harps' cantabile. 
${ }^{4}$ Now loud approaching drums!

Victoria! see'st thou in powder-smoke the banners torn, but flying? the rout of the baffled?

Hearest those shouts of a conquering army?

${ }^{5}$ (Ah, Soul, the sobs of women-the wounded groaning in agony, The hiss and crackle of flames-the blacken'd ruins-the embers of cities,

The dirge and desolation of mankind.)

${ }^{6}$ Now airs antique and medieval fill me;

I see and hear old harpers with their harps, at Welsh festivals;

I hear the minnesingers, singing their lays of love;

I hear the minstrels, gleemen, troubadours, of the feudal ages.

${ }^{7}$ Now the great organ sounds,

Tremulous-while underneath, (as the hid footholds of the earth,

On which arising, rest, and leaping forth, depend,

All shapes of beauty, grace, and strength-all hues we know,

Green blades of grass, and warbling birds-children that gambol and play-the clouds of heaven above,)

The strong base stands, and its pulsations intermits not,

Bathing, supporting, merging all the rest-maternity of all the rest;

And with it every instrument in multitudes,

The players playing-all the world's. musicians,

The solemn hymus and masses, rousing adoration,

All passionate heart-chants, sorrowful appeals,

The measureless sweet vocalists of ages;

And for their solvent setting, Earth's own diapason,

Of winds and woods and mighty ocean waves;

A new composite orchestra-binder of years and climes-ten-fold renewer,

As of the far-back days the poets tell-the Paradiso, 


\section{WHITMAN.}

The straying thence, the separation long, but now the wandering done, The journey done, the Journeyman come home, And Man and Art, with Nature fused again.

8 Tutti ! for Earth and Heaven !

The Almighty Leader now for me, for once, has signal'd with his wand.

9 The manly strophe of the husbands of the world, And all the wives responding.

${ }^{10}$ The tongues of violins!

(I think, O tongues, ye tell this heart, that cannot tell itself;

This brooding, yearning heart, that cannot tell itself.)

$1 \mathrm{Ah}$, from a little child,

Thou knowest, Soul, how to me all sounds became music;

My mother's voice, in lullaby or hymn ;

(The voice-O tender voices-memory's loving voices!

Last miracle of all-O dearest mother's, sister's, voices ;)

The rain, the growing corn, the breeze among the long-leav'd corn, The measur'd sea-surf, beating on the sand,

The twittering bird, the hawk's sharp scream,

The wild-fowl's notes at night, as flying low, migrating north or south,

The psalm in the country church, or, mid the clustering trees, the open air camp-meeting,

The fiddler in the tavern-the glee, the long-strung sailor-song, The lowing cattle, bleating sheep-the crowing cock at dawn.

8

12 All songs of current lands come sounding 'round me, The German airs of friendship, wine and love,

Irish ballads, merry jigs and dances-English warbles, Chansons of France, Scotch tunes-and o'er the rest, Italia's peerless compositions. 
${ }^{13}$ Across the stage, with pallor on her face, yet lurid passion, Stalks Norma, brandishing the dagger in her hand.

${ }^{14}$ I see poor crazed Lucia's eyes' unnatural gleam; Her hair down her back falls loose and dishevell'd.

${ }^{15}$ I see where Ernani, walking the bridal garden, Amid the scent of night-roses, radiant, holding his bride by the hand, *

Hears the infernal call, the death-pledge of the horn.

${ }^{16}$ To crossing swords, and grey hairs bared to heaven, The clear, electric base and baritone of the world, The trombone duo-Libertad forever!

${ }^{17}$ From Spanish chestnut-trees' dense shade, By old and heavy convent walls, a wailing song, Song of lost love-the torch of youth and life quench'd in despair, Song of the dying swan-Fernando's heart is breaking.

${ }^{18}$ Awaking from her woes at last, retriev'd Amina sings;

Copious as stars, and glad as morning light, the torrents of her joy.

19 (The teeming lady comes !

The lustrious orb-Venus contralto-the blooming mother, Sister of loftiest gods-Alboni's self I hear.)

${ }^{20}$ I hear those odes, symphonies, operas;

I hear in the William Tell. the music of an arous'd and angry people;

I hear Meyerbeer's Inuguenots, the Prophet, or Robert;

Gounod's Faust, or Mozart's Don Juan.

${ }^{21} \mathrm{I}$ hear the dance-music of all nations,

The waltz, (some delicious measure, lapsing, bathing me in bliss;) The bolero, to tinkling guitars and clattering castanets. 
${ }^{22}$ I see religious dances, old and new;

I hear the sound of the Hebrew lyre;

I see the Crusaders marching, bearing the Cross on high, to the clang of cymbals;

I hear dervishes monotonously chanting, interspers'd with frantic shouts, as they spin around, turning always towards Meca;

I see the rapt religious dances of the Persians and the Arabs;

Again, at Eleusis, home of Ceres, I see the modern Greeks dancing, I hear them clapping their hands, as they bend their bodies,

I hear the metrical shuffling of their feet.

${ }^{23}$ I see again the wild old Corybantian dance, the performers wounding each other;

I see the Roman youth, to the shrill sound of flageolets, throwing and catching their weapons,

As they fall on their knees, and rise again.

24 I hear from the Mussulman mosque the muezzin calling;

I see the worshippers within,(nor form, nor sermon, argument, nor word, But silent, strange, devout-rais'd, glowing heads-ecstatic faces.)

${ }^{25}$ I hear the Egyptian harp of many strings,

The primitive chants of the Nile boatmen;

The sacred imperial hymns of China,

To the delicate sounds of the king, (the stricken wood and stone;) Or to Hindu flutes, and the fretting twang of the vina,

A band of bayaderes.

${ }^{26}$ Now Asia, Africa leave me-Europe, scizing, inflates me;

To organs huge, and bands, I hear as from vast concourses of voices, Luther's strong hymn, Eine feste Burg ist unser Gott;

Rossini's Stabat Mater dolorosa;

Or, floating in some high cathedral dim, with gorgeous color'd windows,

The passionate Agnus Dei, or Gloria in Excelsis. 
PROUD MUSIC OF THE STORM.

13

${ }^{27}$ Composers! mighty Maestros!

And you, sweet singers of old lands-Soprani! Tenori! Bassi!

To you a new bard, carolling free in the West,

Obeisant, sends his love.

${ }^{28}$ (Such led to thee, O Soul!

All senses, shows and objects, lead to thee,

But now, it seems to me, sound leads o'er all the rest.)

14

${ }^{29}$ I hear the annual singing of the children in St. Paul's Cathedral; Or, under the high roof of some colossal hall, the symphonies, oratorios of Beethoven, Handel, or Haydn;

The Creation, in billows of godhood laves me.

${ }^{30}$ Give me to hold all sounds, (I, madly struggling, cry,)

Fill me with all the voices of the universe,

Endow me with their throbbings-Nature's also,

The tempests, waters, winds-operas and chants-marches and dances, Utter-pour in-for I would take them all.

31 Then I woke softly,

And pausing, questioning awhile the music of my dream,

And questioning all those reminiscences-the tempest in its fury,

And all the songs of sopranos and tenors,

And those rapt Oriental dances, of religious fervor,

And the sweet varied instruments, and the diapason of organs,

And all the artless plaints of love, and grief and death,

I said to my silent, curious Soul, out of the bed of the slumberchamber,

Come, for I have found the clue I sought so long,

Let us go forth refresh'd amid the day,

Cheerfully tallying life, walking the world, the real,

Nourish'd henceforth by our celestial dream. 


\section{WHITMAN.}

32 And I said, moreover,

Haply, what thou hast heard, O Soul, was not the sound of winds, Nor dream of raging storm, nor sea-hawk's flapping wings, nor harsh scream,

Nor vocalism of sun-bright Italy,

Nor German organ majestic - nor vast concourse of voices-nor layers of harmonies;

Nor strophes of husbands and wives-nor sound of marching soldiers, Nor flutes, nor harps, nor bugle-calls of camps;

But, to a new rhythmus fitted for thee,

Poems, bridging the way from Life to Death, vaguely wafted in night air, uncaught, unwritten,

Which, let us go forth in the bold day, and write. 


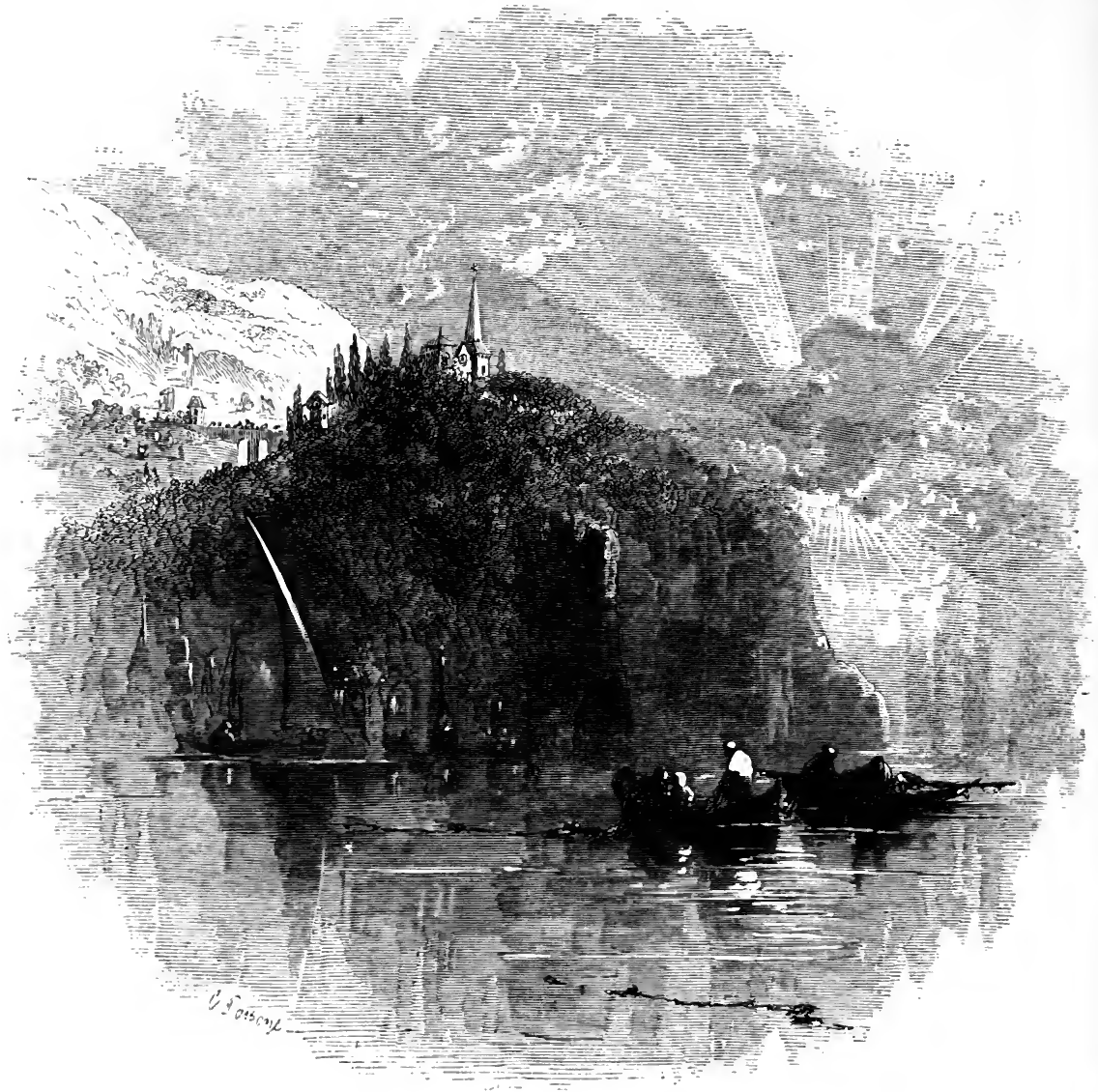

\section{KETCH UM.}

DOLORES.

Is beauty fairer far

Than the divinest dream of him who drew

The stately Eos guiding up the blue

IIer gemmed and golden car, 


\section{KETCHUM.}

From the dusk realm of night

Comes forth the radiant morning, brushing back The elouds like blossoms from her rosy track

With diamond dews bedight.

The priestly mocking-bird

.Wakens the grossbeak with his early hymn, And down the slopes, and through the woodlands dim,

Sweet, holy sounds are heard.

\section{Her gold-enamelled bells}

The tall campanula rings; 'mid daisies white The lithe, slim phalaris* flaunts his pennons bright O'er all the grassy swells.

The benzoin's breath divine

Spices the air ; the jasmine censers swing; Among the ferns beside the darkling spring The mailed nasturtions shine.

The brown bees come and go; His cheerful time the lonely cricket sings; While the quick dragon-fly, on lightning wings, Darts flashing to and fro.

Pomegranates, golden-brown, Drop delicate nectar through each rifted rind; And ghostly witches'-feather $\nmid$ on the wind Comes slowly riding down.

* The ribbon-grass of Southern Texas (Phalaris Americana) is remarkable for its splendid colours.

$t$ The winged seeds of a species of thistle. 


\section{DOLORES.}

The gray cicada sings

Drowsily amid th' acacia's feathery leaves;

Around her web the caterpillar weaves

The last white silken rings.

October silently

His pleasant work fulfils with busy hands, While, cheering him, floats o'er the shining sands

The murmur of the sea.

Deep in the shady dell

The cowherd, whistling at his own rude will, Lists, with bared head, as from the distant hill

Rings out St. Michael's bell,

Calling, with warning lips,

Matron and maid, albeit the south winds blow, To climb the height, and pray for them that go

Down to the sea in ships.

The fishers in the boats,

Mending their nets with murmurous song and noise, Stop sudden, as Dolores' silver voice

From the gray chapel floats.

They think how, o'er the bay, The sailor bridegroom, from her white arms torn, Sailed in the haze and gold of Michaelmas mornOne year ago to-day.

Then, rocking with the tide, They reckon up the news of yesterday, And count what time.to-day within the bay

The home-bound ship may ride. 


\section{KETCHUM.}

Dreaming, the long night hours, Of white sails coming o'er the tossing deep, At dawn this morning from her strange, glad sleep

She rose to gather flowers,

Cups honeyed to the brim, And fruits, and brilliant grasses, and the stems Of myrtles, with their waxen diadems,

'To offer unto him.

Beside the chapel porch, The Gloria ended, lingering now, she turns To look, as on the brightening spire-cross burns The morning's golden torch;

Then sees, with sober glee, The swift prophetic sea-gulls flying south, Far out beyond the landlocked harbour's mouth, Into the open sea.

"Steady, thou freshening breeze," Her dark eyes say, as o'er the sparkling main She gazes; "steady, till thou bring again

The ship from distant seas;

"So, ere his golden wine The setting sun adown the valley pour, Dear eyes may watch with me, beside the door, The autumn day decline."

O breeze! O sea-birds white ! Ye may not bring her from that rocky coastThe stranded ship-nor wrest the tempest-tossed From the black billow's might; 


\section{DOLORES.}

But when she wearily

Shall pray for comfort, of that country tell

Where all the lost are crowned with asphodel, And there is no more sea.

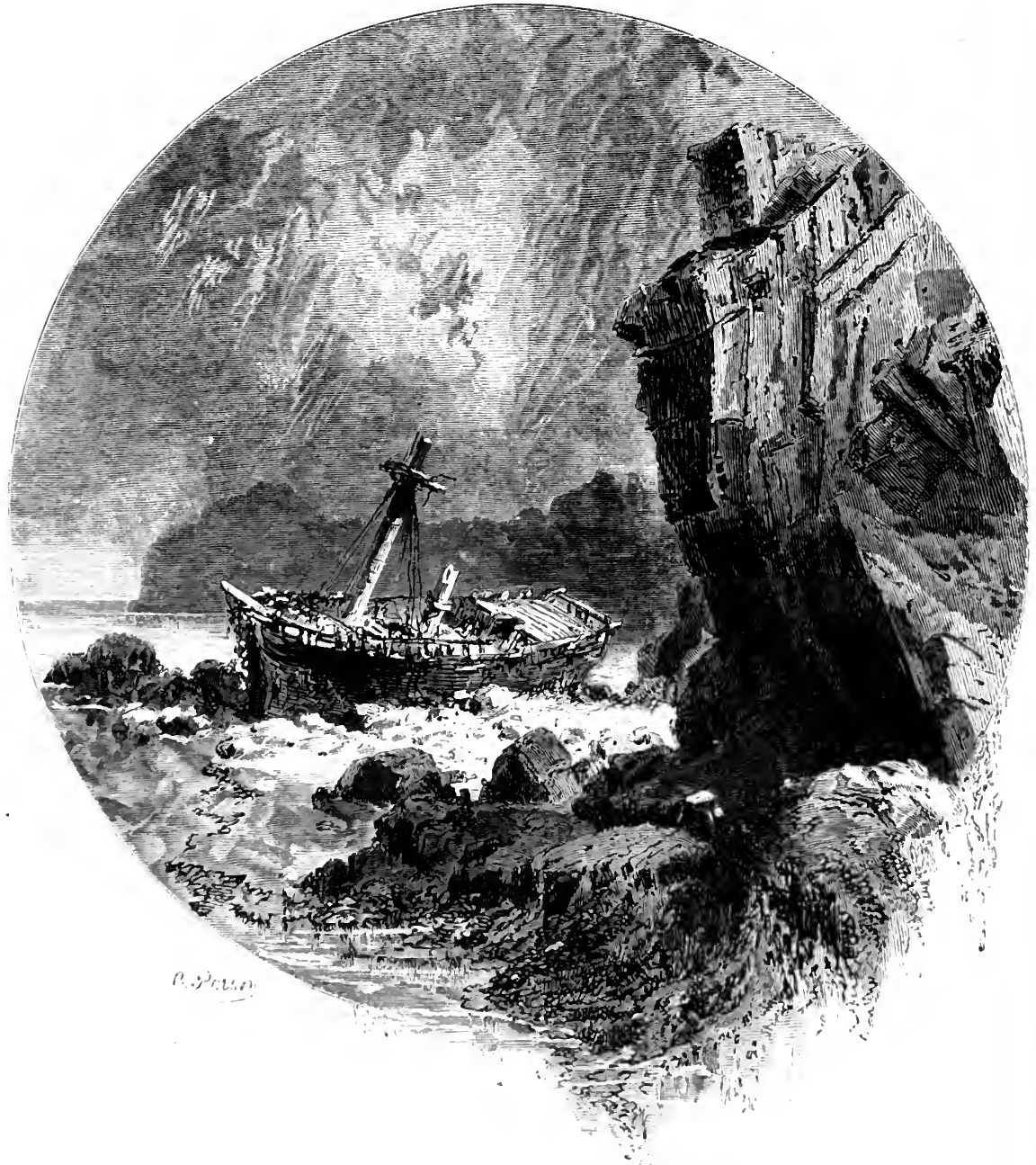




\section{LEMON.}

\section{OLD TIME AND I.}

OLD Time and I the other night

Had a carouse together;

The wine was golden, warm, and bright-

Ay! just like summer weather.

Quoth I, "There's Christmas come again,

And I no farthing richer;"

Time answered, "Ah! the old, old strain-

I prithee pass the pitcher.

"Why measure all your good in gold?

No rope of sand is weaker;

'Tis hard to get, 'tis hard to hold-

Come, lad, fill up your beaker.

Hast thou not found true friends more true,

And loving ones more loving ?" .

I could but say, "A few-a few;

So keep the liquor moving."

"Hast thou not seen the prosp'rous knave

Come down a precious thumper?

His cheats disclosed?" "I have-I have!"

"Well, surely that's a bumper."

"Nay, hold a while; I've seen the just

Find all their hopes grow dimmer."

"They will hope on, and strive, and trust,

And conquer!" "That's a brimmer." 


\section{OLD TIME AND I.}

"Tis not because to-day is dark, No brighter day's before 'em;

'There's rest for every storm-toss'd bark." "So be it! Pass the jorum!"

"Yet I must own I should not mind To be a little richer."

"Labour and wait, and you may findHallo! an empty pitcher." 


\section{UNIVERSITY OF CALIFORNIA LIBRARY BERKELEY}

Return to desk from which borrowed.

This book is DUE on the last date stamped below.

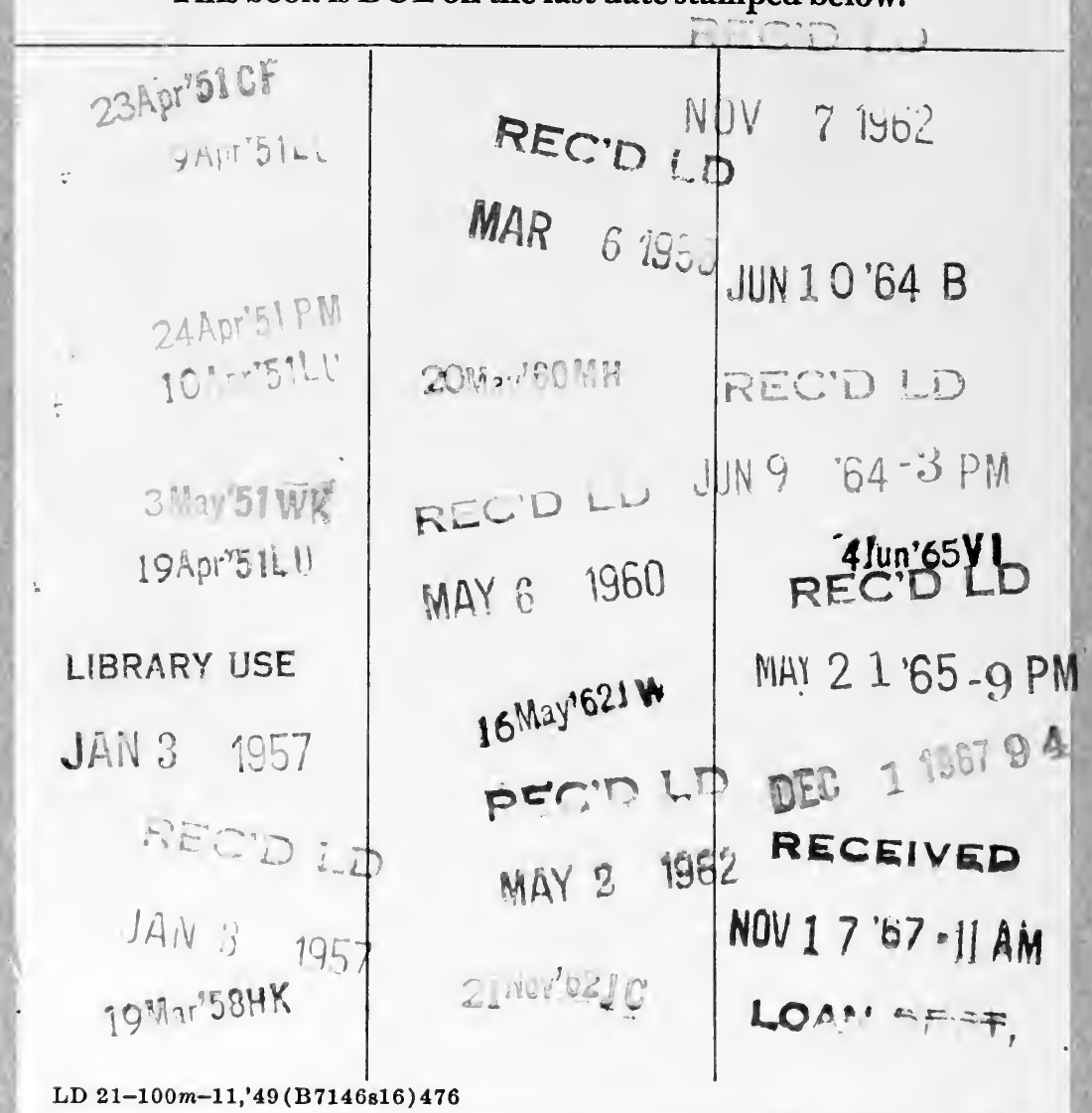


$9 / 97 / 2$

$$
\begin{gathered}
9 / 8 \\
W 738
\end{gathered}
$$

THE UNIVERSITY OF CALIFORNIA LIBRARY 
